UNIVERSIDADE DE SÃO PAULO

ESCOLA DE COMUNICAÇÕES E ARTES

DEPARTAMENTO DE COMUNICAÇÕES E ARTES

MARICI CRISTINE GRAMACHO SAKATA

\title{
GLOBALIZAÇÃO E EDUCAÇÃO: A formação do comunicador social na América Latina
}

\author{
Tese apresentada ao Programa de Pós- \\ Graduação em Comunicação, Área de \\ Concentração: Interfaces Sociais $d a$ \\ Comunicação da Escola de Comunicações e \\ Artes da Universidade de São Paulo, como \\ exigência parcial para a obtenção do Título de \\ Doutor em Ciências da Comunicação sob a \\ orientação da Profa. Dra. Maria Aparecida \\ Baccega.
}

SÃO PAULO

2008 
REITOR DA UNIVERSIDADE DE SÃO PAULO

Profa. Dra. Sueli Vilela

DIRETOR DA ESCOLA DE COMUNICAÇÕES E ARTES

Prof. Dr. Luiz Augusto Milanesi

CHEFE DO DEPARTAMENTO DE COMUNICAÇÕES E ARTES

Prof. Dr. Adilson Odair Citelli 
UNIVERSIDADE DE SÃO PAULO

ESCOLA DE COMUNICAÇÕES E ARTES

DEPARTAMENTO DE COMUNICAÇÕES E ARTES

MARICI CRISTINE GRAMACHO SAKATA

\section{GLOBALIZAÇÃO E EDUCAÇÃO: A formação do comunicador social na América Latina}

Tese apresentada à Área de Concentração:

Interfaces Sociais da Comunicação da Escola de Comunicações e Artes da Universidade de São Paulo, como exigência parcial para a obtenção do Título de Doutora em Ciências da Comunicação sob orientação da Profa. Dra. Maria Aparecida Baccega. 


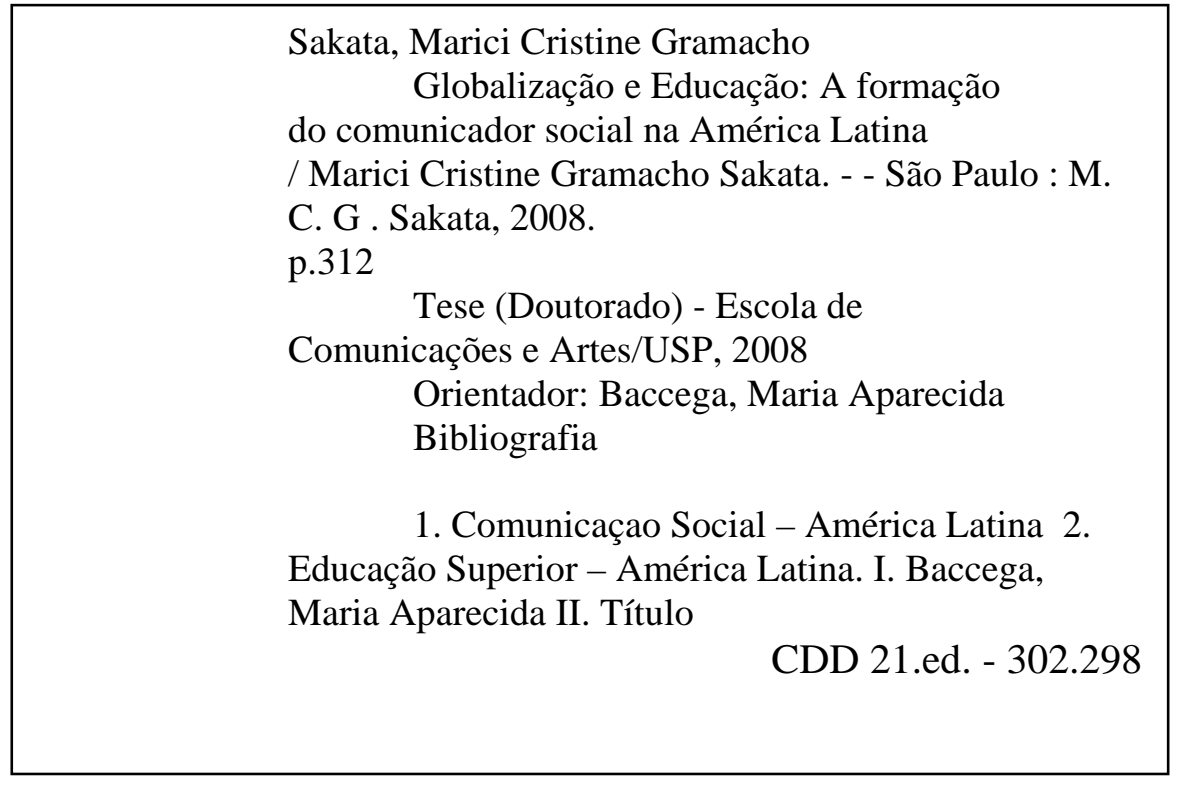

Ficha catalográfica elaborada pelo SBD/ECA/USP Bibliotecária Ana Maria Curvelo 
Banca composta pelos seguintes membros

\author{
Profa. Dra. Maria Aparecida Baccega \\ Presidente - Orientadora
}

Profa. Dra. Margarida M. Krohling Kunsch

Prof. Dr. Clovis de Barros Filho

Prof. Dr. Afrânio Mendes Catani

Profa. Dra. Rose de Melo Rocha 
"Uma crise só se torna um desastre quando respondemos a ela com juizos pré-formados, isto é, com preconceitos. Uma atitude dessas não apenas aguça a crise como nos priva da experiência da realidade e da oportunidade por ela proporcionada à reflexão." (Arendt, 2000) ${ }^{1}$

\footnotetext{
${ }^{1}$ ARENDT, H. Entre o passado e o futuro, São Paulo, Perspectiva, 2005. Tradução de Mauro W. Barbosa do original Between past and future: eight exercises in political thought, 5 ed. 2000. pg. 223

SAKATA, Marici Cristine Gramacho, Globalização e Educação: A formação do comunicador social na América Latina, 2008312 p. (Doutorado - Orientação BACCEGA, M. A.) Escola de Comunicações e Artes da Universidade de São Paulo, São Paulo, SP, 2008
} 


\section{Agradecimentos}

Várias pessoas contribuíram para a realização desta tese, direta ou indiretamente. A todas elas registro minha gratidão.

Agradeço em especial aos meus pais Maria Etelvina Gramacho Sakata e Katsumi Sakata e a toda a minha família, por todo amor e apoio sem o qual não seria possível a realização desta tese.

Agradeço em particular à Profa. Dra. Maria Aparecida Baccega pela orientação e pela dedicação ao longo do processo. O apoio, o interesse pelo tema e as críticas foram fundamentais para o desenvolvimento da tese.

Ao Professor Dr. Edson Luiz Riccio pelo apoio e entusiasmo em discutir todos os assuntos propostos e por estar ao meu lado durante cada passo do meu desenvolvimento acadêmico.

Sinceros agradecimentos aos Professores Drs. Afrânio Catani e Clóvis de Barros Filho, pelas valiosas sugestões e contribuições dadas no exame de qualificação e ao Prof. Sergio Francisco Costa pelas orientações do mestrado que têm sido de grande valia até hoje.

À Universidade de São Paulo, à ECA e aos professores e funcionários.

Ao TECSI - Laboratório de Tecnologia e Sistemas de Informação da FEA USP e equipe.

A todos os professores e pesquisadores que participaram das entrevistas e responderam aos questionários. As respostas e reflexões foram de suma importância para este estudo e de grande incentivo para a continuidade deste trabalho, especialmente por confirmarem a importância do mesmo.

Ao Fundo Sasakawa e seus membros pela bolsa concedida durante determinado período da realização deste doutorado, e pela bolsa FMP - Mobility Program que possibilitou a visita e a realização de entrevistas nas instituições de ensino da França e Espanha, que em muito contribuiram para os resultados desta tese. 


\title{
GLOBALIZAÇÃO E EDUCAÇÃO: A formação do comunicador social na América Latina
}

\author{
SAKATA, Marici Cristine Gramacho, Globalização e Educação: A formação do \\ comunicador social na América Latina, 2008312 p. (Doutorado - Orientação \\ BACCEGA, M. A.) Escola de Comunicações e Artes da Universidade de São \\ Paulo, São Paulo, SP, 2008
}

\section{RESUMO}

O estudo das relações entre a globalização e a educação superior possibilita compreender as questões locais no contexto das discussões e teorias sociais globais. Com isso, o objetivo desta tese é analisar os efeitos da globalização na formação do comunicador, pela análise dos cursos de graduação em Comunicação Social em universidades latino-americanas. Esta pesquisa tem como base o referencial teórico dos Estudos Culturais. Quanto ao tratamento metodológico combinaram-se a pesquisa bibliográfica e a pesquisa qualitativa. Em primeiro lugar buscamos as teorias e modelos de globalização existentes na literatura para compreender a natureza, o objeto, a estrutura e a dinâmica deste fenômeno. Pesquisamos a estrutura e os sistemas de ensino superior de cada país da amostra, as características dos cursos de Comunicação Social, e as mudanças ocorridas no “mercado educacional” da década de 1980 até 2007. Na pesquisa qualitativa, foram analisados os conteúdos das missões e objetivos declarados pelas Instituições de Ensino, aplicou-se um questionário e foram feitas entrevistas com professores. Além das universidades latino-americanas, analisamos Instituições norteamericanas, francesas e espanholas como base de comparação. Algumas instituições francesas e espanholas da amostra foram visitadas. Os relatos foram analisados a partir do referencial teórico e os resultados deste estudo foram de grande valia para melhor compreensão da influência exercida pela globalização sobre os processos educacionais, e onde podemos atuar frente a esse fenômeno como agentes ativos diante das mudanças globais. Outro resultado importante é a constatação de que a Instituição de Ensino é um espaço importante para a reflexão sobre identidade e cultura e, por isso, os cursos de comunicação não podem visar apenas à prática do mercado, o que se verificou ser uma tendência.

Palavras-chave: Comunicação, Educação, Globalização, Universidade, América Latina 


\title{
GLOBALIZATION AND EDUCATION: Higher Education Background in Communication in Latin America
}

\begin{abstract}
The investigation on the relationship between globalization and higher education sponsors a better understanding of local issues within the context of global discussions and social theories. With that in mind, the objective of this thesis was to analyze the effects of globalization on the educational background of Communicators by examining undergraduate Social Communications courses in Latin-American Universities. The present research is based on Cultural Studies theory. As for methodology, literature and qualitative research material were combined. At a first moment globalization theories and models currently available in the literature served as the basis for a better understanding of the nature, the object, the structure, and the dynamics of globalization. The system and structure of High Education of each country in the sample were investigated, as well as Social Communication courses content and the changes that have taken place in the "educational market" from the 1980s until 2007. Missions and objectives stated by each of the Institutions were analyzed through qualitative research. A questionnaire was sent out, and interviews with teaching staff were carried out. North-American, French, and Spanish universities besides Latin American universities were analyzed for the sake of comparison. Some French and Spanish Institutions in the sample were visited. Results were compared with the literature, and they were invaluable for a deeper understanding of how globalization influences educational processes as well as where action can be taken - as active agents facing global changes - in regard to that phenomenon. Another major result was the evidence that educational institutions are a key space for reflection on identity and culture - therefore, Communication Courses should not only focus what was shown to be a trend - market practices.
\end{abstract}

Key-words: Communication, Education, Globalization, University, Latin America 


\section{Lista de Figuras}

Figura 1 - Quadro Teórico: Elementos da Globalização ..................................................32

Figura 2 - Porcentagem do PIB gasto em Educação Superior: Países membros da

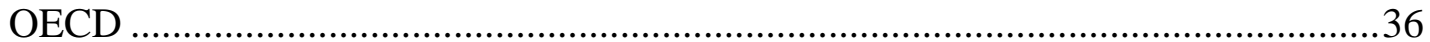

Figura 3 - A Estrutura Simbólica da Identidade Basca..................................................42

Figura 4 - Panorama Histórico das Reformas e Mudanças no Sistema Educacional .....101

\section{Lista de Quadros}

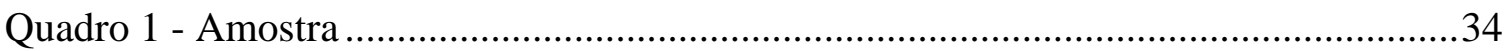

Quadro 2 - Tipologia de Tipos de Reformas Educacionais ...........................................69

Quadro 3 - Modelos de Fornecimento de Educação de acordo com o GATS ...................81

Quadro 4 - Participação dos Países nos Acordos Multilaterais ........................................85

Quadro 5 - Iniciativas do Setor Privado Educacional Internacional.................................88

\section{Lista de Tabelas}

Tabela 1 - Porcentagem do PIB gasto em Educação Superior nos Países da Amostra ....99

Tabela 2 - Gastos Públicos em Educação no Mundo 1975-1985 .....................................99

Tabela 3 - Evolução do número total de matrículas e taxa de crescimento......................100

Tabela 4 - Evolução das faculdades de Comunicação Social de 1984 a 2004 .................100

Tabela 5 - Instituições de Ensino Superior nos EUA e Número de Matrículas ...............135

Tabela 6 - Cursos de Comunicação nos Estados Unidos da América .............................135 


\section{SUMÁRIO}

Agradecimentos.......................................................................................................................v

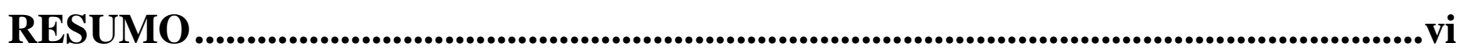

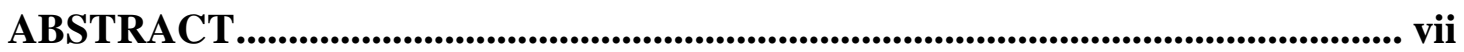

Lista de Figuras................................................................................................ viii

Lista de Quadros ................................................................................................................... viii

Lista de Tabelas .................................................................................................. viii

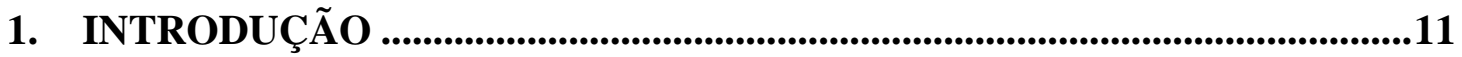

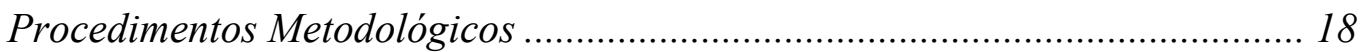

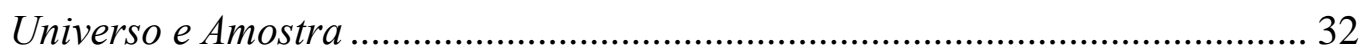

2. O PAPEL DA EDUCAÇÃO NA TRANSMISSÃO DE ELEMENTOS

IDENTITÁRIOS E CULTURAIS EM TEMPOS DE GLOBALIZAÇÃO............38

2.1 A Transmissão de Elementos Identitários e Culturais .................................... 38

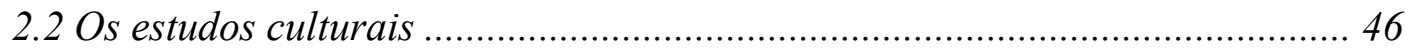

2.3 A Formação do Comunicador e a Globalização.............................................. 49

3. A APROPRIAÇÃO DA EDUCAÇÃO PELO MERCADO..................................54

3.1 Modelos Educacionais e o Sistema Universitário Latino-Americano.............. 54

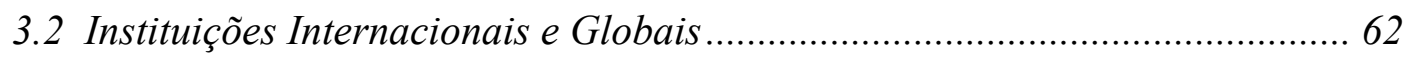

A Globalização e a Internacionalização do Sistema Universitário .................... 62

Declaração e Processo de Bolonha .................................................................... 70

Educação e Modernização na América Latina .................................................. 73

Organismos Internacionais e a Educação como Serviço .................................... 74

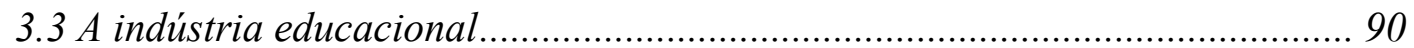

4 . O COMUNICADOR E O PROFISSIONAL GLOBAL......................................94

4.1 Formação Integral versus treinamento ........................................................... 94

4.2 Pesquisa em Universidades Nacionais e Globalizadas.................................. 98

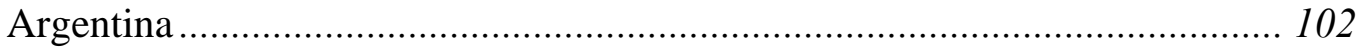

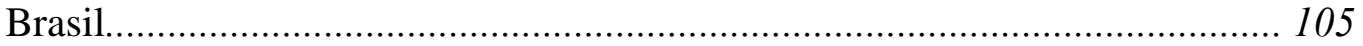

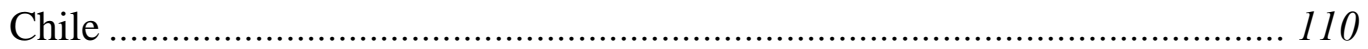

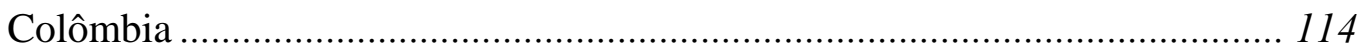

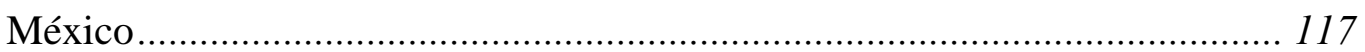

Europa: Espanha e França ..................................................................... 122

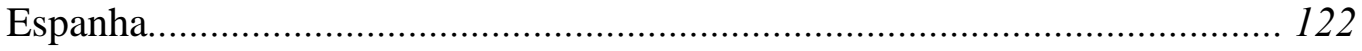

SAKATA, Marici Cristine Gramacho, Globalização e Educação: A formação do comunicador social na América Latina, 2008312 p. (Doutorado - Orientação BACCEGA, M. A.) Escola de Comunicações e Artes da Universidade de São Paulo, São Paulo, SP, 


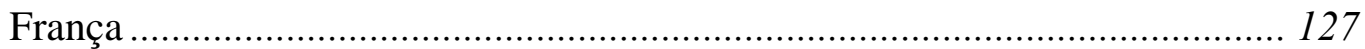

Estados Unidos da América (EUA).............................................................. 133

Resultados das Entrevistas ......................................................................... 138

4.3 Por uma outra globalização da Educação ................................................ 146

5. CONCLUSÃO .....................................................................................................149

O Discurso da Globalização e a Necessidade da Internacionalização ........... 160

6. LIMITAÇÕES DA PESQUISA E PESQUISAS FUTURAS ..............................169

Referências bibliográficas ...............................................................................................170

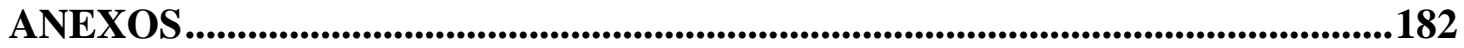

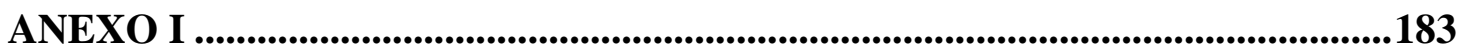

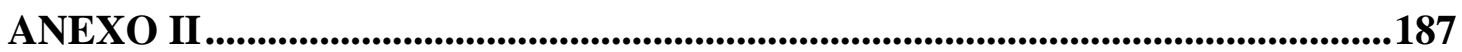

ANEXO III - DIRETRIZES CURRICULARES - BRASIL ....................................309 


\section{INTRODUÇão}

Incontáveis definições de globalização podem ser encontradas em artigos, livros e revistas. O termo globalização está presente nos meios de comunicação e é utilizado tanto para explicar as crises e os problemas mundiais como as grandes evoluções tecnológicas e o crescimento do fluxo de informações e produtos entre países.

Estudar as relações entre globalização e o Sistema de Educação Superior é fundamental para compreendermos a sua influência na formação do comunicador. Entender como se constrói a formação do Comunicador no ambiente globalizado e em constante transformação torna-se fundamental para que possamos: a) adaptar os processos educacionais ao novo ambiente sem perder as características e valores fundamentais deste campo; b) formular Políticas Públicas que garantam a manutenção das características e valores culturais; e c) pensar como devemos nos portar como agentes ativos diante das mudanças globais.

Ressaltamos nesta tese a distinção entre os conceitos de internacionalização e globalização. A internacionalização foi determinante para a criação dos cursos de comunicação na América Latina. Os primeiros cursos de comunicação surgiram na Europa e nos Estados Unidos (Marques de Melo, 2005) ${ }^{2}$ e foram importados para a América Latina. Com o tempo foram se adaptando e se multiplicando. Os cursos europeus e norte-americanos mantinham forte ligação com o setor produtivo pelo seu perfil profissionalista; porém, como estavam em ambiente acadêmico, também eram interdisciplinares e aos poucos a pesquisa foi ganhando espaço. Diferentemente dos processos de internacionalização, em um ambiente globalizado as ações e políticas definidas pelos órgãos internacionais passam a ser impostas e incorporadas às políticas dos países menos desenvolvidos em diversos planos, inclusive no plano educacional. Com isso, os países são pressionados pelos programas de financiamento a atenderem índices e padrões de qualidade. "A compreensão de tais movimentos e forças constitui

\footnotetext{
2 MARQUES DE MELO, José, Diretrizes curriculares para os cursos de comunicação social, Revista Estudos $\mathrm{n}^{0} 22$ Disponível em http://www.abmes.org.br/Publicacoes/Revista_Estudos/estud22/est22$\underline{11 . h t m}$ acesso em 16/07/2005)

SAKATA, Marici Cristine Gramacho, Globalização e Educação: A formação do comunicador social na América Latina, 2008312 p. (Doutorado - Orientação BACCEGA, M. A.) Escola de Comunicações e Artes da Universidade de São Paulo, São Paulo, SP, 2008
} 
parte fundamental da análise sociológica do desenvolvimento, já que este implica sempre alterações no sistema social de dominação e a redefinição das formas de controle e organização da produção e do consumo" (Cardoso e Faletto, 2004) ${ }^{3}$. Considerando que as instituições de um país e seus projetos educacionais são matériasprimas privilegiadas na construção de identidades culturais, as mudanças e impactos decorrentes da globalização afetam a formação do comunicador.

As formas como os Comunicadores vêem o mundo a partir de seus valores e elementos identitários é fundamental para poderem exercer de forma plena seu papel na sociedade. É necessário superar o julgamento do que seja certo ou errado e entender o mundo como algo muito mais complexo e multicultural, onde os extremos das oportunidades, carências, religiões e tradições têm de conviver. Devemos compreender que a diversidade é uma reestruturação em função do conceito do direito à comunicação. (Matellart, 2002) ${ }^{4}$

Assim, percebemos que a formação do comunicador tem características específicas que devem ser analisadas. Quaisquer ações tomadas que visem a regulamentar ou modificar diretrizes devem ser pensadas com o objetivo de atender às particularidades do campo e da área de atuação, além das questões culturais e locais.

Estudar a influência da globalização na formação do comunicador não é freqüente, mas também não é inédito. Porém, esta pesquisa é inédita ao se dedicar ao estudo empírico comparativo entre os cursos superiores de comunicação social na América Latina, abordando a globalização, a formação do comunicador social e os elementos identitários e culturais.

Segundo Lopes (2000) $)^{5}$, o estudo sobre a globalização do mercado cultural nas décadas de 1980-90 revitalizou as pesquisas sobre comunicação política, internacional e cultural. Também nesta década houve o aumento de interesse pelos estudos sobre a comunicação e educação gerando programas de trabalho bidisciplinares ${ }^{6}$.

Assim, o presente estudo vai, também, ao encontro das novas temáticas desenvolvidas no campo da comunicação nas últimas décadas.

\footnotetext{
${ }^{3}$ CARDOSO, F. H. e FALETTO, E. Dependência e desenvolvimento na América Latina: Ensaio de interpretação sociológica, ${ }^{a}$ ed. Civilização Brasileira, Rio de Janeiro, 2004. pg.37

4 MATTELART, A. La diversité culturelle: entre histoire et géopolitique, GRICIS, Globalisme et Pluralistme, Montreal, avril 2002 (Disponível em www.infoamerica.org/documentos_pdf/Mattelart2.pdf) Acesso em 18/07/2005.

${ }^{5}$ LOPES, Maria Immacolata V. O estado da pesquisa de comunicação no Brasil, Temas contemporâneos em comunicação, 2000b

${ }^{6}$ Ibidem, pg.57

SAKATA, Marici Cristine Gramacho, Globalização e Educação: A formação do comunicador social na América Latina, 2008312 p. (Doutorado - Orientação BACCEGA, M. A.) Escola de Comunicações e Artes da Universidade de São Paulo, São Paulo, SP, 2008
} 
A comunicação, conforme Martino $(2001)^{7}$, se propõe a traduzir - pelo ângulo dos processos de produção e circulação de sentido - todo um complexo de transformações que nas décadas recentes vem imprimindo novas feições à sociedade (p.42). Neste processo, conforme Braga $(2001)^{8}$, trata-se de perceber o quê por seus modos e objetivos sociais é, entretanto inerente não a especificações, mas resultante de ou referente a - processos mais amplos de trocas simbólicas e de interações que determinam o que aí se faz. Para Cohn $(2001)^{9}$, o que interessa à comunicação, não é propriamente a questão cultural, mas sim a questão das interações comunicacionais entre diferentes culturas (identidades), ou seja, é necessário utilizar os dados obtidos para observar efetivamente como as interações comunicacionais se dão entre estas identidades culturais e a mídia.

Desta forma, através da pesquisa, buscamos fazer uma análise dos processos de formação a partir do ponto de vista comunicacional, além de termos como objeto de estudo a formação do comunicador.

O levantamento bibliográfico possibilitou verificar a existência de um vasto conjunto de artigos, livros e textos publicados, tanto a respeito do fenômeno da globalização de forma geral, como também específicos à globalização e à educação superior em comunicação social - o que demonstra ser esta uma preocupação presente no campo.

A justificativa da pesquisa é a necessidade de sistematização do conhecimento surgido nas últimas décadas envolvendo a globalização, a educação e a comunicação para compreender como cada país tem reagido à globalização e à manutenção de seus valores e elementos identitários. Além de pesquisas abrangentes que discutam o assunto, é necessário também conhecer as ações locais, identificar os pontos comuns e perceber como as experiências internacionais podem colaborar neste ambiente de intensas transformações.

Este estudo é importante para entender como é possível, por meio dos modelos de globalização, analisar sua influência na educação superior e na formação do comunicador. Isto é necessário para se entender as razões e as conseqüências a curto e

\footnotetext{
${ }^{7}$ MARTINO, L.C. Elementos para uma epistemologia da comunicação, In: Campo da comunicação, Fausto Neto, A., Prado, J. L. A. e Porto, S. D. (Orgs.) Editora Universitária, João Pessoa, 2001

${ }^{8}$ BRAGA, J.L. Constituição do Campo da Comunicação, In: Campo da comunicação, Fausto Neto, A., Prado, J. L. A. e Porto, S. D. (Orgs.) Editora Universitária, João Pessoa, 2001

${ }^{9}$ COHN, Gabriel. O Campo da Comunicação, In: Campo da comunicação, Fausto Neto, A., Prado, J. L. A. e Porto, S. D. (Orgs.) Editora Universitária, João Pessoa, 2001
} 
longo prazos. Espera-se com os resultados perceber como é possível, a partir deste entendimento, maximizar as vantagens e minimizar as desvantagens neste novo cenário.

O objetivo geral desta tese é estudar a influência da globalização na formação do comunicador por meio da análise dos cursos de graduação de comunicação social em universidades Latino-Americanas. Entendemos a influência da globalização como sendo o resultado de ações, políticas e regras estabelecidas por órgãos internacionais recomendados ou impostos aos países, como por exemplo, a entrada da educação na OECD-Organização para a Cooperação e o Desenvolvimento Econômico, a abertura a instituições internacionais, as mudanças na forma de financiamento do governo, a venda de IES-Instituições de Ensino Superior, concorrência e abertura para o mercado, etc.

Entendemos como problema prático (empírico) que a educação superior no ambiente globalizado é guiada pelos países desenvolvidos e, portanto, pela redução e/ou eliminação da autonomia dos países menos desenvolvidos. Neste cenário, ocorre, também, perda de alunos e empregos para instituições estrangeiras e perda de elementos nacionais na educação em decorrência da réplica de modelos importados. Se conseguirmos entender como funciona o processo seremos capazes de tomar decisões importantes e fundamentadas, além de sabermos como melhorar a qualidade sem perder a autonomia. Pretendemos identificar os órgãos e países emissores de regras e de que forma ocorrem as pressões no campo educacional.

Temos como problema da pesquisa a seguinte condição: Quais as influências da globalização na formação do comunicador e de que forma os países menos desenvolvidos perdem autonomia sobre seus próprios processos educacionais?

Os objetivos específicos que guiam este trabalho são: Qual a missão das IESInstituições de Ensino Superior? Qual o objetivo dos cursos de comunicação social na América Latina? Quais as questões-chave resultantes da comparação entre instituições nacionais e globalizadas? É possível extrair conseqüências ou tendências deste cenário?

Devido à globalização, uma das principais mudanças que vem ocorrendo na profissão do comunicador e do pesquisador ${ }^{10}$, assim como em muitas outras profissões, é a movimentação e o deslocamento de pessoas de um país para outro em busca de melhores condições de vida e oportunidades de crescimento profissional. Assim, os profissionais e recém-formados buscam, cada vez mais, estar em conformidade com os

\footnotetext{
${ }^{10}$ LOPES, M. 2000b, O estado da pesquisa ... 2000b pg.17 Segundo Lopes (2000; 17), "Choca-se dentro da comunidade científica da comunicação o processo universalista da globalização com a questão nacional e das classes sociais, a visão de mundo teoricamente desenraizada com o ato de pensar que integra o movimento concreto das coisas”.

SAKATA, Marici Cristine Gramacho, Globalização e Educação: A formação do comunicador social na América Latina, 2008312 p. (Doutorado - Orientação BACCEGA, M. A.) Escola de Comunicações e Artes da Universidade de São Paulo, São Paulo, SP, 2008
} 
padrões mundiais de sua área para que possam ter mobilidade de atuação, seja em outros países, seja em empresas multinacionais em seu próprio país. As instituições de ensino passam a se preocupar com os resultados e não com o processo de formação - e é no processo que os valores e elementos identitários se reforçam. A modernização desenfreada leva à perda do bom senso e do que foi constituído ao longo do tempo a partir da utilização de novas técnicas e teorias de massas.

A pesquisa analisa os fatos e dá continuidade ao longo caminho de questionamentos que este tema envolve. A tese, o argumento, as proposições e hipóteses aceitas provisoriamente, e o quadro teórico que nos auxiliam neste processo, são definidos a seguir.

Como existem grandes diferenças entre os países considerados à frente do processo de globalização e os demais países, a tese a ser defendida é a de que $\boldsymbol{a}$ globalização, como fenômeno mundial, pressiona as Instituições de Ensino Superior a se modernizarem e a formarem profissionais globais de acordo com os modelos criados nos países hegemônicos, pondo em risco os elementos identitários de uma cultura local.

Embora a globalização esteja unindo as nações e intensificando a mobilidade de pessoas, divisas e tecnologia, as evidências sugerem que ela intensifica as pressões em diversas áreas para que países menos desenvolvidos ajam de acordo com padrões estabelecidos pelos mais desenvolvidos. A literatura e o debate na mídia em geral têm suscitado inúmeras questões, causas e conseqüências, definindo a globalização como um fenômeno complexo e em parte responsável pelo aumento da distância entre ricos e pobres, embora alguns destes discursos sejam oriundos exatamente dos países e das organizações que contribuem para tal distanciamento. Alguns autores sugerem que a maneira pela qual as economias latino-americanas se vincularam ao mercado mundial no momento da expansão de suas economias e definiram suas relações com o exterior define hoje seu grau de dependência nas relações internacionais e a intensidade das pressões sobre suas decisões. Neste contexto, mudanças significativas estão ocorrendo no campo educacional como um todo. Dados publicados sobre a América Latina mostram em números a quantidade de instituições públicas e privadas, a forma de financiamento e avaliação da qualidade e a internacionalização das instituições de educação superior vista como prestação de serviço. Há quem alegue que tais mudanças aumentam a busca por qualidade das instituições e que o setor privado preenche a lacuna não atendida pelo setor público. No entanto, as pesquisas demonstram que a 
transferência da educação superior para o setor privado é uma desvantagem para a sociedade, pois deixam de ser instituições sociais autônomas - cujo objetivo é a produção de conhecimento - para objetivarem a manutenção e o retorno financeiro. Em algumas áreas do conhecimento - as mais dispendiosas, como medicina - não há interesse das instituições de ensino superior em manter cursos de graduação e investir em pesquisa de ponta. Existem sistemas mistos que podem atender melhor aos objetivos educacionais do que simplesmente transferir para o setor privado este campo de atuação.

A mercantilização da educação, ou seja, o processo de mundialização do mercado aplicado à educação, conforme Trindade $(1999)^{11}$, resultaria em um modelo, onde o Estado desapareceria e o mercado moldaria os currículos padronizados: "As universidades tornar-se-iam empresas à busca de clientes - alunos disponíveis, sem distinção de nacionalidade - e em concorrência com o mercado mundial para atrair os melhores fatores de produção - professores e os financiamentos - com vistas a maximizar os lucros - quer dizer os meios de desenvolvimento.” Ainda de acordo com Trindade (1999) ${ }^{12}$ assistir-se-ia então, como sob o mercado de bens de consumo, a uma distinção crescente entre produtos de alto valor e produtos de massa, ou seja, pólos de excelência e ensino de massa com crescente perda de financiamento. Tem-se aqui o que alguns autores chamam de globalização negativa.

Cinco proposições e hipóteses para o estudo das mudanças organizacionais nas instituições de ensino superior no contexto da globalização são estabelecidas por Vaira $(2004)^{13}$. Tais proposições e hipóteses nos ajudam a formular parte de nossas hipóteses de acordo com o objetivo da pesquisa. As proposições são:

1 - As mudanças organizacionais devem ser entendidas dentro de um quadro teórico com ampla estrutura e dinâmica institucional.

2 - Os conteúdos dos "imperativos institucionais e competitivos" e das pressões estão sujeitos a um processo de articulação, setorização, especificação e adaptação em relação aos demais campos organizacionais. Imperativos organizacionais, sociais e de mercado

\footnotetext{
11 TRINDADE, H. Rapport Attali: bases da reforma do ensino superior francês In: Universidade em Ruínas na República dos Professores, Editora Vozes, 3ª ed. Rio de Janeiro, 1999a, pg. 89

12 Ibidem

13 VAIRA, M. Globalization and Higher Education Organizational Change: A framework for analysis. Higher Education, 48, 2004 483-510.The influence of globalization on higher education Disponível em http://www.springerlink.com.w10077.dotlib.com.br/(ydkvxm55lp4spz553qxcqiur)/app/home/contribution .asp?referrer=parent\&backto=issue,5,11;journal,10,217;linkingpublicationresults, $1: 102901,1$ Acesso em 10.01.2006

SAKATA, Marici Cristine Gramacho, Globalização e Educação: A formação do comunicador social na América Latina, 2008312 p. (Doutorado - Orientação BACCEGA, M. A.) Escola de Comunicações e Artes da Universidade de São Paulo, São Paulo, SP, 2008
} 
que reformulam continuamente as missões e expectativas da educação superior (Gumport, $2000^{14}$ )

3 - As instituições internacionais e a dinâmica competitiva global pressionam os governos ao exigirem que incorporem imperativos institucionais e competitivos em suas políticas setoriais e em suas estruturas de gestão que afetarão todas as corporações individuais.

4- Pressões institucionais e competitivas no trabalho estão sujeitas a um processo de articulação, especificação e adaptação pela incorporação destas pressões nas próprias estruturas organizacionais individuais, ou seja, estas estruturas tornam-se variações delas mesmas condicionadas ao contexto [alomorfismo - variação de uma mesma estrutura dependendo do contexto em que está condicionado, (Vaira, 2004) ${ }^{15}$ ].

5- O Alomorfismo Organizacional deixa espaço suficiente para a definição e seleção de desempenho dos processos sociais.

A partir das constatações e dos questionamentos são formuladas as seguintes proposições e hipóteses deste trabalho:

1) As mudanças ocorridas no contexto da globalização devem ser entendidas dentro de um quadro teórico onde os principais atores, a dinâmica dos fluxos e os processos e os resultados estejam identificados e possam indicar as pressões competitivas e institucionais, suas origens e seus destinos na estrutura mundial.

Se a constituição de redes e acordos de colaboração possibilita a vantagem competitiva entre as instituições e a aquisição de diplomas reconhecidos internacionalmente, legitima as instituições e os profissionais; então, neste processo, existe baixa resistência das instituições organizacionais nacionais aos imperativos organizacionais - tais imperativos são definidos pelos países hegemônicos, propagados pelas instituições portadoras (carriers) e causadoras de reformulação e adaptação das instituições de ensino locais.

2) As pressões coercitivas das nações-estado vindas por meio de políticas e conteúdos de imperativos institucionais e competitivos são recebidas de diferentes formas e se adaptam de acordo com o governo local em cada um dos países. A maior ou menor influência pelo grau de dependência dos governos em relação a eles, e a incorporação dos imperativos em suas políticas nacionais variam principalmente de acordo com a dependência econômica.

\footnotetext{
${ }^{14}$ GUMPORT, Patricia J. , Academic restructuring: Organizational change and institutional imperatives, Higher Education, Volume 39, Issue 1, Jan 2000, Pages 67 - 91, Disponível em http://www.springerlink.com/(gwqubdaayyngun45xeti20zz)/app/home/contribution.asp?referrer=parent\& backto=issue,4,5;journal,47,217;linkingpublicationresults,1:102901,1 Acesso em 09.02.2006

${ }^{15}$ VAIRA, M. Globalization and Higher Education ... 2004, pg. 498

SAKATA, Marici Cristine Gramacho, Globalização e Educação: A formação do comunicador social na América Latina, 2008312 p. (Doutorado - Orientação BACCEGA, M. A.) Escola de Comunicações e Artes da Universidade de São Paulo, São Paulo, SP, 2008
} 
Se, no processo de avaliação, as instituições devem atender indicadores e padrões mundiais para permanecerem no mercado, então os países mais dependentes economicamente buscam estabelecer seus padrões de qualidade de acordo com os padrões emitidos pelas instituições internacionais e devem se submeter aos acordos internacionais sob a condição de perda de autonomia, e conseqüente perda de financiamentos internacionais.

Se o processo de seleção de entrada e de financiamento segue pressões por padrões mundiais, exigindo outras formas de financiamento que não as do Estado, então, serão necessários adequação e estabelecimento de regras para que se contemplem as questões sociais locais e não se torne um meio de exclusão social, prejudicando os próprios indicadores que serão utilizados na avaliação do país.

3) O campo e as instituições educacionais passam por um processo de adaptação e incorporação das pressões institucionais e competitivas nas suas estruturas organizacionais. Tornam-se variantes morfológicas (alomorfismo), pois se redefinem dentro dos seus próprios padrões, porém no contexto globalizado.

Sob a condição de atrair alunos e ao mesmo tempo justificar que a instituição está inserida na nova ordem mundial, as instituições que enfrentam pressões institucionais e competitivas para mudança passam a fazer uma clara distinção entre conteúdos globais e conteúdos locais, mantendo parte de sua base fundada nos valores da instituição e parte adaptada ao ambiente.

Conhecer como as instituições de ensino são mantidas e financiadas e analisar as missões e os objetivos declarados das instituições e da estrutura dos currículos poderá confirmar se há concordância com os padrões estabelecidos internacionalmente ou ainda distinção entre conteúdos globais e locais nas escolas que se propõem a seguir os padrões mundiais. Os indicadores educacionais e índices econômicos no campo educacional, a literatura e as discussões na mídia poderão guiar o debate e ajudarão a responder algumas indagações: Como os cursos de comunicação estão estruturados? Como se dão os processos de financiamento nas escolas internacionais? Como os países latino-americanos estão posicionados no ambiente global? Quais as barreiras ou incentivos de entradas de instituições estrangeiras nos países?

\section{Procedimentos Metodológicos}

Pesquisamos as teorias sobre modelos de globalização para compreender a natureza, o objeto, a estrutura e a dinâmica da globalização. Achamos importante 
distinguir os diferentes discursos sobre a globalização e definir a globalização do ponto de vista da educação.

A partir daí, utilizamos esta definição para nos auxiliar na compreensão das estruturas dinâmicas da educação superior e definir quais as categorias que influenciam na formação do comunicador.

A tese está baseada em pesquisa bibliográfica, documental e em pesquisa de campo qualitativa. Dos artigos e textos científicos foram extraídos os modelos de globalização a partir dos quais se criou a estrutura de análise e o quadro teórico. Dos documentos dos organismos internacionais foram extraídas normas, estatísticas e acordos entre países no que concerne à educação superior. Foram extraídos dos textos científicos os relatos de experiências e discussões sobre o tema nos países latinoamericanos. A literatura sobre a globalização é ampla e apresenta diversas visões econômicas, sociais e culturais que utilizamos nesta tese para a construção e os fundamentos da estrutura de análise.

É fundamental para a pesquisa que se estabeleça um objeto empírico. O objeto empírico escolhido foi a missão das instituições de ensino superior na América Latina selecionadas na amostra, bem como o objetivo declarado pelas instituições para seus cursos de Comunicação Social.

O critério de seleção dos países da amostra na América Latina foi incluir aqueles onde a pesquisa em comunicação tem sido mais proeminente e com maior quantidade de eventos científicos, publicações e programas acadêmicos. Para uma comparação mais substancial, foram analisadas também universidades da Espanha, França e Estados Unidos da América. As universidades foram selecionadas a partir de critérios como tradição local e em âmbito nacional, posicionamento na classificação internacional, e acessibilidade aos dados. As universidades foram classificadas como nacionais e globalizadas segundo critérios previamente definidos.

A missão das instituições e seus objetivos foram coletados por pesquisa documental com o uso da Internet. Foi feita a análise de conteúdo, onde tentamos classificar as categorias conforme o quadro teórico de referência. Também foi feita uma análise interpretativa a fim de buscar o relacionamento destas categorias com as questões principais referentes à globalização. A facilidade de obtenção das missões e dos objetivos dos cursos na Internet permitiu melhor aproveitamento do tempo. A pesquisa in loco também ocorreu a fim de confirmar por meio de entrevistas e observação, a situação real de parte das instituições pesquisadas e conhecer a opinião 
dos professores frente às mudanças que têm ocorrido no sistema e em sua atividade profissional nos últimos anos.

O objetivo de conceituar a globalização e estabelecer um quadro teórico tem os seguintes propósitos: identificar os caminhos a serem seguidos para a análise; estabelecer um suporte teórico e empírico; e utilizar os indicadores para investigar a relação entre a globalização e a educação. O quadro teórico permite simplificar a complexidade do objeto pela modelagem dos elementos. Também possibilita identificar lacunas, e a partir disso, estruturar pesquisas tanto de forma global como particular. (Woodward et al., 2001 ${ }^{16}$ ). O quadro teórico deve englobar questões em diferentes níveis.

Identificamos os elementos da globalização na visão sistêmica como:

1) Construtos teóricos - conceitos teóricos advindos do contexto empírico que definem o ponto de partida (entradas)

2) Políticas macroeconômicas e Recursos disponíveis - os países hegemônicos, as instituições que emanam políticas, o que cada país dispõe de recursos e sua posição dentro do sistema (recursos)

3) Fluxo e acordos de negociações - como cada país recebe as pressões externas e quais os acordos no campo educacional que envolvem a América Latina (processos)

4) Resultados (saídas)

A partir destes quatro elementos e dos objetivos da pesquisa tentamos compreender as ligações entre as questões globais e as mudanças nas políticas e práticas educativas.

1) Construtos teóricos - conceitos teóricos advindos do contexto empírico e que definem o ponto de partida (entradas)

Dale (2004) ${ }^{17}$ afirma que embora muito se fale sobre globalização e educação, poucas são as tentativas para confrontar teoricamente a natureza e os efeitos da

\footnotetext{
${ }^{16}$ WOODWARD, David, DRAGER, Nick, BEAGLEHOLE, Robert, \& LIPSON, Debra Globalization and health: a framework for analysis and action Bulletin of the World Health Organization, 2001, 79 (9) World Health Organization, 2001.

17 DALE, Roger. Globalização e educação: demonstrando a existência de uma "cultura educacional mundial comum” ou localizando uma "agenda globalmente estruturada para a educação”? Educ. Soc., Campinas, vol. 25, n. 87, p. 423-460, maio/ago. 2004 Disponível em <http://www.cedes.unicamp.br> Tradução de António M. Magalhães do original Globalization and education: demonstrating the existence of a "global common educational culture" or locating a "globally structured agenda for education”? pg. 425

SAKATA, Marici Cristine Gramacho, Globalização e Educação: A formação do comunicador social na América Latina, 2008312 p. (Doutorado - Orientação BACCEGA, M. A.) Escola de Comunicações e Artes da Universidade de São Paulo, São Paulo, SP, 2008
} 
composição e das conseqüências das mudanças das forças supranacionais, e sugere que uma teoria dos efeitos da globalização sobre a educação deve:

(a) especificar a natureza da globalização, (b) indicar claramente o que é que se quer dizer com "educação" e (c) especificar como a globalização afeta a educação, seja diretamente, de forma identificável, ou indiretamente.

Meyer, Boli, Thomas e Ramirez $(1997)^{18}$ diferenciam ocidentalização e globalização e, sobre a ocidentalização, afirmam que o mundo é essencialmente formado por modelos ocidentais transmitidos ao redor do mundo por meio de redes transnacionais e cultura global. De acordo com este enfoque macro-fenomenológico a convergência de formas institucionais como nação-estado, democratização, educação de massa, proteção de direitos das minorias, controle populacional e proteção ambiental não pode ser explicada simplesmente por um auto-interesse localizado ou por uma evolução interna, mas por fontes de pressões isomórficas transmitidas por redes transnacionais ${ }^{19}$ e pelas tentativas de abraçar modelos cognitivos que confiram legitimidade generalizada na ordem mundial dominada pelo Ocidente.

Em seu ensaio sobre a globalização Crenshaw, Paxton, Morishima e Robison $\left(2003^{20}\right)$ afirmam que a habilidade de uma população em abraçar qualquer modelo particular é determinada por propriedades internas (i.e., estruturas favoráveis que podem ter sido moldadas anteriormente à globalização), contato entre atores, Estados e instituições, e o contexto macrossocial no qual este contato acontece (por exemplo, ciclos econômicos ou períodos históricos). Ou seja, deve-se assumir que contatos materiais reais são mais intensos e são mais prováveis na construção dos interesses e compromissos.

A análise dos sistemas mundiais requer o entrelaçamento de três áreas da ação humana coletiva: a econômica, a política e a social (sociocultural). As disciplinas antropologia, economia, ciência política e sociologia - e as teorias e métodos se sobrepõem, possibilitando uma compreensão ampla do sistema. As áreas de ação a

\footnotetext{
18 MEYER, John W., BOLI, John, THOMAS, George M., RAMIREZ, Francisco O. “World Society and the Nation-State.” American Journal of Sociology 103: 144-181. 1997

19 IGOs -Intergovernmental organization - Organizações Intergovernamentais restritas a países associados, como a ONU- Organização das Nações Unidas

INGOs- International nongovernmental organization, Organizações internacionais não governamentais, onde os membros podem ser indivíduos, empresas ou associações, como a Cruz Vermelha, Anistia Internacional, Comitê Olímpico, etc.

${ }^{20}$ CRENSHAW Edward, PAXTON Pamela, MORISHIMA Rumi, ROBISON Kristopher, Globalization, Westernization, and Social Change, January 2003 Globalization Session of the Annual Meetings of the American Sociological Association, Atlanta 2003.
}

SAKATA, Marici Cristine Gramacho, Globalização e Educação: A formação do comunicador social na América Latina, 2008312 p. (Doutorado - Orientação BACCEGA, M. A.) Escola de Comunicações e Artes da Universidade de São Paulo, São Paulo, SP, 2008 
partir de Wallerstein (1999) ${ }^{21}$ e Crenshaw et al. são as que seguem (2003) ${ }^{22}$, com os respectivos indicadores sugeridos:

- A Globalização econômica: requer um mercado global crescentemente integrado e competitivo de produtos, serviços, trabalho, mobilidade de capital e participação em organizações econômicas nacionais. Nas teorias existentes a globalização econômica é vista, por um lado, pela expectativa de especialização e perda na autonomia dos resultados (neoclássica) em prol de benefícios ao longo do tempo para os países e populações; por outro lado, é vista como um conjunto de dependências de naturezas antagônicas advindas do capitalismo internacional que a longo prazo beneficia elites e não necessariamente Estados-nações (teoria crítica). Os indicadores sugeridos para identificar a globalização econômica são: porcentagem do PIB em comércio internacional, fluxo de investimentos internacionais diretos e indiretos e fluxo de capital.

- A Globalização política: requer estruturas globais integradas nas leis, no governo, no exército, bem como na mobilidade crescente de idéias políticas e na participação em organizações políticas supranacionais. Para alguns teóricos, as uniões políticas estabelecem vínculos, e a participação nos organismos internacionais e alianças militares podem gerar trocas transacionais eficientes entre os parceiros ao mesmo tempo em que podem limitar a liberdade no comportamento destas nações por medo de retaliações. Do outro lado, o poder político/militar, ao longo do tempo, segue a ordem econômica capitalista, o que torna necessário separar a globalização econômica da política.

Os indicadores sugeridos da globalização política são: organizações intergovernamentais e não-governamentais, número de visitas diplomáticas recebidas e negociação de armamentos, entre outros.

- A Globalização sociocultural requer um mercado global crescentemente integrado tanto em comunicação como em produtos culturais, e uma mobilidade crescente de indivíduos - por migração ou viagem - e produtos culturais.

Indicadores da globalização sociocultural: turismo anual e fluxo de passageiros, postagem internacional enviada e recebida e importação de filmes e outras mídias.

\footnotetext{
${ }^{21}$ WALLERSTEIN, Immanuel, Análise dos Sistemas Mundiais, 1999 In: Giddens A. e Turner, Jonathan (organizadores) Teoria Social Hoje; tradução de Gilson César Sousa, Sao Paulo: Editora UNESP, 1999 p. 447-470

${ }^{22}$ CRENSHAW Edward, PAXTON Pamela, MORISHIMA Rumi, ROBISON Kristopher, Globalization, Westernization, and Social Change, January 2003 Globalization Session of the Annual Meetings of the American Sociological Association, Atlanta 2003.

SAKATA, Marici Cristine Gramacho, Globalização e Educação: A formação do comunicador social na América Latina, 2008312 p. (Doutorado - Orientação BACCEGA, M. A.) Escola de Comunicações e Artes da Universidade de São Paulo, São Paulo, SP, 2008
} 
Os enfoques principais para a interpretação da globalização, segundo Held e McGrew, $\left(2001^{23}\right)$, são:

- Enfoque Historicista/Determinista - a globalização segue uma lógica pré ordenada que presume uma trajetória histórica ou um estado final único (teleológico).

- Enfoque dos Céticos - toda economia é nacional ou local, baseada em modelos de economia mista européia e neoliberal norte-americana. Há desenvolvimentos de blocos regionais e defasagem crescente entre o norte e o sul. Do ponto de vista cultural a globalização fez ressurgir o nacionalismo e a identidade nacional. Há predomínio do Estado nacional.

- Enfoque Globalista - globalização como conjunto de processos interrelacionados que operam em todos os campos primários do poder social, militar, político e cultural. Aumento do multilateralismo e desgaste do Estado. Desigualdades nas sociedades e no cosmopolitismo, e entre eles, surgimento da cultura popular global, desgaste das identidades políticas e economia transnacional.

Além das análises e enfoques apresentados, há a visão da transnacionalização, que é a visão que utilizamos nesta pesquisa pois parte do enforque globalista mas é uma visão menos radical. No entanto, considera que a unidade do Estado é uma ficção incapaz de dar conta da diversidade de identidades dos indivíduos. (Roche, $2004^{24}$ )

O termo transnacional, segundo Starke-Meyerring $\left(2005^{25}\right)$, é usado mais freqüentemente em contextos econômicos onde há o surgimento de instituições econômicas globais, acordos e políticas. O termo Corporação Transnacional (sigla em inglês - TNC) foi definido pela Conferência das Nações Unidas para o Comércio e Desenvolvimento (UNCTAD), organização que estuda as TNCs e publica relatórios anuais sobre seus desenvolvimentos. TNCs são "grupos que englobam os empreendimentos principais (parent enterprises) e as suas afiliações estrangeiras". O empreendimento principal é definido como aquele que "controla ativos (um mínimo de $10 \%$ de participação ou o poder de voto) de outras entidades em países que não o seu. Os negócios transnacionalizados, ao longo da história, têm facilitado o surgimento de

\footnotetext{
${ }^{23}$ HELD e MCGREW, HELD, D. e McGREW, A. Prós e Contras da Globalização, Rio de Janeiro: Zahar, 2001 do original: Na introduction to the globalization debate, p.18

${ }^{24}$ ROCHE, Jean-Jacques Théories des relations internationales, Paris. Montchrestien, 5 aEd. 2004

${ }^{25}$ STARKE-MEYERRING, Doreen, Meeting the Challenges of Globalization: A Framework for Global Literacies in Professional Communication Programs. Journal of Business and Technical Communication, Vol. 19 No. 4 October, 2005, pg. 468-499
}

SAKATA, Marici Cristine Gramacho, Globalização e Educação: A formação do comunicador social na América Latina, 2008312 p. (Doutorado - Orientação BACCEGA, M. A.) Escola de Comunicações e Artes da Universidade de São Paulo, São Paulo, SP, 2008 
instituições econômicas globais tais como o FMI-Fundo Monetário Internacional, o Banco Mundial e a OMC-Organização Mundial do Comércio.

Entre os casos mais freqüentes de educação transnacional está a instalação de sedes de instituições estrangeiras, a aparição de programas conjuntos entre universidades locais e estrangeiras, programas e currículos homogêneos ou padrão, quando o estudante está em um país diferente daquele ao qual pertence a instituição fornecedora do serviço educativo, pois implica o cruzamento das fronteiras por parte dos professores e dos materiais educativos. (Marquis, 2002 ${ }^{26}$ )

A transnacionalização da educação é melhor compreendida ao se utilizar a estrutura de análise de Cortesão e Stoer $\left(2002^{27}\right)$, pois apresenta uma estrutura do campo educacional baseada no quadro de transnacionalização de Boaventura de Sousa Santos $\left(2002^{28}\right)$. A “grade-de-análise”, segundo os autores, possibilita evidenciar de forma resumida a grande complexidade de situações que têm lugar em diferentes contextos; a possibilidade de identificar uma multiplicidade de situações conjunturais; e o fato de haver um conjunto de processos de transnacionalização de forma mais ou menos evidente, poderá estar presente em contextos reguladores emancipatórios, entre outros. (Cortesão e Stoer, $2002^{29}$ ). A importância deste quadro reside na possibilidade de se compreender em que dimensões atuam os órgãos internacionais envolvidos na educação, os projetos de mobilidade, as associações internacionais, os programas transnacionais: enfim, o que é local e o que é global. Alguns dos pontos chave que servirão de base para as discussões são: os conhecimentos, as políticas e as atividades locais e globais.

Segundo Cortesão e Stoer $\left(2002^{30}\right)$, a estrutura de análise do campo educativo admite sete formas de transnacionalização:

1. Transnacionalização de políticas educativas - Situações de enquadramento das políticas educativas numa sociedade mundial decorrentes de Estados-nação que ainda mantêm características identitárias relacionadas à sua história, geografia, política e situação econômico-cultural

2. Processos de Mercadorização da educação - Mudanças na relação Estado-mercado no campo educativo, com o mercado assumindo papel significativo.

\footnotetext{
${ }^{26}$ MARQUIS, Carlos Nuevos proveedores de educación superior en Argentina y Brasil Investigador del CONICET, Buenos Aires, Agosto 2002 IES/2002/ED/PI/6, Date of Publication: August 2002

27 CORTESÃO, L. e Stoer, S., Cartografando a transnacionalização do campo educativo: o caso português, In: Santos, Boaventura de S. A Globalização e as Ciências Sociais, $2^{\mathrm{a}}$ Ed. São Paulo: Cortez Ed., 2002, p. 377-416

${ }^{28}$ SANTOS, Boaventura de S. A Globalização e as Ciências Sociais, 2a Ed. São Paulo: Cortez Ed., 2002

${ }^{29}$ CORTESÃO, L. e Stoer, S., Cartografando a transnacionalização ........, 2002, p. 377-416

${ }^{30}$ Ibidem
} 
3. Políticas educativas de integração regional - Características particulares, localismos globais, condições periféricas, entre outros.

4. Processos de "educação de migrantes e grupos minoritários" - Preservação da cultura nacional frente à progressiva heterogeneização (no caso de países homogêneos)

5. Processos educativos de que dispõem os "grupos transacionais" - Grupos capazes de se movimentarem em situações que transcendem os limites dos Estados-nação.

6. Desenvolvimento de um projeto de "educação cosmopolita” - Enquadramento democrático para políticas educativas, desenvolvido por meio de identidades transnacionais - cuja característica principal é o bilingüismo cultural - que lhes permitem "atravessar fronteiras"

7. Questões universais - Problemáticas atuais que podem respeitar toda a humanidade e estão relacionadas à possibilidade da existência da cidade educativa.

Estas sete formas são analisadas pelos autores em cinco dimensões:

1. Incidências principais da globalização - Situações predominantes de localismos globalizados, globalismos localizados, cosmopolitismos ou situações relativas à existência de um patrimônio comum da humanidade.

2. Principais áreas de controvérsia - Problemáticas importantes que podem identificar as incidências principais de globalização em cada um dos sete tipos de transnacionalização.

3. Agências transnacionais - Entidades que se movimentam e que atuam no âmbito de cada um dos sete tipos de transnacionalização.

4. Efeitos normativos e institucionais - O resultado do funcionamento das agências transnacionais que atuam em cada tipo de processo de transnacionalização e no âmbito de cada uma das incidências principais de globalização que foram identificadas.

5. Efeito dominante potencial

Não seguimos a grade da forma como foi apresentada pelos autores, mas diversos pontos nos guiaram ao longo da pesquisa.

Quais as influências da globalização e da transnacionalização no campo da Comunicação? Para Starke-Meyerring $\left(2005^{31}\right)$, os profissionais de comunicação já estão sendo e continuarão a ser afetados. A maioria dos empregos na área de comunicação está no setor de serviços, que já constitui a parte maior da economia em países desenvolvidos. Este setor é atravessado também pelo impacto do comércio global - seja na influência dos provedores de serviços, seja por meio de serviços de outros países membros das organizações internacionais.

Neste sentido, tanto o mercado de trabalho como as instituições que formam os comunicadores estão em processo de transição para se adaptarem ao ambiente globalizado. A formação do comunicador sustentada por valores, tradições e bases

\footnotetext{
${ }^{31}$ STARKE-MEYERRING, Doreen, Meeting the Challenges ...... 2005, pg. 468-499

SAKATA, Marici Cristine Gramacho, Globalização e Educação: A formação do comunicador social na América Latina, 2008312 p. (Doutorado - Orientação BACCEGA, M. A.) Escola de Comunicações e Artes da Universidade de São Paulo, São Paulo, SP, 2008
} 
teóricas também está se adaptando ao perfil do profissional solicitado pelo mercado (perfil e habilidades que um profissional deve ter para enfrentar desafios interpostos pela sua área de atuação).

Woodward, Drager, Beaglehole e Lipson, $\left(2001^{32}\right.$ ) sugerem que para ser consistente, um quadro teórico deve ser complementado por evidências empíricas. O primeiro passo é usar tal conceito como base para sintetizar as evidências existentes e seu relacionamento entre as variáveis econômicas, políticas e sociais da educação.

2) Políticas macroeconômicas e recursos disponíveis - os países hegemônicos, as instituições que emanam políticas, o volume de recursos de cada país e sua posição dentro do sistema (recursos).

A globalização vai além da internacionalização e da multinacionalização, uma vez que os sistemas nacionais deixam de ser o núcleo central das atividades e estratégias humanas organizadas. O padrão moderno ocidental de homogeneização e uniformização, concebido por Leibniz e Marx, é substituído pela eliminação de fronteiras, concomitante à criação de particularismo e identidade étnica. (Santos, $2002^{33}$ )

Santos $\left(2002^{34}\right.$; 34) levanta três questões importantes sobre os processos de globalização: a contradição entre a globalização e a localização, a contradição entre o Estado-nação e o não-Estado transnacional, ou seja, o papel do Estado diante das mudanças, e a contradição que ocorre entre o determinismo inevitável e reflexivo e a oportunidade. Santos esboça sua teoria de um sistema mundial em transição (SMET) assentado em práticas complexas e por vezes incoerentes entre si. São elas:

- Práticas Inter-estatais - papel do Estado

- Práticas capitalistas globais - agentes econômicos

- Práticas sociais e culturais - fluxos transnacionais

Todas as práticas ocorrem por meio de instituições e são constituídas de uma lógica de poder, uma forma de direito, conflitos estruturais e critérios de hierarquização.

Não existe um consenso na definição do que seja uma instituição, se considerarmos o longo debate estabelecido nas ciências sociais, tanto pelos teóricos institucionalistas como pelos ‘novos’ institucionalistas. As instituições são definidas por

\footnotetext{
${ }^{32}$ WOODWARD, David, DRAGER, Nick, BEAGLEHOLE, Robert, \& LIPSON, Debra Globalization and health: a framework for analysis and action Bulletin of the World Health Organization, 2001, 79 (9) World Health Organization 2001

${ }^{33}$ SANTOS, Boaventura de S, A Globalização e as Ciências Sociais, 2a Ed. São Paulo: Cortez Ed., 2002

${ }^{34}$ Ibidem. Pg. 25

SAKATA, Marici Cristine Gramacho, Globalização e Educação: A formação do comunicador social na América Latina, 2008312 p. (Doutorado - Orientação BACCEGA, M. A.) Escola de Comunicações e Artes da Universidade de São Paulo, São Paulo, SP, 2008
} 
Scott $\left(2003^{35}\right)$ como sistemas compostos de elementos regulatórios, normativos e cultural-cognitivos que agem para produzir significado, estabilidade e ordem. Fligstein $\left(1997^{36}\right)$ define as instituições como regras e significados compartilhados (implicam que as pessoas tenham conhecimento deles ou que possam ser conhecidos de forma consciente) que definem relações sociais e ajudam a definir quem ocupará quais posições nessas relações, além de guiar a interação propondo modelos cognitivos ou conjunto de significados aos atores para interpretarem o comportamento dos outros.

A instituição social busca sempre o reconhecimento interno e externo. Para Chauí $\left(2003^{37}\right)$, a universidade deveria ser considerada uma instituição social e não uma organização social como tem sido considerada atualmente. Uma instituição social é uma:

prática social fundada no reconhecimento público de sua legitimidade e de suas atribuições, num princípio de diferenciação, que lhe confere autonomia perante outras instituições sociais, e estruturada por ordenamentos, regras, normas e valores de reconhecimento e legitimidade internos a ela.

A organização, segundo Chaú $\left(2003^{38}\right)$, define-se por ser uma prática social determinada pela sua instrumentalidade, com meios administrativos particulares para atingir objetivos particulares. Com isso, as organizações não buscam reconhecimento e legitimidade externa e interna, suas ações cumprem as idéias de eficácia e de sucesso, ou seja, gestão, planejamento, previsão, controle e êxito. Diferente de uma instituição social, uma organização não questiona sua própria existência. As reformas de Estado ocorridas na maior parte do mundo colocaram a educação como um serviço, e as instituições passaram a atuarem como Organizações Sociais. Isso ocorreu não só no setor da educação, como também da saúde e da cultura.

Embora a instituição esteja se transformando em organização, mantemos o uso do termo instituição quando nos referirmos às IES.

\footnotetext{
${ }^{35}$ SCOTT, W. Richard Institutional carriers: reviewing modes of transporting ideas over time and space and considering their consequences Industrial and Corporate Change. Oxford University Press journal $\begin{array}{lllllll}\text { Volume } & \text { (Year): } 12 & \text { (2003) } 4 & \text { Pages: } & \text { 879-894 Disponível em }\end{array}$ http://ideas.repec.org/a/oup/indcch/v12y2003i4p879-894.html 09.02.2006

${ }^{36}$ FLIGSTEIN Neil, Fields, Power, and Social Skill: A Critical Analysis of The New Institutionalisms, German Sociological Association on "Power and Organization" October 1997.

${ }^{37}$ CHAUÍ, Marilena, Seminário: Universidade: Por que e como reformar? MEC/SESu: 6 e 7 de agosto 2003 Disponível em http://firgoa.usc.es/drupal/node/19336 acesso em 27/12/2207

${ }^{38}$ Ibidem

SAKATA, Marici Cristine Gramacho, Globalização e Educação: A formação do comunicador social na América Latina, 2008312 p. (Doutorado - Orientação BACCEGA, M. A.) Escola de Comunicações e Artes da Universidade de São Paulo, São Paulo, SP, 2008
} 
Os elementos institucionais, por sua vez, movem-se no tempo e de um lugar para outro com ajuda de portadores (carriers). Scott $\left(2003^{39}\right.$ ) define quatro tipos distintos de portadores: sistemas simbólicos, sistemas relacionais, rotinas e artefatos. Os portadores não são veículos neutros, e têm efeitos importantes nos elementos transmitidos. Definem, traduzem e disseminam idéias e conceitos racionalizados em um nível supranacional e legitimam as instituições de acordo com seus conceitos. Esta viagem de idéias e tradução de conceitos ocorre não pelas instituições propriamente ditas, mas pelos indivíduos que nelas atuam e definem os sentidos (Latour, $1987^{40}$ )

- Distinguimos aqui dois tipos de instituições: 1) as instituições organizacionais de ensino superior de cada país, e 2) as instituições portadoras, no caso as instituições organizacionais internacionais que atuam globalmente definindo padrões, regras e recomendações que afetam as políticas dos Estados e seus setores organizados. Por exemplo, os acordos políticos internacionais de harmonização do sistema educacional, como o Acordo de Sorbonne-Bologna-Prague (Vaira, 2004 ${ }^{41}$ ) e as políticas macroeconômicas originadas em determinados períodos da história que deram origem à criação de instituições como o Banco Mundial e o FMI - Fundo Monetário Internacional.

Em uma sociedade capitalista os recursos podem ser medidos pela força de trabalho e pelos recursos naturais de que um Estado dispõe. Por meio do trabalho o homem apropria-se das riquezas naturais ou as transforma, e as consome para satisfazer suas necessidades. O trabalho é o meio para a manutenção da vida e para o alcance de seus objetivos, e não um fim em si. Por não sermos capazes de produzir sozinhos todos os elementos necessários para nossa vida, criamos relações sociais na comunidade. Para Weber, o capitalismo moderno pode ser caracterizado como um vasto complexo de instituições interligadas e permanentes que trabalham em busca do lucro com base na prática econômica racional, ou seja, “uma organização capitalista racional do trabalho livre.” 42 Como conseqüência, no capitalismo, o homem é dominado pela geração de dinheiro, combinado com o afastamento estrito de todo prazer espontâneo de viver,

\footnotetext{
${ }^{39}$ SCOTT, W. Richard Institutional carriers: reviewing modes of transporting ideas over time and space and considering their consequences Industrial and Corporate Change. Oxford University Press journal $\begin{array}{llllllll}\text { Volume } & \text { (Year): } 12 & \text { (2003) } 4 & \text { Pg: 879-894 Disponível em }\end{array}$ http://ideas.repec.org/a/oup/indcch/v12y2003i4p879-894.html 09.02.2006

${ }^{40}$ LATOUR, B. (1987) Science in Action: How to Follow Scientists and Engineers through Society. Cambridge, MA: Harvard University Press.

${ }^{41}$ VAIRA, M. Globalization and Higher Education ... 2004, Op. Cit.

${ }^{42}$ WEBER, Max, A ética protestante e o espírito do capitalismo. São Paulo, Martin Claret, 2004

SAKATA, Marici Cristine Gramacho, Globalização e Educação: A formação do comunicador social na América Latina, 2008312 p. (Doutorado - Orientação BACCEGA, M. A.) Escola de Comunicações e Artes da Universidade de São Paulo, São Paulo, SP, 2008
} 
tornando a aquisição o propósito final da vida. Para Cobos $(1998)^{43}$, “Essa inversão daquilo que chamamos de relação natural é evidentemente um princípio-guia do capitalismo e soa estranho para todas as pessoas que não estão sob esta influência capitalista”. Por outro lado, segundo Cardoso e Faletto (2004) ${ }^{44}$, “a expansão do capitalismo comercial e depois do capitalismo industrial vinculou a um mesmo mercado economias que além de apresentar graus variados de diferenciação do sistema produtivo, passaram a ocupar posições distintas na estrutura global do sistema capitalista” desta forma, as relações de dependência e de nível de desenvolvimento são criadas historicamente.

3) Fluxo e acordos de negociações - como cada país recebe as pressões externas e quais acordos, no campo educacional, envolvem a América Latina.

Durante muito tempo as IES mantiveram um mesmo padrão de funcionamento e valores, fundamentado em um sistema político e regulador nacional reproduzido ao longo da história. Estes padrões e valores estão sendo pressionados pelas mudanças ocasionadas pela globalização, que força a redefinição do papel das IES, das suas políticas e prioridades. (Vaira, 2004) ${ }^{45}$

Embora a palavra “acordo” signifique harmonia, conformidade ou concordância de idéias, os acordos firmados entre atores em diferentes posições de poder não necessariamente refletem harmonia entre as partes. Os acordos econômicos e políticos refletem mais uma necessidade de manutenção do equilíbrio econômico do que um desejo social coletivo.

Os países hegemônicos possuem forte poder sobre os acordos comerciais mundiais, e por meio das instituições que os representam criam regras e determinam padrões para assegurarem o cumprimento dos acordos e contratos. Entendemos por hegemônico o Estado em posição privilegiada de poder e com capacidade de manter a estabilidade de seus sistemas. Os enfoques hegemônicos possuem um viés econômico para que se possa pensar em critérios do poder. Um dos enfoques é que a hegemonia serve para conceber outras formas de representação do sistema internacional onde os regimes internacionais veiculam sua liderança. Outro enfoque consiste na visão gramsciniana, em que as estruturas sociais dominantes definem a ordem internacional

\footnotetext{
${ }^{43}$ COBOS, N., Subordination au marché mondial L'individu chez Marx, Maîtrise de philosophie, 19971998 - Université Paris 8 - Disponível em <http://big.chez.tiscali.fr/philosurlenet/THESES/documents/marx.html> Acesso em 09/12/2004

${ }^{44}$ CARDOSO, F. H. e FALETTO, E. Dependência e desenvolvimento na América Latina..... 2004. pg.38

${ }^{45}$ VAIRA, M. Globalization and Higher Education ... 2004, Op. Cit.

SAKATA, Marici Cristine Gramacho, Globalização e Educação: A formação do comunicador social na América Latina, 2008312 p. (Doutorado - Orientação BACCEGA, M. A.) Escola de Comunicações e Artes da Universidade de São Paulo, São Paulo, SP, 2008
} 
de acordo com seus interesses. Um terceiro enfoque, (neogramsciniano), de Robert Cox ${ }^{46}$ define três categorias da hegemonia: as capacidades materiais de um Estado, as idéias (noção partilhada sobre a natureza das relações sociais) e as instituições (meios de estabelecer e perpetuar a ordem). A teoria da estabilidade hegemônica argumenta que somente um ator dominante e hegemônico tem interesse e capacidade para manter a estabilidade de um sistema econômico internacional aberto (Hausken e Plümper, 1997) ${ }^{47}$ e, para isso, usa seu poder para criar regimes econômicos internacionais e deles se beneficiar.

Assim, neste jogo, ou neste campo, como em Bourdieu, as regras a serem seguidas são definidas não por qualquer um dos jogadores mas por aquele que tem domínio e está em posição de destaque. Neste mesmo sentido, as regras e recomendações que as instituições internacionais impõem aos países dependentes de seus financiamentos e apoios são feitas pelos países que dominam o jogo. ${ }^{48}$

A hegemonia também implica soberania. A soberania é definida como a necessidade do Estado de ser governado por um soberano cuja autoridade esteja acima das leis. Carl Schmitt ${ }^{49}$ afirmou que o soberano tem o poder de decidir sobre o Estado de exceção - Estado no qual se faz necessário manter a unidade política não necessariamente atendendo às regras e leis estabelecidas. O conceito de soberania é traduzido de uma época para a outra como forma de organização política e, neste sentido, permeia a sociedade em todas as épocas.

Existem diversos estudos que se propõem compreender a estrutura da globalização e analisar as interações dinâmicas. Centeno et al. $\left(2005^{50}\right)$ afirmam que uma das formas de se analisar a globalização é a Teoria de Redes Sociais (Social

\footnotetext{
${ }^{46}$ ROCHE, Jean-Jacques Théories des relations ..... 2004 p. 140

${ }^{47}$ HAUSKEN, Kjell, and Thomas Plümper. (1997). "Hegemons, Leaders and Followers: A GameTheoretic Approach to the Postwar Dynamics of International Political Economy." Journal of WorldSystems Research 3: 35 - 93. Disponível em http://jwsr.ucr.edu/archive/vol3/v3n1a2.php, Acesso em 09.02.2006

${ }^{48}$ Pode-se fazer um paralelo entre as regras de um jogo politico e as regras dos jogos de linguagem. Em Wittgenstein, enquanto alguns jogos têm regras formais e explícitas, outros têm suas regras criadas à medida que ocorrem, e as apreendemos por meio de simples observação ou prática. A regra é um "indicador de direção" - feita por aquele que faz a regra. O costume de seguir regras faz com que pessoas não fiquem surpresas com elas e apenas as sigam, assim a palavra "conformidade" e a palavra "regra" são inter-relacionadas. Em alguns casos, existem regras que seguimos mesmo sem conhecê-las. Em outros casos, é necessário que estejam explícitas para nós. Nossos comportamentos frente às regras dependem de onde me localizo e qual o instrução/treinamento que recebi. Isto associado ao costume e às instituições. (Wittgenstein, Tractatus)

${ }^{49}$ Autoritas, non veritas facit legem - a autoridade de decidir se sobrepõe à autoridade legal, Notas de Aula: Marilena Chauí, FFLCH/USP, 2005 -

${ }^{50}$ CENTENO, Miguel, CURRAN Sara R., GALLOWAY John, LLOYD Paulette \& SOOD Suresh. Growing Knowledge about ..., 2005.
}

SAKATA, Marici Cristine Gramacho, Globalização e Educação: A formação do comunicador social na América Latina, 2008312 p. (Doutorado - Orientação BACCEGA, M. A.) Escola de Comunicações e Artes da Universidade de São Paulo, São Paulo, SP, 2008 
Network Theory). Na teoria de redes, na globalização, os atores podem ser pessoas, países ou organizações, medidos por viagens, negócios, fluxo de transação de capital e comunicação. Este tipo de análise permite uma clara visualização das redes, revela a estrutura das relações sociais, a intensidade das relações, os beneficiados ou não pelos processos de globalização e as mudanças das relações no tempo. Também inclui construtos potenciais e indicativos de poder. No caso da globalização, as redes podem ter o formato universal - onde as ligações entre os nós são homogêneas - ou o formato de clusters, onde os nós ligam grupos distintos ou hegemônicos e apenas um nó liga os demais. Pela análise de redes Centeno et al. (2005) ${ }^{51}$ visualizaram os grupos de países emergentes representados pela intensidade das negociações mútuas.

\section{4) Resultados}

Quanto à globalização, o ideal seria que os benefícios da globalização se estendessem a todos os países; que fossem removidos os obstáculos de desenvolvimento como déficits, instabilidade e protecionismos; que fossem dadas condições para uma integração bem-sucedida na economia global e que as políticas fossem pensadas e apropriadas para cada país e cada realidade, que os benefícios da globalização recaíssem sobre o sistema educacional de forma a melhorá-lo e ampliá-lo, e que fosse criada a consciência de que países em desenvolvimento ou subdesenvolvidos devessem ter seus sistemas educacionais garantidos e protegidos dos efeitos negativos da globalização.

Por fim, a literatura sobre a Globalização nos mostra que as instituições de Ensino Superior transformadas em Organizações respondem, com maior ou menor resistência, às pressões econômicas, políticas e sociais transportadas ao seu ambiente por meio das instituições portadoras e por meio de políticas, adaptando seu sistema nacional ao sistema mundial.

A figura 1 a seguir ilustra o sistema global e a dinâmica interna conforme a literatura analisada.

\footnotetext{
${ }^{51}$ CENTENO et al, Growing Knowledge about....,2005.
} 


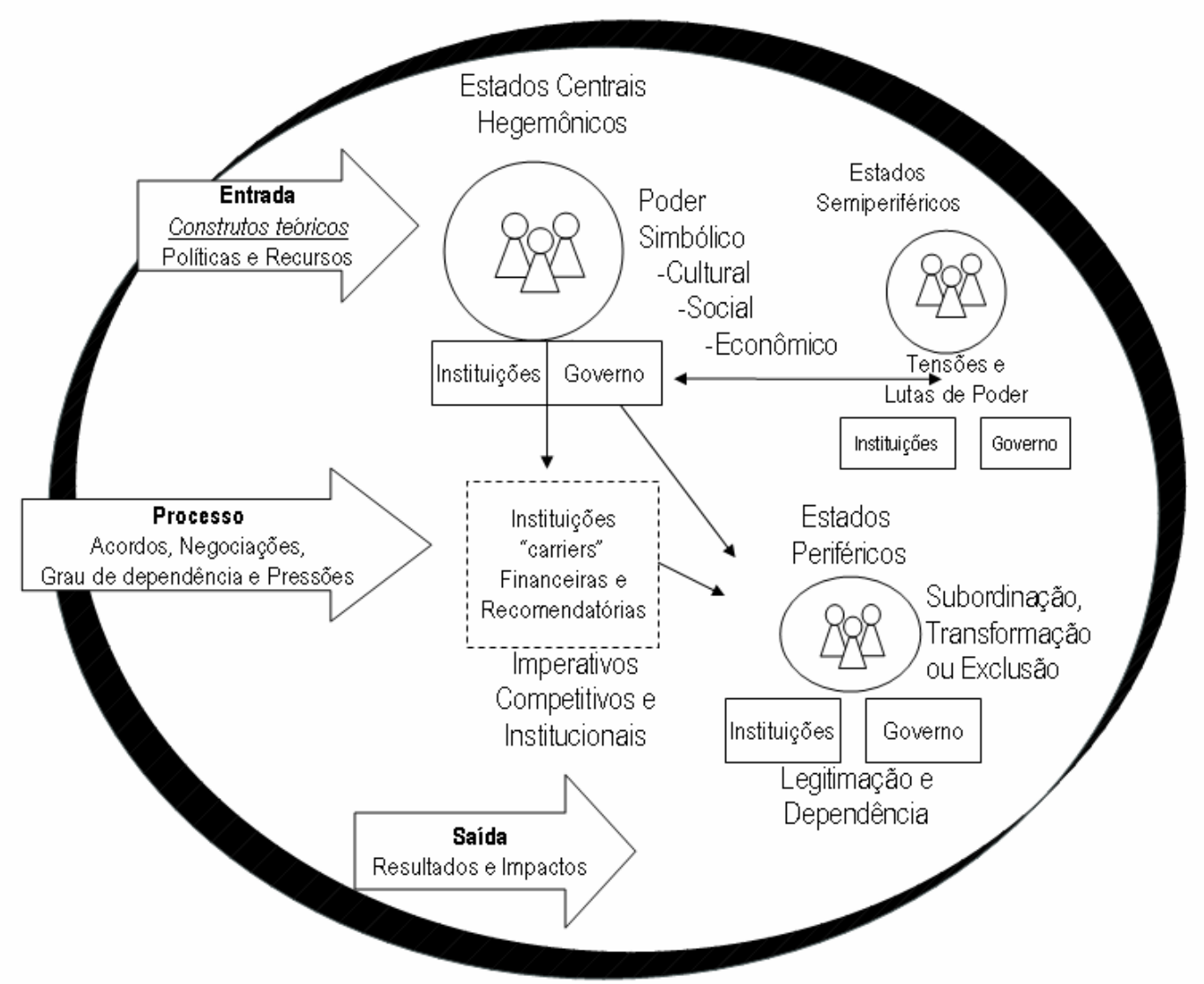

Figura 1 - Elementos da Globalização

\section{Universo e Amostra}

O universo desta pesquisa são as instituições de ensino superior com Cursos de Graduação em Comunicação Social na América Latina. Falar sobre América Latina é falar sobre um universo complexo e com características diversas. Portanto, foi necessário limitarmos a pesquisa pela escolha de uma amostra. Segundo Trindade e Blanquer (2002) ${ }^{52}$

“estabelecer comparações entre a Europa e América Latina pode oferecer múltiplos interesses. Em primeiro lugar, as raízes das concepções e dos sistemas educacionais são as mesmas. Em segundo lugar, os problemas encontrados são de igual natureza ... a internacionalização é uma necessidade para os dois lados, tendo como perspectiva manter relações equilibradas com os Estados Unidos dentro de um 'triângulo atlântico' onde a França tem desempenhado um papel histórico e contemporâneo”.

\footnotetext{
52 TRINDADE, H. e Blanquer, J.M. (orgs.) Os Desafios da Educação Na América Latina, Editora Vozes, Rio de Janeiro, 2002, p.8 
Portanto, comparamos as IES da América Latina com as da França, Espanha e Estados Unidos da América.

Até a década de 1960 seria uma tarefa simples selecionar as universidades mais representativas nos países da América Latina, pois existiam em número reduzido e estas poucas eram, em sua maioria, instituições públicas que atendiam praticamente toda a população matriculada em Ensino Superior no país. Atualmente a quantidade de instituições públicas e privadas existentes dificulta a seleção da amostra; portanto, foi necessário estabelecer alguns critérios, conforme segue:

- Forma de Financiamento: públicas e privadas

- Dimensão e representatividade no país

- Acessibilidade às informações referentes à estrutura e missão do curso

A amostra compreende universidades ${ }^{53}$ que oferecem curso superior em Comunicação. Foram selecionados dois tipos de universidades em cada país da amostra: instituições nacionais ou instituições globalizadas.

Selecionamos duas universidades públicas nacionais e de tradição de cada país e duas universidades cujo objetivo primeiro é ser uma universidade “globalizada”, sendo ela pública ou privada. Como "universidade globalizada” nos utilizamos do conceito de Santos $(2005)^{54}$, ou seja, instituições cuja constituição, características e objetivos atendem à lógica do mercado. Nesta categoria podem funcionar de diferentes formas: pelo sistema de franquia, desenvolvidas em países hegemônicos e distribuídas globalmente, como parte de projetos nacionais para produção de conhecimento e distribuição mundial, ou não.

Os resultados dos países selecionados - Argentina, Brasil, Chile, Colômbia e México - foram comparados com dados de instituições de ensino da Espanha, França e Estados Unidos da América.

O Quadro 1 a seguir apresenta a amostra das instituições analisadas:

\footnotetext{
${ }^{53}$ Em dois casos foram pesquisadas Faculdades (Faculdade Pitágoras e Endicott College México).

${ }^{54}$ SANTOS, Boaventura S. A justiça social vai obrigar a que se comprometa com a justiça cognitiva, Diversa, Revista da Universidade Federal de Minas Gerais - Ano 3 - nº 8 Outubro de 2005 Disponível em www.ufmg.br/diversa/8/entrevista.htm acesso em 02/12/2006
}

SAKATA, Marici Cristine Gramacho, Globalização e Educação: A formação do comunicador social na América Latina, 2008312 p. (Doutorado - Orientação BACCEGA, M. A.) Escola de Comunicações e Artes da Universidade de São Paulo, São Paulo, SP, 2008 
Quadro 1 - Amostra

\begin{tabular}{|c|c|c|}
\hline \multirow{4}{*}{ Argentina } & \multirow{2}{*}{ Nacional } & Universidad de Buenos Aires \\
\hline & & Universidad Nacional de La Plata \\
\hline & \multirow{2}{*}{ Globalizada } & Universidad de Belgrano \\
\hline & & Universidad del Salvador \\
\hline \multirow{4}{*}{ Brasil } & \multirow{2}{*}{ Nacional } & Universidade de São Paulo \\
\hline & & Universidade Federal de Minas Gerais \\
\hline & \multirow{2}{*}{ Globalizada } & Anhembi Morumbi (Laureate) \\
\hline & & Faculdade Pitágoras (Grupo Apollo) \\
\hline \multirow{4}{*}{ Chile } & \multirow{2}{*}{ Nacional } & Universidad de Chile \\
\hline & & Universidad de Santiago de Chile \\
\hline & \multirow{2}{*}{ Globalizada } & Universidad Nacional de Andres Bello (Laureate) \\
\hline & & Universiadad de las Americas (Laureate) \\
\hline \multirow{4}{*}{ Colômbia } & \multirow{2}{*}{ Nacional } & Pontificia Universidad Javeriana \\
\hline & & Universidad De Antioquia \\
\hline & \multirow{2}{*}{ Globalizada } & Universidad Externado de Colombia \\
\hline & & Universidad Central \\
\hline \multirow{4}{*}{ México } & \multirow{2}{*}{ Nacional } & Universidad Nacional Autonoma de Mexico \\
\hline & & Universidad de Guadalajara (UdeG) \\
\hline & \multirow{2}{*}{ Globalizada } & Universidad Del Valle (Laureate) \\
\hline & & Endicott College Mexico \\
\hline \multirow{4}{*}{ Espanha } & \multirow{2}{*}{ Nacional } & Universidad de Deusto \\
\hline & & Universidad Complutense de Madrid \\
\hline & \multirow{2}{*}{ Globalizada } & Mondragon Unibertsitatea \\
\hline & & Universidad Antonio de Nebrija \\
\hline \multirow{4}{*}{ França } & \multirow{2}{*}{ Nacional } & Université de Marseille \\
\hline & & Université de Bourdeaux \\
\hline & \multirow{2}{*}{ Globalizada } & Université Paris X \\
\hline & & Science Po \\
\hline \multirow{4}{*}{$\begin{array}{l}\text { Estados Unidos da } \\
\text { América }\end{array}$} & \multirow{2}{*}{ Nacional } & University Of California \\
\hline & & Pennsylvania State University \\
\hline & \multirow{2}{*}{ Globalizada } & Massachusetts Institute of Technology \\
\hline & & Stanford University \\
\hline
\end{tabular}

Foram coletados os seguintes dados de cada instituição: Missão e Objetivos da instituição, Objetivo do curso de Graduação em Comunicação e Grade Curricular. $O$ texto completo de cada instituição consta do ANEXO II

- Missão - verificar a existência ou ausência da preocupação com a manutenção da identidade cultural e outros elementos identitários.

- Objetivos do Curso - verificar as características do curso (comparabilidade) e o objetivo do curso quanto a questões identitárias.

- Grade Curricular - verificar a existência de disciplinas que se caracterizam mais fortemente (embora a análise seja superficial nesta pesquisa) como reforço aos elementos identitários. Nesta análise tentamos identificar as disciplinas que necessariamente envolvem 
questões culturais e identitárias de forma mais intensa que as disciplinas comuns à área de Comunicação.

No Brasil, Chile e México pelo menos uma das universidades globalizadas selecionadas faz parte do grupo Laureate International Universities (Sylvan Learning Systems). Estas universidades fazem parte de uma rede privada de instituições acadêmicas credenciadas e que mantêm campus em diversos países.

Os resultados da pesquisa empírica servirão de base para testar as hipóteses e fundamentar a discussão da problemática de acordo com o quadro teórico de referência.

Para a seleção das demais universidades - tanto latino-americanas como européias e norte-americanas - outros instrumentos foram utilizados como Rankings Nacionais, Número de Publicações Científicas, Indicação de acadêmicos, etc. Considerando os Rankings Internacionais, como “The Ranking Group” do Institute of Higher Education of Shanghai Jiao Tong University publicado em 2005, entre outros, temos as seguintes universidades de maior representatividade nas Américas (excluindo Estados Unidos e Canadá): Universidade de São Paulo, Universidad Nacional Autonoma México, Universidad Buenos Aires, Universidade Estadual de Campinas, Universidade Federal de Rio de Janeiro e Universidad de Chile.

Diversos indicadores, estatísticas e dados disponíveis para consulta fundamentam as discussões sobre a educação superior e a globalização. No entanto, alguns cuidados devem ser tomados. Para a consulta, é necessário notar que os indicadores disponíveis - como os da OECD, do Banco Mundial, do FMI e dos próprios países - incluem diferentes fontes de recursos para o cálculo da porcentagem. Quanto aos Indicadores Educacionais, estes podem agregar recursos advindos do setor público, do setor privado ou mesmo recursos diretos pagos pelos alunos e destinados tanto para a educação como para a pesquisa científica, salários, moradia, material didático e alimentação, entre outros. Um exemplo das possíveis distorções é o fato de alguns indicadores incluírem os gastos com Hospitais Universitários nos índices de gastos com educação. Isto pode causar grandes distorções em análises comparativas. Outros itens que causam distorções em comparações históricas referem-se ao crescimento demográfico e faixa etária média da população. Portanto, o ideal é verificar todos os itens inclusos no cálculo do indicador. Como neste trabalho não foi possível obter este nível de detalhamento, a comparação está baseada em índices gerais que, embora não conclusivos, nos auxiliam nas discussões sobre esta questão. 
Analisar a porcentagem do PIB de um país destinada a cada setor de atividade indica quais são as prioridades deste país, e demonstra não apenas o grau de importância conferido à educação, mas também permite comparações entre eles. Segundo a OECD - Organização para a Cooperação e o Desenvolvimento Econômico -, os gastos com educação são um investimento que ajuda a impulsionar o crescimento econômico e a produtividade, além de contribuir para o desenvolvimento pessoal e social e reduzir a desigualdade social $^{55}$.

A Figura 2, de forma agregada, mostra a porcentagem do PIB gasta em educação superior em 2003. A parte clara refere-se aos gastos públicos e a parte escura aos gastos privados.

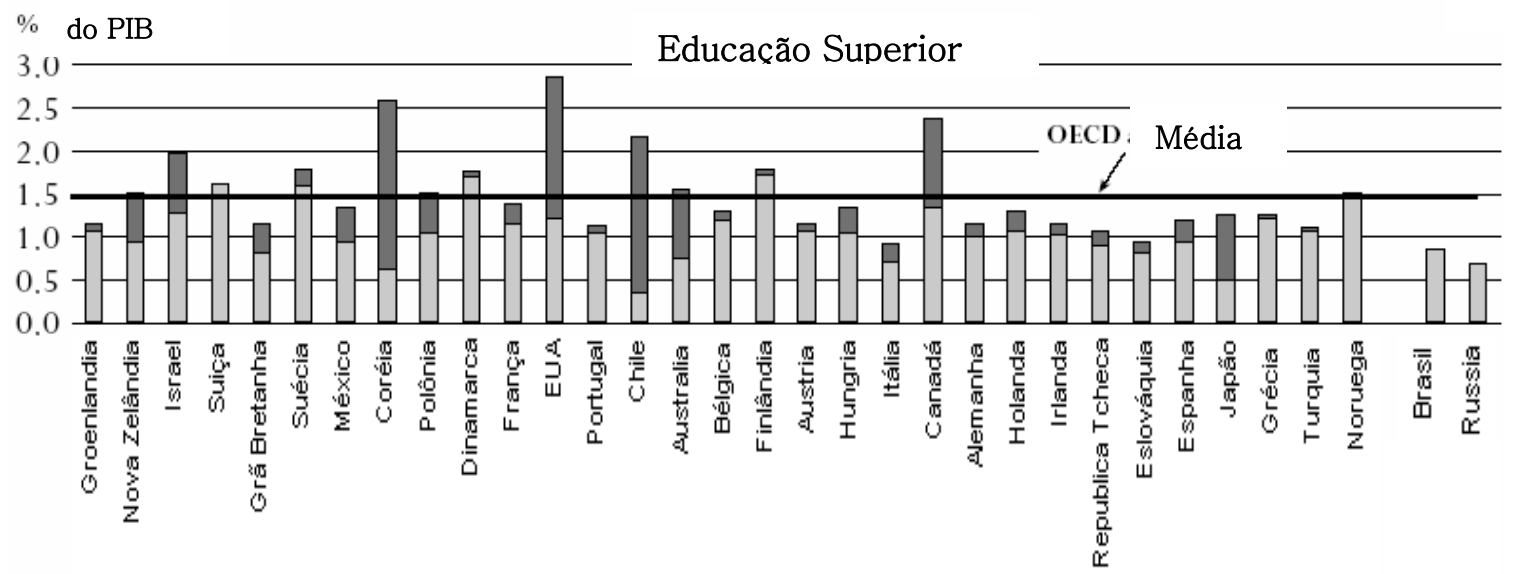

1. Gastos públicos apenas

Figura 2 - Porcentagem do PIB gasto em Educação Superior: Países membros da OECD - Fonte: OECD, Disponível em www.oecd.org/edu/eag2006 acesso em 01/07/2007

O que podemos perceber a partir da figura 2 a respeito dos países analisados neste trabalho é que:

1- Os Estados Unidos apresentam a maior porcentagem de investimentos se considerarmos o público e o privado de forma agregada. No entanto, o gasto público com educação é inferior ao dos países escandinavos como Dinamarca, Noruega e Suécia.

2 - A proporção de investimento público e privado em educação na França (embora se refiram aos recursos fornecidos pelas câmaras de comércio e taxas anuais) são próximas aos demais países da União Européia.

\footnotetext{
${ }^{55}$ Education at a Glance 2006, Expenditure on Educational Institutions Relative to Gross Domestic Product, OECD 2006, p. 196

SAKATA, Marici Cristine Gramacho, Globalização e Educação: A formação do comunicador social na América Latina, 2008312 p. (Doutorado - Orientação BACCEGA, M. A.) Escola de Comunicações e Artes da Universidade de São Paulo, São Paulo, SP, 2008
} 
3 - Na Espanha, embora a porcentagem seja menor que a da França, a proporção de investimentos público e privado é similar.

4 - O México apresenta porcentagens de investimentos abaixo da média da OECD, assim como a França e a Espanha.

5 - O Chile apresenta a menor porcentagem de investimento público de todos os países presentes no quadro, mas que somado ao investimento privado ultrapassa a média da OECD e está abaixo apenas dos Estados Unidos, Coréia do Sul e Canadá.

6 - Os dados referentes ao Brasil mostram apenas os investimentos públicos em educação, e comparativamente não diferem de maneira significativa das porcentagens dos gastos da Espanha ou do México, embora sejam menores.

O quadro não apresenta dados relativos a outros dois países analisados neste trabalho: a Argentina e a Colômbia.

Assim, percebemos a importância dos indicadores, mas também percebemos a importância de uma análise das políticas públicas de cada um dos países, das justificativas para a distribuição dos recursos e as mudanças ocorridas nos últimos anos. E, somente por meio da pesquisa empírica podemos compreender os impactos destas mudanças na educação superior e na formação do comunicador. 


\section{P PAPEL DA EDUCAÇÃO NA TRANSMISSÃO DE ELEMENTOS IDENTITÁRIOS E CULTURAIS EM TEMPOS DE GLOBALIZAÇÃO}

\subsection{A Transmissão de Elementos Identitários e Culturais}

Os conhecimentos e técnicas desenvolvidas e acumuladas ao longo da história são necessários para nossa manutenção, por isso, somos capazes de acumular conhecimentos adquiridos de forma direta através de nossas experiências vividas, mas também através da cultura e da educação. Assim, criamos o mundo artificial $^{56}$ à nossa volta através do trabalho incorporado em outras atividades, na cultura e nos valores, também criamos novas necessidades e novos valores e liberdades de opções. Nesse processo, não somente transformamos a natureza, mas também transformamos a nossa própria natureza. Desta forma, nos apropriamos dessa evolução e a transmitimos, e isso passa a constituir nossa história, caracterizando-nos, assim, como um ser histórico, atuante no mundo. A escola não é uma instituição isolada. Ela se insere em um quadro político, econômico e social e por isso, sofre influências do ambiente externo e, portanto a escola também sofre influências da globalização.

Por razões econômicas e políticas, a globalização tem sido um dos principais fenômenos responsáveis pela crescente pressão para a definição de identidades - sejam elas identidades nacionais, culturais ou de outra natureza. A tecnologia disponível tem servido para unir as pessoas em grupos e tem dado vozes a movimentos emancipatórios. Por outro lado, também tem provocado uma perda de autonomia e fragmentação do sujeito. Para Hall ${ }^{57}$ “novas” identidades estão surgindo e o homem moderno está cada vez mais fragmentado, descentrado social e culturalmente e em “crise de identidade”, ou seja, sua identidade tornou-se móvel e corre o risco de ser, inclusive, contraditória. A globalização tem contribuído ainda mais para esta fragmentação do sujeito, pois produz uma variedade de possibilidades de identificações, tornando as identidades mais políticas e posicionais. Ao mesmo tempo em que são criados grupos que tentam recuperar tradições puras do passado, estes mesmos grupos acabam excluindo e afastando o outro.

\footnotetext{
${ }^{56}$ Marx e Weber apresentam o conceito de mundo artificial

${ }^{57}$ HALL, Stuart, A identidade cultural na pós-modernidade, DP\&A, Rio de Janeiro, 2003

SAKATA, Marici Cristine Gramacho, Globalização e Educação: A formação do comunicador social na América Latina, 2008312 p. (Doutorado - Orientação BACCEGA, M. A.) Escola de Comunicações e Artes da Universidade de São Paulo, São Paulo, SP, 2008
} 
Quanto à sua definição, Hegel define identidade como algo construído dialogicamente por meio de processos de reconhecimento mútuo. Para Hegel, reconhecimento designa uma relação ideal de reciprocidade entre sujeitos: cada um vendo o outro como um igual, embora separado. Assim, cada um se torna um sujeito individual somente a partir do ato de reconhecer o outro e de ser reconhecido por ele. Para Fraser ${ }^{58}$ esta definição de identidade é a utilizada nas políticas de reconhecimento. Porém este modelo de identidade ${ }^{59}$ é problemático, pois o não-reconhecimento fere a identidade e, portanto a autora enfatiza o psíquico em detrimento das instituições sociais e da interação social. O modelo de Hegel também enfatiza a identidade do grupo exercendo pressão moral sobre os membros individuais para se adequarem a uma cultura de grupo, negando as complexidades individuais e definindo limites claros entre uma cultura e outra. Nega a heterogeneidade interna, as interações e as transculturalidades, além de criar disputas internas de poder para representação do grupo.

São muitos os teóricos e as teorias que tratam da questão da identidade. A literatura é abrangente e pode ser vista sob a ótica da psicologia, da sociologia e da comunicação. No contexto deste trabalho, entendemos Identidade como construções sociais e culturais formadas pela alteridade. Tal identidade não é escolhida, mas inscrita em relações de poder e, portanto, está em constante processo de movimentação (e transformação) dependendo como o sujeito é representado pelos sistemas culturais e sociais que o rodeiam. (Magalhães, Coracini, Grigoletto, 2006) ${ }^{60}$

Quanto à identidade cultural, vemos que a Cultura não busca o particular, mas sim o indivíduo e sua relação com o universal. Eagleton $(2000)^{61}$ define Cultura como:

Cultura é em si mesma o espírito da humanidade individualizando-se em obras específicas; e o seu discurso liga o individual e o universal. O âmago do eu e a verdade da humanidade, sem a mediação do historicamente particular. Ao universalizar seu individual, o espírito realiza sua verdadeira identidade. (p.84)

A literatura também nos mostra que a educação é responsável pela transmissão de nossos valores, nossa cultura e nossos elementos identitários, ou tradição, como em Arendt, tanto por meio da relação professor-aluno, instituição-aluno, como também de

\footnotetext{
58 FRASER, Nancy: Recognition, New Left Review, 3 may/jun 2000 p. 109

${ }^{59}$ FRASER, Nancy, Reconhecimento sem ética? Lua Nova, São Paulo, 70: 101-138, 2007

60 MAGAlHÃES, I, GRIGOLETTO, M, e CORACINI, M. (org.) Práticas Identitárias, Língua e Discurso, São Carlos, Claraluz, 2006. pg.5

${ }^{61}$ EAGLETON, T. A idéia de Cultura, Editora Unesp, 2000

SAKATA, Marici Cristine Gramacho, Globalização e Educação: A formação do comunicador social na América Latina, 2008312 p. (Doutorado - Orientação BACCEGA, M. A.) Escola de Comunicações e Artes da Universidade de São Paulo, São Paulo, SP, 2008
} 
seu plano pedagógico, sua missão e estrutura curricular. Concordamos com Oliveira $(2006)^{62}$ que as instituições e seus projetos educacionais são matéria-prima privilegiada na construção de identidades.

No entanto, verificamos que a educação é uma das formas - que está perdendo força - de reforçarmos valores e cultura. Se o movimento de globalização leva a uma homogeneização dos $\operatorname{cursos}^{63}$, padronização e diminuição dos currículos, seja para concorrer com o mercado internacional seja para diminuir custos, isso nos leva a crer que cada vez mais os valores culturais e elementos identitários não estarão expressos na grade curricular, ficando a cargo da relação professor-aluno, sem garantias formais para que isso ocorrera.

Por outro lado, a pressão pela busca de identidades continua a ocorrer na sociedade devido à globalização e à fragmentação do sujeito. Desta maneira, formamse grupos com elementos e objetivos comuns. Alguns grupos têm se destacado pelos movimentos que realizaram nas últimas décadas, como os nacionalistas, os de direitos civis, feministas e ecológicos, entre outros.

Os elementos identitários estão representados na sociedade pelas instituições, pelas práticas, pelos rituais e pelas estruturas de poder e por isso, a instituição de ensino tem grande importância em pensar as múltiplas identidades. No contexto da educação, Bernstein $^{64}$ cunhou o termo “discurso pedagógico oficial” que Oliveira (2006) ${ }^{65}$ utiliza para explicar que as “identidades pedagógicas” têm como objetivo o controle sobre os discursos que regulam os conteúdos e o processo de “entrada” na instituição escolar. Desta forma mantêm e preservam (se assim o quiserem) as tradições, seja no campo religioso, cultural ou nacionalista. As práticas discursivas desempenham papel fundamental nesse processo de construção de representações coletivas. Atualmente, o sistema educacional tem se adaptado às leis mercadológicas e simbólicas e,

62 OLIVEIRA, M. B. F., Alteridade e Construção de Identidades pedagógicas: (re) visitando teorias dialógicas, In: Magalhães, I, Grigoletto, M, e Coracini, M. (org.) Práticas Identitárias, Língua e Discurso, São Carlos, Claraluz, 2006.

63 Há propostas de homogeneização internacional dos currículos, como no caso do curso de Ciências Contábeis onde há a sugestão do currículo mundial definido pelo ISAR UNCTAD

${ }^{64} \mathrm{O}$ termo "discurso pedagógico official” (official pedagogic discourse) foi firmado pelo sociologo ingles Basil Bernstein (1924-2000), que o utilizou para categorizar os discursos do Estado na educação revelados nos documentos de políticas públicas, currículos e critérios de avaliação. Para ele, o discurso pedagógico oficial estabelece relações entre o governo e todos os demais envolvidos na educação, e isso auxilia na construção de diferentes identidades e diferentes categorias de alunos. In: Bourne, Jill (2008) Official pedagogic discourses and the construction of learners' identities. In, Hornberger, Nancy H. (ed.) Encyclopedia of Language and Education., Springer. (In Press) Disponível em http://eprints.soton.ac.uk/41452/, acesso em 04/12/2006

${ }^{65}$ OLIVEIRA, M. B. F., Alteridade e Construção de Identidades ....., 2006. pg. 29-30

SAKATA, Marici Cristine Gramacho, Globalização e Educação: A formação do comunicador social na América Latina, 2008312 p. (Doutorado - Orientação BACCEGA, M. A.) Escola de Comunicações e Artes da Universidade de São Paulo, São Paulo, SP, 2008 
conseqüentemente tem reconstruído sua identidade a partir de elementos retrospectivos e prospectivos.

A questão da identidade não é um problema somente nos países e povos menos desenvolvidos, mas tem sido um ponto de grande discussão dentro da Comunidade Européia. Para Mauleón (2003) ${ }^{66}$ a Europa deve ser entendida dentro de uma estrutura complexa e não-linear. Os europeus devem criar uma identidade européia por razões políticas e devem manter sua identidade nacional. No entanto, no campo educacional, segundo Figueiral $(2003)^{67}$ as mudanças impostas pela comunidade européia nem sempre têm sido feitas levando em consideração esta estrutura, e muitos professores adaptaram suas aulas e seu programa para integrar-se aos diferentes modelos sem realmente saber os fundamentos destes novos modelos. Com isso, elementos identitários nacionais podem ser perdidos.

Entre as universidades selecionadas na Espanha, uma delas está situada no país Basco, que é o caso da Universidade de Deusto. Os cursos são oferecidos em duas línguas oficiais, o castelhano e o basco.

Os estudantes da Universidade de Deusto e das universidades francesas da amostra, conforme pesquisado pessoalmente, têm acesso a praticamente os mesmos livros que se encontram disponíveis no Brasil, principalmente as obras de Bourdieu, Mattelart, Giddens etc. De certa forma, o conhecimento está globalizado. Isso significa que a diferença no processo de leitura e introspecção das informações se deve à interação com o professor e colegas e a partir da cultura de cada povo. Se não houvesse o fator de interação e de cultura, como conseqüência da internacionalização e da globalização, o profissional estaria sendo formado de maneira homogênea em qualquer que fosse a instituição. No entanto, não é possível falar em um povo que não tenha sua própria cultura e identidade; portanto, as diferenças existem.

Para compreender melhor a questão identitária no caso específico da Universidade de Deusto, acrescenta-se aqui um aparte sobre a identidade Basca. Para Cuadra e Cuadra (2005) ${ }^{68}$ a identidade cultural Basca não está clara e a definição de “vasquidad” não é única. No entanto, os autores buscam, a partir de conceitos teóricos e

\footnotetext{
${ }^{66}$ MAULEÓN, Xavier Etxeberría, Borderline Europeans: Nationalism and Fundamentalism, In: Gomes, Ines European Identity: Individual, Group and Society, Chacon, Universidad de Deusto, Bilbao, Espanha. 2003, p. 128

${ }^{67}$ FIGUEIRAL, Lurdes, Is the European Model being rejected? Repercussions in the field of Education In: Gomes, Ines European Identity: Individual, Group and Society, Chacon, Universidad de Deusto, Bilbao, Espanha, 2003, p. 121

${ }^{68}$ CUADRA, A. e CUADRA, P, La identidad Vasca en el Mundo, European Union, 2005

SAKATA, Marici Cristine Gramacho, Globalização e Educação: A formação do comunicador social na América Latina, 2008312 p. (Doutorado - Orientação BACCEGA, M. A.) Escola de Comunicações e Artes da Universidade de São Paulo, São Paulo, SP, 2008
} 
de pesquisa, definirem a identidade basca. Segundo pesquisa feita pelo Governo Basco em $2003^{69}$ para se considerar Basco, a amostra da pesquisa considerou que:

64\% - devem se sentir Bascos

$50 \%$ - devem viver e trabalhar em um país Basco

$28 \%$ - devem ter nascido no país Basco

$11 \%$ - devem falar Euskera

10\% - devem descender de uma família Basca

O quadro denominado “a estrutura simbólica da identidade Basca” também pode ser utilizado para compreender a questão da construção da identidade uma vez que está fundamentada em diversas teorias psicológicas e sociológicas. O quadro é reproduzido a seguir (Figura 3)

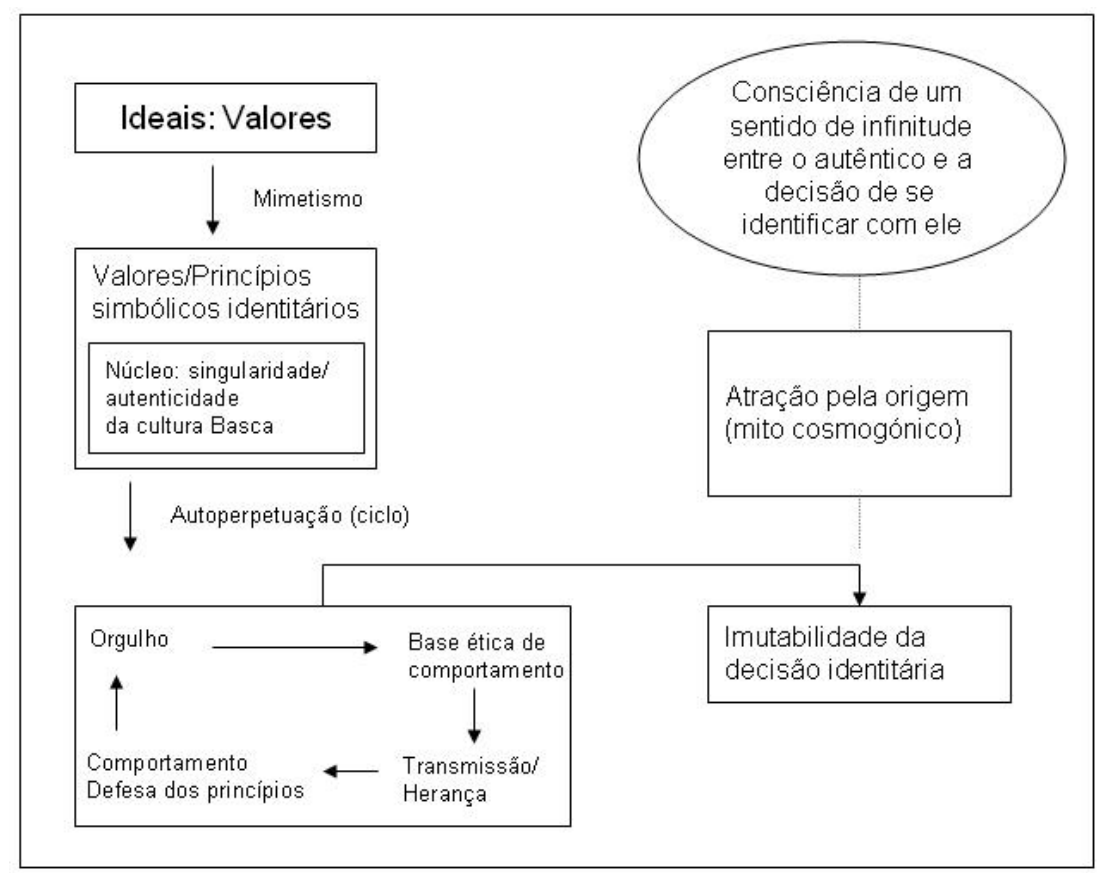

Fonte: Cuadro e Cuadro (2005) ${ }^{70}$

Figura 3 - A Estrutura Simbólica da Identidade Basca

Esta discussão é retomada quando comparamos os objetivos e currículos das universidades.

A partir dos conceitos apresentados, entendemos que o conteúdo transmitido pelos currículos reflete a identidade da instituição educacional envolvida no processo, seja ela uma identidade tradicional ou contemporânea; portanto, esta instituição influencia nas identidades que serão construídas ou reforçadas por meio das relações educacionais diárias que ocorrem em diferentes níveis (professor, aluno, instituição, currículo, conteúdo, avaliações, mercado, poder, financiamento, etc.).

\footnotetext{
${ }^{69}$ Cuadra, A. e Cuadra, La identidad Vasca en ....., 2005, p.5

${ }^{70}$ Ibidem
}

SAKATA, Marici Cristine Gramacho, Globalização e Educação: A formação do comunicador social na América Latina, 2008312 p. (Doutorado - Orientação BACCEGA, M. A.) Escola de Comunicações e Artes da Universidade de São Paulo, São Paulo, SP, 2008 
Multiculturalismo, Reconhecimento e Redistribuição no ambiente globalizado

Embora a discussão deste trabalho não se concentre, especificamente, nas questões referentes ao multiculturalismo, ao reconhecimento e à redistribuição, concordamos que estes têm sido pontos centrais no debate de cientistas políticos e filósofos contemporâneos, e estão na base dos conflitos e reivindicações sociais no mundo globalizado. A discussão travada no campo educacional quanto a cotas para grupos étnicos, redistribuição de vagas e programas de bolsas são elaborados a partir destas questões. Neste sentido, faz-se necessário, neste ponto, uma breve análise dessas questões que serão também retomadas ao final deste trabalho.

$\mathrm{Na}$ atualidade, a complexidade das relações sociais, a globalização, as mudanças políticas mundiais, o multiculturalismo e as diferenças religiosas, entre tantos outros "títulos" dados às diferentes formas de interação entre os homens, influenciam profundamente o rumo que tais discussões tomam. No entanto, podemos afirmar que dificilmente tais questões serão resolvidas em um breve espaço de tempo, nem que desaparecerão. Com isso, o debate permanece em aberto e muitos autores extraem suas fontes empíricas a partir de sua própria vivência. Quatro autores aqui analisados buscam ampliar seu quadro normativo a fim de construírem teorias críticas sociais sobre o reconhecimento e redistribuição: Honneth ${ }^{71}$, Habermas, Taylor ${ }^{72}$ e Fraser $^{73}$.

Honneth $^{74}$ tentou relacionar o avanço da Teoria Social no quadro da teoria da comunicação partindo da luta social introduzida por Maquiavel e retomada por Hobbes e Hegel. Para Hegel a luta é um "medium central de um processo de formação ética do espírito” e isso fornece bases para se pensar a necessidade de instituições que garantam a liberdade de cada um e que ao mesmo tempo as regule. A teoria do reconhecimento sistematiza as lutas sociais, e a realização pessoal do indivíduo autônomo depende do desenvolvimento da autoconfiança, do auto-respeito e da auto-estima, que podem ser obtidos por meio das relações de reconhecimento mútuo. Tais relacionamentos devem ser estabelecidos e ampliados por meio da luta por reconhecimento na sociedade, luta

\footnotetext{
${ }^{71}$ HONNETH, A. Luta por reconhecimento. A gramática moral dos conflitos sociais. Tradução de Kampf um Anerkennung, Frankfurt, Suhrkamp, 1992

72 TAYLOR, C. A política do reconhecimento (In: Argumentos filosóficos. São Paulo Edições Loyola, 2000

${ }^{73}$ FRASER, N. Da redistribuição ao reconhecimento? Dilemas da justiça na era pós-socialista. In: Souza, Jessé (org) Democracia hoje. Brasília, UnB, 2001; pg. 248

${ }^{74}$ HONNETH, A. Luta por reconhecimento. A gramática moral ....., 1992; pg. 5

SAKATA, Marici Cristine Gramacho, Globalização e Educação: A formação do comunicador social na América Latina, 2008312 p. (Doutorado - Orientação BACCEGA, M. A.) Escola de Comunicações e Artes da Universidade de São Paulo, São Paulo, SP, 2008
} 
essa que também se trava no trabalho e na luta de classes, como descrito por Marx, e no poder, como descrito por Foucault. Os elementos de análise utilizados por Honneth ao criticar o poder aproximam-se de Habermas, pois este também encontrou em Foucault argumento sobre o agir comunicativo. Honneth articula sua própria teoria social no domínio da experiência humana: teorias abstratas ou questões particulares são substituídas por uma visão mais ampla que envolve perda, ausência de auto-estima, jurisprudência e, sobretudo, a luta pelo restabelecimento de relações de mútuo reconhecimento como forma de auto-realização, afirmando com isso a importância do relacionamento social para o desenvolvimento da identidade pessoal.

A articulação do reconhecimento e redistribuição em Habermas se dá no âmbito da teoria dos direitos individuais e lutas por reconhecimento de identidades coletivas. No Estado Democrático de Direito, as arenas políticas discutem objetivos coletivos e a distribuição de bens coletivos, porém distribuídos ou utilizados individualmente. Habermas, por sua vez, afirma que Hegel descobriu a dimensão da interação na linguagem e esta pode ser transferida para o âmbito das relações e assim construir uma teoria do agir comunicativo ${ }^{75}$. No campo empírico isto se traduziria na necessidade de movimentos sociais e espaços públicos, entre outros. Habermas também discute as questões referentes a feminismo ${ }^{76}$, multiculturalismo, minorias étnicas e eurocentrismo, entre outras. Cada uma destas questões faz parte da articulação em destacar que não se pode sacrificar a conquista normativa de uma autocompreensão nacional fundamentando-se em velhas noções étnicas ${ }^{77}$. Para o autor, a necessidade de reconhecimento como nação se dá principalmente em tempos de crise, e assim a coletividade que se vê como comunidade com identidade própria está próxima da conquista de seu reconhecimento.

Para Taylor ${ }^{78}$, o reconhecimento é uma necessidade humana vital e não mera cortesia que devemos conceder às pessoas. O reconhecimento movimenta ações populares advindas de grupos minoritários de diversas naturezas. Possui vínculo com a identidade, com a compreensão de quem somos e que nos define como seres humanos. Está presente a idéia de universalização dos direitos. Taylor utiliza como base para sua

\footnotetext{
${ }^{75}$ HABERMAS, J. The theory of Communicative Action, Beacon Press 1987

76 HABERMAS, J. A luta por reconhecimento no Estado democrático de direito (In: A inclusão do outro. São Paulo, Edições Loyola, 2002)

77 Ibidem; pg. 267

78 TAYLOR, C. A política do reconhecimento (In Argumentos filosóficos. São Paulo Edições Loyola, 2000)

SAKATA, Marici Cristine Gramacho, Globalização e Educação: A formação do comunicador social na América Latina, 2008312 p. (Doutorado - Orientação BACCEGA, M. A.) Escola de Comunicações e Artes da Universidade de São Paulo, São Paulo, SP, 2008
} 
fundamentação empírica as questões das mulheres e a dos negros na história, cujas imagens construídas pelos demais sujeitos na sociedade os projetaram como seres inferiores. Aprofunda-se também na questão das minorias religiosas e principalmente o multiculturalismo Canadense - o caso de Quebec. Taylor refaz o caminho histórico do reconhecimento iniciado por Hegel na dialética do Senhor e do Escravo e discute a questão do orgulho próprio presente em Rousseau. O foco principal de sua análise é a questão do multiculturalismo. No entanto, Taylor ${ }^{79}$ traz à luz a diferença entre reconhecimento como "genuína expressão de respeito e insuportável paternalismo”. Estes erros advindos de teorias mal-acabadas afetam a política ao buscar valores iguais para questões diferentes.

Em Fraser ${ }^{80}$, "Toda luta contra injustiça, quando corretamente entendida, implica demandas por redistribuição e reconhecimento”. Assim, esclarece e distingue estes dois conceitos, buscando “conceitualizar reconhecimento cultural e igualdade social de forma que ambos se sustentem e não enfraqueçam um ao outro. Fraser acrescenta que apenas por meio da abstração das complexidades do mundo real é possível elaborar esquemas conceituais. Com isso, sua argumentação se fundamenta na distinção dos tipos ideais de coletividade social até o ponto em que seja capaz de propor uma estratégia política para integrar demandas por reconhecimento com "reivindicações por redistribuição com um mínimo de interferência mútua”. Fraser distingue injustiça, do ponto de vista meramente teórico (estrutura político-econômica), e do ponto de vista cultural ou simbólica (padrões sociais de representação). Neste tipo de injustiça está presente o não-reconhecimento. Como remédio ao problema da injustiça econômica está a redistribuição, enquanto para a injustiça cultural está o reconhecimento da diversidade. Mas ambos estão de tal maneira interligados que um pressupõe o outro.

Para analisar os sujeitos, Fraser busca em Marx a concepção de classe explorada que existe como uma coletividade apenas em virtude de sua posição nessa estrutura e de sua relação com outras classes - neste caso, a redistribuição seria o único remédio para a venda da força de trabalho mal recompensada. A questão se torna mais complexa quando não se está nos extremos da redistribuição e do reconhecimento, ou seja, injustiça social ou cultural, por exemplo, nas questões de raça e de gênero onde ambas as injustiças estão presentes. Neste caso, a saída inclui descentralização, reavaliação e

\footnotetext{
${ }^{79}$ FRASER, N. Da redistribuição ao reconhecimento? ....., 2001, pg. 272

${ }^{80}$ Ibidem, pg. 248

SAKATA, Marici Cristine Gramacho, Globalização e Educação: A formação do comunicador social na América Latina, 2008312 p. (Doutorado - Orientação BACCEGA, M. A.) Escola de Comunicações e Artes da Universidade de São Paulo, São Paulo, SP, 2008
} 
transformação. Alguns movimentos podem ser contraditórios, como no caso da questão feminina quando a redistribuição visa a eliminar a diferença de gênero e o reconhecimento visa a valorizar suas especificidades. Fraser acredita em uma abordagem de elementos transitórios e alternativos e retoma a questão ainda não resolvida da redistribuição, enquanto Honneth desconsidera a saída radical e afirmativa, considerando o restabelecimento das relações mútuas como forma de auto-realização. Habermas por sua vez pensa no Estado democrático de direito e discute as questões do multiculturalismo expostas por Taylor. No entanto, todos buscam uma visão normativa para tais questões enquanto articulam suas teorias críticas sociais.

Em resumo, uma série de questões políticas, teóricas e sociais são levantadas pelos quatro pensadores a fim de fundamentarem suas Teorias Críticas da Sociedade. Cada um encontra respostas em determinado caminho ou mesmo em caminhos similares. A complexidade da sociedade atual fornece uma infinidade de dados empíricos, que embora distintos em cada país possuem semelhanças quando tratados conceitualmente de forma ampla. O que procuramos mostrar é que tanto a identidade como o seu reconhecimento são questões complexas e que estão em constante debate.

\subsection{Os estudos culturais}

Para podermos compreender analiticamente o que significa identidade nacional e elementos identitários e culturais utilizamos os conceitos e a metodologia de análise dos Estudos Culturais.

Dado que devemos manter e cultivar elementos identitários e culturais, a pergunta que nos fazemos é como estes elementos se formam e se fixam em cada grupo e como novos grupos se formam. A cultura é a maneira pela qual os grupos se distinguem uns dos outros e a importância dos Estudos Culturais se deve à sua capacidade de fornecer meios para discutir como tais grupos distintos se formam.

Conforme García-Canclini $(1997)^{81}$, há muitos estudos culturais que tratam de comunicação, consumo e mercantilização, mas há poucos dados empíricos, e nem sempre uma reflexão teórica que questione esta prática. Não gostaríamos de nos deixar

\footnotetext{
81 GARCÍA-CANCLINI, Néstor, El malestar en los estudios culturales”. México, 1997, Revista Fractal ano 2, v. 2, no 6, p. 45, jul/set. Disponível em: http://www.fractal.com.mx/F6cancli.html. Acesso em: $10 / 12 / 2007$

SAKATA, Marici Cristine Gramacho, Globalização e Educação: A formação do comunicador social na América Latina, 2008312 p. (Doutorado - Orientação BACCEGA, M. A.) Escola de Comunicações e Artes da Universidade de São Paulo, São Paulo, SP, 2008
} 
levar por nenhum dos dois caminhos. O objetivo de utilizar os estudos culturais como base de análise é uma tentativa de resolver as questões teóricas levantadas que se utilizam dos conceitos de cultura e confrontá-las com os dados empíricos.

Cultura e identidade não se separam do contexto econômico e político. Podemos perceber isso em um exemplo a seguir:

Até há pouco tempo, os Estados Unidos adotavam uma política clara e agressiva de divulgar sua cultura e o American way of life (sobre isso ver Mattelart ${ }^{82}$ ) para o mundo por meio de seus produtos e filmes. No Brasil houve a política pan-americana, a criação do Instituto Brasil-Estados Unidos, entre outros. Diversos países efetivamente se americanizaram com esta política. Porém, devido aos ataques terroristas ocorridos em 2001, os EUA alteraram as políticas de visto de entrada e de tratamento a estrangeiros e criaram novas políticas de imigração. Com isso, sua população está cada vez mais isolada do resto do mundo e vice-versa. No entanto, do ponto de vista comercial, os grupos de investimento norte-americanos estão entrando intensamente em diversos países por meio de fusões ou aquisições como, por exemplo, a entrada dos grupos norte-americanos de investidores em instituições educacionais na América Latina.

Neste sentido, como se sente um indivíduo que estudou em uma faculdade que pertence a um grupo de investidores norte-americanos, com uma cultura norteamericana, que estudou para ser um profissional global, que aprendeu inglês e que assiste a filmes de Hollywood e, que em um dado momento, tem seu visto negado para entrar nos Estados Unidos da América? Este indivíduo tem os elementos necessários para compreender esta situação? Está apto a diferenciar as práticas das políticas, a questão da multiculturalidade, da desterritorialização e da reterritorialização, das ideologias que estão ligadas a esta questão? Ou seja, conseguimos perceber a cultura como algo indissociável do contexto político e econômico?

Embora haja uma americanização no mundo, também há em alguns países uma resistência à americanização e um espírito de nacionalidade inconsciente, e não racional, que luta por se manter. No dia-a-dia, tentamos manter nossa língua, nossa religião e nossos costumes. No entanto, a América Latina tem uma história de imigração. Segundo Ortiz (1986) ${ }^{83}$, o Brasil está permanentemente construindo sua identidade nacional.

\footnotetext{
${ }^{82}$ MATTELART, A. Diversidade cultural e mundialização, Parábola, São Paulo, 2005

83 ORTIZ, R. Cultura brasileira e identidade nacional. 2.ed. São Paulo: Brasiliense, 1986

SAKATA, Marici Cristine Gramacho, Globalização e Educação: A formação do comunicador social na América Latina, 2008312 p. (Doutorado - Orientação BACCEGA, M. A.) Escola de Comunicações e Artes da Universidade de São Paulo, São Paulo, SP, 2008
} 
Desta forma, a venda de uma formação para um "profissional global” sem que se tenha antes definido sua identidade local e sem que se crie espaço para discutir o nacional gera uma falta de pertencimento, ou seja, uma "crise de identidade”.

A crítica de García-Canclini (1997) ${ }^{84}$ presente no texto $O$ mal-estar dos estudos culturais é muito pertinente para este trabalho. Os tratados sendo celebrados no mundo - aproximando os países no sentido de liberalizar o comércio - também provocam um aumento no intercâmbio sócio-cultural. Novos convênios, ou melhor, novos monopólios, surgem e proporcionam maior facilidade para a entrada de empresas multinacionais - como editoras, redes de TV, universidades e centros artísticos - em diferentes países. Este novo cenário modifica a imagem das sociedades reciprocamente - e influencia os estilos de vida. A pergunta que García-Canclini lança coincide com a nossa: Temos instrumentos intelectuais suficientes para enfrentar a situação? Perguntamos também se temos meios que nos permitam dialogar. Ou se estamos reagindo a tempo à rápida mudança ou nos deixando levar pelas circunstâncias?

Os Estudos Culturais (EC) foram desenvolvidos na Inglaterra para dar conta da substituição de foco - da produção para o consumo - no sujeito e na cultura. Os estudos culturais surgiram na década de 1960 na Universidade de Birmingham e tiveram um apogeu na década de 1990 quando o mundo se viu frente a questões culturais (virada cultural) e ideológicas a serem definidas e resolvidas. Neste movimento de estudos culturais a "alta cultura” não foi mais suficiente para dar conta das mudanças que estavam ocorrendo; signos, consumo e ideologia, entre outros, passaram a ser peças chave para compreender o momento. O termo cultura, como algo abrangente e múltiplo, presente em todas as camadas sociais, foi necessário. No entanto, quase 20 anos depois, muito se alterou e a globalização desempenhou um papel importante nesta mudança. Desta forma, não seguimos aqui os estudos culturais da forma como concebidos em Birmingham.

Os estudos culturais foram concebidos no campo interdisciplinar de maneira oposta ao que se fazia anteriormente, ou seja, separações entre os diversos tipos de cultura como se elas não interagissem. Os conceitos de lutas de classes, populações subalternas e alienação permanecem com novas visões e conceitos adequados à contemporaneidade, não apenas pela visão de acadêmicos anglo-saxões, mas agregando

${ }^{84}$ GARCÍA-CANCLINI, Néstor, El malestar en los estudios culturales. Fractal, México, ano 2, v. 2, nº 6 , p. 45, jul/sept. 1997 Disponível em: <http://www.fractal.com.mx/F6cancli.html>. Acesso em: 05/01/2008.

SAKATA, Marici Cristine Gramacho, Globalização e Educação: A formação do comunicador social na América Latina, 2008312 p. (Doutorado - Orientação BACCEGA, M. A.) Escola de Comunicações e Artes da Universidade de São Paulo, São Paulo, SP, 2008 
o enriquecimento de debates com a participação de autores de diversos países que tentaram interpretar suas mudanças locais e criar conceitos gerais. A "nova esquerda" definiu a cultura como sendo os novos meios de comunicação, a indústria cultural e os aparelhos ideológicos. Denning (2005) ${ }^{85}$ cita que a nova esquerda hoje é uma esquerda global cujos antagonistas simbólicos são o FMI e a OMC.

O que significa cultura global? Uma comercialização internacional de mercadorias ou um reconhecimento de valores locais? De fato, há várias questões a serem resolvidas, entre elas: A cultura atualmente é emancipadora? É utilizada para ações afirmativas? É uma resistência à sociedade capitalista? Que significado a sociedade tem dado à cultura no contexto da globalização?

Se o que garantia a identidade como algo natural - estabelecido, seguido e aceito por todos - não existe mais, surge então, uma crise. Pertencemos a uma comunidade virtual e nossa sociedade é em rede, mas esta não substitui a real. Desta forma, buscamos em algum lugar esta identidade. Para García-Canclini (1997) ${ }^{86}$ ela se reestrutura em meio a conjuntos interétnicos, transclassistas e transnacionais disponíveis no ambiente global, gerando novas formas de segmentação.

Os Estudos Culturais nos fornecem a fundamentação para pensar estas questões.

\subsection{A Formação do Comunicador e a Globalização}

\section{O Campo da Educação}

Cada sociedade possui seus valores, tradições e culturas. As culturas, na concepção de Bourdieu (2003) ${ }^{87}$, são produções simbólicas que contribuem para a integração real e fictícia da sociedade no seu conjunto. Tais produções fazem parte de um sistema simbólico, onde são instrumentos de conhecimento e de comunicação. Como instrumentos, têm o poder de construção da realidade - poder simbólico - que tende a estabelecer uma ordem gnosiológica, o sentido imediato do mundo (e, em particular, do mundo social) que supõe um conformismo lógico, ou seja, uma concepção

\footnotetext{
${ }^{85}$ DENNING, Michael. A Cultura na era dos três mundos. Ed. Francis, 2005, p. 162

${ }^{86}$ GARCÍA-CANCLINI, Néstor, El malestar en los estudios culturales. Fractal, México, ano 2, v. 2, nº 6, p. 45, jul/sept. 1997 Disponível em: <http://www.fractal.com.mx/F6cancli.html>. Acesso em: 05/01/2008.

${ }^{87}$ BOURDIEU, P. O Poder Simbólico, 6º Edição, Tradução Fernando Tomaz do Original Le pouvoir symbolique - Rio de Janeiro; Bertrand Brasil, 2003
}

SAKATA, Marici Cristine Gramacho, Globalização e Educação: A formação do comunicador social na América Latina, 2008312 p. (Doutorado - Orientação BACCEGA, M. A.) Escola de Comunicações e Artes da Universidade de São Paulo, São Paulo, SP, 2008 
homogênea do tempo, do espaço, do número e da causa que torna possível a concordância entre as inteligências.

A cultura dominante dissimula a função de divisão na função de comunicação: separa e legitima, compelindo todas as culturas a se definirem pela sua distância em relação à cultura dominante. “cumprem a sua função política de instrumentos de imposição ou de legitimação da dominação, que contribuem para assegurar a dominação de uma classe sobre outra e para a domesticação dos dominados. (Bourdieu, 2003) ${ }^{88}$

Para o autor, as relações de comunicação são sempre relações de poder que dependem do poder material ou simbólico acumulado pelos agentes ou instituições envolvidas nessas relações. No entanto, só exercem seu poder se reconhecidos pela sociedade, o que significa que o poder não está nos sistemas, mas nas relações (como em Foucault) entre os que o exercem e os que a ele se submetem.

Este espaço social de dominação e de conflitos, onde os indivíduos agem segundo sua posição social e orientados por uma estratégia política de investimento objetivamente orientada, é o que Bourdieu (2003) ${ }^{89}$ define como campo. Em um campo as relações sociais estão distribuídas na forma de capital, seja cultural ou simbólico. Os participantes de cada campo são dotados das capacidades para desempenhar funções e da prática das lutas para atingir seus objetivos e garantir sua sobrevivência. Tais relações definem-se independentemente da consciência humana. Na estrutura do campo (hierarquia de posições, tradições, instituições e história) os participantes adquirem um conjunto de disposições para agir de acordo com as possibilidades existentes dentro desta estrutura objetiva, que o autor denomina habitus. As disposições são aquisições de maneiras de ser permanentes e duráveis que conduzem o sujeito a resistir e a se opor às forças do campo. Por um lado, tais sujeitos correm o risco de ficar defasados em relação aos demais; mas por outro lado, isto pode conduzi-lo a lutar por mudanças e adequação das estruturas à sua disposição ${ }^{90}$. Bourdieu trabalha os conceitos de campo, capital e habitus para explicar as interações na sociedade.

No campo educativo incluímos as escolas e instituições de pesquisa, as políticas educacionais, os currículos, as normas, os atores/professores e dirigentes e os políticos, entre outros.

\footnotetext{
${ }^{88}$ BOURDIEU, P. O Poder ....., 2003, pg. 11

${ }^{89}$ Ibidem, p.127

90 Sobre o Habitus, ver BARROS, F. e MARTINO, L. M, O Habitus na Comunicação, São Paulo, Ed. Paulus, 2003

SAKATA, Marici Cristine Gramacho, Globalização e Educação: A formação do comunicador social na América Latina, 2008312 p. (Doutorado - Orientação BACCEGA, M. A.) Escola de Comunicações e Artes da Universidade de São Paulo, São Paulo, SP, 2008
} 
Estas noções de campo, produção e poder simbólicos são ao mesmo tempo pontos de partida e fundamentos deste trabalho.

Quando comentamos que os trabalhadores competem entre si para garantir sua subsistência está implícita a influência da educação neste processo. A educação atualmente mais contribui para a geração de trabalhadores individualizados e subsumidos do que para homens livres. O que vemos com mais freqüência atualmente, em todos os níveis, é a busca do ser humano por mais qualificações, o uso de seu “tempo livre” para adquirir “empregabilidade” (Antunes e Alves, 2004 ${ }^{91}$ ) por meio da aquisição de conhecimentos e informações, e a cobrança de escolas mais eficientes que formem indivíduos prontos para atuar no mercado de trabalho.

No nível da educação superior, pode-se ver cada vez mais o direcionamento da universidade para a indústria, por meio das parcerias universidade-empresa e da incessante busca de produção de conhecimento para fins econômicos. (Peters, 2003) ${ }^{92}$ A educação passou a ser a forma de gerar conhecimento para atuar em favor do mercado, tornando-se assim, responsável pela criação de classes de trabalhadores do conhecimento e se transformando em um negócio lucrativo. Isso nos leva de volta à questão sobre o papel da educação no sistema atual como suporte à superestrutura para manutenção de seu equilíbrio. (Burke, 2000) ${ }^{93}$ Por esta razão a educação deve sempre ser analisada, discutida e refletida pelos membros da sociedade.

Podemos perceber que devido à tecnologia contamos hoje com uma eficiente força de produção. No entanto, em vez de vivermos em uma sociedade mais justa e desenvolvida, temos cada vez mais desigualdades e desempregos em algumas áreas. Vemos hoje uma pequena parcela da população com controle dos meios de produção ( $e$ de educação) e a globalização intensificando cada vez mais estas questões. Assim, o papel da escola é fazer com que os alunos tenham consciência de si mesmos. A escola deve ser um espaço de formação, de transmissão de conhecimento e cultura, um espaço para vivenciar e experimentar a complexidade das relações humanas. Um local onde se possa aprender o que é democracia, sociedade, cultura, valores e liberdade, e aprender a analisar, criticar e amar o mundo. Quanto aos docentes, estes devem possuir

\footnotetext{
${ }^{91}$ ANTUNES, Ricardo e Alves, Giovanni, As mutações no mundo do trabalho na era da mundialização do capital Educ. Soc., Campinas, vol. 25, n. 87, p. 335-351, maio/ago. 2004 Disponível em $<$ http://www.cedes.unicamp.br> Acesso em 08/12/2004

${ }^{92}$ PETERS, Michael, Post-structuralism and marxism: education as knowledge capitalism, J. Education Policy, 2003, Vol 18. No.2 p.115-129

93 BURKE, Barry 2000, Karl Marx and informal education. Disponível em < http://www.infed.org/thinkers/et-marx.htm> Acesso em 09/12/2004

SAKATA, Marici Cristine Gramacho, Globalização e Educação: A formação do comunicador social na América Latina, 2008312 p. (Doutorado - Orientação BACCEGA, M. A.) Escola de Comunicações e Artes da Universidade de São Paulo, São Paulo, SP, 2008
} 
conhecimentos, habilidades e atitudes para que sejam profissionais reflexivos e pesquisadores.

A formação de um profissional não se dá apenas com o ensino superior formal, pois formação é algo mais amplo ${ }^{94}$ e que se dá ao longo da vida. Incluem-se na formação alguns pilares básicos: além do curso superior a experiência prática, a educação contínua ao longo de sua carreira e as certificações profissionais. Bourdieu vai mais além, adicionando a estes pilares os conceitos de capital cultural e capital social que estão presentes e influenciam a vida de cada um por meio do sistema educacional.

No campo da comunicação, para Moura (2002) ${ }^{95}$

"Os graduandos devem possuir um embasamento condizente com as atribuições específicas das profissões de Jornalista, Relações Públicas e Publicitárias, existindo a necessidade de um aprendizado para a formação profissional na Área”. O currículo do Curso de Comunicação Social projeta, em suas matérias ou disciplinas, os conhecimentos necessários às práticas profissionais vinculadas ao mercado de trabalho.... Assim, fica evidente que o ensino tem um papel relevante na qualificação do futuro profissional”

Os conhecimentos para a prática profissional são adquiridos principalmente por meio dos cursos de graduação em comunicação. No entanto, Capparelli e Stumpf $\left(2001^{96}\right)$ diz que a estrutura curricular de muitas universidades dá ao aluno somente instrumentos para atuar no mercado de trabalho.. Na verdade, isto é apenas uma parte da responsabilidade dos cursos superiores, à qual não devem se limitar.

Do ponto de vista profissional o comunicador social deve ter espírito crítico para lidar com pesquisa, opinião pública, comunicação institucional, imagem e política. O fator mercadológico e gerencial tem um peso forte no perfil do novo comunicador, e isso reflete na forma como os cursos de Comunicação Social são estruturados. A Comunicação tradicional, centralizada e instrumental, atuando apenas no nível táticooperacional não atende às exigências da competitividade global, à forte pressão de consumidores e investidores, à crescente demanda de informação dos empregados, à constante necessidade de transformação da empresa (Carneiro, 1998 ${ }^{97}$ ). O novo perfil do comunicador pode ser sintetizado em três competências essenciais: de estrategista, de

\footnotetext{
${ }^{94}$ TRINDADE, H. e Blanquer, J.M, Os Desafios da Educação ....., 2002, pg. 8

${ }^{95}$ MOURA, Claudia P. de, O curso de comunicação social no Brasil: do currículo mínimo às novas diretrizes curriculares, EDIPCURS, Porto Alegre, 2002, p. 15

${ }^{96}$ CAPPARELLI, Sérgio e Stumpf, Ida. El campo acadêmico de la comunicación, revisitado. In: Lopes, M.I.V e Fuentes, R (comps.) Comunicación: Campo y Objeto de Estúdio. Guadalajara: Iteso, 2001.

${ }^{97}$ CARNEIRO, Eraldo O papel da comunicação nos processos de mudanças está a exigir um profissional com um olho na invenção e outro na gestão. Revista Comunicação Empresarial Ano 8 No $294^{\circ}$ Trimestre de 1998 Disponível em: http://www.aberje.com.br/antigo/revista/n29/artigoc.htm Acesso em 14.02.2006

SAKATA, Marici Cristine Gramacho, Globalização e Educação: A formação do comunicador social na América Latina, 2008312 p. (Doutorado - Orientação BACCEGA, M. A.) Escola de Comunicações e Artes da Universidade de São Paulo, São Paulo, SP, 2008
} 
gestor e de líder. Isso evidencia que a gerência anseia não por um técnico altamente especializado em comunicação, mas por um estrategista que coloque a comunicação a serviço do cumprimento da visão e dos propósitos da organização.

Para Galindo e Marin (1998) ${ }^{98}$ o comunicador não é um técnico, e, portanto, deve ter consciência de sua responsabilidade perante a sociedade e da ética no desempenho da sua profissão. Por isso, deve saber manipular o instrumental tecnológico e o conteúdo cultural, para poder estabelecer prioridades e identificar os campos do conhecimento que permitam melhor compreender o comportamento do homem na sua complexidade individual e coletiva. Em pesquisa realizada junto a órgãos públicos federais da capital federal do Brasil, Brandão, Martinez e Costa (2002) ${ }^{99}$ tentaram levantar quais os atributos desejados pelos empregadores para o profissional de comunicação. Os resultados indicam que o perfil do profissional exigido pelo mercado de trabalho é aquele que possui iniciativa, criatividade, inovação e comprometimento, além de conhecimentos para realizar atividades de planejamento e estratégia.

\footnotetext{
98 GALINDO Daniel e MARIN Sérgio, A Info - Formação do Publicitário, In: Publicidade: Análise da produção publicitária e da formação profissional, TARSITANO, Paulo Rogério (Org.) São Paulo Brasil 1998 Coleção Gt's ALAIC-Asociación Latinoamericana de Investigadores de la Comunicación UMESP, Universidade Metodista de São Paulo, $\mathrm{n}^{\circ} \quad 01 . \quad$ Disponível em http://www.eca.usp.br/alaic/Livro\%20GTP/index.htm Acesso em 01.02.2006

99 BRANDÃO Elizabeth, MARTINEZ Maria Cecília, COSTA, Francisco de Assis Silva, Perfil do comunicador social sob a ótica do empregador, Anais do ALAIC 2002 VI Congreso Latinoamericano de Ciencias de la Comunicación, Bolívia, Santa Cruz de la Sierra, 5-8 de junho de 2002 - GT Comunicación Organizacional y Relaciones Públicas Disponível em http://www.eca.usp.br/alaic/material\% 20congresso\%202002/congBolivia2002/trabalhos\%20completos\%20Bolivia\%202002/GT\%20\%206\%20 \%20margarida\%20kunsch/Elizabeth\%20Brandao\%20e\%20maria\%20cecilia.doc Acesso em 14.02.2006

SAKATA, Marici Cristine Gramacho, Globalização e Educação: A formação do comunicador social na América Latina, 2008312 p. (Doutorado - Orientação BACCEGA, M. A.) Escola de Comunicações e Artes da Universidade de São Paulo, São Paulo, SP, 2008
} 


\section{A APROPRIAÇÃo dA EDUCAÇÃo PELO MERCADO}

\subsection{Modelos Educacionais e o Sistema Universitário Latino-Americano}

Em Rousseau (1762) $)^{100}$ a educação nos chega pela natureza, pelos homens e pelas coisas. Pela natureza temos o desenvolvimento interno das nossas faculdades e órgãos; pelos homens aprendemos a fazer uso desse desenvolvimento; e pelos objetos, adquirimos nossa própria experiência. A educação pelos homens é a única em que se pode exercer domínio; mesmo assim, é uma arte e como tal é difícil realizá-la com êxito. Por isso, a necessidade de tantos esforços para se aproximar dos objetivos educacionais, muito embora alguns nunca sejam atingidos. Educar é levar o indivíduo a alcançar aquilo que lhe é mais específico como ser humano, isto é, sua intelectualidade, sua afetividade e seus hábitos, com o objetivo da realização de um ideal. (Gilles, 1983) ${ }^{101}$. De acordo com Paulo Freire, ensinar não é transferir conhecimentos ou conteúdos, nem é a ação pela qual um sujeito criador dá forma. O formador é o sujeito e o objeto ao mesmo tempo, assim como o formando. Na troca, ambos ensinam e ambos aprendem $^{102}$.

Para Morin (2003) ${ }^{103}$, a missão de educar para esta nova era significa “fortalecer as condições de possibilidade e emergência de uma sociedade-mundo composta por cidadãos protagonistas, conscientes e criticamente comprometidos com a construção de uma civilização planetária”. Neste sentido, a missão do educador não é menor, ela supõe “fé na cultura e fé nas possibilidades do espírito humano, supõe simultaneamente, arte, fé e amor"

A educação também é um dos principais elementos responsáveis pelas transformações sociais. Pensar a educação é enfrentar desafios e buscar soluções para os problemas que permeiam a sociedade.

O currículo é uma das partes do processo de aprendizado e deve estar combinado com as características dos alunos e o contexto em que se situa (o contexto é uma das

\footnotetext{
${ }^{100}$ ROUSSEAU, J.J., Emílio ou da Educação, tradução de Emile, ou, De l’éducation (1762) por Roberto Leal Ferreira, $2^{\mathrm{a}}$ Ed. - São Paulo: Martins Fontes, 1999

${ }^{101}$ GILLES, T. R. , Filosofia da Educação, São Paulo: EPU, 1983

${ }^{102}$ FREIRE, P. Pedagogia da Autonomia, São Paulo, Ed. Paz e Terra. 1996, p.25.

${ }^{103}$ MORIN, Edgar. Ciurana, Emilio Roger. Motta, Raúl Domingo Educar na era planetária : O pensamento complexo como método de aprendizagem pelo erro e incerteza humana.. 2003. São Paulo; Brasília: Cortez; Unesco. P.98-99

SAKATA, Marici Cristine Gramacho, Globalização e Educação: A formação do comunicador social na América Latina, 2008312 p. (Doutorado - Orientação BACCEGA, M. A.) Escola de Comunicações e Artes da Universidade de São Paulo, São Paulo, SP, 2008
} 
questões discutidas quando há a globalização da educação). O Currículo é a proposta educacional feita por uma instituição que se responsabiliza pela sua fundamentação, implementação e avaliação. É composto por um conjunto de conteúdos, experiências e processos. A construção de um currículo parte sempre de um ideal (currículo ideal) e é determinado pelos fatores e condições existentes, se transforma no currículo real efetivamente, e se divide em explícito e oculto. O "currículo oculto" ${ }^{104}$ compreende as concepções e valores que a instituição transmite aos estudantes de maneira formal e inconsciente, por meio de cobranças de comportamento e resultados. As variáveis que o influenciam são: recursos, professores, ambiente, contexto e alunos.

Os determinantes do currículo são: - história, - ideologia, - avaliações, - tempo, interesse de grupos profissionais, - e interesses de grupos étnicos e religiosos, enquanto os componentes são: 1) Objetivo, 2) Conteúdo, 3) Avaliação, 4) Metodologia, 5) Recursos. Os componentes são também as fases da elaboração de um currículo, de forma cíclica, para se formar ou se ajustar. Deve-se perguntar qual o objetivo, qual o conteúdo essencial para atender este objetivo, qual o papel dos professores e o que esperar dos alunos. Como ocorre o aprendizado? Todas estas questões devem estar sempre presentes no momento da concepção e avaliação do currículo e também na definição de um projeto pedagógico. As principais concepções de currículo - de maneira simplificada - seguem as linhas de Piaget sobre o desenvolvimento cognitivo, de Rogers sobre o racionalismo acadêmico, de Paulo Freire sobre a relevância pessoal e reconstrução social e Skinner sobre o desenvolvimento tecnológico.

Para a construção de um projeto pedagógico completo, a instituição deve pensar no perfil do graduando, nos objetivos do curso e no verdadeiro papel da educação.

Cabe aos gestores das instituições de ensino definirem as melhores estratégias de acordo com sua missão. Para Gilles (1983) ${ }^{105}$ cabe à filosofia da educação considerar a dimensão da assimilação e a dimensão intersubjetiva para conscientizar o educando das exigências de sua integração na coletividade; e considerar, ainda, a dimensão crítica, para que o educando tenha capacidade de avaliar a realidade em que vive. Isto se faz necessário para que a escolha dos objetivos e meios seja coerente com as necessidades fundamentais dos indivíduos.

Na maioria dos países do ocidente a educação superior abrange cursos seqüenciais, de graduação, pós-graduação e extensão ministrados em instituições de

\footnotetext{
${ }^{104}$ Notas de aula, Krasilschik, Miriam, FE-USP 2005

105 GILLES, T. R , Filosofia da Educação, ...., 1983, p.. 29

SAKATA, Marici Cristine Gramacho, Globalização e Educação: A formação do comunicador social na América Latina, 2008312 p. (Doutorado - Orientação BACCEGA, M. A.) Escola de Comunicações e Artes da Universidade de São Paulo, São Paulo, SP, 2008
} 
ensino superior, públicas ou privadas ${ }^{106}$. As instituições pluridisciplinares de formação dos quadros profissionais, de pesquisa, de extensão e de domínio e cultivo do saber humano são tidas como universidades.

As instituições de ensino, e também as universidades, são herdeiras das instituições do mundo greco-romano que assumiram formatos diferentes no contexto religioso islâmico e cristão. (Wanderley, 2003) ${ }^{107}$ No contexto cristão, o direito de ensinar estava nas mãos da igreja - as escolas capitulares. Studium significava o estabelecimento de ensino superior; e universitas a organização corporativa responsável pelo funcionamento e manutenção da autonomia do Studium. As faculdades eram divisões administrativas do studium. (Ranieri, 1994) ${ }^{108}$

No início do século XII, com a licença do papa, do rei ou do imperador e com validade universal e direito de lecionar em toda cristandade, os "studia generalia”, eram freqüentados por estudantes, professores e clérigos que gozavam de privilégios e proteções - vê-se aqui o início da distinção entre a elite acadêmica e não-acadêmica em uma sociedade. A partir dos "Studia Generalia" surgiram no século XIII as universidades, e entre elas, as cinco pioneiras - os anos de fundação divergem entre os autores - na Itália, Salerno e Bolonha, na França, Paris e Montpellier e na Inglaterra, Oxford. No século XIII foram fundadas 14 novas universidades (Trindade, 2002) ${ }^{109}$.

As instituições escolares adquiriram diversos formatos ao longo dos séculos e estiveram, na maioria das vezes, estritamente influenciadas, quando não controladas, pelo sistema econômico-político vigente. Como por exemplo, as universidades medievais possuíam um caráter conservador e teológico, eram internatos com aulas orais e defesas de teses. Tinham o saber como um fim em si mesmo e eram criadas para formar uma elite aristocrática, enquanto que após a revolução industrial os cursos passaram a se voltar para especialidades segundo as divisões do trabalho (Wanderley, 2003) ${ }^{110}$. As universidades sempre buscaram autonomia e certa independência da Igreja e do Estado - embora nem sempre este objetivo tenha sido alcançado - o

\footnotetext{
${ }^{106}$ Art 44 e 45: Título IV - Da Organização da Educação Nacional Lei No 9.394, de 20 de dezembro de 1996 - DOU 23 de dezembro de 1996 - seção 1 - Página 27839

${ }^{107}$ WANDERLEY L. E. W. O que é universidade, Editora Brasiliense, São Paulo, 2003, p.15

${ }^{108}$ RANIERI, Nina Beatriz, Autonomia Universitária: As Universidades Públicas e a constituição federal de 1988, São Paulo: Editora da Universidade de São Paulo, 1994, pg. 37

109 TRINDADE, H. e Blanquer, J.M. Os Desafios da Educação ......, 2002 pg.15

${ }^{110}$ WANDERLEY L. E. W. O que é universidade...., 2003, pg. 18.
}

SAKATA, Marici Cristine Gramacho, Globalização e Educação: A formação do comunicador social na América Latina, 2008312 p. (Doutorado - Orientação BACCEGA, M. A.) Escola de Comunicações e Artes da Universidade de São Paulo, São Paulo, SP, 2008 
princípio da autonomia universitária, contudo, havia sido firmemente enraizado, e seu renascimento, voltado a fins sociais, se mostraria inexorável” (Ranieri, 1994) ${ }^{111}$.

A aquisição de informações, o acesso às tecnologias e à educação para o mercado de trabalho na globalização têm redefinido os objetivos das instituições de Ensino Superior.

\section{Conceitos - Educação Superior Pública, Privada e Confessional}

A sistematização da educação superior, segundo Ranieri (2000) $)^{112}$, compreende a educação:

a) pública religiosa, séculos XVI e XVII, voltada à formação do cristão;

b) pública estatal, século XVIII, voltada à formação do militar e funcionário do Estado;

c) pública nacional, século XIX, destinada ao cidadão;

d) pública democrática, século XX, com participação popular nos governos com objetivo de formar o homem completo.

Percebe-se com esta sistematização o caráter predominantemente público da educação superior. A noção de educação pública - criada, dirigida e mantida por autoridades oficiais - iniciou-se na Europa Ocidental a partir do século XVI. Desta forma, a educação formal, além de ser um direito individual e social, é também um instrumento de ação política e de interesse do Estado. (Ranieri, 2000) ${ }^{113}$

Ribeiro (2003) $)^{114}$ observa que, no século XX, o caráter público da educação, está baseado em valores Republicanos que englobam a laicidade, igualdade e liberdade de oportunidade, e seus resultados devem difundir-se por toda a sociedade e não somente no âmbito do privilégio. Neste sentido, a educação pública tem o caráter da apropriação social de seus resultados - o que não deve ser confundido com universidade gratuita.

No Brasil, a organização da educação se configura por instituições:

- Públicas - criadas ou incorporadas, mantidas e administradas pelo Poder Público.

\footnotetext{
${ }^{111}$ RANIERI, Nina Beatriz, Educação Superior, Direito e Estado. São Paulo: Editora da Universidade de São Paulo, Fapesp, 2000

112 Ibidem, pg. 38

113 Ibidem, pg. 37

${ }^{114}$ RIBEIRO, R. Janine, A Universidade e a Vida Atual, Rio de Janeiro: Campus, 2003, pg. 150-155

SAKATA, Marici Cristine Gramacho, Globalização e Educação: A formação do comunicador social na América Latina, 2008312 p. (Doutorado - Orientação BACCEGA, M. A.) Escola de Comunicações e Artes da Universidade de São Paulo, São Paulo, SP, 2008
} 
- Privadas ${ }^{115}$ - mantidas e administradas por pessoas físicas ou jurídicas de direito privado, podendo ser:

o Particulares em sentido estrito, assim entendidas as que são instituídas e mantidas por uma ou mais pessoas físicas ou jurídicas de direito privado que não apresentem as características dos incisos abaixo;

o Comunitárias, assim entendidas as que são instituídas por grupos de pessoas físicas ou por uma ou mais pessoas jurídicas, inclusive cooperativas de professores e alunos que incluam na sua entidade mantenedora representantes da comunidade;

o Confessionais, assim entendidas as que são instituídas por grupos de pessoas físicas ou por uma ou mais pessoas jurídicas que atendam à orientação confessional e ideologia específica e ao disposto no inciso anterior;

o Filantrópicas, na forma da lei.

\section{Influências - Modelos Napoleônico, Humboldtdiano e Norte-americano}

Em um panorama histórico, três modelos educacionais se destacam nos séculos XIX e XX: o modelo alemão "Humboldtiano", o francês "Napoleônico” e o norteamericano de massas, chamado "Modelo Americano". Oliveira et al, (2000) ${ }^{116}$ destacam as principais características de cada modelo conforme descrito a seguir:

- O modelo educacional alemão foi elaborado por Wilhelm Von Humboldt, fundador da Universidade de Berlim e também ministro da educação. Foi implantado na Universidade de Berlim no século XIX e denominou-se “Modelo Humboldtiano”. Este modelo destaca-se pela elitização e enfatizava o conhecimento erudito, enciclopédico e neo-humanista (aproximava as humanidades e as ciências) e o ensino e a pesquisa. Para Humboldt, sem a pesquisa, não há críticas e discussões e o ensino não se inova. Também se caracterizava pela descentralização e liberdade de cátedra. Humboldt idealizou uma universidade autônoma em relação ao Estado, com o propósito de buscar soluções aos problemas gerados pela sociedade.

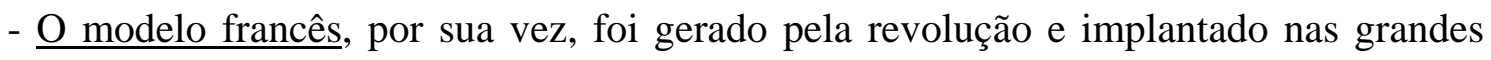
escolas de Paris e denominava-se modelo napoleônico. Este modelo destaca-se também

\footnotetext{
115 Art 19 e 20: Título IV - Da Organização da Educação Nacional Lei No 9.394, de 20 de dezembro de 1996 - DOU 23 de dezembro de 1996 - seção 1 - Página 27839

${ }^{116}$ OLIVEIRA et al, Preparando o futuro...., 2000

SAKATA, Marici Cristine Gramacho, Globalização e Educação: A formação do comunicador social na América Latina, 2008312 p. (Doutorado - Orientação BACCEGA, M. A.) Escola de Comunicações e Artes da Universidade de São Paulo, São Paulo, SP, 2008
} 
pela elitização, porém, atrelado ao Estado (heteronomia), com sistema de cátedras, e hipercentralização (um único currículo para todo o império) e hierarquização das grandes escolas (grandes ècoles) com privilégios acima das faculdades. O modelo é politizado e com orientação aos cursos técnicos e de engenharia. Há, também, neste modelo características militares, como uniformes e insígnias.

- O modelo norte-americano caracteriza-se por ser um ensino de massa embora conserve nichos de excelência em universidades de primeira linha. Destaca-se neste modelo a autonomia e a diversidade de tipos de instituições, como universidades comunitárias, privadas e estaduais, e associações entre instituições educacionais e empresas, tendo como foco o ensino técnico e os ofícios manuais. Outra característica é a estrutura departamental com disciplinas dissociadas das antigas cátedras e a especialização das áreas e níveis de conhecimento. A orientação é diversificada - ciência e humanidades. Do ponto de vista financeiro, este modelo apresenta competitividade acirrada entre as instituições e disputa por fundos de pesquisa, flexibilidade em todos os níveis - tanto no currículo como nos salários - e segue o modelo taylorista, ou seja, os padrões da indústria são reproduzidos no ensino.

Estes modelos influenciaram as instituições educacionais de diversos países e em alguns deles foram fielmente reproduzidos como no caso das colônias francesas, alemãs e britânicas.

Diversas mudanças ocorreram neste campo ao longo dos séculos. Os países europeus, pressionados pela crescente demanda de vagas no ensino superior, também aderiram ao sistema norte-americano, que de certa forma influenciou grande parte do sistema educacional do mundo. O inglês passou a ser a língua dominante no ambiente científico e o sistema norte-americano se destacou, tendo como seguidores até mesmo as universidades européias - vide o número de programas de MBA - Master in Business Administration - norte-americanos e os convênios universidade-empresa oferecidos.

Os países em desenvolvimento, pressionados por organismos internacionais e influenciados pelo sistema econômico vigente, foram se reestruturando com base no sistema norte-americano.

A educação superior na América Latina, assim como em grande parte do mundo, no último século, passou por uma fase de transição tanto econômica como política e social. No entanto, a universidade tem sobrevivido e se adaptado a todas as mudanças ocorridas ao longo dos séculos desde sua formação, atravessando momentos de guerras, crises, transições políticas e tecnológicas.

SAKATA, Marici Cristine Gramacho, Globalização e Educação: A formação do comunicador social na América Latina, 2008312 p. (Doutorado - Orientação BACCEGA, M. A.) Escola de Comunicações e Artes da Universidade de São Paulo, São Paulo, SP, 2008 
Para falarmos em educação superior na América Latina é necessário conhecermos como as instituições de ensino foram constituídas, quais são suas heranças históricas e as modificações sofridas nos diferentes regimes políticos. A Europa e a América Latina comungam das mesmas tradições e concepções sobre a Universidade. O Sistema Universitário da Espanha chegou à América Latina somente no século XVI, ou seja, quatro séculos depois de sua criação. A primeira universidade foi trazida à República Dominicana pelos dominicanos em 1538 e após esta data, outras ordens religiosas, como os jesuítas e franciscanos, implantaram universidades no México, Peru, Chile e Argentina. (Trindade e Blanquer, 2002 ${ }^{117}$; Wanderley, 2003 ${ }^{118}$ ).

No Brasil, a primeira universidade teve início em 1920 no Rio de Janeiro, e reuniu a Escola de Engenharia, de Direito e Medicina. A diferença entre a herança espanhola e portuguesa é fundamental para a compreensão do processo de desenvolvimento universitário. Nos séculos XVI, XVII, XVIII e XIX, enquanto ainda não havia universidades no Brasil, a América Espanhola já contava com 56 universidades públicas e 5 universidades privadas. A Espanha contava com maior número de universidades e com um sistema mais avançado que Portugal no mesmo período.

Na América Espanhola a universidade tinha como modelo a união entre o Estado e a Igreja. Após a independência, segundo Trindade $\left(2002^{119}\right)$, os países hispanoamericanos transformaram o modelo tradicional em republicano oligárquico. Houve uma tentativa de romper com o caráter colonialista e criar instituições públicas e laicas para as novas repúblicas, instituições voltadas para o desenvolvimento profissional e não tanto para a pesquisa - sendo a maioria influenciada pelo modelo napoleônico. A universidade na América Portuguesa se desenvolveu de forma diferente. O Brasil estava impedido de criar universidades, e Portugal possuía um sistema de ensino superior mais atrasado que o da Espanha. Assim, formaram-se faculdades e escolas isoladas a partir de 1808, também seguindo o modelo napoleônico, não de forma unitária, mas comparável a uma confederação de faculdades. Durante este período sem universidades, as elites brasileiras se formavam principalmente na Universidade de Coimbra e nos Seminários - cujo nível de ensino poderia superar algumas

\footnotetext{
117 TRINDADE, H. e Blanquer, J.M. Os Desafios da ....., 2002.

${ }^{118}$ WANDERLEY L. E. W. O que é universidade...., 2003.

119 TRINDADE, H., A universidade numa perspectiva comparada - O ensino superior na América Latina: um olhar longitudinal e comparativo, 2002 In: TRINDADE, H. e Blanquer, J.M. (orgs.) Os Desafios da Educação Na América Latina, Editora Vozes, Rio de Janeiro, 2002, pg.8

SAKATA, Marici Cristine Gramacho, Globalização e Educação: A formação do comunicador social na América Latina, 2008312 p. (Doutorado - Orientação BACCEGA, M. A.) Escola de Comunicações e Artes da Universidade de São Paulo, São Paulo, SP, 2008
} 
universidades. As universidades no Brasil só se estabeleceram no período da República, no século XX.

No século XX o modelo dominante de universidade pública na América espanhola consistia em uma instituição nacional, laica e autônoma, enquanto que no Brasil, as universidades eram regionais, públicas, laicas e não-autônomas criadas a partir da fusão de faculdades. O movimento reformista na América hispânica impulsionou a transformação da universidade republicana elitista em instituição antioligárquica, cujas questões principais eram co-gestão, gratuidade, liberdade de ensino e autonomia universitária. O movimento iniciado na universidade de Córdoba, na Argentina, se propagou pelo Peru, Chile e Uruguai, entre outros, e em 1920 chegou ao México, à Venezuela e América Central. No Brasil, este movimento chegou pela UNEUnião Nacional dos Estudantes - em 1960, com as reivindicações de co-gestão e extinção da cátedra vitalícia. Estes movimentos criaram uma tradição latino-americana: o ensino com compromisso social. (Trindade, $2002^{120}$ )

As instituições latino-americanas desenvolveram seus modelos de ensino superior fortemente baseados nos modelos europeus até 1960. Na década de 1960, as questões políticas que alteraram a estrutura e funcionamento das Instituições de Ensino Latino-Americanas e a expansão do sistema geraram o aumento de matrícula, diferenciação e multiplicação das instituições, presença do setor privado, aumento no número de docentes e mudança na forma de financiamento. (Bentacur, 2000 ${ }^{121}$ ) Com isso, o modelo norte-americano chamou a atenção por sua característica de educação em massa e tipos de instituições diferenciadas. Foi nessa época que cresceu o número de universidades privadas e não-confessionais. Para Trindade (2002 ${ }^{122}$ ), foi o momento do surgimento da complexa relação entre massificação e privatização.

$\mathrm{Na}$ América Latina, em 1950, apenas 2\% dos jovens tinham acesso à Universidade. A massificação se deu entre 1980 e 1990, passando a um percentual de 16,6\%. O número triplicou em alguns países se comparado à taxa de crescimento. No Brasil, não houve massificação no ensino público como nos demais países da América Latina, mas uma expansão significativa do ensino privado. São maioria nas instituições

\footnotetext{
${ }^{120}$ TRINDADE, H. e Blanquer, J.M. Os Desafios da ......, 2002, p. 21

${ }^{121}$ BENTACUR, N. Reforma de La gestion publica y políticas universitárias en América Latina a finales del siglo XX, 2000, Educação Superior: Avaliação da Produção Científica. Peixoto M .(org) Belo Horizonte, Imprensa Universitária da UFMG

${ }^{122}$ TRINDADE, H., A universidade numa ......., 2002, pg.8

SAKATA, Marici Cristine Gramacho, Globalização e Educação: A formação do comunicador social na América Latina, 2008312 p. (Doutorado - Orientação BACCEGA, M. A.) Escola de Comunicações e Artes da Universidade de São Paulo, São Paulo, SP, 2008
} 
privadas os estudantes na Colômbia, no Brasil e no Chile, e minoria no México, na Argentina e no Uruguai (Trindade, 2002) ${ }^{123}$.

\subsection{Instituições Internacionais e Globais}

\section{A Globalização e a Internacionalização do Sistema Universitário}

O termo “globalização” se popularizou nas décadas de 1960 e 1970. Hoje é tema de intenso debate intelectual e popular (Held e Mcgrew, 2001) ${ }^{124}$. O fenômeno da globalização é comumente visto como "a ordem do dia; uma palavra da moda, uma encantação mágica, uma senha capaz de abrir as portas de todos os mistérios presentes e futuros.” (Bauman, 1996) ${ }^{125}$ ou “um fenômeno multifacetado com dimensões econômicas, sociais, políticas, culturais, religiosas e jurídicas interligadas de modo complexo (Santos, 2002) ${ }^{126}$.” Talvez a globalização seja tudo isso junto.

Para compreender a relação entre globalização e educação há a necessidade de se ter uma visão ampla que apreenda as relações entre as várias dimensões, a estrutura de suas interligações e as forças atuantes. Sem esta forma de análise não seria possível uma compreensão adequada. Por outro lado, é necessário que sejam feitos recortes para dar conta do objetivo proposto.

Transportando esta temática para o campo da pesquisa, criam-se diversos desafios e problemas. Um dos problemas que Murphy e Kraidy (2003) ${ }^{127}$ encontraram nos estudos de International Communication Theory serve como base para a vigilância metodológica deste estudo. Os autores afirmam que compreender como a globalização atua localmente nos processos e estruturas sociais tem sido uma meta freqüentemente não alcançada nas pesquisas. Esta dificuldade está na junção de foco das macroestruturas sistêmicas com os microprocessos pesquisados. Neste sentido, o que deve ser evitado é a inabilidade de articular efetivamente as meta-teorias do imperialismo com as pesquisas empíricas, sistemáticas e comparativas locais. Ou seja, faz-se necessário uma transição gradual entre o global e o local para que o discurso não

\footnotetext{
123 TRINDADE, H., A universidade numa ......, 2002

${ }^{124}$ HELD, D. e McGREW, A. Prós e Contras da Globalização, Rio de Janeiro: Zahar, 2001 do original: an introduction to the globalization debate.

125 BAUMAN, Z. Globalização, as conseqüências humanas, tradução Marcus Cortesão e Ianni, O. A sociedade Global, $4^{\text {a }}$ Ed. Rio de Janeiro: Civilização Brasileira, 1996, pg. 7

${ }^{126}$ SANTOS, Boaventura de S. A Globalização e as Ciências ....., 2002 pg.26.

127 MURPHY, P. Kraidy, M. Internacional Communication, Ethnography, and the Challenge of Globalization, Communication Theory, Thirteen: Three, August 2003, pg.304-323
}

SAKATA, Marici Cristine Gramacho, Globalização e Educação: A formação do comunicador social na América Latina, 2008312 p. (Doutorado - Orientação BACCEGA, M. A.) Escola de Comunicações e Artes da Universidade de São Paulo, São Paulo, SP, 2008 
se perca em generalizações por um lado e detalhes pontuais por outro. É necessário que a investigação nos conduza à construção dos objetos e fatos científicos integrados à teoria a fim de formar conceitos que expliquem e interpretem as causas e efeitos, relações de dependências, identidade e diferença entre todos os objetos que constituem o campo investigado (Chauí, 2000) ${ }^{128}$. Voltando à conceituação de globalização, segundo Ianni (1996) ${ }^{129}$

“A globalização não é um fato acabado, mas um processo em marcha. Enfrenta obstáculos, sofre interrupções, mas generaliza-se e aprofunda-se como tendência. Por isso, há nações e continentes nos quais a globalização pode desenvolver-se ainda mais, tem ainda espaços a conquistar."

Por ser um processo dinâmico, e em marcha, e capaz de provocar uma continuidade no acontecimento dos fatos para uma determinada direção, faremos aqui uma breve retrospectiva histórica e uma revisão da literatura sobre a globalização e seus efeitos.

A globalização difere das outras formas de abertura ao ambiente internacional nos seguintes fatores: extensão e nível de integração internacional; ausência de colonialismo declarado; aparecimento de instituições internacionais que governam o direito comercial, tratados e comunidades econômicas regionais; e avanços tecnológicos que tornaram a comunicação e o transporte mais baratos e rápidos (Crenshaw et. al, $2003^{130}$; Meyer et. al, 1997) $)^{131}$

Do ponto de vista econômico a globalização ultrapassa os conceitos de internacionalização, pois não implica apenas na venda de mercadorias a outras localidades; implica principalmente, formas de integração entre nações cujas atividades econômicas são distintas entre si. Embora diversos autores considerem a globalização um fenômeno que já vem ocorrendo nos últimos dois séculos, a globalização que vivenciamos atualmente está baseada principalmente no progresso tecnológico ocorrido nas ultimas décadas. Tal processo possibilitou um aumento no fluxo de informações, nas mudanças das formas de comunicação, na mídia, e na agilização da movimentação de mercadorias entre as localidades. A política liberal juntamente com o fim de

\footnotetext{
${ }^{128}$ CHAUÍ, M. Convite à Filosofia, Editora Ática, 12ª Edição, São Paulo, 2000, pg. 251

${ }^{129}$ IANNI, Octavio. A Sociedade Global. 4ª Edição Rio de Janeiro: Civilização Brasileira, 1996, pg. 24

${ }^{130}$ CRENSHAW et. al., Globalization, Westernization, and ....., 2003.

${ }^{131}$ MEYER et. al, World Society and ....., 1997
} 
barreiras comerciais tem intensificado a velocidade das mudanças. Neste sentido, todos estamos envolvidos, de uma forma ou de outra, neste contexto.

A globalização tem causado mudanças fundamentais na economia e na política mundial. Na visão de teóricos sociais o mundo de hoje é organizado e acelerado pela globalização (Hobsbawn, $1998^{132}$, Kellner, $2002^{133}$, Bates, $2003^{134}$ ). Do ponto de vista 2de Hirst $\left(2002^{135}\right)$ a globalização tem promovido interconexão, em âmbito internacional. No entanto, para Zinkin $\left(2001^{136}\right)$, esta depende de uma idéia que por sua vez é materializada em produtos, instituições ou investimentos, como os projetos desenvolvidos pelo Banco Mundial, entre outros (Neu et al. 2002) ${ }^{137}$.

A globalização pode ser estudada de inúmeras formas, dependendo do foco do pesquisador. Muitas definições são dadas a este fenômeno e uma delas, onde a maioria dos conceitos é convergente, é a de que a globalização é um fenômeno comunicacional, tecnológico e principalmente econômico no qual o comércio internacional, investimentos e fluxo de capital crescente conduzem à integração de sistemas econômicos e políticos locais, sustentados por trocas sociais, culturais, e tecnológicas. (Riccio e Sakata, 2004) $^{138}$. Por não ocorrer de forma homogênea em todos os países, isto significa que algumas regiões podem ser mais globalizadas que outras - dependendo do que é considerado como o objeto de globalização, isto é: capitais financeiros, produtos físicos, serviços, profissionais, educação, informação, conhecimento e cultura, ou o conjunto de todas elas. A informação, o conhecimento e a cultura, por exemplo, podem ser facilmente globalizados porque podem ser compartilhados simultaneamente ao redor do mundo devido ao desenvolvimento dos sistemas de comunicações (Giddens, 1999) ${ }^{139}$. O termo sistema é bastante utilizado neste contexto, e em especial o termo

\footnotetext{
${ }^{132}$ HOBSBAWN, E, The Nation and Globalization, Constellations Volume 5, N1, Blackwell Publishers, USA, 1998

133 KELLNER, D. Theorizing Globalization, Sociological Theory 20:3 Nov. American Sociological Association, USA, 2002

134 BATES, R., Administering the Global Trap, The Role of Educational Leaders, Educational Management \& Administration, Sage Publication, London, Vol 30(2) 139-156, 2002

${ }^{135}$ HIRST, P and Thompson, G. (2002) The Future of Globalization, Cooperation and Conflict: Journal of the Nordic International Studies Association, Vol.37(3): 247-265 Sage Publications

136 ZINKIN, M, Not New and Never Costless: Globalization, International Relations, Sage Publications, Vol. 15(5):27-36. 2001

${ }^{137}$ NEU, D. Ocampo Gomez, E., Ponce de León, O, Flores Zepeda, M. (2002), 'Facilitating’ globalization processes: Financial technologies and the World Bank, Accounting Forum; Sep-Dec, Vol. 26 Issue 3/4 , p.271

${ }^{138}$ RICCIO, E. SAKATA, M. Globalization and Internationalization. Prague, 2004 Proceedings of 27th European Accounting Conference, April 2004

${ }^{139}$ GIDDENS, A. Runaway World: How Globalization is Reshaping our lives, London: Profile Books, 1999, p.10

SAKATA, Marici Cristine Gramacho, Globalização e Educação: A formação do comunicador social na América Latina, 2008312 p. (Doutorado - Orientação BACCEGA, M. A.) Escola de Comunicações e Artes da Universidade de São Paulo, São Paulo, SP, 2008
} 
sistema-mundo que Ortiz (2003) ${ }^{140}$ define "como um conjunto articulado no interior do qual todos os elementos se encontrariam funcionalmente determinados pelo todo”.

A literatura diferencia internacionalização e globalização. Para Daly (1999) ${ }^{141}$ e Ortiz (2003) $)^{142}$, o termo globalização às vezes é confundido com o termo internacionalização: enquanto o primeiro se refere à integração econômica global de economias nacionais em uma economia global (seja do ponto de vista historicista, determinista ou globalista), ou seja, organizado a partir de uma estratégia mundial e voltada para um mercado mundial, o segundo refere-se à importância crescente de relações internacionais, tratados e alianças e expansão geográfica das atividades econômicas através de fronteiras nacionais, o que não é um fenômeno novo, e baseia-se fortemente em dados estatísticos. Estudos desenvolvidos por McCabe $(2001)^{143}$; e Kwick (2001) ${ }^{144}$ também fazem esta distinção entre os dois termos e sugerem que há consensos que interessam a ambos os conceitos. Desta forma, globalização é uma força que cria a necessidade da adoção de padrões, conceitos, cultura e tecnologia, ao mesmo tempo que afeta, como um todo, vários ou muitos países ou regiões, que adotam intencionalmente ou não - essas mudanças. Internacionalização, por outro lado, é o processo pelo qual um país desenvolve um curso de ação para estabelecer relações ou tratados com outra nação ou nações, enquanto objetiva a cooperação e entendimento, e cria com isso um fluxo de informação, de bens e recursos econômicos, de conhecimento, tecnologia e troca educacional, etc., e isso também pode ser considerado um tipo de resposta de um determinado país às forças da globalização. A internacionalização pode ser usada por países menos desenvolvidos como um instrumento, por reduzir a abertura entre o país e as forças de globalização.

Pelo ponto de vista da internacionalização, as instituições de ensino superior já têm estabelecido acordos internacionais de intercâmbio de alunos e professores, programas de pesquisa em comum, duplo diploma, e outras atividades com universidades estrangeiras para impulsionar a compreensão de outras culturas, outros

\footnotetext{
${ }^{140}$ ORTIZ, R. Mundialização e Cultura, São Paulo, Brasiliense, 2003, p.24

${ }^{141}$ DALY, H., Globalization versus Internationalization: Some Implications, School of public affairs, University of Maryland, 1999 URL: http:///www.globalpolicy.org/globaliz/econ/herman2.htm accessed in 11.3.2003

142 ORTIZ, R. Mundialização e Cultura, São Paulo, Brasiliense, 2003, p.15

${ }^{143}$ MCCABE, L. Globalization and Internationalization: The Impact of Education Abroad Programs, Journal of Studies in International Education, Vol. 5 No. 2, Summer 2001, pg. 138-145

${ }^{144}$ KWIEK, M, The Internationalization and Globalization in Central and East European Higher Education, Society for Research in Higher Education International News, No47, November: 2001, pg. 35

SAKATA, Marici Cristine Gramacho, Globalização e Educação: A formação do comunicador social na América Latina, 2008312 p. (Doutorado - Orientação BACCEGA, M. A.) Escola de Comunicações e Artes da Universidade de São Paulo, São Paulo, SP, 2008
} 
valores e sistemas educacionais. Porém, o que ocorre atualmente é a globalização da educação, e os resultados da globalização no ensino superior incluem a introdução e o crescimento de instituições internacionais, de centros de certificação, de padrões para currículo e sistemas de transferência de crédito, e de programa de educação on-line, entre outros.

No cenário da globalização, cresce a competição entre todos os campos, inclusive na educação: as agendas das Instituições Educacionais começam a contemplar estratégias e adaptação frente às pressões internacionais. (Kumar \& Usunier, 2001 ${ }^{145}$, Kwiek, $2001^{146}$, Wallace, $2003^{147}$ ).

Sahlberg (2004) ${ }^{148}$ afirma que as implicações pedagógicas sob o efeito da globalização ainda não foram estudadas o suficiente. Para ele, a globalização está afetando o ensino e o aprendizado de três formas: a) o desenvolvimento educacional está em geral baseado em uma agenda global unificada; b) o ensino e a aprendizagem padronizada têm sido utilizados como veículo para melhorar a qualidade; e c) a ênfase na competição está cada vez em evidência entre os indivíduos e as escolas. Tal padronização pode ser improdutiva na preparação dos estudantes, e, por isso, há que se repensar a forma como as escolas estão se organizando. Assim como hoje a educação busca modelos no mercado de negócios, segundo Sahlberg $(2004)^{149}$, o currículo já seguiu modelos baseados nos princípios de economia de mercado segundo Taylor. O modelo neoliberal atual tem resultado em separações cada vez mais profundas entre escolas de boa qualidade e de má qualidade avaliadas por índices, padrões e dados quantitativos.

Conforme exposto, a Internacionalização e a globalização são fenômenos distintos e isto implica também diferenciação na criação de currículos com objetivos de internacionalização e de globalização.

Os autores a seguir definem os itens que deveriam constar em um currículo internacionalizado. São eles:

- Declaração de missão e objetivos de internacionalização, Internacionalização de currículos, da faculdade, da estrutura organizacional de programas de negócio

\footnotetext{
${ }^{145}$ KUMAR, R, Usunier, Jean-Claude, Management Education in a Globalizing World Lessons from the French Experience, Management Learning, Sage Publications, London Vol. 32(3): 363-391. 2001

${ }^{146}$ KWIEK, M, The Internationalization and......, 2001

${ }^{147}$ WALLACE, M., Managing the Unmanageable, Coping with Complex Educational Change, Educational Management \& Administration, Vol. 31 (19) 9-29: Sage Publication, 2003

${ }^{148}$ SAHLBERG Pasi, Teaching and Globalization, Managing Global Transitions Volume 2 Number 1 Spring, 2004

${ }^{149}$ Ibidem
}

SAKATA, Marici Cristine Gramacho, Globalização e Educação: A formação do comunicador social na América Latina, 2008312 p. (Doutorado - Orientação BACCEGA, M. A.) Escola de Comunicações e Artes da Universidade de São Paulo, São Paulo, SP, 2008 
internacionais e de acordos e convênios internacionais. (Kwok e Arpan, 1994) $)^{150}$

- Preparação dos estudantes para profissões internacionais definidas; conduzir à qualificações profissionais reconhecidas internacionalmente; conduzir diplomas duplos; ter cursos optativos oferecidos em universidades no estrangeiro; ter pessoal para conferências locais sobre assuntos internacionais; oferecer programas interdisciplinares cobrindo mais de um país; contemplar enfoques comparativos em idiomas estrangeiros; focalizar assuntos comparativos em comunicação; prover treinamento em habilidades inter-culturais nas quais o conteúdo é projetado especialmente para estudantes estrangeiros. (IDP Education Austrália, 1995) ${ }^{151}$ :

- Estratégia de integração - Inclusão de aspectos internacionais nos cursos existentes, estratégia de foco: focar a exigência de uma dimensão internacional para cursos particulares; estratégia especializada: oferecer um ou mais cursos especializados em assuntos internacionais; e estratégia prática: Aplicar teorias internacionais e ensinar algo específico por meio de atividades como programas de estágio com companhias envolvidas em mercados internacionais, programas de intercâmbio, treinamento cultural e troca de professores. (Tyagi, 2001) ${ }^{152}$

Tais itens são importantes no processo de internacionalização e não prejudicam os objetivos da educação. Por outro lado, um exemplo de globalização e estandardização já implementado em educação é a Declaração de Bolonha e o ECTS (Sistema Europeu de Transferência de Crédito), que representou uma das bases fundamentais para a implementação de tratados entre países da União Européia. Embora estas mudanças tenham sido projetadas para os países europeus, outras regiões do mundo - como os EUA e o Canadá e alguns países asiáticos - estão celebrando acordos específicos para alinhar seus sistemas educacionais com o sistema europeu e integrarem este sistema.

Marginson (2000) ${ }^{153}$ afirma que com a globalização, a vida acadêmica tem sido pressionada a mudar certos atributos acadêmicos individuais, como os relacionados a competência tecnológica, comunicações, competência lingüística, diversidade cultural,

\footnotetext{
${ }^{150}$ KWOK, Chuck C. Y., Arpan, Jeffrey S. A comparison of international business education at U.S. and European business schools in the 1990s Management International Review v. 34 no. 4 p. 357-79, 1994 ${ }^{151}$ IDP Education Australia, Curriculum development for internationalization. OECD/CERI study. DEET, Canberra:20, 1995

${ }^{152}$ TYAGI, P. Internationalization of Marketing Education: Current Status and Future Challenges, Marketing Education Review, Vol.11 Number 1 Spring, 2001

${ }^{153}$ MARGINSON, S. Rethinking Academic Work in the Global Era, Journal of Higher Education Policy \& Management, May, Vol. 221 pg. .23, 2000.
}

SAKATA, Marici Cristine Gramacho, Globalização e Educação: A formação do comunicador social na América Latina, 2008312 p. (Doutorado - Orientação BACCEGA, M. A.) Escola de Comunicações e Artes da Universidade de São Paulo, São Paulo, SP, 2008 
flexibilidade discursiva, administração de trabalho e demandas por múltiplos papéis em uma organização. Embora a globalização tenha criado exigências adicionais para preparar os estudantes para uma economia global (Smith, 2002) ${ }^{154}$, por outro lado, também está gerando e criando novos empregos para indústrias que lidam com informação nesta economia. Pela necessidade de atender uma demanda crescente de profissionais com habilidades internacionais e de responder a indicadores internacionais, alguns países têm seu setor educacional pressionado tanto para gerar resultados educacionais como financeiros.

No Brasil, como na América Latina, inúmeras pressões estão ocorrendo no ensino superior. Entre elas podemos citar o aumento quantitativo da demanda devido ao aumento da população e de egressos do ensino médio, as reformas para se adaptar à tecnologia, a revisão e o remapeamento das áreas do conhecimento e aos movimentos emancipatórios e ações afirmativas advindas de discussões referentes à injustiça social histórica. Uma das principais conseqüências é a falta de recursos para atender às pressões. Quanto à questão do remapeamento das áreas de conhecimento, a possibilidade de poder pesquisar assuntos inter, multi e transdisciplinares é extremamente importante e representaria um grande avanço para as universidades. No entanto, a burocracia da instituição pública e a questão de "poder" intensifica a dificuldade de relacionamento entre os departamentos.

A tipologia de Sahlberg (2004) ${ }^{155}$ mostra a reforma educacional no processo de globalização. As quatro categorias são: reformas com base em eqüidade (equityoriented reforms), reformas com base em reestruturação (restructuring-oriented reforms), reformas com base em financiamento (financing-oriented reforms) e reformas com base na padronização (standardization-oriented reforms).

\footnotetext{
${ }^{154}$ SMITH, M., Globalisation and local experience: encounters with difference in a UK school, The sociological Review , 2002.

${ }^{155}$ SAHLBERG, P. Teaching and ....., 2004.

SAKATA, Marici Cristine Gramacho, Globalização e Educação: A formação do comunicador social na América Latina, 2008312 p. (Doutorado - Orientação BACCEGA, M. A.) Escola de Comunicações e Artes da Universidade de São Paulo, São Paulo, SP, 2008
} 
Quadro 2 - Tipologia de Tipos de Reformas Educacionais

\begin{tabular}{|c|c|c|c|}
\hline $\begin{array}{l}\text { Equidade. Reforma para } \\
\text { fortalecer o papel político da } \\
\text { educação e mobilidade } \\
\text { social e democrática, } \\
\text { igualdade social e de } \\
\text { oportunidade. }\end{array}$ & $\begin{array}{l}\text { Aumento da equidade de } \\
\text { oportunidades econômicas e } \\
\text { sociais com enfoque em } \\
\text { pelo menos um acesso a boa } \\
\text { educação básica a todos os } \\
\text { estudantes. }\end{array}$ & $\begin{array}{l}\text { Mudança dos gastos } \\
\text { públicos dos níveis mais } \\
\text { altos para os mais baixos de } \\
\text { educação. Expansão da } \\
\text { concepção de qualidade de } \\
\text { educação para além de } \\
\text { conhecimento e habilidades } \\
\text { em assuntos centrais. } \\
\text { Movimento para um } \\
\text { currículo integrado. } \\
\text { Ênfase no profissionalismo } \\
\text { dos professores. }\end{array}$ & $\begin{array}{l}\text { Estender a educação básica } \\
\text { de alta qualidade para o } \\
\text { grupo de baixa renda } \\
\text { incluindo jovens e adultos } \\
\text { que não têm o conhecimento } \\
\text { básico e habilidades. } \\
\text { Meninas e populações } \\
\text { rurais, crianças com } \\
\text { necessidades especiais, } \\
\text { crianças em risco, grupos } \\
\text { marginalizados e refugiados. }\end{array}$ \\
\hline $\begin{array}{l}\text { Financiamento. Reforma do } \\
\text { sistema de ensino para } \\
\text { ajustar os cortes de } \\
\text { orçamento do setor público } \\
\text { e reduzir recursos } \\
\text { disponíveis para financiar a } \\
\text { educação. }\end{array}$ & $\begin{array}{l}\text { Aumento da relação custo- } \\
\text { benefício pela redução dos } \\
\text { gastos públicos em } \\
\text { educação e melhoria da } \\
\text { eficiência no uso de } \\
\text { recursos e na qualidade da } \\
\text { educação. }\end{array}$ & $\begin{array}{l}\text { Reforma da educação por } \\
\text { meio da relação aluno- } \\
\text { professor, aperfeiçoando a } \\
\text { rede escolar e } \\
\text { racionalizando a } \\
\text { administração escolar. }\end{array}$ & $\begin{array}{l}\text { Descentralização da } \\
\text { administração escolar, maior } \\
\text { opção para escolha de } \\
\text { escolas, e administração } \\
\text { privada da provisão para } \\
\text { educação. Responsabilidade } \\
\text { de âmbito local para } \\
\text { melhorar a relação custo- } \\
\text { benefício. }\end{array}$ \\
\hline
\end{tabular}

Fonte: Sahlberg (2004; $70^{156}$ ) Tradução: Autora

\section{A lógica interna da tipologia de Sahlberg indica a reforma da educação rumo a}

uma crescente orientação ao mercado. O resultado para a sociedade, é que as instituições baseadas em estruturas rígidas e inertes não estão aptas a criar conhecimento e inovações ou mesmo desenvolver auto-aprendizado em uma sociedade do conhecimento. Percebemos que a tipologia de Sahlberg segue a lógica da globalização, dos padrões e privatizações entre outros.

A questão da globalização e da padronização dos currículos pode ser vista sob o ponto de vista exclusivamente técnico e visando a objetivos financeiros, como sob o

${ }^{156}$ SAHLBERG, P. Teaching and ....., 2004.

SAKATA, Marici Cristine Gramacho, Globalização e Educação: A formação do comunicador social na América Latina, 2008312 p. (Doutorado - Orientação BACCEGA, M. A.) Escola de Comunicações e Artes da Universidade de São Paulo, São Paulo, SP, 2008 
ângulo humanístico, com vistas à formação global. Com a globalização as pessoas buscam uma formação que permita competir no mercado de trabalho, mas também porque têm a informação de que é possível conhecer novas culturas, vivenciar outros países e buscar soluções para problemas de seu próprio país.

\section{Declaração e Processo de Bolonha}

A declaração de Bolonha foi estabelecida por 29 países em junho de 1999, com o objetivo de se criar um Espaço Europeu para educação. Com isso, estabeleceu-se a necessidade de uma reforma estrutural do sistema de educação superior. O debate e as mudanças caminharam relativamente rápido e, em maio de 2005, 45 países já participavam como signatários no processo de Bolonha ${ }^{157}$.

Cronologicamente, as seguintes declarações foram feitas:

1998 - Sorbonne Declaration: França, Itália, Reino Unido e Alemanha assinaram a Declaração de "harmonização da arquitetura do sistema de educação superior Europeu" na Universidade de Sorbonne em Paris

1999 - Bologna Declaration: Vinte ministros europeus responsáveis pela educação superior formaram as bases para o estabelecimento de um Espaço Europeu de Educação Superior que deverá estar funcionando até 2010. Tornou-se o “Processo de Bolonha” 2001 - Prague Communiqué: Quatro novos países se juntam ao processo, no qual foi feita uma menção aos aspectos sociais que devem ser considerados na reforma educacional.

2003 - Berlin Communiqué: Quarenta países passaram a fazer parte do processo, incluindo a Rússia e o Sudoeste da Europa. Programas de Doutorado (PhD) foram incluídos no escopo do Espaço Europeu de Educação Superior.

2005 - Bergen Communiqué: Cinco novos países foram incluídos ao processo. Os Ministros da educação da Europa concordaram em estabelecer padrões europeus e linhas diretrizes para garantia da qualidade.

2007 - London Communiqué: Inclusão de Montenegro no processo. As prioridades para 2009 decididas na reunião foram: Mobilidade, Dimensão social, Coleta de dados,

\footnotetext{
${ }^{157}$ Declaração de Bolonha, Disponível em http://www.eua.be/eua/jsp/en/upload/OFFDOC_BP_bologna_declaration.1068714825768.pdf, acesso em 10/11/2006

SAKATA, Marici Cristine Gramacho, Globalização e Educação: A formação do comunicador social na América Latina, 2008312 p. (Doutorado - Orientação BACCEGA, M. A.) Escola de Comunicações e Artes da Universidade de São Paulo, São Paulo, SP, 2008
} 
Empregabilidade, inserir o European Higher Education Area em um contexto global e fazer um balanço das atividades.

2009 - Benelux Communiqué a se realizar em Louvain-la-Neuve, Bélgica.

2010 - European Higher Education Area - prazo para estabelecimento do Espaço Europeu.

A participação no processo de Bolonha é voluntária e não há legislações envolvidas. As instituições envolvidas em cada país são universidades, institutos, estudantes, agências educacionais, etc. As reformas estão baseadas em objetivos simples, e todos os países participantes concordaram em compatibilizar o sistema de graus em três ciclos: graduação - Licenciatura (undergraduates - Bachelor degrees) e pós-graduação Mestrado e Doutorado (graduates - Master e PhD degrees), ou seja, o LMD - Licenciatura, Mestrado e Doutorado.

O processo de Bolonha, segundo suas publicações, não pretende harmonizar os sistemas de educação nacionais, mas apenas prover ferramentas para interligá-los, ou seja, a intenção é permitir que a diversidade dos sistemas e das universidades nacionais em termos de cultura, linguagem e missão sejam mantidas. O "Espaço Europeu de Educação Superior” deve melhorar a transparência entre os sistemas educacionais bem como criar ferramentas para facilitar o reconhecimento de graus e qualificações acadêmicas, mobilidade e trocas entre instituições. No entanto, há muita crítica ao processo de Bolonha. Diversos pesquisadores acreditam que o propósito da integração foi fundamentalmente econômico e com o objetivo de manter a competitividade com os demais sistemas educacionais mundiais. A crítica é pertinente e o Processo de Bolonha, assim como os demais acordos estabelecidos na área de educação, devem ser pensados em conjunto com a sociedade. Os resultados devem ser constantemente analisados pela população e é de extrema importância que seja mantida uma visão crítica. Desta forma será possível adequar e aperfeiçoar o sistema para que ele atenda não somente a interesses financeiros mas principalmente aos interesses sociais.

O Processo de Bolonha foi assinado por Ministros da educação, representantes das Universidades Européias, Institutos de Educação Superior Profissional, Estudantes (ESIB), Agências de certificação de qualidade (ENQA) e a CEPES-UNESCO (UNESCO-CEPES) United Nations Educational, Scientific and Cultural Organisation European Centre for Higher Education. O processo tem o apoio da Comissão Européia, da União Européia e do Conselho Europeu. 
As instituições envolvidas são:

- European University Association (EUA)

- European Association of Institutions in Higher Education (EURASHE)

- The National Unions of Students in Europe

- The National Union of Students (NUS)

- European Commission (EC)

- The Council of Europe (CoE)

- European Association for Quality Assurance in Higher Education (ENQA)

- ENIC-NARIC Network (National recognition information centres in EU member states (the NARICs) and in non-EU European countries (the ENICs)

- UNESCO European Centre for Higher Education (UNESCO-CEPES) UNESCOCEPES

- The Bologna Secretariat

Os objetivos estabelecidos na Declaração de Bolonha são:

1. Adoção de um sistema de graus facilmente legíveis e comparáveis, e também a implementação do suplemento de diploma, para promover a empregabilidade de cidadãos europeus e a competitividade internacional do sistema de ensino superior europeu.

2. Adoção de um sistema essencialmente baseado em três ciclos principais, a graduação e a pós-graduação, com mestrado e doutorado. ( $1^{\circ}$ ciclo: 3 anos, $2^{\circ}$ ciclo: 2 anos, $3^{\circ}$ ciclo: 3 anos). O acesso ao segundo e terceiro ciclo requererá conclusão próspera do primeiro ciclo, que deve ter duração de no mínimo três anos. O grau dado após o primeiro ciclo deve ser relevante para a entrada no mercado de trabalho europeu como uma qualificação. O grau no segundo ciclo deve conferir o título de mestre e/ou doutor.

3. Estabelecimento de um sistema de créditos - como o sistema ECTS - com meios próprios de promover a mobilidade de estudantes. Também podem ser adquiridos créditos em contextos não-educacionais, como aprendizagem ao longo da vida.

4. Promoção de mobilidade superando obstáculos, com atenção particular para:

- estudantes: acesso a oportunidades para estudar, estagiar e exercer serviços relacionados

- professores, pesquisadores e pessoal administrativo, reconhecimento e valorização de períodos gastos em um contexto europeu com pesquisa, ensino e treinamento sem prejudicar os direitos estatutários.

5. Promoção de cooperação européia que garanta a qualidade com o objetivo de desenvolver critérios comparativos e metodologias. 
6. Promoção das dimensões européias necessárias em ensino superior, particularmente para desenvolvimento de currículo, cooperação interinstitucional, planejamento de mobilidade e programas integrados de estudo, treinamento e pesquisa.

Outros três objetivos/ações incluídos no Prague Communiqué de 2001:

7. Aprendizagem ao longo da vida;

8. Instituições de ensino superior e estudantes;

9. Promover a atratividade do EHEA-Espaço de Ensino Superior Europeu.

Uma décima linha de ação foi introduzida no Berlim Communiqué de 2003 :

10. Promover os estudos doutorais e a sinergia entre o EHEA e a ERA-Espaço de Pesquisa Europeu.

\section{Educação e Modernização na América Latina}

Mudanças consideráveis têm acontecido em todas as áreas na América Latina como resultado da globalização. A educação superior na América Latina responde a uma das grandes preocupações dos governos locais devido à sua dimensão. Conforme dados do $\mathrm{BID}^{158}$, a matrícula universitária foi estimada em 7,4 milhões de estudantes em 2003.

A Modernização da educação na América Latina tem sido discutida em fóruns nacionais e mundiais, e principalmente na Unesco.

Perry (2003) ${ }^{159}$ discute a desvantagem dos países da América Latina e Caribe em relação aos Estados Unidos e Europa e para tanto analisa a forte interação entre ensino e tecnologia. Afirma que "esta relação contribui significativamente para explicar as diferenças em produtividade e ingressos entre os países da América Latina e outros”. Como resultado de sua análise ${ }^{160}$, afirma que “o diagnóstico que surge destas análises é que, até pouco tempo, os países da América Latina e Caribe não davam a merecida importância à inovação, à ciência e à tecnologia dentro de suas estratégias de desenvolvimento. ... Sem dúvida, a abertura dos países da América Latina e Caribe os têm brindado com um maior acesso às diversas tecnologias que se têm desenvolvido no exterior.” Neste sentido, o autor, dentro do paradigma do mercado

\footnotetext{
${ }^{158}$ SEGRERA, F. L. (2003) El impacto de la globalización y las políticas educativas em los sistemas de educação, Las universidades en América Latina: ¿Reformadas o alteradas? (Buenos Aires: CLACSO), 39-58.

${ }^{159}$ PERRY, G. Cerrando la brecha en educación y tecnología, Banco Mundial 25, 1-4. 2003

160 Ibidem, p. 3

SAKATA, Marici Cristine Gramacho, Globalização e Educação: A formação do comunicador social na América Latina, 2008312 p. (Doutorado - Orientação BACCEGA, M. A.) Escola de Comunicações e Artes da Universidade de São Paulo, São Paulo, SP, 2008
} 
global, ressalta a importância de um esforço destes países em desenvolverem o ensino e a tecnologia simultaneamente para poderem “competir” globalmente.

Além de pesquisas, existem também na América Latina espaços para compartilhamento de informações sobre as instituições de ensino como a "Red Regional de Innovaciones Educativas INNOVEMOS”, que tem como objetivo atuar como: fórum permanente de reflexão, produção, intercâmbio e difusão de conhecimentos e práticas a cerca das inovações e o intercâmbio educativo, para contribuir ao aprimoramento da qualidade e eqüidade da educação e suas distintas modalidades e programas. Este sistema inclui instituições de natureza e âmbito de competência distinta, níveis territoriais distintos e diferentes áreas temáticas e é coordenada pela Oficina Regional de Educação da UNESCO/Santiago e financiada pelo governo da Espanha. A rede conta até hoje com a participação de 15 países: Argentina, Bolivia, Brasil, Colômbia, Chile, Cuba, Equador, El Salvador, Espanha, México, Panamá, Peru, República Dominicana, Uruguai e Venezuela.

No Brasil, a Secretaria de educação superior ligada ao Ministério da educação dispõe do Departamento de Projetos Especiais de Modernização e Qualificação do Ensino Superior - DEPEM. Neste departamento foi criado o Programa de Modernização e Consolidação da Infra-Estrutura Acadêmica das Instituições Federais de Ensino Superior (IFES) e Hospitais Universitários (Hus), que visa a renovar e inovar práticas e metodologias de ensino e equipar ou reequipar a estrutura física dos laboratórios e oficinas didáticas das 52 Instituições Federais de Ensino Superior do $\mathrm{MEC}^{161}$.

Assim, nota-se que existem diversas intenções por parte dos dirigentes e órgãos governamentais em apoiar o desenvolvimento da educação visando a modernização e a qualidade.

\section{Organismos Internacionais e a Educação como Serviço}

Além dos órgãos nacionais, existem atualmente diversas organizações internacionais de natureza intergovernamental que atuam no campo educacional. Podem-se distinguir os organismos internacionais envolvidos com o sistema de educação superior em organismos financeiros e de recomendação. Os principais organismos financeiros são o Banco Mundial (World Bank), o Fundo Monetário

\footnotetext{
${ }^{161}$ MEC, Dados Disponíveis em: http://www.mec.gov.br/Sesu/moderniz.shtm Acesso em 05.10.2005
} 
Internacional (FMI), o Banco Interamericano de Desenvolvimento (BID) e Organização para a Cooperação e Desenvolvimento Econômico (OCDE). Os principais organismos de recomendações são a Organização das Nações Unidas para a Educação, a Ciência e a Cultura (UNESCO), Organização Mundial do Comércio (OMC), Organização das Nações Unidas (ONU) e a Comissão Econômica para a América Latina e o Caribe (CEPAL), entre outros.

Embora não exerçam poder de decisão, os organismos internacionais, principalmente os financeiros, têm grande influência sobre as políticas dos países, e suas metas emergem a partir dos modelos dos países à frente do desenvolvimento. Cada organismo segue sua linha de políticas e não necessariamente concordam entre si. Tanto os financeiros como os de recomendação atuam fortemente em pesquisas e estatísticas, e inúmeros documentos são disponibilizados em formato digital para acesso. Tais documentos são altamente relevantes para a análise do desenvolvimento dos setores em determinados países e em comparação aos demais.

Uma breve definição de cada um dos organismos será feita, a começar pelas três mais importantes instituições que “controlam a globalização” (Stiglitz, 2000) ${ }^{162}$ : o FMI, o Banco Mundial e a OMC.

O FMI - Fundo Monetário Internacional - surgiu no final da Segunda Guerra Mundial, criado pelos líderes mundiais para controlar as finanças dos países por meio da garantia do valor das moedas e reservas dos países com base no padrão-ouro. Sua tarefa é assegurar estabilidade econômica global. Exerce pressão internacional sobre os países que não contribuem para a manutenção da demanda global agregada e fornece liqüidez (empréstimos) para nações em períodos de dificuldade. É uma instituição pública mantida por contribuintes do mundo todo e reporta-se aos ministros da fazenda e aos bancos centrais dos governos do mundo. Somente os Estados Unidos têm poder de veto - a votação é baseada no poder econômico dos países no final da Segunda Guerra Mundial (Stiglitz, 2000) ${ }^{163}$. O FMI concede recursos somente aos países que se engajam em políticas como corte de gastos, aumento de impostos e elevação de taxas de juros para retração da economia.

O Banco Mundial - Banco Internacional para a Reconstrução e Desenvolvimento - foi criado em 1944, como um Banco Internacional para a

${ }^{162}$ STIGLITZ, Joseph, A globalização e seus malefícios, A promessa não-cumprida de benefícios globais. São Paulo Ed. Futura, 2000 Tradução Bazán Tecnologia e Lingüística do original Globalization and its discontents.

${ }^{163}$ Ibidem, pg. 39

SAKATA, Marici Cristine Gramacho, Globalização e Educação: A formação do comunicador social na América Latina, 2008312 p. (Doutorado - Orientação BACCEGA, M. A.) Escola de Comunicações e Artes da Universidade de São Paulo, São Paulo, SP, 2008 
Reconstrução e o Desenvolvimento, juntamente com o FMI, como parte de um esforço para financiar a reconstrução da Europa após a Segunda Guerra Mundial.

Em 1970, como parte do programa de diminuição da pobreza, o setor educativo foi incorporado. O Banco Mundial passou então a agrupar um grupo de experts para desenvolver estudos sobre as regiões. Na década de 1980 o Banco Mundial passou a agir conjuntamente com o FMI, ou seja, os empréstimos só eram feitos com a aprovação do FMI e conseqüentemente quando os países cumpriam as condições impostas pelo Fundo. Em 1980, o Banco Mundial fez a primeira intervenção na educação secundária por meio de empréstimos baseados em políticas públicas. Uma das conseqüências desta ação pode ser vista pelo período de grande privatização do setor. Em 1990, elaborou documentos de política para a educação básica (1990); educação técnica (1992) e educação Superior (1994). (Fonte: Banco Mundial)

A educação superior, assim como diversos outros setores, nos países latinoamericanos, passou por momentos de crise no último século e com isso, a depender cada vez mais de financiamento internacional, e a se submeter a propostas dos organismos, em especial os de financiamento. Uma das propostas foi a de incentivar a educação privada a fim de diversificar a fonte de financiamento. O Banco Mundial também recomendou a reestruturação da gestão e estabeleceu procedimentos obrigatórios para obter recursos, como implementação de sistema de certificação, autoavaliação e avaliação externa, e participação do setor produtivo nos Conselhos.

O IFC - International Finance Corporation se define como um braço privado do Grupo Banco Mundial. O IFC foi criado em 1956 com o objetivo de promover o investimento sustentável no setor privado em países em desenvolvimento, ajudando a reduzir a pobreza e melhorar a vida das pessoas. O IFC provê empréstimos, patrimônio líqüido, finanças estruturadas, produtos para gestão de risco e serviços de assessoria para construir o setor privado em países em desenvolvimento. Como qualquer outro investidor do setor privado e emprestadores comerciais, o IFC busca retornos lucrativos, precifica suas finanças e serviços de acordo com o mercado e divide os riscos totais com seus parceiros. (IFC, $2006^{164}$ )

A presença do IFC no setor educacional terciário tem se intensificado. Segundo a própria instituição, o IFC apóia o desenvolvimento de universidades privadas em economias em desenvolvimento, tanto presencial como e-learning. O IFC ajuda os

\footnotetext{
${ }^{164}$ IFC report on regions 2006 http://www.ifc.org/ifcext/lac.nsf/AttachmentsByTitle /AR2006_LAC_Overview/\$FILE/AR2006_LAC.pdf

SAKATA, Marici Cristine Gramacho, Globalização e Educação: A formação do comunicador social na América Latina, 2008312 p. (Doutorado - Orientação BACCEGA, M. A.) Escola de Comunicações e Artes da Universidade de São Paulo, São Paulo, SP, 2008
} 
investidores privados e patrocinadores a articular e implementar estratégias que irão facilitar o desenvolvimento de instituições de terceiro grau de qualidade nos países em desenvolvimento. O interesse do IFC é apoiar o setor privado no desenvolvimento de treinamento pós-secundário vocacional e técnico (para capacitar pessoas para os setores industriais e força de trabalho). Os resultados obtidos devem ser para o bem público e para gerar retornos justos aos investidores.

O IFC tem participado ativamente na América Latina. O primeiro investimento se deu em 1956 no valor de 2 milhões de dólares para a empresa Siemens produzir equipamentos no Brasil. Após 50 anos, mais de 31 bilhões de dólares foram investidos na América Latina e Caribe. Na Argentina, o IFC investiu 6 bilhões de dólares em 112 empresas. No Brasil, em 1970, o IFC investiu 8 bilhões de dólares em 167 empresas incluindo o primeiro projeto petroquímico. No México, o IFC investiu 80 milhões de dólares no grupo Visa, que é hoje o FemsA (Fomento economico mexicano, S.A.). Na Colômbia ${ }^{165}$, desde 1990, o IFC auxilia no desenvolvimento de um mercado de capital mais eficiente e apoiou a primeira companhia de hipotecas.

O México, a Colômbia e o Chile tornaram-se membros do IFC em 1955. O Brasil, a Argentina e a França em 1956, e a Espanha em 1960. (IFC, 2007) ${ }^{166}$

No setor de educação superior, foram localizados os seguintes projetos latinoamericanos no IFC:

No Brasil, o Projeto Número 24398 (2005/2006), do Fundo de Educação para o Brasil (FEBR) se refere a um projeto estimado em 71 milhões de dólares, sendo mais de 16 milhões do IFC. A FEBR foi organizada pelo Banco Pátria, um dos maiores do Brasil em private equity, e com isso adquiriu 69\% das ações do Anhanguera Educacional S.A. (AES), grupo educacional privado voltado para estudantes de ensino superior de baixa renda. O AES possuía 10 campi e cerca de 16.800 alunos em 2005. O objetivo do fundo, segundo o projeto, é investir em uma estratégia de expansão num período de 3 anos, focando cidades de pequeno e médio porte no Estado de São Paulo e outras regiões no Sudeste (região mais próspera do Brasil). ${ }^{167}$ (Ver Anexo I para texto integral)

\footnotetext{
165 IFC, http://www.ifc.org/ifcext/CHEPublication.nsf/6d82f125

5172104a85256bdd006631e8/1f9d70a85e2544c285256c02006efdc6/\$FILE/Colombia.pdf.

${ }^{166}$ IFC, 2007. Disponível em http://www.ifc.org/ifcext/about.nsf /Content/Member_Countries_Chronological acesso em 07/07/2007

167 A Anhanguera Educacional Participações S.A. comprou em outubro de 2007 a Universidade para o Desenvolvimento do Estado e Região do Pantanal (Uniderp) e outras cinco instituições de ensino superior de Mato Grosso do Sul que pertencem ao empresário Pedro Chaves Santos Filho, reitor da

SAKATA, Marici Cristine Gramacho, Globalização e Educação: A formação do comunicador social na América Latina, 2008312 p. (Doutorado - Orientação BACCEGA, M. A.) Escola de Comunicações e Artes da Universidade de São Paulo, São Paulo, SP, 2008
} 
Na Argentina foram localizados dois projetos. O Projeto Número 9886 (2000), da Universidad del Salvador (USAL) se refere a um projeto de 20 milhões de dólares, sendo 10 milhões do IFC. Na Argentina as universidades devem ser operadas como fundações sem fins lucrativos, e no caso da USAL, é a Asociación Civil Universidad del Salvador quem opera. O projeto, estimado em 4 anos, tinha como proposta melhorar o Campus de Pilar, na Província de Buenos Aires, ou seja, construir novas salas de aula, auditório, biblioteca, dormitórios e clínicas. A justificativa do IFC para este investimento é de que liderando esta iniciativa de investir em uma instituição educacional demonstrará aos outros investidores a viabilidade comercial de investimentos privados em instituições como a USAL, uma vez que cria mercados novos e levanta capital para financiar o crescimento de instituições de ensino. ${ }^{168}$

O outro projeto é o de Número 8545 (1998) da Universidad de Belgrano - UB, Argentina. A UB é gerida pela Fundación Universidad de Belgrano "Doctor Avelino Porto". O projeto foi estimado em 49 milhões de dólares, sendo 22 milhões do IFC para melhorar sua posição de competitividade no setor privado de educação superior. O projeto se referia à construção de um novo prédio, refinanciar o empréstimo e ajudar a capitalizar um programa de empréstimos para alunos.

\section{Investimento no Mercado de Educação Superior (Brasil, Argentina e} Colômbia) - o ponto de vista do IFC - o IFC também publica - para possíveis investidores - o boletim Edinvest que contém informações sobre determinados Mercados, como por exemplo, o de educação superior em determinados países. (Investiment Outlook). O EdInvest $\left(2000^{169}\right)$ apresenta um sumário sobre o Mercado Educacional Privado Brasileiro, Argentino e Colombiano.

Uniderp. Com estas aquisições, nos seis estabelecimentos, totalizam 37 mil alunos e 1.400 funcionários. Ou seja, um aumento de 20200 alunos de 2005 a 2007. Também em 2007 a Anhanguera Educacional abriu seu capital na Bolsa de Valores de São Paulo (Bovespa) que, segundo fonte, teve 75\% dos papéis comprados por investidores estrangeiros - atualmente não há limites legais para o investimento estrangeiro em universidades no País - e captou $R \$ 350$ milhões. Em julho de 2007 outros dois grupos privados também abriram o capital na Bovespa, o grupo Pitágoras, de Minas Gerais (do Grupo internacional Apollo) e a Universidade Estácio de Sá, no Rio - maior instituição de ensino superior do Brasil em número de alunos, com 176 mil matriculados.

Agência Estado, Anhanguera compra grupo de 6 universidades, 02/10 - 12:57 Disponível em

http://ultimosegundo.ig.com.br/educacao/2007/10/02/anhanguera_compra_grupo_de_6_universidades_10 28862.html acesso em 27/12/2007

${ }^{168}$ IFC, idem Increases in productivity could be jeopardized unless the education system is able to match the demands of the market for well-educated, skilled and flexible graduates. Investments in the private system will complement an overcrowded public system and enhance the overall quality of higher education and its graduates.

${ }^{169}$ World Bank Investment Opportunities In Private Education In Brazil, EdInvest, 2000, Disponivel em http://www.ifc.org/ifcext/CHEPublication.nsf/bf3b1473553819eb85256bdd0067f34d//9867d25e9cabc06 85256c02006e573a/\$FILE/Brazil.pdf. acesso em 01/07/2007

SAKATA, Marici Cristine Gramacho, Globalização e Educação: A formação do comunicador social na América Latina, 2008312 p. (Doutorado - Orientação BACCEGA, M. A.) Escola de Comunicações e Artes da Universidade de São Paulo, São Paulo, SP, 2008 
No caso do mercado brasileiro, é destacada a estabilidade do mercado brasileiro nos últimos anos. O boletim afirma que apesar do sistema privado não receber incentivo direto do governo a pesquisa realizada pela SIEEESP em 1997 revelou que 90\% das escolas são Companhias Limitadas. As principais cadeias destacadas são: UNIP, Positivo, Pitágoras e COC, além do Instituto Radial e o Colégio Pentágono, todas voltadas para o público de média renda. O boletim traz, também, a prospecção para expansão e o potencial para investimento, conforme destacamos a seguir:

Prospecção para expansão: 1) a influência da globalização da economia no setor educacional privado, o que gera demanda de profissionais mais qualificados especialmente nas empresas internacionais; 2) aumento do desemprego e conseqüentemente aumento na procura por maior qualificação profissional; 3) demanda por educação privada devido à insuficiência do setor público.

Potencial para o investimento do IFC: 1) Em geral a economia brasileira está melhorando; 2) o regime regulatório para educação privada não é tão oneroso como em outros países em desenvolvimento e muitas empresas educacionais tiveram imenso sucesso atuando neste regime. O governo também aprova o investimento em educação privada e não impõe obstáculos para investimos externos; 3) o setor é um dos mais vibrantes e inovadores de todos os países pesquisados e há indicativos de que as maiores escolas e cadeias estariam interessadas em investir através do IFC; 4) Como há demanda para expansão e obstáculos para levantar fundos em bancos, o investimento externo se torna atrativo; e 5) há uma crescente tendência de escolas privadas procurarem fundos internacionais baseando-se nos modelos de sucesso do Colégio Porto Seguro (de origem alemã), Miguel Cervantes (de origem espanhola), e outros.

No caso do mercado argentino, a primeira parte do boletim sumariza o cenário educacional argentino e as políticas atuais. Quanto ao potencial de investimento do IFC, são destacados os seguintes pontos:

O histórico apresenta um quadro desencorajador à primeira vista para qualquer organização que procura oportunidades de investimento em educação na Argentina.

A educação privada está sujeita a numerosos regulamentos que protegem a autonomia e passam por inspeções periódicas, o que desencoraja os investidores potenciais. No entanto, a ineficiência do sistema atual e o crescimento do setor privado em educação na Argentina demonstram a busca por alternativas - o que significa oportunidades de investimentos e um clima moderavelmente favorável. Ensino superior 
e treinamento vocacional parecem oferecer as melhores oportunidades para investimento de IFC, por serem as áreas de maior crescimento e as que sofrem menor restrição por parte dos órgãos reguladores do governo. Porém, as universidades só podem operar como instituições sem fins lucrativos.

No caso do mercado colombiano, o boletim mostra que o setor privado é grande, e mais de $60 \%$ dos estudantes universitários estão no setor privado. O potencial para investimento neste setor na Colômbia para o IFC é muito positivo pelas seguintes razões: 1) o governo sinalizou que investimentos estrangeiros são bem-vindos. O International Investments Act apóia investimentos externos baseados nos princípios de Igualdade (mesmo tratamento para os investimentos nacionais e internacionais), Universalidade (investimentos externos são permitidos em quaisquer setores da economia) e Diminuição de Burocracia; 2) o sistema regulatório não impõe fardos ao setor privado educacional; 3) há um setor privado germinando, buscando investimento adicional para se expandir; 4) grande demanda por educação privada.

Desta forma, podemos perceber que há mais barreiras de entrada na Argentina do que no Brasil.

A OMC - Organização Mundial do Comércio e o GATS - Acordo geral de comércio e serviços - educação como serviço - Uma terceira organização econômica internacional que controla as relações comerciais internacionais criada foi: a Organização Mundial do Comércio-OMC (WTO-World Trade Organization). A OMC não estabelece regras, mas um fórum de negociações, e assegura que os acordos sejam cumpridos. O tratamento que tem sido dado à Educação superior pelos organismos internacionais como a OMC tem provocado diversas mudanças no setor. Uma delas é decorrente da visão da Educação como um serviço.

Segundo Knight (2002 ${ }^{170}$;2), o comércio de serviços de ensino superior é uma indústria que envolve bilhões de dólares, incluindo recrutamento de estudantes internacionais, estabelecimento de campi universitários no estrangeiro, franquias e educação à distância ${ }^{171}$.

As regras multilaterais para comercialização internacional de serviços só surgiram com a criação do GATS - Acordo Geral de Comércio em Serviços (General

\footnotetext{
${ }^{170}$ KNIGHT, Jane. Trade in Higher Education Services: The Implications of GATS. The Observatory on Borderless Higher Education March, 2002

${ }^{171}$ Knight afirma que o termo 'internacionalização não lucrativa' foi cunhado para distinguir educação internacional de comércio em serviços de educação objeto do GATS - General Agreement on Trade in Services

SAKATA, Marici Cristine Gramacho, Globalização e Educação: A formação do comunicador social na América Latina, 2008312 p. (Doutorado - Orientação BACCEGA, M. A.) Escola de Comunicações e Artes da Universidade de São Paulo, São Paulo, SP, 2008
} 
Agreement on Trade in Services) - sob a tutela da Organização Mundial do Comércio OMC que congrega 144 países e foi projetado e ativado em 1995 para aumentar a liberalização do comércio internacionalmente.

A primeira parte do GATS é a estrutura que contém os princípios e as regras gerais; a segunda consiste nas agendas nacionais que listam os compromissos específicos de cada país para o acesso de seus mercados domésticos por fornecedores estrangeiros. A terceira parte consiste em anexos que detalham limitações específicas para cada setor.

No quadro “Modos de fornecimento de acordo com o GATS” Knight (2002) ${ }^{172}$ apresenta os quatro modos e os aplica à educação superior

Quadro 3 - Modelos de Fornecimento de Educação de acordo com o GATS

\begin{tabular}{|c|c|c|c|}
\hline $\begin{array}{c}\text { Modos de } \\
\text { fornecimento de } \\
\text { acordo com o } \\
\text { GATS }\end{array}$ & Explicação & $\begin{array}{c}\text { Exemplos na } \\
\text { Educação Superior }\end{array}$ & $\begin{array}{c}\text { Tamanho e Potencial de } \\
\text { Mercado }\end{array}$ \\
\hline $\begin{array}{l}\text { 1. Fornecimento } \\
\text { de fronteira }\end{array}$ & $\begin{array}{l}\text { a prestação de um serviço } \\
\text { que cruza fronteiras (não } \\
\text { requer o movimento físico } \\
\text { do consumidor) }\end{array}$ & $\begin{array}{l}\text { - educação à distância } \\
\text { - e-learning } \\
\text {-universidades virtuais }\end{array}$ & $\begin{array}{l}\text { - Atualmente um mercado } \\
\text { relativamente pequeno } \\
\text { - visto como um grande } \\
\text { potencial pelo uso das novas } \\
\text { Tec. de Informação e } \\
\text { Comunicação -TIC e } \\
\text { especialmente a Internet }\end{array}$ \\
\hline $\begin{array}{l}\text { 2. Consumo no } \\
\text { exterior }\end{array}$ & $\begin{array}{l}\text { - prestação de um serviço } \\
\text { envolvendo o movimento } \\
\text { de } \\
\text { consumidores para o país } \\
\text { provedor }\end{array}$ & $\begin{array}{l}\text { - estudantes que vão } \\
\text { para outro país para } \\
\text { estudo }\end{array}$ & $\begin{array}{l}\text { - atualmente representa a } \\
\text { maior parte do mercado } \\
\text { global em serviços de } \\
\text { educação }\end{array}$ \\
\hline $\begin{array}{l}\text { 3. Presença } \\
\text { comercial }\end{array}$ & $\begin{array}{l}\text { - o prestador de serviço } \\
\text { estabelece ou tem a } \\
\text { presença de instalações } \\
\text { comerciais em outro país } \\
\text { para prestar o serviço }\end{array}$ & $\begin{array}{l}\text { - filial local ou } \\
\text { campi satélites } \\
\text { - união de parcerias } \\
\text { - franchising } \\
\text { - arranjos com } \\
\text { instituições locais }\end{array}$ & $\begin{array}{l}\text { - interesse crescente e } \\
\text { potencial forte para } \\
\text { crescimento futuro } \\
\text { - o mais controverso uma } \\
\text { vez que isto parece fixar } \\
\text { regras internacionais sobre } \\
\text { investimento estrangeiro }\end{array}$ \\
\hline $\begin{array}{l}\text { 4. Presença de } \\
\text { pessoas nativas }\end{array}$ & $\begin{array}{l}\text { - Viagem de pessoas para } \\
\text { outros países } \\
\text { temporariamente para } \\
\text { prestar serviço }\end{array}$ & $\begin{array}{l}\text { - professores e } \\
\text { pesquisadores } \\
\text { trabalhando } \\
\text { no exterior }\end{array}$ & $\begin{array}{l}\text { - potencialmente um } \\
\text { mercado forte dada a ênfase } \\
\text { na mobilidade de } \\
\text { profissionais }\end{array}$ \\
\hline
\end{tabular}

Fonte: KNIGHT, Jane. Trade in Higher Education Services: The Implications of GATS. The Observatory on Borderless Higher Education March 2002 - Traduzido pela autora.

O Comércio em educação está organizado em cinco categorias de serviços. Estas categorias estão baseadas na Classificação Central de Produtos (CPC) Provisória das Nações Unidas.

As Categorias de serviços e atividades incluídas são:

${ }^{172}$ KNIGHT, Jane. Trade in Higher Education ....., 2002.

SAKATA, Marici Cristine Gramacho, Globalização e Educação: A formação do comunicador social na América Latina, 2008312 p. (Doutorado - Orientação BACCEGA, M. A.) Escola de Comunicações e Artes da Universidade de São Paulo, São Paulo, SP, 2008 
- Educação Primária (CPC 921): pré-escola, serviços educacionais. Não inclui serviço de cuidados especiais

- Educação Secundária (CPC 922): secundário; técnico e secundário vocacional; e serviços para deficientes

- Educação Superior (CPC 923): educação secundária técnica e secundário vocacional; outros serviços de ensino superior que conduzem a um grau universitário ou equivalente;

- Educação de Adultos (CPC 924): educação de adultos fora do sistema de educação regular

- Outras Educações (CPC 929): todos os demais serviços de educação ainda não classificados.

Apesar de tudo, a OMC leva em consideração uma porcentagem maior de propostas apresentadas pelos Estados Unidos e pela União Européia, restando cerca de 15\% para o resto do mundo, o que dificulta o poder de decisão.

Segundo Paulino (2002) ${ }^{173}$,

As relações internacionais de troca do Brasil e outros países em desenvolvimento como os da América Latina não são muito positivas. $O$ Brasil, por exemplo, exporta um volume cada vez maior de mercadorias e obtém pela sua venda no mercado internacional um montante cada vez mais reduzido de recursos. Exportam-se mercadorias com cada vez menos valor agregado e importam-se produtos cada vez mais sofisticados.

\section{A OCDE - Organização para a Cooperação e Desenvolvimento Econômico}

foi criada em 1948 como OECE - Organização Européia de Cooperação Econômica - e em 1961, com a entrada dos Estados Unidos e do Canadá, passou a ser denominada OCDE - Organização para a Cooperação e o Desenvolvimento Econômico. As preocupações da OCDE são de fundo econômico. Em 1948, estipulou o uso completo da mão-de-obra disponível, e com isso criou, em 1953, a Agência Européia de Produtividade, e em 1958, o Bureau do Pessoal Científico e Técnico. Em 1970 criou o

\footnotetext{
173 PAULINO, Luís Antônio, O Brasil, seus sócios e seus negócios, São Paulo em Perspectiva, 16(2): 8293, 2002
} 
Comitê de Educação, tendo como lema a convicção de que a ciência é a força-motriz do progresso. (Teodoro, 2003) ${ }^{174}$

Foi decidido na Conferência de Washington, em 1987, que a OCDE publicaria o documento "Education at a Glance” sobre a qualidade do ensino. Após a análise de 50 indicadores, a OCDE reuniu-os em categorias: indicadores de entrada, indicadores de resultados, indicadores de processo e indicadores de recursos humanos e financeiros.

As estatísticas de educação da OCDE em 2005, no "Education at a Glance", incluem uma análise do tempo de aprendizado de um estudante fora da escola em comparação com o desempenho de escolas públicas e privadas; a comparação com a participação de membros da força de trabalho em educação continuada e treinamento e dados da distribuição de receita por indivíduo com diferentes níveis educacionais, bem como as primeiras evidências de resultados não-econômicos da educação. (Besley ${ }^{175}$, 2005)

\section{A UNESCO - Organização das Nações Unidas para a Educação, a Ciência e}

a Cultura foi constituída pela união de 20 países na Conferência de Londres em 1945 e foi oficializada em 1946. A Organização, sediada na França, tem 191 (dado de 2005) Estados membros e seis membros associados. O objetivo principal da UNESCO é contribuir para a paz e segurança do mundo promovendo colaboração entre nações por meio de educação, ciência, cultura e comunicação. O mandato de 2005 pretende cumprir 1) estudos em educação, ciência, cultura e comunicação; 2) o avanço, transferência e compartilhamento de conhecimento para pesquisa, treinamento e atividades pedagógicas; 3) estabelecimento de padrões para a preparação e adoção de instrumentos internos e recomendações estatutárias; 4) expertise por meio de cooperação técnica entre os membros para suas políticas em desenvolvimento e projetos; e 5) a troca de informação especializada. Desde a década de 1990 a Unesco elabora agenda de intercâmbios para a educação superior. A agenda da Unesco também recomenda critérios de avaliação e financiamento como o estabelecimento de mecanismos de certificação, bonificações por produtividade acadêmica, critérios bem definidos e constantes para financiamento da educação, e também sugere a diversificação das fontes de financiamento.

\footnotetext{
174 TEODORO, A. Globalização e educação: políticas educacionais e novos modos de governo - São Paulo: Cortez, Instituto Paulo Freire, 2003. Coleção Perspectiva, v.9, pg. 61

175 BESLEY, Steve, 'Education at a Glance' OECD Indicators 2005, POLICY WATCH Policy, Qualifications and Standards Division - Edexcel 2005/78 - September 2005

SAKATA, Marici Cristine Gramacho, Globalização e Educação: A formação do comunicador social na América Latina, 2008312 p. (Doutorado - Orientação BACCEGA, M. A.) Escola de Comunicações e Artes da Universidade de São Paulo, São Paulo, SP, 2008
} 
As conferências regionais da Unesco - de 1996 a 1998 - identificaram as principais causas e efeitos deste processo de mutação que tem afetado a Educação Superior. São eles: mundialização, internacionalização, regionalização, democratização, massificação, marginalização, fragmentação e tecnologia. A missão da educação superior, segundo a UNESCO é de servir aos indivíduos e a sociedade através: do trabalho, da pesquisa, da formação e relacionamento com outros setores da sociedade para contribuir para o crescimento e desenvolvimento do país.

Nesta perspectiva, a pesquisa em educação superior exerce o papel de compreender o novo mercado de políticas globais e de orientar como construir um projeto que esteja adequado à sociedade atual e aos padrões internacionais. A pesquisa e a educação superior têm sido alvos do fórum internacional promovido pela UNESCO, o que tem contribuído enormemente para análise e debates sobre a educação superior, tanto regional como internacionalmente. Existe, no entanto uma acentuada defasagem e diferenças na educação superior entre países desenvolvidos e subdesenvolvidos.

O documento publicado pela UNESCO na Conferência Mundial de Paris, em 1995, sobre políticas e mudanças no ensino superior motivou um seminário internacional em Brasília, no Congresso Nacional, com parlamentares da comissão de educação e reitores brasileiros e latino-americanos. Ainda no mesmo contexto, realizou-se uma conferência em Havana, em 1996, onde foi elaborado o documento “Declaração e Plano de Ação”. Participantes de outros continentes levaram seus planos de ação à reunião da UNESCO nesse mesmo ano. A UNESCO publicou, então, dois documentos que resultaram das discussões em todos os continentes. O primeiro se refere à Declaração Mundial sobre a educação superior no Século XXI e os desafios para pôr em prática a reforma do ensino superior. O segundo se refere ao marco da ação prioritária para as mudanças da educação superior. (ver Trindade, 1999 ${ }^{176}$ ) As reformas da UNESCO enfatizam que o Estado tem um compromisso com o ensino superior.

O BID - Banco Interamericano de Desenvolvimento foi fundado em 1959 como instituição de desenvolvimento, oferece programas de empréstimos e cooperação técnica para projetos de desenvolvimento econômico e social aos países latinoamericanos. É a principal fonte de financiamento multilateral para projetos de desenvolvimento, bem como de promoção do comércio e integração regional na

${ }^{176}$ TRINDADE, H. Rapport Attali: bases da reforma do ensino ....., 1999a. pg. 117-122

SAKATA, Marici Cristine Gramacho, Globalização e Educação: A formação do comunicador social na América Latina, 2008312 p. (Doutorado - Orientação BACCEGA, M. A.) Escola de Comunicações e Artes da Universidade de São Paulo, São Paulo, SP, 2008 
América Latina e no Caribe. Para o BID (1998 ${ }^{177}$ ), o comportamento do ensino superior na América Latina e no Caribe varia muito entre diferentes países e setores, assim como entre instituições e entre unidades dentro das instituições. Diante desta constatação, o BID concentra o ensino superior em quatro funções principais:

(i) liderança acadêmica, que visa à pesquisa de alta qualidade para preparação de elites intelectuais; (ii) educação profissional, que visa ao preparo para funções específicas e trabalhos em pesquisa e extensão que requerem educação formal; (iii) educação técnica, constituída por programas de curta duração para preparar profissionais para cargos médios no mercado de trabalho e pesquisas relacionadas ao desenvolvimento tecnológico e científico do país; e (iv) educação superior em geral. A educação superior, em geral, é definida por educação pós-secundária, que forma pessoas que não encontram empregos que correspondam diretamente aos seus campos de estudo - não é funcional. Visa ao ensino das profissões cujo mercado de trabalho está saturado ou indefinido.

\section{A UNCTAD/ONU - Conferência das Nações Unidas para o Comércio e} Desenvolvimento - foi fundada em 1964 quando os países em desenvolvimento ganharam força e conseguiram criar na ONU a Conferência das Nações Unidas para o Comércio e Desenvolvimento (UNCTAD), que foi fundamental para a aprovação, em 1974, do documento “Nova Ordem da Economia Internacional”, que visava mais cooperação, trocas, solidariedade, respeito às culturas, religiões e políticas. (Siqueira, 2004) $)^{178}$

Uma das conseqüências da Internacionalização é a abertura de mercados, e uma das conseqüências da globalização, como já exposto anteriormente, é a mercantilização da Educação. A entrada de instituições de ensino estrangeiras nos países sejam elas periféricos ou não, se encontra em plena expansão.

O Quadro 4 a seguir mostra a participação dos países nos acordos multilaterais:

Quadro 4 - Participação dos Países nos Acordos Multilaterais

\begin{tabular}{|l|l|l|}
\hline & \multicolumn{1}{|c|}{ GATS } & \multicolumn{1}{c|}{ OMC } \\
\hline Argentina & Contracting Party - October 11, 1967 & Member - January 1, 1995 \\
\hline Brasil & Contracting Party - July 30, 1948 & Member - January 1, 1995 \\
\hline
\end{tabular}

${ }^{177}$ BID - Banco Interamericano de Desenvolvimento, Quem Somos, 1998 Disponível em : http://www.iadb.org/ Data de Acesso: 26.01.2006

${ }^{178}$ SIQUEIRA, A. C. A regulamentação do enfoque comercial no setor educacional via OMC/GATS, Revista Brasileira de Educação, Maio-Ago, N. 26, 2004

SAKATA, Marici Cristine Gramacho, Globalização e Educação: A formação do comunicador social na América Latina, 2008312 p. (Doutorado - Orientação BACCEGA, M. A.) Escola de Comunicações e Artes da Universidade de São Paulo, São Paulo, SP, 2008 


\begin{tabular}{|l|l|l|}
\hline Continuação & \multicolumn{1}{|c|}{ GATS } & \multicolumn{1}{c|}{ OMC } \\
\hline Colômbia & Contracting Party - October 3, 1981 & Member - April 30, 1995 \\
\hline Chile & Contracting Party - March 16, 1949 & Member - January 1, 1995 \\
\hline Mexico & Contracting Party - August 24, 1986 & Member - January 1, 1995 \\
\hline
\end{tabular}

Fonte: Multilateral Agreements - WTO / GATT World Trade Organization | General Agreements on Tariffs and Trade. Disponível em: http://www.sice.oas.org/agreemts/wto_e.asp\#WTO\%20|\%20GATT Acesso em 13/09/2006

A relação entre a OMC e as mudanças referentes à educação podem ser notadas a partir da cronologia adaptada de Barelli (2003) ${ }^{179}$ e Siqueira (2004) ${ }^{180}$, a seguir:

1. 1995 - Criação da classificação setorial dos serviços na OMC - GATS, incluindo serviços educacionais e suas subdivisões: básica, fundamental, superior e cursos especializados.

2. 2000 - Início das negociações mandatadas. Os países passam a discutir diretrizes para o setor e apresentam documentos declaratórios de interesse e compromissos na área.

3. 2001 - Rodada de negociações da OMC para discutir propostas gerais e definição de data (30 de junho de 2002) para os países apresentarem os pedidos iniciais em educação.

4. 30 de junho de 2002 - Apresentação dos pedidos iniciais e definição de prazo indicativo de oito meses para os países apresentarem as suas ofertas. Brasil recebe pedidos de serviços educacionais de seis países (Austrália, Nova Zelândia, Estados Unidos, Peru, Noruega e Japão) e faz pedidos educacionais para Austrália, Canadá, Índia, México, Japão, Estados Unidos, Coréia, e União Européia.

5. 31 de março de 2003 - Dez países apresentam em Genebra as suas ofertas iniciais. (O Brasil não apresenta oferta inicial, assim como outros 130 países)

6. 12 a 22 de maio de 2003 - Reunião do Conselho de Serviços da OMC.

7. 23 de agosto de 2003 - foi lançado um abaixo-assinado internacional pela retirada da educação do GATS. Grupos em diversos países articulam-se em encontros, pela criação de listas de discussão e websites para disponibilização de material $^{181}$. Em contrapartida, os grupos interessados na comercialização da

\footnotetext{
${ }^{179}$ BARELLI, Suzana Escola tipo exportação Folha de S. Paulo - Caderno Sinapse, 29/04/2003

${ }^{180}$ SIQUEIRA, A. C. A regulamentação do enfoque comercial no setor educacional via OMC/GATS, Revista Brasileira de Educação, Maio-Ago, N. 26, 2004

${ }^{181}$ Ibidem

SAKATA, Marici Cristine Gramacho, Globalização e Educação: A formação do comunicador social na América Latina, 2008312 p. (Doutorado - Orientação BACCEGA, M. A.) Escola de Comunicações e Artes da Universidade de São Paulo, São Paulo, SP, 2008
} 
educação contam com a pressão dos organismos como Global Alliance for Transnational Education (GATE); World Education Market; Banco Mundial: EdInvest/IFC; Heritage Foundation; US Coalition of Service Industries (USCI), entre outros.

8. Maio de 2006 - Brasil rejeitou a proposta para abrir o setor de educação apresentada por Austrália, Nova Zelândia, Estados Unidos e Cingapura na Organização Mundial do Comércio (OMC), durante reunião em Genebra ${ }^{182}$.

Um dos itens do GATS, conforme Siqueira (2004) ${ }^{183}$, visa eliminar as exigências de validação de cursos, títulos e autorizações para o exercício profissional de cada país, substituindo-as por uma certificação internacional. Na Europa, a principal agência multilateral é o Conselho de Reitores das Universidades Européias (CRUE) e Processo de Bolonha.

Em 2003 foi realizado um abaixo-assinado internacional pela retirada da Educação no GATS. Siqueira (2004) lista as instituições que constam no abaixoassinado e achamos válido reproduzi-las aqui:

GATScrit; GATSwatch; Education is not for sale; Right-to-education; Global Services Network; Challengeglobalization; ITAPI - Tradeobservatory; Polaris Institute; Third World Network; Jubileesouth; Corpwatchindia; Transattac; Alternative Liste Duisburg (Alemanha); Appel pour une école démocratique (Bélgica); Asociación de Estudiantes de Derecho, Universidad Autonoma de Madrid (Espanha); AstA Uni Düsseldorf, Essen, Kassel, Mainz, Münster, Wuppertal (Alemanha); Attac Berlin, Hamburg, Düsseldorf, Potsdam (Alemanha); Attac France (França); Attac-Universiteit Gent (Bélgica); Campaign for Free Education (Reino Unido); Casa Diritti Sociali (Itália); Sindicato de Enseñanza de Sevilla (Espanha); DIDAweb Comunità di educatori in rete (Itália); Die sozialistische Jugend (Alemanha); Escuela Libre Paideia (Espanha); Movimento Di Cooperazione Eductiva (Itália); Focus on the Global South (Tailândia); Il Gruppo Saperi del Social Forum di Firenze (Itália); Initiative Berliner Sozialforum (Alemanha); Internacional de la Educación (Bélgica); Internationale Socialisters Ungdom (Dinamarca); Kritische StudentInnen Utrecht (Países Baixos); Kulturattac (Alemanha); Laent - Laboratorio apprendimento e nuove tecnologie, Capoterra (Itália); Lithuanian National Union of Students (Lituânia); Movement for Modern School (Bulgária); Public Interest Advocacy Centre (Austrália); Redazione della rivista italiana di scuola "écolle" (Itália); ReferentInnenRat der Humboldt Universität zu Berlin (Alemanha); Scudag Network (Alemanha); SDAJ Münster (Alemanha); Sindacato Italiano Unicobas Scuola (Itália); Socialist Worker Student Society (Reino Unido); Studentska sekcija Foruma mladih SDP-a Hrvatska (Croácia); Klub studenata Hrvatskih studija Sveucilista u Zagrebu (KSHS), Hrvatska (Croácia); Syndicat français SUD Etudiant (França); Union des Etudiantes de Suisse (UNES) (Suíça); Universal Proutist Student Federation (UPSF) (Worldwide); Unione Svizzera degli Universitari (USU) (Suíça); Verband Sozialistischer StudentInnen Österreich (Áustria); World Development Movement, Londres (Inglaterra).

\footnotetext{
${ }^{182}$ Portal MEC, 17/05/2006

183 SIQUEIRA, A. C. A regulamentação do enfoque ......, 2004
}

SAKATA, Marici Cristine Gramacho, Globalização e Educação: A formação do comunicador social na América Latina, 2008312 p. (Doutorado - Orientação BACCEGA, M. A.) Escola de Comunicações e Artes da Universidade de São Paulo, São Paulo, SP, 2008 
A entrada de instituições estrangeiras na América Latina teve início em 1957 no Panamá e se intensificou a partir de 1980 nos demais países. As primeiras iniciativas do setor de educação superior privado internacional na América Latina são apresentadas no Quadro 5 a seguir:

Quadro 5 - Iniciativas do Setor Privado Educacional Internacional

\begin{tabular}{|c|c|}
\hline País & Histórico \\
\hline Argentina & $\begin{array}{l}\text { A Universidade de Bolonha abriu uma sede em Buenos Aires em } 1998 \text { e } \\
\text { a Escuela Superior de Administración y Dirección de Empresas } \\
\text { (ESADE) da Espanha criou em } 2003 \text { um centro de formação para altos } \\
\text { executivos, la Fundación para el Desarrollo Empresarial y Social. }\end{array}$ \\
\hline Brasil & $\begin{array}{l}\text { Participação de } 50 \% \text { do Grupo Apollo na Faculdade Pitágoras. } \\
\text { Aquisição de } 51 \% \text { da Anhembi Morumbi pelo grupo Laureate em } 2005 \\
\text { e aquisição de } 70 \% \text { do Grupo Anhanguera Educacional em } 2006 \text { pelo } \\
\text { IFC do Banco Mundial através do Banco Pátria. O Grupo Anhanguera } \\
\text { adquiriu a FIZO-Faculdade Integrada Zona Oeste em São Paulo - e } \\
\text { outras Faculdades no interior do Estado. O Whitney Internacional } \\
\text { University System, capitalizado pelo fundo de investimento norte- } \\
\text { americano Best Associates, investiu na compra das Faculdades Jorge } \\
\text { Amado de Salvador. }\end{array}$ \\
\hline Colômbia & $\begin{array}{l}\text { A presença de universidades estrangeiras não teve avanço significativo } \\
\text { devido a restrições legais que obrigam as universidades particulares que } \\
\text { desejam prestar serviço de educação superior a se organizarem como } \\
\text { fundação ou corporação sem fins lucrativos. Mas há vários } \\
\text { investimentos e parcerias. }\end{array}$ \\
\hline Chile & $\begin{array}{l}\text { O Institute for Executive Development (IEDE) instalou um campus em } \\
\text { Santiago, em 1995, vinculado à Universidade Européia de Negócios e } \\
\text { com supervisão do Conselho Superior de Educação. Duas universidades } \\
\text { pertencem ao Grupo Laureate International Education: Universidade } \\
\text { Nacional Andrés Bello e Universidad de las Américas. }\end{array}$ \\
\hline México & $\begin{array}{l}\text { Em } 1996 \text { a Endicott College foi a primeira a se instalar. O Grupo } \\
\text { Laureate é proprietário da Universidad Del Valle. }\end{array}$ \\
\hline Panamá & $\begin{array}{l}\text { O primeiro campus de uma universidade estrangeira foi a Florida State } \\
\text { University, aberta em } 1957 \text {. }\end{array}$ \\
\hline Paraguai & Não localizamos dados de instituições estrangeiras instaladas \\
\hline Peru & $\begin{array}{l}\text { Iniciaram-se em } 2000 \text { alguns projetos de entradas de instituições } \\
\text { estrangeiras }\end{array}$ \\
\hline Porto Rico & $\begin{array}{l}\text { As } 4 \text { instituições que preencheram os requisitos e licença do Conselho } \\
\text { de educação superior foram Phoenix University (Apollo Group), } \\
\text { Cambridge College, University of Sarasota (adquirida por Argosy) e la } \\
\text { Nova South Eastern University instituições que em } 2004 \text { começaram a } \\
\text { se estabelecer para iniciar seu funcionamento. }\end{array}$ \\
\hline Uruguai & Em 2003 alguns projetos estavam em desenvolvimento \\
\hline
\end{tabular}


Fonte: Adaptado de Aupetit $\left(2005^{184}\right)$

Devido a barreiras e limitações, algumas universidades iniciaram projetos de associações e redes com instituições estrangeiras. Outras redes transnacionais surgiram sobretudo nos anos 1990 (Aupetit, 2005 ${ }^{185}$ ):

Instituto Panamericano de Alta Dirección de Empresa -IPADE (Cd. de México, México, 1967), Instituto de Altos Estudios Empresariales (Buenos Aires, Argentina, 1978), Programa de Alta Dirección (Piura, Perú, 1979), Instituto de Alta Dirección Empresarial (Bogotá, Colombia, 1985), Instituto de Desarrollo Empresarial (Guayaquil, Ecuador, 1993), Instituto de Estudios Empresariales de Montevideo (Montevideo, Uruguay, 1994), Escuela de Negocios Tayasal (Cd. de Guatemala, Guatemala, 1996), Instituto Superior de Empresas (ISI) de Sao Paulo (Sao Paulo, Brasil, 1996) e Escuela de Estudios Superiores de la Empresa (Santiago, Chile, 1998)

Quanto às origens destas instituições estrangeiras, o relatório de Aupetit identificou que:

As instituições têm origem em sua maioria na Espanha: Universidad Autónoma de Barcelona, Universidad Complutense de Madrid, Universidades de Sevilla, de Deusto e de la Coruña, Universidad Nacional de Educación a Distância - UNED, Universidad Oberta de Catalunya - UOC, Universidades Politécnicas de Madrid e de Catalunya, Instituto de Empresa e Escuela de Alta Dirección.

O relatório também conclui que as nacionalidades das instituições instaladas em cada país dependem de questões geográficas, tradições histórico-culturais e vínculos políticos e econômicos. O México e a Colômbia estão fortemente influenciados pelos Estados Unidos; a Argentina e o Uruguai pela Europa, e o Caribe anglófono pelas instituições norte-americanas e inglesas. Alguns países são simultaneamente provedores e consumidores de educação, como a Argentina, o Chile, o México e o Peru. Cuba é um prestador importante de serviços educativos, principalmente no Caribe espanhol.

\footnotetext{
184 AUPETIT, Sylvie Didou, Internacionalización y proveedores externos de educación superior en los países de América Latina y en el Caribe: principales problemáticas. Departamento de Investigaciones Educativas - Centro de Investigación y de Estudios Avanzados (DIE/CINVESTAV) MÉXICO Marzo 2005 Síntesis realizada por contrato (No. 886.369.4) con el Instituto Internacional para la Educación Superior en América Latina y el Caribe (IESALC) de la UNESCO.

185 AUPETIT, Sylvie Didou, Internacionalización y proveedores ....., 2005.

SAKATA, Marici Cristine Gramacho, Globalização e Educação: A formação do comunicador social na América Latina, 2008312 p. (Doutorado - Orientação BACCEGA, M. A.) Escola de Comunicações e Artes da Universidade de São Paulo, São Paulo, SP, 2008
} 


\subsection{A indústria educacional}

Nos Estados Unidos da América a discussão a respeito da educação como bem ou serviço parece estar ultrapassada. O investimento neste setor tem dado um retorno financeiro satisfatório e o termo "Education Industry - Indústria Educacional ou da Educação” tem sido cada vez mais freqüente. Um número crescente de investidores (venture capital) em empresas de educação tem surgido e com isso várias instituições de ensino em todos os níveis têm sido criadas ou compradas. Para os investidores o maior concorrente é o governo. As ações dos grandes grupos educacionais estão cotadas na bolsa, e isto já é uma realidade também no Brasil, com o Grupo Anhanguera Educacional. Um dos maiores grupos norte-americanos é o “Edison Schools”. Uma das freqüentes justificativas veiculadas na mídia para o bom desempenho dos grupos privados é a má qualidade do ensino fornecido pelo governo.

A educação profissional tem sido em geral privada ou mesmo organizada pelas próprias empresas (Universidades Corporativas). Dada a experiência das empresas privadas em treinamento, elas têm estendido seu foco para outros níveis de educação, do jardim de infância a programas de doutorado.

Alguns dos principais grupos educacionais norte-americanos são:

- Carreer Education Corporation (CEC, 2007) ${ }^{186}$ : fundada em 1994, tem crescido por meio de aquisições e expansão das atividades. Possui 26 escolas e 8 campi.

A última aquisição do grupo foi o Whitman Education Group, Inc. que inclui 22 escolas em 13 estados norte-americanos. Fora dos EUA, o grupo comprou em 2003 a INSEEC Group, que operava 9 escolas de ensino superior na França.

- Corinthian Colleges (CCI, 2007) ${ }^{187}$ : uma das maiores empresas nesta área nos EUA, opera 94 escolas em 24 Estados e 32 escolas em 7 províncias canadenses.

- Apollo Group (University of Phoenix): fundada em 1973 tem como subsidiária a University of Phoenix e a University of Phoenix Online, o Institute for Professional Development, o College for Financial Planning, e o Western International University. É líder no mercado e tem como foco os programas de educação superior para profissionais. O Apollo Group tem recebido um número crescente de matrículas e afirma ter duplicado o número de matrículas e receita

\footnotetext{
${ }^{186}$ CEC- Carrer Education Corporation, 2007 Disponível em http://www.careered.com/about.aspx acesso em 31/07/2007

${ }^{187}$ CCI - Corinthian Colleges, CCI, 2007 Disponível em http://www.cci.edu/ acesso em 31/07/2007

SAKATA, Marici Cristine Gramacho, Globalização e Educação: A formação do comunicador social na América Latina, 2008312 p. (Doutorado - Orientação BACCEGA, M. A.) Escola de Comunicações e Artes da Universidade de São Paulo, São Paulo, SP, 2008
} 
entre 2001 e 2005. O grupo colocou suas ações na bolsa de valores em Dezembro de 1994.

- Laureate International (Laureate, 2006) ${ }^{188}$ A rede Laureate, conforme dados divulgados pelo grupo, possui 20 instituições credenciadas na Ásia, Europa, e Américas e cerca de 215.000 alunos. Suas ações estão cotadas na Nasdaq com volume de capital superior a 600 milhões de dólares. Segundo a própria instituição, o objetivo do grupo é oferecer programas técnicos, de graduação e pós-graduação com qualidade e voltados para a experiência educacional internacional. O grupo afirma que "Cada instituição está imersa na cultura local e também compartilha programas acadêmicos e serviços estudantis de outras universidades-membro.” 189 ... A filosofia do grupo é “A Laureate International Universities acredita que quando estudantes de educação superior são bem sucedidos, o país prospera e o mundo se beneficia”. E o objetivo é que os estudantes tenham uma educação profissional que lhes propicie competitividade no mercado de trabalho globalizado.

- $\quad$ ITT Educational Services, Inc. - "ESI" (SEC Info, 2007) ${ }^{190}$ - atua desde 1969 e é líder de mercado em programas de ensino superior em tecnologia incluindo cursos de graduação. Em junho de 2007, a ESI operava 93 Institutos Tecnológicos - ITT em 34 Estados, com 49.000 alunos. Estes programas concentram-se predominantemente na carreira ligada à tecnologia. Suas ações estão na New York Stock Exchange. Os programas são certificados pelo Departamento de Educação dos EUA. Os programas oferecem conteúdos tradicionais mesclados com conceitos aplicados. Algumas escolas são: a School of Information Technology, a School of Electronics Technology, a School of Drafting and Design, entre outras.

\footnotetext{
${ }^{188}$ Laureate International Universities, Disponível em http://www.laureate.net/introduction.php acesso em $02 / 11 / 2006$

189 Our Philosophy: Broadening Access to Higher Education Benefits Students, Economies and Societies Laureate International Universities is guided by these core beliefs:

- Education is a global driving force for social mobility and economic stability.

- Societies and nations win when more investment occurs in post-secondary education, regardless of the source of funding.

- Individual dreams are fulfilled, and societies are advanced, by broadening access to university-level education among underserved students and markets, particularly where governments are unable to meet growing demand.

- The demands of an increasingly competitive global economy call for access to a higher education that equips students with the knowledge, skills and international perspective required by all professions.

Our Approach: Focusing on Student Outcomes by Delivering Internationally Minded Education Locally

190 SEC Info, Fran Finnegan \& Company Disponível em http://www.secinfo.com/dsvR3.735d.htm Fri, 3 Aug 2007 acesso em 03/07/2007

SAKATA, Marici Cristine Gramacho, Globalização e Educação: A formação do comunicador social na América Latina, 2008312 p. (Doutorado - Orientação BACCEGA, M. A.) Escola de Comunicações e Artes da Universidade de São Paulo, São Paulo, SP, 2008
} 
- A Education Management Corporation (EDMC, 2007) ${ }^{191}$ é uma das maiores empresas nos EUA em número de matrículas e receita. Possui 76 campi em 25 Estados e 2 campi no Canadá. Possui cerca de 11.000 funcionários e professores e mais de 80.000 alunos. Oferece programas em diversas áreas, da especialização ao doutorado. Os professores são instrutores e profissionais, sendo que a maioria possui grande experiência profissional. O EDMC oferece programas com enfoque no profissional e sua crença é: a excelência na educação é medida pelos resultados práticos que melhoram a vida dos estudantes levandoos a fazerem importantes contribuições no mercado de trabalho e na comunidade. Entre as instituições do grupo estão: Argosy University, The Art Institutes, Brown Mackie College e South University.

- Whitney Internacional University System, capitalizado pelo fundo de investimento norte-americano Best Associates, grupo norte-americano de investidores. De acordo com informações fornecidas em seu portal da Internet o grupo implementa seu sistema de "acesso em massa" à educação superior por meio de parceria com universidades locais em países em desenvolvimento onde investe ou cria alianças. Com isso "facilita o rápido crescimento de matrículas em um mundo faminto por ensino superior”. No ano de 2006 o grupo investiu no Panamá, na Colômbia, no Brasil e na Argentina e está expandindo para mais países da América Latina, do Norte da África e do Oriente Médio. As instituições que fazem parte do Grupo são: Faculdades Jorge Amado no Brasil; Universidad Empresarial Siglo 21 na Argentina; Politecnico Grancolombiano, Fundacion CompuClub e Bogota Community College na Colombia e Universidad del Istmo no Panamá. Na administração do grupo há principalmente executivos com experiência em empresas multinacionais e de investimentos. No comitê há dois brasileiros, um responsável por Educação a Distância, ex-executivo da Fundação Getúlio Vargas, e o segundo, que é membro do conselho, o ex-ministro da Educação, Dr. Paulo Renato Souza.

Em artigo publicado e reproduzido na página da Internet do grupo ${ }^{192}$, um deles chama a atenção para o novo modelo de universidade que está surgindo e que supera o modelo “obsoleto do passado”. Segundo o artigo “estas novas espécies são orientadas

${ }^{191}$ Education Management Corporation - EDMC, 2007 Disponível em www.edmc.com acesso em 01/07/207

${ }^{192}$ MINOGUE, Rev. John P., The 20th Century University Is Obsolete, Inside Higher EdSeptember 5, 2006 Disponível em http://insidehighered.com/views/2006/09/05/minogue. acesso em 30/12/2007

SAKATA, Marici Cristine Gramacho, Globalização e Educação: A formação do comunicador social na América Latina, 2008312 p. (Doutorado - Orientação BACCEGA, M. A.) Escola de Comunicações e Artes da Universidade de São Paulo, São Paulo, SP, 2008 
ao mercado. Seu mecanismo de sobrevivência fundamental é a habilidade para evoluir rapidamente a novos ambientes e se posicionar no mercado. Considerando que não contam com professores com estabilidade de emprego podem rapidamente descartar disciplinas que não se relacionam com o mercado. Considerando que não seguem processos acadêmicos, podem rapidamente comercializar programas e adquirir market share."

Outro ramo lucrativo nesta área que tem surgido nos EUA são as Organizações de Gestão Educacional, as EMO - Education Management Organizations (Hentschke, Oschman, Snell, 2007) ${ }^{193}$. As EMO são organizações com fins lucrativos que fornecem serviços completos para operar escolas públicas. Estabelecem contratos com escolas distritais dos EUA e utilizam o dinheiro de impostos e venture capital para administrarem escolas públicas. A Edison School opera 130 escolas. As outras grandes EMOs dos EUA são: Mosaica Education, National Heritage Academies e Beacon Education Management.

Segundo Aupetit (2005) ${ }^{194}$ alguns pesquisadores se interessam em entender como as universidades nacionais se comportam frente às mudanças advindas da globalização que as levaram a desenvolver políticas de internacionalização, como a Colômbia, o Equador, o Paraguai e o Peru. Outros pesquisadores analisam a conformação do setor transnacional de educação superior e as respostas governamentais frente aos fornecedores externos como Argentina, Chile, República Dominicana e Uruguai. Espera-se, também, compreender os dispositivos de autorização, habilitação, normas de credenciamento e reconhecimentos de título, entre outros.

O discurso da globalização impulsionou a Internacionalização e isso trouxe elementos positivos para a educação e pesquisa. No entanto, a globalização na América Latina e Caribe se deu de forma desorganizada, e conforme Yarzabal (2001) ${ }^{195}$ afirma, se deu com uma orientação evidente do sul para o norte e não contribuiu significativamente para o fortalecimento dos sistemas de educação, ciência e tecnologia da região.

Neste trabalho, tentamos analisar se a globalização contribuiu positivamente ou não para o sistema educacional latino-americano e se afetou as práticas identitárias.

\footnotetext{
${ }^{193}$ HENTSCHKE, Guilbert C., Oschman, Scot e Snell, Lisa, 2007 Education Management Organizations: Growing a For-profit Education Industry with Choice, Competition, and Innovation Disponível em 216.219.139.105/pb21.pdf acesso em 31/07/2007

${ }^{194}$ AUPETIT, Sylvie Didou, Internacionalización y proveedores ......, 2005. pg. 34

${ }^{195}$ YARZABAL L. "Impactos del neoliberalismo sobre la educación superior en América Latina". CIPEDES, n. 1 (12), marzo 2001pg. 9-15.
}

SAKATA, Marici Cristine Gramacho, Globalização e Educação: A formação do comunicador social na América Latina, 2008312 p. (Doutorado - Orientação BACCEGA, M. A.) Escola de Comunicações e Artes da Universidade de São Paulo, São Paulo, SP, 2008 


\section{O COMUNICADOR E O PROFISSIONAL GLOBAL}

\subsection{Formação Integral versus treinamento}

Para podermos falar sobre as mudanças ocorridas na formação do comunicador tentamos definir aqui qual seria a formação ideal.

Historicamente, no Brasil, apesar de existir desde o período colonial a profissão de jornalista, esta teve um marco importante em 1938 com o decreto 910, que visava promover a criação de escolas de preparação ao jornalismo e a regulamentação da profissão. Em maio de 1943, o Decreto-Lei 5.480 determinou a criação do ensino superior em jornalismo. Em 1947 surgiu o primeiro curso de Jornalismo na Faculdade Cásper Libero. Em 1961 foi estabelecido o primeiro currículo mínimo de comunicação através do decreto 51.218 e, em 1969, com objetivo de controle, o governo militar instituiu o Decreto-Lei $n^{\circ}$ 972/69 (art. 4º inciso V) estabelecendo a obrigatoriedade do diploma para exercício da profissão. Na década de 1990 houve em todo o mundo uma valorização e uma preocupação com a profissão do jornalista e comunicador, principalmente pela importância de sua atividade e necessidade de uma atitude ética. A obrigatoriedade do diploma ainda é um item de discussão, e em 2004 houve novo debate e projetos para eliminação da obrigatoriedade, que, no entanto, ainda permanece em vigor.

A partir de 1997 o MEC convocou as IES a apresentarem propostas dos cursos superiores com o objetivo de serem sistematizados em diretrizes por comissões de especialistas. O objetivo das diretrizes é garantir uma identidade aos cursos e ao mesmo tempo conferir liberdade e autonomia às IES na composição e organização dos mesmos. O documento final estimula a formação geral com habilidades diferenciadas. As diretrizes curriculares nacionais dos cursos de Comunicação Social tiveram seu parecer aprovado em Abril de $2001^{196}$. Neste documento, o egresso ${ }^{197}$ de Curso de Graduação em Comunicação, em qualquer de suas habilitações, deve caracterizar-se por:

\footnotetext{
196 Disponível em http://portal.mec.gov.br/cne/arquivos/pdf/CES0492.pdf

197 Parecer CNE/CES nº 492, de 3 de abril de 2001, Disponível em http://portal.mec.gov.br/cne/index.php?option=com_content\&task=view\&id=75\&Itemid=227 acesso em $01 / 01 / 2008$

SAKATA, Marici Cristine Gramacho, Globalização e Educação: A formação do comunicador social na América Latina, 2008312 p. (Doutorado - Orientação BACCEGA, M. A.) Escola de Comunicações e Artes da Universidade de São Paulo, São Paulo, SP, 2008
} 
1. sua capacidade de criação, produção, distribuição, recepção, e análise crítica referentes às mídias, às práticas profissionais e sociais relacionadas com estas, e a suas inserções culturais, políticas e econômicas;

2. sua habilidade em refletir a variedade e mutabilidade de demandas sociais e profissionais na área, adequando-se à complexidade e velocidade do mundo contemporâneo;

3. sua visão integradora e horizontalizada - genérica e ao mesmo tempo especializada de seu campo de trabalho, possibilitando o entendimento da dinâmica das diversas modalidades comunicacionais e das suas relações com os processos sociais que as originam e que destas decorrem;

4. utilizar criticamente o instrumental teórico-prático oferecido em seu curso, sendo, portanto competente para posicionar-se de um ponto de vista ético-político sobre o exercício do poder na comunicação, sobre os constrangimentos a que a comunicação pode ser submetida, sobre as repercussões sociais que enseja e ainda sobre as necessidades da sociedade contemporânea em relação à comunicação social.

Quanto às competências e habilidades, os termos utilizados no documento são: interpretar, explicar e contextualizar informações; formular pautas, questões; avaliar criticamente produtos e práticas; compreender os impactos das práticas na sociedade, a postura ética e o compromisso com a cidadania, entre outros.

A formação do comunicador sempre esteve em constante diálogo com a sociedade, especialmente pela posição que este profissional ocupa como intérprete e intermediador dos acontecimentos. Portanto, espera-se que o comunicador e o jornalista tenham comportamentos que correspondam às expectativas não somente do empregador, mas da sociedade como um todo.

A partir das Diretrizes Curriculares, da pesquisa realizada nas instituições de Ensino da amostra, assim como das entrevistas, sintetizamos as características essenciais do comunicador, que são, entre outras:

A Capacidade de interpretar fatos; Racionalidade; Visão integradora; Pensamento Crítico; Postura ética; Visão de mundo; Compromisso com a sociedade; Competências e habilidades específicas; Capacidade de comunicação e expressão e Autonomia.

O que o currículo mínimo pretende é permitir que cada instituição atenda às características sócio-culturais da região, as possibilidades da escola e o interesse dos alunos. A questão não é de criar um currículo predominantemente humanista nem predominantemente técnico. Ambos são fundamentais para a formação, não apenas do 
profissional mas do ser humano. O importante é que a IES tenha como projeto uma formação ampla e não corra o risco de cair em um tecnicismo nem a uma submissão às novas tecnologias. As disciplinas humanísticas e técnicas não devem ser consideradas como dois blocos distintos e independentes, mas uma deve fornecer instrumentos para se pensar, refletir e questionar a outra. Pensar criticamente uma técnica é fundamental para o desenvolvimento do ser integral e é esta formação que devemos buscar.

Considerando que estas capacidades devem ser desenvolvidas durante o curso de Comunicação Social em uma instituição de ensino superior, então que características a instituição deve ter para conseguir alcançar este objetivo? O que a instituição se propõe a oferecer aos alunos depende fortemente de como os alunos estão preparados a receber; pois isto depende de sua cultura e capital social. Portanto este processo de ensinoaprendizado mediado pela instituição depende de vários elementos.

Para analisar os tipos de instituições utilizamos o conceito de tipo-ideal ${ }^{198}$ proposto do Weber ${ }^{199}$, ou seja, é feita uma acentuação de um ou mais pontos de vista sobre o que é a instituição de ensino, além de uma síntese de características e elementos deste caso em particular. O objetivo não é definir o que é uma instituição de ensino ideal, ou padrão ou a média das instituições, nem como deveriam ser, mas defini-las por propósitos analíticos a fim de que possamos interpretá-las e compará-las com o que há na realidade.

Distinguimos dois tipos-ideais de instituições de ensino para a formação de Comunicadores:

a) Instituições tradicionais e sem fins lucrativos cuja visão de educação é de bem social. Financiadas pelo Estado ou instituições sem fins lucrativos. Selecionam seus novos alunos com base no mérito. São instituições sociais.

b) Instituições vocacionais e com fins lucrativos cuja educação é um serviço. Fazem parte da “Indústria Educacional”. Não há processo de seleção. São organizações sociais.

Ambos os tipos de instituições de ensino são sistemas intermediários que definem os bem qualificados, os qualificados e os não qualificados. Fazem parte deste sistema, os

\footnotetext{
${ }^{198}$ O termo "ideal” não é utilizado no sentido de ser uma idealização de algo perfeito, mas no sentido de uma idéia que não existe na realidade, mas que é constituída a partir de elementos da realidade por razões puramente teóricas e analíticas.

${ }^{199}$ COHN, G. (org) Weber, Trad. Die Objektivität Sozialwissenschaftlicher und Sozialpolitischer Erkenntniss de 1973, São Paulo, 2004, p.111
}

SAKATA, Marici Cristine Gramacho, Globalização e Educação: A formação do comunicador social na América Latina, 2008312 p. (Doutorado - Orientação BACCEGA, M. A.) Escola de Comunicações e Artes da Universidade de São Paulo, São Paulo, SP, 2008 
alunos, o processo de ensino, os professores, o currículo e os dirigentes internos e externos.

A seguir a distinção entre os dois tipos-ideais de instituições de ensino:

\section{A}

\section{Aluno}

Os alunos escolhem a instituição pelo renome, pela reconhecida qualidade e padrão de ensino e pesquisa. Já possuem boa formação anterior, dominam a língua falada e escrita e possuem capital cultural e social.

\section{Ensino}

O ensino é respaldado por recursos tecnológicos, laboratórios equipados e ampla disponibilidade de fontes de pesquisa. Há eventos que complementam a formação e o ensino é voltado para a formação integral.

\section{Professores}

São mestres e doutores. Passam por processo seletivo para contratação baseada em sua produção científica. A continuidade da carreira depende da dedicação em pesquisa e possuem estabilidade de emprego. Possuem autonomia em sala de aula.

\section{Currículo}

Segue as diretrizes. Tem como objetivo a transmissão do conhecimento e sua reflexão. Privilegia a formação integral.

\section{Dirigentes internos e externos}

Instituição dirigida por docentes que coordenam as funções administrativas. Atendem aos interesses da sociedade e têm como meta a excelência acadêmica, o aperfeiçoamento dos projetos pedagógicos e o desenvolvimento da pesquisa. Prestam contas ao governo ou ao mantenedor, a partir destas metas.

\section{B}

\section{Ensino}

Há pouco material disponível para consulta. Utilizam-se apostilas e material sumarizado. As metodologias de ensino são limitadas devido ao grande número de alunos por sala de aula. O ensino é voltado para a prática e acompanha a demanda do mercado.

\section{Professores}

A contratação atende os padrões mínimos exigidos pelo governo. Não há estabilidade no emprego. Lecionam em mais de uma instituição e em diversas disciplinas, independente de sua área de especialidade. Não possuem autonomia em sala de aula.

\section{Currículo}

Segue as diretrizes. Forte apelo mercadológico. Privilegia 0 ensino técnico e vocacional. Currículo enxuto.

\section{Dirigentes internos e externos}

Os dirigentes atendem aos interesses dos proprietários e acionistas. Seguem critérios de eficácia administrativa e têm como meta o lucro. São dirigidas por profissionais da área de gestão e finanças. São fiscalizadas para que atendam aos requisitos mínimos exigidos pelo governo e sociedade.

As diferenças entre os dois tipos são significativas, principalmente quanto à finalidade de cada uma delas. Ambas as caracterizações são extremas. Na realidade há 
instituições onde esta distinção não é possível, porém, como mencionado anteriormente, a distinção é feita apenas por razões teóricas.

A instituição do Tipo A depende do sucesso de outras instituições que formam seus alunos antes de chegarem ao processo de seleção, ou seja, as Escolas de Ensino Fundamental e Médio. Também dependem do capital cultural e social dos alunos para seu sucesso. Este tipo de instituição depende fortemente de um comprometimento da sociedade em lutar pela sua existência, ampliação e manutenção. Por não ter fins lucrativos é criticada em sua forma de gestão. Também é criticada por não se encaixar nos padrões das empresas no ambiente capitalista.

As instituições do Tipo B são empresas de prestação de serviços (organizações sociais) e seguem todos os padrões de empresa capitalista para poderem se manter no ambiente altamente competitivo. Utilizam estratégias de marketing para expandir seu volume de alunos e utilizam o conceito cliente-fornecedor. Por serem empresas flexíveis e altamente lucrativas exercem influência em setores governamentais. Desta forma, garantem sua sobrevivência no mercado.

A questão que propomos a partir destes dois tipos de instituição é que o tipo A é uma instituição possível, mas que não pode se expandir se não tiver o financiamento do governo, o que não ocorre com a instituição do tipo $\mathrm{B}$, cuja expansão é uma de suas metas.

A pesquisa realizada a seguir analisa instituições reais. Ao final da pesquisa retomamos os conceitos de Tipo Ideal expostos e iremos comparar com os resultados obtidos.

\subsection{Pesquisa em Universidades Nacionais e Globalizadas}

Os cinco países analisados são: Argentina, Brasil, Chile, Colômbia e México. Comparar tais países em cada detalhe de seu sistema de ensino superior seria inviável neste momento e não é o objetivo deste trabalho. O histórico e as características de cada sistema têm sido amplamente publicados e divulgados. São apresentados alguns dados gerais a partir de documentos, de estatísticas e da literatura sobre o atual quadro do Sistema Educacional nestes países antes de apresentar os resultados da pesquisa. 
A Tabela 1 a seguir apresenta algumas características gerais e educacionais destes países e a porcentagem do PIB gasto em instituições educacionais (setor público e privado).

Tabela 1 - Porcentagem do PIB gasto em educação superior nos Países da Amostra

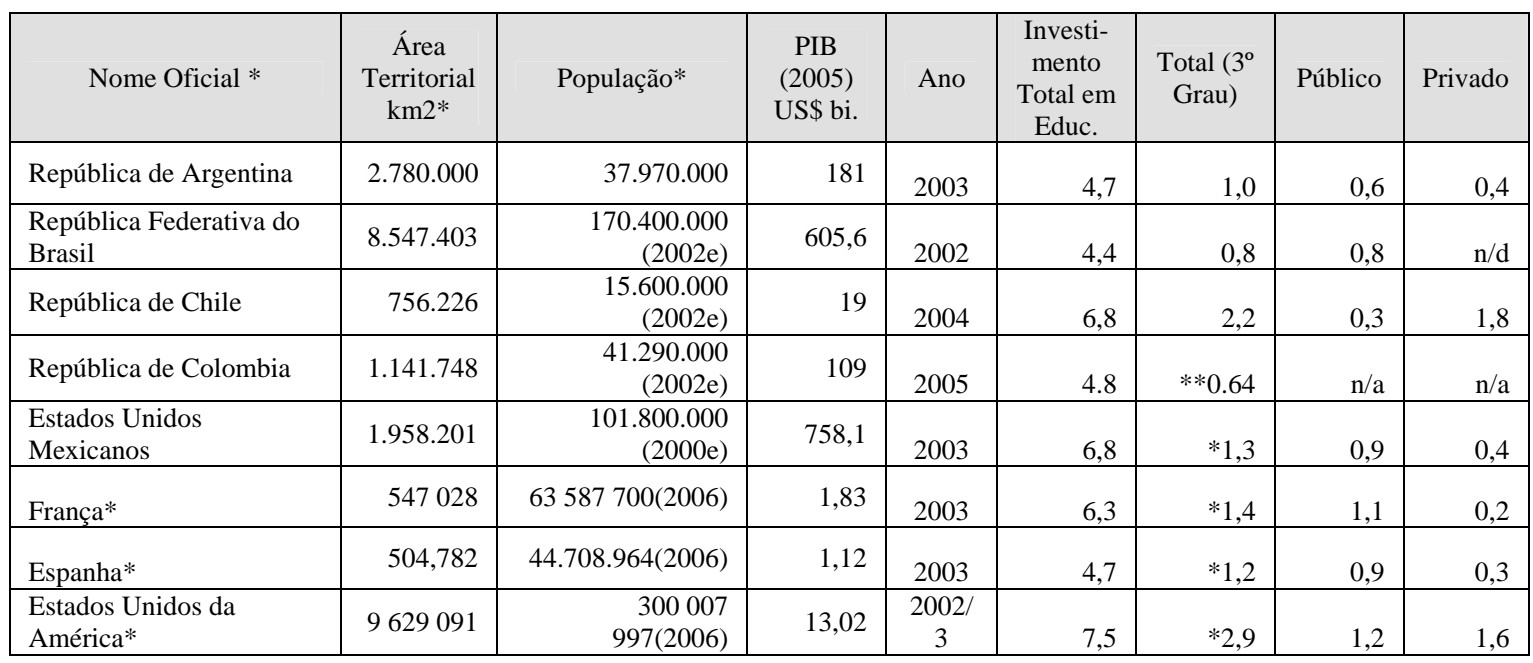

*Fonte: Instituto Internacional de la UNESCO para la Educación Superior en América Latina y el Caribe (IESALC) http://www.unesco.org.ve/ acesso em 14/07/2005

* Fontes: UNESCO/UIS WEI (www.uis.unesco.org/publications/wei2006); OECD countries: OECD 2006 (www.oecd.org/edu/eag2006).

**World Bank http://devdata.worldbank.org/edstats/SummaryEducationProfiles/Country

Data/GetShowData.asp?sCtry=COL,Colombia acesso em 06/07/07

Segundo dados (até 1985) da Unesco, conforme tabela 2, o percentual do PIB investido dos países da América Latina é inferior ao total investido pelos demais países desenvolvidos.

Tabela 2 - Gastos Públicos em Educação no Mundo 1975-1985

\begin{tabular}{|l|c|c|}
\hline \multicolumn{1}{|c|}{$\begin{array}{c}\text { Gasto público em educação } \\
\text { 1975-1985 }\end{array}$} & em milhões de dólares & em \% do PNB* \\
\hline \multirow{3}{*}{ Total Mundial } & $1975-330.117$ & 5.5 \\
& $1980-618.195$ & 5.5 \\
& $1985-681.195$ & 5.6 \\
\hline \multirow{2}{*}{ Países em Desenvolvimento } & $1975-40.433$ & 3.6 \\
& $1980-93.384$ & 3.9 \\
\multirow{2}{*}{ América Latina } & $1985-95.846$ & 4.1 \\
\hline
\end{tabular}

Fonte: sobre a base de dados UNESCO, Anuário Estatístico, 1988

* PNB = PIB + RLRE (Renda Líquida Recebida do Exterior) 
Em 1950 menos de 2\% dos jovens latino-americanos tinham acesso à universidade. Em 1960 esta porcentagem subiu para 6\% e entre 1980-1990 se deu o início da massificação da educação superior. A porcentagem subiu para 13.5\% e 16,6\% respectivamente. A tabela 3 mostra a evolução nestes cinco países da América Latina. (Trindade, 2002) $)^{200}$

Tabela 3 - Evolução do número total de matrículas e taxa de crescimento

\begin{tabular}{|c|c|c|c|c|c|c|c|c|}
\hline & $\mathbf{1 9 7 0}$ & $\begin{array}{c}\text { Setor } \\
\text { priv. }\end{array}$ & $\mathbf{1 9 8 1 / 8 2}$ & $\begin{array}{c}\text { Setor } \\
\text { priv. }\end{array}$ & $\mathbf{1 9 8 9 / 9 1}$ & $\begin{array}{c}\text { Setor } \\
\text { priv. }\end{array}$ & $\mathbf{2 0 0 1}$ & $\begin{array}{c}\text { \% } \\
\text { tx/pop } \\
\mathbf{2 0 0 1}\end{array}$ \\
\hline Argentina & $\begin{array}{c}274.634 \\
(100)\end{array}$ & $17 \%$ & $\begin{array}{c}550.556 \\
(200)\end{array}$ & $22 \%$ & $\begin{array}{c}1.077 .212 \\
(393)\end{array}$ & $15 \%$ & 1.290 .126 & $3 \%$ \\
\hline Brasil & $\begin{array}{c}430.473 \\
(100)\end{array}$ & $55 \%$ & $\begin{array}{c}1.345 .000 \\
(312)\end{array}$ & $63 \%$ & $\begin{array}{c}1.570 .860 \\
(365)\end{array}$ & $60 \%$ & $1.206 .273 *$ & $1 \%$ \\
\hline Chile & $\begin{array}{c}76.979 \\
(100)\end{array}$ & $34 \%$ & $\begin{array}{c}118.978 \\
(155)\end{array}$ & $37 \%$ & $\begin{array}{c}249.482 \\
(324)\end{array}$ & $52 \%$ & $464.707 * *$ & $3 \%$ \\
\hline Colômbia & $\begin{array}{c}85.560 \\
(100)\end{array}$ & $46 \%$ & $\begin{array}{c}306.269 \\
(358)\end{array}$ & $59 \%$ & $\begin{array}{c}474.787 \\
(555)\end{array}$ & $57 \%$ & $859,409 * * *$ & $2 \%$ \\
\hline México & $\begin{array}{c}118.011 \\
(100)\end{array}$ & $15 \%$ & $\begin{array}{c}785.419 \\
(418)\end{array}$ & $15 \%$ & $\begin{array}{c}1.078 .190 \\
(573)\end{array}$ & $17 \%$ & $2.144 .400 \#$ & $2 \%$ \\
\hline
\end{tabular}

Fonte: Trindade, 2002, p.25

* INEP/MEC

** Fuente: División de Educación Superior e Instituto Nacional de Estadísticas INE. Ministério da Educação, Governo do Chile http://compendio.educador.cl/docMatricula2006/2.5.xls

*** www.mineducacion.gov.co

\# Anuario estadístico 2002. Población escolar de licenciatura en universidades e institutos tecnológicos. Resúmenes y series históricas. Dirección de estadística, ANUIES http://207.248.162.4/servicios/e_educacion/docs/estadisticas_2002.htm

O quadro 4 a seguir mostra a evolução das faculdades de Comunicação Social de 1984 a 2004 na América Latina.

Tabela 4 - Evolução das faculdades de Comunicação Social de 1984 a 2004

\begin{tabular}{|l|c|c|}
\hline \multicolumn{1}{|c|}{ PAÍs } & $\begin{array}{c}\text { Número de faculdades de } \\
\text { Comunicação Social em } \\
\mathbf{1 9 8 4}\end{array}$ & $\begin{array}{c}\text { Número de faculdades de } \\
\text { Comunicação Social até } \\
\mathbf{2 0 0 4}\end{array}$ \\
\hline Argentina & 14 & 50 \\
\hline Brasil & 71 & 105 \\
\hline Chile & 6 & 36 \\
\hline Colômbia & 9 & 35 \\
\hline México & 42 & 50 \\
\hline Venezuela & 3 & 14 \\
\hline TOTAL & 145 & 290 \\
\hline
\end{tabular}

Fonte: FELAFACS ${ }^{201}$

200 TRINDADE, H e Blanquer, J. Os desafios da educação na América Latina, Petrópolis, RJ: Vozes, 2002. p.24-25

${ }^{201}$ LÓPEZ-García, Xosé, Pereira-Fariñas, Xosé, Hernández-Soto, Tatiana, PORTADA Planes de estudios de Comunicación en América Latina, Disponível em http://chasqui.comunica.org/content/view/466/128/ Acesso em 31/08/2006

SAKATA, Marici Cristine Gramacho, Globalização e Educação: A formação do comunicador social na América Latina, 2008312 p. (Doutorado - Orientação BACCEGA, M. A.) Escola de Comunicações e Artes da Universidade de São Paulo, São Paulo, SP, 2008 
Segundo a Figura 4 a seguir, podemos notar as principais ocorrências que causaram mudanças nas Instituições de Ensino Superior nos países da amostra ao longo das últimas 50 décadas.

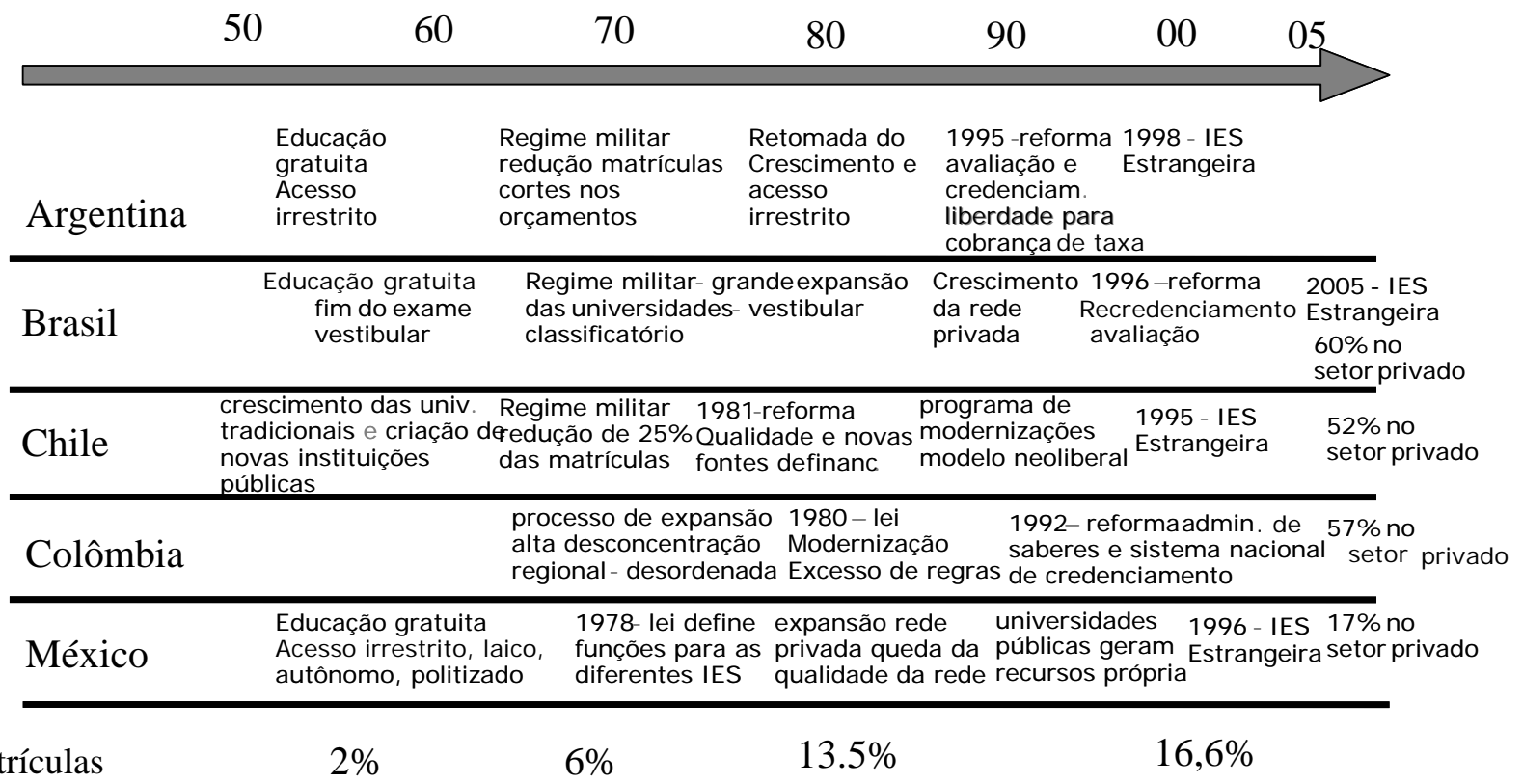

Figura 4 - Panorama Histórico das Reformas e Mudanças no Sistema Educacional

Segundo dados estatísticos disponibilizados pelos Ministérios da Educação dos cinco países, temos o seguinte panorama:

No Brasil, o Curso/Carreira de Comunicação Social teve, em 2004, 189.644 matrículas do total de 4.163.733, o que representa 5\% do total de matrículas. Comunicação Social é o $6^{\circ}$ curso em ordem de matrícula, após Administração, Direito, Pedagogia, Engenharia e Letras. ${ }^{202}$ No Chile, o Curso/Carreira de Periodismo teve, em 2005, 1765 matrículas do total de 78.238, o que representa 2\% do total de matrículas. Ocupa a $10^{\circ}$ posição no número total de matrículas, sendo Engenharia Civil, Direito e Engenharia Comercial as três primeiras. Na Colômbia, o Curso/Programa de Comunicação Social teve, em 2005, 6.847 matrículas do total de 1.212.037, o que representa 0,56\% do total de matrículas. No México, o Curso Ciências de la Comunicación teve, em 2002, 15.905 matrículas do total de 458.769, o que representa 3\% do total de matrículas.

202 Fonte (Figura) : MEC/INEP/DEAES - CENSO 2003 Disponível em
http://www.inep.gov.br/superior/censosuperior/default.asp Acesso em 09/07/2006

SAKATA, Marici Cristine Gramacho, Globalização e Educação: A formação do comunicador social na América Latina, 2008312 p. (Doutorado - Orientação BACCEGA, M. A.) Escola de Comunicações e Artes da Universidade de São Paulo, São Paulo, SP, 2008 
Embora o curso de Comunicação não represente o maior número de matrículas, podemos notar que há crescimento no número de instituições ofertando o curso e isto conseqüentemente representará um crescimento no número de matrículas.

A questão mercadológia é um ponto importante se considerarmos a competição de cada país no sistema mundial. No entanto, esta pesquisa preocupa-se com os elementos identitários presentes na educação. E para tanto, a pesquisa de campo se faz necessária. A pesquisa possibilita verificar as diferenças entre as instituições de educação superior nacionais e globalizadas nos países da América Latina e se esta diferença pode afetar a formação do Comunicador.

Antes da análise dos dados é fornecido um panorama geral da educação superior em cada país da amostra. Considerando que o histórico e os detalhes da educação superior nos respectivos países têm sido amplamente publicados, acredita-se não haver necessidade de relatá-los aqui.

\section{Argentina}

As instituições de ensino argentinas sofreram forte impacto das ditaduras militares. Nas décadas de 1940 e 1950 tiveram início as políticas de acesso irrestrito à rede pública de educação superior. Em 1958 foi feita a primeira reforma com o objetivo de instituir a pesquisa no sistema universitário; houve, também, a criação do CONYCET e a diferenciação institucional que, com isso, credenciou as instituições privadas para emitir certificados. Na década de 1970 - regime militar - houve uma redução do número de matrículas devido a cortes no orçamento e cobrança de matrícula na rede pública. Na década de 1980 houve a reintrodução do acesso irrestrito pelo primeiro governo democrático. Em 1995 foi feita uma lei instituindo a reforma do regime econômico, a adoção de marco jurídico comum, a avaliação e o credenciamento institucional e a liberdade de ingresso e de cobrança.

Quanto ao investimento público no setor, este diminuiu 21,4\% entre 1980 e 1989. No entanto, em 2006 a rede pública respondia por $85 \%$ das matrículas e com o sistema de ensino superior concentrado na Capital e em Rosário e Córdoba.

As universidades nacionais selecionadas na amostra foram a Universidade de Buenos Aires (UBA) e Universidad Nacional de La Plata (UNPL). As universidades globalizadas selecionadas foram Universidad de Belgrano (UB) e Universidad Del Salvador (USAL). A população Argentina é contrária à cobrança de mensalidades, 
embora a cobrança seja autorizada pelo ministério. Isso é um dos motivos que tem dificultado a entrada de instituições estrangeiras no país. No entanto, há diversos cursos oferecidos por instituições estrangeiras em parceria com instituições privadas. Para a seleção das universidades globalizadas utilizou-se o critério de universidade privada. Outras características que fizeram com que considerássemos a instituição de Belgrano globalizada é o fato de oferecer a Alianzas IES Privadas-Privadas de MBA en Negócios Internacionales Finanzas de la Empresa y Marketing com a Escola de Gestão de Lyon, França $^{203}$. Segundo Marquis (2002) ${ }^{204}$ a Universidad de Belgrano oferece duplo diploma de MBA com a Universidad de Barcelona; com a L'Ecole de Management de Lyon; e com a Florida International University. Também oferece duplo diploma com a Universidad de Alcalá de Henares, com a Ecole d’Architecture de Marseile-Luminy, com a Universidad Politécnica de Madrid, entre outras. A Universidad del Salvador possui convênios com as universidades: State University of New York-Albany, Georgetown University, Universidad de Deusto-Bilbao, Universitá degli Studi di Pisa, Universidad Carlos III, Université París X e a Université París I, para cursos de pósgraduação.

Iniciamos aqui um recorte e uma análise das missões declaradas das universidades por país.

\begin{tabular}{|l|l|l|}
\hline \multirow{3}{*}{ Argentina } & \multirow{2}{*}{ Nacional } & Universidad de Buenos Aires \\
\cline { 2 - 3 } & \multirow{2}{*}{ Globalizada } & Universidad Nacional de La Plata \\
\cline { 3 - 3 } & & Universidad de Belgrano \\
\hline
\end{tabular}

A Universidad de Buenos Aires (UBA) é pública e é a de maior prestígio na Argentina. É gratuita e de acesso irrestrito. A Universidad Nacional de La Plata (UNLP) também é pública e tradicional. No primeiro item da missão da UBA lê-se que a universidade tem como fim a promoção, difusão e preservação da cultura e para tanto, está em contato direto com o pensamento universal e presta particular atenção aos problemas argentinos. O segundo item de sua missão é contribuir para o desenvolvimento da cultura mediante estudos humanistas.

\footnotetext{
${ }^{203}$ AUPETIT, Sylvie Didou, Internacionalización y proveedores externos de educación superior en los países de América Latina y en el Caribe:principales problemáticas, (DIE/CINVESTAV) síntesis realizada por contrato (No. 886.369.4) con el Instituto Internacional para la Educación Superior en América Latina y el Caribe (IESALC) de la UNESCO. México, Marzo 2005

${ }^{204}$ MARQUIS, Carlos, Nuevos proveedores de educación superior en Argentina y Brasil, Buenos Aires, Agosto 2002 Disponível em www.unesco.org acesso em 01/05/2006
} 
O lema da UNLP é “Pro Scientia et Pátria”. Diz-se pioneira nos estudos e desenvolvimentos culturais, artísticos e científicos. No documento a respeito de seu plano estratégico são citados a crise da educação superior argentina e o compromisso da universidade com a educação; portanto, seu plano estratégico não significa a materialização de um produto nem a aplicação de um procedimento, mas sim imaginar objetivos comuns de toda a sociedade para superar a crise.

Quanto às universidades globalizadas, pelo fato de a Argentina não possuir uma universidade de capital internacional, selecionamos duas universidades privadas sem fins lucrativos (Autônomas, mas sob avaliação do Ministério de Cultura y EducaciónCoNEAU), a Universidad de Belgrano (UB) e a Universidad Del Salvador (USAL). (Não foram localizadas informações sobre os mantenedores destas instituições)

Os princípios que regem a UB são: Autonomia, Pluralismo, Ecumenismo, Republicanismo e Interdependência social. No princípio da autonomia lê-se que os planos de estudo são fruto de reflexão, experiência nacional e internacional e interação com a sociedade. E, no princípio de republicanismo, lê-se que a universidade apóia o sistema de vida que se dá pura e simplesmente na constituição nacional.

A USAL foi fundada por Jesuítas em 1622, porém em 1975 sua administração foi passada para um grupo de laicos. Na missão da USAL é ressaltado diversas vezes o compromisso assumido pelo grupo da responsabilidade de preservar a identidade da Universidade. O objetivo da universidade é a formação integral, como pessoa e como argentino. Lutam contra o ateísmo e o materialismo e rechaça todo modelo cultural exógeno e materialista. Na formação como Argentino, a missão da USAL é afirmar a consciência nacional histórica e afirmar sua própria identidade.

Concluímos que na UBA e na UNLP é clara a preocupação com a identidade nacional. Na UB já não é tão explícita, e na USAL é extremamente forte (mais como uma preocupação dos jesuítas em garantirem que o grupo laico as seguirá). No entanto, como visto anteriormente, tanto a UB como a USAL receberam recursos do IFC para se modernizarem e mantêm compromisso com a competitividade no setor.

Análise dos Dados e Comparação - Curso e Grade

O curso da UBA oferece o diploma de licenciado em Ciencias de la Comunicación Social. É um curso de 5 anos, sendo 1 ano de ciclo básico, 3 anos da carreira e um ano de trabalhos finais. O objetivo é formar alunos pesquisadores em nível 
nacional e internacional para empresas públicas ou privadas. Oferece disciplinas obrigatórias de Sociedade e Estado, Sociologia, Antropologia Social e Cultural e História Social Argentina e Latino-Americana.

O curso da UNLP oferece diploma de licenciamento em Comunicación Social com Orientación em Planificación Comunicacional ou Periodismo. Oferece um ciclo comum e um ciclo superior. Inclui disciplinas obrigatórias de Comunicação e Cultura, Antropologia Social e Cultural, e disciplinas optativas de História Argentina Contemporânea, História Contemporânea da América Latina, Economia Política e Problemática Econômica Argentina.

O curso da UB oferece diploma de licenciamento em Periodismo e tem como objetivo assegurar excelência e sólida preparação teórico-prática profissional para serem verdadeiros atores sociais, empreendedores, democráticos e solidários, com duas disciplinas obrigatórias de História Argentina, uma disciplina optativa de Arte Argentina Contemporânea e uma de Literatura Argentina Contemporânea.

O curso da USAL oferece diploma de licenciamento em Periodismo e tem como objetivo a formação teórica, técnica e prática para o exercício profissional ...em um contexto mundial globalizado. A universidade vê a necessidade de impor conhecimentos e capacidades de análise epistemológica, ética, social, política e econômica para entender a complexidade do fenômeno da globalização. O curso oferece disciplinas de Filosofia, História Argentina e Teologia.

A UBA e a UNLP oferecem maior número de disciplinas relacionadas ao pensamento crítico, às questões culturais e aos elementos identitários. A USAL também demonstra preocupação com a identidade cultural, mas o foco é a necessidade de se criar um profissional no contexto globalizado. No entanto, indica que, para isso, o profissional precisará de pensamento crítico e não de ferramentas práticas, o que é uma declaração importante. A UB, apesar de concordar, só oferece três disciplinas, sendo apenas uma obrigatória e referente ao contexto nacional.

Brasil

O Censo 2000, do Sistema de Avaliação do Ensino Superior do INEP, registrou, em 30/04/2000, a existência de 10.585 cursos presenciais de graduação no Brasil, oferecidos por 1.180 Instituições de Ensino Superior (IES) com um total de 2.694.245 matriculados. 
Historicamente, assim como a Argentina, o Sistema Educacional Brasileiro também passou por uma série de mudanças no período das ditaduras militares.

A Reforma de 1966 incluiu uma política de pós-graduação dando ênfase acadêmica a mestrados e doutorados científicos ou stricto sensu. A reforma de 1968 205 privilegiou a pesquisa determinando: (a) a organização das universidades em institutos científicos e escolas profissionais, todos com estrutura departamental e a possibilidade de criar seus programas de pós-graduação; (b) o regime de ensino por sistema de créditos e de professores com dedicação em tempo integral e (c) o requisito de titulação acadêmica para a promoção na carreira. Apenas a rede pública (e as universidades católicas) se enquadram ao modelo de research university e contam com o apoio do sistema de fomento à Ciência e Tecnologia.

O sistema contou com a expansão contínua de recursos na década de 1970 para as áreas de exatas e biológicas, que durou até 1980. A inflação teve efeitos negativos sobre o financiamento do ensino superior. Na década de 1970 foi criado o programa de capacitação docente (PICD) e ampliada a rede universitária pública para todos os Estados. Neste período foi adotada a política liberal de autorização da criação de estabelecimentos privados de ensino superior. Entre as décadas de 1970 e 1980 a rede privada cresceu rapidamente. A lei de 1996 (N. 9394) determinou a especialização das universidades em áreas do saber e delimitou os conceitos de autonomia enfatizando a avaliação e o recredenciamento periódicos.

Quanto às universidades federais, o Ministro da Educação e Esportes, com a Colaboração do Conselho Nacional de Educação, encarregou-se de coordenar o planejamento da Educação Nacional; bem como o financiamento dos diferentes Estados. O Ministério dirige uma rede de escolas federais, incluindo universidades, IES, escolas técnicas e de agricultura e centros tecnológicos. Além disso, fiscaliza o setor de educação superior. A educação superior está composta por 851 instituições, das quais $15 \%$ são universidades, sendo $10 \%$ federais e os $75 \%$ restantes instituições isoladas $(633)^{206}$. A Coordenação de Aperfeiçoamento do Pessoal de Nível Superior (CAPES) foi criada para coordenar esforços com o objetivo de alcançar a qualidade.

Consideramos para esta pesquisa as universidades públicas como sendo as nacionais. Selecionamos uma Estadual (USP) e uma Federal (UFMG). Quanto às

\footnotetext{
${ }^{205}$ AMARAL, N. C., Catani, A. M., OLIVEIRA, J. F. O financiamento público da educação superior brasileira: mudanças e desafios. Revista Brasileira de Política e Administração da Educação, PiracicabaSP, v. 19, n. 2, p. 221-241, 2003.

${ }^{206}$ Dados de 2004/2005, Fonte: UNESCO

SAKATA, Marici Cristine Gramacho, Globalização e Educação: A formação do comunicador social na América Latina, 2008312 p. (Doutorado - Orientação BACCEGA, M. A.) Escola de Comunicações e Artes da Universidade de São Paulo, São Paulo, SP, 2008
} 
universidades globalizadas, selecionamos a Faculdade Pitágoras ${ }^{207}$ e a Anhembi Morumbi. No Brasil, a Faculdade Pitágoras, de Minas Gerais foi a primeira a possuir participação internacional em seu capital. O grupo norte-americano Apollo International possui 50\% do capital da Pitágoras. Segundo a instituição, a metodologia utilizada é adaptada da Universidade de Phoenix, EUA, que também pertence ao Grupo Apollo. A compra da Anhembi Morumbi foi o primeiro caso onde a aquisição internacional foi superior a 50\%. A Anhembi Morumbi foi fundada em 1970 como uma escola de turismo. Teve um grande crescimento no número de alunos a partir de 1990. A partir de 2003, o fundador da instituição, Gabriel Monteiro Rodrigues, segundo documentos publicados, sentiu a necessidade de aumentar a eficiência da instituição e reestruturá-la. Para isso, o fundador contratou um Banco (Pátria) para que aumentasse a receita da instituição. Em 2004 a instituição teve uma rentabilidade de mais de 50 milhões de reais. Em dezembro de 2005, o grupo Laureate adquiriu 51\% das ações da Anhembi Morumbi e espera adquirir o restante das ações até 2013.

Em agosto de 2006 foi anunciado o investimento do IFC - International Finance Corporation - de 12 milhões de dólares em universidades privadas por meio do Banco Pátria. Com isso, foram adquiridos $70 \%$ do controle acionário da Anhanguera Educacional, que contava com mais de 20 mil alunos em quatro faculdades e um centro universitário no Estado de São Paulo. O IFC também possui investimentos em educação privada no México, no Chile, na Turquia e na Nigéria, entre outros. ${ }^{208}$

Quanto aos cursos de Comunicação Social, no Brasil, segundo a Resolução N ${ }^{\circ}$ 02/84, os cursos oferecidos são Cursos de Comunicação Social com habilitação em:

- Jornalismo

- Relações Públicas

- Publicidade e Propaganda

- Produção Editorial

- Rádio e TV

- Cinema.

\footnotetext{
${ }^{207}$ A Faculdade Pitágoras não é uma universidade, mas foi selecionada por possuir capital estrangeiro investido.

208 Jornal da Ciência Investimento, Terça-feira, 01 de Agosto de 2006, Disponível em http://www.fapema.br/2006/noticia.php?id=234 Acesso em 10/08/2006
} 
Devem ter duração mínima de quatro anos letivos e máxima de sete anos letivos. A estrutura modular define um tronco comum em ciências sociais, ciências da comunicação, filosofia e arte, e um específico, além de projetos experimentais.

\begin{tabular}{|l|l|l|}
\hline \multirow{3}{*}{ Brasil } & \multirow{2}{*}{ Nacional } & Universidade de São Paulo \\
\cline { 2 - 3 } & \multirow{2}{*}{ Globalizada } & Universidade Federal de Minas Gerais \\
\cline { 3 - 3 } & & Anhembi Morumbi (Laureate) \\
\hline
\end{tabular}

Das instituições analisadas, a Universidade de São Paulo (USP) é uma instituição pública e gratuita. O acesso é feito por meio de exame seletivo, e é a universidade mais tradicional e renomada do país. A missão da USP é promover a pesquisa e o progresso da ciência. Procura formar especialistas em todos os ramos da cultura. O lema da instituição é “vencerás pela ciência”.

A Universidade Federal de Minas Gerais (UFMG) é uma instituição pública, federal e gratuita. Tem como missão gerar e difundir conhecimentos científicos, tecnológicos e culturais, formando indivíduos críticos e éticos. Busca a qualidade, a autonomia e apoio a programas nacionais. No texto de sua missão, a UFMG diz estar inserida em cooperação acadêmica e científica multilateral e afirma ser esta uma necessidade e uma força política na defesa da educação como bem público e na luta contra uma globalização predatória e geradora de crescentes desigualdades.

A Anhembi Morumbi (AM) é uma instituição privada. Em 2005, 51\% de suas ações foram adquiridas pelo grupo Laureate International Education. Sua missão é “contribuir para a construção de um mundo melhor”. A visão da AM é ser uma instituição moderna, arrojada e inovadora. Tem como valores a responsabilidade, o respeito à diversidade com estímulo ao pensamento crítico e ao relacionamento multicultural. Segundo a instituição, os cursos antecipam tendências do mercado e criam novos padrões educativos. A parceria com o grupo Laureate significa “oportunidade de formação e atuação mundial, por meio de programas exclusivos de intercâmbio, múltipla diplomação, estágio internacional, entre outros”.

A Faculdade Pitágoras (FP) se define como "Uma empresa de educação superior, fruto da rede de ensino Pitágoras (MG, Brasil)”, com “uma proposta que é uma volta às tradições clássicas da boa educação e que, ao mesmo tempo, contém uma forte incorporação de novas tecnologias, tanto originárias dos avanços da informática e 
comunicações como da psicologia.” Busca desenvolver o pensamento crítico e construir um Brasil mais justo e solidário.

As missões nas duas universidades nacionais revelam preocupação com a ciência. A USP procura formar especialistas para os ramos da cultura enquanto a UFMG explicita claramente sua posição quanto à educação como bem público e se posiciona contra a globalização predatória. Na AM a missão também traz a importância do pensamento crítico e da relação multicultural. No entanto, em propaganda no rádio, veiculada no mês de novembro de 2006 a AM anunciou o curso de Hotelaria com "o currículo idêntico ao da Escola parceira na Suíça”. Na FP o foco está voltado para a questão tecnológica e uma volta às tradições clássicas da educação. Não há referência a questões culturais e políticas nacionais e há a declaração explícita de serem uma empresa. Em comparação com as missões das universidades argentinas, os textos trazem bem menos preocupação com os elementos identitários e com a defesa da nação.

\section{Análise dos Dados e Comparação - Curso e Grade}

A Escola de Comunicações e Artes da USP iniciou suas atividades em 1966. Tem os cursos mais concorridos de toda a Universidade. Segundo a instituição, ela vive a contemporaneidade e está atenta às inovações e à qualidade do ensino. O curso de Comunicação Social com Habilitação em Jornalismo tem disciplinas de História, Pensamento Filosófico, Economia e Ética, como obrigatórias e, como optativas, oferece as disciplinas de Cultura e Literatura Brasileira, História da Cultura, Sociologia na Era Virtual, Jornalismo, Saúde e Cidadania, Política Internacional/Jornalismo, Jornalismo em Agrobusiness e Meio Ambiente no Brasil, entre outras.

O Curso de Comunicação Social da FAFICH-UFMG foi criado em 1962. Segundo a instituição o currículo é flexível. As disciplinas oferecidas ${ }^{209}$ incluem: História do Jornalismo do Brasil e Comunicação e Cultura.

O Curso de Comunicação Social da AM teve início em 1970. O Curso é voltado à formação de profissionais responsáveis, éticos e abertos às novas oportunidades de mercado. O curso prepara para a prática, desenvolve uma visão crítica e prepara o aluno para o mercado global. É a “primeira universidade global do Brasil”. Na grade do curso há disciplina obrigatória de Cultura Brasileira, História Política e Econômica Contemporânea e Ciência.

\footnotetext{
${ }^{209}$ Os dados coletados não permite diferenciar as disciplinas optativas das obrigatórias. 
O Curso de Jornalismo da FP tem como essência a prática acadêmica no âmbito do Jornalismo Empresarial. Na grade curricular, há disciplinas de Humanidades, Sociologia, Comunicação e Cultura e Política e Economia no Brasil Pós-Guerra.

Os quatro cursos oferecem disciplinas com conteúdo referente ao Brasil e à Cultura. As duas instituições “globalizadas” têm uma forte preocupação com a prática, conforme expressa em seus objetivos, embora também incluam em suas grades disciplinas referentes ao Brasil. Ambas as instituições globalizadas preocupam-se de forma mais intensa com o instrumentalismo do conhecimento. No entanto, quanto às disciplinas, as quatro têm conteúdos similares, o que também é resultado do currículo mínimo do MEC.

Chile

A educação superior do Chile, até 1980, era composta por um total de 8 universidades: 2 estatais e 6 privadas (sendo 3 católicas e 3 laicas) todas com financiamento direto do Estado. As transformações ocorridas na educação superior no Chile são apresentadas aqui com base em Esquivel (1998) $)^{210}$ e Lavados (2002) ${ }^{211}$. Entre o período de 1967 e 1973 houve crescimento das universidades tradicionais e a criação de novas instituições públicas. Também houve um aumento da pesquisa científica e da pós-graduação. Na década de 1970 este processo foi interrompido pelo golpe militar e acarretou uma queda de 25\% nas matrículas. Na década de 1980, a reforma introduziu mecanismos de mercado no sistema, com os seguintes objetivos: desconcentrar geograficamente a rede pública e privada; criar três níveis de formação pós-secundária, e três segmentos institucionais para oferecê-las; manter o sistema universitário público e privado tradicional; expandir e diferenciar a rede pública com novas universidades provinciais e institutos profissionais; apoiar o crescimento de estabelecimentos privados em todos os níveis e reformar o sistema de financiamento público, reduzindo em muito a participação do Estado e vinculando-a a indicadores de

210 ESQUíVEL, Juan Carlos Campbell, Novas Perspectivas nas Políticas de Educação Superior na América Latina, In CATANI, Afrânio (Orgs) Novas perspectivas nas políticas de educação superior na América Latina no limiar do século XXI, Campinas, SP: Autores Associados, 1998, p.247-255

${ }^{211}$ LAVADOS, Jaime, Reflexiones sobre la educación superior chilena. In: TRINDADE, Hélgio e GLANQUER, Jean-Michel (Orgs.) Os desafios da educação na América Latina. Petrópolis, RJ: Vozes, 2002, p.94-114

SAKATA, Marici Cristine Gramacho, Globalização e Educação: A formação do comunicador social na América Latina, 2008312 p. (Doutorado - Orientação BACCEGA, M. A.) Escola de Comunicações e Artes da Universidade de São Paulo, São Paulo, SP, 2008 
qualidade. A lei de 1981 também enfatizou a qualidade e eqüidade, o desenvolvimento da cultura científico-tecnológica e a diversificação de fontes de financiamento.

Algumas transformações marcantes, segundo Esquível $\left(1998^{212}\right)$, se deram a partir de 1981, como parte do programa de modernizações inspirado no modelo neoliberal. Tal mudança se deu na estrutura, na organização e no financiamento das instituições universitárias e foi marcada principalmente pela transição de uma participação estatal quase exclusiva para um sistema privado cada vez mais presente. Em 1982 ocorreu a separação radical entre as universidades do Estado e as privadas.

Até 1980, 50\% dos recursos do setor educacional eram destinados ao nível superior e 50\% aos níveis pré-escolar, básico e médio. Em 1990 estas porcentagens mudaram para 20\% e 80\% respectivamente (Esquível, 1998) ${ }^{213}$. Esta mudança se deu a partir de um diagnóstico do regime militar no qual as oito universidades representavam um esquema fechado e praticamente monopolista financiado pelo Estado, carente de controle e em processo de crescimento inorgânico. O regime propôs então um plano de ação neoliberal. No entanto, estas ações tinham como propósito o enfraquecimento institucional e financeiro das universidades públicas. O que de fato ocorreu até 1990. De 1980 a 1990 o financiamento foi reduzido acima de $40 \%$ e, em parte, isto foi compensado pelo aumento das cobranças de mensalidades e pela venda de serviços e contratos com setores públicos e privados.

Oito universidades existiam até 1980, e em 1997 já eram mais de 60 universidades, 73 institutos profissionais e 127 centros de formação técnica, instituições estas de diferentes tamanhos, estruturas, programas, e principalmente desequilíbrio quanto à infra-estrutura de qualidade e serviços oferecidos. Esquível (1998) ${ }^{214}$ discute os problemas que estas mudanças causaram no sistema de educação superior com relação a carreiras, investimentos e limitações. As carreiras de maior custo continuaram a ser assumidas por instituições com financiamento público.

Quanto às modalidades de financiamento, a partir de 1981 houve a implantação de:

1) Aporte fiscal direto distribuído entre as universidades tradicionais.

2) Aporte fiscal indireto outorgado pelo Estado entre as instituições que matriculam estudantes entre as 27.500 melhores pontuações na prova de aptidão

\footnotetext{
${ }^{212}$ ESQUíVEL, Juan Carlos Campbell, Novas Perspectivas nas ....., 1998, p.247-255 Op. Cit.

213 Ibidem

${ }^{214}$ Ibidem
}

SAKATA, Marici Cristine Gramacho, Globalização e Educação: A formação do comunicador social na América Latina, 2008312 p. (Doutorado - Orientação BACCEGA, M. A.) Escola de Comunicações e Artes da Universidade de São Paulo, São Paulo, SP, 2008 
(PAA). Este passa a ser um elemento competitivo entre as instituições que buscam os melhores alunos para obter recursos financeiros.

Além de:

Mensalidades; créditos universitários; fundos concursáveis e aportes econômicos de setores empresariais, doações, convênios de cooperação de interesse produtivo.

Enfim, uma infinidade de fontes de recursos que dão uma idéia de empresa educativa onde o fator econômico custo-benefício seja o ponto chave.

\begin{tabular}{|l|l|l|}
\hline \multirow{4}{*}{ Chile } & \multirow{2}{*}{ Nacional } & Universidad de Chile \\
\cline { 2 - 3 } & \multirow{2}{*}{ Globalizada } & Universidad de Santiago de Chile \\
\cline { 3 - 3 } & & Universidad Nacional de Andres Bello (Laureate) \\
\hline
\end{tabular}

A Universidad de Chile (UC) é a mais antiga e tradicional do país ${ }^{215}$, é pública e autônoma. A missão declarada da UC é dedicar-se ao ensino e à pesquisa e estar a serviço do país no contexto universal da cultura. Procura contribuir para o desenvolvimento espiritual e material da Nação e velar pelo patrimônio cultural e identidade nacional. Constitui-se como uma reserva intelectual e por isso deve ter completo conhecimento da realidade nacional. A UC procura responder criativamente aos desafios da globalização e afirma que tal resposta não deve consistir meramente em induzir comportamentos adaptativos restritos às exigências do mercado. Segundo sua missão, a UC tem o compromisso com os interesses nacionais e com a manutenção e projeção da identidade cultural e valores. O processo de internacionalização deve seguir critérios para que não desconsidere as prioridades do país e os direitos sociais.

A Universidad de Santiago de Chile (USACH) foi fundada em 1849. É estatal e pública e segundo sua missão, está a serviço da sociedade. Sua missão está associada ao desenvolvimento do país. Tem respondido positivamente aos desafios impostos pelo mundo global por meio de acordos interinstitucionais e convênios de intercâmbio e está trabalhando para credenciar seus cursos e melhorá-los. A instituição preocupa-se com a criação, a preservação, o cultivo e a transmissão do conhecimento.

215 O papa Paulo V, em 1619, instituiu que nos conventos que estivessem a mais de 200 milhas das universidades de México e de Lima e nos que se ensinassem artes e teologia, os estudantes poderiam obter os graus de bacharel, licenciado, mestre e doutor. Em 1622, nasceu a primeira universidade chilena, Santo Tomás de Aquino. Disponível em http://www.uchile.cl/historia/historia.html acesso em $02 / 07 / 2006$

SAKATA, Marici Cristine Gramacho, Globalização e Educação: A formação do comunicador social na América Latina, 2008312 p. (Doutorado - Orientação BACCEGA, M. A.) Escola de Comunicações e Artes da Universidade de São Paulo, São Paulo, SP, 2008 
A Universidade Andrés Bello (AIEP), pertencente ao grupo Laureate, é de caráter privado. Tem como missão formar profissionais e técnicos capazes de se inserirem no mundo empresarial no marco da economia globalizada, e com isso contribuir para o desenvolvimento do país. Busca promover treinamento acadêmico que responderá aos desafios de um mundo interconectado cada vez mais dinâmico.

A Universidad de Las Américas (UAmericas) foi criada em 1981 como um “Grupo Corporativo Universidad de Las Américas”. Hoje pertence ao grupo Laureate. A missão da Universidad de las Américas é também objetiva e se resume a aumentar a força de trabalho por meio da educação, independente de sua origem social.

A UC ressalta diversas vezes o compromisso com a nação, com a preservação da cultura e com a identidade. A missão da UC é claramente manter os elementos identitários Chilenos. A USACH também se preocupa com as questões da globalização, e sua resposta a isto é a internacionalização por meio de acordos e convênios. Mostra preocupação com o credenciamento de seus cursos e também com a preservação e transmissão do conhecimento. A universidade globalizada AIEP mostrase preocupada com o caráter instrumentalista do conhecimento. Não aborda a questão cultural e nacional. A UAmericas tem uma missão clara de capacitar mão-de-obra. Não há referências a quaisquer outras questões. As missões das universidades tradicionais e das universidades globalizadas são completamente diferentes, tanto na apresentação quanto na missão propriamente dita. As duas universidades tradicionais apresentam preocupações com uma série de questões culturais, identitárias, nacionais e de qualidade, e as globalizadas têm como missão a capacitação profissional.

\section{Análise dos Dados e Comparação - Curso e Grade}

O curso de Licenciatura em Comunicação Social - Periodismo da UC visa a uma formação generalista com disciplinas científicas e técnicas. O objetivo é formar um profissional apto a trabalhar em qualquer área da sociedade. A grade curricular inclui disciplinas de cultura, comunicação e identidade, estudos culturais e enfoque latinoamericano.

O curso de Licenciatura em Comunicação Social - Periodismo da USACH também se propõe a formar profissionais com base na cultura e nos fenômenos que afetam as pessoas na sociedade. Na grade curricular, estão presentes disciplinas como Filosofia, Psicologia, Sociologia, História da Cultura, História do Chile, Ordem Econômica Mundial e História Universal Contemporânea. 
O curso técnico de nível superior em Comunicação e Relações Públicas da UNAB forma técnicos para atuarem em todo o tipo de empresa que requer implementação de estratégias de comunicação de massa e/ou serviços de assessoria. A grade não apresenta disciplinas relacionadas à História, Sociologia e Cultura.

O curso de Licenciamento em Ciências da Comunicação - Periodista da UAmericas não faz parte da Escola de Comunicações, onde são oferecidos os cursos de Relações Públicas, Publicidade e Comunicação Audiovisual e Multimídia. O Curso é oferecido pela Escola de Periodismo da Faculdade de Humanidades, Ciências Jurídicas e Sociais. O curso tem como missão formar profissionais capacitados em diversos aspectos e éticos. Na grade curricular há disciplinas de História Contemporânea, Atualidade Nacional e Internacional e Economia e Sociedade.

A grade da UC confirma a missão da instituição, com disciplinas relacionadas à cultura e identidade. A grade da USACH também apresenta várias disciplinas ligadas a história e cultura. Percebemos que a missão está refletida na grade curricular das duas instituições nacionais, no aspecto da identidade e cultura. A grade da UNAB reflete sua missão em formar profissionais/técnicos. A UAmericas, apesar de não explicitar em sua missão a preocupação com questões culturais e nacionais, oferece três disciplinas relacionadas à história e sociedade.

\section{Colômbia}

A história do sistema educacional Colombiano mostra períodos pacíficos e de conflitos. Na década de 1970 o sistema se alterou com o processo de expansão quando houve alta desconcentração regional.

O sistema apresenta uma dualidade: 1) setor universitário privado de alto prestígio (Partido Conservador, interesses católicos) e 2) setor público (Partido Liberal, Laico)

Os gastos públicos em educação, segundo dados orçamentários, cresceram a uma taxa média de $4.1 \%$ ao ano entre 1980 e 1988. Entretanto, a taxa de crescimento dos gastos com as universidades nacionais, estaduais e municipais e para o IFCES Instituto de Fomento da educação superior - foi de apenas 2.5\%. O gasto por aluno calculado em 28 universidades públicas com base em 100 em 1980 caiu para 75 em 1989. Por outro lado, o setor privado se financia com matrículas e taxas cobradas aos 
estudantes, além da venda de outros serviços (hospitalares, de consultorias e ensino) à comunidade.

A reforma de 1992 enfatizou a questão administrativa e o sistema nacional de credenciamento. Com base na Lei 30 de 1992, a Colômbia passou a ter o Servicio público de la educación superior. Também constam desta lei os princípios, os objetivos, a ação, a organização das instituições e os programas das universidades, instituições universitárias, escolas tecnológicas, instituições técnicas profissionais, títulos, exames de estado, autonomia, política de fomento.

Tudo o que se relaciona ao ensino superior na Colômbia é responsabilidade do Presidente da República, que atua junto com o Ministro de Educación Nacional, assessorado pelo Consejo Nacional de Educación Superior - CESU. O CESU também regulamenta o Sistema Nacional de Acreditación, o Sistema Nacional de Información, os exames de Estado, entre outras funções. O órgão que executa as políticas educacionais traçadas pelo governo é o Instituto Colombiano para el Fomento de la Educación Superior - ICFES, instituição pública nacional ligada ao Ministério da Educação.

Na Colômbia, a presença de universidades estrangeiras é baixa devido a restrições legais. Embora haja, também, mecanismos de regulação para "serviços educacionais transnacionais” no Chile, na Argentina e no Brasil, na Colômbia as leis são mais restritivas, pois as empresas interessadas devem se organizar como fundação ou cooperação sem fins lucrativos. (Zarur, 2004) ${ }^{216}$

Na Colômbia as empresas sempre destacam a melhora que poderiam gerar nas IES. No entanto, para Zarur (2004) ${ }^{217}$ o que se discute no outro extremo é a perda da identidade nacional e o surgimento da chamada Macdonaldização da educação superior. Segundo o mesmo autor as universidades colombianas com forte parceria estrangeira são: Universidad Externado de Colombia, Universidad Santo Tomás, Universidad Central, Fundación Universitaria Manuela Beltrán e Fundación Universitaria Monserrate. Por esta razão e por razão de acessibilidade, optou-se por analisar a Universidad Externato de Colombia e Universidad Central.

\footnotetext{
${ }^{216}$ ZARUR, C. Los nuevos proveedores externos de educación superior em Colombia, Asociación Colombiana de Universidades-ASCUN-. Bogotá, mayo de 2004. p.72

${ }^{217}$ Ibidem. p.45
} 


\begin{tabular}{|l|l|l|}
\hline \multirow{3}{*}{ Colômbia } & \multirow{2}{*}{ Nacional } & Pontificia Universidad Javeriana \\
\cline { 2 - 3 } & \multirow{2}{*}{ Globalizada } & Universidad De Antioquia \\
\cline { 3 - 3 } & & Universidad Externado de Colombia \\
\hline
\end{tabular}

A Pontifícia Universidade Javeriana (Javeriana) é uma instituição não-oficial (fundação) e tem como missão melhorar a pesquisa e contribuir para solução de problemas sociais, como valores éticos, instrumentalização do ser humano, crise nos valores nacionais, falta de identidade cultural, intolerância e discriminação, deficiência e irracionalidade com o meio ambiente.

A Universidad de Antioquia (UDEA) é uma instituição estatal criada em 1878. Seu plano de desenvolvimento propõe ajudar o desenvolvimento social por intermédio de seus professores e alunos, cumprir sua função social, além de formar cidadãos idôneos e éticos. Não pretende ser um instrumento de transmissão de conhecimento apenas, mas ter capacidade de ajudar a transformar as condições sociais do país. "Una universidad que cada vez está más cercana al corazón de su pueblo”.

A Universidad Externado de Colombia foi criada em 1886 com forte influência européia. Sua missão é ensinar e pesquisar a partir de uma visão humanista. O Externado trabalha para a reafirmação da identidade nacional, para a integração dos países latino-americanos e para a formação de alunos conscientes de seus compromissos com a nação.

A Universidad Central (UCentral) foi criada em 1966 e desde então tem como missão contribuir para a formação de capital social e cultural. O objetivo da instituição é a educação integral dirigida à formação ética, humanística e científica, assim como o conhecimento e a identificação da realidade social do país. Esta formação integral inclui o sentido de cidadania, o comprometimento com o país e com a identidade latinoamericana.

Apesar de o Externado e a UCentral manterem ampla parceria estrangeira, a missão revela forte preocupação com os problemas nacionais, com a formação integral e com a preservação da identidade. As quatro missões analisadas, tanto das universidades nacionais como das “globalizadas”, não demonstram caráter instrumentalista. De fato, o termo “universidades globalizadas” não corresponde às missões acima, e poderíamos afirmar que são universidades internacionalizadas. 
Análise dos Dados e Comparação - Curso e Grade

O curso de Comunicação Social da Javeriana, assim como a universidade como um todo, tem como missão a formação integral do profissional. Busca formar comunicadores capazes de articular ações e processos culturais do país com visão universal e histórica. A grade inclui disciplinas que abrangem o contexto sócio-político do país e demais componentes sócio-humanísticos.

O curso de Comunicação Social - Periodista da UDEA tem como missão formar comunicadores de diferentes áreas que contribuíram para os processos de desenvolvimento institucional e social da região e do país. A grade é composta por disciplinas de sociologia, História da América Latina, Psicologia e Ética.

O Curso de Comunicação Social - Periodista do Externado foi criado em 1976 e pretende formar Comunicadores com conhecimento da realidade nacional e internacional, que sejam pesquisadores, gestores e comunicadores. A grade inclui disciplinas de Antropologia Cultural, Seminário de História da Cultura, História da Colômbia, Constituição Colombiana, Ética, Cultura Colombiana, Economia, Estado e Sociedade na Colômbia, Conflitos Internacionais, e outras disciplinas optativas referentes à Economia e História.

O Curso de Comunicação Social e Periodista da UCentral tem como objetivo formar comunicadores para produção de mídias e gestão de projetos de alto impacto social. Os alunos devem ter a capacidade de compreender, a partir de sua própria subjetividade, os problemas políticos, sociais e culturais do país e do mundo. A grade inclui como disciplina obrigatória a disciplina de ação social. (Não foi possível acessar a lista de disciplinas optativas).

Assim como a missão geral das quatro universidades analisadas, o objetivo do curso e a grade curricular levam à mesma observação. Não foi possível fazer distinções entre as universidades nacionais e as globalizadas e de fato, não caberia classificar as Universidades Externado e UCentral como globalizadas no sentido do termo aqui utilizado.

México

Durante o período de 1920 a 1990 a educação superior no México esteve fortemente atrelada ao governo central e ao Sindicato Nacional de Trabalhadores da Educação (SNTE). O Partido Revolucionário Institucional (PRI) dominou a política 
nacional e manteve os líderes do SNTE sobre seu controle pelo oferecimento de cargos e salários às suas lideranças. Neste mesmo período, a universidade prosperou em pesquisas e número de matrículas, passando de 200.000 estudantes em 1960 a 1.200 .000 em 2000. O Sistema de ensino superior no México era de acesso irrestrito e gratuito. Em sua maioria laico, autônomo e politizado. Funcionou como espaço político do sistema uni-partidário mexicano por muitos anos, ou seja, um canal de expressão da esquerda.

O financiamento não-vinculado ao planejamento e à coordenação permitiu a expansão espontânea do sistema, o que levou a um crescimento desproporcional e tornou-se ingovernável quando os recursos diminuíram na década de 1980. Com isso, na década de 1980, a rede privada iniciou sua expansão aproveitando a crise da rede pública. Nesta década, o Estado promoveu a desconcentração regional e a diferenciação institucional da rede pública, assumindo o financiamento de universidades estaduais e criando Institutos Tecnológicos públicos na maioria dos Estados.

A fim de sair de uma crise na década de 1980, o governo buscou se reestruturar. O Governo de Salinas (1989) ${ }^{218}$ criou políticas para melhorar a qualidade e a relevância dos sistemas de ensino superior e com isso tentou recuperar as instituições públicas. Também foi em seu governo que houve mudanças nos seguintes quesitos:

(1) a valorização da diferenciação do sistema, com a criação de Universidades Tecnológicas estreitamente ligadas a comunidades empresariais locais, oferecendo cursos de curta duração (dois anos) inspirados nos Institutos Tecnológicos franceses e nos Community Colleges norte-americanos;

(2) o estabelecimento de uma Comissão Nacional de Avaliação para orientar processos simultâneos de auto-avaliação institucional, de avaliações externas de currículos e avaliação individual de professores (por alunos e pares) e pesquisadores;

(3) recuperação dos níveis reais de financiamento do início dos anos 80 e substituição parcial do sistema de repasse automático baseado no número de alunos;

(4) pressões para que as instituições públicas diversifiquem suas fontes de recursos;

(5) introdução de exames de seleção para o ingresso na universidade e de exames de certificação dos formados.

Teve início na década de 1990 um projeto de privatização do ensino superior: “a transformação do ensino superior no México dos anos 90 pode ser entendida como um processo de construção de um pacto entre o Estado e os grandes empresários em relação

\footnotetext{
218 SCHWARTZMAN, Simon, Notas sobre os sistemas de ensino superior da América Latina Disponível em http://www.schwartzman.org.br/simon/america_latina.htm acesso em 10/08/2006

SAKATA, Marici Cristine Gramacho, Globalização e Educação: A formação do comunicador social na América Latina, 2008312 p. (Doutorado - Orientação BACCEGA, M. A.) Escola de Comunicações e Artes da Universidade de São Paulo, São Paulo, SP, 2008
} 
ao que deve ser feito com a educação superior pública” (Aboites, 2000) ${ }^{219}$ e as instituições particulares de ensino médio e superior passaram a representar 59,1\% em 1998.

A ascensão de Vicente Fox ao poder, ex-executivo da Coca-cola e com forte visão empresarial, acelerou o processo de privatização com a cobrança de mensalidades em instituições públicas e a abertura de seus laboratórios para a iniciativa privada.

Os acordos entre México e Estados Unidos e também Canadá provocaram várias mudanças internas, inclusive no campo educacional. Devido a empréstimos feitos por meio do Banco Mundial, do FMI e da OCDE várias contrapartidas tiveram de ser feitas, contrapartidas estas que afetaram as políticas educacionais. Um dos principais pontos do tratado de livre comércio que afeta diretamente a educação superior é o fato de que oferecer educação superior pública viola o princípio de livre comércio estabelecido, podendo o Estado ser processado por não atender ao artigo. Os cursos realizados nos dois outros países do acordo passam a ser referências, alterando o foco de pesquisa e ensino para atender às avaliações, perdendo assim seus valores e tradições locais.

A adesão ao tratado de livre comércio com os Estados Unidos e Canadá acelerou a tomada de decisões que transformaram a área educacional em um mercado. Há resistência da Academia e da sociedade. No entanto, o único ponto que permaneceu inalterado é a gratuidade da UNAM.

Segundo Marin-Marin (1998) $)^{220}$ a complexidade do sistema de educação superior aumentou com a entrada das instituições estrangeiras no México e com o apoio político e financeiro de personalidades mexicanas como no caso da Endicott College de Boston (em 1996), cujo Conselho Diretivo conta com o ex-governador do Estado do México Ignacio Pichardo Pagaza.

\begin{tabular}{|l|l|l|}
\hline \multirow{4}{*}{ México } & \multirow{2}{*}{ Nacional } & Universidad Nacional Autonoma de Mexico \\
\cline { 3 - 3 } & & Universidad de Guadalajara (UdeG) \\
\cline { 2 - 3 } & \multirow{2}{*}{ Globalizada } & Universidad Del Valle (Laureate) \\
\cline { 3 - 3 } & & Endicott College Mexico \\
\hline
\end{tabular}

219 ABOITES, Hugo. A privatização da educação superior no México: novas e velhas realidades. In: Gentili. P. (org.) Universidades na penumbra: neoliberalismo e reestruturação. São Paulo, Cortez, 2001.

220 MARÍN-Marin, Alvaro El analisis de la educación superior en México mediante la teoría del caos, Sincronía Winter/Invierno, 1998 Jalisco, México Citando El Financiero, 18 de abril de 1996, p.34 Disponível em http://sincronia.cucsh.udg.mx/caos.htm acesso em 01/12/2006 
A Universidad Nacional Autonoma de Mexico (UNAM) é a mais tradicional e importante Universidade do México e foi fundada em 1551. É a maior da AméricaLatina e considerada uma das melhores também. Concentra um total de 269.000 alunos. É pública e descentralizada do Estado mexicano. A UNAM tem como missão (anima) "Por mi raza hablará el espíritu”, ou seja, a raça e a pátria têm um destacado significado para a instituição.

A Universidad de Guadalajara (UdeG) é pública e descentralizada do governo, tem mais de duzentos anos e é uma instituição tradicional no México. A instituição mostra sua preocupação com a modernização e a tecnologia para melhorar sua qualidade. A missão da UdeG é de uma educação integral dos alunos para a tolerância, amor à pátria e à humanidade. A instituição se preocupa com a pluralidade de pensamentos e busca resgatar, conservar, acrescentar e difundir a cultura, a ciência e a tecnologia.

A Universidad Del Valle de México (UVM) pertence ao grupo Laureate. A UVM operou durante 40 anos (desde 1960) antes de ser adquirida pelo grupo. Sua missão é “de uma instituição que, de maneira integral, educa com equilíbrio entre os enfoques científicos-técnicos e ético-cultural, de acordo com as necessidades sociais, a busca da verdade e o bem comum, fundamentando-se em uma filosofia institucional e em seu modelo educativo.”

A Endicott College México é uma franquia da Endicott College fundada em 1939 por iniciativa privada em Massachusetts, Estados Unidos da América. O objetivo da instituição com este campus no México é ajudar a preparar os residentes Mexicanos para a vida em uma comunidade global cada vez mais interdependente. Parte do curso é feito no México e o restante na instituição norte-americana. O campus foi criado em 1996 com cursos em inglês.

No caso do México, a missão declarada das universidades nacionais se distancia significativamente da missão das universidades globalizadas. Enquanto as nacionais, assim como nos demais casos analisados anteriormente, mostram preocupação com a formação integral, com a cultura e a nação, as globalizadas não fazem referência a nenhuma destas questões. Em artigo publicado por Camacho (2006) ${ }^{221}$, tanto a UVM como a Endicott são mencionadas como “corporação transnacional” e “aristocrática”

221 CAMACHO, Zósimo, Extranjeros al acecho de la educación, Contralinea, (2006) Disponível em Http://www.contralinea.com.mx/archivo/2006/enero/htm/extranjeros_acecho_educaion.htm acesso em $01 / 12 / 2006$

SAKATA, Marici Cristine Gramacho, Globalização e Educação: A formação do comunicador social na América Latina, 2008312 p. (Doutorado - Orientação BACCEGA, M. A.) Escola de Comunicações e Artes da Universidade de São Paulo, São Paulo, SP, 2008 
respectivamente. $\mathrm{O}$ autor também lista outras 26 sociedades mexicanas com investimento estrangeiro, classificadas como prestação de serviços de educação superior.

Análise dos Dados e Comparação - Curso e Grade

A UNAM oferece o curso de Licenciatura em Ciências da Comunicação. O perfil a ser formado é de um profissional com sólida formação social e humanística, tendo como referencial as ciências sociais e a cultura. A grade do curso oferece disciplinas de Economia, História do México em todos os semestres do tronco comum, Identidade cultural, Identidade Corporativa e História Contemporânea.

A UdeG oferece a Licenciatura em Comunicação Pública. A instituição faz uma longa apresentação do curso e fala sobre a importância da comunicação pública na sociedade no sentido de facilitar as discussões sociais e a participação e qualidade das relações. O curso propõe analisar as mudanças culturais e sócio-culturais da sociedade, analisar o processo histórico dos meios de comunicação e lógicas de produção, sempre a partir do contexto sócio-cultural. As disciplinas da grade incluem Ética, Problemas Sócio-econômicos e Políticos do México, Teorias da Globalização, Economia e os Meios de Comunicação no México e em Jalisco (região).

A UVM oferece a Licenciatura em Ciências da Comunicação. A carreira forma profissionais com visão humanista e enfoque multidisciplinar. Pretende desenvolver habilidades lingüísticas e técnicas e sugere instituições para trabalhar. A grade curricular possui disciplinas obrigatórias de Ética e Função Social das Mídias e as demais disciplinas são técnicas. No item denominado "Desenvolvimento Universitário" há tópicos de formação cultural, visão global e entorno sócio-político e econômico do México. Não está claro pelo documento analisado se é uma disciplina.

A Endicott oferece Bacharelado em Ciência da Comunicação. O objetivo está escrito em formato de matéria publicitária "Você já pensou em estar atrás das câmeras em uma rede de TV, agência de propaganda ou jornal?” A proposta do curso é preparar os alunos para atuarem no campo da comunicação, na indústria ou dar continuidade aos estudos. A descrição geral das disciplinas refere-se a atividades práticas e "hands-on experience”. O estágio é obrigatório e a instituição diz ter todos os recursos tecnológicos necessários para o aprendizado.

As missões das instituições estão claramente refletidas na grade curricular. As duas instituições nacionais adotam a missão de formar profissionais aptos a atuarem na 
sociedade e no campo da comunicação a partir de disciplinas técnicas e pensamento humanístico. As duas instituições globalizadas possuem forte orientação mercadológica e tecnicista. A Endicott é voltada inteiramente ao mercado internacional.

\section{Europa: Espanha e França}

Com o objetivo de comparar as mudanças ocorridas na América Latina com as mudanças ocorridas em países desenvolvidos, o mesmo estudo foi feito com universidades da Espanha e França, principalmente pela similaridade que guardam com as instituições latino-americanas, mas também pela ligação histórica; e dos Estados Unidos da América pela importância que têm no cenário da globalização.

Para esta tese foram visitadas pessoalmente as quatro universidades Francesas da amostra e a Universidade de Deusto, na Espanha. ${ }^{222}$

\section{Espanha}

O princípio de autonomia das universidades Espanholas foi proclamado na Constituição de 1978. Hoje o ensino superior universitário compreende ${ }^{223}$ :

- 50 universidades públicas

- 17 universidades privadas

- 7 universidades da Igreja Católica.

As universidades são entidades autônomas de direito público. Elas estabelecem suas ofertas de formação em dois tipos de diploma:

- Diploma oficial com validade no território Espanhol.

- Diploma próprio da universidade mas sem reconhecimento nacional como MBA, por exemplo.

Segundo Gonzalez (1998) ${ }^{224}$ o início do ensino de jornalismo na Espanha se deu em 1887 na Universidad de Salamanca com Fernando Araujo. A primeira escola, no

\footnotetext{
${ }^{222}$ Na Universidade de Deusto permaneci durante o período de um mês (Janeiro de 2007) como parte do programa FMP-Fundo Sasakawa.

${ }^{223}$ Onisep 2007, Disponível em http://www.onisep.fr/onisep-portail/portal/media-

type/html/group/gp/page/interieur.espace.listeDocs/js_peid/InitInterieurEspaceListeDocs/js_peid/ListeDo cs? reference. code $=33929309175$ ea851073165fa677ec7\&reference.langue $=$ fr\&reference.version $=0$ \&espa ceDoc $=\&$ typeDoc=systeme_educatif\&codeSelectionne $=\&$ rechercheParReference=true\&afficheFilAriane $=$ true acesso em 09/07/2007

${ }^{224}$ GONZALEZ, Aurora, La formación académica y profesional del periodista In: Barrera, Carlos (org.) Del gacetero al profissional del periodismo, Madid, 1998, livro produzido a partir de "Actas de III Encuentro de la Asociación de Historiadores de la Comunicación de la Faculdad de Comunicación de la Universidad de Navarra (Pamplona).

SAKATA, Marici Cristine Gramacho, Globalização e Educação: A formação do comunicador social na América Latina, 2008312 p. (Doutorado - Orientação BACCEGA, M. A.) Escola de Comunicações e Artes da Universidade de São Paulo, São Paulo, SP, 2008
} 
entanto, surgiu após Angel Herrera fazer uma viagem aos Estados Unidos e visitar as principais escolas de jornalismo norte-americanas. Com isso, Herrera apoiou a criação da primeira escola de periodismo na Espanha que foi organizada e institucionalizada por Nicolas Gonzales Ruiz em 1926.

A primeira escola estabelecia três objetivos principais:

- a formação moral e ética;

- a preparação para a defesa da igreja;

- o conhecimento da técnica periodista.

Com isso, o objetivo geral do curso era formar pessoas aptas a servirem à igreja e à prática de jornalismo. O curso tinha dois públicos: os já formados e os jovens.

O primeiro currículo (plan de estudio ordinário) implementado em 1932 na escola “El Debate” era conforme segue:

\begin{tabular}{|c|c|c|c|c|}
\hline $1^{\circ}$ curso & $2^{\circ}$ curso & $3^{\circ}$ curso & $4^{\circ}$ curso & $5^{\circ}$ curso \\
\hline $\begin{array}{l}\text { Criteriologia de } \\
\text { Balmes (filosofia) } \\
\text { Gramática } \\
\text { castellana } \\
\text { Francês } \\
\text { Mecanografia } \\
\text { Tipografia }\end{array}$ & $\begin{array}{l}\text { Apologética } \\
\text { Redação } \\
\text { Francês } \\
\text { Mecanografia } \\
\text { Taquigrafia } \\
\text { Tipografia }\end{array}$ & $\begin{array}{l}\text { Cultura religiosa } \\
\text { Redação } \\
\text { jornalística } \\
\text { Notícias e arte } \\
\text { Inglês } \\
\text { Tipografia } \\
\text { Taquigrafia }\end{array}$ & $\begin{array}{l}\text { Ética } \\
\text { Reportagem } \\
\text { Edição } \\
\text { Administração } \\
\text { Jornalismo } \\
\text { Inglês }\end{array}$ & $\begin{array}{l}\text { Teologia social } \\
\text { Editoriais e } \\
\text { normas de } \\
\text { direção } \\
\text { Reportagens } \\
\text { Correspondên- } \\
\text { cias } \\
\text { Inglês }\end{array}$ \\
\hline
\end{tabular}

\section{Disciplinas gerais}

Apologética, Repórter, Gramática, Redação, Editorial, Encíclicas, Políticas estrangeiras, Política agrária, Economia, Teatro e crítica teatral, Administração pública

Com este currículo se buscava uma formação prática, mas também cultural. Quanto aos teóricos da Comunicação, segundo Galindo (1998) ${ }^{225}$ os que mais se destacavam na Espanha, até 1998, eram: Augusto Perez Perchet, Alfredo Cabazán, Modesto Ortiz, Rafael Mainar e Salvador Miguijón.

Na Espanha, os títulos estabelecidos pelo Ministério da Educação e Ciência $\left(2007^{226}\right)$ na área de comunicação são os seguintes:

\section{Periodismo}

225 GALINDO, J. La historia de la periodistica en España, In: Barrera, Carlos (org.) Del gacetero al profissional del periodismo, Madrid, 1998, livro produzido a partir de “Actas de III Encuentro de la Asociación de Historiadores de la Comunicación de la Faculdad de Comunicación de la Universidad de Navarra (Pamplona). pg. 223

${ }^{226}$ TITULACIONES ESTABLECIDAS POR EL GOBIERNO CIENCIAS Ministerio de Educación y Ciencia de España, Disponivel em Thttp://www.mec.es/univ/jsp/plantilla.jsp?id=1803 acesso em 09/07/2007

SAKATA, Marici Cristine Gramacho, Globalização e Educação: A formação do comunicador social na América Latina, 2008312 p. (Doutorado - Orientação BACCEGA, M. A.) Escola de Comunicações e Artes da Universidade de São Paulo, São Paulo, SP, 2008 
O Decreto real 1428/1991, de 30 de agosto, estabeleceu o título universitário oficial de Licenciado em Periodismo bem como as diretrizes gerais dos planos de estudos. Neste decreto, consta que o título deve proporcionar uma formação especializada no âmbito da elaboração, gestão e difusão da atividade informativa jornalística em diversos âmbitos temáticos e meios de comunicação. Deve articular-se com o primeiro e o segundo ciclo e ter duração de 4 a 5 anos.

\section{Comunicación audiovisual}

O Decreto real 1427/1991, de 30 de agosto, estabeleceu o título universitário oficial de Licenciado em Comunicación Audiovisual. O ensino deve proporcionar uma formação adequada no campo da elaboração informativa e de criação, produção e realização de diversos meios de comunicação audiovisual.

\section{Publicidad y relaciones públicas}

O Decreto real 1386/1991, de 30 de agosto, estabeleceu o título universitário oficial de Licenciado em Publicidad y Relaciones Públicas. O ensino deve proporcionar uma formação especializada na criação, desenho e produção de comunicação publicitária, bem como em estratégias e aplicações das relações públicas.

A seguir, apresentamos as universidades analisadas.

\begin{tabular}{|l|l|l|}
\hline \multirow{3}{*}{ Espanha } & Nacional & Universidad de Deusto*** \\
\cline { 2 - 3 } & & Universidad Complutense de Madrid*** \\
\cline { 2 - 3 } & Globalizada & Mondragon Unibertsitatea \\
\cline { 2 - 2 } & & Universidad Antonio de Nebrija** \\
\hline
\end{tabular}

* universidade privada listada no Ranking Atlas of Science

(http://www.atlasofscience.net/atlas/script/irank_div.asp?f=1 Spain Time slicing:1990-2004 Institutional ranking)

** Consta em $9^{\circ}$ lugar no ranking feito pela Universidad de Barcelona

*** Universidades Nacionais que, segundo o relatório de Aupetit $\left(2005^{227}\right)$, são instituições estrangeiras provedoras de educação na América Latina.

A missão declarada pela Universidad de Deusto afirma ter no âmbito institucional uma opção por temas sociais de interdependência, distribuição de recursos, migração, direitos humanos, desenvolvimento, pobreza e meio ambiente, ética e sociedade e também os estudos sobre identidade cultural individual e coletiva, além dos processos de integração européia. Também afirma que a missão, por ser uma Universidade Jesuíta, é o serviço de fé, por meio da ciência e cultura, que deve se desenvolver em um clima e em uma dinâmica de diálogo entre os agentes religiosos,

227 AUPETIT, Sylvie Didou, Internacionalización y proveedores ....., 2005.

SAKATA, Marici Cristine Gramacho, Globalização e Educação: A formação do comunicador social na América Latina, 2008312 p. (Doutorado - Orientação BACCEGA, M. A.) Escola de Comunicações e Artes da Universidade de São Paulo, São Paulo, SP, 2008 
culturais e sociais com respeito aos que crêem e aos que não crêem. A internacionalização não exclui regiões e está mais voltada à Europa e América latina.

Segundo a missão da Universidad Complutense de Madrid, além de ser um centro de excelência acadêmica e de pesquisa, deve se abrir às problemáticas sociais internas e de seu entorno social; daí que uma das diretrizes de seu Programa de Governo seja a necessidade de impulsionar permanentemente medidas concretas que favoreçam a integração e a igualdade real de oportunidades das pessoas com necessidades especiais na UCM.

A Mondragon Unibertsitatea faz parte da Mondragón Corporación Cooperativa $(M C C)$ : um grupo de empresas que atuam em diferentes setores, concentrado na região basca. É uma escola criada em 1997 a partir da junção de três cooperativas educacionais. Desta forma, existe a missão da corporação e a missão da Universidade. A missão do grupo é apresentada a partir de um modelo de gestão com três blocos: Estratégia, Agentes e Resultados, e com isso, o grupo afirma que não existem empresas excelentes com resultados deficientes. Já a Mondragon Unibertsitatea, instituição sem fins lucrativos e de iniciativa e vocação social como declaram, é de utilidade pública. Tem como compromisso a educação e a orientação prática dos estudos, o que eles chamam de formação integral dos estudantes. A missão, o objetivo e a descrição da universidade destacam a importância da ligação com o grupo MCC para permitir que os alunos, desde o início, tenham contato com o mundo corporativo. Conforme declaram, empenham-se em uma clara vocação humanista e comprometida com o entorno, com a sua sociedade e com o tempo.

A Universidad Antonio de Nebrija é uma instituição privada com vocação internacional e espírito prático, segundo sua própria definição. A missão é manter o alto rigor no ensino acadêmico e na investigação científica para contribuir com a formação e o desenvolvimento profissional e humano dos estudantes e com o progresso da sociedade. É a primeira universidade Espanhola em porcentagem de alunos estrangeiros e muitos dos alunos cursam parte do curso no exterior. A universidade demonstra bastante preocupação com a oferta de especializações e com a inserção do aluno no ambiente profissional.

As universidades nacionais são as mais antigas e tradicionais da Espanha e são, na maioria, confessionais. Por isso ressaltam a grande preocupação com a formação integral e com questões sociais. A Universidad de Deusto, pelo fato de estar situada na região basca, explicita também a preocupação com a identidade cultural. As missões 
das Nacionais também se distanciam significativamente da missão das universidades globalizadas. Embora a Mondragon demonstre preocupação com as questões humanistas e sociais, ela está subordinada financeiramente a um grupo cuja missão é obter resultados nos investimentos. Já a Universidad Antonio de Nebrija é clara em estabelecer que sua missão é a vocação internacional e a formação profissional. Não há, desta forma, menção à formação integral, à cultura ou às questões sociais.

Análise dos Dados e Comparação - Curso e Grade

Na Universidad de Deusto, o curso oferecido é a licenciatura en Humanidades: Comunicación. O objetivo é formar profissionais da comunicação capazes de conceber conteúdos e gerenciá-los. O curso propõe prover aos alunos conhecimentos e habilidades necessárias para a atividade profissional em mídias, empresas, serviços de informações etc. O curso tem duração de cinco anos. Até 2007 ainda não havia sido alterado para três anos como sugere o Processo de Bolonha. Algumas das disciplinas obrigatórias, além das disciplinas da área de comunicação, são: Historia Universal, Latín y Cultura Clásica, Lengua Española, Lengua Vasca, Literatura Española y Vasca, Historia del Pensamiento Filosófico y Científico, Historia Contemporánea, Psicología, Antropología Social.

Na Universidad Complutense de Madrid é oferecido o curso de Licenciatura de Periodismo. O curso tem duração de cinco anos e algumas disciplinas que se destacam são Economía Mundial, Economía de España, Comunicación en la Unión Europea, Instituciones comunitárias, Influencia sociocultural de las nuevas tecnologías de la información e Economía de la Unión Europea. No entanto, são todas disciplinas optativas.

A Mondragon Unibertsitatea segue um "Modelo Educativo denominado Proyeto Mendeberri”, que é um modelo trilingüe e que, segundo a instituição, se caracteriza pelo desenvolvimento de competências e valores no próprio processo formativo de caráter prático, com uso de novas tecnologias. A universidade oferece o curso de Licenciatura en Comunicación Audiovisual, que tem o objetivo de formar comunicadores integrais especializados no âmbito da comunicação audiovisual. A única disciplina que se destaca é a Análisis del entorno social y de su evolución histórica (obrigatória).

SAKATA, Marici Cristine Gramacho, Globalização e Educação: A formação do comunicador social na América Latina, 2008312 p. (Doutorado - Orientação BACCEGA, M. A.) Escola de Comunicações e Artes da Universidade de São Paulo, São Paulo, SP, 2008 
A Universidad Antonio de Nebrija ${ }^{228}$ oferece o curso de Licenciatura en Periodismo no Departamento de Periodismo e Comunicação Audiovisual com cinco especializações, sendo uma delas Cultura e Humanidades (Programa Sofia - Programa comum a todos os cursos). A duração do curso é de quatro anos. O objetivo principal é garantir a cada aluno as habilidades, aptidões e capacidades necessárias para exercer sua profissão com segurança, confiança e êxito. Algumas disciplinas que se destacam são: Mundo Contemporâneo, España Contemporanea e La Ética del Voluntariado en la Sociedad Actual.

As duas universidades nacionais oferecem disciplinas mais voltadas à formação integral do aluno. A descrição dos cursos também demonstra a preocupação em atender estes objetivos. As duas universidades globalizadas demonstram forte preocupação com a formação profissional do aluno, e a Nebrija, até pelo seu histórico, demonstra preocupação com a internacionalização do curso e com a formação de um profissional apto a atuar em um mercado globalizado. Há diversas ofertas de disciplinas em línguas inglesa, francesa e alemã.

\section{França}

Na França, o Sistema Universitário constitui o maior pólo de ensino superior. São: 2.275.000 estudantes inscritos no sistema superior, sendo 1.421 .719 em universidades $^{229}$. Há 89 universidades na França. Os gastos anuais do governo com educação por aluno são:

Ensino Médio (Liceu): 10.170 euros

Ensino Universitário: 6.700 euros

Ensino Preparatório: 13.100 euros

O gasto por estudante na Franca ocupa a $15^{\mathrm{a}}$ posição no ranking da OCDE 230

Segundo dados do Ministério da Educação Francês, em 2004 ${ }^{231}$, 82,3 \% dos gastos totais com educação foram financiados pelo Estado. As famílias e empresas

\footnotetext{
${ }^{228}$ Nota-se que o reitor desta Universidade (data 2007) é também consultor do FMI, BM, BID e EU (http://universidades.universia.es/rectores/cv/fernando-fernandez-nebrija.pdf)

${ }^{229}$ Ministério da Educação Nacional - França, Disponível em http://www.education.gouv.fr/pid10/enseignement-superieur-et-recherche.html acesso em 09/07/2007

${ }^{230}$ Idem, Disponível em http://www.education.gouv.fr/cid1015/service-des-relations-internationales-desuniversites.html, acesso em 09/07/2007

${ }^{231}$ Idem, Disponível em http://www.education.gouv.fr/pid8/le-systeme-educatif.html Acesso em 16/07/2007

SAKATA, Marici Cristine Gramacho, Globalização e Educação: A formação do comunicador social na América Latina, 2008312 p. (Doutorado - Orientação BACCEGA, M. A.) Escola de Comunicações e Artes da Universidade de São Paulo, São Paulo, SP, 2008
} 
arcaram com o restante. O total aproximado corresponde a 7,1\% do PIB e, deste total gasto com educação 12\% destinaram-se ao Ensino Superior Público.

O Estado Francês detém o monopólio dos graus e títulos universitários. As instituições privadas só podem emitir certificado de escolaridade. No entanto, as instituições privadas podem receber ajuda do Estado para funcionarem. Na França estes estabelecimentos representam 30\% do total e são compostos pelos Institutos Confessionais e as Escolas de Engenharia e de Comércio. Do total de alunos inscritos, cerca de 14\% estão no sistema privado. Os cidadãos franceses ou de origem de países membros da União Européia podem criar instituições de ensino privadas. Cidadãos de outros países devem obter uma autorização junto ao conselho acadêmico de Educação Nacional.

Em 2006 havia 58 instituições privadas com apoio do governo, sendo 13 instituições livres - institutos católicos autorizados a cooperar com as instituições públicas, 32 escolas de engenharia e 13 escolas de gestão.

Os três tipos de instituições de educação superior são:

1. Instituições públicas de caráter científico, cultural e profissional

2. Instituições públicas de caráter administrativo

3. Outras instituições de ensino superior

Quanto à formação do comunicador, na França, a associação dos comunicólogos optou pelo uso do termo Sciences de l'Information et de la Comunication (2007) ${ }^{232}$. Antes da reforma educacional o curso superior denominado Informação e Comunicação correspondia a um diploma universitário de tecnologia (D.U.T). A duração do curso era de dois anos. ${ }^{233}$ Devido ao processo de Bolonha e a entrada da França no Espaço Europeu de educação superior, os planos pedagógicos foram refeitos, e os cursos de dois anos tiveram de ser complementados com mais um ano de especialização para passarem a se chamar Licence Professionnelle, o que corresponde ao curso de Graduação de acordo com a definição de Bolonha.

As licences professionnelles na área de Comunicação e Informação disponíveis em 2006 na França ${ }^{234}$ são:

Activites et Techniques de Communication / Atividades e Técnicas de Comunicação

\footnotetext{
${ }^{232}$ SFSIC - Société Française des Sciences de l'Information et de la Communication , disponível em http://www.sfsic.org/portail/index.php acesso em 09/07/2007

233 Ministério da Educação Nacional - França, Formations et diplomes Disponível em http://www.education.gouv.fr/cid178/programmes-pedagogiques-nationaux.html acesso em 09/07/2007

${ }^{234}$ Licences Professionnelles Rentrée universitaire 2006 Disponível em http://www.sup.adc.education.fr/lplst/ acesso em 0907/2007
}

SAKATA, Marici Cristine Gramacho, Globalização e Educação: A formação do comunicador social na América Latina, 2008312 p. (Doutorado - Orientação BACCEGA, M. A.) Escola de Comunicações e Artes da Universidade de São Paulo, São Paulo, SP, 2008 
Metiers de L'edition / Editoração

Reseaux et Telecommunications / Redes e Telecomunicações

Ressources Documentaires et Bases de Donnees / Fontes Documentais e Bases de Dados

Systemes Informatiques et Logiciels / Sistemas de Informação e Computação

Techniques et Activites de L'image et du Son / Técnicas e Atividades de Imagem e Som

Segundo o programa pedagógico do Ministério da Educação da França ${ }^{235}$, o objetivo geral da formação é fomentar seus estudantes a se tornarem técnicos qualificados no campo da informação e da comunicação. Propondo uma formação polivalente e uma especialização que os prepare para o exercício futuro.

As cinco opções são:

- Comunicação Organizacional (Communication des Organisations - CO)

- Gestão da Informação e Documentação nas Organizações (Gestion de

l'Information et du Document dans les Organisations - GIDO)

- Jornalismo (Journalisme)

- Biblioteconomia (Métiers du Livre et du Patrimoine - MLP) :

- Publicidade (Publicité)

O Plano pedagógico tem como finalidade propiciar aos estudantes o saber, o saber fazer e, sobretudo, a Cultura Profissional. Nos módulos de formação, o Ministério define que $40 \%$ devem se referir à unidade de Ensino - Expressão e Comunicação e Ciências Humanas e Sociais; e 60\% devem se referir a Métodos e Práticas Profissionais.

O conceito de universidade globalizada como definimos, ainda não existe em grande quantidade na França devido aos princípios estabelecidos pelo Estado em relação à Educação como um todo. Um exemplo de universidade globalizada na França (Davidenkoff, 2002) $^{236}$ na área de Engenharia é a presença do Georgia Institute of Technology (Georgia Tech), Universidade Norte-Americana (Atlanta) no país. Com 322 milhões de dólares de orçamento anual, a Geórgia Tech compete com outras duas instituições privadas, o MIT e Harvard. Desde 1991 a Georgia Tech se instalou na Europa, no pólo tecnológico de Metz. Com isso os alunos fazem uma parte do curso na França e uma parte nos EUA e recebem o duplo diploma Georgia Tech Lorraine de

\footnotetext{
235 Ministère de l'éducation nationale, de l'enseignement supérieur et de la recherche Septembre 2005 Programme Pédagogique National du DUT « Information - communication » Disponivel em http://www.education.gouv.fr/ acesso em 09/07/2007

${ }^{236}$ DAVIDENKOFF, Emmanuel, Chronique France Info - Rubrique Education, Passage antenne le mardi 21 mars 2002 Relations presse - Radio

SAKATA, Marici Cristine Gramacho, Globalização e Educação: A formação do comunicador social na América Latina, 2008312 p. (Doutorado - Orientação BACCEGA, M. A.) Escola de Comunicações e Artes da Universidade de São Paulo, São Paulo, SP, 2008
} 
engenharia. Segundo a escola, a filosofia é “formar tomadores de decisão multiculturais para as empresas globais ${ }^{237}$. O grupo também tem campus em Cingapura e Xangai.

\begin{tabular}{|l|l|l|}
\hline \multirow{2}{*}{ França } & \multirow{2}{*}{ Nacional } & Université de Marseille \\
\cline { 2 - 3 } & \multirow{2}{*}{ Globalizada } & Université de Bourdeaux \\
\cline { 2 - 3 } & & Université Paris $\mathrm{X}^{* * *}$ \\
\hline
\end{tabular}

*** Universidades Nacionais que, segundo o relatório de Aupetit $\left(2005^{238}\right)$, são instituições estrangeiras provedoras de educação na América Latina .

Como o sistema de educação superior é centralizado, as Universidades fazem parte de um único sistema, e por isso não apresentam as missões e valores por instituição como nos demais países analisados. A missão consta do portal do Ministério (Ministère Èducation National ${ }^{239}$ ) e inclui “grandes princípios” inspirados na revolução de 1789, nas leis de 1881 e 1889 e na constituição de 1958.

A organização de um ensino público obrigatório gratuito e laico em todos os níveis é um dever do Estado. Os princípios são:

- Liberdade de ensino - O sistema privado convive com o sistema público, e ambos obtêm ajuda do Estado. No entanto, somente o Estado pode emitir diplomas e graus Universitários com validade nacional.

- Gratuidade - A gratuidade do ensino primário foi estabelecida em 1881 e a do ensino secundário, em 1933.

- Neutralidade - Prega-se aos professores e alunos a neutralidade do ponto de vista filosófico e político.

- Laicidade - A partir de 1882 o sistema educativo passou a ser laico, reforçado e ampliado pelo Estado em 1905, o que significa ausência de disciplinas de religião e laicidade dos funcionários.

- Obrigatoriedade - Desde 1882 a educação é obrigatória a partir dos 6 aos 14 anos de idade.

A Science Po, diferente das demais, possui uma missão independente onde critica o sistema de ensino e pesquisa francês uma vez que ambos estão separados. Os laboratórios e centros de pesquisa são geridos pelos organismos como CNRS-Centre National de la Recherche Scientifique e INSERM-Institut National de la Santé et de la Recherche Médicale, e estes não possuem estrutura suficiente para manter o bom

\footnotetext{
237 former des décideurs multicuturels pour les entreprises globales

238 AUPETIT, Sylvie Didou, Internacionalización y proveedores ....., 2005.

${ }^{239}$ Ministère Ėducation National - Disponível em http://www.education.gouv.fr/pid8/le-systemeeducatif.html Acesso em 16/07/2007
}

SAKATA, Marici Cristine Gramacho, Globalização e Educação: A formação do comunicador social na América Latina, 2008312 p. (Doutorado - Orientação BACCEGA, M. A.) Escola de Comunicações e Artes da Universidade de São Paulo, São Paulo, SP, 2008 
funcionamento do sistema; e a pesquisa que geram estão separadas da Universidade. Com isso, a Science Po diz diferir-se em três pontos das demais universidades: possui centros de pesquisa perfeitamente integrados à Universidade, seleciona de forma superficial os alunos no primeiro ano, e é proprietária de sua estratégia educativa e científica.

Não é possível fazer uma comparação entre as Missões dado que na maior parte dos casos é a mesma para todo o sistema de educação superior na França, exceto a Science Po, como apresentado anteriormente. O país considera a Educação um direito do cidadão, e é dever do Estado provê-la de forma gratuita até o nível secundário. A educação superior é pública ou ligada ao sistema público, e, embora não seja gratuita, a taxa de manutenção é bastante inferior se comparada às instituições privadas dos demais países analisados. Desta forma, os princípios estabelecidos são respeitados e se refletem na forma de organização das instituições, muito embora não estejam livres de deficiências e críticas, como a feita pela própria Science Po.

\section{Análise dos Dados e Comparação - Curso e Grade}

Para podermos fazer uma comparação entre os países, foram selecionados os cursos de graduação que mais se assemelham com o sistema latino-americano. O sistema de educação superior é estruturado de forma diferente. Para o curso de graduação francês ser equivalente ao Brasileiro é necessário considerar os três anos de Licence mais um ano do Master.

A Université de Provence - Université Aix-Marseille já realizou a reforma sugerida pelo Acordo de Bolonha, e está no sistema LMD (Licenciatura - 3 anos, Mestrado- 2 anos, Doutorado-3 anos) desde 2004. O curso oferecido pelo département des sciences de l'information et de la communication (SIC) é a Licence professionnel em Information et communication ${ }^{240}$ com dois anos de duração e o primeiro ano do Mestrado Master Sciences Humaines et Sociales Mention : Métiers de la communication et de la médiation. O objetivo da Licenciatura é estudar as teorias da comunicação e as práticas audiovisuais para favorecer uma reflexão crítica sobre o estado do conhecimento. Os estudos provêm uma boa base de cultura geral. O Mestrado tem como objetivo formar o aluno para o setor profissional, mas também para a pesquisa, levando em consideração as negociações internacionais, a língua, a cultura e

\footnotetext{
${ }^{240}$ Université de Provence, Aix Marseille 1 Disponível em http://www.up.univ-mrs.fr acesso em $16 / 07 / 2007$

SAKATA, Marici Cristine Gramacho, Globalização e Educação: A formação do comunicador social na América Latina, 2008312 p. (Doutorado - Orientação BACCEGA, M. A.) Escola de Comunicações e Artes da Universidade de São Paulo, São Paulo, SP, 2008
} 
as civilizações, a filosofia e a psicologia social. As disciplinas são voltadas à área de comunicação. Uma das descrições das disciplinas que se destacam é a de "Análise Crítica da Sociedade da Comunicação e do Espaço Midiático no contexto da Globalização”.

A Université de Bordeaux 3 oferece o curso Licence - Licence Professionnelle Communication et information - Presse et édition d'entreprise no IUT Michel de Montaigne de 2 anos e o Master no ISIC Institut des Sciences de l'Information et de la Communication $\left(1^{\circ}\right.$ ano $\left.{ }^{241}\right)$ Masters Recherche Communication, organisation et territoires. A Licenciatura tem como objetivo ensinar conhecimentos teóricos e práticos em Informação e Comunicação. As disciplinas oferecidas durante os dois primeiros anos têm como objetivo ensinar e reforçar a cultura geral e métodos de trabalho necessários para a vida profissional, sendo elas: História, Letras, História da Arte, Filosofia, Psicologia, Sociologia e Economia. No Mestrado, um dos objetivos é estudar as questões do mundo contemporâneo, as transformações e desenvolvimentos.

A Université Paris $\mathrm{X}^{242}$ oferece o curso de Licence en Sciences de l'Information et de la Communication (2 anos) e o Master Recherche Sciences humaines et sociales Mention: Sciences de l'information et de la communication - Spécialité: Informationcommunication: mutations et enjeux pour la société ( $1^{\circ}$ ano). O objetivo do curso é formar estudantes com cultura e metodologia apropriada para exercer a carreira de comunicação, informação e documentação e a carreira de pesquisador. Das disciplinas obrigatórias, não se destaca nenhuma disciplina humanística.

A Université Science Po é constituída pelo Institut d'Etudes Politiques de Paris, instituição pública de ensino superior e pela Fondation Nationale des Sciences Politiques, fundação privada sem fins lucrativos, responsável por gerir os centros de pesquisa, biblioteca entre outros. O curso oferecido é de Journalisme - Licence e o master Communication de l'Ecole de la Communication, cujo objetivo é que o aluno adquira competências fundamentais, acadêmicas e profissionais para o exercício da profissão. O curso pretende dar ao aluno uma cultura geral para que ele possa compreender e analisar os fenômenos mundiais. Fala sobre a importância de uma cultura econômica e a necessidade de adquirir uma cultura histórica. Das disciplinas que destacamos estão: Política Mundial, Fés Religiosas, Política Francesa. No mestrado o

\footnotetext{
${ }^{241}$ ISIC Institut des Sciences de l'information et de la Communication, Université Michel de Montaigne http://www.isic.u-bordeaux3.fr/index.php?op=page\&rub_id=787 e http://www.isic.ubordeaux3.fr/upload/documents/guide_Mast_Rech.rtf Acesso em 01/10/2007

${ }^{242}$ Université Paris X, Disponível em www.u-paris10.fr/ acesso em 16/07/2007

SAKATA, Marici Cristine Gramacho, Globalização e Educação: A formação do comunicador social na América Latina, 2008312 p. (Doutorado - Orientação BACCEGA, M. A.) Escola de Comunicações e Artes da Universidade de São Paulo, São Paulo, SP, 2008
} 
foco é voltado para a formação profissional e internacional com grande destaque para a língua inglesa.

As universidades analisadas são similares e apresentam disciplinas comuns à área de Comunicação e Jornalismo. As duas universidades consideradas Nacionais não dão tanta ênfase à formação profissional em sua descrição quanto as globalizadas, embora todas ofereçam disciplinas voltadas para este objetivo. A preocupação com a inserção profissional aparece mais no nível de Mestrado se for profissional e de formação de pesquisador se for Mestrado de Pesquisa. As duas universidades nacionais destacam a importância da formação integral e da Cultura. Das universidades globalizadas, ambas citam a preocupação com a cultura, especialmente a Science Po, que cita de forma intensa. A questão profissional tem maior destaque na Université Paris X.

Estados Unidos da América (EUA)

O sistema educacional dos EUA também era dotado de uma característica elitista, que a partir do século XX foi sendo substituída por um sistema inclusivo, principalmente com a criação dos Colleges - instituições comunitárias abertas para a população.

Segundo Eckel e King (2004) ${ }^{243}$ o Ensino Superior dos Estados Unidos está baseado no Sistema Educacional Britânico e também na Universidade Alemã e seu caráter é profundamente influenciado por três convicções filosóficas:

1. Ideais Jeffersonianos - limitada ação do governo e liberdade para Estados, comunidades e indivíduos estabelecerem instituições de ensino superior;

2. Capitalismo e convicção na racionalidade de mercados - faculdades e universidades dos Estados Unidos da América competem por estudantes, professores, e financiamentos supondo que com isso tenham maior sucesso que a concorrência, em lugar de planejamentos centralizados, melhor diversidade e maior qualidade;

3. Compromisso de igualdade de oportunidade e mobilidade social.

\footnotetext{
${ }^{243}$ ECKEL, Peter D., King, Jacqueline E. (2004) An Overview of Higher Education in the United States: Diversity, Access, and the Role of the Marketplace, Ed. American Council on Education Disponível em https://www.acenet.edu/bookstore/pdf/2004_higher_ed_overview.pdf acesso em $27 / 07 / 2007$

SAKATA, Marici Cristine Gramacho, Globalização e Educação: A formação do comunicador social na América Latina, 2008312 p. (Doutorado - Orientação BACCEGA, M. A.) Escola de Comunicações e Artes da Universidade de São Paulo, São Paulo, SP, 2008
} 
A quantidade de alunos matriculados em cursos que conferem grau em instituições de Ensino Superiores nos EUA em milhões era de 8.531 em 1970, passou para 14.262 em 1995 e atingiu 17.272 em 2004, e espera-se um aumento de 12\% até 2014. (NCES ${ }^{244}$ ) Quanto ao tipo de curso, os mais procurados são: Administração, Ciências Sociais e História e Educação. Segundo pesquisa feita pelo Centro Nacional de Estatística ${ }^{245}$, algumas áreas têm tido um número decrescente de alunos ao longo dos anos; porém outras áreas cresceram 20\% entre 1998-99 e 2003-04, e estas incluem recreação, lazer, comunicação e jornalismo e artes entre outros. O número de instituições em 1970 era de 2.525, sendo 1.060 públicas e 1.465 privadas. Em 1990 passou para 3.535, sendo 1.563 públicas e 1.972 privadas, e em 2005 chegou a 4.216, sendo 1.700 públicas e 2.516 privadas. Estima-se que foram conferidos 1.416.000 diplomas de bacharel, 562.000 de mestres e 47.200 de doutores em 2004.

Não existe um modelo único de universidade nos Estados Unidos da América (EUA), pois cada Estado é independente para criar ou desenvolver seu modelo de instituição. A maioria das universidades públicas é estadual, foram fundadas e são operadas por entidades governamentais estaduais. Cada Estado conta com pelo menos uma universidade pública e os Estados maiores chegam a ter mais de uma dezena. As únicas universidades federais existentes são operadas pelo exército.

As mais prestigiosas universidades dos EUA e as primeiras nos rankings internacionais são universidades privadas. Como o governo também fornece uma quantidade limitada de recursos financeiros tanto para as universidades públicas quanto para as privadas, ambas captam recursos por meio de cobrança de taxas de manutenção, de doações da iniciativa privada, e também têm se expandido internacionalmente. Várias universidades consideradas nos rankings das melhores dos EUA mantêm filiais no exterior, como China, Cingapura, Inglaterra, Itália e Espanha entre outras, principalmente oferecendo cursos de educação continuada. Consideramos estas como universidades globalizadas.

Devido à diferença do Sistema Educacional dos EUA e do Sistema Europeu e Latino-Americano, os dados não foram coletados para comparar as universidades nacionais com as globalizadas e também para analisar como funcionam quanto à estrutura e ao financiamento, e como os cursos de comunicação são oferecidos.

\footnotetext{
${ }^{244}$ U.S. Department of Education, National Center for Education Statistics. (2005). Projections of Education Statistics to 2014 (NCES 2005-074), Disponivel em http://nces.ed.gov/fastfacts/FAQTopics.asp?type=2 acesso em 27/07/2007 ${ }^{245}$ Disponível em: http://nces.ed.gov/programs/digest/d05/tables/xls/tabn243.xls acesso em 27/07/2007
} 
Como os EUA são um dos países considerados hegemônicos e exportadores de educação superior, tanto as universidades públicas quanto as privadas possuem atividades em outros países e cobram taxas e anuidades. Desta forma, selecionamos as principais universidades dos EUA conforme rankings mundiais e separamos em nacionais, as públicas, e em globalizadas, as privadas.

A tabela 5 a seguir apresenta dados de 2001 a respeito do número de instituições e matrículas. Das 6.458 instituições de ensino superior*, 2.099 são públicas, sendo que destas pouco mais de 600 são universidades. Embora o número de instituições privadas sem fins lucrativos seja menor que aquelas com fins lucrativos, o número de matriculados é significativamente maior. Isso acontece porque a maioria das instituições privadas com fins lucrativos oferece cursos para executivos e não emitem diplomas, apenas certificados. Neste sentido, o Sistema Público ainda responde por $76 \%$ do número de matriculados.

Tabela 5 - Instituições de Ensino Superior nos EUA e Número de Matrículas

\begin{tabular}{|l|r|r|r|r|}
\hline & \multicolumn{1}{|c|}{ Públicas } & $\begin{array}{c}\text { Privadas sem fins } \\
\text { lucrativos }\end{array}$ & $\begin{array}{c}\text { Privadas com fins } \\
\text { lucrativos }\end{array}$ & \multicolumn{1}{c|}{ Total } \\
\hline Instituições & $2.099(33 \%)$ & $1.941(30 \%)$ & $2.418(37 \%)$ & $6.458 *$ \\
\hline Matriculas & $12.370 .079(76 \%)$ & $3.198 .354(20 \%)$ & $765.701(5 \%)$ & 16.334 .134 \\
\hline
\end{tabular}
Fonte: Eckel \& King $\left(2004^{246}\right)$

* Este total inclui instituições que não conferem grau, e por isso difere do total de 4.216 Instituições apresentado anteriormente que incluem apenas Colleges e universidades que conferem grau.

Os Anglo-saxões usam os termos Communication Science, Comunication Research ou Communication Scholarship para a Formação em Comunicação. Nos Estados Unidos da América os programas acadêmicos com ofertas de formação em Comunicação estão divididos em nove áreas de concentração e a quantidade de ofertas, segundo dados de 2000, pode ser vista na tabela 6 a seguir:

Tabela 6 - Cursos de Comunicação nos Estados Unidos da América

\begin{tabular}{|l|c|c|c|}
\hline Ofertas de formação superior com ênfase em & Graduação & Mestrado & Doutorado \\
\hline Publicidade & 89 & 23 & 5 \\
\hline Comunicação & 282 & 120 & 46 \\
\hline
\end{tabular}

${ }^{246}$ ECKEL, Peter D., King, Jacqueline E. An Overview of Higher Education in the United States: Diversity, Access, and the Role of the Marketplace, Ed. American Council on Education, 2004 Disponível em https://www.acenet.edu/bookstore/pdf/2004_higher_ed_overview.pdf acesso em 27/07/2007 p. 2

SAKATA, Marici Cristine Gramacho, Globalização e Educação: A formação do comunicador social na América Latina, 2008312 p. (Doutorado - Orientação BACCEGA, M. A.) Escola de Comunicações e Artes da Universidade de São Paulo, São Paulo, SP, 2008 


\begin{tabular}{|l|c|c|c|}
\hline Filme e Cinema & 57 & 25 & 7 \\
\hline Ciência da Informação & 27 & 11 & 2 \\
\hline Jornalismo e Comunicação de Massa & 239 & 66 & 20 \\
\hline Relações Públicas & 141 & 35 & 8 \\
\hline Rádio, TV, Transmissão e Telecomunicações & 212 & 53 & 14 \\
\hline Discurso & 169 & 50 & 17 \\
\hline Especializações relacionadas & 125 & 50 & 14 \\
\hline
\end{tabular}

Fonte: http://www.aca.iupui.edu/cq-i/tabulate.cfm Original: January 1997 Garland C. Elmore, Shari Held, Dan Craig, Vince Cannon - IUPUI - Updated: October 2000 - Records updated by users )

As universidades são analisadas a seguir:

\begin{tabular}{|l|l|l|}
\hline \multirow{2}{*}{$\begin{array}{l}\text { Estados } \\
\text { Unidos da } \\
\text { América }\end{array}$} & \multirow{2}{*}{ Nacional } & University Of California \\
\cline { 3 - 3 } & \multirow{2}{*}{ Globalizada } & Pennsylvania State University \\
\cline { 3 - 3 } & & Sassachusetts Institute of Technology \\
\hline
\end{tabular}

A universidade pública University of California $^{247}$ UC - Berkeley possui cerca de 209.000 alunos, 10 campi. A missão da UC é excelência em pesquisa e serviços. Segundo a instituição, todos trabalham juntos para o avanço do conhecimento científico, humano e profissional, melhorando a qualidade de vida da cidade, da região, do Estado e do mundo. A missão é servir à sociedade como centro de aprendizagem e educar estudantes universitários, pós-graduandos, profissionais, assim como gerar pesquisa e outros serviços públicos.

A universidade pública Pennsylvania State University ${ }^{248}$, conhecida como Penn State é uma universidade pública que melhora a vida das pessoas na Pensilvânia, na Nação e no mundo por meio de programas de pesquisa e educação de alta qualidade. Sua atividade deve promover desenvolvimento humano e econômico pela expansão do conhecimento e sua aplicação nas ciências aplicadas, sociais, artes, humanidades etc.

A universidade privada Massachusetts Institute of Technology ${ }^{249}$ (MIT) foi fundada em 1865 por William B. Rogers, cientista cuja crença era de que para a competência profissional é melhor unir o ensino e a pesquisa e concentrá-los em problemas do mundo real. A missão do MIT é avançar o conhecimento e educar alunos em ciência e tecnologia e outras áreas que irão melhor servir à nação e ao mundo no

\footnotetext{
${ }^{247}$ University of Califórnia, Disponível em http://www.universityofcalifornia.edu/aboutuc/mission.html acesso em 27/07/2007

${ }^{248}$ Pennsylvania State University Disponível em http://www.psu.edu/bulletins/bluebook/ acesso em 27/07/2007

249 MIT Disponivel em http://cms.mit.edu/academics/undergrad/ acesso em 25/07/2007

SAKATA, Marici Cristine Gramacho, Globalização e Educação: A formação do comunicador social na América Latina, 2008312 p. (Doutorado - Orientação BACCEGA, M. A.) Escola de Comunicações e Artes da Universidade de São Paulo, São Paulo, SP, 2008
} 
século XXI. Também buscam desenvolver habilidade e paixão pelo trabalho sábio, criativo e efetivo para o progresso da humanidade.

A universidade privada Stanford University ${ }^{250}$ foi criada em 1891 por Leland Stanford, que doou sua fortuna ganha com mineração e construção de estradas de ferro. Uma das primeiras a aceitar mulheres como alunas, laica e declaradamente vocacional segundo a própria instituição, formando cidadãos cultos e úteis, enquanto as demais se preocupavam apenas com a cultura. (...and avowedly practical, producing "cultured and useful citizens" when most were concerned only with the former). A missão (motto) da universidade é "Die Luft der Freiheit weht", (O vento da liberdade sopra), frase do humanista Ulrich von Hutten. É um convite para pesquisa aberta e livre na busca do ensino e da pesquisa.

As missões das instituições públicas e das privadas não diferem. Todas focalizam a busca pela qualidade da educação e da pesquisa com o objetivo de melhorar a sociedade e o mundo. Não há referência às questões culturais.

\section{Análise dos Dados e Comparação - Curso e Grade}

A University of California oferece o curso de Jornalismo pela Graduate School of Jornalism. O objetivo é produzir profissionais de jornais, televisão e novas mídias que se coloquem em posição de liderança e influência. O programa tem grande preocupação com a prática profissional. Há poucas disciplinas obrigatórias, e as que existem referem-se a Reportagem, Tecnologia, Ética e Estágio.

A Pennsylvania State University oferece o curso de Comunicação cuja missão é educar os estudantes para a cidadania em uma sociedade na qual a comunicação e as informações são peças fundamentais e a base do processo democrático. Preocupa-se com a necessidade de o aluno se adaptar às constantes mudanças. Duas disciplinas se destacam: Política Econômica e Cultura.

\section{A Massachusetts Institute of Technology oferece o programa Comparative} Media Studies (CMS) que se compromete com a arte de pensar por mídias, domínios teóricos, contextos culturais e períodos históricos. O programa requer o mínimo de disciplinas possíveis como obrigatórias (são apenas 10), sendo 6 optativas do departamento, para que os alunos possam escolher o maior número de disciplinas de

\footnotetext{
${ }^{250}$ Stanford University Disponível em http://communication.stanford.edu/courses/index.html acesso em $27 / 07 / 2007$

SAKATA, Marici Cristine Gramacho, Globalização e Educação: A formação do comunicador social na América Latina, 2008312 p. (Doutorado - Orientação BACCEGA, M. A.) Escola de Comunicações e Artes da Universidade de São Paulo, São Paulo, SP, 2008
} 
outras áreas, tanto no MIT como em Harvard. O objetivo é formar o aluno para um emprego que ainda não existe.

A Stanford University oferece o curso de Jornalismo. O curso teve início em 1911, no Departamento de Letras, com as disciplinas de redação. Hoje há o Departamento de Comunicação e Jornalismo na Escola de Ciências e Humanidades. Os estudantes devem fazer um número determinado de disciplinas básicas de comunicação e no penúltimo ano optar pelo Major in Communication. O curso também requer que o aluno curse um número mínimo de disciplinas e o restante pode ser escolhido pelo aluno, sendo que parte destas disciplinas devem ser cursadas fora da área de Comunicação. Destacamos as disciplinas de Perspectiva em Jornalismo Norteamericano e Questões de Representação na Política Americana.

Conforme mencionado anteriormente, os programas de graduação dos EUA diferem significativamente dos programas europeus e latino-americanos, que apresentam um grande número de disciplinas obrigatórias e uma grade curricular a ser seguida. Nos EUA, o aluno deve cursar um pequeno número de disciplinas (core) e optar pelas demais. Isso ocorre nas quatro universidades analisadas. Independentemente de serem públicas ou privadas, não é possível verificar se os alunos cursam ou não disciplinas com conteúdos ligados à cultura e história do país. Na Stanford, que é a única que explicita mais as opções de disciplinas oferecidas, podemos verificar a existência de duas disciplinas com conteúdo referente a questões locais.

\section{Resultados das Entrevistas}

As questões da globalização e sua influência na Educação e na formação do comunicador são amplas. Esta discussão tem surgido em maior intensidade nos congressos, nas associações estudantis $\left(\mathrm{UNE}^{251}\right)$ e nas publicações científicas devido ao

\footnotetext{
${ }^{251}$ Linhas de Atuação da UNE - Luta contra a mercantilização do ensino - A UNE lançou, no $11^{\circ}$ Coneb (Conselho Nacional de Entidades de Base) a campanha "Nossa Educação não está a Venda", encampada pelo movimento estudantil por meio de abaixo-assinados, adesivos, panfletos e cartazes. A idéia é chamar a atenção para o fato de que a exploração comercial da educação superior sem restrição ao capital estrangeiro é um equívoco imposto hoje ao ensino brasileiro. Atualmente, $70 \%$ das matrículas se verificam em instituições particulares. Sem a regulamentação, corremos o risco de ter uma desnacionalização da educação superior, que é um dos elementos da formação da identidade nacional. As investidas das grandes corporações internacionais e de países como os EUA visam a compra de nossas universidades e inclusão da educação nos Acordos Gerais de Comércio e Serviços da Organização Mundial do Comércio, como se fosse mais um produto a entrar no atacado mundial. Disponível em http://www.une.org.br/ acesso em 26/07/2007
}

SAKATA, Marici Cristine Gramacho, Globalização e Educação: A formação do comunicador social na América Latina, 2008312 p. (Doutorado - Orientação BACCEGA, M. A.) Escola de Comunicações e Artes da Universidade de São Paulo, São Paulo, SP, 2008 
aumento de universidades e escolas privadas com fins lucrativos na última década. No entanto, na visão dos professores ela surge principalmente a partir de uma questão: A Educação hoje é um bem ou um serviço?

$\mathrm{Na}$ América Latina, principalmente no Brasil, a entrada de instituições estrangeiras é recente e as influências ainda começam a ser notadas pelos professores. No entanto, no exterior, as influências da globalização já fazem parte do dia-a-dia. Para complementarmos a pesquisa documental, realizamos entrevistas com professores e pesquisadores de instituições de ensino superior estrangeiras e tentamos entender quais as principais mudanças ocorridas nos últimos anos e a visão pessoal de cada um sobre esta questão.

Os entrevistados foram identificados neste trabalho pela instituição a que pertencem. Alguns professores não autorizaram a publicação dos nomes para garantir que sua opinião não fosse considerada como sendo a de sua instituição. (Os dados completos dos entrevistados podem ser consultados com a autora).

Foram realizadas entrevistas nos meses de janeiro e fevereiro de 2007 com professores da área de Comunicação das seguintes IES :

- França: Université Paris X Nanterre (UPX), Université du Sud Toulon$\operatorname{Var}(\mathrm{UTLV})$

- Espanha : Universidad de Deusto (UD)

Também foram realizadas entrevistas informais com professores de outras áreas das seguintes IES:

França, Ecole Central de Marseille (ECM), Sciences Po (SPo), Euromed Marseille (EM), Université Bourdeaux (UBO), Université Paris IX Dauphine (UPIX), Ecole de Commerce de Rouen (UR), Université de Pau et des Pays d’Adour (UPau), Ecole Supérieur du Commerce Extérieur (ESCE), além de IES da República Tcheca e Alemanha

Nas entrevistas procuramos abordar alguns dos seguintes pontos:

- As mudanças ocorridas na estrutura da instituição e nos cursos nos últimos anos, especialmente após o Processo de Bolonha.

- O perfil dos alunos e as principais dificuldades e desafios atuais.

- A preocupação com a “concorrência” entre as universidades nacionais e as "globalizadas" 
Perguntamos sobre as mudanças ocorridas na estrutura da instituição e nos cursos nos últimos anos, especialmente após o Processo de Bolonha. Segundo o professor (1) da UPX a mudança principal ocorrida na Educação, de forma geral nos últimos anos quanto à forma de ensino, é que o professor hoje deve ensinar o processamento e uso da informação e não a informação propriamente dita, porque praticamente todos já têm acesso à informação ou podem ter por meio da Internet. Isto faz com que sejam necessárias mudanças na estrutura da instituição e nos currículos.

Quanto às mudanças nos cursos, para o professor (10) da UD os cursos de graduação terão de mudar de 5 para 4 anos por causa do Bolonha. Para o professor (11) da UD, com o processo de Bolonha e o programa Erasmus, o número de alunos intercambistas aumentou significativamente e o interesse por um segundo idioma também.

Para o professor (12), também da UD, o governo da Espanha conta com diretrizes para se adequar ao processo de Bolonha. Na UD o objetivo é a formação integral e não a formação técnica; com isso a inovação da instituição está no modelo pedagógico que foi criado e não houve muita mudança na instituição desde o processo de Bolonha.

Perguntamos sobre as principais dificuldades e desafios atuais e o perfil dos alunos. Quanto aos principais desafios, foi praticamente unânime a preocupação das IES em manter o número de alunos, e, portanto, criar estratégias para atrair alunos. Comentaram sobre esta questão os professores da UPau, UPX, UTLV, entre outras. Na visão do professor (1) da UPX, as três questões que mais preocupam as universidades francesas atualmente são: Questão demográfica, Questão de recursos/financiamento e Questão de ranking. A questão demográfica está atrelada à questão de financiamento. O professor informou que o orçamento das universidades está baseado no número de alunos inscritos, e como a França tem uma taxa de crescimento populacional baixa, é preciso atrair alunos de outros países. Desta forma, a França tem investido em atrair estudantes estrangeiros, principalmente chineses, para manter os recursos públicos. Quanto à questão de ranking, poucas universidades francesas estão em posição de destaque no ranking internacional, porque estão espalhadas pela França e não possuem volume de publicações no exterior. O pesquisador (7) da UPX também afirmou que a educação on-line é uma das formas de manter o número de alunos. 
Para o professor (5) da EM, o Professor não deve ser um vendedor de educação e as escolas não podem ter esse objetivo; no entanto, é o que tem ocorrido. Os alunos estão se sentindo na posição de clientes.

Perguntamos sobre a preocupação com a "concorrência" entre as universidades nacionais e as "globalizadas". Para o professor (4) da ECM, a escola não pode mais ser elitista, há que se ampliar o número de vagas. Para o entrevistado da Sciences Po (3) a internacionalização da universidade seria mais fácil se o relacionamento acadêmico não fosse estruturado como uma venda, como ocorre nas escolas norte-americanas.

Para o professor (5) da EM, por serem pagas, as Grandes Ecoles sempre tiveram o conceito de aluno-cliente, o que não acontece nas universidades. Agora, por questões de competição, as Grandes Ecoles são obrigadas a fazer pesquisa, o que é difícil, pois sua mentalidade é de educação como negócio. Professor não deve ser um vendedor de educação e as escolas não podem ter esse objetivo.

Para o professor (6) da UBX, as escolas privadas na França ainda se destinam, na maioria, a pessoas com poucos recursos financeiros. Seu objetivo é o lucro. Não oferecem muita qualidade e também não são internacionais. As públicas estão tentando se adaptar às mudanças, mas é um longo processo, pois há áreas sem a mínima noção do que está acontecendo no mundo, ou do que são padrões e processos internacionais.

Para o professor (8) da UPIX os professores e a instituição sabem muito bem qual a diferença entre educação e negócio, e entendem a educação como um bem. No entanto, há a necessidade de obter recursos para continuarem existindo.

Para o professor (11) da UD a globalização influenciou a estrutura do curso, como por exemplo, a criação do curso “Euroculture”. Para o professor (12), também da UD, o curso de comunicação tem apresentado estabilidade no número de alunos e na procura. As três universidades (Mondagron, San Sebastian e Deusto) fazem propaganda na televisão e na mídia, pois o mercado europeu é muito pequeno. Sem propaganda não conseguiriam o número suficiente de alunos. A UD é a mais tradicional e a primeira da região. Os alunos com mais recursos financeiros escolhem entre as três IES. Escolhem a UD pela tradição, ou a pública pelo renome, ou a Mondragon por ser mais técnica e voltada ao mercado.

Na visão do professor (2) da UTLV houve um grande crescimento no número de universidades privadas com o crescimento de alunos estrangeiros. Como há concorrência, a universidade pública não consegue se atualizar tão rápido para oferecer 
aos alunos o estado-da-arte do assunto ou a tecnologia de ponta. Então, na visão do professor, a universidade deveria ficar com o conhecimento geral do primeiro e segundo ano, fornecendo uma base para pensar, enquanto as particulares deveriam fornecer especializações, ensino tecnológico e profissional, uma vez que também não têm como investir em todas as áreas.

Para o professor (15), da ESCE, com a internacionalização e a competição entre as escolas, os credenciamentos tornaram-se necessários, como o AASB e o EQUIS.

Dois outros professores europeus também foram entrevistados, e embora não sejam da França ou da Espanha, fizeram comentários pertinentes.

Para o professor (20), de uma universidade pública da República Tcheca, as universidades públicas continuam sendo as melhores, mas muitas universidades particulares de baixa qualidade têm surgido. Para o professor (21) de uma instituição de ensino superior da Alemanha, o sistema alemão é tradicional e o sistema privado é visto como questionável. Este ano (2006) a Alemanha começou a cobrar taxas aos alunos, mas continua sendo pública. Começou a cobrar taxa porque há muitos estrangeiros vindo de seus países onde a educação é paga para poderem estudar de graça na Alemanha e isso sobrecarregou o sistema. Ainda se questiona muito na Alemanha uma educação que não seja um bem social.

Quanto aos questionários, foram enviados questionários estruturados aos professores de Comunicação das universidades da amostra. Do total de 110, 16 retornaram (14\%). Como a pesquisa não tem como objetivo coletar os dados principais por meio de questionários, e nem fazer um tratamento estatístico das respostas, consideramos que as respostas dos professores contribuíram para a discussão dos resultados encontrados pela análise das IES e para a pesquisa como um todo.

As questões enviadas foram respondidas por professores das seguintes IES:

- Argentina: Universidad de Buenos Aires (UBA), Universidad Nacional de La Plata (UNLP) e Universidad del Salvador (USAL)

- Brasil: Universidade Federal de Minas Gerais (UFMG)

- Chile: Universidad de Chile (UCL), Universidad Nacional de Andres Bello (UNAB)

- México: Universidad Nacional Autônoma de Mexico (UNAM)

Destas, apenas duas IES são globalizadas conforme nossa definição. São elas a USAL e a UNAB. 
- EUA: University of California (UCAL), Massachussetts Institute of Technology (MIT), Stanford University (SU)

Perguntamos se o professor sente sua instituição mais preocupada com a formação de um profissional global ou com uma formação integral e geral. Como resposta, tivemos que: nas universidades latino-americanas, a maioria dos professores afirmou que suas IES estão preocupadas com a formação integral e geral, embora não deixem de se preocupar com a questão profissional (alguns acrescentaram). Apenas um professor da USal declarou que a instituição se preocupa mais com a formação profissional. Nas IES norte-americanas, as respostas tanto dos professores das IES públicas como privadas afirmaram que a preocupação da instituição é com a formação profissional.

Perguntamos também se o professor sente que a expansão das Escolas e universidades privadas em seu país ou região gerou concorrência ou colaboração entre elas e se houve uma mudança percebida no nível de qualidade. Como resultado tivemos que: Exceto quatro professores que responderam que não houve nem concorrência nem colaboração, todos os demais concordaram que a expansão gerou concorrência entre as IES. Três professores argentinos das universidades nacionais afirmaram que a competição não gerou melhora na educação, e dos dois professores de universidades globalizadas que responderam a questão, um acredita que a qualidade vem crescendo e o outro disse que depende da universidade, seria necessário analisar cada caso.

Destacamos a seguir alguns comentários feitos sobre esta questão: O Professor Ricardo Castro S., que autorizou a citação de seu nome, da Escuela de Comunicación da Facultad de Humanidades y Educación, Universidad Andrés Bello do Chile fez um importante comentário acerca da qualidade das IES privadas no Chile. Segundo Castro, a demanda de alunos com curso secundário permitiu a criação de instituições privadas. Com o passar do tempo, estas IES conseguiram se posicionar por sua qualidade e gestão do conhecimento. Ao longo deste processo houve muitas dificuldades, principalmente pelo fato de serem vistas como entidades comerciais. No entanto, várias IES cumpriram as necessidades dos estudantes com responsabilidade acadêmica, com programas sérios e sistemas de financiamento acessivel a mais estudantes. Desta forma, as IES privadas competem com as entidades tradicionais dentro destes padrões de qualidade.

Um comentário feito por um professor da UNAM, do México, refere-se aos sistemas de avaliação. Com o objetivo de avaliar a qualidade, nem cumprem esta 
função e são utilizados de forma a favoreceram as instituições - tanto públicas como privadas - quanto a financiamento, mas não à qualidade.

Dois professores dos EUA concordam que a existência dos dois sistemas público e privado - leva a uma melhora na qualidade, mas depende da origem dos estudantes e de sua renda.

Outra pergunta feita foi quanto à existência de espaço em sala da aula para discutir questões culturais e nacionais, e quanto ao grau de interesse dos alunos para estas questões. As respostas foram: Exceto dois professores, todos os demais responderam positivamente a estas questões. Há espaço para discussão e há interesse por parte dos estudantes. Quanto ao interesse, alguns comentaram que não é em demasia ou que está se perdendo gradativamente. O interesse surge mais pela necessidade de cumprir créditos ou por incentivo do professor. Segundo o professor da Universidade Nacional de La Plata "Hay muchas materias que abordan cuestiones culturales, desde los medios, hasta las ONG y los organismos sociales, un ejemplo, Estela de Carlotto presidenta de Abuelas de Plaza de Mayo tiene una catedra de DD.HH.(Derechos Humanos) Los alumnos se interesan y plantean sus inquietudes"

Perguntamos se na opinião dos professores o Estado deveria ser o responsável por prover educação superior ou se esta função deveria ser dividida com o mercado como vem sendo feita. Os professores das universidades nacionais Argentinas afirmam que o Estado deveria ser o grande responsável pela educação superior, e que parte da opinião pública também concorda com a gratuidade. Quanto às privadas, estas devem ser supervisionadas pelo Estado. Houve destaque também para a responsabilidade do Estado em educar seu povo, e em soluções para os problemas do país a partir dos resultados de pesquisas realizadas pelas universidades. Dois professores de universidades globalizadas Argentinas afirmam que esta função deve ser compartilhada com o mercado e todos os professores das demais IES latino-americanas e norteamericanas concordam que esta função ou responsabilidade deve ser dividida com o mercado.

Para a OMC, os serviços são considerados um bem que têm de obedecer aos critérios de máxima liberalização e se abrir ao capital estrangeiro, com o objetivo de maximizar o lucro das companhias que investem nestes setores, especialmente o transnacional. Neste sentido, perguntamos se na opinião dos professores a educação deveria ser vista e administrada como um serviço conforme a definição da OMC - 
Organização Mundial do Comércio ${ }^{252}$. Para um dos professores da UBA, decididamente não, e não só por questões ético-ideológicas: mas assim como a saúde, a segurança e a justiça, trata-se de eficácia, e cedo ou tarde a intervenção mercantil leva a um colapso de maior importância. A fraude e a máxima rentabilidade nos itens mencionados não podem ser comparadas ao mercado de produtos. Para um dos professores da UNLP, “La educación no se debe concevir como un servicio sino como un bien, hoy están tratando de imponer la responsabilidad social universitaria como la responsabilidad social empresaria, y la verdad que es una barbaridad ya que la universidad siempre trabajo con responsabilidad y al servicio de su nación”.

Alguns professores desconheciam o conceito de serviço da OMC, inclusive um dos professores da UCAL dos EUA, e vários destes responderam que a educação deve ser um serviço público. Neste caso, concordamos com o professor da USAL que disse que a educação deve ser administrada como um serviço no sentido de alcançar seus propósitos da melhor forma e com qualidade, no entanto, deve ser um bem. Dois professores de universidades globalizadas da Argentina e Chile responderam positivamente a esta questão. Para o professor da Argentina, há uma combinação entre necessidade e serviço, pois a educação superior, diferente da educação básica, atende necessidades específicas. Para o professor do Chile, devemos administrar de forma eficiente e responsável o que oferecemos. O processo de elaboração da Educação conta com a participação de profissionais, técnicos e mão-de-obra. Educação é um serviço na medida em que se entrega algo a quem a escolhe, e quem a recebe exigirá a qualidade prometida. Para o professor da UCL, se for um serviço comercial, transacionável e administrado por privados, como requer a OMC, acabará por discriminar os mais pobres. Para o professor da UNAM, deve ser um direito do cidadão a partir do qual poderá melhorar sua qualidade de vida e contribuir para o desenvolvimento do país. Para os professores dos EUA, dois concordam que sim e dois são contrários, sendo um deles do MIT.

As respostas trazem discussões interessantes, confirmam as hipóteses deste trabalho e mostram que entre os professores das universidades nacionais e globalizadas há diferença de pensamento mas se alinham com a missão das respectivas IES.

252 "In WTO, the services are considered a good that must obey the criteria of maximum liberalization and opening to the foreign capital, aiming at maximizing the profit of companies which invest in these sectors, especially the transnational ones." Fonte: OMC 


\subsection{Por uma outra globalização da Educação}

Retomando o conceito de tipo-ideal e comparando com a realidade encontrada por meio da pesquisa, podemos afirmar que as instituições globalizadas tendem ao Tipo B e as Instituições Nacionais tendem ao Tipo A. Poderíamos dizer que isto se dá devido ao capitalismo e às novas tecnologias das últimas décadas. No entanto, em Bourdieu e Passeron $\left(1967^{253}\right)$ já havia o comentário de que a educação apta a formar homens integrais havia sido substituída desde 1940 por uma reflexão de cunho mais técnico e operacional, para se alcançar a rentabilidade da educação no processo de desenvolvimento econômico. Segundo nota, deste mesmo artigo, esta questão pode ser verificada também nos escritos do século XIX sobre a necessidade da educação profissional em contraposição ao excesso de educação clássica. De fato, o problema surge com o capitalismo e a racionalidade econômica. Freqüentemente, lemos nos jornais estudos sobre a crise da educação e vemos que todos os resultados são medidos a partir de indicadores que medem apenas a racionalização dos recursos, ou seja, número de evasões, número de diplomados, a produtividade e o rendimento, entre outros. Também nos deparamos com comparações entre sistemas educacionais de diferentes países, diferentes culturas e sistemas políticos. Cada sistema de ensino está fortemente ligado à sua história, regime político e cultura local. As comparações que não levam em conta estas questões correm o risco de descaracterizarem um sistema e induzirem à criação de outro que não corresponde às características locais.

O que se percebe com a pesquisa é que as instituições nacionais preservam muitas das características locais, tanto em sua missão, como em sua estrutura. Há uma preocupação com a cidadania, com os valores nacionais e com a formação integral. As instituições globalizadas, por outro lado, privilegiam a formação prática e a rápida colocação do aluno no mercado de trabalho. Algumas instituições globalizadas por terem sido adquiridas recentemente por grupos internacionais ainda preservam algumas características anteriores, no entanto, já apresentam indícios de mudança.

Pelo fato das instituições globalizadas, em sua maioria, seguirem a lógica capitalista e a racionalidade econômica, dificilmente modificarão sua forma de atuar.

\footnotetext{
${ }^{253}$ BOURDIEU, Pierre, PASSERON, Jean-Claude, La reproduction. Eléments pour une théorie du système d'enseignement Paris, Editions de Minuit, 1970.

SAKATA, Marici Cristine Gramacho, Globalização e Educação: A formação do comunicador social na América Latina, 2008312 p. (Doutorado - Orientação BACCEGA, M. A.) Escola de Comunicações e Artes da Universidade de São Paulo, São Paulo, SP, 2008
} 
Inclusive a força de seu discurso e sua penetração na mídia tem alterado a forma de atuar das instituições nacionais forçando a seguirem esta mesma lógica.

Segundo Teixeira (1969) ${ }^{254}$ “ninguém desconhece que se a educação é cada vez mais fraca, o anúncio e a propaganda são cada vez mais fortes e a nossa sociedade é uma sociedade cujo objetivo se reduz ao de consumir cada vez maiores quantidades de bens materiais”. Neste sentido, Santos que (2000) ${ }^{255}$ diz que na atualidade as empresas produzem o consumidor antes do produto e por isso necessitam de um império de informação e publicidade e como conseqüência, vivemos em um sistema ideológico construído ao redor do consumo e da informação ideologizada, que acaba sendo o motor das ações públicas e privadas. Para Santos, o consumismo unido à competitividade levam a um emagrecimento moral e intelectual da pessoa, à redução da personalidade e da visão de mundo.

As instituições globalizadas, no limite, se não forem regulamentadas, tendem naturalmente à geração de serviços/produtos a serem consumidos e à competitividade. Não por serem contra a educação integral ou por desprivilegiarem a educação, mas pelo simples fato de que são Organizações/Empresas que têm a educação como um serviço a ser vendido visando ao lucro.

Não podemos negar que há uma ambivalência na Indústria Educacional. Há uma razão instrumental movida por questões econômico-financeiras, mas há também um ganho social. De uma escola destinada apenas à elite passamos para uma escola de massa que resulta um crescente número de diplomados anualmente, com maiores chances de alcançar um bem-estar mínimo e espaços na sociedade. No entanto, estes espaços alcançados se limitam às funções de mão-de-obra e não de cidadãos atuantes na sociedade. Porém, não podemos nos contentar com estes ganhos, é necessário irmos além e buscar uma outra globalização, assim como defendeu Milton Santos.

Os efeitos da globalização estão sendo discutidos ao redor do mundo, não são irreversíveis. Os debates e a atenção que têm sido dados aos desmatamentos e ao aquecimento global demonstram que é possível repensar a globalização, buscar alternativas e agir de forma diferente apesar das barreiras e dificuldades encontradas ao longo do caminho.

\footnotetext{
${ }^{254}$ TEIXEIRA, A. Educação e o mundo moderno, Companhia Editora Nacional, São Paulo, 1969, p.158

255 SANTOS, M. Por uma outra globalização, Editora Record, Rio de Janeiro, 2000, (14 Ed. 2007), p.49

SAKATA, Marici Cristine Gramacho, Globalização e Educação: A formação do comunicador social na América Latina, 2008312 p. (Doutorado - Orientação BACCEGA, M. A.) Escola de Comunicações e Artes da Universidade de São Paulo, São Paulo, SP, 2008
} 
A tecnologia permite que em vez de uma única voz, indivíduos e grupos se manifestem e tenham espaço para se expressar. Por enquanto, são discursos fragmentados, mas que podem tomar corpo e força em pouco tempo.

A crise da educação também tem sido discutida e a má qualidade de algumas organizações educacionais também tem levado a se questionar o sistema. Embora o momento atual seja de expansão da Indústria Educacional esta também terá seus resultados analisados pela população.

Acredito que uma possibilidade de se ter um sistema educacional equilibrado seria alterar o sistema privado para um sistema misto. O sistema privado da forma como se apresenta não é capaz de cumprir com os objetivos da verdadeira Educação. 


\section{Conclusão}

Iniciamos esta pesquisa com o objetivo de estudar a influência da globalização na formação do comunicador por meio da análise dos cursos de graduação em Comunicação Social nas universidades latino-americanas.

Quanto às proposições e hipóteses apresentadas no início da pesquisa, concluímos que a compreensão da dinâmica do processo de globalização identifica os agentes que detêm o poder simbólico e as agências internacionais que funcionam como transmissores de imperativos competitivos e institucionais. Percebemos, com a pesquisa, a baixa resistência dos países aos imperativos devido à legitimação que estes conferem às Instituições de Ensino Superior (IES). As IES anunciam seus acordos internacionais como uma vantagem competitiva; no entanto, ultrapassam o limite da internacionalização se submetendo a sistemas de credenciamento internacionais, financiamento privado internacional e homogeneização de currículos tanto na formação do comunicador como em áreas de ensino.

As pressões coercitivas são recebidas de formas diferentes; no entanto, os países da América Latina estão reagindo de forma similar, alguns com maior, outros com menor resistência. A incorporação dos imperativos em suas políticas nacionais varia de acordo com a dependência econômica. Os membros da OMC devem aceitar a classificação da educação como serviço, assim como o México já fez. Alguns países membros latino-americanos estão discutindo esta questão; porém, paralelamente, a educação nos vários países já atende aos padrões do mercado e as instituições privadas e grupos internacionais competem entre si como prestadores de serviços. Por exemplo, no caso da França, por não possuir a mesma dependência econômica que os países da América Latina, mantém a opção de oferecer a educação superior como um bem e direito do cidadão e não permitir que instituições privadas (com exceções das confessionais e Grand Ecoles) emitam diplomas, embora os discursos de privatização sejam cada vez mais freqüentes. A Espanha segue a mesma política, mas não restringe a emissão de diplomas às instituições públicas.

As IES, para se adaptarem às pressões e para competir no mercado, estão se reestruturando e internacionalizando. No entanto, algumas IES se redefinem dentro de seus próprios padrões e o que se percebe é que para atender a um mercado internacional 
e competir com as instituições consideradas de excelência, no caso as norte-americanas, algumas instituições nacionais estão deixando de considerar os conteúdos locais e oferecendo apenas os conteúdos técnicos e globais.

O Brasil, por meio do Ministério da Educação (MEC), estabelece regras para o currículo mínimo na formação do comunicador no qual consta a obrigatoriedade de disciplinas humanísticas e generalistas. Como conseqüência, tanto as IES nacionais como as globalizadas mantêm disciplinas de história, política e cultura nacional nos currículos de comunicação.

O sistema privado está se expandindo nos países da América Latina. No Brasil o sistema privado atende 60\% dos alunos, no Chile 53\%, e na Colômbia, 57\%. Embora o sistema educacional norte-americano seja altamente competitivo e voltado ao mercado, o sistema público norte-americano ainda é responsável por $76 \%$ do número de matriculados, ou seja, a educação ainda segue as diretrizes e regulamentações do governo e, portanto, pode funcionar mesmo que haja mudanças na forma de financiamento. Somente o México e Argentina registram números semelhantes - nestes dois países, $80 \%$ dos alunos estão matriculados no setor público.

Os resultados da pesquisa confirmam a tese de que a globalização, como fenômeno mundial, pressiona as Instituições de Ensino Superior a se modernizarem e a formarem um profissional global de acordo com os modelos criados nos países hegemônicos, pondo em risco os elementos identitários de uma cultura local. As entrevistas com os docentes também reforçam que as universidades globalizadas têm a preocupação de formar um profissional global seguindo padrões mundiais. Pela análise dos programas e missões das universidades, há muita preocupação em utilizar novas técnicas e não há preocupação aparente com a tradição por parte das instituições globalizadas. A tendência é seguir os modelos norte-americanos e a lógica do mercado.

$\mathrm{Na}$ parte teórica abordamos as políticas macroeconômicas e, a partir da literatura, podemos afirmar que as instituições são constituídas sob regras e significados compartilhados que definem relações sociais e posições de poder. Algumas instituições privadas norte-americanas em maior grau, mas também as francesas e espanholas, estão adquirindo IES ou investindo em IES em diversos países. As instituições francesas e espanholas competem com as norte-americanas. As instituições espanholas - por razões de língua e história - têm facilidade de entrar no mercado latino-americano, enquanto que os EUA têm mais facilidade em entrar no mercado por meio de investimentos em ações ou aquisições.

SAKATA, Marici Cristine Gramacho, Globalização e Educação: A formação do comunicador social na América Latina, 2008312 p. (Doutorado - Orientação BACCEGA, M. A.) Escola de Comunicações e Artes da Universidade de São Paulo, São Paulo, SP, 2008 
Quanto a posições de poder, os EUA ocupam a posição de emissor de regras nas instituições mundiais como o Banco Mundial, FMI, OMC, etc. Esta posição é determinante nos acordos e fluxos de negociação. Os EUA em maior grau, mas também a França e a Espanha, possuem poder de decisão e veto, e têm o poder de pressionar países periféricos a seguirem suas regras. Embora alguns países latino-americanos sejam contrários à entrada da educação como serviço na OMC, a discussão só foi considerada e retirada da pauta para discussão quando a França se manifestou. Países periféricos ainda exercem pouca ou nenhuma influência nas decisões tomadas em nível global.

Quanto às conseqüências da globalização sobre o sistema, um exemplo é o que ocorre no Brasil. O Brasil não possui uma regulamentação sobre a participação de grupos internacionais na Educação. O Projeto de Lei 7200 de 2006 e a Reforma Educacional que está em discussão ${ }^{256}$ sugere um limite de 30\% de capital internacional por IES. Enquanto esta discussão está ocorrendo e o projeto ainda não foi levado para votação, os grupos internacionais estão aproveitando para entrar no país. A Anhembi Morumbi vendeu 51\% das ações para o grupo internacional Laureate e 69\% das ações da Anhangüera Educacional foram adquiridas pelo Banco Pátria por meio de capital estrangeiro oriundo do IFC. O Whitney Internacional University System, capitalizado pelo fundo de investimento norte-americano Best Associates também investiu R\$ 23 milhões na compra das Faculdades Jorge Amado de Salvador. Segundo o relatório do IFC $^{257}$, o Brasil é um mercado promissor para investimentos estrangeiros e há baixa resistência do governo. Os grupos estrangeiros já estão em diversos países latinoamericanos oferecendo os "serviços de educação" em diversos níveis. Os relatórios do IFC e o boletim para investidores deixam claro como o mercado educacional latinoamericano é visto pelos órgãos internacionais e anunciado como um produto à venda para investidores internacionais.

O objetivo geral deste trabalho foi identificar os órgãos e países que influenciam e emanam regras para o sistema globalizado, como atuam e como as regras surgem. Este objetivo foi cumprido uma vez que identificamos diversos órgãos, como o Banco Mundial, o FMI, a OMC, o IFC, entre outros, que têm influenciado o Sistema Educacional Mundial, e os resultados de suas ações já podem ser medidos em alguns

\footnotetext{
${ }^{256}$ Discussão em andamento - Proposta pelo governo em Dezembro de 2004 e em discussão até esta data de 2007.

${ }^{257}$ IFC report on regions 2006 http://www.ifc.org/ifcext/lac.nsf/AttachmentsByTitle/ AR2006_LAC_Overview/\$FILE/AR2006_LAC.pdf

SAKATA, Marici Cristine Gramacho, Globalização e Educação: A formação do comunicador social na América Latina, 2008312 p. (Doutorado - Orientação BACCEGA, M. A.) Escola de Comunicações e Artes da Universidade de São Paulo, São Paulo, SP, 2008
} 
países a partir das mudanças ocorridas. Um exemplo é a força que as empresas educacionais adquiriram após a entrada da Educação (embora não plenamente aceita), como um serviço na OMC, e como o conceito se espalhou pelo mundo. Esta expansão pode ser percebida pelo aumento significativo de instituições adquiridas ou criadas pelos grandes grupos Educacionais como Laureate, INSEEC e Apollo, entre outros. Qual a mudança ocasionada por estas ações? Por um lado, pode ter tido um impacto indireto ou não-revelado e, portanto, difícil de ser medido, mas por outro, há um impacto direto que pode ser claramente medido pelos anúncios e propagandas feitas por estas instituições para conseguirem alunos. Um dos impactos é a oferta de cursos exatamente iguais aos das instituições internacionais. Outro impacto é o currículo enxuto - que prepara o aluno para o mercado de trabalho - com o maior número possível de disciplinas práticas, o que poderia até ser adequado e estar de acordo com sua missão, não fosse o fato de se tratar de uma instituição que se declara ser uma universidade, cuja missão é formar um cidadão e prover uma educação integral e humana. Ambos impactos são negativos no sentido de preservar os elementos identitários e de formar cidadãos autônomos e críticos. Conforme dissemos no início do trabalho, os cursos de comunicação surgiram com objetivo profissionalizante, mas pelo fato de estarem dentro das universidades, a pesquisa sempre caminhou junto. Passados tantos anos, sugerimos a retomada desta discussão uma vez que os cursos de comunicação oferecidos pelas universidades globalizadas são profissionalizantes mas nestas não há pesquisa sendo desenvolvida paralelamente.

Como objetivo específico, nos propusemos a analisar e comparar o conteúdo, a missão de cada instituição de ensino e os objetivos dos cursos de Comunicação Social das universidades nacionais com as globalizadas, e com isso, obtermos resultados empíricos para a discussão. A distinção entre universidades nacionais e globalizadas seguiu alguns critérios previamente definidos. As universidades nacionais, em sua maioria públicas e confessionais, têm como missão, na quase totalidade dos casos, a preocupação em formar um ser humano completo através de uma educação moral, intelectual e de fé, para que sejam pessoas íntegras, que compreendam a realidade do país e da sociedade, etc. A missão das universidades globalizadas e das que foram recentemente adquiridas e ainda mantêm a missão dos fundadores), é claramente instrumentalista, profissionalizante, e formadora de mão-de-obra apta a lidar com a tecnologia para atuar nas empresas de classe mundial. 
A principal preocupação na formação do comunicador nas universidades globalizadas, exceto nas universidades colombianas da amostra, é basicamente formar um profissional apto a lidar com as últimas tecnologias, flexível para se adaptar às mudanças do mercado, e com conhecimento em diversas áreas da comunicação para entrar rapidamente no mercado de trabalho. Estas percepções - adquiridas a partir da leitura das missões e objetivos - foram confirmadas com a análise das grades curriculares, onde se comprovou a pouca oferta de disciplinas humanistas e multiculturais e pouco destaque ao desenvolvimento do pensamento crítico nas universidades globalizadas em grande parte dos cursos da amostra. Por um lado, os educadores e filósofos da educação são claros quando afirmam a importância de se ter uma formação integral e humana para que sejam alcançados os propósitos da educação. Por outro lado, vemos a proliferação de organizações sociais - e não mais de instituições sociais - com objetivos de lucro e com uma administração voltada para seu negócio em particular, oferecendo cursos cada vez mais tecnicistas. A realidade está se distanciando cada vez mais do discurso dos educadores e, com isso, percebemos também que ocorrerá uma perda para a sociedade como um todo. A grande massa dos cidadãos será cada vez mais treinada e não mais educada.

Por causa da globalização e das novas tecnologias, os cursos de comunicação social enfrentam novos desafios. Desta forma, torna-se necessário - além de ampliar o debate sobre reformas curriculares, paradigmas de ensino e conteúdo - pensar sobre a missão e os objetivos das IES e seu papel na sociedade.

Nesta pesquisa, compartilhamos experiências com professores e pesquisadores de outros países sobre este assunto. Como resultado, percebemos que diversas IES latino-americanas estão debatendo estas questões e se vêem obrigadas a se adaptar ao contexto global. As respostas às pressões globais estão ocorrendo de formas diferentes e os resultados positivos e negativos destas experiências devem ser compartilhados entre todos. Também consideramos importante verificar como estão agindo os países que estão à frente na globalização, quais objetivos pretendem alcançar e quais as mudanças que estão ocorrendo em suas IES e nos cursos de Comunicação Social. Esta comparação deve ser feita constantemente por meio de pesquisas, seminários e congressos. 
No Seminário ECA FELAFACS, realizado em $2004^{258}$, um dos objetivos era abordar a necessidade do ensino de Comunicação Social, desenvolver projetos inter e transdisciplinares em detrimento de abordagens fragmentárias, que dificultam a formação de uma visão totalizadora de uma realidade complexa. Esta pesquisa, no entanto, mostrou que a tendência das universidades globalizadas é formar um profissional apto a atuar no mercado global. Concomitantemente, a fim de manterem sua eficácia e rentabilidade, tentam manter um currículo enxuto, com formação em três anos (como no caso europeu) e disciplinas de conteúdo prático.

Se as novas instituições tiverem como objetivo atender seus "clientes", preparando-os para entrarem rapidamente no mercado de trabalho, estas instituições buscarão oferecer disciplinas voltadas para as necessidades do mercado. Isto pode gerar três problemas principais: o primeiro deles é que dificultará cada vez mais a idéia de uma educação integral, onde haja tempo e espaço para desenvolver projetos inter e transdisciplinares; o segundo é que, procurando atender o mercado, e dado que o mercado está sob constantes mudanças que ocorrem em períodos cada vez mais curtos, acabarão formando seus alunos para atuarem no mercado de "ontem” deixando de cumprir também este objetivo; e o terceiro é que a concorrência entre as IES intensificará ainda mais estas questões, cada vez mais fazendo com que as IES se portem como empresas dentro da Indústria Educacional.

Para que as IES cumpram seus objetivos de formar comunicadores, percebemos a necessidade de estarem atentas também à formação dos professores e ao papel do professor - a peça-chave neste processo. Os professores são os responsáveis não apenas por compartilhar com seus alunos o conhecimento, mas também transmitir-lhes os elementos identitários particulares de sua cultura e de seu país. São os responsáveis pela moderação de discussões e estímulo ao desenvolvimento do pensamento crítico, do aprender a pensar, a questionar, e a buscar soluções para os problemas do país, do mercado de trabalho e do mundo. Isso pode ocorrer tanto em disciplinas humanísticas como técnicas, no entanto, deve estar explícito na missão da IES e deve ser apoiado pelo corpo diretivo.

O professor que se porta como vendedor de educação, o chamado “dador de aula” ou como referido por Paulo Freire, a educação “bancária” terá em sua sala de aula

\footnotetext{
${ }^{258}$ LOPES, M. I. V. e BACCEGA, M. A. (orgs), Seminário ECA-FELAFACS: Comunicação - O Sentido da Formação para o Século XXI, ECA USP, 15-16 de Maio de 2004. Relatório Final.

SAKATA, Marici Cristine Gramacho, Globalização e Educação: A formação do comunicador social na América Latina, 2008312 p. (Doutorado - Orientação BACCEGA, M. A.) Escola de Comunicações e Artes da Universidade de São Paulo, São Paulo, SP, 2008
} 
clientes e não alunos. Esta relação cliente-fornecedor põe em risco todos os projetos de formação integral que as universidades públicas latino-americanas ainda conservam.

Acreditamos que mesmo escolas técnicas, voltadas ao treinamento, podem transmitir aos alunos, por meio da relação professor-aluno e da sua postura em sala, os valores e elementos identitários da cultura local. O discurso da globalização tem provocado - tanto por parte dos alunos como por parte dos professores - a aceitação passiva da condição de cliente-fornecedor. A cultura da qualidade trazida também pelos discursos da globalização leva a uma busca por mecanismos de controle de qualidade e sistemas de recompensa. Estes mecanismos, da forma como são utilizados, independente do contexto, prejudicam profundamente os projetos regionais, uma vez que na maioria dos casos as métricas são impostas por instituições internacionais cujos fundamentos definidores foram criados por países hegemônicos.

Levamos em consideração que o "sujeito moderno” tem vontade de vir-a-ser, de agir e de ser reconhecido dentro de seu grupo social. Porém, na maior parte do tempo este sujeito moderno encontra-se absorvido em sua vida cotidiana, precisando competir e se autopreservar. Ao mesmo tempo, é constantemente submetido a informações e discursos explícitos ou subliminares vindos de todas as direções; é levado a crer que seu valor na sociedade é medido somente do ponto de vista econômico, somente na qualidade de profissional ativo ${ }^{259}$. Com isso, na maior parte das vezes, o sujeito moderno é incapaz de pensar o todo social, e torna-se cada vez mais passivo e dependente do governo no que se refere à estruturação de sua vida social. Portanto, cabe ao professor, a todo o momento, não deixar seus alunos se esquecerem de que devem ter consciência de si, e são livres tanto para seguir regras sociais como para criálas ou alterá-las dentro da coletividade.

A escola é lugar de reflexão da sociedade e de formar cidadãos que contribuirão para o desenvolvimento do país, não apenas do ponto de vista econômico mas também social. A escola é também uma instituição cultural e tem como compromisso social a reprodução e a transmissão da cultura. Para Baccega (2004) $)^{260}$.

A escola apresenta-se como a instituição que, ressignificada, pode desempenhar um papel fundamental na formação das novas gerações para a transformação e formação de

\footnotetext{
${ }^{259}$ RIBEIRO, R. Janine, A sociedade contra o social, São Paulo: Companhia das Letras, 2000 p.23

${ }^{260}$ BACCEGA, M.A. Da Informação ao Conhecimento: ressignificação da escola XXVII Congresso Brasileiro de Ciências da Comunicação, INTERCOM 2004 - Anais.. Tema central: Comunicação, acontecimento e memória, Porto Alegre PUC do Rio Grande do Sul 30 de agosto a 3 de setembro de 2004

SAKATA, Marici Cristine Gramacho, Globalização e Educação: A formação do comunicador social na América Latina, 2008312 p. (Doutorado - Orientação BACCEGA, M. A.) Escola de Comunicações e Artes da Universidade de São Paulo, São Paulo, SP, 2008
} 
cidadãos capazes de desvelar as ideologias que circulam nos meios de comunicação (... ) À Escola compete, portanto, capacitar o aluno para não apenas "mover-se na sociedade”, seguindo o que e como deve sentir e fazer, mas, sobretudo, ter condições de mover, de modificar esse mesmo ambiente, o que só pode acontecer a partir da ressignificação dos sentidos, da reconstrução das normas e regras prescritas.

Retomando os resultados do Seminário ECA FELAFACS, realizado em $2004^{261}$, reforçamos aqui a necessidade de as IES estimularem manifestações da cultura local, acolhendo-as até mesmo a título de expressão de uma resistência à instabilidade do mundo contemporâneo. Interessar-se pelo glocal na crença legítima de que só se é universal quando se é local.

Nesta pesquisa, um dos professores da UNAM respondeu que sua instituição tem promovido diversos seminários que contemplam os problemas nacionais, a globalização e as questões culturais. Embora este mesmo professor tenha afirmado que o interesse dos alunos é mediano, movido apenas pela necessidade de completar os créditos necessários para sua formação e incrementar o currículo para o mercado de trabalho, a oferta de atividades extra-curriculares - apesar da IES possuir um currículo enxuto - ainda é uma forma de garantir que elementos identitários serão transmitidos, além de despertar o interesse em alguns alunos. Segundo um dos professores pesquisados, o interesse do aluno não se dá por “geração espontânea”. É necessário o comprometimento da instituição e do docente em tentar que os alunos se interessem por estes temas e compreendam a sua importância. Através de atividades extras e com o uso de novas tecnologias, os alunos podem participar ativamente de novos processos sociais de criação e manipulação de símbolos.

Analisar a missão, os objetivos e a estrutura curricular poderia não ser suficiente para concluir se está havendo ou não a perda de elementos identitários e culturais na formação do comunicador. No entanto, a literatura nos mostrou que a escola é parte importante do processo social de educação e é responsável pela transmissão de nossos valores, nossa cultura e nossos elementos identitários, tanto por meio da relação professor-aluno, instituição-aluno, como também de seu plano pedagógico, sua missão e estrutura curricular. Concordamos com Oliveira (2006) $)^{262}$ que as instituições e seus projetos educacionais são matéria-prima privilegiada na construção de identidades. Pela

\footnotetext{
${ }^{261}$ LOPES, M. I. V. e Baccega, M. A. (orgs), Seminário ECA-FELAFACS: Comunicação - O Sentido da Formação para o Século XXI, ECA USP, 15-16 de Maio de 2004. Relatório Final.

262 OLIVEIRA, M. B. F., Alteridade e Construção de Identidades pedagógicas: (re) visitando teorias dialógicas, In: Magalhães, I, Grigoletto, M, e Coracini, M. (org.) Práticas Identitárias, Língua e Discurso, São Carlos, Claraluz, 2006.

SAKATA, Marici Cristine Gramacho, Globalização e Educação: A formação do comunicador social na América Latina, 2008312 p. (Doutorado - Orientação BACCEGA, M. A.) Escola de Comunicações e Artes da Universidade de São Paulo, São Paulo, SP, 2008
} 
estratégia de pesquisa escolhida não foi possível coletar informações referentes às relações pessoais, embora a entrevista com os docentes tenha contribuído em parte para esta questão. No entanto, pela missão declarada da instituição, seus objetivos e como são cumprindos por meio da estrutura curricular, podemos responder nossas questões bem como definir novas questões para pesquisas futuras.

Se para Cohn $(2001)^{263}$, a cultura que interessa à área de comunicação é a interação entre as diferentes culturas com as mídias, poderíamos então acreditar que os cursos de comunicação deveriam oferecer disciplinas que reforcem as identidades culturais, discutam as diferentes culturas e tratem desta interação com a mídia. Se isto existe, está embutido no conteúdo de alguma disciplina, pois a pesquisa mostrou que há poucas disciplinas que se referem à cultura. No Brasil, por haver um currículo mínimo obrigatório, as quatro instituições pesquisadas oferecem uma disciplina cujo tema é cultura. Na França, as quatro instituições também demonstram forte preocupação com a cultura, oferecendo disciplinas sobre este tema. Nos demais países pesquisados, não houve outros casos nos quais as quatro IES apresentassem disciplinas de cultura. O que concluímos com isto é que se uma das formas de reforçarmos valores e culturas é por meio da educação, esta forma está perdendo força. Se o movimento que vemos leva a uma homogeneização dos cursos, a padronização e a diminuição dos currículos, seja para concorrer com o mercado educacional seja para diminuir custos, isso nos leva a crer que cada vez mais os valores culturais e elementos identitários não estarão expressos na grade curricular, ficam a cargo da relação professor-aluno, sem garantias formais de que isso ocorrerá.

Dos resultados das entrevistas e questionários, concluímos que ainda é possível, embora esteja cada vez mais limitado, ter espaço para discussão de assuntos que sejam importantes para a sociedade e para a cultura local nos cursos de comunicação social. No entanto, algumas respostas chamam a atenção para a diminuição ou mesmo falta de interesse por parte dos alunos e dos professores que não se vêem mais como intelectuais, mas como vendedores de alguma especialidade profissional.

Nos Estados Unidos da América, o sistema de educação superior é considerado uma indústria/sistema bem-sucedida do ponto de vista de investimento em pesquisas, número de alunos, etc. O Ato de 1944 (G.I.Bill) determinou como prioridade o acesso à educação superior e, de 1960 a 1970, o sistema teve um rápido crescimento com a

\footnotetext{
${ }^{263}$ COHN, G. O campo da Comunicação, In: Campo da comunicação, Fausto Neto, A., Prado, J.L.A. e Porto, S.D. (Orgs) Editora Universitária, João Pessoa, 2001

SAKATA, Marici Cristine Gramacho, Globalização e Educação: A formação do comunicador social na América Latina, 2008312 p. (Doutorado - Orientação BACCEGA, M. A.) Escola de Comunicações e Artes da Universidade de São Paulo, São Paulo, SP, 2008
} 
criação e expansão dos Community Colleges. No entanto, devido a grandes mudanças mundiais, este sistema tem sido discutido pelo governo, que sinalizou a necessidade urgente de reformas.

A Secretaria de Educação do governo norte-americano publicou em setembro de $2006^{264}$ um relatório apontando as principais vantagens, falhas e recomendações do sistema. Alguns comentários da secretária Margaret Spelling neste relatório chamaram a atenção durante a leitura, e são inclusive tema de debates em fórum na Internet. Neste relatório, a secretária, entre outras coisas, afirma que:

- durante muitos anos o sistema de educação superior (norte-americano) tem sido a inveja do mundo (envy of the world).

- durante tanto tempo temos nos mantido muito à frente de nossos competidores; assim, passamos a não nos preocupar em competir.

- pela nossa falta de atenção, outros países estão educando mais cidadãos e em níveis mais altos que os nossos, e ainda pior, eles estão nos ultrapassando...

- neste ambiente dirigido ao consumo, os estudantes se preocupam menos com a distinção das faculdades e formato do curso, on-line ou não. Ao invés disso eles se preocupam, assim como nós, com resultados.

- A OECD indicou que nossa nação está "rankeada” entre os $12^{a}$. maiores países industrializados em obter resultados em educação superior. Outros doze países estão nos nossos calcanhares.

Com isso, concluem que as principais causas são: os colégios não preparam os alunos adequadamente para continuar os estudos; alguns alunos não fazem curso superior por falta de informação ou alto custo e falta de auxílio; muito tempo gasto em nivelamento de inglês e matemática, e falta a preocupação das instituições em garantir o sucesso dos alunos; os cursos são concluídos mesmo sem atingir os resultados esperados pela sociedade.

As metas estabelecidas pela comissão neste relatório - que abrange todos os tipos de instituições - são: a) um sistema de educação superior, de classe mundial, que crie conhecimento novo e contribua para a prosperidade econômica e competitividade global; b) um sistema acessível a todos os (norte)-americanos ao longo da vida; c)

\footnotetext{
${ }^{264}$ U.S. Department of education - Contract No. ED-06-C0-0013, September 2006 A test of Leadership charting the future of U.S. Higher education, A Report of the Commission Appointed by Secretary of Education Margaret Spellings Disponível em www.ed.gov/about/bdscomm/list/hiedfuture/reports/prepub-report.pdf acesso em 01/07/2007
}

SAKATA, Marici Cristine Gramacho, Globalização e Educação: A formação do comunicador social na América Latina, 2008312 p. (Doutorado - Orientação BACCEGA, M. A.) Escola de Comunicações e Artes da Universidade de São Paulo, São Paulo, SP, 2008 
instituições de alta qualidade e eficientes no sentido de oferecerem preços mais acessíveis aos alunos e às instituições que os apóiam; d) um sistema que forneça competências necessárias para se adaptarem à economia em constante transição; e) instituições adaptadas a mudanças tecnológicas, demográficas e à globalização, na qual se incluam novos fornecedores e novos paradigmas - de universidades com fins lucrativos à educação a distância.

Para atingir estas metas, a comissão propõe recomendações a todos os envolvidos na indústria. São eles: faculdades, universidades, instituições de credenciamento, governo estadual e federal, escolas primárias e secundárias, comunidade, pais e alunos. As recomendações para cada uma das dificuldades são:

- Acesso: maior integração entre o segundo e o terceiro graus e com o mercado de trabalho. Melhoria de informações e redução de barreiras para auxílio financeiro.

- Custo e acessibilidade: programa com enfoque em corte de custos e melhora da produtividade, com desenvolvimento de novos benchmarks, diminuição de custo por aluno e redução das barreiras para transferência. O Estado e Federação devem usar a tecnologia para diminuir custos e cargas regulatórias.

- Ajuda financeira: simplificação do sistema de financiamento e maior adequação às necessidades dos alunos e às prioridades do país.

- Aprendizado: Novas pedagogias, currículos, uso de tecnologia e flexibilidade.

- Transparência e Accountability: Os custos, preços e resultados devem ser divulgados em um processo mais transparente para que consumidores e gestores possam medir a eficácia das Instituições.

- Inovação: Melhorar as práticas de ensino em particular nas áreas de ciência e matemática. Desenvolver uma estratégia nacional para aprendizado ao longo da vida, para manter nossos cidadãos e nação na frente da revolução do conhecimento.

Como ações idênticas em contextos diferentes nem sempre geram resultados idênticos, não podemos concluir que o que está ocorrendo nos EUA ocorrerá nos demais países. A Europa está discutindo estas mesmas ações e criou o Processo de Bolonha para cumprir os mesmos objetivos. Atualmente, o Mercosul também discute e dá inicio à criação de universidades do Mercosul. Desta forma, está claro que as tendências mundiais das Instituições de Ensino Superior e das políticas públicas são convergentes e que o mundo está se tornando multipolar, mas a educação como serviço começa a ser uma realidade no mundo. 
Podemos considerar que este relatório é apenas um documento que não será executado, mas também podemos considerar que este será o futuro a ser seguido pelo governo e pelas instituições educacionais norte-americanas. Se considerarmos a segunda hipótese, e partindo do pressuposto que as instituições de boa parte do mundo tendem a seguir este modelo, ou são forçadas a segui-lo, vemos aqui indícios de como será o futuro das IES em geral.

No Brasil, em discussões realizadas sobre o projeto de Reforma Educacional lançado em Dezembro de 2004 pelo MEC, também tem sido proposta uma diminuição do tempo total de formação do curso superior, como forma de diminuir gastos, além de ampliar e criar mecanismos que aproximem as faculdades das empresas e/ou indústrias. Nos cursos de pós-graduação esta proposta já entrou em vigor e os programas que não formam seus pós-graduandos no prazo estabelecido são avaliados negativamente.

Percebemos o movimento das IES européias e latino-americanas em adotar um padrão Educacional norte-americano, seja pela diminuição crescente de financiamento público, seja pela lógica capitalista de ganhar mercado e vender educação, seja por copiar padrões considerados de qualidade, ou seja, pelo simples fato de copiar as que são consideradas como as melhores nos rankings internacionais. Ao mesmo tempo, vemos neste relatório que os EUA identificaram uma crise em seu próprio sistema, em que suas universidades (antes motivo de inveja do mundo) - por serem muito caras estão restringindo o acesso da maioria da população. Isso tem levado a sociedade norteamericana a ficar em um nível inferior aos demais países, e universidades do mundo inteiro a competirem nesta "Indústria”. O modelo norte-americano está mostrando que inclui falhas e que a solução é oferecer mais bolsas e mais cursos a custo baixo para a população. Enquanto isso, o sistema europeu e latino-americano de educação gratuita para todos está caminhando para um sistema globalizado e privatizado com cobrança de taxas e anuidades.

\section{O Discurso da Globalização e a Necessidade da Internacionalização}

O discurso das instituições que têm interesse na globalização da educação superior é o de que:

1) A entrada e a expansão de instituições com fins lucrativos no sistema gera competitividade e, conseqüentemente, gera o aumento da qualidade de ensino. 
2) A entrada de instituições estrangeiras no país aumenta a oportunidade dos alunos fazerem estágios no exterior e terem currículos mais adequados ao mercado global.

3) A homogeneização dos currículos, a diminuição dos anos escolares e a competição aumentam a eficácia das instituições, e com isso, a diminuição dos preços, garantindo o acesso de boa parte da população a estas instituições.

Há também os discursos, como em Sánchez-Sosa \& Lerner Febres (2002) ${ }^{265}$, de que a globalização na América Latina ajudou a mudar as relações das universidades com respeito às políticas públicas paternalistas, e que o financiamento estatal das universidades é uma forma regressiva de distribuição que favorece os grupos mais bem remunerados.

No entanto, com relação a estes três itens, a pesquisa mostrou que:

1) A competição não necessariamente gerou aumento na qualidade. Na visão de alguns professores e na literatura, o que ocorreu foi o contrário ou não houve quaisquer alterações. Houve uma expansão de cursos voltados ao mercado profissional e percebemos uma falta de comprometimento com a educação integral e uma grande preocupação com o treinamento para o mercado de trabalho. Na visão de alguns professores entrevistados, os alunos passaram a ser clientes, a instituição passou a ser o fornecedor e os professores passaram a ser vendedores de informação. Esta mudança de relação não melhorou a qualidade do ensino. Algumas das instituições privadas pesquisadas são de altíssimos níveis de qualidade, no entanto o foco é a formação profissional.

2) A entrada de instituições estrangeiras aumentou a oportunidade dos alunos de fazerem intercâmbio e estágios no exterior. No entanto, para que as instituições possam gerir estes intercâmbios de forma eficiente e com baixo custo são necessárias mudanças nos currículos, diferentemente do que ocorre na internacionalização, onde as diferenças não são vistas como barreiras. Algumas instituições seguem os mesmos currículos e utilizam os mesmos materiais didáticos que a matriz, e nestes casos é nítida a perda de elementos identitários e culturais. Em diversos países, as instituições acreditam que ter o inglês como língua oficial é a grande vantagem competitiva para atrair alunos.

\footnotetext{
${ }^{265}$ SÁNCHEZ-Sosa, J, Lerner Febres, Salomon, Academic freedom and social responsibility: the ole of university organizations and possible instruments for international monitoring, Higher Education Policy 15, 2002, pp. 385-390

SAKATA, Marici Cristine Gramacho, Globalização e Educação: A formação do comunicador social na América Latina, 2008312 p. (Doutorado - Orientação BACCEGA, M. A.) Escola de Comunicações e Artes da Universidade de São Paulo, São Paulo, SP, 2008
} 
3) O valor da mensalidade nem sempre é a principal barreira para o acesso ao ensino superior. Um exemplo disso é a rápida expansão do sistema de educação privado no Brasil. No entanto, o grande número de vagas ociosas tem como principal fator, além do custo, a deficiência na educação primária e secundária, a alta taxa de desemprego, a falta de informação e de consciência do governo em incentivar e garantir educação aos cidadãos.

Até meados do século XX, nos países desenvolvidos, a idéia de educação bem conceituada consistia em estudar na França e cursar uma universidade na Alemanha. (Oliveira et. al, 2000) ${ }^{266}$. O discurso da internacionalização tem ocorrido ao longo da história e a internacionalização tem sido positiva, por isso, o discurso da globalização inclui discursos de internacionalização. Os acordos internacionais com instituições estrangeiras é uma resposta positiva à globalização. A partir dos acordos, os alunos têm a oportunidade de passar um período em outro país, ou receber um aluno estrangeiro em seu país, e com isso ele percebe outras realidades e percebe-se a si mesmo.

A Associação Internacional de Universidades (IAU), conforme Jaramillo, $\left(2003^{267}\right.$ ) considera a internacionalização um componente de solidariedade internacional e um instrumento de primeira ordem para incrementar a eficiência dos processos de ensino-aprendizagem. A Associação também considera que a internacionalização deva fazer parte do programa das IES e que os currículos devem incluir ensino de idiomas, mas também a comparação de temas globais com temas locais e regionais.

Segundo a Declaração Mundial $(1998)^{268}$, a internacionalização da educação Superior deve conter princípios de solidariedade e cooperação. Deve haver constituição de redes acadêmicas e espaços acadêmicos, e de acordo com Jaramillo (2003) ${ }^{269}$, o objetivo deve ser de fortalecer nossa identidade para então passarmos a fazer parte do contexto internacional onde a globalização está presente.

Assim, educa-se algo novo para o mundo velho que está em constante mudança,

\footnotetext{
266 OLIVEIRA, A. G et al. Preparando o futuro: educação, ciência e tecnologia - suas implicações para a formação da cidadania. Revista Bras. Est. Pedag. Brasília, V. 81, n.198, p. 316-341, maio/ago, 2000 267 JARAMILLO, Isabel Cristina: "La Internacionalización de la Universidad Colombiana. Un instrumento para el cambio”, ASCUN, 2003, p. 18.

${ }^{268}$ Declaração Mundial sobre Educação Superior no Século XXI: Visão e Ação, Paris, 9 de outubro de 1998

269 JARAMILLO, Isabel Cristina: “La Internacionalización de la Universidad Colombiana. Un instrumento para el cambio”, ASCUN, 2003, p. 18.
} 
educa-se sempre do ponto de vista da geração passada na esperança de que se possa reconstruir o mundo, colocá-lo em ordem e ao mesmo tempo preservá-lo de sua mortalidade. (Arendt, 2000) 270 $^{270}$

A universidade do século passado tinha um ensino de alta qualidade, no entanto, destinava-se apenas a uma elite. Com o aumento das universidades privadas e os sistemas mistos, mais pessoas estão tendo acesso ao ensino superior. A crise enfrentada pela universidade em parte se dá pelo fato de não poder atender à demanda, por não atingir a qualidade de acordo com rankings e por não ter recursos para investir como deveria. Todas estas crises são crises recentes que ocorreram devido à democratização do ensino superior, à globalização e à mercantilização da educação.

Para mantermos a democratização do ensino, o próximo passo é investir na qualidade, ou seja, investir em escolas, envolver a sociedade e manter valores nacionais, culturais e identitários.

As instituições privadas com fins lucrativos e com objetivos puramente instrumentalistas devem entender que são parte de um sistema mais amplo e que seu produto é a formação de seres humanos; que o lucro é uma parte do processo e que investir na qualidade de ensino é investir em seu próprio futuro. A missão deve ser mais bem explicitada, deve deixar mais clara a função de formação-treinamento para o mercado de trabalho sem, no entanto, esquecer a formação de pessoas que fazem parte da sociedade. As universidades, por sua vez, que têm como missão a formação integral, devem ter consciência desta missão, que vai além do treinamento para o mercado. Se considerarmos o objetivo da universidade, este não é de formar para o mercado de trabalho, mas tem obrigação com a excelência, pesquisa, extensão e inovação. É necessário que se compreenda a importância da autonomia da universidade no ensino e na pesquisa para o desenvolvimento e progresso do país.

Há realmente uma crise da educação ou há uma educação em constante processo de mudança? Utilizar a expressão ‘crise da educação' sem uma leitura correta do contexto em que está inserida e dos atores envolvidos soa verdadeiramente como uma estratégia política em busca de atenção da mídia e de eleitores. Isso não significa que não haja uma crise - pois há problemas nítidos neste sistema - mas são as questões (cíclicas) econômicas e sociais que afetam o sistema educacional e requerem sua

${ }^{270}$ ARENDT, H. Entre o passado e o futuro, Perspectiva. Reimpr. 2000

SAKATA, Marici Cristine Gramacho, Globalização e Educação: A formação do comunicador social na América Latina, 2008312 p. (Doutorado - Orientação BACCEGA, M. A.) Escola de Comunicações e Artes da Universidade de São Paulo, São Paulo, SP, 2008 
reformulação e readaptação. Este período de transição é o momento para debates e discussões a fim de se compreender quais os caminhos a serem tomados.

Quando se fala em crise é necessário verificar de onde e por quem o discurso está sendo emitido. A crise na educação ocorre de diferentes formas. Para os proprietários de instituições privadas, a crise significa falta de alunos matriculados, falta de apoio e incentivo do governo. Para as instituições públicas, a crise se dá pela falta de financiamento para a pesquisa e baixos salários para professores. Para o governo, a crise é a impossibilidade de atender à demanda de educação superior e atender aos índices impostos pelo FMI - Fundo Monetário Internacional e Banco Mundial.

Pensar a Educação é enfrentar desafios e buscar soluções para os problemas que permeiam a sociedade. A Educação também é um dos principais elementos responsáveis pelas transformações sociais. As boas instituições sociais, entre elas a escola, para Rousseau "são as que melhor sabem desnaturar o homem, retirar-lhe sua existência absoluta para dar-lhe uma relativa, e transferir o eu para a unidade comum”, ou seja, as que tornam o indivíduo uma parte da unidade só perceptível no todo, que é a sociedade em que vive. Para que o projeto pedagógico seja praticável em si mesmo, deve-se considerar que aquilo que tem de bom esteja na natureza da coisa, ou seja, que a proposta seja conveniente ao homem. Deve-se considerar também a facilidade de execução, que depende de diversas circunstâncias, dependendo do método, da condição e do país.

Conforme Arendt (2000) ${ }^{271}$, há uma crise periódica da educação na América do norte. Não somente na América do norte, como identificou a autora, mas também na América Latina, a educação tem se tornado um problema político de primeira grandeza. A educação adquire esta carga política porque se trata de uma terra de imigrantes que somente por meio da instrução poderá desempenhar sua função no Estado e na sociedade. Muitas vezes é na escola que os alunos aprendem a língua do seu novo país, e é na escola que aprendem a separar elementos de sua tradição para agir de acordo com a sociedade de tradição européia das maiorias das capitais latino-americanas. No entanto, não a ponto de dizer que é na escola que ele adquirirá a mobilidade social, pois segundo Bourdieu (1966 ${ }^{272}$; 41), “tudo tende a mostrar que ele (o sistema escolar) é um

\footnotetext{
${ }^{271}$ ARENDT, H. Entre o passado e o futuro, Perspectiva. Reimpr. 2000, pg. 221

272 BOURDIEU, P. A Escola conservadora: as desigualdades frente à escola e a cultura. Escritos de Educação 6 ${ }^{a}$ Ed. Ed. Vozes. Orgs. Nogueira M, e Catani, A. tradução do original de 1966, “L'École conservatrice. Lês inégalités devant l'école et la culture” publicado na Revue française de sociologie , Paris, 7 (3), p. 325-347. 1996

SAKATA, Marici Cristine Gramacho, Globalização e Educação: A formação do comunicador social na América Latina, 2008312 p. (Doutorado - Orientação BACCEGA, M. A.) Escola de Comunicações e Artes da Universidade de São Paulo, São Paulo, SP, 2008
} 
dos fatores mais eficazes de conservação social, pois fornece a aparência de legitimidade às desigualdades sociais, e sanciona a herança cultural e o dom social tratado como dom natural.”

O rendimento escolar, ou o índice de aproveitamento dos alunos de todos os níveis, têm suas causas não apenas na "vontade e disposição” do indivíduo, mas na sua herança cultural, no habitus - esquema de classificação do mundo, interiorizado ao longo da trajetória social, individual ou coletiva, que se torna a inclinação pela qual essa trajetória ascendente tende a prolongar-se e realizar-se - nas expectativas familiares, e no seu conhecimento acumulado (capital intelectual) durante a vida. Para Bourdieu $(1996)^{273}$, cada família transmite - direta ou indiretamente - capital cultural e ethos a seus filhos, que por sua vez contribuem para definir suas atitudes frente à instituição escolar, entre outros. Esta herança influencia tanto na experiência escolar como em seu êxito desde a pré-escola até chegar ao ensino superior.

Com isso, no momento de democratização da educação e da abertura das escolas para a massa, deve-se ter a percepção de que o mau desempenho ou o fracasso do indivíduo, que muitas vezes é o primeiro membro da família a freqüentar o ensino, não é resultado apenas de uma falta de vontade em ascender socialmente, mas sim o resultado de um complexo conjunto de variáveis que muitas vezes determinam o fracasso ou o êxito de um indivíduo no percurso acadêmico.

Quanto à gestão financeira, este é um fator determinante para que as IES alcancem seus objetivos. Uma instituição sem fins lucrativos deve ter uma gestão financeira tão boa quanto uma instituição com fins lucrativos. No entanto, o que diferencia uma instituição da outra são os objetivos reais, pois os declarados na maioria das vezes são similares. O objetivo real de uma instituição com fins lucrativos é o lucro. Com isso, muito do que se faz é para garantir o lucro da instituição.

A sociedade também deve entender sua importância dentro do Sistema Educacional. Nos Estados Unidos da América, um grande número de alunos não está nas universidades privadas, mas sim nos Community Colleges. O sistema misto apresenta diversas vantagens.

O papel do Estado no financiamento da educação superior é fundamental. No entanto, o Estado envolvido na educação garante a pesquisa e a inclusão. O Estado também deve garantir que as IES tenham um currículo mínimo que contemple

\footnotetext{
${ }^{273}$ BOURDIEU, P. A Escola conservadora......, 1966 Op. Cit.
}

SAKATA, Marici Cristine Gramacho, Globalização e Educação: A formação do comunicador social na América Latina, 2008312 p. (Doutorado - Orientação BACCEGA, M. A.) Escola de Comunicações e Artes da Universidade de São Paulo, São Paulo, SP, 2008 
disciplinas com conteúdo nacional e cultural, e disciplinas que incentivem o pensamento crítico sobre a sociedade atual.

A preservação da identidade cultural de um povo e seu reconhecimento é um direito de todos e um princípio que deve ser respeitado internacionalmente, independente da origem da IES.

"As inovações mais eficientes são aquelas de caráter local, que emanam da base, se desenvolvem com a participação dos próprios usuários e respeitam as manifestações de cada cultura" (Huberman, 1973) ${ }^{274}$.

É consenso que a economia exerce um papel de destaque no paradigma dominante deste século que é a globalização (Ianni, 1996) ${ }^{275}$ e é por esta lente que muitas das decisões locais e mundiais têm sido tomadas. Não foi possível realizar uma análise detalhada de cada país latino-americano pela limitação de tempo. No entanto, pela própria definição de globalização, os países ocidentais têm passado por mudanças similares em seus processos, alguns de forma mais acelerada que outros; porém, há uma tendência comum que pode ser notada. A análise destas tendências permite uma melhor compreensão do que está ocorrendo e possibilita um pensamento crítico a este respeito.

Nesta discussão final tentamos encontrar formas possíveis de se pensar a formação do comunicador em um sistema global, onde seja possível preservar valores identitários e culturais específicos de cada nação e onde o público possa conviver com o privado em vez de competir. Procuramos ainda identificar de que forma e como é possível intervir para minimizar os impactos negativos e potencializar os positivos da globalização.

O objetivo dos EUA - conforme exposto no Relatório Spelling para os próximos anos - é claro e objetivo, ou seja, é assegurar a capacidade de suas universidades de alcançar a liderança global em áreas estratégicas fundamentais como ciência, engenharia, medicina, e outras profissões de conhecimento. Aumentar o investimento federal em áreas críticas para a competitividade global de nossa nação e um

\footnotetext{
${ }^{274}$ HUBERMAN, A. M. Cómo se realizan los cambios en la educación: una contribución al estudio de la innovación. Experiencias e innovaciones en educación, No. 4. 1973. UNESCO-OEI. París. In Blanco, G. Rosa Estado del arte sobre las innovaciones educativas en America Latina, Convenio Andrés Bello, 2000 ${ }^{275}$ IANNI, Octavio. A Sociedade Global. $4^{\text {a }}$ Edição Rio de Janeiro: Civilização Brasileira, 1996 
compromisso renovado em atrair as melhores e mais brilhantes mentes da nação e do mundo para conduzirem a próxima onda de Inovação Americana. ${ }^{276}$

Nos países periféricos, o desenvolvimento científico e tecnológico e, portanto, a possibilidade de inovação, é dependente da universidade. No Brasil, cerca de $90 \%$ das pesquisas são feitas em universidades e destas, 95\% em universidades públicas. Neste sentido, garantir a excelência da universidade não significa garantir um setor da economia, mas o próprio progresso do país.

Os países da América Latina e Caribe sofreram diversas crises e períodos de inflação e hiperinflação. Como conseqüência, a partir da década de 1980, passaram por reformas, e em 1990, após o “consenso de Washington” a região atingiu uma estabilidade macroeconômica e abriu seus mercados. No entanto, isto não foi suficiente para manter o crescimento sustentável ${ }^{277}$ e ocorreram crises nos anos de 2001 e 2002. Com isso, a América Latina e o Caribe ainda sofrem problemas econômicos.

A idéia de integração regional está em discussão há bastante tempo. No entanto, no campo educacional a integração ainda é pequena. Os obstáculos para esta integração implicam questões econômico-financeiras e comerciais entre as regiões e economias. Existem vários órgãos e grupos de discussão sobre a integração latino-americana, como o projeto REDIMA (Rede de diálogo macroeconômico) iniciado em 2000 pela CEPAL com o objetivo de: estabelecer um sistema informal de monitoramento macroeconômico regional que não seja dependente de requisitos institucionais ou das desigualdades das juntas políticas ou econômicas, mas que possa ser útil a cada participante, que o mantenha relacionado a seus pares, e assegure uma certa continuidade da reflexão comum sub-regional. ${ }^{278}$ Este projeto vê a solução para a integração regional em uma opção dinâmica de “competição cooperativa”, ou seja, de um processo que deve desenvolver a demanda de integração e coordenação por parte dos atores nacionais mediante a aprendizagem da cooperação regional. Pensar a integração ou a colaboração é um passo para o desenvolvimento.

\footnotetext{
${ }^{276}$ U.S. Department of education - Contract No. ED-06-C0-0013, September 2006 A test of Leadership charting the future of U.S. Higher education, A Report of the Commission Appointed by Secretary of Education Margaret Spellings Disponível em www.ed.gov/about/bdscomm/list/hiedfuture/reports/prepub-report.pdf acesso em 01/07/2007

${ }^{277}$ REDIMA, Análisis de la dinámica macroeconómica de América Latina y el Caribe y sus implicaciones para la integración económica regional. Reunión sobre la "Dinámica Macroeconómica de América Latina y el Caribe y la Integración Regional” Caracas, Venezuela 15 al 16 de septiembre de 2005 SP/RDMALCIR/Di No $1-05$

${ }^{278}$ REDIMA, Análisis de ....., 2005

SAKATA, Marici Cristine Gramacho, Globalização e Educação: A formação do comunicador social na América Latina, 2008312 p. (Doutorado - Orientação BACCEGA, M. A.) Escola de Comunicações e Artes da Universidade de São Paulo, São Paulo, SP, 2008
} 
Enfim,

Considerando as limitações existentes em qualquer pesquisa, conseguimos cumprir o objetivo proposto. No entanto, os resultados mostraram que ainda é necessário continuar pesquisando e principalmente agindo de forma consciente para que nossos valores e identidade não se percam ao longo do processo de globalização.

Uma Nação cuja população com oferta de educação em todos os níveis, incluindo a educação superior, é uma nação que tem maior capacidade de competir no mercado global. Mas mais importante, uma população educada e que tenha consciência de sua identidade nacional e cultural, consegue competir com igualdade no mercado global, mas, além disso, torna-se um povo autônomo, consciente de si e do mundo. Paulo Freire recusou o ensino "bancário” que deforma a criatividade do educando e do educador; porém, mesmo que este ensino persista, que o educando mantenha sua curiosidade e estímulo a se arriscar e se imunizar contra este poder apassivador. Concordamos ainda com Paulo Freire que diz que ensinar exige rigorosidade metódica, pesquisa, respeito aos saberes dos educandos, criticidade, estética e ética, corporeificação das palavras pelos exemplos, risco, aceitação do novo e rejeição a qualquer forma de discriminação, reflexão crítica sobre a prática, reconhecimento e a assunção da identidade cultural. Isso mostra que ensinar vai muito além da transmissão de conhecimento e da formação técnica para o mercado de trabalho. Cada instituição de ensino deve manter ao menos o espírito de instituição social, e seus professores e coordenadores devem ter em mente qual o verdadeiro papel da Educação e a importância da sua função. A formação do comunicador também deve ser constantemente repensada. Em suma, devemos compreender, conforme concluído por Lopes e Baccega, (2004) ${ }^{279}$ : o caráter mutável do cenário de atuação do profissional marcada por mudanças estruturais na sociedade; discutir e pensar os currículos no âmbito das tendências socio-técnicas e no âmbito do mercado, mas também quanto à sua contribuição no ensino e na pesquisa; desenvolver projetos inter e transdisciplinares em detrimento de abordagens fragmentárias; reconhecer o campo de reflexão sobre a formação em comunicação como uma instância capaz de estimular a melhoria das práticas docentes e gerar mudanças sociais de maior alcance.

Pensar a formação do comunicador não se limita a conteúdos, muito pelo contrário, o conteúdo é uma pequena parte deste complexo processo.

\footnotetext{
${ }^{279}$ LOPES, M. I. V. e Baccega, M. A. Seminário ECA FELAFACS - Comunicação - O sentido da formação para o século XXI, 15 e 16 de Maio de 2004, São Paulo, Relatório Final.

SAKATA, Marici Cristine Gramacho, Globalização e Educação: A formação do comunicador social na América Latina, 2008312 p. (Doutorado - Orientação BACCEGA, M. A.) Escola de Comunicações e Artes da Universidade de São Paulo, São Paulo, SP, 2008
} 


\section{LIMITAÇÕES DA PESQUISA E PESQUISAS FUTURAS}

Esta pesquisa contou com várias limitações. A principal delas foi a amplitude do tema e dos objetivos propostos. Analisar a globalização requer trabalhar com uma grande quantidade de teorias e autores. Por ser um tema multidisciplinar, nos leva a estudar e trabalhar com temas sobre os quais não temos conhecimentos prévios. No entanto, o que se apresentou como limitação foi também o que nos motivou a dar continuidade à pesquisa e tomar a decisão de ampliá-la em vários momentos. Entendemos que para este trabalho seria inviável discutir a fundo cada teoria, e, portanto, optamos por utilizar os autores mais conceituados em cada área e nos limitar a discutir as questões dentro da nossa capacidade.

Estudar vários países em um único trabalho, sem parceiros internacionais, também limita as discussões e aprofundamentos. Entendemos que a análise, em alguns momentos, se deu de forma superficial. Para suprir alguma destas falhas, foi muito importante realizar as entrevistas e aplicar os questionários. As respostas foram essenciais para confirmar os resultados obtidos por meio da pesquisa em documentos e literatura. A leitura de artigos de autores de cada um dos países foi também fundamental para este entendimento. A pesquisa mostrou que há grupos bastante ativos discutindo estas questões na Argentina e Chile. Seria muito interessante juntar esforços e compartilhar conhecimentos.

Foi fundamental a visita às universidades européias e conversar com seus docentes para sentir que as preocupações dos professores e das IES, sejam elas européias ou latino-americanas, são muito similares, ou seja, o processo de globalização está acima das IES e está afetando a todos, tanto países ricos como pobres.

Diversas pesquisas futuras podem ser realizadas. Seria muito importante aprofundar as entrevistas, levantar mais informações sobre as mudanças que estão ocorrendo nas universidades nacionais e globalizadas, conhecer as competências esperadas pela sociedade para o Comunicador do século XXI, e pesquisar as mudanças nos demais países latino-americanos. 


\section{Referências bibliográficas}

ABOITES, Hugo. A privatização da educação superior no México: novas e velhas realidades. In: Gentili. P. (org.) Universidades na penumbra: neoliberalismo e reestruturação. São Paulo, Cortez, 2001.

AGÊNCIA Estado, Anhanguera compra grupo de 6 universidades, 02/10 - 12:57 Disponível em http://ultimosegundo.ig.com.br/educacao/2007/10/02/ anhanguera_compra_grupo_de_6_universidades_1028862.html acesso em $27 / 12 / 2007$

AMARAL, N. C., Catani, A. M., OLIVEIRA, J. F. O financiamento público da educação superior brasileira: mudanças e desafios. Revista Brasileira de Política e Administração da Educação, Piracicaba-SP, v. 19, n. 2, p. 221-241, 2003.

ANTUNES, Ricardo e Alves, Giovanni, As mutações no mundo do trabalho na era da mundialização do capital Educ. Soc., Campinas, vol. 25, n. 87, p. 335-351, maio/ago. 2004 Disponível em <http://www.cedes.unicamp.br> Acesso em $08 / 12 / 2004$

ARENDT, H.Entre o passado e o futuro, São Paulo, Perspectiva, 2005. Tradução de Mauro W. Barbosa do original Between past and future: eight exercises in political thought, 5 ed. 2000.

AUPETIT, Sylvie Didou, Internacionalización y proveedores externos de educación superior en los países de América Latina y en el Caribe: principales problemáticas. Departamento de Investigaciones Educativas - Centro de Investigación y de Estudios Avanzados (DIE/CINVESTAV) MÉXICO Marzo 2005 Síntesis realizada por contrato (No. 886.369.4) con el Instituto Internacional para la Educación Superior en América Latina y el Caribe (IESALC) de la UNESCO.

BACCEGA, M.A. Da Informação ao Conhecimento: ressignificação da escola XXVII Congresso Brasileiro de Ciências da Comunicação, INTERCOM 2004 - Anais.. Tema central: Comunicação, acontecimento e memória, Porto Alegre PUC do Rio Grande do Sul 30 de agosto a 3 de setembro de 2004

BARELLI, Suzana Escola tipo exportação Folha de S. Paulo - Caderno Sinapse, 29/04/2003

BARROS, F. e Martino, L. M, O Habitus na Comunicação, São Paulo, Ed. Paulus, 2003

BATES, R., Administering the Global Trap, The Role of Educational Leaders, Educational Management \& Administration, Sage Publication, London, Vol 30(2) 139-156, 2002

BAUMAN, Z. Globalização, as conseqüências humanas, tradução Marcus Cortesão e Ianni, O. A sociedade Global, 4ª Ed. Rio de Janeiro: Civilização Brasileira, 1996

BENTACUR, N. Reforma de La gestion publica y políticas universitárias en América Latina a finales del siglo XX, 2000, Educação Superior: Avaliação da Produção Científica. Peixoto M .(org) Belo Horizonte, Imprensa Universitária da UFMG

BESLEY, Steve, 'Education at a Glance' OECD Indicators 2005, POLICY WATCH Policy, Qualifications and Standards Division - Edexcel 2005/78 - September 2005 
BID - Banco Interamericano de Desenvolvimento, Quem Somos, 1998 Disponível em : http://www.iadb.org/ Data de Acesso: 26.01.2006

BOURDIEU, P. A Escola conservadora: as desigualdades frente à escola e a cultura. Escritos de Educação 6a Ed. Ed. Vozes. Orgs. Nogueira M, e Catani, A. tradução do original de 1966, “L’École conservatrice. Lês inégalités devant l'école et la culture” publicado na Revue française de sociologie , Paris, 7 (3), p. 325-347. 1996

O Poder Simbólico, $6^{\circ}$ Edição, Tradução Fernando Tomaz do Original Le pouvoir symbolique - Rio de Janeiro; Bertrand Brasil, 2003

BOURDIEU, Pierre, PASSERON, Jean-Claude, La reproduction. Eléments pour une théorie du système d'enseignement Paris, Editions de Minuit, 1970.

BOURNE, Jill, Official pedagogic discourses and the construction of learners' identities. In, Hornberger, Nancy H. (ed.) Encyclopedia of Language and Education., Springer. (In Press) Disponível em http://eprints.soton.ac.uk/41452/, acesso em 04/12/2006

BRAGA, J.L. Constituição do Campo da Comunicação, In: Campo da comunicação, Fausto Neto, A., Prado, J. L. A. e Porto, S. D. (Orgs.) Editora Universitária, João Pessoa, 2001

BRANDÃO Elizabeth, MARTINEZ Maria Cecília, COSTA, Francisco de Assis Silva, Perfil do comunicador social sob a ótica do empregador, Anais do ALAIC 2002 VI Congreso Latinoamericano de Ciencias de la Comunicación, Bolívia, Santa Cruz de la Sierra, 5-8 de junho de 2002 - GT Comunicación Organizacional y Relaciones Públicas Disponível em http://www.eca.usp.br/alaic/material\%20congresso\%202002/congBolivia2002/tra balhos\%20completos\%20Bolivia\%202002/GT\%20\%206\%20\%20margarida\%20k unsch/Elizabeth\%20Brandao\%20e\%20maria\%20cecilia.doc Acesso em 14.02.2006

BURKE, Barry 2000, Karl Marx and informal education. Disponível em < http://www.infed.org/thinkers/et-marx.htm> Acesso em 09/12/2004

CAMACHO, Zósimo, Extranjeros al acecho de la educación, Contralinea, (2006) Disponível em Http://www.contralinea.com.mx/archivo/2006/enero/htm/extranjeros_acecho_edu caion.htm acesso em 01/12/2006

CAPPARELLI, Sérgio e Stumpf, Ida. El campo acadêmico de la comunicación, revisitado. In: Lopes, M.I.V e Fuentes, R (comps.) Comunicación: Campo y Objeto de Estúdio. Guadalajara: Iteso, 2001.

CARDOSO, F. H. e FALETTO, E. Dependência e desenvolvimento na América Latina: Ensaio de interpretação sociológica, $8^{a}$ ed. Civilização Brasileira, Rio de Janeiro, 2004.

CARNEIRO, Eraldo O papel da comunicação nos processos de mudanças está a exigir um profissional com um olho na invenção e outro na gestão. Revista Comunicação Empresarial Ano 8 No $294^{\circ}$ Trimestre de 1998 Disponível em: http://www.aberje.com.br/antigo/revista/n29/artigoc.htm Acesso em 14.02.2006

CCI - Corinthian Colleges, CCI, 2007 Disponível em http://www.cci.edu/ acesso em $31 / 07 / 2007$

SAKATA, Marici Cristine Gramacho, Globalização e Educação: A formação do comunicador social na América Latina, 2008312 p. (Doutorado - Orientação BACCEGA, M. A.) Escola de Comunicações e Artes da Universidade de São Paulo, São Paulo, SP, 2008 
CEC-Carrer Education Corporation, 2007 Disponível em http://www.careered.com/ about.aspx acesso em 31/07/2007

CENTENO Miguel, CURRAN Sara R., GALLOWAY John, LLOYD Paulette \& SOOD Suresh. Growing Knowledge about Growing Knowledge about Globalization (GKG) Observing Trade, 1980-2001. Institute for the Study of the Americas Institute for the Study of the Americas University of London University of London, September 19, 2005 September 19, 2005 Disponível em www.princeton.edu/ ina/gkg Acesso em 2/01/2006

CHAUÍ, M. Convite à Filosofia, Editora Ática, 12ª Edição, 2000 São Paulo

Seminário: Universidade: Por que e como reformar? MEC/SESu: 6 e 7 de agosto 2003 Disponível em http://firgoa.usc.es/drupal/node/19336 acesso em $27 / 12 / 2207$

COBOS, N., Subordination au marché mondial L’individu chez Marx, Maîtrise de philosophie, 1997-1998 - Université Paris 8 - Disponível em $<$ http://big.chez.tiscali.fr/philosurlenet/THESES/documents/marx.html> Acesso em 09/12/2004

COHN, Gabriel. O Campo da Comunicação, In: Campo da comunicação, Fausto Neto, A., Prado, J. L. A. e Porto, S. D. (Orgs.) Editora Universitária, João Pessoa, 2001 (org) Weber, São Paulo, 2004, p.111

CORTESÃO, L. e Stoer, S., Cartografando a transnacionalização do campo educativo: o caso português, In: Santos, Boaventura de S. A Globalização e as Ciências Sociais, $2^{a}$ Ed. São Paulo: Cortez Ed., 2002, p. 377-416

CRENSHAW Edward, PAXTON Pamela, MORISHIMA Rumi, ROBISON Kristopher, Globalization, Westernization, and Social Change, January 2003 Globalization Session of the Annual Meetings of the American Sociological Association, Atlanta 2003.

CUADRA, A. e Cuadra, P, La identidad Vasca en el Mundo, European Union, 2005

DALE, Roger. Globalização e educação: demonstrando a existência de uma "cultura educacional mundial comum" ou localizando uma "agenda globalmente estruturada para a educação”? Educ. Soc., Campinas, vol. 25, n. 87, p. 423-460, maio/ago. 2004 Disponível em <http://www.cedes.unicamp.br> acesso em 10.02.2007

DALY, H., Globalization versus Internationalization: Some Implications, School of public affairs, University of Maryland, 1999 URL: http://www.globalpolicy.org/globaliz/econ/herman2.htm accessed in 11.3.2003

DAVIDENKOFF, Emmanuel, Chronique France Info - Rubrique Education, Passage antenne le mardi 21 mars 2002 Relations presse - Radio

DECLARAÇÃO Mundial sobre Educação Superior no Século XXI: Visão e Ação, Paris, 9 de outubro de 1998

DENNING, Michael. A Cultura na era dos três mundos. Ed. Francis, 2005

EAGLETON, T. A idéia de Cultura, Editora Unesp, 2000

ECKEL, Peter D., King, Jacqueline E. (2004) An Overview of Higher Education in the United States: Diversity, Access, and the Role of the Marketplace, Ed. American 
Council on Education em https://www.acenet.edu/bookstore/pdf/2004_higher_ed_overview.pdf acesso em 27/07/2007 p. 2

EDUCATION Management Corporation - EDMC, 2007 Disponível em www.edmc.com acesso em 01/07/2007

ENDICOTT College Mexico, Disponível em http://www.endicott.edu/servlet/ RetrievePage?site=endicott\&page=Mexico, acesso em 02/12/2006

ESQUÍVEL, Juan Carlos Campbell, Novas Perspectivas nas Políticas de Educação Superior na América Latina, In CATANI, Afrânio (Orgs) Novas perspectivas nas políticas de educação superior na América Latina no limiar do século XXI, Campinas, SP: Autores Associados, 1998, p.247-255

FACULDADE Pitágoras, Disponível em www.faculdadepitagoras.com.br/ acesso em 03/11/2006

FIGUEIRAL, Lurdes, Is the European Model being rejected? Repercussions in the field of Education In: Gomes, Ines European Identity: Individual, Group and Society, Chacon, Universidad de Deusto, Bilbao, Espanha, 2003

FLIGSTEIN Neil, Fields, Power, and Social Skill: A Critical Analysis of The New Institutionalisms, German Sociological Association on "Power and Organization" October 1997.

FRASER, Nancy. Da redistribuição ao reconhecimento? Dilemas da justiça na era póssocialista. In: Souza, Jessé (org) Democracia hoje. Brasília, UnB, 2001; 248

.,, Reconhecimento sem ética? Lua Nova, São Paulo, 70: 101-138, 2007

., Recognition, New Left Review, 3 may/jun 2000 p. 109

FREIRE, P. Pedagogia da Autonomia, São Paulo, Ed. Paz e Terra. 1996, p.25.

GALINDO Daniel e MARIN Sérgio, A Info - Formação do Publicitário, In: Publicidade: Análise da produção publicitária e da formação profissional, TARSITANO, Paulo Rogério (Org.) São Paulo Brasil 1998 Coleção Gt's ALAICAsociación Latinoamericana de Investigadores de la Comunicación UMESP, Universidade Metodista de São Paulo, $\mathrm{n}^{\circ} 01$. Disponível em http://www.eca.usp.br/alaic/Livro\%20GTP/index.htm Acesso em 01.02.2006

GALINDO, J. La historia de la periodistica en España, In: Barrera, Carlos (org.) Del gacetero al profissional del periodismo, Madrid, 1998, livro produzido a partir de "Actas de III Encuentro de la Asociación de Historiadores de la Comunicación de la Faculdad de Comunicación de la Universidad de Navarra (Pamplona).

GARCÍA-Canclini, Néstor, El malestar en los estudios culturales”. México, 1997, Revista Fractal ano 2, v. 2, $\mathrm{n}^{\circ}$ 6, p. 45, jul/set. Disponível em: http://www.fractal.com.mx/F6cancli.html. Acesso em: 10/12/2007

GIDDENS, A. Runaway World: How Globalization is Reshaping our lives, London: Profile Books, 1999, p.10

GILLES, T. R. , Filosofia da Educação, São Paulo: EPU, 1983

GONZALEZ, Aurora, La formación académica y profesional del periodista In: Barrera, Carlos (org.) Del gacetero al profissional del periodismo, Madid, 1998, livro produzido a partir de “Actas de III Encuentro de la Asociación de Historiadores de 
la Comunicación de la Faculdad de Comunicación de la Universidad de Navarra (Pamplona).

GUMPORT, Patricia J. , Academic restructuring: Organizational change and institutional imperatives, Higher Education, Volume 39, Issue 1, Jan 2000, Pages 67 - 91, Disponível em http://www.springerlink.com/ (gwqubdaayyngun45xeti20zz)/app/home/contribution.asp?referrer=parent\&backto =issue,4,5;journal,47,217;linkingpublicationresults,1:102901,1 Acesso em 09.02.2006

HABERMAS, J. A luta por reconhecimento no Estado democrático de direito (In: A inclusão do outro. São Paulo, Edições Loyola, 2002) The theory of Communicative Action, Beacon Press 1987

HALL, Stuart, A identidade cultural na pós-modernidade, DP\&A, Rio de Janeiro, 2003

HAUSKEN, Kjell, and Thomas Plümper. (1997). "Hegemons, Leaders and Followers: A Game-Theoretic Approach to the Postwar Dynamics of International Political Economy." Journal of World-Systems Research 3: 35 - 93. Disponível em http://jwsr.ucr.edu/archive/vol3/v3n1a2.php acesso em 09.02.2006

HELD, D. e McGREW, A. Prós e Contras da Globalização, Rio de Janeiro: Zahar, 2001 do original: Na introduction to the globalization debate.

HENTSCHKE, Guilbert C., Oschman, Scot e Snell, Lisa, 2007 Education Management Organizations: Growing a For-profit Education Industry with Choice, Competition, and Innovation Disponível em 216.219.139.105/pb21.pdf acesso em 31/07/2007

HIRST, P and Thompson, G. (2002) The Future of Globalization, Cooperation and Conflict: Journal of the Nordic International Studies Association, Vol.37(3): 247265 Sage Publications

HOBSBAWN, E, The Nation and Globalization, Constellations Volume 5, N1, Blackwell Publishers, USA, 1998

HONNETH, A. Luta por reconhecimento. A gramática moral dos conflitos sociais. Tradução de Kampf um Anerkennung, Frankfurt, Suhrkamp, 1992

HORNBERGER, Nancy H. (ed.) Encyclopedia of Language and Education., Springer. (In Press) Disponível em http://eprints.soton.ac.uk/41452/, acesso em 04/12/2006

HUBERMAN, A. M. Cómo se realizan los cambios en la educación: una contribución al estudio de la innovación. Experiencias e innovaciones en educación, No. 4. 1973. UNESCO-OEI. París. In Blanco, G. Rosa Estado del arte sobre las innovaciones educativas en America Latina, Convenio Andrés Bello, 2000

IANNI, Octavio. A Sociedade Global. 4a Edição Rio de Janeiro: Civilização Brasileira, 1996

IDP Education Australia, Curriculum development for internationalization. OECD/CERI study. DEET, Canberra:20, 1995

IFC, report on regions 2006 Disponível em http://www.ifc.org/ifcext/ lac.nsf/AttachmentsByTitle/AR2006_LAC_Overview/\$FILE/AR2006_LAC.pdf

IFC, 2007. Disponível em http://www.ifc.org/ifcext/about.nsf/Content/ Member_Countries_Chronological acesso em 07/07/2007

SAKATA, Marici Cristine Gramacho, Globalização e Educação: A formação do comunicador social na América Latina, 2008312 p. (Doutorado - Orientação BACCEGA, M. A.) Escola de Comunicações e Artes da Universidade de São Paulo, São Paulo, SP, 2008 
ISIC Institut des Sciences de l'information et de la Communication, Université Michel de Montaigne, 2007, - $\quad$ http://www.isic.ubordeaux3.fr/index.php?op=page\&rub_id=787 e http://www.isic.ubordeaux3.fr/upload/documents/guide_Mast_Rech.rtf

IUT Michel de Montaigne, http://www.iut.u-bordeaux3.fr/site/jsp/site/Portal.jsp

JARAMILLO, Isabel Cristina: "La Internacionalización de la Universidad Colombiana. Un instrumento para el cambio”, ASCUN, 2003, p. 18.

JORNAL da Ciência Investimento http://www.fapema.br/2006/noticia.php?id=234Terça-feira, 01 de Agosto de 2006

KNIGHT, Jane. Trade in Higher Education Services: The Implications of GATS. The Observatory on Borderless Higher Education March 2002

KELLNER, D. Theorizing Globalization, Sociological Theory 20:3 Nov. American Sociological Association, USA, 2002

KUMAR, R, Usunier, Jean-Claude, Management Education in a Globalizing World Lessons from the French Experience, Management Learning, Sage Publications, London Vol. 32(3): 363-391. 2001

KWIEK, M, The Internationalization and Globalization in Central and East European Higher Education, Society for Research in Higher Education International News, No47, November: 3-5. 2001

KWOK, Chuck C. Y., Arpan, Jeffrey S. A comparison of international business education at U.S. and European business schools in the 1990s Management International Review v. 34 no. 4 p. 357-79, 1994

LATOUR, B. (1987) Science in Action: How to Follow Scientists and Engineers through Society. Cambridge, MA: Harvard University Press.

LAUREATE International Universities, Disponível em http://www.laureate.net /introduction.php acesso em 02/11/2006

LAVADOS, Jaime, Reflexiones sobre la educación superior chilena. In: TRINDADE, Hélgio e GLANQUER, Jean-Michel (Orgs.) Os desafios da educação na América Latina. Petrópolis, RJ: Vozes, 2002, p.94-114

LICENCES Professionnelles Rentrée universitaire 2006 Disponível em http://www.sup.adc.education.fr/lplst/ acesso em 0907/2007

LOPES, M. I. V. e Baccega, M. A. (orgs), Seminário ECA-FELAFACS: Comunicação - O Sentido da Formação para o Século XXI, ECA USP, 15-16 de Maio de 2004. Relatório Final.

LOPES, Maria Immacolata V. O estado da pesquisa de comunicação no Brasil, Temas contemporâneos em comunicação, 2000b

LÓPEZ-García, Xosé, Pereira-Fariñas, Xosé, Hernández-Soto, Tatiana, PORTADA Planes de estudios de comunicación en América Latina, Disponível em http://chasqui.comunica.org/content/view/466/128/ Acesso em 31/08/2006

MAGALHÃES, I, Grigoletto, M, e Coracini, M. (org.) Práticas Identitárias, Língua e Discurso, São Carlos, Claraluz, 2006.

MARGINSON, S. Rethinking Academic Work in the Global Era, Journal of Higher Education Policy \& Management, May, Vol. 221 p.23 13p. 2000 
MARÍN-Marin, Alvaro El analisis de la educación superior en méxico mediante la teoría del caos, Sincronía Winter/Invierno 1998 Jalisco, México Citando El Financiero, 18 de abril de 1996, p.34 Disponível em http://sincronia.cucsh.udg.mx/caos.htm acesso em 01/12/2006

MARQUES DE MELO, José, Diretrizes curriculares para os cursos de comunicação social, Revista Estudos $\mathrm{n}^{0} 22$ Disponível em http://www.abmes.org.br/ Publicacoes/Revista_Estudos/estud22/est22-11.htm acesso em 16/07/2005)

MARQUIS, Carlos Nuevos proveedores de educación superior en Argentina y Brasil Investigador del CONICET, Buenos Aires, Agosto 2002 IES/2002/ED/PI/6, Date of Publication: August 2002

MARTINO, L.C. Elementos para uma epistemologia da comunicação, In: Campo da comunicação, Fausto Neto, A., Prado, J. L. A. e Porto, S. D. (Orgs.) Editora Universitária, João Pessoa, 2001

MATTELART, A. La diversité culturelle: entre histoire et géopolitique, GRICIS, Globalisme et Pluralistme, Montreal, avril 2002 (Disponível em www.infoamerica.org/documentos_pdf/Mattelart2.pdf) Acesso em 18/07/2005.

MAULEÓN, Xavier Etxeberría (2003, p. 128) Borderline Europeans: Nationalism and Fundamentalism, In: Gomes, Ines European Identity: Individual, Group and Society, Chacon, Universidad de Deusto, Bilbao, Espanha.

MCCABE, L. Globalization and Internationalization: The Impact of Education Abroad Programs, Journal of Studies in International Education, Vol. 5 No. 2, Summer 2001

MEC, Dados Disponíveis em: http://www.mec.gov.br/Sesu/moderniz.shtm Acesso em 05.10.2005

MEYER, John W., John Boli, George M. Thomas, Francisco O. Ramirez. "World Society and the Nation-State." American Journal of Sociology 103: 144-181. 1997

MINISTÈRE de l'éducation nationale, de l'enseignement supérieur et de la recherche Septembre 2005 Programme Pédagogique National du DUT « Information communication » Disponivel em http://www.education.gouv.fr/ acesso em 09/07/2007

.,Disponível em http://www.education.gouv.fr/pid8 /le-systemeeducatif.html Acesso em 16/07/2007

.,Formations et diplomes Disponível em http://www.education.gouv.fr/ cid178/programmes-pedagogiques-nationaux.html acesso em 09/07/2007

MINOGUE, Rev. John P., The 20th Century University Is Obsolete, Inside Higher EdSeptember 5, $2006 \quad$ Disponível em http://insidehighered.com/views/2006/09/05/minogue. acesso em 30/12/2007

MIT Disponivel em http://cms.mit.edu/academics/undergrad/ acesso em 25/07/2007

MORIN, Edgar. Ciurana, Emilio Roger. Motta, Raúl Domingo Educar na era planetária: O pensamento complexo como método de aprendizagem pelo erro e incerteza humana.. 2003. São Paulo; Brasília: Cortez; Unesco. P.98-99

MOURA, Claudia P. de, O curso de comunicação social no Brasil: do currículo mínimo às novas diretrizes curriculares, EDIPCURS, Porto Alegre, 2002, p. 15 
MURPHY, P. Kraidy, M. Internacional Communication, Ethnography, and the Challenge of Globalization, Communication Theory, Thirteen: Three, August 2003, pp.304-323

NEU, D. Ocampo Gomez, E., Ponce de León, O, Flores Zepeda, M. (2002), 'Facilitating' globalization processes: Financial technologies and the World Bank, Accounting Forum; Sep-Dec, Vol. 26 Issue 3/4 , p.271

OECD, Education at a Glance 2006, Expenditure on Educational Institutions Relative to Gross Domestic Product, OECD 2006, p. 196

OLIVEIRA, A. G et. al. Preparando o futuro: educação, ciência e tecnologia - suas implicações para a formação da cidadania. Revista Bras. Est. Pedag. Brasília, V. 81, n.198, p. 316-341, maio/ago, 2000

OLIVEIRA, M. B. F., Alteridade e Construção de Identidades pedagógicas: (re) visitando teorias dialógicas, In: Magalhães, I, Grigoletto, M, e Coracini, M. (org.) Práticas Identitárias, Língua e Discurso, São Carlos, Claraluz, 2006.

ORTIZ, R. Mundializacao e Cultura, São Paulo, Brasiliense, 2003, p.24 Cultura brasileira e identidade nacional. 2.ed. São Paulo: Brasiliense, 1986

PAULINO Luís Antônio O Brasil, seus sócios e seus negócios, São Paulo em Perspectiva, 16(2): 82-93, 2002

PERRY, G. Cerrando la brecha en educación y tecnología, Banco Mundial 25, 1-4. 2003

PENNSYLVANIA State University Disponível em http://www.psu.edu/bulletins/ bluebook/ acesso em 27/07/2007

PETERS, Michael, Post-structuralism and marxism: education as knowledge capitalism, J. Education Policy, 2003, Vol 18. No.2 p.115-129

Pontificia Universidad Javeriana, Disponível em www.javeriana.edu.co acesso em 10/08/2006

RANIERI, Nina Beatriz, Autonomia Universitária: As Universidades Públicas e a constituição federal de 1988, São Paulo: Editora da Universidade de São Paulo, 1994

Educação Superior, Direito e Estado. São Paulo: Editora da Universidade de São Paulo, Fapesp, 2000

REDIMA, Análisis de la dinámica macroeconómica de América Latina y el Caribe y sus implicaciones para la integración económica regional. Reunión sobre la "Dinámica Macroeconómica de América Latina y el Caribe y la Integración Regional” Caracas, Venezuela 15 al 16 de septiembre de 2005 SP/RDMALCIR/Di N $1-05$

RIBEIRO, R. Janine, A sociedade contra o social, São Paulo: Companhia das Letras, 2000 p.23

A Universidade e a Vida Atual, Rio de Janeiro: Campus, 2003

RICCIO, E. SAKATA, M. Globalization and Internationalization. Prague, 2004 Proceedings of 27th European Accounting Conference, April 2004 
ROCHE, Jean-Jacques Théories des relations internationales, Paris. Montchrestien, $5^{\mathrm{a} E d}$. 2004

ROUSSEAU, J.J., Emílio ou da Educação, tradução de Emile, ou, De l'éducation por Roberto Leal Ferreira, $2^{\mathrm{a}}$ Ed. - São Paulo: Martins Fontes, 1999, pg. 54

SAHLBERG Pasi Teaching and Globalization, Managing Global Transitions Volume 2 Number 1 Spring 2004

SÁNCHEZ-Sosa, J, Lerner Febres, Salomon, Academic freedom and social responsibility: the ole of university organizations and possible instruments for international monitoring, Higher Education Policy 15, 2002, pp. 385-390

SANTOS, Boaventura de S. A Globalização e as Ciências Sociais, $2^{\text {a }}$ Ed. São Paulo: Cortez Ed., 2002

A justiça social vai obrigar a que se comprometa com a justiça cognitiva, Diversa, Revista da Universidade Federal de Minas Gerais - Ano 3 - n 8 Outubro de 2005 Disponível em www.ufmg.br/diversa/8/entrevista.htm acesso em 02/12/2006, pg. 33

SANTOS, M. Por uma outra globalização, Editora Record, Rio de Janeiro, 2000, $\left(14^{\circ}\right.$ Ed. 2007), p.49

School of Humanities, Arts, and Social Sciences - Comparative Media Studies Disponivel em http://cms.mit.edu/academics/undergrad/ acesso em 25/07/2007

SCHWARTZMAN, Simon, Notas sobre os sistemas de ensino superior da América Latina Disponível em http://www.schwartzman.org.br/simon/america_latina.htm acesso em 10/08/2006

SCOTT, W. Richard Institutional carriers: reviewing modes of transporting ideas over time and space and considering their consequences Industrial and Corporate Change. Oxford University Press journal Volume (Year): 12 (2003) 4 Pages: 879894 Disponível em http://ideas.repec.org/a/oup/indcch/v12y2003i4p879-894.html 09.02.2006

SEC Info, Fran Finnegan \& Company Disponível em http://www.secinfo.com/dsvR3.735d.htm Fri, 3 Aug 2007 acesso em 03/07/2007

SEGRERA, F. L. (2003) El impacto de la globalización y las políticas educativas em los sistemas de educação, Las universidades en América Latina: ¿Reformadas o alteradas? (Buenos Aires: CLACSO), 39-58.

SFSIC - Société Française des Sciences de l'Information et de la Communication , disponível em http://www.sfsic.org/portail/index.php acesso em 09/07/2007

SIQUEIRA, A. C. A regulamentação do enfoque comercial no setor educacional via OMC/GATS, Revista Brasileira de Educação, Maio-Ago, 2004 N. 26

SMITH, M., Globalisation and local experience: encounters with difference in a UK school, The sociological Review 2002

STANFORD University Disponível em http://communication.stanford.edu/ courses/index.html acesso em 27/07/2007

STARKE-MEYERRING, Doreen, Meeting the Challenges of Globalization: A Framework for Global Literacies in Professional Communication Programs.

SAKATA, Marici Cristine Gramacho, Globalização e Educação: A formação do comunicador social na América Latina, 2008312 p. (Doutorado - Orientação BACCEGA, M. A.) Escola de Comunicações e Artes da Universidade de São Paulo, São Paulo, SP, 2008 
Journal of Business and Technical Communication, Vol. 19 No. 4 October 2005 468-499

STIGLITZ, Joseph, A globalização e seus malefícios, A promessa não-cumprida de benefícios globais. São Paulo Ed. Futura, 2000 Tradução Bazán Tecnologia e Lingüística do original Globalization and its discontents.

TAYLOR, C. A política do reconhecimento (In: Argumentos filosóficos. São Paulo Edições Loyola, 2000)

TEIXEIRA, A. Educação e o mundo moderno, Companhia Editora Nacional, São Paulo, 1969, p.158

TEODORO, A. Globalização e educação: políticas educacionais e novos modos de governo - São Paulo: Cortez, Instituto Paulo Freire, 2003. Coleção Perspectiva, v.9

TRINDADE, H, Blanquer, J. Os desafios da educação na América Latina, Petrópolis, RJ:Vozes, 2002. p.24

- (orgs.) Os Desafios da Educação Na América Latina, Editora Vozes, Rio de Janerio, 2002, p.8

TRINDADE, H. Rapport Attali: bases da reforma do ensino superior francês In: Universidade em Ruínas na República dos Professores, Editora Vozes, $3^{\text {a }}$ ed. Rio de Janeiro, 1999a

A universidade numa perspectiva comparada - O ensino superior na América Latina: um olhar longitudinal e comparativo, 2002 In: TRINDADE, H. e Blanquer, J.M. (orgs.) Os Desafios da Educação Na América Latina, Editora Vozes, Rio de Janerio, 2002, p.8

TYAGI, P. (2001) Internationalization of Marketing Education: Current Status and Future Challenges, Marketing Education Review, Vol.11 Number 1 Spring

U.S. Department of education - Contract No. ED-06-C0-0013, September 2006 A test of Leadership - charting the future of U.S. Higher education, A Report of the Commission Appointed by Secretary of Education Margaret Spellings Disponível em www.ed.gov/about/bdscomm/list/hiedfuture/reports/pre-pub-report.pdf acesso em $01 / 07 / 2007$

U.S. Department of Education, National Center for Education Statistics. (2005). Projections of Education Statistics to 2014 (NCES 2005-074), Disponivel em http://nces.ed.gov/fastfacts/FAQTopics.asp?type=2 acesso em 27/07/2007

UNIVERSITÉ de Provence, Aix Marseille 1 Disponível em http://www.up.univ-mrs.fr acesso em 16/07/2007

UNIVERSITÉ Paris X, Disponível em www.u-paris10.fr/ acesso em 16/07/2007

UNIVERSITY of Califórnia, Disponível em http://www.universityofcalifornia.edu/ aboutuc/mission.html acesso em 27/07/2007

UC Berkeley Graduate School of Journalism Disponível em http://journalism.berkeley.edu/ acesso em 27/07/2007

Universidad de las Americas, Disponível em http://www.uamericas.cl/ acesso em 01/11/2006

Universidad Andrés Bello, Disponível em http://www.aiep.cl/ acesso em 01/11/2006

SAKATA, Marici Cristine Gramacho, Globalização e Educação: A formação do comunicador social na América Latina, 2008312 p. (Doutorado - Orientação BACCEGA, M. A.) Escola de Comunicações e Artes da Universidade de São Paulo, São Paulo, SP, 2008 
Universidad Central, Disponível em http://www.ucentral.edu.co/ acesso em 10/08/2006

Universidad de Antioquia, Disponível em www.udea.edu.co acesso em 10/08/2006

Universidad de Belgrano, Disponível em www.ub.edu.ar/ acesso em 10/06/2006

Universidad de Chile, Disponível em www.uchile.cl/ acesso em 02/11/2006

Universidad de Guadalajara (UdeG), Disponível em http://www.cucsh.udg.mx/categoria.php?id=30 acesso em 01/11/2006

Universidad de Santiago de Chile, Disponível em http://www.usach.cl/index.php acesso em $01 / 11 / 2006$

Universidad Del Salvador, Disponível em www.salvador.edu.ar/fcecs/ acesso em 10/06/2006

Universidad del Valle de México, Disponível em http://www.uvmnet.edu/, acesso em $02 / 12 / 2006$

Universidad Externado de Colômbia, Disponível em http://www.uexternado.edu.co/ comunicacion/enfasis.htm acesso em 10/08/2006

Universidad Nacional Autonoma de Mexico, Disponível em www.unam.mx, acesso em $01 / 11 / 2006$

Universidad Nacional de La Plata, Disponível em http://www.perio.unlp.edu.ar/grado/index.php, acesso em 01/06/2006

Universidade de Sao Paulo, Escola de Comunicações e Artes, Disponível em www.eca.usp.br acesso em 03/12/2006

Universidade Federal de Minas Gerais, Disponível em www.ufmg.br acesso em 04/12/2006

VAIRA, M. Globalization and Higher Education Organizational Change: A framework for analysis. Higher Education, 48, 2004 483-510.The influence of globalization on higher education Disponível em http://www.springerlink.com.w10077. dotlib.com.br/(ydkvxm55lp4spz553qxcqiur)/app/home/contribution.asp?referrer= parent\&backto=issue,5,11;journal,10,217;linkingpublicationresults,1:102901,1 Acesso em 10.01.2006

WALLACE, M., Managing the Unmanageable, Coping with Complex Educational Change, Educational Management \& Administration, Vol. 31 (19) 9-29: Sage Publication, 2003

WALLERSTEIN, Immanuel, Análise dos Sistemas Mundiais, 1999 In: Giddens A. e Turner, Jonathan (organizadores) Teoria Social Hoje; tradução de Gilson César Sousa, Sao Paulo: Editora UNESP, 1999 p. 447-470

WANDERLEY L. E. W. O que é universidade, Editora Brasiliense, São Paulo, 2003, p.15

WEBER, Max, A ética protestante e o espírito do capitalismo. São Paulo, Martin Claret, 2004

WOODWARD, David, DRAGER, Nick, BEAGLEHOLE, Robert, \& LIPSON, Debra Globalization and health: a framework for analysis and action Bulletin of the World Health Organization, 2001, 79 (9) World Health Organization, 2001.

SAKATA, Marici Cristine Gramacho, Globalização e Educação: A formação do comunicador social na América Latina, 2008312 p. (Doutorado - Orientação BACCEGA, M. A.) Escola de Comunicações e Artes da Universidade de São Paulo, São Paulo, SP, 2008 
WORLD Bank Investment Opportunities In Private Education In Brazil, EdInvest, 2000, Disponivel em http://www.ifc.org/ifcext/CHEPublication.nsf/bf3b1 473553819eb85256bdd0067f34d/f9867d25e9cabc0685256c02006e573a/\$FILE/Br azil.pdf. acesso em 01/07/2007

YARZABAL L. "Impactos del neoliberalismo sobre la educación superior en América Latina”. CIPEDES, n. 1 (12), marzo 2001:9-15.

ZARUR, C. "Los nuevos proveedores externos de educación superior em Colombia", Asociación Colombiana de Universidades-ASCUN-. Bogotá, mayo de 2004. p.72

ZINKIN, M, Not New and Never Costless: Globalization, International Relations, Sage Publications,Vol. 15(5):27-36. 2001 


\section{ANEXOS}




\title{
ANEXO I
}

\author{
Project Number 24398 \\ Project Name Fundo de Educação para o Brasil \\ Country Brazil \\ Sector T - Education Services \\ Company Name Fundo de Educação para o Brasil \\ Environmental Category B \\ Date SPI Disclosed 21 Dec 2005 \\ Projected Board Date 23 Jan 2006 \\ Project Name Fundo de Educação para o Brasil
}

\section{Project sponsor and major shareholders of project company}

The project sponsor is the Fundo de Educação para o Brasil (the "Fund" or "FEBR"). FEBR is an investment vehicle focused on the post-secondary education segment in Brazil. FEBR was structured by Banco Pátria, one of Brazil's leading private equity firms, to explore investment opportunities in the Brazilian post-secondary education market. Today, FEBR has among its investors highly respected operators in the Brazilian post-secondary education market and influential business leaders. FEBR owns a $69 \%$ stake in AES.

\section{Total project cost and proposed IFC investment}

The total project cost is expected to be $\$ 71$ million. IFC's participation in financing the projects will be comprised of a \$12 million loan and a \$4.5 million equity investment.

\section{Location of project and description of site}

AES' expansion strategy will be focused on small to medium sized cities in the state of São Paulo and other regions in the Brazilian Southeast - the country's most prosperous - over a 3 year implementation period.

\section{Description of company and purpose of project}

The Fundo de Educação para o Brasil (the Fund or FEBR) was structured by Banco Patria, one of Brazil's leading private equity firms, as an investment vehicle focused on the post-secondary education segment in Brazil. FEBR has one single asset, a controlling stake in Anhanguera Educacional S.A. (AES). The Fund will channel its investments in the sector through AES. AES is a private, for profit, São Paulo based, post-secondary education company with 10 campuses and average enrollment of 16,800 students in 2005. AES focuses on offering good quality, affordable education to lowerincome students in Brazil. IFC's investment of up to \$16 million will be used to fund part of AES' expansion strategy, centered on building new campuses in small to medium sized cities in the state of São Paulo and other regions in the Brazilian Southeast - the country's most prosperous - over a 3 year implementation period.

\section{Environmental and social issues - Category}

This is a Category B project according to IFC's Procedure for Environmental and Social Review of Projects because a limited number of specific environmental and social impacts may result which can be avoided or mitigated by adhering to generally recognized performance standards, guidelines or design criteria. The review of this project consisted of appraising technical and environmental / social information submitted by the project sponsor. Issues to be addressed include minor fire and life safety provisions for school buildings.

\section{For inquiries about the project, contact:}

Alexandre Texeira de Assumpção Saigh, Director Banco Patria Av. Brig. Faria Lima, 2055 - 7o andar 01452001 - São Paulo - Brazil 


\author{
$* * * * * * * * * * * * * * * * * * * * * * * * * * * * * * * * * * * * * * *$ \\ Project Number 9886 \\ Project Name Universidad del Salvador \\ Country Argentina \\ Sector T - Education Services \\ Company Name Universidad del Salvador \\ Environmental Category B \\ Date SPI Disclosed 14 Jun 2000 \\ Projected Board Date 27 Jul 2000 \\ Project Name Universidad del Salvador
}

\title{
Project sponsor and major shareholders of project company
}

USAL was founded over forty years ago by the company of the Jesuits, an ordained Catholic group with the primary objective of providing quality education under strict academic and discipline standards. USAL's administrative arm has been run since 1975 by a group of highly qualified professionals, who run the education business under high management, transparency and accountability standards. The operating arm is headed by experienced education professionals, who direct the education centers under high academic and discipline standards. As required by Argentine law, the University operates as a not-for-profit foundation, Asociación Civil Universidad del Salvador. Excess cash flow is typically reinvested in the University via capital improvements or additional operating expenditures. The University's status as a not-for-profit has no material legal implications on borrowing procedures.

\section{Total project cost and proposed IFC investment}

The estimated project cost is \$20 million over the next four years. The proposed IFC financing is a $\$ 10$ million A loan for IFC's own account.

\section{Location of project and description of site}

The project will focus on the University's existing campus of Pilar in the province of Buenos Aires. The Pilar region represents an attractive market attributable to its strategic position (located about $55 \mathrm{kms}$ from Buenos Aires), strong population growth (from 131,000 inhabitants in 1991 to over 700,000 at present) and the presence of an industrial park with over 180 companies (and 120 satellite companies located outside of the park). Historically, the area has been residential, but is increasingly attracting businesses following the construction of highways linking the town to Buenos Aires. The Pilar campus is located near bus terminals and the intersection of several important downtown streets

\section{Description of company and purpose of project}

The proposed \$20 million five-year project, which focuses on the University’s campus of Pilar in the province of Buenos Aires, entails the construction of: - new classrooms; a large auditorium; - a library; - student dormitories, - a veterinarian clinic; and - three outpatient clinics. The project will consolidate the University's position of leadership, improve and broaden the subjects taught, alleviate the current shortage of space and help accommodate further growth. The role of the education system is crucial in supplying the human resources required for faster economic growth and successful competition in the global markets. Argentina's industrial and services sector underwent a major restructuring following the opening of the economy in 1991 to improve quality, productivity and profitability. These developments, coupled with the increasing globalization of markets, have induced a shift in the skills required by today's labor 
force. Companies are seeking more qualified employees and increasingly demanding individuals with a post-secondary education. Increases in productivity could be jeopardized unless the education system is able to match the demands of the market for well-educated, skilled and flexible graduates. Investments in the private system will complement an overcrowded public system and enhance the overall quality of higher education and its graduates. Education remains a sector where financial institutions generally are unwilling to invest. By taking the lead, IFC will demonstrate to others the commercial viability of private investment in institutions like USAL. The success of this, and other IFC education projects, should help to create a market where none exists today for raising capital to fund the growth, quality and efficiency improvement of learning institutions.

\section{Environmental and social issues - Category}

This is a Category B project according to IFC's Procedure for Environmental and Social Review of Projects, because a limited number of specific environmental and/or social impacts may result which, can be avoided or mitigated by adhering to generally recognized performance standards, guidelines or design criteria.

\section{For inquiries about the project, contact:}

Lic. Javier ALonso Hidalgo Universidad del Salvador Vice Rector Academico Viamonte 18561056 Buenos Aires- Argentina Telephone: 541148131408

\section{Project Number 8545}

Project Name Universidad de Belgrano

Country Argentina

Sector T - Education Services

Company Name Fundacion Universidad de Belgrano "Doctor Avelino Porto"

Environmental Category B

Date SPI Disclosed 2 Apr 1998

Project Name Universidad de Belgrano

Technical Partner and/or Major Shareholders Fundación Universidad de Belgrano

\section{Summary Of Project Information (SPI)}

Project Cost Including Proposed IFC Investment

The proposed US\$49 million project will help Universidad de Belgrano ("UB") improve its competitive position in the private higher education sector. The main components of the project include: (a) the construction and furnishing of a new 28,000 sq.m. building ("Torre II”)with an estimated cost of US\$41 million, (b) refinancing UB's expensive short term debt (US\$6 million), and (c) helping UB capitalize a US\$ 2 million student loan financing program aimed at students which would otherwise not be able to afford tuition at a private school. IFC is proposing to provide Universidad de Belgrano with a US\$22 million loan.

\section{Location of Project and Description of Site}

The new building will be located in Belgrano, City of Buenos Aires.

Description of Company and Purpose of Project

Universidad de Belgrano is one of the oldest and largest private universities in Argentina. The project will alleviate the current shortage of space and help accommodate expected growth. The project will also help fund a student loan financing program. With a higher education system almost entirely financed by public funds, a 
low level of efficiency and a lack of capital investment, the project, which will help a private university fill in some of

the existing gaps, will strengthen a sector which is key to maintaining competitiveness in an outward-oriented economy. In 1995 the World Bank approved a US\$165 million 'Higher Education Reform Project', to help support the Government of Argentina's efforts to improve the coverage, quality and efficiency of higher education. With the World Bank's support, the Government is also trying to improve the legal and regulatory environment for the creation of new institutions and programs in the private sector. The proposed IFC investment will help complement the World Bank's strategy for the higher education sector.

\section{Environmental Category and Issues}

This is an environmental review category B project. Environmental, occupational health, and safety issues include: source and adequacy of water supply; treatment and disposal of sewage; waste/garbage management and disposal including hazardous wastes from labs; potential use of asbestos and CFCs; and fire protection and life safety. Water and sewer service is provided by the municipal utility, Aguas Argentinas. Solid waste will not contain hazardous materials, as the building will be devoted to offices and lecture halls.

Because the structure is of all new construction, no asbestos-containing materials will be used, and all cooling systems will be CFC-free. The building is being designed to meet National Fire Protection Association (NFPA) Life Safety Code 101, which should meet World Bank guidelines for fire and life safety. The sponsor will be required install fire doors and other means necessary to isolate the new building from the existing structure. Compliance will be verified by a desk review by an expert in fire safety prior to first

disbursement.

The is available from the Public Information Center.

Date SPI sent to InfoShop April 2, 1998

"This Summary of Project Information is prepared and distributed to the public in advance of consideration of the proposed transaction by the Corporation's Board of Directors. It is provided for the purpose of enhancing the transparency of IFC's activities and should not be construed as presuming the outcome of IFC Board consideration.”

For Additional Information contact: Corporate Relations Unit telephone: (202) 473-7711

facsimile: (202) 974-4384

SAKATA, Marici Cristine Gramacho, Globalização e Educação: A formação do comunicador social na América Latina, 2008312 p. (Doutorado - Orientação BACCEGA, M. A.) Escola de Comunicações e Artes da Universidade de São Paulo, São Paulo, SP, 2008 


\section{ANEXO II}

\section{INSTITUIÇÕES DE ENSINO SUPERIOR}

A tabela a seguir resume as instituições que foram analisadas:

\begin{tabular}{|c|c|c|c|c|}
\hline & \multicolumn{2}{|c|}{ Nacional } & \multicolumn{2}{|c|}{ Globalizada } \\
\hline 1. Argentina & $\begin{array}{l}\text { 1.1 Universidad de } \\
\text { Buenos Aires }\end{array}$ & $\begin{array}{l}\text { 1.2. Universidad } \\
\text { Nacional de La } \\
\text { Plata }\end{array}$ & $\begin{array}{l}\text { 1.3 Universidad } \\
\text { de Belgrano (1) }\end{array}$ & $\begin{array}{l}\text { 1.4 Universidad } \\
\text { del Salvador (1) }\end{array}$ \\
\hline 2. Brasil & $\begin{array}{l}\text { 2.1 Universidade } \\
\text { de São Paulo }\end{array}$ & $\begin{array}{l}\text { 2.2 Universidade } \\
\text { Federal de Minas } \\
\text { Gerais }\end{array}$ & $\begin{array}{l}\text { 2.3 Anhembi } \\
\text { Morumbi } \\
\text { (Laureate) }\end{array}$ & $\begin{array}{l}\text { 2.4 Faculdade } \\
\text { Pitágoras } \\
\text { (Grupo Apollo) }\end{array}$ \\
\hline 3. Chile & $\begin{array}{l}\text { 3.1 Universidad de } \\
\text { Chile }\end{array}$ & $\begin{array}{l}\text { 3.2 Universidad de } \\
\text { Santiago de Chile }\end{array}$ & $\begin{array}{l}\text { 3.3 Universidad } \\
\text { Nacional de } \\
\text { Andres Bello } \\
\text { (Laureate) }\end{array}$ & $\begin{array}{l}\text { 3.4 Universiadad } \\
\text { de las Americas } \\
\text { (Laureate) }\end{array}$ \\
\hline 4. Colômbia & $\begin{array}{l}\text { 4.1 Pontificia } \\
\text { Universidad } \\
\text { Javeriana }\end{array}$ & $\begin{array}{l}\text { 4.2 Universidad De } \\
\text { Antioquia }\end{array}$ & $\begin{array}{l}4.3 \text { Universidad } \\
\text { Externado de } \\
\text { Colombia }\end{array}$ & $\begin{array}{l}\text { 4.4 Universidad } \\
\text { Central }\end{array}$ \\
\hline 5. México & $\begin{array}{l}\text { 5.1 Universidad } \\
\text { Nacional } \\
\text { Autonoma de } \\
\text { Mexico }\end{array}$ & $\begin{array}{l}5.2 \text { Universidad de } \\
\text { Guadalajara } \\
\text { (UdeG) }\end{array}$ & $\begin{array}{l}5.3 \text { Universidad } \\
\text { Del Valle } \\
\text { (Laureate) }\end{array}$ & $\begin{array}{l}5.4 \text { Endicott } \\
\text { College Mexico }\end{array}$ \\
\hline 1. Espanha & $\begin{array}{l}\text { 1.1 Universidad } \\
\text { de Deusto*** }\end{array}$ & $\begin{array}{l}\text { 1.2. Universidad } \\
\text { Complutense de } \\
\text { Madrid*** }\end{array}$ & $\begin{array}{l}\text { 1.3 Mondragon } \\
\text { Unibertsitatea }\end{array}$ & $\begin{array}{l}1.4 \text { Universidad } \\
\text { Antonio de } \\
\text { Nebrija ** }\end{array}$ \\
\hline 2. France & $\begin{array}{l}\text { 2.1 Université de } \\
\text { Marseille }\end{array}$ & $\begin{array}{l}2.2 \text { Université de } \\
\text { Bordeaux }\end{array}$ & $\begin{array}{l}2.3 \text { Université } \\
\text { Paris } \mathrm{X} * * *\end{array}$ & $\begin{array}{l}\text { 2.4 Science Po } \\
* * *\end{array}$ \\
\hline $\begin{array}{l}\text { 3. Estados } \\
\text { Unidos da } \\
\text { América }\end{array}$ & $\begin{array}{l}\text { 3.1 University Of } \\
\text { California } \\
\text { (Pública) }\end{array}$ & $\begin{array}{l}\text { 3.2 Pennsylvania } \\
\text { State University } \\
\text { (Pública) }\end{array}$ & $\begin{array}{l}3.3 \\
\text { Massachusetts } \\
\text { Institute of } \\
\text { Technology } \\
\text { (Privada) }\end{array}$ & $\begin{array}{l}\text { 3.4 Stanford } \\
\text { University } \\
\text { (Privada) }\end{array}$ \\
\hline
\end{tabular}

(1) Fundos IFC

\section{Argentina - Universidades Nacionais}

\section{$\underline{1.1 \text { Universidad de Buenos Aires - Facultad de Ciencias Sociales }} \underline{280}$}

- Características e Missão da Instituição:

I.- La Universidad de Buenos Aires es una entidad de derecho público que tiene como fines la promoción, la difusión y la preservación de la cultura. Cumple este propósito en contacto directo permanente con el pensamiento universal y presta particular atención a los problemas argentinos.

${ }^{280}$ Disponível em http://www.fsoc.uba.ar/carreras/comu.htm acesso em 01/05/2006 
II.- La Universidad contribuye al desarrollo de la cultura mediante los Estudios humanistas, la investigación científica y tecnológica y la creación artística. Difunde las ideas, las conquistas de la ciencia y las realizaciones artísticas por la enseñanza y los diversos medios de comunicación de los conocimientos.

III.- La Universidad es una comunidad de profesores, alumnos y graduados, Procura la formación integral y armónica de sus componentes e infunde en ellos el espíritu de rectitud moral y de responsabilidad cívica. Forma investigadores originales, profesionales idóneos y profesores de carrera, socialmente eficaces y dispuestos a servir al país. Encauza a los graduados en la enseñanza y en las tareas de investigación, y a través de ellos estrecha su relación con la sociedad.

$I V$.- La Universidad es prescindente en materia ideológica, política y religiosa, asegura dentro de su recinto la más amplía libertad de investigación y de expresión, pero no se desentiende de los problemas sociales, políticos e ideológicos, sino que los estudia científicamente.

$V$.- La Universidad, además de su tarea específica de centro de estúdios y de enseñanza superior procura difundir los beneficios de su acción cultural y social directa, mediante la extensión universitaria.

VI.- La Universidad estudia y expone objetivamente sus conclusiones sobre los problemas nacionales; presta asesoramiento técnico a las instituciones privadas y estatales de interés público y participa en las actividades de empresas de interés general.

- Características e Objetivos do Curso de Comunicação ou Especialidade da Instituição:

Licenciatura en Ciencias de la Comunicación Social

Diploma de Licenciado en Ciencias de la Comunicación Social - 5 años.

a) Orientación en Opinión Pública y Publicidad

b) Orientación en Comunicación y Promoción Comunitaria

c) Orientación en Politicas y Planificación de la Comunicación

d) Orientación en Periodismo

e) Orientación en Comunicación y Procesos Educativos

Objetivo: La Licenciatura en Ciencias de la Comunicación Social se desarrolla en 3 etapas: Ciclo Básico (1 año), Tronco de la Carrera (3 años) y orientaciones terminales (1 año). Estas orientaciones presentan 5 posibilidades de elección: Periodismo, Comunicaciones y Procesos Educativos, Opinión Pública y Publicidad, Comunicación y Promoción Comunitario. Políticas y Planificación de la Comunicación. Su objetivo es contribuir a la formación de profesionales que puedan manejar con espíritu crítico y de manera creativa desde los recursos más simples hasta los más sofisticados para el ejercicio de la comunicación.

Perfil: Campo Ocupacional: Los egresados de la Carrera de Ciencias de la Comunicación Social tendrán capacitación para desempeñarse como:

- Comunicadores especializados en la investigación de la comunicación en el nivel nacional e internacional;

- Especialistas en comunicación para la opinión pública;

- Especialistas en comunicación para los procesos educativos (institucionales y a distancia);

- comunicadores en empresas privadas y públicas: a) Comunicación institucional y b) Imagen pública;

- Planificadores y expertos en políticas de comunicación;

- Periodistas de medios gráficos, radiales, audiovisuales; y planificadores de proyectos periodísticos.

SAKATA, Marici Cristine Gramacho, Globalização e Educação: A formação do comunicador social na América Latina, 2008312 p. (Doutorado - Orientação BACCEGA, M. A.) Escola de Comunicações e Artes da Universidade de São Paulo, São Paulo, SP, 2008 
Nota: En el segundo cuatrimestre del año 2004 se estima el inicio del Profesorado en Ciencias de la Comunicación.

- Grade Curricular

Carrera: Ciencias de la Comunicacion - Licenciatura en Ciencias de la Comunicacion

\section{I.-Del Ciclo Básico Común}

MATERIAS

Introducción al Pensamiento Científico

Introducción al Conocimiento de la Sociedad y el Estado

Sociología

Elementos de Semiología y Análisis del Discurso

Psicología

Economía

II.-Materias Comunes

Teorías y Practicas de la Comunicación I

Semiótica I -de los Géneros Contemporáneos-

Principales Corrientes del Pensamiento Contemporáneo

Metodología y Técnicas de la Investigación Social

Historia Social General I

Antropología Social y Cultural

Taller de Expresión I

Taller de Radiofónica -Radio-

Historia Social Argentina y Latinoamericana II

Teorías y Practicas de la Comunicación II

Elementos de Economía y Concepciones del Desarrollo

Semiótica II -Medios-

Derecho a la Información

Historia General de los Medios y Sistemas de

Comunicación

Taller de Introducción a la Informática, a la Telemática y al Cuatrimest

Procesamiento de Datos

Taller de Expresión II -Audiovisual-

Psicología y Comunicación

Teorías y Practicas de la Comunicación III

Políticas y Planificación de la Comunicación

Seminario de Diseño Gráfico y Publicidad

Seminario de Cultura Popular y Cultura Masiva

Seminario de Informática y Sociedad

Taller de Expresión III

Taller de Comunicación Comunitaria, o Taller de

Comunicación Publicitaria o Taller de Comunicación

Periodística $(*)$

Idioma Ingles o Francés o Alemán o Italiano $\left.{ }^{* *}\right)$
CARGA

Duración HORARIA Año

Cuatrimest

6 Horas

1ro.

Cuatrimest

Cuatrimest

Cuatrimest

Cuatrimest

6 Horas

1ro.

6 Horas 1ro.

6 Horas 1 ro.

Cuatrimest

6 Horas

1ro.

6 Horas 1 ro.

Anual 4 Horas 2do.

Anual 4 Horas 2do.

Cuatrimest 4 Horas 2do.

Cuatrimest 4 Horas 2do.

Cuatrimest 4 Horas 2do.

Cuatrimest 4 Horas 2do.

Anual 4 Horas 2do.

Cuatrimest 4 Horas 2/3ro.

Cuatrimest 4 Horas 3ro.

Cuatrimest 4 Horas 3ro.

Cuatrimest 4 Horas 3ro.

Cuatrimest 4 Horas 3ro.

Cuatrimest 4 Horas 3ro.

Cuatrimest 4 Horas 3ro.

4 Horas 3ro.

Anual 4 Horas 3ro.

Cuatrimest 4 Horas 3ro.

Cuatrimest 4 Horas 4to.

Cuatrimest 4 Horas 4to.

Cuatrimest 4 Horas 4to.

Cuatrimest 4 Horas 4to.

Cuatrimest 4 Horas 4to.

Anual 4 Horas 4to.

Cuatrimest 4 Horas 3/4to.

3 Cuatrimest 4 Horas

(*) Uno de los cuatro idiomas a elección del estudiante. Puede cursar uno como obligatorio y otro como optativo.

III.- De las Orientaciones*

SAKATA, Marici Cristine Gramacho, Globalização e Educação: A formação do comunicador social na América Latina, 2008312 p. (Doutorado - Orientação BACCEGA, M. A.) Escola de Comunicações e Artes da Universidade de São Paulo, São Paulo, SP, 2008 
ORIENTACION EN PERIODISMO

Teorías Sobre el Periodismo

Cuatrimest

4 Horas

5 to.

Planificación de la Actividad Periodística I

Cuatrimest

4 Horas

Cuatrimest

4 Horas

Planificación de la Actividad Periodística II

Cuatrimest

6 Horas

4 Horas

Historia del Arte y su Relación con los Medios Masivos

de Comunicación, o bien una materia a elección entre las

Cuatrimest

6 Horas

5to.

Taller de Orientación en Periodismo***

Anual

5 to.

5 to.

5 to.

5 to.

*El estudiante tiene la obligación de cursar una de las cinco orientaciones. Puede cursar en forma sucesiva o simultánea más de una orientación.

**El estudiante debe elegir una de las tres opciones.

Al concluir la orientación, el estudiante debe presentar una tesina realizada en el ámbito del taller con el aporte de apoyos pedagógicos. Lo mismo vale para el resto de las orientaciones.

\section{ORIENTACION EN POLITICAS Y PLANIFICACION DE LA} COMUNICACION

Teorías del Estado y la Planificación

Metodología del Planeamiento en Comunicación

Legislación (Comparada)

Dos Materias a elección entre:

Teorías del Estado y la Planificación II

Planificación en Informática y Telecomunicaciones

Política Internacional en Comunicaciones

Economía de la Información

Seminario Preparado Para Tal Fin

Taller de la Orientación en Políticas y Planificación de la Anual

Comunicación

\section{ORIENTACION EN COMUNICACION Y PROCESOS EDUCATIVOS}

Comunicación y Educación

Cuatrimest

4 Horas

5 to.

Sociología de la Educación

Cuatrimest

6 Horas

Cuatrimest

4 Horas

5 to.

Tecnologías Educativas

Dos Materias a elección entre:

Historia de la Educación Argentina

Análisis Institucional

Técnicas de la Actividad Grupal

Metodología del Planeamiento en Comunicación

Seminario Preparado Para Tal Fin

Taller de la Orientación en Comunicación y Procesos

Educativos

Cuatrimest

4 Horas

5to.

Cuatrimest

4 Horas

5 to.

Cuatrimest

4 Horas

Cuatrimest

4 Horas

Cuatrimest

6 Horas

Anual

6 Horas

5 to.

5 to.

5 to.

\section{ORIENTACION EN OPINION PUBLICA Y}

PUBLICIDAD

Comercialización

Campañas Publicitarias

Cuatrimest

4 Horas

5to.

Cuatrimest

4 Horas

5 to.

Cuatrimest

4 Horas

5 to.

Técnicas de Investigación de Opinión Publica y Mercado

Una materia a elección entre las de las restantes

orientaciones o un seminario preparado para tal fin.
Cuatrimest

Cuatrimest
6 Horas

5to.

4/6 Horas 5to. 
Metodología del Planeamiento en Comunicación

$\begin{array}{lll}\text { Cuatrimest } & 4 \text { Horas } & 5 \text { to. } \\ \text { Cuatrimest } & 6 \text { Horas } & 5 \text { to. } \\ \text { Cuatrimest } & 4 \text { Horas } & 5 \text { to. } \\ \text { Cuatrimest } & 4 \text { Horas } & 5 \text { to. } \\ \text { Cuatrimest } & 4 \text { Horas } & 5 \text { to. }\end{array}$

Promoción de Actividades Comunitarias

Comunicación y Educación

Análisis Institucional

Una materia a elección entre las de las restantes orientaciones o un seminario preparado para tal fin.

Taller de la Orientación en Comunicación y Promoción Comunitaria

\subsection{Universidad Nacional de La Plata - Facultad de Periodismo y Comunicación $\underline{\text { Social }}^{281}$}

\section{- Características e Missão da Instituição}

La Universidad Nacional de La Plata tiene un perfil particular que la distingue y caracteriza, que comienza a delinearse en 1905 y surge de la confluencia de dos conceptos fundamentales. Por una parte, la interpretación tradicional del término "Universidad", como ámbito natural del saber. Por otra, la idea actualizada del conocimiento científico de base experimental, social y artístico en sus distintas expresiones.La Universidad Nacional de La Plata, bajo el lema "Pro Scientia et Patria» fiel a las ideas rectoras que le dieron origen, ha sido y sigue siendo pionera en estudios y desarrollos culturales, artísticos y cientificos de avanzada. Esto le ha proporcionado el prestigio que, sumado al fecundo accionar de su presente, la sitúa entre las principales del pais, del continente americano y del mundo. La docencia, la investigación y la extensión configuran los pilares básicos de esta Universidad. Actualmente cuenta con 15 Facultades y una Escuela Superior de Trabajo Social, donde estudian 76.500 alumnos. En los últimos años registró un promedio de inscripciones cercano a los 24 mil aspirantes, mientras que de sus aulas egresan anualmente alrededor 4.500 estudiantes.La oferta académica de la UNLP incluye 104 carreras de grado -146 títulos- y 134 de posgrado (más del 50\% categorizadas por la Comisión Nacional de Evaluación y Acreditación Universitaria-CONEAU-). Además cuenta con cinco Colegios Preuniversitarios con una matrícula aproximada de 5 mil alumnos.La planta de trabajadores de la UNLP está compuesta por 8.032 docentes y 2.143 no docentes.

La educación pública en general y en particular la educación superior transitan por un momento álgido y decisivo. Al igual que la sociedad argentina, afronta una de las mayores crisis de su historia y en ese marco, pareciera que todo está en discusión. Debe repensarse y repasar su rumbo histórico, pero sobre todo fundamentar fuertemente ante la comunidad, la importancia de su existencia y de su crecimiento como insumo indispensable para alimentar expectativas de progreso sustentable y con equidad. Las oportunidades de acceso a la educación superior y el sostenimiento de su calidad al alcance de todos son la base y la vigencia del debate... Definir un plan estratégico para la UNLP -que de eso se trata la respuesta a tal pregunta-, no debiera entenderse como la materialización de un "producto" ni la aplicación de un "procedimiento", aún siendo éste el resultado de un exhaustivo y riguroso análisis técnico, ni de una apertura a la participación circunstancial de su comunidad, ni la conjunción de ambas; sino que debiera asumirse como un "proceso" participativo, permanente

\footnotetext{
${ }^{281}$ Universidad Nacional de La Plata, Disponível em http://www.perio.unlp.edu.ar/grado/index.php, acesso em 01/06/2006
}

SAKATA, Marici Cristine Gramacho, Globalização e Educação: A formação do comunicador social na América Latina, 2008312 p. (Doutorado - Orientação BACCEGA, M. A.) Escola de Comunicações e Artes da Universidade de São Paulo, São Paulo, SP, 2008 
y definitivo. La Universidad debe predicar con su ejemplo en las instituciones públicas y privadas y en las comunidades, la necesidad de planificar y gestionar participativamente para poder progresar. Debe demostrarse y demostrar que es capaz de contar con un plan concertado entre los diversos sectores que la componen, que trascienda cada periodo de gestión, versátil en las estrategias para cumplirlo y firme en sus objetivos. El pensamiento estratégico aplicado a la Universidad, supone una forma de imaginar objetivos comunes a toda su comunidaddocentes, no docentes, alumnos y graduados-, una manera de sortear las dificultades que las circunstancias y los diversos actores sociales presentan para alcanzarlos e identificar el camino más corto para lograr esos objetivos y conseguir el progreso aspirado, pero desde un conocimiento preciso de la realidad universitaria y de las aspiraciones de su gente. Comenzar a pensar estratégicamente se vuelve indispensable para canalizar la vitalidad participativa de la comunidad universitaria en un proyecto común que refleje las inquietudes de todos a partir de propuestas sensatas y arraigadas en aspiraciones colectivas, pero también en posibilidades reales de alcanzarlas.

- Características e Objetivos do Curso de Comunicação ou Especialidade da Instituição

La Facultad de Periodismo y Comunicación Social brinda, a través de su plan de estudios (reformado en 1998), la posibilidad de elegir entre tres opciones:

Profesorado en Comunicación Social.

Licenciatura en Comunicación Social con orientación en Planificación Comunicacional.

Licenciatura en Comunicación Social con orientación en Periodismo.

El diseño curricular comprende, además, una etapa previa a los estudios de Grado: el Curso Introductorio, que es de carácter obligatorio, aunque no eliminatorio.

La carrera consta de dos etapas:

El Ciclo Común que se completa con 20 asignaturas aprobadas y

El Ciclo Superior que, en el caso de la Licenciatura se completa con las 12 materias restantes y la tesis. Para el Profesorado, esta etapa comprende 10 materias y una Práctica de la Enseñanza.

$\underline{\text { Tesis }}$

De esta manera, el Plan de estudios divide al proceso pedagógico en tres áreas, en donde quedan enmarcadas las materias de toda la carrera, con el objeto de evitar la fragmentación del conocimiento mediante criterios de articulación:

Área Comunicacional: Propone como eje las relaciones entre la Sociedad y los Medios.

Área Contextual: Propone como eje la contextualización de las relaciones comunicacionales.

Área de Producción: Propone como eje a la producción como momento fundamental del proceso de Enseñanza - Aprendizaje.

- Grade Curricular

\author{
Ciclo Común
}

MATERIAS DE CURSADA ANUAL OBLIGATORIA:

Taller de Producción Gráfica I

Taller de Producción Radiofónica I

Taller de Producción Audiovisual I

Taller de Comprensión y Producción de Textos I

Taller de Comprensión y Producción de Textos II

Taller de Análisis de la Información

MATERIAS OBLIGATORIAS DE CURSADA CUATRIMESTRAL:

Comunicación y Medios

SAKATA, Marici Cristine Gramacho, Globalização e Educação: A formação do comunicador social na América Latina, 2008312 p. (Doutorado - Orientação BACCEGA, M. A.) Escola de Comunicações e Artes da Universidade de São Paulo, São Paulo, SP, 2008 
Comunicación y Teorías

Comunicación y Cultura

Lingüistica y Métodos de Análisis Lingüisticos

Metodología de la Investigación Social

Opinión Pública

MATERIAS OPTATIVAS DE CURSADA CUATRIMESTRAL:

CURSADA OBLIGATORIA:

Antropología Social y Cultural

Semiótica

Psicología Social

CURSADA LIBRE:

Historia Argentina Contemporánea

Historia Contemporánea de América Latina

Problemas Filosóficos

Economía Política y Problemática Económica Argentina

Derecho de la Comunicación

Historia del siglo XX

Capacitación en Idioma Extranjero

Problemas Sociológicos Contemporáneos

El Ciclo Común se completa con 20 (veinte) asignaturas aprobadas de las cuales 7 (siete) se seleccionarán del listado de 10 (diez) opciones (de cursada obligatoria o libre).

Para poder cursar las Orientaciones de la Licenciatura y/o Profesorado, se deberán haber aprobado 11 (once) asignaturas por lo menos, de las cuales 6 (seis) deben ser de aquellas que tienen carácter obligatorio.

Idioma extranjero: se podrá optar por uno de los cinco idiomas que ofrece el Plan de Estudios. Ellos son: Inglés, Francés, Alemán, Italiano y Portugués.

Orientación Periodismo

MATERIAS DE CURSADA ANUAL:

Taller de Producción Gráfica II

Taller de Producción Radiofónica II

Taller de Producción Audiovisual II

Taller de Periodismo de Investigación

Taller de Producción Nivel III (se puede optar por Gráfica, Radiofónica o Audiovisual)

MATERIAS CUATRIMESTRALES:

OBLIGATORIAS:

Historia de las Ideas y los Procesos Políticos

OPTATIVAS DE CURSADA OBLIGATORIA:

Seminario Interdisciplinario I

Seminario Interdisciplinario II

Comunicación y Educación

Taller de Escritura Creativa

OPTATIVAS DE CURSADA LIBRE:

Historia del Periodismo y las Comunicaciones en Argentina

Relaciones Internacionales y Comunicación

Análisis y Crítica de Medios

Taller de Tecnologías en Comunicación

Seminario Permanente de Tesis

\section{TESIS}

Para obtener el título de Licenciado en Comunicación Social con Orientación en Periodismo, se deberán aprobar los niveles II de los Talleres de Producción, uno de los niveles III de dichos Talleres, las asignaturas Taller de Periodismo de Investigación e Historia de las Ideas y los

SAKATA, Marici Cristine Gramacho, Globalização e Educação: A formação do comunicador social na América Latina, 2008312 p. (Doutorado - Orientação BACCEGA, M. A.) Escola de Comunicações e Artes da Universidade de São Paulo, São Paulo, SP, 2008 
Procesos Politicos, 6 (seis) asignaturas optativas y la Tesis de grado.

Entre las seis optativas que se deben aprobar, se pueden elegir hasta 2 (dos) Seminarios

Interdisciplinarios y hasta 2 (dos) Equivalencias Universitarias.

La Tesis tendrá dos posibles lógicas de construcción: una orientada al desarrollo y la producción, y la otra orientada a la investigación.

Equivalencias Universitarias: Los regímenes de cursada serán determinados por la Facultad de Origen.

\section{Universidades Globalizadas}

\subsection{Universidad de Belgrano - Licenciatura em Periodismo ${ }^{282}$}

\section{- Características e Missão da Instituição}

La Universidad de Belgrano fue creada por el Doctor Avelino Porto el 11 de septiembre de 1964 en conformidad con la ley $N^{\circ} 14.557$ sancionada en el año 1958 que reglamentó el funcionamiento de las universidades privadas en la República Argentina. Esa ley establecía: Que las universidades privadas debían constituirse como entidades sin fines de lucro, y Que antes de alcanzar la autorización definitiva para funcionar, debia transcurrir un ciclo de estudios completo para las carreras cursadas en el establecimiento además de acreditar una calidad académica satisfactoria. Actualmente las universidades privadas se rigen por la Ley 24.521 dictada el 20 de julio de 1995 que mantiene las obligaciones mencionadas y además expresamente estableció:La autonomía académica e institucional. Instancias de autoevaluación y evaluación externa, estas últimas a realizarse por la Comisión Nacional de Evaluación y Acreditación Universitaria o por agencias privadas de evaluación y acreditación reconocidas por el Ministerio de Cultura y Educación (CoNEAU) Su primera sede se encontraba en Sucre y Cramer en lo que en ese momento se conocía como el "Pueblo de Belgrano". Inició sus actividades con 90 estudiantes, 28 profesores y un empleado.Las consultas efectuadas por el Ministerio de Cultura y Educación a las Academias Nacionales de las respectivas disciplinas que funcionaban en la Universidad y a los expertos más destacados en cada una de ellas, determinaron que el día 26 de Enero de 1970 el Presidente de la Nación concendiera a la Universidad de Belgrano la autorización definitiva para funcionar.

Principios institucionales

Cinco principios rigen la vida universitaria de la institución desde sus inicios:

Autonomía: total independencia de grupos políticos, empresariales, religiosos o culturales. Los planes de estudio (si bien están sujetos a la aprobación del Ministerio de Cultura y Educación) son el fruto de la reflexión, de la experiencia nacional e internacional y de la interacción en la sociedad.

Pluralismo: académico, político y religioso. La Universidad sólo exige consideración para con las normas de convivencia académica, respeto a sus principios y rigor intelectual en el tratamiento de todos los temas.

Ecumenismo: la comunidad universitaria alberga a todas las convicciones religiosas y rechaza de plano toda discriminación.

Republicanismo: la Universidad apoya el sistema de vida que se asienta pura y exclusivamente en la Constitución Nacional y en las ideas que la fundamentan.

Interdependencia social: apunta a generar lazos que integren a la institución con el sector productivo en particular y con la sociedad en general.

${ }^{282}$ Universidad de Belgrano, Disponível em www.ub.edu.ar/ acesso em 10/06/2006

SAKATA, Marici Cristine Gramacho, Globalização e Educação: A formação do comunicador social na América Latina, 2008312 p. (Doutorado - Orientação BACCEGA, M. A.) Escola de Comunicações e Artes da Universidade de São Paulo, São Paulo, SP, 2008 
- Características e Objetivos do Curso de Comunicação ou Especialidade da Instituição

\section{Licenciatura en Periodismo}

Asegura excelencia y una sólida preparación teórico-práctica profesional a través de asignaturas obligatorias especificas y de formación general, éstas últimas con disciplinas optativas complementarias que permitirán a los egresados un desempeño óptimo.

Otorga conocimientos completos de gramática y de análisis del discurso, argumentación, polémica, retórica, y de los distintos tipos de mensajes que se usan en periodismo. Además, las bases conceptuales y técnicas para una redacción adecuada a los diferentes estilos de expresión periodística.

Forma en teoría de los medios de comunicación y de la sociedad, y en el conocimiento del contenido de los medios.

Otorga conocimientos sobre la organización y estructura de la empresa periodística radial, gráfica y televisiva. También acerca de las distintas tareas y funciones que puede cumplir un periodista en cada una de ellas.

Otorga el necesario buen desarrollo del sistema fonatorio, y del lenguaje gestual y verbal para crear el hábito de hablar con soltura y precisión, expresando ideas bien conformadas y ajustadas a un pensamiento, lo cual capacita plenamente para el ejercicio del periodismo radial y televisivo y para la docencia.

Da conocimientos de metodología y técnica de la investigación periodística, a través de distintos procedimientos específicos, históricos y sociológicos. Otorga conocimientos de las grandes líneas del desarrollo de la Historia Argentina contemporánea, en sus aspectos económicos, sociales, políticos y culturales, entre otros.

Forma para el adecuado análisis de la política internacional contemporánea, de los fenómenos previos inmediatos y posteriores de la Guerra Fría, así como del funcionamiento de los más importantes tratados y organismos internacionales.

Otorga conocimientos de derecho general, público y privado, así como de los aspectos legales más importantes vinculados a la actividad periodistica, a través del análisis de los casos jurisprudenciales más importantes.

Entrena para usar las diferentes técnicas de entrevistas y reportajes, adecuándolas a las circunstancias del medio para el cual se efectúen, y a las personas y distintas situaciones en que ellas se produzcan.

Brinda conocimientos sobre los valores éticos, y los problemas morales de la actualidad vinculados al ejercicio de la profesión (valor de la vida, aborto, corrupción, derechos humanos, adicciones, respeto por la privacidad y protección de las fuentes).

Capacita para la producción y edición en medios gráficos, radiales y televisivos, pasando por el diseño gráfico, la ubicación de la publicidad, las distintas tipografias, técnicas de reproducción, sonido, filmación e imagen.

Características destacables de la carrera

- Formación teórico-práctica que busca lograr que sus egresados sean verdaderos actores sociales, emprendedores, democráticos y solidarios, es decir, auténticos agentes de transformación.

- Preparación para incrementar la capacidad de expresión oral y escrita.

- Pasantías para los estudiantes de los últimos años de la carrera en medios gráficos, televisivos o radiales, y también en sectores de prensa en empresas privadas $u$ organismos estatales.

- Presencia de destacados profesionales del periodismo en las cátedras y en mesas redondas, seminarios y conferencias.

- Posibilidad de intercambio internacional con prestigiosas universidades del exterior.

SAKATA, Marici Cristine Gramacho, Globalização e Educação: A formação do comunicador social na América Latina, 2008312 p. (Doutorado - Orientação BACCEGA, M. A.) Escola de Comunicações e Artes da Universidade de São Paulo, São Paulo, SP, 2008 
- Estructura curricular debidamente balanceada entre la teoría y la práctica, acorde a las nuevas realidades y necesidades de la profesión, con la posibilidad además, durante el último año de la Carrera, de cumplir con una legítima vocación de especialización.

- Presentación de una tesina o trabajo de investigación como requisito de graduación.

\section{RESPUESTAS a PREGUNTAS sobre la carrera de Licenciatura en Periodismo}

1. ¿Por qué en esta carrera en la UB hay tantos trabajos prácticos?

Porque el periodismo, si bien tiene ineludibles fundamentos teóricos, es una actividad eminentemente práctica. Por eso en la UB, sin descuidar la formación teórica, se realiza una intensa actividad práctica.

2. ¿Por qué la en carrera de Periodismo de la UB suelen concurrir periodistas a las clases? Porque en los planes de estudio se contempla la necesidad de generar en las aulas un clima de debate inteligente.

3. ¿Por qué en la UB suelen publicarse libros escritos entre profesores y alumnos? Porque los planes de estudio de la carrera están concebidos para transmitir una formación práctica con un fuerte sustento teórico. Por eso la publicación de notas y libros, dos de ellos usados como bibliografía básica no sólo en la UB, sino también en universidades del país y Latinoamérica es el resultado de la formación que brinda la UB.

4. ¿Por qué, en la UB, parte de los cursos de la carrera se dictan en los estudios de radio y TV que tiene la Facultad?

Porque la UB considera que un alumno de Periodismo debe aprender viviendo situaciones periodísticas reales.

5. ¿Por qué los alumnos de Periodismo de la UB trabajan en la revista digital de la Carrera y colaboran con la BBC de Londres?

Porque entre la UB y esas instituciones existe un convenio de trabajo conjunto en marcha.

6. ¿Por qué los planes de estudio de la UB incluyen la enseñanza de filosofía, literatura, historia y economía?

Porque son disciplinas imprescindibles al paradigma de la sociedad de la información y la UB forma profesionales de la información debidamente informados.

7. ¿Por qué en la UB la carrera tiene un sistema tan exigente?

Porque el periodismo es exigente, y la UB busca formar periodistas aptos para desempeñarse en cualquier área profesional.

8. ¿Por qué en la UB existe proximidad entre alumnos y docentes?

Porque los cursos tienen un número limitado de alumnos y eso posibilita trabajos individuales y en equipo con supervisión permanente de los profesores. Esta circunstancia exige un diálogo enriquecedor y un acercamiento profesional.

9. ¿Por qué en el plan de estudios de Periodismo la UB incluye la tecnología digital e Internet?

Porque la tecnología digital es parte insoslayable en una carrera de Comunicaciones. La moderna tecnología posibilita una información rápida y actualizada para su posterior procesamiento. El acceso a Internet permite navegar en el mundo de la información para ver contenidos, imágenes, animaciones y recorridos virtuales, por lo que es un poderoso y necesario sustento de nuestro oficio.

10. ¿Por qué un egresado de la UB está preparado para la actividad privada o estatal, en relación de dependencia o de manera independiente?

Porque los planes de estudio contemplan, por parte de los alumnos, la participación en empresas periodísticas, organismos estatales y no gubernamentales, lo que genera un antecedente de inserción laboral para nuestros futuros egresados. La carrera de Periodismo, en las diferentes áreas de su competencia, aproxima al alumno al mundo profesional con diversas 
prácticas en medios de comunicación, empresas y estudios profesionales. Los métodos de trabajo, la tutela de las prácticas y su evaluación otorgan a nuestros estudiantes una experiencia laboral previa a su graduación.

¿Por qué en la UB el título permite realizar estudios de posgrado?

Porque los estudios de Periodismo en la UB son de cuatro años de duración, y habilitan, como carrera de grado mayor, a la realización de estudios de postgrado en el país y en el exterior.

- Grade Curricular

Lic. Periodismo - Título final: Lic. Periodismo

El plan de estudio se complementa con un conjunto de materias OFG (Optativas de Formación General) y OFE (Optativas de Formación Específica) que varían según el año de cursación.

\begin{tabular}{|c|c|c|}
\hline Código & 1er. Año Materia & Horas semanales \\
\hline 1 & LENGUA I & 5 \\
\hline 2 & LENGUA II & 5 \\
\hline 3 & FUND. DEL LENGUAJE PERIOD. I & 4 \\
\hline 4 & FUND. DEL LENGUAJE PERIOD. II & 4 \\
\hline 5 & COMUNICACIÓN DE MASAS & 4 \\
\hline 6 & HISTORIA DE LOS MED.DE COMUN. & 5 \\
\hline 7 & EXPRESIÓN ORAL I & 5 \\
\hline 8 & EXPRESIÓN ESCRITA I & 5 \\
\hline 9 & PRÁCTICA PROFESIONAL I & 6 \\
\hline Código & Matérias Optativas Gerais & Horas semanales \\
\hline 201 & DERECHOS HUMANOS & 2 \\
\hline 204 & TEORÍA DE LA COMUN. HUMANA & 2 \\
\hline 205 & ARTE ARGENT.CONTEMPORANEO & 2 \\
\hline 206 & HIST.DE LA CIENCIA Y TÉCNICA & 2 \\
\hline Código & 2do. Año Materia & Horas semanales \\
\hline 10 & LENGUA III & 4 \\
\hline 11 & LENGUA IV & 4 \\
\hline 12 & HISTORIA ARG. CONTEMP. I & 5 \\
\hline 13 & HISTORIA ARG. CONTEMP. II & 5 \\
\hline 14 & METOD.Y TÉC.INVEST.PERIOD. I & 5 \\
\hline 15 & METOD.Y TÉC.INVEST.PERIOD. II & 5 \\
\hline 16 & EXPRESIÓN ORAL II & 5 \\
\hline 17 & EXPRESIÓN ESCRITA II & 5 \\
\hline 18 & PRÁCTICA PROFESIONAL II & 6 \\
\hline Código & Matérias Optativas Gerais & Horas semanales \\
\hline 212 & PSICOLOGÍA SOCIAL & 2 \\
\hline 218 & ECOLOGÍA Y MEDIO AMBIENTE & 2 \\
\hline 213 & FILOSOFÍA & 2 \\
\hline 222 & PSICOLOGÍA POLÍTICA & 2 \\
\hline Código & 3er. Año Materia & Horas semanales \\
\hline 19 & ASPEC.LEG.ACTIV. PERIODIS. I & 5 \\
\hline
\end{tabular}

SAKATA, Marici Cristine Gramacho, Globalização e Educação: A formação do comunicador social na América Latina, 2008312 p. (Doutorado - Orientação BACCEGA, M. A.) Escola de Comunicações e Artes da Universidade de São Paulo, São Paulo, SP, 2008 
1.4 Universidad del Salvador - Facultad de Ciencias de la Educación y de la Comunicación Social $^{283}$

- Características e Missão da Instituição

La Universidad del Salvador, ubicada en la ciudad Argentina de Buenos Aires, fue fundada por la Compañia de Jesús, que fundara en la ciudad de Córdoba en el año 1622 la primera Universidad argentina. Crea el 8 de junio de 1944 el Instituto Superior de Filosofía, en la sede del Colegio del Salvador. Este Instituto constituye el más próximo antecedente de la Universidad del Salvador.

${ }^{283}$ Universidad Del Salvador, Disponível em www.salvador.edu.ar/fcecs/ acesso em 10/06/2006 
En el año 1955, por Decreto $N^{\circ}$ 6403, el Poder Ejecutivo Nacional autoriza el funcionamiento de las universidades privadas y al año siguiente, el 2 de mayo, se firma el Acta de fundación de las Facultades Universitarias del Salvador.

El 15 de mayo de 1958 se cambia su nombre por el de Institutos Universitarios del Salvador, los cuales son reconocidos con fecha 8 de diciembre de 1959, por Decreto $N^{o} 16.365$ como universidad privada con el nombre de "Universidad del Salvador".

Desde su fundación, la Universidad dependió de la Compañia de Jesús, quien designó a sus más altas autoridades por intermedio de la Asociación Civil Universidad del Salvador. En marzo de 1975 la Compañía confió la conducción a un grupo de laicos, quienes asumieron la responsabilidad de preservar la identidad de la "Universidad del Salvador" en el cumplimiento de sus fines y objetivos.

Cuando la Universidad, a través del Consejo de Laicos manifiesta la intensa necesidad de preservar su identidad, el R. P. Provincial le presenta el Documento "Historia y cambio", donde quedan delineados los puntos en los que la Nueva Universidad del Salvador deberá apoyarse para ser fiel a sí misma, para rescatar su "continuidad en el espiritu jesuitico: lucha contra el ateísmo, avance mediante el retorno a las fuentes, universalismo a través de las diferencias"..

Estos tres pivotes orientarán la espiritualidad y la misión de la Universidad del Salvador. Será una Universidad "fundada en la fe, es decir crítica e innovadora", una institución que, llevada por un sentido trascendente, religioso de la vida, ponga de manifiesto la crisis del ateísmo moderno-desde su perspectiva inmanente-, su imposibilidad de juzgar globalmente la aventura del hombre contemporáneo. Una Universidad cuya acción hacia adelante sea fiel a las fuentes marcadas por la institución organizante de San Ignacio de Loyola. Una Universidad que asuma la "seguridad de que la verdad encarnada sólo se muestre en el juego diverso de lo creado".

Objetivos de la Universidad del Salvador

La Universidad del Salvador, según su Estatuto Académico, tiene por finalidades esenciales y especificas:

- La formación integral -científica, humanística y cristiana- de sus estudiantes, en todas las carreras o especialidades, en orden a la promoción de profesionales, docentes e investigadores;

- La investigación cientifica capaz de demostrar la síntesis armónica de la ciencia y de la fe; Y en general toda docencia superior encaminada a la visión cristiana de los distintos problemas humanos.

Formación Integral

La tarea de "formación integral" que la Universidad se propone, supone necesariamente: La formación como persona

La Universidad del Salvador definida a si misma como "Comunidad de Iglesia enraizada en la Nación Argentina" cree que no puede haber formación integral que explicita o implícitamente no conduzca a la cosmovisión cristiana. La lucha por la formación personal es una lucha contra las concepciones materialistas y degradantes del ser humano. La Universidad del Salvador es una Universidad confesional y por lo mismo debe ser fiel al mensaje evangélico, y al espíritu de la Compañia de Jesús que la creó y le entregó un estilo de fidelidad a la Iglesia y de apertura al diálogo.

La formación como argentino

La Universidad debe afirmar la conciencia nacional histórica, afirmar la propia identidad, para acceder, desde ella, a lo universal. La Universidad rechaza todo modelo cultural exógeno y materialista, que sea ajeno al sentir de nuestro pueblo, o con mentalidad tecnocrática como único patrón. Busca volver a las fuentes, destacar la continuidad de un proceso que, desde la doble vertiente hispánica e indígena y la incorporación luego de la inmigración europea y latinoamericana, abona nuestra identidad y existencia como Nación. Rescatar lo más propio es también ir a la historia viva del pueblo, a su creatividad inmanente, factor esencial de la cultura nacional. La formación como profesional Acompañada por los anteriores, la formación científica y/o técnico-profesional, tendrá un terreno fértil y un hombre concreto -argentinodonde asentarse. Así, el camino de la especialización debe ser iluminado por la claridad que

SAKATA, Marici Cristine Gramacho, Globalização e Educação: A formação do comunicador social na América Latina, 2008312 p. (Doutorado - Orientação BACCEGA, M. A.) Escola de Comunicações e Artes da Universidade de São Paulo, São Paulo, SP, 2008 
emana de la conciencia de la unidad del saber revirtiendo el proceso actual de dispersión del conocimiento. Se trata de recuperar la esencia de la "Universidad", abandonando el camino que conduce a la "multiversidad". La formación científica, la técnica y profesional debe conjugar la generalización con la especialización, es decir, debe conocer cuáles son los grandes problemas (a nivel individual, regional, nacional y mundial) y, en lo particular, debe ser capaz de desarrollar investigación, docencia y aplicación técnica de su disciplina, con un alto nivel de conocimiento de la misma. Deben formarse cientificos capaces del desarrollo de su especialidad, con una perspectiva no unilateral. El especialista debe tener la creatividad suficiente como para adaptar el modelo creado, fuera de su realidad circundante, a la modalidad regional y nacional. Un aspecto de esto último, también función de la Universidad y sus graduados, es la adaptación de la tecnología a las propias necesidades y circunstancias. De ello adviene la responsabilidad de criticar concepciones vigentes en las que la tecnología es motor de la historia y no un instrumento integrado al desarrollo de la comunidad.

- Características e Objetivos do Curso de Comunicação ou Especialidade da Instituição

\section{Periodismo \\ LICENCIADO EN PERIODISMO}

Objetivo: Para egresados de institutos terciarios en Comunicación Social, Periodismo, Locución o similares. La Licenciatura en Periodismo tiene por finalidad la formación teórica, técnica y práctica de los estudiantes, para el ejercicio profesional del periodismo y las telecomunicaciones. En los últimos años han surgido nuevos requerimientos académicos y profesionales para la preparación ética y deontológica de los futuros periodistas, sobre todo frente al avance de las técnicas y el gran desarrollo de las empresas de comunicación social. El presente diseño curricular concilia en forma eficiente y sinérgica una sólida base teórica con una moderna aproximación práctica al fenómeno de la comunicación social y el periodismo, en un contexto mundial de globalización y acelerado cambio tecnológico. El objeto de los profesionales formados en la Licenciatura en Periodismo es la información sobre la realidad en sus diferentes formas y niveles. Se entiende el Periodismo como el proceso inherente a la observación de los hechos de interés público, el tratamiento de la información sobre los mismos y su conveniente divulgación a través de medios gráficos, audiovisuales y digitalizados. De tal modo, la complejidad del fenómeno impone un conocimiento y capacidad de análisis epistemológico, ético, social, político y económico que ayuden a comprender mejor la problemática de la actividad y supervisar la calidad de las decisiones de los responsables de los sistemas de comunicación social públicos y privados

\section{- Grade Curricular}

Plan de Estudio

Plan de Estudios

Resolución Rectoral N* 162/03

C :

2 años de duración

Cuatrimestral

Primer Año

$\begin{array}{lll} & & \begin{array}{l}\text { C: } \\ \text { Cuatrimestral } \\ \text { A: Anual } \\ \text { Horas }\end{array} \\ \text { Semanales } & \text { Duración } & \begin{array}{l}\text { Horas } \\ \text { Totales }\end{array} \\ 4 & \text { A } & 144 \\ 4 & \text { A } & 144 \\ 4 & \text { C } & 72 \\ 4 & \text { A } & 144 \\ 4 & \text { A } & 144 \\ 4 & \text { C } & 72\end{array}$

Introducción a la Comunicación Social

Análisis de Opinión Pública

Psicología

Documentación e Investigación Periodística

Análisis y Evaluación Periodística

Análisis Internacional de Noticias

SAKATA, Marici Cristine Gramacho, Globalização e Educação: A formação do comunicador social na América Latina, 2008312 p. (Doutorado - Orientação BACCEGA, M. A.) Escola de Comunicações e Artes da Universidade de São Paulo, São Paulo, SP, 2008 
Filosofía

Segundo Año

Medios de Comunicación Social

Estadística Social y Técnicas de Computación

Economía Política

Historia Argentina

Ética Profesional

Dagramación y Programación Periodística

Tecnología Cinematográfica

Periodismo e Internet

Teología

Presentación de Tesina: 200

Carga horaria: 1928

$\begin{array}{ll}\text { A } & 144 \\ \text { C } & 72 \\ \text { C } & 72 \\ \text { C } & 72 \\ \text { C } & 72 \\ \text { A } & 144 \\ \text { C } & 72 \\ \text { C } & 72 \\ \text { A } & 144\end{array}$

\section{BRASIL}

\begin{tabular}{|l|l|l|l|l|}
\hline $\begin{array}{l}\text { 2. } \\
\text { Brasil }\end{array}$ & $\begin{array}{l}2.1 \text { Universidade } \\
\text { de São Paulo }\end{array}$ & $\begin{array}{l}2.2 \text { Universidade } \\
\text { Federal de Minas } \\
\text { Gerais }\end{array}$ & $\begin{array}{l}2.3 \text { Anhembi } \\
\text { Morumbi } \\
\text { (Laureate) }\end{array}$ & $\begin{array}{l}2.4 \text { Faculdade } \\
\text { Pitágoras } \\
\text { (Grupo Apollo) }\end{array}$ \\
\hline
\end{tabular}

\section{Universidades Nacionais}

\section{1 $\underline{\text { Universidade de São Paulo - Escola de Comunicações e Artes }} \underline{284}$}

\section{- Características e Missão da Instituição}

A Universidade de São Paulo foi criada em 1934, por decisão do governador de São Paulo, Armando de Salles Oliveira. Teve como mentor intelectual Júlio Mesquita Filho, então diretor do Jornal O Estado de S. Paulo, que publicava ostensivamente artigos e estudos favoráveis à criação de uma universidade em São Paulo e sobre os problemas do ensino superior e universitário no Brasil.

Missão: A USP foi criada com a finalidade de promover a pesquisa e o progresso da ciência; transmitir pelo ensino conhecimentos que enriqueçam ou desenvolvam o espirito e que sejam úteis à vida; e formar especialistas em todos os ramos da cultura e em todas as profissões de base científica ou artística. A tônica da instituição é "Vencerás pela ciência". Está em seus objetivos desenvolver um ensino vivo, acompanhando as transformações na área do conhecimento e mantendo-se em permanente diálogo com a sociedade, numa produtiva integração entre o ensino, a pesquisa e a extensão.

USP oferece cursos de bacharelado e de licenciatura em todas as áreas do conhecimento. Na pós-graduação, dez dos vinte e três programas nacionais receberam nota máxima atribuída pela Coordenação de Cooperação de Pessoal de Nivel Superior (Capes), do Ministério de Educação.

USP de 1999 mostraram que nas unidades de ensino e de pesquisa foram oferecidos em conjunto cerca de 617 cursos, sendo 130 de graduação, freqüentados por cerca de 40.000 estudantes, e 487 de pós-graduação, dos quais 257 de mestrado e 230 de doutorado. A USP

\footnotetext{
${ }^{284}$ Universidade de Sao Paulo, Escola de Comunicações e Artes, Disponível em www.eca.usp.br acesso em 03/12/2006
} 
forma anualmente na graduação uma média de 4.600 estudantes. Em recursos humanos, a comunidade uspiana é constituída por 4.705 professores e 14.659 funcionários.

Com a finalidade de manter uma boa comunicação com o público interno e externo, a USP integra na Coordenadoria de Comunicação Social da USP (CCS) todas as midias oficiais - a Rádio USP, a TV USP, a Agência USP, a Revista USP, o Jornal da USP, o Portal Web da USP e a Revista Espaço Aberto. (www.usp.br em 02/12/2006)

- Características e Objetivos do Curso de Comunicação ou Especialidade da Instituição

A Escola de Comunicações e Artes da Universidade de São Paulo iniciou suas atividades em março de 1967. Com o nome inicial de Escola de Comunicações Culturais passou a marcar o seu pioneirismo, seja na inovadora estrutura curricular, seja na qualificação especializada do profissional da Comunicação, para o então emergente mercado de trabalho nas indústrias culturais do país. Desde o início, seu corpo docente passou a abrigar especialistas das diversas áreas do saber, que se voltavam, então, para o ensino e a pesquisa nessa nova área do conhecimento a ser consolidada. Esses primeiros professores, para poderem ministrar disciplinas e posteriormente orientar pesquisas, defenderam suas teses em regime de doutorado direto, dentro do modelo europeu que prevalecia naquele momento, nas universidades brasileiras.

\section{Biblioteconomia}

Comunicação Social - Habilitação em Editoração

Comunicação Social - Habilitação em Jornalismo

Comunicação Social - Habilitação em Publicidade e Propaganda

Comunicação Social - Habilitação em Relações Públicas

Curso Superior de Audiovisual diurno

Hoje, pela diversidade de áreas oferecidas, a ECA se caracteriza como uma Escola que vive a contemporaneidade, sempre atenta às inovações e à qualidade do ensino superior. A Escola de Comunicações e Artes da Universidade de São Paulo iniciou suas atividades em 1966 com o nome inicial de Escola de Comunicações Culturais. Nessas quatro décadas de existência, passou por amplas modificações, refletindo as mudanças ocorridas na sociedade.

Seus cursos estão entre os mais procurados da USP. A relação candidato/vaga para o vestibular é a mais alta, especialmente nas áreas de Publicidade e Propaganda, Turismo e Jornalismo. São 22 habilitações profissionais em cursos regulares de graduação, das quais 15 são voltadas à área de Artes: Cenografia; Direção Teatral; Interpretação Teatral; Teoria do Teatro; Escultura; Gravura; Multimídia e Intermídia; Pintura; Composição; Regência; Instrumento; Canto e Arte Lírica; Licenciatura em Educação Artística com Habilitação em Música; Licenciatura em Educação Artística com Habilitação em Artes Cênicas; e Licenciatura em Educação Artística com Habilitação em Artes Plásticas. Há quatro habilitações na área de Comunicação Social: Jornalismo, Editoração, Publicidade e Propaganda e Relações Públicas, além dos cursos de Biblioteconomia, Turismo e Superior do Audiovisual. Contribuindo para uma melhor formação de seus alunos, existem empresas juniores, administradas por estudantes, que prestam assessoria com qualidade profissional em diversas áreas de mercado. Desde o seu início, a ECA se destaca pelo nivel da atividade acadêmica e pela projeção conquistada por exalunos em suas áreas de atuação.

A qualidade de seus cursos, complementada por uma estrutura adequada de laboratórios, estúdios, ateliês e uma biblioteca com rico acervo, coloca-a numa posição de vanguarda em sua área. O investimento pedagógico e cultural da ECA faz dela não apenas uma instituição de alto nível, mas também a pioneira em formação de docentes, pela sua pós-graduação, que atuam em outras instituições do Brasil e do exterior.

\section{- Grade Curricular}

SAKATA, Marici Cristine Gramacho, Globalização e Educação: A formação do comunicador social na América Latina, 2008312 p. (Doutorado - Orientação BACCEGA, M. A.) Escola de Comunicações e Artes da Universidade de São Paulo, São Paulo, SP, 2008 
$1^{\circ}$ Período Ideal

CJE0502 Legislação e Deontologia do Jornalismo

CJE0508 Teoria da Comunicação I

CJE0510 Fundamentos Teoricos da Historia

CJE0518 Pensamento Filosofico

CJE0522 Tecnicas Graficas Em Jornalismo

CJE0585 Ciências da Linguagem - Fundamentos das Práticas Midiáticas I

CJE0587 Laboratório de Iniciação ao Jornalismo

Subtotal:

$2^{\circ}$ Período Ideal

CJE0506 Fundamentos de Economia

CJE0517 Historia das Doutrinas Politicas

CJE0586 Ciências da Linguagem - Fundamentos das Práticas Midiáticas II

CJE0600 Jornalismo no Rádio e na Tv

CJE0615 Ética

CJE0629 Teoria da Comunicação II

CJE0508 - Teoria da Comunicação I

Subtotal:

$3^{\circ}$ Período Ideal

CJE0432 Gerenciamento de Empresas Jornalísticas

CJE0469 Historia do Jornalismo I (geral)

CJE0563 Conceitos e Gêneros do Jornalismo

CJE0589 Elementos de Fotojornalismo

CJE0590 Laboratório de Jornalismo Impresso I

CJE0587 - Laboratório de Iniciação ao Jornalismo

CJE0623 Ciências da Linguagem - Fundamentos das Práticas Midiáticas III

Subtotal:

$4^{\circ}$ Período Ideal

CJE0442 Historia do Jornalismo II (brasil)

CJE0497 Ciências da Linguagem - Fundamentos das Práticas Midiáticas IV

CJE0602 Laboratorio de Jornalismo Impresso II

CJE0590 - Laboratório de Jornalismo Impresso I

Subtotal:

$5^{\circ}$ Período Ideal

CJE0524 Laboratorio de Jornalismo Impresso III

CJE0602 - Laboratorio de Jornalismo Impresso II

CJE0526 Telejornalismo

CJE0600 - Jornalismo no Rádio e na Tv

CJE0597 Especialização em Jornalismo: Livro- Reportagem

CJE0603 Radiojornalismo
Créd. Créd. Carga

Aula Trab. Horária

$2 \quad 0 \quad 30$

$2 \quad 0 \quad 30$

$2 \quad 0 \quad 30$

$2 \quad 0 \quad 30$

32105

$30 \quad 45$

$4 \quad 4 \quad 180$

$18 \quad 6 \quad 450$

Créd. Créd. Carga

Aula Trab. Horária

$2 \quad 0 \quad 30$

2030

$3 \quad 0 \quad 45$

$\begin{array}{lll}4 & 2 & 120\end{array}$

$3 \quad 0 \quad 45$

2030

162300

Créd. Créd. Carga

Aula Trab. Horária

$\begin{array}{lll}2 & 0 & 30\end{array}$

$2 \quad 2 \quad 90$

24150

34165

$6 \quad 5 \quad 240$

Requisito

$\begin{array}{lll}3 & 0 & 45\end{array}$

$\begin{array}{lll}18 & 15 & 720\end{array}$

Créd. Créd. Carga

Aula Trab. Horária

2290

$\begin{array}{lll}3 & 0 & 45\end{array}$

$12 \quad 5 \quad 330$

$17 \quad 7 \quad 465$

Créd. Créd. Carga

Aula Trab. Horária

$5 \quad 5 \quad 225$

$4 \quad 2 \quad 120$

Requisito

Requisito

$\begin{array}{lll}2 & 2 & 90\end{array}$

43150

SAKATA, Marici Cristine Gramacho, Globalização e Educação: A formação do comunicador social na América Latina, 2008312 p. (Doutorado - Orientação BACCEGA, M. A.) Escola de Comunicações e Artes da Universidade de São Paulo, São Paulo, SP, 2008 
CJE0600 - Jornalismo no Rádio e na Tv Subtotal:

$6^{\circ}$ Período Ideal

CJE0532 Projetos em Rádio

CJE0603 - Radiojornalismo

CJE0533 Projetos em Televisão

CJE0526 - Telejornalismo

CJE0599 Jornalismo Online - Paradigmas e Conteúdos Subtotal:

\section{$7^{\circ}$ Período Ideal}

CJE0601 Laboratorio de Jornalismo Impresso - Revista CJE0602 - Laboratorio de Jornalismo Impresso II CJE0604 Documentários em Vídeo

CJE0526 - Telejornalismo

CJE0533 - Projetos em Televisão

CJE0600 - Jornalismo no Rádio e na Tv

Subtotal:

\section{$8^{\circ}$ Período Ideal}

CJE0411 Projeto Experimental Em Jornalismo

CJE0432 - Gerenciamento de Empresas Jornalísticas

CJE0442 - Historia do Jornalismo II (brasil)

CJE0469 - Historia do Jornalismo I (geral)

CJE0497 - Lógica e Práticas Discursivas Jornalísticas

CJE0502 - Legislação e Deontologia do Jornalismo

CJE0506 - Fundamentos de Economia

CJE0508 - Teoria da Comunicação

CJE0510 - Fundamentos Teoricos da Historia

CJE0517 - Historia das Doutrinas Politicas

CJE0518 - Pensamento Filosofico

CJE0522 - Tecnicas Graficas Em Jornalismo

CJE0524 - Laboratorio de Jornalismo Impresso III

CJE0526 - Telejornalismo

CJE0532 - Projetos em Rádio

CJE0533 - Projetos em Televisão

CJE0559 - Sociologia da Era Virtual

CJE0563 - Conceitos e Gêneros do Jornalismo

CJE0585 - Ciências da Linguagem - Fundamentos das Práticas Midiáticas I

CJE0586 - Ciências da Linguagem - Fundamentos das Práticas Midiáticas II

CJE0587 - Laboratório de Iniciação ao Jornalismo

CJE0589 - Elementos de Fotojornalismo

CJE0590 - Laboratório de Jornalismo Impresso I

CJE0597 - Especialização em Jornalismo: Livro- Reportagem

CJE0599 - Jornalismo Online - Paradigmas e Conteúdos

CJE0600 - Jornalismo no Rádio e na Tv

CJE0601 - Laboratorio de Jornalismo Impresso - Revista

CJE0602 - Laboratorio de Jornalismo Impresso II

CJE0603 - Radiojornalismo

CJE0604 - Documentários em Vídeo $\begin{array}{lll} & & \text { Requisito } \\ 15 & 12 & 585\end{array}$

Créd. Créd. Carga

Aula Trab. Horária

$\begin{array}{lll}4 & 3 & 150 \\ & & \text { Requisito } \\ 8 & 2 & 180 \\ & & \text { Requisito } \\ 4 & 2 & 120 \\ 16 & 7 & 450\end{array}$

Créd. Créd. Carga

Aula Trab. Horária

83210

83210

$\begin{array}{lll}16 & 6 & 420\end{array}$

Requisito

Requisito

Requisito

Créd. Créd. Carga

Aula Trab. Horária

$5 \quad 20 \quad 675$

Requisito

Requisito

Requisito

Requisito

Requisito

Requisito

Requisito

Requisito

Requisito

Requisito

Requisito

Requisito

Requisito

Requisito

Requisito

Requisito

Requisito

Requisito

Requisito

Requisito

Requisito

Requisito

Requisito

Requisito

Requisito

Requisito

Requisito

Requisito

Requisito

SAKATA, Marici Cristine Gramacho, Globalização e Educação: A formação do comunicador social na América Latina, 2008312 p. (Doutorado - Orientação BACCEGA, M. A.) Escola de Comunicações e Artes da Universidade de São Paulo, São Paulo, SP, 2008 


\begin{tabular}{|c|c|}
\hline CJE0615 - Ética & Requisito \\
\hline \multicolumn{2}{|l|}{ ou } \\
\hline CJE0432 - Gerenciamento de Empresas Jornalísticas & Requisito \\
\hline CJE0442 - Historia do Jornalismo II (brasil) & Requisito \\
\hline CJE0469 - Historia do Jornalismo I (geral) & Requisito \\
\hline CJE0497 - Ciências da Linguagem - Fundamentos das Práticas Midiáticas IV & Requisito \\
\hline CJE0502 - Legislação e Deontologia do Jornalismo & Requisito \\
\hline CJE0506 - Fundamentos de Economia & Requisito \\
\hline CJE0508 - Teoria da Comunicação I & Requisito \\
\hline CJE0510 - Fundamentos Teoricos da Historia & Requisito \\
\hline CJE0517 - Historia das Doutrinas Politicas & Requisito \\
\hline CJE0518 - Pensamento Filosofico & Requisito \\
\hline CJE0522 - Tecnicas Graficas Em Jornalismo & Requisito \\
\hline CJE0524 - Laboratorio de Jornalismo Impresso III & Requisito \\
\hline CJE0526 - Telejornalismo & Requisito \\
\hline CJE0532 - Projetos em Rádio & Requisito \\
\hline CJE0533 - Projetos em Televisão & Requisito \\
\hline CJE0563 - Conceitos e Gêneros do Jornalismo & Requisito \\
\hline CJE0585 - Ciências da Linguagem - Fundamentos das Práticas Midiáticas I & Requisito \\
\hline CJE0586 - Ciências da Linguagem - Fundamentos das Práticas Midiáticas II & Requisito \\
\hline CJE0587 - Laboratório de Iniciação ao Jornalismo & Requisito \\
\hline CJE0589 - Elementos de Fotojornalismo & Requisito \\
\hline CJE0590 - Laboratório de Jornalismo Impresso I & Requisito \\
\hline CJE0597 - Especialização em Jornalismo: Livro- Reportagem & Requisito \\
\hline CJE0600 - Jornalismo no Rádio e na Tv & Requisito \\
\hline CJE0601 - Laboratorio de Jornalismo Impresso - Revista & Requisito \\
\hline CJE0602 - Laboratorio de Jornalismo Impresso II & Requisito \\
\hline CJE0603 - Radiojornalismo & Requisito \\
\hline CJE0604 - Documentários em Vídeo & Requisito \\
\hline CJE0615 - Ética & Requisito \\
\hline CJE0623 - Ciências da Linguagem - Fundamentos das Práticas Midiáticas III & Requisito \\
\hline CJE0629 - Teoria da Comunicação II & Requisito \\
\hline otal: & 675 \\
\hline
\end{tabular}

Disciplinas Optativas Livres

$1^{\circ}$ Período Ideal

CJE0627 Artes Visuais e Editoração

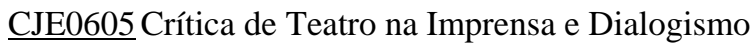

CJE0606 Design Editorial II

CJE0593 Edição Não Linear

CJE0614 Estudo de Caso - Imprensa Diária

CJE0618 Estudo de Caso - o Radiojornalismo

CJE0626 Introdução a Editoração

CJE0598 Introdução às Tecnologias de Informação On Line

CJE0584 Marketing em Empresas Informativas e Editoriais

CJE0247 Metodologia para Produção Editorial Impressa

CJE0622 Políticas Públicas em Comunicação e Leitura

Créd. Créd. Carga
Aula
$\begin{array}{lll}2 & 2 & \text { Trab. Horária } \\ 2 & 2 & 90 \\ 2 & 2 & 90 \\ 3 & 2 & 105 \\ 3 & 0 & 45 \\ 3 & 0 & 45 \\ 2 & 2 & 90 \\ 2 & 2 & 90 \\ 4 & 2 & 120 \\ 2 & 0 & 30 \\ 2 & 2 & 90\end{array}$

$2^{\circ}$ Período Ideal

CJE0395 Cultura e Literatura Brasileira I

Créd. Créd. Carga

Aula Trab. Horária

CJE0621 Design Editorial I

$\begin{array}{lll}4 & 2 & 120 \\ 2 & 2 & 90\end{array}$

SAKATA, Marici Cristine Gramacho, Globalização e Educação: A formação do comunicador social na América Latina, 2008312 p. (Doutorado - Orientação BACCEGA, M. A.) Escola de Comunicações e Artes da Universidade de São Paulo, São Paulo, SP, 2008 
CJE0595 Discursos Jornalísticos e Estigmas Sociais

$\begin{array}{lll}3 & 0 & 45 \\ 2 & 2 & 90 \\ 3 & 0 & 45 \\ 3 & 0 & 45 \\ 2 & 0 & 30 \\ 4 & 0 & 60 \\ 2 & 0 & 30 \\ 2 & 2 & 90 \\ 3 & 4 & 165 \\ & & \text { Requisito } \\ 3 & 2 & 105 \\ 2 & 0 & 30\end{array}$

CJE0382 Edição de Artes

CJE0613 Estudo de Caso - Imprensa Semanal

CJE0619 Estudo de Caso - o Telejornalismo

CJE0499 História da Ciência

CJE0580 História da Cultura e da Escrita

CJE0625 História da Editoração II

CJE0617 Introdução à Pesquisa Científica

CJE0616 Jornalismo das Grandes Reportagens

CJE0587 - Laboratório de Iniciação ao Jornalismo

CJE0541 Jornalismo, Saúde e Cidadania

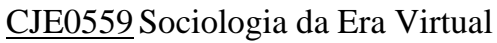

Créd. Créd. Carga

$3^{\circ}$ Período Ideal

CJE0396 Cultura e Literatura Brasileira II

CJE0249 História da Editoração I

Aula Trab. Horária

CJE0330 Legislação e Ética da Indústria Editorial

$\begin{array}{lll}4 & 2 & 120\end{array}$

$2 \quad 0 \quad 30$

$2 \quad 0 \quad 30$

CJE0556 Leitura e Producao de Textos

$2 \quad 2 \quad 90$

$4^{\circ}$ Período Ideal

CJE0620 Ciência e Informação Jornalística

CJE0384 Edicao de Livros Populares

CJE0539 Editoração em Historia-em-quadrinhos

CJE0582 História da Comunicação e da Opinião Pública

Créd. Créd. Carga

Aula Trab. Horária

CJE0381 Indústria Editorial e Planejamento em Comunicação

CJE0551 Jornalismo Cientifico

$2 \quad 0 \quad 30$

$4 \quad 0 \quad 60$

$3 \quad 3 \quad 135$

$4 \quad 0 \quad 60$

$2 \quad 0 \quad 30$

32105

CJE0523 Jornalismo Comparado

$2 \quad 0 \quad 30$

CJE0489 Jornalismo Economico

42120

$5^{\circ}$ Período Ideal

CJE0561 Edição de Texto em Revistas

CJE0575 Jornalismo e Saúde: A Experiência Brasileira

Créd. Créd. Carga

Aula Trab. Horária

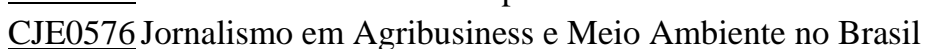

$\begin{array}{lll}2 & 2 & 90 \\ 3 & 0 & 45 \\ 3 & 0 & 45\end{array}$

$6^{\circ}$ Período Ideal

Créd. Créd. Carga

Aula Trab. Horária

CJE0610 Cultura e Literatura Brasileira III

44180

CJE0564 Edição de Imagem em Revistas

$2 \quad 2 \quad 90$

CJE0543 Gestão de Negócios Eletrônicos em Empresas Informativas $3 \quad \begin{array}{lll}3 & 0\end{array}$

CJE0432 - Gerenciamento de Empresas Jornalísticas

CJE0583 História e Estética da Fotografia

CJE0434 Jornalismo Sindical

CJE0596 Os Desafios do Jornalismo: Perspectivas e Futuro da Profissão

90

20030

$2 \quad 2 \quad 90$

$7^{\text {o }}$ Período Ideal

Créd. Créd. Carga

Aula Trab. Horária

CJE0482 Politica Internacional e Jornalismo

34165

Curso: Comunicação Social - Habilitação em Jornalismo - Carga Horária Total Aula + Trabalho 4590 horas

SAKATA, Marici Cristine Gramacho, Globalização e Educação: A formação do comunicador social na América Latina, 2008312 p. (Doutorado - Orientação BACCEGA, M. A.) Escola de Comunicações e Artes da Universidade de São Paulo, São Paulo, SP, 2008 


\subsection{Universidade Federal de Minas Gerais - Curso de Comunicação Social ${ }^{285}$}

\section{- Características e Missão da Instituição}

Visando ao cumprimento integral das finalidades estatutárias, a Universidade Federal de Minas Gerais assume como missão gerar e difundir conhecimentos cientificos, tecnológicos e culturais, destacando-se como instituição de referência nacional, formando indivíduos críticos e éticos, com uma sólida base científica e humanistica, comprometidos com intervenções transformadoras na sociedade e com o desenvolvimento sócio-econômico regional e nacional.

\section{Dos Princípios Institucionais}

A gestão responsável de uma IES pública como a UFMG deve, primeiramente, preservar os patamares de solidez e de qualidade atingidos ao longo de décadas de investimentos de toda ordem, dado o seu caráter estratégico no conjunto do patrimônio acadêmico, científico e cultural brasileiro. A UFMG atua no sentido de defender esse patrimônio de maneira lúcida e transparente, sem corporativismo, mas em nome do interesse público e do futuro do país. Para tanto, a Instituição busca orientar-se por estes princípios:

- Defesa de um sistema de educação superior sólido, diversificado, com padrões crescentes de qualidade, atendidos os requisitos de infra-estrutura e recursos humanos, capazes de manter tal sistema nas melhores condições de funcionamento possíveis;

- Estabelecimento de políticas de ensino, pesquisa e extensão que assegurem níveis crescentes de legitimidade institucional;

- Gratuidade de ensino, entendida como não-cobrança de anuidade ou mensalidade nos cursos regulares de Educação Básica e Profissional, de Graduação, de Mestrado e de Doutorado;

- Afirmação do caráter público e da identidade acadêmica da UFMG;

- Defesa permanente da autonomia universitária;

- Interação continuada com a sociedade;

- Consolidação crescente dos programas voltados para a inserção nacional e internacional

- Apoio ao desenvolvimento de políticas públicas voltadas para a busca de sociedades mais igualitárias e mais justas;

- Gestão racional, transparente e democrática do orçamento e do cotidiano da Universidade;

- Aperfeiçoamento de um modelo de gestão descentralizada, priorizando a estrutura colegiada e em permanente diálogo com todas as instâncias que compõem a comunidade universitária;

- Respeito à diversidade das forças que constituem a Universidade, fonte de sua maior riqueza, incluindo-se ai tanto os segmentos docente, discente $e$ de funcionários técnicos $e$ administrativos, quanto diferentes perfis de atuação individual e de campos disciplinares.

Inserção Regional, Nacional e Internacional

A UFMG é uma instituição pública de ensino superior historicamente comprometida tanto com o desenvolvimento do estado de Minas Gerais como do país. Para consolidar essa missão, ela procura disseminar suas formas de atuação em áreas geograficamente diversificadas, investindo permanentemente nas dimensões quantitativa e qualitativa dos projetos acadêmicos, científicos, tecnológicos e culturais em andamento ou em fase de planejamento. (...)

Partindo da compreensão de que a educação superior cumpre uma função estratégica no desenvolvimento econômico, social e cultural das nações, a UFMG constrói formas efetivas de cooperação institucionais bi/multilaterais nos contextos regional, nacional e internacional. Constitui uma das prioridades institucionais a integração entre os diversos niveis $e$ modalidades de ensino, pesquisa e extensão, buscando privilegiar os projetos e programas de impacto acadêmico e social com repercussões de caráter local, regional, nacional e internacional. A implementação dessa política advém da compreensão da comunidade

${ }^{285}$ Universidade Federal de Minas Gerais, Disponível em www.ufmg.br acesso em 04/12/2006

SAKATA, Marici Cristine Gramacho, Globalização e Educação: A formação do comunicador social na América Latina, 2008312 p. (Doutorado - Orientação BACCEGA, M. A.) Escola de Comunicações e Artes da Universidade de São Paulo, São Paulo, SP, 2008 
universitária de que a expansão do ensino superior público, gratuito e de qualidade constitui instrumento indispensável para atenuar e mesmo superar as situações de desigualdade social que se verificam, de um lado, intra-regional e inter-regionalmente, e, de outro, nos cenários internacionais.

Dentre os inúmeros projetos de alcance nacional, ressalte-se a efetiva atuação da UFMG na Universidade Virtual Pública do Brasil, a UNIREDE, consórcio que reúne mais de 70 instituições públicas de ensino superior, cujo objetivo é democratizar o acesso à educação de qualidade por meio da oferta de cursos a distância.

Ao lado da inserção regional e nacional, a UFMG tem tido uma presença marcante em importantes redes e consórcios internacionais interuniversitários. A cooperação acadêmica e científica multilateral tornou-se uma nova necessidade não somente no estabelecimento de parcerias de qualidade geradoras de conhecimento e na formação de grupos temáticos envolvendo vários países e continentes, mas também como força política na defesa da educação como bem público e na luta contra uma globalização predatória e geradora de crescentes desigualdades. Dentre os consórcios dos quais a UFMG tem participado ativamente, destacamse o Grupo Montevidéu, que tem como foco central o Mercosul e engloba instituições do Brasil, Argentina, Uruguai, Paraguai e Chile, o Grupo Tordesilhas, do qual participam instituições da Espanha, Portugal e Brasil, o Grupo Columbus, composto por universidades européias e latino-americanas, a Associação das Universidades de Língua Portuguesa (AULP), o Portal Universia, que estabelece interação via redes de website para acesso a informações e serviços destinados à comunidade universitária, o Conselho Universitário Iberoamericano (CUIB) e a Rede de Universidades Euro-latinoamericanas, cujo encontro bianual, ocorreu na UFMG, em julho de 2003, com a participação de mais de 150 Reitores e professores de universidades européias e latino-americanas. Muitas das atividades desses consórcios têm produzido excelentes resultados, criando condições para novas formas de cooperação, como no caso da Associação de Universidades do Grupo Montevidéu que impulsiona enormemente a parceria com os países da América do Sul, através de ações e pesquisas conjuntas, as quais se realizam no interior dos Núcleos Disciplinares e Comitês Acadêmicos; e dos intercâmbios concretizados no âmbito do Programa Escala de mobilidade docente e discente.

- Características e Objetivos do Curso de Comunicação ou Especialidade da Instituição:

Comunicação Social

Oferecido na modalidade de bacharelado, com habilitações em Publicidade e Propaganda, Relações Públicas, Jornalismo e Radialismo, o curso abrange o entendimento e o domínio da comunicação na sociedade, conforme as especificidades e os objetivos de cada habilitação.

Duração: quatro anos troca de experiências, construindo uma rede de ações e intervenções transformadoras em áreas temáticas distintas, definidas segundo prioridades sociais regionais e nacionais.

O curso de Comunicação Social da Fafich - UFMG foi criado em 1962, como Curso de Jornalismo. Em 1969 recebeu a denominação atual. A partir de 1985 passou a oferecer quatro habilitações: Publicidade e Propaganda, Relações Públicas, Jornalismo e Radialismo (Rádio e TV).

Seu currículo é flexivel, ou seja, o aluno tem a possibilidade de escolher grande parte das atividades acadêmicas que quer desenvolver e, assim, obter uma formação diferenciada.

São oferecidas 100 vagas por Vestibular divididas em duas entradas semestrais.

O currículo do curso de Comunicação Social da UFMG, implantado no ano 2000, é caracterizado pela flexibilização. O seu percurso pode envolver o trânsito por conteúdos e habilidades profissionais diferenciadas. Esse modelo amplia o leque de atividades oferecidas ao estudante e o quadro de oferta do professor e permite um melhor aproveitamento dos potenciais de ambos. O currículo é composto por disciplinas obrigatórias concentrados no

SAKATA, Marici Cristine Gramacho, Globalização e Educação: A formação do comunicador social na América Latina, 2008312 p. (Doutorado - Orientação BACCEGA, M. A.) Escola de Comunicações e Artes da Universidade de São Paulo, São Paulo, SP, 2008 
início e no final do curso; disciplinas optativas, atividades complementares, oficinas, laboratórios, formação complementar e eletiva e atividades de síntese e conclusão de curso.

- Grade Curricular

Tabela periódica de oferta de disciplinas:

Empreendimento e Gestão da com.

Mercadologia

Of. de Edição de Televisão

Of. de Técnicas de Estúdio de Televisão

Oficina de Técnicas de Pesquisa e Reportagem

Oficina de Redação em Jornalismo

OCV: Produção Gráfica

Teorias e Métodos Jornalísticos

Historia do Jornalismo do Brasil I

Linguagem Tec. Prod. Video e TV

Tec. Proc. Em RP

Tec. Proc. Ling. Com. Visual

Tec. Proc. Em PP 45/03

Com. e Cultura

Semiótica dos Meios Audiovisuais

Of. de Elementos da Ling. Musical

Of. de Criação e Prod. em Multimídia

OCV: Vendas e Promoções

Ling. Tec. Prod. Rádio

Oficina de Fotojornalismo

Evol. e Crítica da Fotografia

Análise e Critica de Filmes

Pesquisa de mercado

Of. de Fot. Publicitária

Oficina de Campanhas de Comunicação

Oficina de Diagramação Jornalística

Oficina de entrevista

Of. de Planejamento Gráfico em PP

Oficina de Telejornalismo

Of. de Vídeo Documentário

OCV: Mídia

OCV: Planejamento de Campanha

OCV. Radiojornalismo

Jornalismo Empresarial

Metodologia de Pesq. Científica em Comunicação

Narrativa Jornalística

Planej. da Com. Organizacional

Políticas de Comunicação

Produção da Notícia

Tec. de Com Dirigida

Teoria da Opinião Pública

TCS: Redação

Of. de Teledramaturgia

OCV: Direção de Arte

\section{LABORATÓRIOS}

Agência 90/06 5. ${ }^{\circ}$ Conhecimentos técnicos do processo de produção

da notícia

Organização de eventos $90 / 065 .^{\circ}$ Conhecimentos de planejamento e com. dirigida

Produção em Rádio 90/06 5. Conhecimentos de linguagem e técnica de rádio

SAKATA, Marici Cristine Gramacho, Globalização e Educação: A formação do comunicador social na América Latina, 2008312 p. (Doutorado - Orientação BACCEGA, M. A.) Escola de Comunicações e Artes da Universidade de São Paulo, São Paulo, SP, 2008 
Produção em TV 90/06 5. ${ }^{\circ}$ Conhecimentos de câmera e edição

Criação Visual: 90/06 5.o/6. Conhecimentos avançados de linguagem gráfica

Assessoria de comunicação $90 / 065 . \% 6 .{ }^{\circ}$ Conhecimentos de planejamento e com. dirigida e jornalismo empresarial

Criação Publicitária 90/06 5.\% $6{ }^{\circ}$ Conhecimentos avançados de redação publicitária

e dos processos publicitários

Hoje em Dia 90/06 5. $\%{ }^{\circ}$ Conhecimentos técnicos do processo de produção

da noticia

Processos Jornalísticos 90/06 5. $\% 6 .{ }^{\circ}$ Conhecimentos de telejornalismo

Outro Sentido 90/06 6. $\%{ }^{\circ}{ }^{\circ}$ Conhecimentos técnicos avançados do processo de

produção da notícia

Planejamento de comunicação

\section{Universidades Globalizadas}

\subsection{Universidade Anhembi Morumbi - Curso de Comunicação Social}

\section{- Características e Missão da Instituição}

Missão - Contribuir para a construção de um mundo melhor, produzindo conhecimento e formando talentos criativos e empreendedores, capazes de ter sucesso em sua vida pessoal, social e profissional.

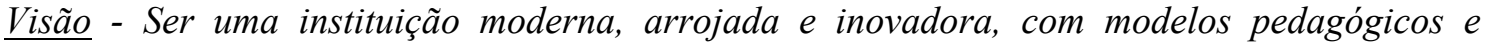
administrativos diferenciados e capazes de desenvolver, nos alunos, sua competência para empreender e inovar em sua atuação profissional.

Valores -Responsabilidade corporativa, compromisso social, transparência e ética.; - Convivio universitário saudável, fraterno e coletivo., - Participação ativa do indivíduo no seu desenvolvimento e crescimento., - Respeito à diversidade, com estímulo ao pensamento crítico e ao relacionamento multicultural., - Aprendizado técnico e profissional, porém sem perder a visão humanista.; - Trabalho participativo e em equipe.

Posicionamento -Inovação e criatividade A Anhembi Morumbi, uma instituição inovadora e criativa, oferece cursos arrojados e diferenciados, que antecipam as tendências de mercado, criando novos padrões educacionais.

Visão de negócios - Desenvolvemos em nossos alunos a capacidade de, dentro de suas especialidades, empreender e identificar constantemente oportunidades de negócios

Segundo a instituição, a parceria com o grupo Laureate representa "oportunidade de formação e atuação mundial, por meio de programas exclusivos de intercâmbios para complemento da grade curricular, múltipla diplomação, estágio internacional, entre outros."

- Características e Objetivos do Curso de Comunicação ou Especialidade da Instituição

O Curso de Comunicação Social teve início em 1970 e em 1971 foi fundada a Faculdade de Turismo do Morumbi, com o primeiro curso superior de Turismo no Brasil a formar graduados na área. Na Anhembi Morumbi o curso de Comunicação possui as seguintes especializações: Cinema, Jornalismo, Produção Editorial, Publicidade e Propaganda e Rádio e $T V$.

Qualidade de ensino reconhecida internacionalmente

SAKATA, Marici Cristine Gramacho, Globalização e Educação: A formação do comunicador social na América Latina, 2008312 p. (Doutorado - Orientação BACCEGA, M. A.) Escola de Comunicações e Artes da Universidade de São Paulo, São Paulo, SP, 2008 
A comunicação não tem mais fronteiras e novos campos de trabalho se abrem para jornalistas talentosos e bem qualificados. Na Anhembi Morumbi - uma das melhores universidades do pais na área de comunicação - o curso de Jornalismo é voltado à formação de profissionais socialmente responsáveis, com postura ética e abertos às novas oportunidades de mercado. Aqui, você aprende a dominar diferentes linguagens e adequá-las a meios diversos. Para potencializar seu aprendizado e aproximá-lo do mercado de trabalho são realizadas atividades práticas em meios impressos e eletrônicos, incluindo a produção do site www.anhembi.br/jornalismo. A infra-estrutura oferecida pela Anhembi Morumbi é uma das mais atualizadas, com laboratórios de produção audiovisual para internet, fotografia e telejornalismo.

Vivencie a cultura da excelência e inovação

- Curso inovador, reconhecido entre os melhores do país pelo Guia do Estudante Abril, do qual obteve três estrelas.

- Aprendizado focado em conceitos e técnicas de comunicação em evidência na atualidade, como gestão de informação e produção jornalística para novas mídias digitais.

- Atividades práticas em meios eletrônicos e impressos desde o primeiro semestre do curso, promove conhecimentos humanísticos, estimula a obtenção de repertório cultural e ajuda a desenvolver visão crítica da realidade.

- O portal com a produção acadêmica e jornalística, onde os alunos podem colocar em prática todo seu talento, pode ser conferido pelo www. anhembi.br/jornalismo.

Prepare-se para o mercado global

Surgem novas oportunidades de trabalho em veículos segmentados e assessorias de comunicação, assim como em sites, emissoras de televisão e produtoras independentes. Ao concluir o curso, você estará preparado para:

- Atuar como repórter, redator e editor em meios impressos, eletrônicos e digitais;

- Atuar como assessor e gestor em agências de comunicação e de notícias e em setores de comunicação de empresas e organizações não-governamentais;

- Trabalhar como freelancer ou montar sua própria empresa de serviços jornalísticos.

Universidade Anhembi Morumbi: um mundo de oportunidades

O ensino global já está ao seu alcance. Como integrante da Rede Internacional de

Universidades Laureate, na Anhembi Morumbi você usufrui de uma série de beneficios

exclusivos:

- acesso a conteúdos acadêmicos internacionais

- programas de intercâmbio, pagando a mesma mensalidade da Anhembi Morumbi

- possibilidade de validar seus créditos cursados em outras universidades da Rede

- Global Career Center, com mais de 30 mil vagas de estágio e empregos no exterior

É um mundo de oportunidades que só a primeira e única universidade global do Brasil pode oferecer.

Legislação Portaria 1173 de 17/04/02.

- Grade Curricular

Grade do curso de Jornalismo (Publicada em: 02/03/2006)

Jornalismo - Bacharelado

\begin{tabular}{|l|l|l|l|l|l|}
\hline $\begin{array}{l}\text { Perí } \\
\text { odo }\end{array}$ & $\begin{array}{l}\text { Disciplinas do } \\
\text { Curso }\end{array}$ & $\begin{array}{l}\text { Disciplinas do } \\
\text { Curso }\end{array}$ & $\begin{array}{l}\text { Disciplinas do } \\
\text { Curso }\end{array}$ & Disciplinas do Curso & Disc. Optativas \\
\hline $5^{\circ}$ & $\begin{array}{l}\text { Técnicas de } \\
\text { Redação e } \\
\text { Edição } \\
\text { em Jornal } \\
\text { (TL) }\end{array}$ & $\begin{array}{l}\text { Planejamento } \\
\text { Gráfico em Meio } \\
\text { Impresso } \\
\text { (TL) }\end{array}$ & $\begin{array}{l}\text { Fotojornalismo } \\
\text { (TL) }\end{array}$ & $\begin{array}{l}\text { Cultura Brasileira } \\
\text { (T) }\end{array}$ & $\begin{array}{l}\text { Optativa V (Jornalismo } \\
\text { Esportivo) }\end{array}$ \\
\cline { 4 - 6 } & & $\begin{array}{l}\text { Jornalismo Cultural } \\
\text { (TP) }\end{array}$ & $\begin{array}{l}\text { Agência Experimental } \\
\text { (Jornal Noticiário) }\end{array}$ \\
\hline
\end{tabular}

SAKATA, Marici Cristine Gramacho, Globalização e Educação: A formação do comunicador social na América Latina, 2008312 p. (Doutorado - Orientação BACCEGA, M. A.) Escola de Comunicações e Artes da Universidade de São Paulo, São Paulo, SP, 2008 


\begin{tabular}{|c|c|c|c|c|c|}
\hline \multirow[t]{2}{*}{$6^{\circ}$} & \multirow{2}{*}{$\begin{array}{l}\text { Técnicas de } \\
\text { Redação e } \\
\text { Edição } \\
\text { em Revista } \\
\text { (TL) }\end{array}$} & $\begin{array}{l}\text { Ciência e } \\
\text { Divulgação } \\
\text { Científica no } \\
\text { Brasil (T) } \\
\end{array}$ & $\begin{array}{l}\text { História Política e } \\
\text { Econômica } \\
\text { Contemporânea } \\
(\mathrm{T})\end{array}$ & $\begin{array}{l}\text { Jornalismo Político } \\
\text { (TP) }\end{array}$ & $\begin{array}{l}\text { Optativa VI } \\
\text { (A Opinião no Jornalismo } \\
\text { Brasileiro) }\end{array}$ \\
\hline & & $\begin{array}{l}\text { Comunicação } \\
\text { Digital } \\
\text { (T) }\end{array}$ & $\begin{array}{l}\text { Jornalismo e } \\
\text { Cidadania } \\
\text { (T) }\end{array}$ & $\begin{array}{l}\text { Jornalismo } \\
\text { Econômico } \\
\text { (TP) }\end{array}$ & $\begin{array}{l}\text { Agência Experimental } \\
\text { (Revista Tema) }\end{array}$ \\
\hline \multirow[t]{2}{*}{$7^{\circ}$} & \multirow{2}{*}{$\begin{array}{l}\text { Laboratório de } \\
\text { Telejornalismo } \\
\text { Digital } \\
\text { (L) }\end{array}$} & \multirow{2}{*}{$\begin{array}{l}\text { Laboratório de } \\
\text { Webjornalismo } \\
\text { (L) }\end{array}$} & \multirow{2}{*}{$\begin{array}{l}\text { Laboratório de } \\
\text { Radiojornalismo } \\
\text { Digital } \\
\text { (L) }\end{array}$} & \multirow{2}{*}{$\begin{array}{l}\text { Elaboração de } \\
\text { Projeto Experimental } \\
\text { em Jornalismo } \\
{[20 \% \text { on-line] }(\mathrm{P})}\end{array}$} & $\begin{array}{l}\text { Optativa VII (Jornalismo } \\
\text { Investigativo) }\end{array}$ \\
\hline & & & & & $\begin{array}{l}\text { Agência Experimental } \\
\text { (Portal de Jornalismo) }\end{array}$ \\
\hline $8^{\circ}$ & \multicolumn{4}{|c|}{$\begin{array}{l}\text { Projeto Experimental - Produção Jornalística } \\
\text { (P) }\end{array}$} & $\begin{array}{l}\text { Palestras: O Mercado de } \\
\text { Trabalho Jornalístico }\end{array}$ \\
\hline
\end{tabular}

T - disciplina teórica

P- disciplina prática

$\mathrm{L}$ - disciplina laboratorial

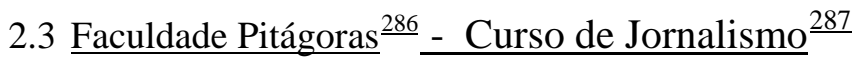

\section{- Características e Missão da Instituição}

Conceito - Educação superior com alta qualidade (forma, conteúdo e aplicabilidade) e a um custo acessivel para um grande número de alunos.

Visão - Atuar como co-responsáveis com nossos alunos na realização de suas carreiras e projetos de vida.

Missão Educacional - Capacitar alunos a tornarem-se profissionais competentes para enfrentar os desafios de um mundo em constante mutação. Participar ativamente do processo de melhoria da qualidade educacional do país e do aumento do número de vagas acessiveis à população de renda média.

Missão Empresarial -

Desenvolver e aplicar know-how em educação superior, recorrendo ao uso da tecnologia para oferecer educação de qualidade para muitos, em escala.

Foco-Autonomia intelectual e de vida dos alunos, motivando-os para o desempenho competente como seres humanos, cidadãos e profissionais, desenvolvendo:

habilidades de análise, interpretação e reflexão crítica sobre problemas e oportunidades; a expressão destas habilidades através da comunicação oral e escrita, idiomas e recursos informatizados; a capacidade de atuar e interagir em equipes multidisciplinares e o senso de coresponsabilidade social.

Acreditamos: Na vida e em tudo que a valoriza; No ensino superior como meio de compreendermos e transformarmos positivamente a nossa realidade; Na vanguarda educacional e tecnológica que estamos propondo e em seu beneficio direto para os alunos; Nos vínculos de amizade e nas relações de trabalho com alunos, professores e parceiros; $\mathrm{Na}$ construção de um Brasil mais justo e solidário, através de nossos alunos, professores e parceiros; Na transparência de nossas ações e números, e em nossa responsabilidade comunitária.

- Características e Objetivos do Curso de Comunicação ou Especialidade da Instituição

\footnotetext{
${ }^{286}$ Embora não seja uma Universidade, foi selecionada para análise.

${ }^{287}$ Faculdade Pitágoras, Disponível em www.faculdadepitagoras.com.br/ acesso em 03/11/2006
}

SAKATA, Marici Cristine Gramacho, Globalização e Educação: A formação do comunicador social na América Latina, 2008312 p. (Doutorado - Orientação BACCEGA, M. A.) Escola de Comunicações e Artes da Universidade de São Paulo, São Paulo, SP, 2008 
A faculdade Pitágoras possui curso de Jornalismo, Publicidade e Propaganda e Turismo de Aventura.

O curso de Jornalismo oferece aos seus alunos uma formação que os permitam atuar de forma empreendedora frente a essa nova identidade profissional que se vislumbra. Por esse motivo, uma das essências desta graduação é centralizar as práticas acadêmicas no âmbito do Jornalismo Empresarial e com todos os seus desdobramentos, ou seja, atuando nos campos de trabalho em jornais impressos, emissoras de televisão, assessorias de comunicação e em emissoras de rádio.

- Grade Curricular

JORNALISMO - Data da oficialização desta grade: 18.07.2006

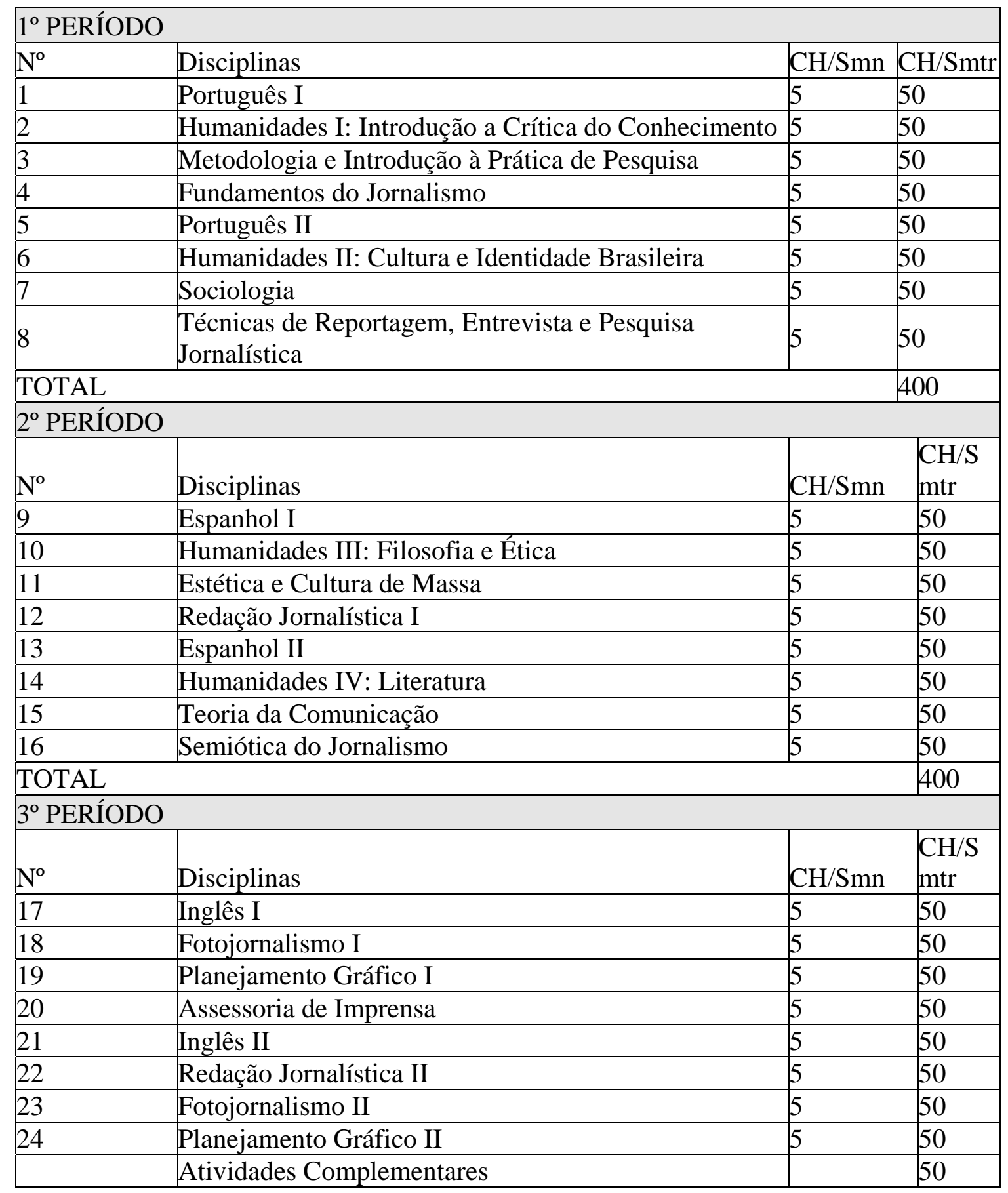

SAKATA, Marici Cristine Gramacho, Globalização e Educação: A formação do comunicador social na América Latina, 2008312 p. (Doutorado - Orientação BACCEGA, M. A.) Escola de Comunicações e Artes da Universidade de São Paulo, São Paulo, SP, 2008 


\begin{tabular}{|c|c|c|c|}
\hline TOTAL & & & 450 \\
\hline $4^{\circ}$ PERÍC & & & \\
\hline $\mathrm{N}^{\mathrm{o}}$ & Disciplinas & $\mathrm{CH} / \mathrm{Smn}$ & $\begin{array}{l}\mathrm{CH} / \mathrm{S} \\
\mathrm{mtr}\end{array}$ \\
\hline 25 & Comunicação e Cultura & 5 & 50 \\
\hline 26 & Marketing & 5 & 50 \\
\hline 27 & Radiojornalismo I & 5 & 50 \\
\hline 28 & Redação Jornalística III & 5 & 50 \\
\hline 29 & Legislação e Ética da Comunicação & 5 & 50 \\
\hline 30 & Radiojornalismo II & 5 & 50 \\
\hline 31 & Cinema & 5 & 50 \\
\hline 32 & Redação Jornalística IV & 5 & 50 \\
\hline & Atividades Complementares & & 50 \\
\hline TOTAL & & & 450 \\
\hline $5^{\circ}$ PERÍC & & & \\
\hline $\mathrm{N}^{\mathrm{o}}$ & Disciplinas & $\mathrm{CH} / \mathrm{Smn}$ & $\begin{array}{l}\mathrm{CH} / \mathrm{S} \\
\mathrm{mtr}\end{array}$ \\
\hline 33 & Ciência Política & 5 & 50 \\
\hline 34 & Psicologia & 5 & 50 \\
\hline 35 & Radiojornalismo III & 5 & 50 \\
\hline 36 & Política e Economia no Brasil Pós-Guerra & 5 & 50 \\
\hline 37 & Gestão Empresarial Contemporânea & 5 & 50 \\
\hline 38 & Cibercultura e Jornalismo digital & 5 & 50 \\
\hline 39 & Jornalismo na Internet I & 5 & 50 \\
\hline 40 & Telejornalismo I & 5 & 50 \\
\hline & Atividades Complementares & & 50 \\
\hline TOTAL & & & 450 \\
\hline $6^{\circ}$ PERÍC & & & \\
\hline $\mathrm{N}^{\mathrm{o}}$ & Disciplinas & $\mathrm{CH} / \mathrm{Smn}$ & $\begin{array}{l}\mathrm{CH} / \mathrm{S} \\
\mathrm{mtr}\end{array}$ \\
\hline 39 & Comunicação Institucional & 5 & 50 \\
\hline 40 & Teoria do Jornalismo & 5 & 50 \\
\hline 41 & Telejornalismo II & 5 & 50 \\
\hline 42 & Economia & 5 & 50 \\
\hline 43 & Telejornalismo III & 5 & 50 \\
\hline 44 & $\begin{array}{l}\text { Assessoria de Comunicação e Relacionamento com a } \\
\text { Mídia }\end{array}$ & 5 & 50 \\
\hline 45 & Jornalismo na Internet II & 5 & 50 \\
\hline 46 & Teoria da Imagem & 5 & 50 \\
\hline & Atividades Complementares & & 50 \\
\hline TOTAL & & & 450 \\
\hline $7^{\circ}$ PERÍC & & & \\
\hline $\mathrm{N}^{\mathrm{o}}$ & Disciplinas & $\mathrm{CH} / \mathrm{Smn}$ & $\begin{array}{l}\mathrm{CH} / \mathrm{S} \\
\mathrm{mtr}\end{array}$ \\
\hline 47 & Empresa Simulada I & 5 & 50 \\
\hline 48 & Projeto Experimental em Jornalismo I & 5 & 100 \\
\hline 49 & Política de Comunicação & 5 & 50 \\
\hline 50 & Eletiva I & 5 & 50 \\
\hline
\end{tabular}

SAKATA, Marici Cristine Gramacho, Globalização e Educação: A formação do comunicador social na América Latina, 2008312 p. (Doutorado - Orientação BACCEGA, M. A.) Escola de Comunicações e Artes da Universidade de São Paulo, São Paulo, SP, 2008 


\begin{tabular}{|l|l|l|l|}
\hline 51 & Empresa Simulada II & 10 & 50 \\
\hline 52 & Projeto Experimental em Jornalismo II & 10 & 100 \\
\hline \multicolumn{2}{|l|l|}{} & \multicolumn{2}{l|}{} \\
\hline TOTAL & Atividades Complementares & \multicolumn{2}{l|}{450} \\
\hline $8^{\circ}$ PERÍODO & Disciplinas & CH/Smn & $\begin{array}{l}\mathrm{CH} / \mathrm{S} \\
\mathrm{mtr}\end{array}$ \\
\hline$N^{\circ}$ & Projeto Experimental em Jornalismo III & 5 & 100 \\
\hline 53 & Eletiva II & 5 & 50 \\
\hline 54 & Eletiva III & 10 & 50 \\
\hline 55 & Projeto Experimental em Jornalismo IV & 20 & 200 \\
\hline 56 & Atividades Complementares & & 50 \\
\hline & & & 450 \\
\hline TOTAL & & & \\
\hline
\end{tabular}

\section{CHILE}

\begin{tabular}{|l|l|l|l|l|}
\hline $\begin{array}{l}\text { 3. } \\
\text { Chile }\end{array}$ & $\begin{array}{l}\text { 3.1 Universidad de } \\
\text { Chile }\end{array}$ & $\begin{array}{l}3.2 \text { Universidad de } \\
\text { Santiago de Chile }\end{array}$ & $\begin{array}{l}\text { 3.3 Universidad } \\
\text { Nacional de } \\
\text { Andres Bello } \\
\text { (Laureate) }\end{array}$ & $\begin{array}{l}\text { 3.4 Universiadad } \\
\text { de las Americas } \\
\text { (Laureate) }\end{array}$ \\
\hline
\end{tabular}

\section{Universidades Nacionais}

\subsection{Universidad de Chile - Instituto de la Comunicación e Imagen $\underline{288}$}

- Características e Missão da Instituição

Misión de la Universidad de Chile

La Misión de la Universidad de Chile es la establecida en el proyecto de nuevo Estatuto:

Artículo $1^{\circ}$ La Universidad de Chile, Persona Jurídica de Derecho Público, Autónoma, es una Institución de Educación Superior del Estado de carácter nacional y público, con personalidad jurídica y patrimonio propio, con plena autonomía académica, económica y administrativa, dedicada a la enseñanza superior, investigación, creación y extensión en las ciencias, las humanidades, las artes y las técnicas, al servicio del país en el contexto universal de la cultura. Artículo $2^{\circ}$. La generación, desarrollo, integración y comunicación del saber en todas las áreas del conocimiento y dominios de la cultura, constituyen la misión y el fundamento de las actividades de la Universidad, conforman la complejidad de su quehacer y orientan la educación que ella imparte.

La Universidad asume con vocación de excelencia la formación de personas y la contribución al desarrollo espiritual y material de la Nación. Cumple su misión a través de las funciones de docencia, investigación y creación en las ciencias y las tecnologías, las humanidades y las artes, y de extensión del conocimiento y la cultura en toda su amplitud. Procura ejercer estas funciones con el más alto nivel de exigencia.

Artículo $3^{\circ}$. Es responsabilidad de la Universidad velar por el patrimonio cultural y la identidad nacionales e impulsar el perfeccionamiento del sistema educacional del país. En

${ }^{288}$ Universidad de Chile, Disponível em www.uchile.cl/ acesso em 02/11/2006

SAKATA, Marici Cristine Gramacho, Globalização e Educação: A formação do comunicador social na América Latina, 2008312 p. (Doutorado - Orientação BACCEGA, M. A.) Escola de Comunicações e Artes da Universidade de São Paulo, São Paulo, SP, 2008 
cumplimiento de su labor, la Universidad responde a los requerimientos de la Nación constituyéndose como reserva intelectual caracterizada por una conciencia social, critica y éticamente responsable y reconociendo como contenido de su misión la atención de los problemas y necesidades del país. Con ese fin, se obliga al más completo conocimiento de la realidad nacional y a su desarrollo por medio de la investigación y la creación; postula el desarrollo integral, equilibrado y sostenible del país, aportando a la solución de sus problemas desde la perspectiva universitaria, y propende al bien común y a la formación de una ciudadanía inspirada en valores democráticos, procurando el resguardo y enriquecimiento del acervo cultural nacional y universal.

Artículo $4^{\circ}$. Los principios orientadores que guían a la Universidad en el cumplimiento de su misión, inspiran la actividad académica y fundamentan la pertenencia de sus miembros a la vida universitaria son: la libertad de pensamiento y de expresión; el pluralismo; y la participación de sus miembros en la vida institucional, con resguardo de las jerarquías inherentes al quehacer universitario. Forman parte también de estos principios orientadores: la actitud reflexiva, dialogante y crítica en el ejercicio de las tareas intelectuales; la equidad y la valoración del mérito en el ingreso a la Institución, en su promoción y egreso; la formación de personas con sentido ético, cívico y de solidaridad social; el respeto a personas y bienes; el compromiso con la institución; la integración y desarrollo equilibrado de sus funciones universitarias, y el fomento del diálogo y la interacción entre las disciplinas que cultiva.

Visión de futuro de la Universidad de Chile

La Visión de Futuro de la Universidad de Chile señala las ideas matrices que orientan la formulación de esta propuesta de proyecto de desarrollo institucional para la Universidad de Chile, en su carácter de universidad estatal, pública, nacional y de calidad internacional. Estas ideas matrices son las siguientes:

a) El desarrollo de la Universidad de Chile debe ser consistente con su misión histórica, su naturaleza estatal y pública, y su compromiso nacional

i) La naturaleza estatal y pública y la trayectoria histórica de nuestra universidad nos impone la tarea permanente de ser referente nacional, tanto por la calidad inherente de nuestras actividades y nuestros rendimientos y la capacidad de definir estándares para el país en cada disciplina y en cada programa docente, como también por el ejercicio de los valores de tolerancia, pluralismo y equidad, independencia intelectual y libertad de pensamiento, respeto y preservación de la diversidad en todos los ámbitos de su quehacer.

ii) La Universidad de Chile debe repensar y proyectar su misión, adecuándose a los desafios que plantean los cambios históricos, y sobre todo anticipándolos.

iii) Esta tarea supone un esfuerzo constante de actualización frente a los problemas y desafios que plantea el contexto. En tal sentido, la consistencia con la misión histórica de la universidad no se inspira en una idealización metafísica de su pasado, sino con la recreación autocrítica y permanente de dicha misión. Y desde luego no puede escapársenos que las condiciones y el entorno que determinan hoy a una tarea semejante son particularmente complejos.

iv) El compromiso nacional debe impulsarnos a constituir grupos amplios y diversos para analizar permanentemente, siempre desde un alto nivel académico, los problemas que enfrenta nuestra sociedad -la pobreza y las desigualdades, las amenazas medio-ambientales, la violencia, la discriminación en todas sus manifestaciones, el debilitamiento de la ética pública e individual, las limitaciones en educación y cultura, etc. -, y para contribuir a superarlos, así como también para prever los eventuales desarrollos y conflictos que estén latentes en la situación histórica.

b) La Universidad de Chile debe realizar su labor creadora, formadora y de interacción manteniendo permanente coherencia con los parámetros internacionales de excelencia académica.

i) Ningún desempeño académico puede emprenderse hoy a espaldas de los parámetros de evaluación y acreditación que tienen vigencia internacional y que establecen criterios de excelencia académica.

ii) Pero también debe tenerse en cuenta que estos parámetros no deben ser aplicados irreflexivamente, sin consideración del contexto, de las premisas y efectos de ese desempeño.

SAKATA, Marici Cristine Gramacho, Globalização e Educação: A formação do comunicador social na América Latina, 2008312 p. (Doutorado - Orientação BACCEGA, M. A.) Escola de Comunicações e Artes da Universidade de São Paulo, São Paulo, SP, 2008 
La excelencia no puede ser disociada ni del compromiso institucional y social del ejercicio académico ni de su pertinencia.

iii) En este sentido, es preciso enfatizar la relación indisoluble entre excelencia y compromiso nacional que define a la Universidad de Chile, a fin de que converjan en un mismo objetivo institucional y se refuercen mutuamente, sin privilegiar uno de tales factores en detrimento del otro. De cualquier modo, se debe enfatizar que la excelencia es imprescindible para asegurar un impacto nacional -y por cierto, también internacional-provisto de autoridad y validez $y$, por ende, de credibilidad política y social. Si bien es factible la excelencia sin compromiso social, el compromiso sin excelencia es imposible.

iv) La excelencia académica contribuye también a incrementar el sentido de pertenencia y de identidad universitaria. De ahi que sea imperioso realizar esfuerzos conscientes y positivos de mejoramiento general y de corrección en todas aquellas áreas y actividades que así lo requieran.

c) La Universidad de Chile debe responder creativa y eficazmente a las condiciones y desafios que plantea la globalización y la inserción del país en el orden mundial.

i) La respuesta que la Universidad debe proyectar no puede consistir meramente en inducir comportamientos adaptativos que se restrinjan a las exigencias y condicionamientos que plantea el mercado laboral y el sistema social del trabajo. La Universidad debe mantener una vigilancia crítica sobre el modelamiento de la totalidad social por el mercado, proyectando los horizontes de expectativas de los sujetos individuales y sociales a partir de la indagación libre y creadora, la generación y fomento de valores y la pública y plural discusión en torno a los problemas, objetivos y metas del país.

ii) En particular, no puede omitirse que la solvencia histórica de un proceso de desarrollo económico y social requiere de premisas culturales, en cuya configuración le cabe un papel determinante a la institución universitaria, y sobre todo a la nuestra que por misión tiene un compromiso expreso con los intereses nacionales $y$, por ende, con el mantenimiento $y$ proyección de nuestra identidad cultural y valórica.

iii) En este sentido, la Universidad debe contribuir a la elaboración de perspectivas y estrategias para la solución de los problemas del desarrollo tanto en el nivel del país como de la integración del mismo a la región y al contexto latinoamericano, orientada por una clara vocación de fomento de la paz, las libertades cívicas, el pluralismo y la tolerancia, la equidady la participación irrestricta en los bienes materiales y simbólicos, y animada por el rechazo explícito de toda forma de discriminación.

iv) Por otra parte, en el esquema de la globalización, la integración del trabajo universitario a redes internacionales es un imperativo de los tiempos, no sólo por la necesidades inherentes a los procesos de conocimiento, que requieren intensivamente la configuración de estructuras y estrategias de colaboración e intercambio, sino porque ya no es posible pensar en una institución universitaria que pueda auto-abastecerse, y lo que estamos acostumbrados a llamar el "claustro" tiende a convertirse cada vez más en una comunidad virtual.

v) En este sentido, la internacionalización plantea desafios especificos en la mayoría de los aspectos de la gestión y el desempeño universitarios, debido a la tendencia a reproducir o emplear mecánicamente estándares determinados a partir de otras experiencias, otros procesos y otros proyectos, con la consiguiente pérdida de la capacidad de autodeterminación y la incorporación sin reparos a la división internacional del trabajo intelectual. Dicha internacionalización debe ser monitoreada mediante la aplicación coherente de los criterios de calidad, pertinencia y equidad, a fin de mantener bajo control la posibilidad de una apertura que desconsidere o simplemente omita prioridades de país y derechos sociales.

- Características e Objetivos do Curso de Comunicação ou Especialidade da Instituição

Licenciado en Comunicación Social com Título profesional de Periodista. Oferecido por el Instituto de la Comunicación e Imagen con duración de 10 semestres académicos, jornada diurna, currículum semiflexible

SAKATA, Marici Cristine Gramacho, Globalização e Educação: A formação do comunicador social na América Latina, 2008312 p. (Doutorado - Orientação BACCEGA, M. A.) Escola de Comunicações e Artes da Universidade de São Paulo, São Paulo, SP, 2008 
La Licenciatura en Comunicación Social tiene como objetivo otorgar una formación general y sistemática, con un adecuado fundamento cientifico y humanístico en las distintas disciplinas que abarca el área de las ciencias y técnicas de la comunicación social. Los estudios profesionales de la carrera de Periodismo se fundamentan en las ciencias de la comunicación y tienen como finalidad proporcionar conocimientos y técnicas, y desarrollar habilidades que permitan desempeñarse como experto en materias relacionadas con los medios informativos y técnicas de la comunicación en general.

Campo laboral: Los periodistas pueden desempeñarse en diversas áreas del quehacer de una sociedad. Conocidos como reporteros, su trabajo es clave en el mundo de los medios de comunicación, diarios, revistas, televisión, radioemisoras e internet. También pueden ejercer en el medio publicitario, en los departamentos de comunicaciones de empresas, bancos y organizaciones.

\section{- Grade Curricular}

Instituto de la Comunicación e Imagen Grado académico: Periodismo Plan de estúdios

\begin{tabular}{|c|c|c|c|c|}
\hline \multicolumn{5}{|l|}{ Primer Año } \\
\hline Asignaturas y Actividades Curriculares & Hrs. & Cred. & Sem. & Régimen \\
\hline LENGUAJE Y CULTURA & 6 & 8 & I & Semestral \\
\hline COMUNICACION E IDENTIDAD & 6 & 8 & I & Semestral \\
\hline REDACCION PERIODISTICA & 8 & 12 & $\mathrm{I}$ & Semestral \\
\hline ETICA Y TRATAMIENTOS PERIODISTICOS & 6 & 10 & I & Semestral \\
\hline CURSO ELECTIVO & 2 & 5 & I & Semestral \\
\hline SEMIOLOGIA & 6 & 10 & II & Semestral \\
\hline CULTURA VISUAL CONTEMPORANEA & 6 & 8 & II & Semestral \\
\hline TALLER DE REPORTEO & 6 & 10 & II & Semestral \\
\hline TALLER DE REDACCION & 8 & 10 & II & Semestral \\
\hline LIBERTAD DE EXPRESION & 2 & 5 & II & Semestral \\
\hline \multicolumn{5}{|l|}{ Segundo Año } \\
\hline Asignaturas y Actividades Curriculares & Hrs. & Cred. & Sem. & Régimen \\
\hline COMUNICACION INTERPERSONAL & 6 & 10 & III & Semestral \\
\hline ANALISIS DE LA IMAGEN FIJA & 6 & 8 & III & Semestral \\
\hline TALLER DE CRONICA Y ENTREVISTA & 6 & 10 & III & Semestral \\
\hline EXPRESION ORAL Y CORPORAL & 6 & 8 & III & Semestral \\
\hline CURSO ELECTIVO & 2 & 5 & III & Semestral \\
\hline CLASICOS DE LA COMUNICACION & 6 & 10 & IV & Semestral \\
\hline EL PROBLEMA DEL CONOCIMIENTO & 6 & 8 & IV & Semestral \\
\hline ANALISIS DE LA IMAGEN AUDIOVISUAL & 4 & 6 & IV & Semestral \\
\hline TALLER DE REPORTAJE & 6 & 10 & IV & Semestral \\
\hline FOTOGRAFIA & 6 & 10 & IV & Semestral \\
\hline CURSO ELECTIVO & 2 & 5 & IV & Semestral \\
\hline \multicolumn{5}{|l|}{ Tercer Año } \\
\hline Asignaturas y Actividades Curriculares & Hrs. & Cred. & Sem. & Régimen \\
\hline CULTURA DE MASAS E INDUSTRIA CULTURAL & 6 & 10 & $\mathrm{~V}$ & Semestral \\
\hline EPISTEMOLOGIA DE LA COMUNICACION & 6 & 8 & $\mathrm{~V}$ & Semestral \\
\hline PERIODISMO RADIOFONICO & 6 & 10 & $\mathrm{~V}$ & Semestral \\
\hline TALLER DE FOTOGRAFIA & 6 & 10 & $\mathrm{~V}$ & Semestral \\
\hline
\end{tabular}




\begin{tabular}{|c|c|c|c|c|}
\hline DERECHO A LA INFORMACION & 4 & 6 & $\mathrm{~V}$ & Semestral \\
\hline CURSO ELECTIVO & 2 & 5 & $\mathrm{~V}$ & Semestral \\
\hline ESTUDIOS CULTURALES & 6 & 10 & VI & Semestral \\
\hline EL PROCESO DE INVESTIGACION & 8 & 10 & VI & Semestral \\
\hline PRODUCCION PERIODISTICA RADIAL & 6 & 8 & VI & Semestral \\
\hline TALLER DE NARRATIVA AUDIOVISUAL & 6 & 6 & VI & Semestral \\
\hline PERIODISMO TELEVISIVO & 6 & 8 & VI & Semestral \\
\hline \multicolumn{5}{|l|}{ Cuarto Año } \\
\hline Asignaturas y Actividades Curriculares & Hrs. & Cred. & Sem. & Régimen \\
\hline ENFOQUES LATINOAMERICANOS & 6 & 10 & VII & Semestral \\
\hline $\begin{array}{l}\text { TECNICAS DE INVESTIGACION EN } \\
\text { COMUNICACION }\end{array}$ & 6 & 8 & VII & Semestral \\
\hline TEORIA Y PRACTICAS MULTIMEDIA & 6 & 8 & VII & Semestral \\
\hline PRODUCCION PERIODISTICA EN TELEVISION & 6 & 8 & VII & Semestral \\
\hline ADMINISTRACION Y GESTION DE MEDIOS, O & 4 & 6 & VII & Semestral \\
\hline $\begin{array}{l}\text { PLANIFICACION ESTRATEGICA DE LA COM. } \\
\text { ORGANIZACIONAL }\end{array}$ & 4 & 6 & VII & Semestral \\
\hline $\begin{array}{l}\text { COMUNICACION POLITICA Y ESPACIO } \\
\text { PUBLICO }\end{array}$ & 6 & 10 & VIII & Semestral \\
\hline TALLER DE INVESTIGACION & 6 & 12 & VIII & Semestral \\
\hline TALLER DE PERIODISMO DE INVESTIGACION & 6 & 8 & VIII & Semestral \\
\hline TALLER DE PERIODISMO MULTIMEDIA & 6 & 8 & VIII & Semestral \\
\hline $\begin{array}{l}\text { CREACION Y DESARROLLO DE MEDIOS } \\
\text { ESCRITOS, O }\end{array}$ & 6 & 6 & VIII & Semestral \\
\hline $\begin{array}{l}\text { GESTION DE COMUNICACION INTERNA Y } \\
\text { EXTERNA }\end{array}$ & 6 & 6 & VIII & Semestral \\
\hline \multicolumn{5}{|l|}{ Quinto Año } \\
\hline Asignaturas y Actividades Curriculares & Hrs. & Cred. & Sem. & Régimen \\
\hline PRACTICAS PROFESIONALES & $2(600)^{*}$ & 18 & IX & Semestral \\
\hline ELECTIVO DE COMPETENCIA PERIODISTICA & 8 & 8 & IX & Semestral \\
\hline ELECTIVO DE COMPETENCIA PERIODISTICA & 8 & 8 & IX & Semestral \\
\hline $\begin{array}{l}\text { CREACION Y DESARROLLO DE MEDIOS } \\
\text { AUDIOVISUALES, O }\end{array}$ & 6 & 8 & IX & Semestral \\
\hline $\begin{array}{l}\text { RELACIONES PUBLICAS Y } \\
\text { ORGANIZACIONALES }\end{array}$ & 6 & 8 & IX & Semestral \\
\hline \multicolumn{5}{|c|}{$\begin{array}{l}\text { * Las } 600 \text { horas deben acreditarse según Reglamento Específico de Prácticas Profesionales del Instituto } \\
\text { Interdisciplinario de la Comunicación e Imagen }\end{array}$} \\
\hline PROCESO DE TITULACION & 4 & 22 & $\mathrm{X}$ & Semestral \\
\hline ELECTIVO DE COMPETENCIA PERIODISTICA & 8 & 8 & $\mathrm{X}$ & Semestral \\
\hline ELECTIVO DE COMPETENCIA PERIODISTICA & 8 & 8 & $\mathrm{X}$ & Semestral \\
\hline TALLER DE DESARROLLO DE PROYECTOS, O & 6 & 10 & $\mathrm{X}$ & Semestral \\
\hline $\begin{array}{l}\text { TALLER DE CAMPAÑAS DE COMUNICACION } \\
\text { ORGANIZACIONAL }\end{array}$ & 6 & 10 & $\mathrm{X}$ & Semestral \\
\hline \multicolumn{5}{|l|}{ Actividades Finales de Titulación } \\
\hline \multicolumn{5}{|l|}{ MEMORIA DE TITULO } \\
\hline EXAMEN DE TITULO & & & & \\
\hline & & & & \\
\hline
\end{tabular}

SAKATA, Marici Cristine Gramacho, Globalização e Educação: A formação do comunicador social na América Latina, 2008312 p. (Doutorado - Orientação BACCEGA, M. A.) Escola de Comunicações e Artes da Universidade de São Paulo, São Paulo, SP, 2008 


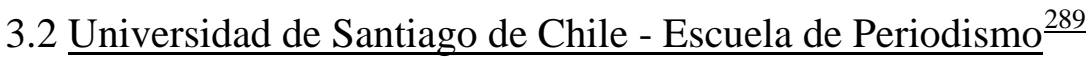

\section{- Características e Missão da Instituição}

Nacida como Escuela de Artes y Oficios en 1849, la Universidad de Santiago de Chile es hoy una universidad compleja y completa, que cuenta con más de 18.000 alumnos en un campus único, en 58 carreras de pregrado en siete Facultades, la Escuela de Arquitectura y el Programa de Bachillerato en Ciencias y Humanidades, abarcando las distintas áreas del conocimiento. Asimismo, imparte 11 programas de doctorado, 38 de magister y un gran número de cursos de especialización y programas de postitulo. Es una Universidad estatal y pública, al servicio de la sociedad, guiada por valores como la excelencia, pluralismo, tolerancia, respeto a las personas, libertad académica, responsabilidad social, humanismo, cooperación. Sus actividades están encaminadas a entregar una docencia de calidad, realizar investigación vinculada con el desarrollo del país, procurar una buena calidad de vida a los integrantes de la comunidad universitaria, realizar una gestión administrativa y académica moderna y eficiente y establecer vinculaciones con universidades y entidades nacionales $e$ internacionales. La historia institucional ha estado marcada por el cambio, por el trabajo tesonero, empuje y dedicación de las personas que han transitado por ella y han entregado lo mejor de sí para avanzar, sortear dificultades y dolores. El objetivo principal siempre ha sido colaborar con el desarrollo del país, a través de la formación de profesionales, líderes con sentido y responsabilidad social; de la investigación vinculada a las necesidades del entorno social; de la extensión, llevando la imagen de la Universidad a la comunidad externa con charlas, exposiciones, conciertos, teatro, y realizando una vasta labor cultural y de difusión de su quehacer, utilizando también todas las posibilidades que entregan las últimas tecnologías de comunicación. La Universidad de Santiago de Chile ha sabido responder a los desafios que le impone el mundo global, ha dado un fuerte impulso a la integración internacional por medio de redes interinstitucionales y convenios de intercambio y colaboración con universidades de los distintos continentes. Asimismo, está trabajando arduamente para completar la acreditación de todas sus carreras y cumplir con los planes de mejoramiento que se propuso en las diferentes áreas, con la fortaleza que siempre la ha distinguido, con el aporte generoso de toda una comunidad universitaria que se sustenta en una tradición de trabajo, capacidad creativa, mística y empuje que mira con optimismo el futuro.A. Visión Para el desarrollo de la visión, la Comisión generó diversas propuestas, discutidas en reuniones y talleres, de acuerdo a información recopilada, análisis interno y externo, encuestas, estudios de visiones de distintas universidades nacionales e internacionales y los ámbitos de diferenciación. La nueva Visión se construyó en el Taller de Planificación efectuado en Millahue, en conjunto con el Consejo

Académico en pleno.

\section{Vision}

Ser una universidad de excelencia, líder een la gestión e innovación tecnológica y del conocimiento, sustentada en las ciencias y las humanidadees, con impacto nacional, reconocimiento internacional y responsabilidad social

Misión actual:

"La Universidad de Santiago de Chile, como institución de educación superior estatal de excelencia, se preocupa, en un nivel avanzado, de la creación, preservación, cultivo, transmisión y búsqueda del conocimiento mediante la investigación, la docencia y la extensión en el campo de las ciencias, las artes, las humanidades y la tecnología. Su quehacer debe estar al servicio de la sociedad, debe desarrollar la conciencia crítica en un ambiente pluralista y con práctica de la libertad de expresión. Con este fin, la Universidad de Santiago de Chile

\footnotetext{
${ }^{289}$ Universidad de Santiago de Chile, Disponível em http://www.usach.cl/index.php acesso em $\underline{01 / 11 / 2006}$
}

SAKATA, Marici Cristine Gramacho, Globalização e Educação: A formação do comunicador social na América Latina, 2008312 p. (Doutorado - Orientação BACCEGA, M. A.) Escola de Comunicações e Artes da Universidade de São Paulo, São Paulo, SP, 2008 
enfatiza la formación integral de los alumnos y su adecuada inserción a la realidad nacional e internacional."

Misión propuesta:

"La Universidad de Santiago de Chile como institución de educación superior estatal de excelencia, tiene como misión contribuir en un nivel avanzado a la creación, preservación, cultivo, transmisión y búsqueda del conocimiento mediante la investigación, la docencia y la extensión en el campo de las ciencias, la tecnología, las artes y las humanidades. Su quehacer está al servicio de la sociedad, desarrollando la conciencia crítica en un ambiente pluralista y con práctica de la libertad de expresión. Con este fin, la Universidad de Santiago de Chile enfatiza la formación integral de profesionales y graduados y su adecuada inserción en la realidad nacional e internacional."

C. Valores

Estaremos guiados por una serie de valores centrales que definirán nuestros actos y nos unirán como comunidad universitaria.

- Excelencia; Pluralismo; Tolerancia; Libertad académica; Respeto a las persona;Responsabilidad social; Humanismo; Cooperación: Apoyamos las relaciones que fomentan la cooperación con otras instituciones académicas, con instituciones públicas y privadas para desarrollar las oportunidades de educación e investigación existentes en la Universidad.

- Características e Objetivos do Curso de Comunicação ou Especialidade da Instituição

Departamento

Escuela de Periodismo

Perfil

El aspirante a la carrera deberá poseer una gran vocación de servicio hacia la comunidad privilegiando la necesidad de información que tiene la sociedad por sobre los intereses individuales, una vocación profunda por conocer los fenómenos que afectan a las personas socialmente organizadas y que son factibles de convertirse en acontecimientos que la gante debe conocer, además de saber interpretar y relacionarlos con otros. Cultura personal que le permita reconocer las diversas disciplinas que se vinculen con la formación profesional que requiere un periodista integral.

Cатро

El campo ocupacional del periodista es el de los medios de comunicación social, es decir, la comunicación masiva que se realiza a través de la prensa escrita, las radioemisoras y la televisión. En ese campo, los profesionales del periodismo pueden realizar distintas funciones en el proceso de transmisión de noticias e informaciones que requiere la sociedad. Debido a las caracteristicas del perfil académico-profesional diseñado, los periodistas que forma la Universidad de Santiago de Chile, además, un amplio campo ocupacional en las empresas privadas e instituciones públicas del país, sectores en los que sus servicios serán requeridos en el área de las comunicaciones internas y externas para analizar problemas de la comunicación institucional, planificar y realizar estrategias comunicacionales y de relaciones públicas.

Observaciones

(9) La carrera de Periodismo conduce al grado académico de Licenciado en Comunicación Social y al Título Profesional de Periodista.

\section{- Grade Curricular}

SAKATA, Marici Cristine Gramacho, Globalização e Educação: A formação do comunicador social na América Latina, 2008312 p. (Doutorado - Orientação BACCEGA, M. A.) Escola de Comunicações e Artes da Universidade de São Paulo, São Paulo, SP, 2008 


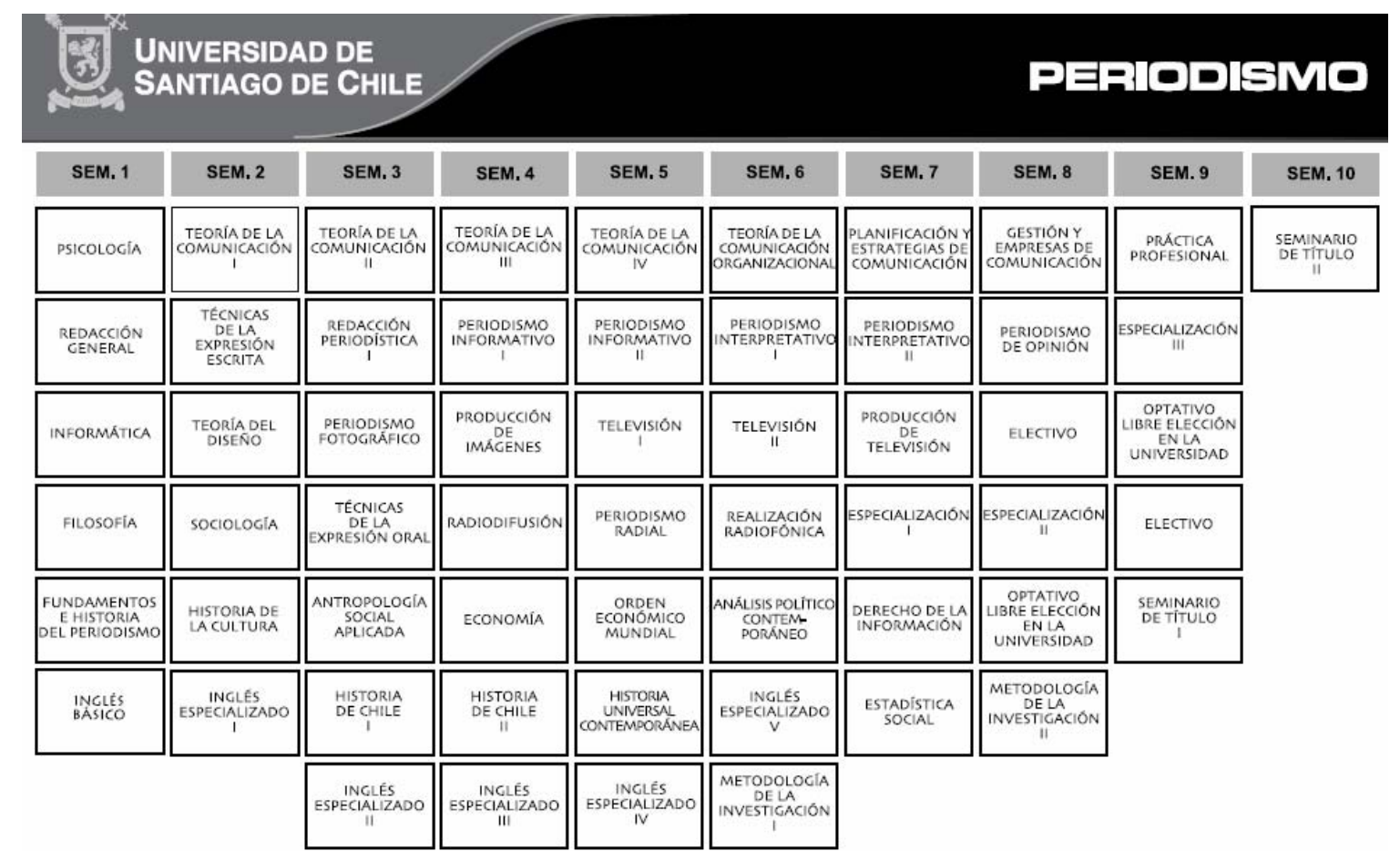

Periodismo, Ciencias Sociales, Carrera, Diurna, Título Profesional de Periodista

Grado Académico Licenciado en Comunicación Social, Puntaje Mínimo Postulación 2007600 Vacantes 200750 Último Matriculado 2006 643,00 Duración 5 años, en régimen semestral. Valor $2006 \$ 1.737 .500$.- referencial Matrícula $2006 \$ 57.400$ referencial

\section{Universidades Globalizadas}

\subsection{Universidad Andrés Bello - Facultad de Ciencias Sociales ${ }^{290}$}

- Características e Missão da Instituição

Universidad Andrés Bello (UNAB) is one of the largest and most prestigious private universities in Chile. With campuses in Santiago and Vina del Mar and a research station in Quintay, $U N A B$ provides more than 50 undergraduate and graduate degree programs in a wide variety of academic disciplines. The university was granted autonomy by the Chilean Higher Education Authority in 1999, and is home to an extensive Health Sciences school. UNAB's mission is to provide students with academic training that is responsive to the challenges of a dynamic and increasingly interconnected world.

AIEP de la Universidad Nacional de Andres Bello

Visión Institucional - El Instituto Profesional AIEP aspira a proyectarse como la principal institución de formación tecnológica del país, por su matrícula, calidad del servicio educativo, cobertura geográfica, disposición a la innovación permanente de los modelos formativos y solidez de su gestión.

Su posicionamiento y liderazgo se sustenta en un proyecto educativo flexible y la diversidad de su oferta académica que responde eficientemente a las competencias laborales exigidas por el

${ }^{290}$ Universidad Andrés Bello, Disponível em http://www.aiep.cl/ acesso em 01/11/2006

SAKATA, Marici Cristine Gramacho, Globalização e Educação: A formação do comunicador social na América Latina, 2008312 p. (Doutorado - Orientação BACCEGA, M. A.) Escola de Comunicações e Artes da Universidade de São Paulo, São Paulo, SP, 2008 
quehacer económico del país y a las necesidades educativas de los distintos segmentos de jóvenes y adultos.

Desde un punto de vista corporativo, se caracteriza por la diversidad de su oferta académica, la extensión de su cobertura geográfica y la consolidación de su proyecto educativo orientado a la creación de soluciones educacionales expresadas en distintas modalidades formativas, transformando a la institución en una organización que signifique reales oportunidades de desarrollo para quienes demandan sus servicios. Este modelo representa la base de su posicionamiento, lo cual significa obtener reconocimiento del entorno por su compromiso con la educación del país.

Misión Institucional

El propósito del Instituto Profesional AIEP es formar profesionales y técnicos capaces de insertarse eficientemente en el mundo de la empresa, en el marco de una economía globalizada y por este medio, ser un aporte activo al desarrollo del país.

Su proyecto educativo responde a las necesidades del mundo del trabajo incrementando las posibilidades de empleabilidad de sus egresados, es por esto que la formación por competencias laborales, el espiritu emprendedor, la autogestión, el dominio del inglés y el desarrollo de actitudes y valores acordes al desempeño laboral y social constituyen los ejes que articulan su proyecto educativo, en el marco de un esquema de flexibilidad formativa y de continuidad de estudios.

El Instituto Profesional AIEP educa a jóvenes y adultos provenientes de diferentes estratos de la población cuyo interés es el progreso a través de la educación, lo cual implica considerar en nuestra propuesta la compatibilización de la actividad laboral y educacional.

En su quehacer se propone contribuir a la valorización de la educación profesional y técnica como generadora de oportunidades y como aporte a la equidad y al desarrollo del pais.

- Características e Objetivos do Curso de Comunicação ou Especialidade da Instituição

\section{Comunicación y Relaciones Públicas}

Campo ocupacional

La formación de este técnico le permite desenvolverse en las áreas de Comunicación Organizacional, Marketing y Relaciones Públicas, pudiendo desempeñarse en todo tipo de empresas e instituciones públicas y privadas, que requieran de la implementación de estrategias de comunicación masiva.

Las competencias adquiridas durante su formación lo capacitan, al mismo tiempo, para generar sus propios espacios de trabajo, a través de la creación y gestión de microempresas o la prestación de servicios de asesoría en el área comunicacional.

Duración de 4 Semestres + Proceso de Titulación

Requisitos de ingreso: Licencia de Enseñanza Media y Certificado de Nacimiento.

- Grade Curricular

SAKATA, Marici Cristine Gramacho, Globalização e Educação: A formação do comunicador social na América Latina, 2008312 p. (Doutorado - Orientação BACCEGA, M. A.) Escola de Comunicações e Artes da Universidade de São Paulo, São Paulo, SP, 2008 


\section{Técnico en Comunicación y Relaciones Públicas \\ Malla Curricular $2007^{(1) \text { y (2) }}$}

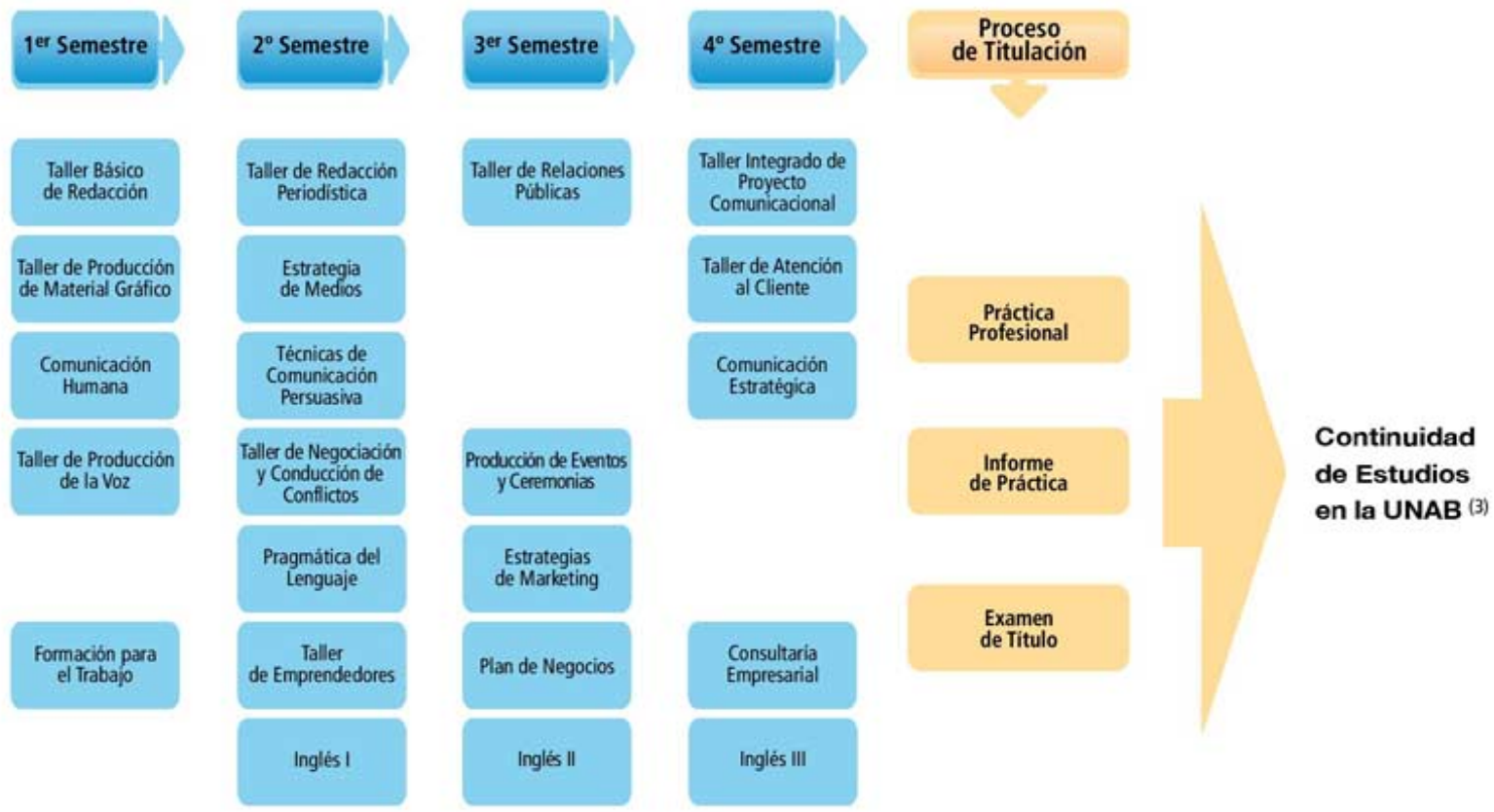

Título: Técnico de Nivel Superior en Comunicación y Relaciones Públicas

(1) Mallas syjetas a cambios de acuerdo a las necesidades del campo laboral y sus exigencias

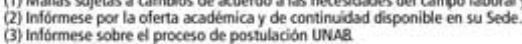

\section{4 $\underline{\text { Universiadad de las Americas - Escuela de Comunicaciones }}{ }^{291}$}

\section{- Características e Missão da Instituição}

Visión y Misión

Universidad de Las Américas responde a la realidad país, reconociendo que el único camino posible para aumentar la fuerza laboral capacitada es la educación. Segundo, que cualquier joven debe tener la oportunidad de cursar estudios superiores, independiente de su origen socio-económico y su recorrido escolar y, tercero, que los actuales trabajadores también deben tener la posibilidad de acceder a educación superior y/o perfeccionamiento profesional.

- Características e Objetivos do Curso de Comunicação ou Especialidade da Instituição

Escuela de Comunicaciones

La Escuela de Comunicaciones se orienta a la formación de profesionales estrategas en comunicación, ya sea en la industria audiovisual, publicitaria o corporativa. Asimismo, busca lograr que sus egresados cuenten con un cuerpo de conocimientos, técnicas y habilidades que les permita dar una asesoría del más alto nivel. Actualmente se vive una época de cambios, donde el concepto "aldea global" acuñado por Mac Luhan cobra especial fuerza. En este panorama se hace imprescindible que las organizaciones se inserten dentro de la comunidad, a fin de crear vinculaciones provechosas.

${ }^{291}$ Universiadad de las Americas, Disponível em http://www.uamericas.cl/ acesso em 01/11/2006

SAKATA, Marici Cristine Gramacho, Globalização e Educação: A formação do comunicador social na América Latina, 2008312 p. (Doutorado - Orientação BACCEGA, M. A.) Escola de Comunicações e Artes da Universidade de São Paulo, São Paulo, SP, 2008 
Relaciones Públicas

Publicidad

Comunicación Audiovisual y Multimedia

La misión de la Escuela de Periodismo se orienta a formar profesionales con una excelente redacción en todos los géneros periodísticos, con un eficiente manejo multimedial y tecnológico, capacitados para el diseño y la gestión de medios de comunicación.

Profesional con sólidos fundamentos éticos, capaces de desarrollarse en todos los campos de la comunicación y de liderar e interpretar los grandes cambios de la sociedad.

Formamos periodistas para la era digital, que se puedan desempeñar con éxito no sólo en medios tradicionales, sino que también en los nuevos formatos electrónicos.

Título: Periodista

Grado Académico: Licenciado en Ciencias de la Comunicación

Régimen Duración Malla

Pregrado Diurno 10 Semestres

Pregrado Vespertino 11 Semestres

Fundamentos de la carrera

La Escuela de Periodismo de Universidad de Las Américas busca formar periodistas y comunicadores para la era digital, que se puedan desempeñar con éxito no sólo en medios tradicionales (televisión, diarios, revistas, radios), sino que también en los nuevos formatos electrónicos y en los más variados ámbitos del mundo empresarial. Por ello, los planes formativos de nuestra Universidad están estrechamente ligados al notable avance que han experimentado -y que experimentan- las comunicaciones a nivel mundial.

Orientación de la Carrera

Preparar periodistas con una muy buena base teórica y, a la vez, práctica por la vía de los talleres.

Formar profesionales con capacidad de desarrollar estrategias de comunicación social.

Formar profesionales con competencias en las nuevas tecnologías de la información, comunicación y los medios digitales.

Formación de profesionales con una visión actual del periodismo y con especializaciones temáticas.

Profundizar el acercamiento del periodismo con la industria de las comunicaciones sociales y las empresas (desde Pymes a grandes).

Perfil Profesional

Profesionales que se integren al mercado con mentalidad creativa e innovadora.

Profesionales que acepten los desafios de los nuevos tiempos (era digital).

Profesionales con reconocida capacidad de emprendimiento y de autogestión empresarial.

Profesionales que interactúen en las empresas con idoneidad, desde la gestión a la producción y realización de temas en las áreas de su incumbencia.

Profesionales de carácter polifuncional con especializaciones temáticas.

Con una visión estratégica de las comunicaciones y conocimiento avanzado del idioma inglés.

Campo Ocupacional

Medios de comunicación tradicionales escritos (diarios pagados y gratuitos); audiovisuales (canales de televisión abierta y cerrados, y radios AM, FM y digitales)

Medios electrónicos (diarios electrónicos y páginas web).

Departamentos comunicacionales de empresas productivas, sean estas grandes, medianas o pequeñas.

SAKATA, Marici Cristine Gramacho, Globalização e Educação: A formação do comunicador social na América Latina, 2008312 p. (Doutorado - Orientação BACCEGA, M. A.) Escola de Comunicações e Artes da Universidade de São Paulo, São Paulo, SP, 2008 
Instituciones y reparticiones públicas.

Organizaciones diversas (municipios, fundaciones, corporaciones)

Empresas de asesorías y comunicaciones corporativas.

En comandos de alianzas y/o partidos políticos, antes, durante y después de campañas politicas.

Compañias de marketing y publicidad (redacción de campañas, insertos, boletines, comunicados y otros impresos)

- Grade Curricular

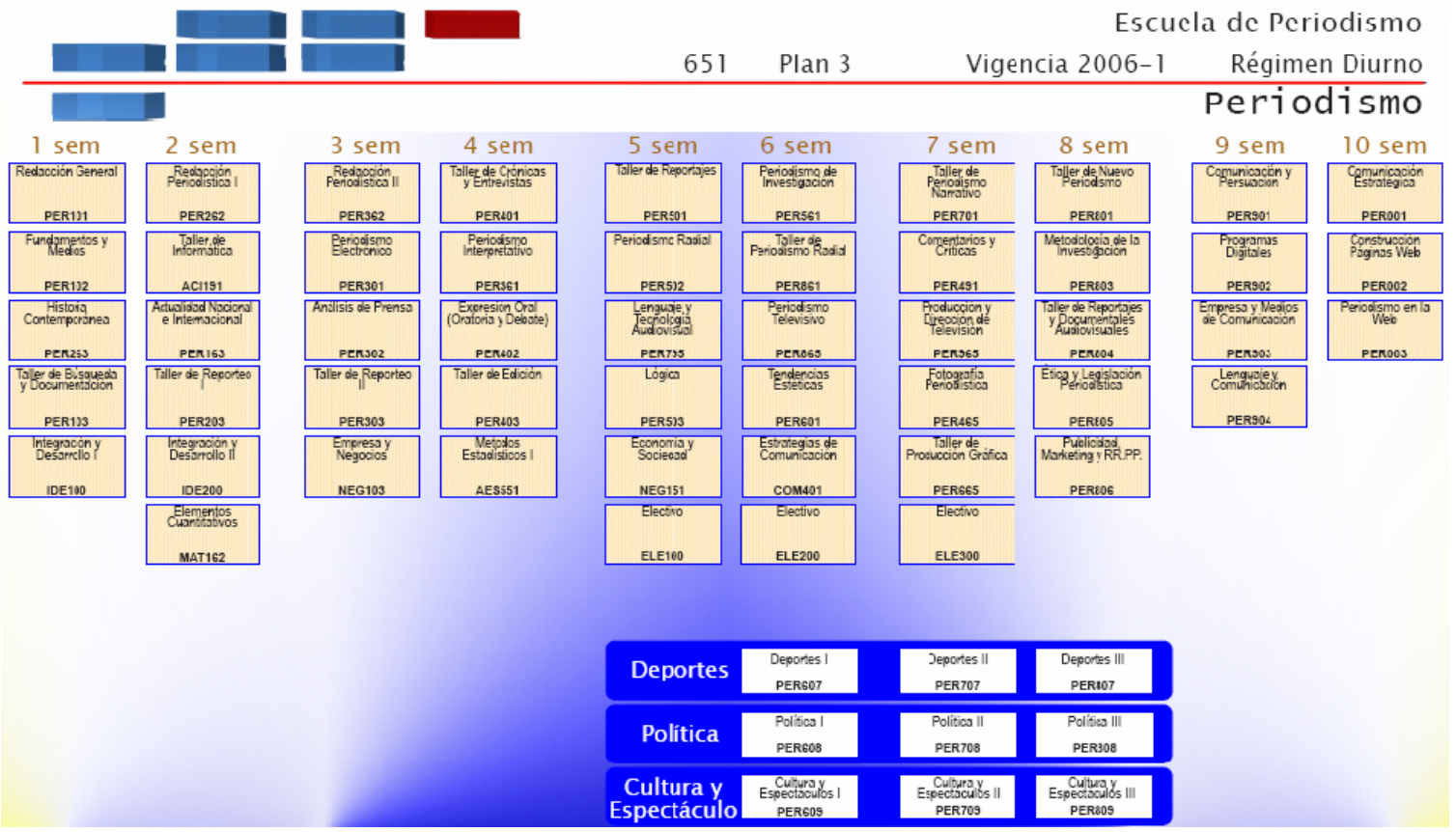




\section{COLÔMBIA}

\begin{tabular}{|l|l|l|l|l|}
\hline $\begin{array}{l}\text { 4. } \\
\text { Colômbia }\end{array}$ & $\begin{array}{l}4.1 \text { Pontificia } \\
\text { Universidad } \\
\text { Javeriana }\end{array}$ & $\begin{array}{l}4.2 \text { Universidad De } \\
\text { Antioquia }\end{array}$ & $\begin{array}{l}4.3 \text { Universidad } \\
\text { Externado de } \\
\text { Colombia }\end{array}$ & $\begin{array}{l}4.4 \text { Universidad } \\
\text { Central }\end{array}$ \\
\hline
\end{tabular}

\section{Universidades Nacionais}

\section{1 $\underline{\text { Pontificia Universidad Javeriana - Facultad de Comunicación y Lenguaje }}{ }^{292}$}

\section{- Características e Missão da Instituição}

Instituição não oficial - fundação. Reg.Calif.-Acred.Voluntaria Misión

En el inmediato futuro, la Universidad Javeriana impulsará prioritariamente la investigación y la formación integral centrada en los currículos; fortalecerá su condición de universidad interdisciplinaria; y vigorizará su presencia en el país, contribuyendo especialmente a la solución de las problemáticas siguientes:

- La crisis ética y la instrumentalización del ser humano.

- El poco aprecio de los valores de la nacionalidad y la falta de conciencia sobre la identidad cultural.

- La intolerancia y el desconocimiento de la pluralidad y la diversidad.

- La discriminación social y la concentración del poder económico y político.

- La inadecuación e ineficiencia de sus principales instituciones.

- La deficiencia y la lentitud en el desarrollo científico y tecnológico.

- La irracionalidad en el manejo del medio ambiente y de los recursos naturales.

Acuerdo $N^{\circ} 0066$ del Consejo Directivo Universitario, 22 de abril de 1992

El Proyecto Educativo de la Pontificia Universidad Javeriana comprende las directrices concretas para el ejercicio de las funciones universitarias que desarrolla la Comunidad Educativa en el marco de la Formación Integral de sus miembros y en la perspectiva de la Interdisciplinariedad.

Las funciones de Docencia, Investigación y Servicio convergen en el quehacer general de la Institución y generan relaciones interpersonales y de organización que involucran a todos los estamentos de la Universidad $y$ aun a personas o entidades de fuera de ella. Acuerdo No; 0066 del Consejo Directivo Universitario, 22 de abril de 1992

- Características e Objetivos do Curso de Comunicação ou Especialidade da Instituição

La Facultad de Comunicación y Lenguaje se propone los siguientes objetivos:

- Articular en relación interdisciplinaria las áreas del conocimiento indispensables para la comprensión de la información, la significación y la comunicación.

- Generar procesos de investigación permanente para el desarrollo del estatuto teórico de los campos del saber correspondientes a las ciencias de la información, la comunicación y el lenguaje.

- Contribuir a la formación integral de profesionales, especialistas e investigadores en los ámbitos de la información, la comunicación y el lenguaje, que fundamenten su quehacer desde

292 Pontificia Universidad Javeriana, Disponível em www.javeriana.edu.co acesso em 10/08/2006

SAKATA, Marici Cristine Gramacho, Globalização e Educação: A formação do comunicador social na América Latina, 2008312 p. (Doutorado - Orientação BACCEGA, M. A.) Escola de Comunicações e Artes da Universidade de São Paulo, São Paulo, SP, 2008 
la propia realidad sociocultural y desarrollen las respectivas habilidades cognoscitivas e instrumentales movidos por criterios éticos coherentes con la búsqueda de una sociedad justa y participativa.

El Departamento de Comunicación es una unidad académica que desarrolla la reflexión en torno a los procesos de producción, circulación, recepción y usos de mensajes y procesos comunicativos, mediante la investigación, los servicios docentes en programas académicos de pre y postgrado; los servicios de educación continua y las asesorías empresariales.

El Departamento de Comunicación de la Universidad Javeriana aborda el campo de la comunicación a partir de cuatro conceptos: interacción, significación, actores y contexto.

La interacción que va más allá del mero intercambio de información y de la negociación. Es el intercambio de sentido, donde los mensajes, las personas de una cultura y la realidad se ponen en relación para que se produzca un acercamiento, una "contaminación", una "fricción" que no necesariamente lleva al entendimiento, pero que sí relaciona a los seres humanos y los hace concientes de sus semejanzas y diferencias.

La significación que es el espacio de encuentro, un momento de la comunicación, el lugar que permite que la comunicación pueda ser posible, ya sea a través del texto, de los signos o de los códigos.

Los actores, ya sean sujetos o funciones sociales, capaces de interpretar, expresar y transformar la cultura y el orden social. Estos actúan en un contexto, en un ámbito o realidad particular, que delimita y a la vez abre nuevos horizontes.

Características

La Carrera de Comunicación Social se creó en 1963, mediante la resolución $N^{\circ} 3557$ del Ministerio de Educación Nacional.

Títulos: Comunicador(a) social y Comunicador(a) Social-Periodista

Duración: Cinco años; Tipo: Pregrad; Modalidad: Presencial ; Jornada: 7:00 a.m. - 9:00 p.m. $N^{\circ}$ de Créditos: 180; $N^{\circ}$ de profesores de planta: $26 ; N^{\circ}$ de profesores de hora cátedra: 170

\section{OBJETIVOS}

Busca la formación integral de profesionales competentes en el conocimiento de los procesos de comunicación social y su aplicación en un campo profesional especifico: periodismo, publicidad, comunicación organizacional, producción audiovisual, radiofónica o editorial. La formación en estos campos implica la comprensión global de los procesos de comunicación en relación con los fenómenos socioculturales y la adquisición de habilidades para utilizar eficiente y constructivamente los respectivos lenguajes y medios de comunicación en la producción y recepción de mensajes.

Promover la formación y el desarrollo de la autonomía a través de un currículo flexible.

Orientar las acciones de formación y las posteriores acciones profesionales hacia el desarrollo del país y la intervención en grupos y comunidades menos favorecidas en lo intelectual, lo físico y lo económico.

Reconocer que la comunicación se ubica dentro de los procesos sociales y culturales y por ende requiere el concurso de las ciencias humanas y sociales, pero no de manera independiente, sino en cuanto que éstas iluminan y son iluminadas por los mismos procesos y acciones comunicacionales.

Comprender los procesos complejos de construcción, circulación y recepción de mensajes y la manera como éstos se han ido formalizando en diferentes momentos y lugares.

Conocer y desarrollar las diversas modalidades de expresión humana que alcanzan nuevas dimensiones y otras extensiones con los desarrollos tecnológicos y que ponen en evidencia la sensibilidad y creatividad del ser humano.

\section{PERFILES}

1. Perfil de ingreso

El programa busca que los aspirantes se aproximen al siguiente perfil:

SAKATA, Marici Cristine Gramacho, Globalização e Educação: A formação do comunicador social na América Latina, 2008312 p. (Doutorado - Orientação BACCEGA, M. A.) Escola de Comunicações e Artes da Universidade de São Paulo, São Paulo, SP, 2008 
Sensibilidad por la realidad social, politica, económica y cultural tanto del país como del mundo que lo rodea y, además, una actitud crítica frente a cualquier situación.

Interés por la lectura, la escritura, el cine, la televisión, la multimedia y afinidad con las artes. Preferiblemente con excelencia en alguna forma de expresión.

Actitud investigativa para crear nuevos conocimientos sobre la realidad social y los diversos campos del saber y hacer comunicacional.

Alto desempeño en la expresión oral, escrita y audiovisual. Conocimientos básicos de informática aplicada.

Aptitud para conocer las propuestas que les ofrece la ciencia para profundizar en el conocimiento del mundo y del campo de la comunicación.

Actitud para trabajar en organizaciones públicas o privadas, nacionales o internacionales $y$, preferiblemente, para ser gestor de sus propias empresas y proyectos de comunicación.

Disposición para aprender a comunicarse en un segundo idioma

2. Perfil de egreso

El Comunicador Social Javeriano estará en capacidad de:

Comprender el desarrollo humano y comunitario mediante situaciones que posibiliten la búsqueda de la verdad, el ejercicio de la libertad con autonomía y responsabilidad, así como la convivencia basada en el respeto a la diferencia, la participación, la igualdad, la equidad, el compromiso y la justicia social.

Desarrollar nuevas maneras de hacer comunicación que sean expresión de creatividad humana y que generen la participación para la construcción de nuevos mundos con sentido.

Articular las acciones de comunicación y los procesos sociales, politicos, económicos y culturales del pais, como base del compromiso para la comprensión y la intervención social.

Tener una visión universal (esto es, universitaria) que permita comprender la transversalidad de la comunicación por su intrínseca interrelación con los demás quehaceres humanos; conocer sistemáticamente el mundo que nos rodea y la realidad especifica en la que hemos de intervenir; tener una perspectiva histórica y amplia del mundo que posibilite la apropiación crítica de la cultura para articular el interés público con los proyectos personales.

Realizar estudio, análisis, reflexión y producción de la comunicación a partir de núcleos problemáticos que respondan a situaciones en las que intervienen las acciones de comunicación y que por ello sean tareas por descifrar, comprender y proyectar.

Asumir la investigación como fundamento y respaldo de cualquiera de las actividades comunicacionales que se realicen, en las que se haga presente la curiosidad y admiración, la observación y sistematización rigurosas, la visión analítica y crítica, buscando fomentar la actitud investigativa como base de toda acción profesional.

Diseñar proyectos que enmarquen y den mayor dimensión a los productos y procesos de comunicación (el comunicador como gestor de proyectos en todos los campos).

Realizar productos comunicacionales reconociendo las técnicas como condicionantes y posibilitadoras de la creatividad y la invención humanas, sustentadas en categorías conceptuales y acompañadas de procesos reflexivos sobre la propia producción.

3. Perfil ocupacional o profesional

Según el énfasis profesional elegido, el egresado del programa de Comunicación Social de la Universidad Javeriana se podrá desempeñar profesionalmente en alguno de los siguientes campos:

Periodismo: El periodista puede desarrollar su profesión en medios impresos, audiovisuales y digitales, no sólo en las grandes empresas informativas, sino también de los medios de comunicación local y regional. En ellos, este periodista está capacitado para desempeñar diversas funciones: redactor o reportero, redactor jefe y editor en los impresos; director de contenidos en proyectos de prensa digital; investigador, reportero, guionista y libretista de espacios informativos en radio y televisión. Además, puede trabajar en las oficinas de comunicación de instituciones públicas y privadas, en la elaboración de información y en la dirección de medios para públicos externos. Así mismo, está preparado para apoyar y desarrollar investigaciones en organizaciones no gubernamentales y distintas instituciones de carácter cientifico.

SAKATA, Marici Cristine Gramacho, Globalização e Educação: A formação do comunicador social na América Latina, 2008312 p. (Doutorado - Orientação BACCEGA, M. A.) Escola de Comunicações e Artes da Universidade de São Paulo, São Paulo, SP, 2008 


\section{ESTRATEGIAS PEDAGÓGICAS}

Las estrategias comprenden cursos, seminarios, talleres, laboratorios, tutorías, pasantías y prácticas profesionales $O$ sociales.

\section{PASANTİAS Y PRÁCTICAS PROFESIONALES}

Las pasantías corresponden a un nivel intermedio de formación de los estudiantes. Son los trabajos que los estudiantes desarrollarán en proyectos concretos, relacionados con el campo profesional al que pertenecen y liderados por profesores. Las pasantías tienen dos créditos y pueden hacerse hasta durante dos semestres consecutivos.

Las prácticas profesionales se realizan en décimo semestre, los estudiantes son ubicados en diversas empresas y entidades: Ministerio de la Cultura, Hábitat para la Humanidad, Alcaldía Mayor de Bogotá, El Tiempo, Revista Cambio, CityTV, Walter Thompson, CNN Miami, CocaCola, Maloka, etc.

\section{INTERCAMBIOS Y CONVENIOS}

La Pontificia Universidad Javeriana ofrece en la actualidad convenios con aproximadamente 120 universidades en el exterior y 12 universidades en Colombia.

1. Convenios Internacionales

Convenios multilaterales:

ISEP-International Student Exchange Program: Programa al cual están afiliadas instituciones de educación superior en el mundo entero. En este programa se abre un amplio abanico de posibilidades de intercambio reciproco con 108 universidades estadounidenses y 33 universidades de otros países (Australia, Canadá, Francia, Suiza, etc.).

Intercampus: Programa de cooperación entre España y América Latina que posibilita la estadía de máximo doce semanas en universidades españolas a estudiantes universitarios de último grado de pregrado, estudiantes de posgrado, docentes y gestores universitarios.

El Dorado: Programa de intercambio entre universidades de Colombia y Francia, dirigido a docentes, investigadores, estudiantes de pregrado y posgrado de cualquier área.

CREPUQ-ASCUN: Programa de intercambio estudiantil entre universidades de Colombia y de la Provincia de Québec (Canadá), a través del cual los estudiantes javerianos pueden cursar un período académico en una de las diez universidades afiliadas en Québec.

Convenios bilaterales:

Programas de intercambio y cooperación bilateral entre estudiantes, profesores $e$ investigadores, con aproximadamente 90 universidades en el exterior (Alemania, Brasil, Corea, Chile, Escocia, Estados Unidos, Italia, etc.)

Convenios AUSJAL:

Cooperación entre las universidades que pertenecen a la Asociación de Universidades confiadas a la Compañía de Jesús en América Latina (Argentina, Brasil, Chile, El Salvador, Perú y Venezuela).

Convenios nacionales:

Programa Sígueme: programa de intercambio estudiantil con 12 de las principales universidades del país (Universidad de Antioquia, Universidad Pontificia Bolivariana, Universidad EAFIT, Universidad Externado de Colombia, Universidad Industrial de Santander, Pontificia Universidad Javeriana —en las sedes de Bogotá y Cali-; Universidad Nacional de Colombia —en las sedes de Bogotá, Medellín y Manizales-; Universidad del Norte, Universidad del Valle).

\section{- Grade Curricular}

\section{PLAN DE ESTUDIOS \\ 1. Características del plan de estudios}

Flexibilidad

Desarrollo de la autonomía

Enfoque interdisciplinario

Sistema de créditos (180)

SAKATA, Marici Cristine Gramacho, Globalização e Educação: A formação do comunicador social na América Latina, 2008312 p. (Doutorado - Orientação BACCEGA, M. A.) Escola de Comunicações e Artes da Universidade de São Paulo, São Paulo, SP, 2008 


\section{Diversidad metodológica}

Núcleo de Formación Fundamental (138 Créditos: 77\%): Incluye los conocimientos y prácticas necesarios para la fundamentación del campo de la comunicación y su relación con otras disciplinas. Además, experiencias y actividades de enseñanza y aprendizaje que posibilitan al estudiante la apropiación de conocimientos y conceptos básicos, asi como de las competencias $y$ destrezas que definen de manera específica y esencial la formación en la disciplina y le permiten al egresado ser reconocido como miembro de la comunidad académica o profesional de la comunicación.

Núcleo de formación profesional (42 créditos: 23\%): Promueve la apropiación y aplicación de conocimientos en un campo especifico, dentro de la misma área de conocimiento de la comunicación.

Componente conceptual y disciplinar: Está orientado a formar el estudiante en el campo de la comunicación, sus enfoques, escuelas y autores.

Componente sociohumanístico: Comprende los saberes que complementan la formación integral del comunicador y contribuye a la sensibilización del estudiante hacia la responsabilidad social, el compromiso ético, el diálogo interdisciplinario y la comprensión del contexto sociopolítico del país y el contexto internacional.

Componente de expresión: Aborda las modalidades de expresión humana que posibilitan la comunicación, alcanzan nuevas dimensiones con el desarrollo de las tecnologías y manifiestan la sensibilidad y creatividad del ser humano.

Componente de investigación: Está orientado a la compresión y aplicación de los métodos de investigación en comunicación y los diversos campos profesionales.

Componente técnico: Se ocupa de capacitar al estudiante en el uso y aprovechamiento de los medios, sistemas y tecnologías de comunicación e información.

Componente de gestión: Busca que el estudiante comprenda el campo profesional y esté prepararlo para diseñar, dirigir y desarrollar proyectos, procesos y estrategias de comunicación.

Ciclo I (primer año): Conocimiento, por parte del estudiante, del ámbito social, científico y profesional de la comunicación, intensificación sus aptitudes y afianzamiento de las competencias mínimas en diversas formas de expresión.

Ciclo II (segundo a cuarto año): Desarrollo de competencias profesionales comunes de los comunicadores sociales y especificas de los campos profesionales.

Ciclo III (quinto año): Finalización de estudios académicos e inserción en el mundo laboral.

\section{2 $\underline{\text { Universidad de Antioquia - Comunicacion Social }}^{293}$}

\section{- Características e Missão da Instituição}

La Universidad de Antioquia es una institución estatal del orden departamental, que desarrolla el servicio público de la Educación Superior, creada por la Ley LXXI del 4 de diciembre de 1878 del Estado Soberano de Antioquia, organizada como un ente Universitario Autónomo con régimen especial, vinculada al Ministerio de Educación Nacional en lo atinente a las políticas y a la planeación del sector educativo y al Sistema Nacional de Ciencia y Tecnología. Goza de personería jurídica, autonomías académica, administrativa, financiera y presupuestal, y gobierno, rentas y patrimonio propios e independientes; se rige por la Constitución Politica, la Ley 30 de 1992, las demás disposiciones que le sean aplicables de acuerdo con su régimen especial, y las normas internas dictadas en ejercicio de su autonomía.

\section{Presentación}

${ }^{293}$ Universidad de Antioquia, Disponível em www.udea.edu.co acesso em 10/08/2006

SAKATA, Marici Cristine Gramacho, Globalização e Educação: A formação do comunicador social na América Latina, 2008312 p. (Doutorado - Orientação BACCEGA, M. A.) Escola de Comunicações e Artes da Universidade de São Paulo, São Paulo, SP, 2008 
Con este Plan de Desarrollo, la Institución da un paso adelante en la construcción de la Universidad del futuro. Una universidad que por medio de sus profesores y estudiantes, con sus conocimientos y sus capacidades para investigar se convierte en un factor fundamental del desarrollo social, y es fuente permanente de renovación académica, científica y cultural. Fernando González, con su agudo sentido de comprender a la humanidad, adquirido en esa búsqueda continua por aprender a vivir con intensidad los detalles de la existencia, decía: "la Universidad está en cada uno de vosotros... asi pues, si vais a Heilderberg, a la Sorbona, a Roma, buscando Universidad, sois desertores de la Universidad, desesperados fugitivos de vosotros mismos..." Entender que la Universidad está en cada uno de nosotros, que es una de las expresiones sociales y por tanto se debe a la sociedad, que no es nuestra en particular sino de todos en general, es una tarea ardua que requiere la transformación hacia una nueva cultura; pero si descubrimos esa parte de su esencia, hemos dado un paso fundamental para superar los conflictos que hoy nacen con ingenua facilidad, por la apropiación individual que quieren hacer de ella quienes la pretenden convertir en un instrumento para una u otra ideología, para uno u otro poder. Aprender a levantar los cimientos de una sociedad culta es una tarea de siglos. Quizás faltan aún muchas guerras y demasiados conflictos. Allanados éstos, con el concurso de hombres capaces de superar el pesimismo y contrarrestar la negligencia, vendrán la tolerancia, el respeto y la solidaridad, esos valores que no han logrado trascender la retórica y a los cuales hay que inventarles un sentido humano para hacerlos accesibles al entendimiento. Sólo así aprenderemos el verdadero alcance de la democracia, de la autonomía, de la libertad y del compromiso del universitario con el desarrollo de la humanidad.

Hoy, querámoslo o no, comienza una nueva etapa para la Universidad pública colombiana y ella no depende solamente de los cambios despertados con las nuevas leyes, y que han permitido que los diferentes estamentos participen, así sea modestamente, pues todavía no se ha entendido con suficiente claridad la importancia de asumir los retos de la autogestión, sino también con la conciencia adquirida por nuestros dirigentes, acerca de que la Universidad tiene que cumplir una función social, lo cual no se logra sino formando ciudadanos idóneos, ética y científicamente preparados, comprometidos con el cambio y capaces de llevar la Universidad, en nuestro caso particular, a todos los rincones del Departamento. Para lograrlo, apoyados en los avances tecnológicos que parece nos aproximaran a un nuevo siglo de las luces, hace falta la imaginación, que como cantera de la inteligencia, invente modelos novedosos y flexibles, propicie la interdisciplinariedad que de por sí sola es capaz de producir una verdadera revolución curricular, incremente el trabajo en equipo que nos ayude a resolver las diferencias, integre a los egresados y llegue a los medios, a la industria, a los gremios y al pueblo mismo, lo que significa salirse de los esquemas tradicionales que han anquilosado la cátedra, y propicie por esas y otras razones, el suficiente desprendimiento, para que el investigador acepte que mucha parte de su trabajo puede ser realizado por estudiantes y profesores del común, y de ese modo, la función de investigar, ese eje que el Estatuto general ha definido como el motor del desarrollo científico, haga parte de la rutina diaria de los claustros

universitarios.

La Universidad no puede seguir siendo un mero instrumento de la transmisión pasiva del conocimiento. Tiene que sacudirse internamente, renovarse moral e intelectualmente, diseñar modelos pedagógicos que la saquen de la mediocridad, producir nuevos conocimientos por medio del fortalecimiento de sus investigaciones básicas y aplicadas, vincularse a la sociedad a la cual se debe y, sobre todo, ser un factor en la transformación de las condiciones de vida de nuestro pueblo. Sin este último elemento, no pasará de ser una entidad condicionada por realidades demasiado crudas, atosigada en medio de la incertidumbre y sin capacidad de reaccionar.

En suma, con este plan la Institución consolida un modelo de universidad que siempre está preocupada por la búsqueda de la excelencia, con posibilidades de competir en el medio nacional e internacional, con gran cobertura, con capacidad para ayudar a transformar las condiciones sociales del país, con un espiritu permanente de renovación, de controversia y de

SAKATA, Marici Cristine Gramacho, Globalização e Educação: A formação do comunicador social na América Latina, 2008312 p. (Doutorado - Orientação BACCEGA, M. A.) Escola de Comunicações e Artes da Universidade de São Paulo, São Paulo, SP, 2008 
investigación. Una universidad que cada vez está más cercana al corazón de su pueblo. JAIME RESTREPO CUARTAS.

Rector, Universidad de Antioquia.

- Características e Objetivos do Curso de Comunicação ou Especialidade da Instituição

Facultad de Comunicaciones

Departamento de Comunicación Social comunicacion social-periodismo

Misión do Curso

Formar Comunicadores Sociales - Periodistas que se desempeñen con idoneidad en las distintas áreas profesionales que les competen, para que contribuyan a los procesos de desarrollo institucionales y sociales de la región y del país, con su trabajo responsable, analítico, creativo, participativo, y desarrollar programas de alta calidad en investigación, extensión, producción y asesoría.

Título que otorga El programa otorgará el título de Comunicador Social - Periodista

Perfil profesional

El Comunicador Social - Periodista egresado de la Universidad de Antioquia podrá desempeñarse como periodista de radio, prensa y televisión, director o realizador de medios audiovisuales, director, asesor y ejecutor de proyectos de comunicación organizacional, relaciones públicas y comunicación para el desarrollo.

Misión da Facultad

La Facultad de Comunicaciones de la Universidad de Antioquia desarrolla el servicio público de la educación en Comunicación, Comunicación Audiovisual y Multimedial, Periodismo, Lingüística y Literatura, mediante la docencia, la investigación y la extensión. Sus integrantes están comprometidos con la excelencia académica, el desarrollo humano y social, y la promoción de la ética ciudadana.

Ofrece programas de pregrado y posgrado, cuyos contenidos y pedagogía se evalúan y mejoran de acuerdo con los desarrollos académicos y las necesidades sociales y laborales. Desarrolla la investigación disciplinar y aplicada con participación de profesores y estudiantes y ofrece programas de extensión en sus diferentes modalidades.

Visión

Para el trienio 2004-2007 la Facultad de Comunicaciones seguirá consolidando sus actividades académicas y administrativas, para contribuir al logro de los objetivos del Plan de Desarrollo de Antioquia en las áreas de la Comunicación, la Comunicación Audiovisual y Multimedial, el Periodismo, la Literatura y la Lingüistica, mediante programas de docencia, investigación y extensión, en la sede central y en las diferentes regionales del Departamento de Antioquia.

- Grade Curricular

Universidad de Antioquia - Facultad de Comunicaciones - Departamento de comunicación social

Vigente a partir del semestre 1 de 2001

\begin{tabular}{|l|l|l|l|l|l|} 
SEM & CODIGO NOMBRE DE LA & TIPO & CRED & HORAS & REQUISITO
\end{tabular}

SAKATA, Marici Cristine Gramacho, Globalização e Educação: A formação do comunicador social na América Latina, 2008312 p. (Doutorado - Orientação BACCEGA, M. A.) Escola de Comunicações e Artes da Universidade de São Paulo, São Paulo, SP, 2008 


\begin{tabular}{|c|c|c|c|c|c|c|}
\hline & MATERIA & & & $\overline{T T E O .}$ & $\overline{P R A C .}$ & \\
\hline \multirow[t]{6}{*}{$I$} & $\begin{array}{l}\text { 1201-101 INTROD. C. } \\
\text { COMUNICACIÓN }\end{array}$ & 1 & 04 & 4 & 0 & \\
\hline & $\begin{array}{l}\text { 1203-100 INTROD. A LA } \\
\text { SOCIOLOGÍA }\end{array}$ & 1 & 04 & 4 & 0 & \\
\hline & $\begin{array}{l}\text { 1201-111 TALLER DE } \\
\text { LENGUAJE. }\end{array}$ & 3 & 03 & 2 & 2 & \\
\hline & $\begin{array}{l}\text { 1201-121 TALLER DE } \\
\text { ESCRITURA }\end{array}$ & 3 & 03 & 2 & 2 & \\
\hline & $\begin{array}{l}\text { 1203-165 INTR. HIST. AMERI. } \\
\text { LATINA }\end{array}$ & 1 & 04 & 4 & 0 & \\
\hline & 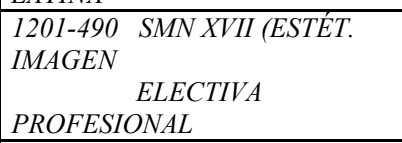 & 3 & 02 & & & \\
\hline SEM & $\begin{array}{l}\text { CODIGO NOMBRE DE LA } \\
\text { MATERIA }\end{array}$ & $T I P O$ & CRED & & $\begin{array}{l}\text { RAS } \\
P R A C .\end{array}$ & REQUISITO \\
\hline \multirow[t]{6}{*}{$I I$} & $\begin{array}{l}\text { 1203-180 INTRODUCC. } \\
\text { PSICOLOGÍA }\end{array}$ & 1 & 04 & 4 & 0 & \\
\hline & $\begin{array}{l}\text { 1202-264 SEMIOLOGIA } \\
\text { GENERAL }\end{array}$ & 1 & 04 & 4 & 0 & 1201-101 INTRO. C. CCION \\
\hline & $\begin{array}{l}\text { 1201-207 COMPOSICION } \\
\text { ESPAÑOLA }\end{array}$ & 3 & 03 & 2 & 2 & $\begin{array}{l}\text { 1201-111 TALLER DE LENG 1201- } \\
121 \text { TALLER DE ESCR }\end{array}$ \\
\hline & $\begin{array}{l}\text { 1203-310 SOCIOLOGIA DE LA } \\
\text { COMUNICACIÓN }\end{array}$ & 1 & 04 & 4 & 0 & $\begin{array}{l}\text { 1201-101 INT C. CCION } \\
100 \text { INT A LA SOCIOL }\end{array}$ \\
\hline & $\begin{array}{l}\text { 1201-485 SMN PROYECTOS } \\
\text { DE COM. }\end{array}$ & 5 & 02 & & 2 & \\
\hline & ELECTIVA BASICA I & 1 & 04 & 4 & 0 & \\
\hline \multirow[t]{6}{*}{$I I I$} & $\begin{array}{l}1201-203 \text { REDACCION } \\
\text { PERIODISTICA }\end{array}$ & 5 & 04 & 4 & 0 & $\begin{array}{l}\text { 1201-101 INT C. CCION 1201-207 } \\
\text { COMP. ESPAN } O L A\end{array}$ \\
\hline & $\begin{array}{l}\text { 1201-205 COMUNICACIÓN } \\
\text { SOCIAL }\end{array}$ & 1 & 03 & 3 & 0 & $\begin{array}{l}\text { 1201-101 INT C CCION } 1203-100 \\
\text { INT SOCIOLOGIA }\end{array}$ \\
\hline & $\begin{array}{l}\text { 1201-213 COMUNICACIÓN } \\
\text { GRAFICA }\end{array}$ & 3 & 03 & 2 & 3 & 1201-101 INT C CCION \\
\hline & \begin{tabular}{|ll}
$1201-472$ & EXPRESION ORAL
\end{tabular} & 3 & 04 & 3 & 2 & 1201-101 INT C CCION \\
\hline & \begin{tabular}{|ll} 
1201-236 FOTOGRAFIA \\
\end{tabular} & 1 & 04 & 2 & 2 & $\begin{array}{l}\text { 40 CREDITOS APROBADOS 1201- } \\
101 \text { INT C CCION }\end{array}$ \\
\hline & $\frac{\text { ELECTIVA BASICA }}{\mathrm{II}}$ & 1 & 04 & 4 & 0 & \\
\hline \multirow[t]{7}{*}{$I V$} & $\begin{array}{l}\text { 1203-280 PSICOLOGIA DE LA } \\
\text { CCION }\end{array}$ & 1 & 04 & 4 & 0 & $\begin{array}{l}\text { 1201-101 INT C CCION } 1201-180 \\
\text { INT PSICOLOGIA }\end{array}$ \\
\hline & \begin{tabular}{|ll} 
1201-211 PERIODISMO I \\
\end{tabular} & 5 & 04 & 4 & 0 & $\begin{array}{l}\text { 1201-203 RED. PERIODIST. 1201-205 } \\
\text { CCION SOCIAL 1201-213 CCION } \\
\text { GRAFICA }\end{array}$ \\
\hline & 1201-468 INFORMATICA & 1 & 04 & 4 & 0 & \\
\hline & 1201-221 RADIO I & 3 & 03 & 2 & 3 & $\begin{array}{l}\text { 1201-203 RED. PERIODIST. 1201-205 } \\
\text { CCION SOCIAL }\end{array}$ \\
\hline & $\begin{array}{l}\text { 1201-235 MEDIOS } \\
\text { INTERACTIVOS }\end{array}$ & 3 & 02 & 0 & 0 & $\begin{array}{l}\text { 1201-233 FOTOGRAFIA } 1201-234 \\
\text { LAB. FOTOGRAF. }\end{array}$ \\
\hline & 1201-215 OPINION PUBLICA & 1 & 03 & 3 & 0 & 1201-205 CCION SOCIAL \\
\hline & 1201-217 INVESTIGACION I & 1 & 04 & 4 & 0 & 1201-205 CCION SOCIAL \\
\hline \multirow[t]{6}{*}{$V$} & 1201-305 INVESTIGACION II & 1 & 04 & 3 & 3 & 1201-217 INVESTIGACION I \\
\hline & $\begin{array}{l}\text { 1201-307 CCION Y } \\
\text { DESARROLLO }\end{array}$ & 3 & 03 & 2 & 3 & $\begin{array}{lll}\text { 1201-215 OPINION PUBLICA } & 1201- \\
221 \text { RADIO I I I } & 1201-217 & \\
\text { INVESTIGACION I } & & \\
\end{array}$ \\
\hline & 1201-311 PERIODISMO II & 3 & 04 & 3 & 3 & 1201-211 PERIODISMO I \\
\hline & 1201-321 RADIO II & 3 & 03 & 1 & 5 & $\begin{array}{ll}\text { 1201-221 RADIO I } & 1201-211 \\
\text { PERIODISMO I } & \\
\end{array}$ \\
\hline & $\begin{array}{l}\text { 1201-463 DERECHO } \\
\text { COSTITUCIONAL }\end{array}$ & 1 & 04 & 4 & 0 & $\begin{array}{l}\text { 1201-211 PERIODISMO I } 1201- \\
221 \text { RADIO I }\end{array}$ \\
\hline & $\begin{array}{l}\text { ELECTIVA } \\
\text { HUMANIDADES }\end{array}$ & 1 & 04 & 4 & 0 & \\
\hline \multirow[t]{5}{*}{$V I$} & 1201-330 RADIOPERIODISMO & 1 & 04 & 3 & 3 & $\begin{array}{l}\text { 1201-311 PERIODISMO II 1201-321 } \\
\text { RADIO II }\end{array}$ \\
\hline & 1201-333 CINE I & 1 & 03 & 3 & 0 & $\begin{array}{l}\text { 1201-235 MEDIOS INTERACTIVOS } \\
\text { 1201-311 PERIODISMO II }\end{array}$ \\
\hline & \begin{tabular}{|ll} 
1201-340 TELEVISION I \\
\end{tabular} & 3 & 03 & 3 & 0 & $\begin{array}{l}\text { 1201-235 MEDIOS INTERACTIVOS } \\
\text { 1201-321 RADIO II }\end{array}$ \\
\hline & $\begin{array}{l}\text { 1201-341 RELACIONES } \\
\text { PUBLICAS I }\end{array}$ & 1 & 03 & 3 & 0 & $\begin{array}{l}\text { 80 CREDITOS APROBADOS 1201- } \\
217 \text { INVESTIGACIÓN I 1201-307 } \\
\text { CCION Y DLLO }\end{array}$ \\
\hline & 1201-351 PUBLICIDAD I & 1 & 03 & 3 & 0 & 1201-305 INVESTIGACION II \\
\hline
\end{tabular}

SAKATA, Marici Cristine Gramacho, Globalização e Educação: A formação do comunicador social na América Latina, 2008312 p. (Doutorado - Orientação BACCEGA, M. A.) Escola de Comunicações e Artes da Universidade de São Paulo, São Paulo, SP, 2008 


\begin{tabular}{|c|c|c|c|c|c|c|}
\hline & & & & & & 1201-311 PERIODISMO II \\
\hline & $\begin{array}{l}\text { SEMINARIO (ELECT. } \\
\text { PROFESIONAL) }\end{array}$ & 5 & 02 & 2 & 0 & \\
\hline & $\begin{array}{l}\text { 1201-350 REPORTERISMO } \\
\text { GRÁFICO }\end{array}$ & 1 & 04 & 3 & 3 & $\begin{array}{l}\text { 1201-236 FOTOGRAFIA 1201-311 } \\
\text { PERIODISMO II }\end{array}$ \\
\hline & $\begin{array}{l}C C S-470 \quad \text { SMN II (TLL } \\
\text { NARRACION) (ELECTIVA } \\
\text { PROFESIONAL) } \\
\end{array}$ & 3 & 02 & 1 & 3 & $\begin{array}{l}\text { 1201-203 RCCION PERIODIS 1201- } \\
236 \text { FOTOGRAFIA }\end{array}$ \\
\hline \multirow[t]{6}{*}{ VII } & 1201-313 PERIODISMO III & 5 & 04 & 4 & 0 & $\begin{array}{l}\text { 1201-305 INVESTIGAC. II 1201-311 } \\
\text { PERIODISMO II }\end{array}$ \\
\hline & $\begin{array}{l}\text { 1201-407 ADMON EMPRESAS } \\
\text { CCION }\end{array}$ & 1 & 03 & 3 & 0 & 1201-330 RADIOPERIODISM \\
\hline & $\begin{array}{l}\text { 1201-445 RELACIONES } \\
\text { PÚBLICAS II }\end{array}$ & 1 & 04 & 3 & 3 & 1201-341 RELAC. PÚBLIC. I \\
\hline & $\begin{array}{l}\text { 1201-431 TELEVISION II } \\
\text { (ELECTIVA PROFESIONAL) }\end{array}$ & 3 & 03 & 2 & 3 & $\begin{array}{ll}\text { 1201-340 TELEVISIÓN I } & 1201-311 \\
\text { PERIODISMO II } & \\
\end{array}$ \\
\hline & $\begin{array}{l}\text { 1201-435 CINE II } \\
\text { (ELECTIVA PROFESIONAL) }\end{array}$ & 3 & 03 & 2 & 3 & 1201-333 CINE I \\
\hline & 1201-454 EDICION & 5 & 04 & 4 & 0 & $\begin{array}{l}\text { 1201-213 CCION GRAFICA 1201- } \\
311 \text { PERIODISMO II }\end{array}$ \\
\hline \multirow[t]{11}{*}{ VIII } & $\begin{array}{l}\text { 1201-458 ETICA DE LA } \\
\text { CCION }\end{array}$ & 1 & 02 & 2 & 0 & 1201-330 RADIOPERIODIS. \\
\hline & $\begin{array}{l}1201-456 \text { SMN III } \\
\text { (PLANEACION) }\end{array}$ & 1 & 02 & 2 & 0 & 1201-305 INVESTIGACION II \\
\hline & \begin{tabular}{|l|}
$1201-479$ SMN X \\
PERIODISMO ECOLÓGICO \\
(ELECTIVA) \\
\end{tabular} & 5 & 02 & & & 1201-311 PERIODISMO II \\
\hline & $\begin{array}{l}\text { 1201-483 SMN XIII } \\
\text { PERIODISMO ECONÓMICO } \\
\text { (ELECTIVA) }\end{array}$ & 5 & 02 & 1 & 3 & 1201-203 RED. PERIODÍS. \\
\hline & $\begin{array}{l}\text { I201-465 SMN VI } \\
\text { PERIODISMO Y LITERATURA } \\
\text { (ELECTIVA) }\end{array}$ & 5 & 02 & 2 & 0 & 1201-311 PERIODISMO II \\
\hline & $\begin{array}{l}\text { 1201-466 T. V. INFORMATIVA } \\
\text { (ELECTIVA) }\end{array}$ & 3 & 03 & 2 & 3 & 1201-311 PERIODISMO II \\
\hline & $\begin{array}{l}\text { 1201-484 SMN XIV SALA DE } \\
\text { REDACCIÓN (ELECTIVA) }\end{array}$ & 5 & 03 & 1 & 3 & 1201-211 PERIODISMO I \\
\hline & $\begin{array}{l}\text { 1201-488 HRIA DE LA PRENSA } \\
\text { EN COLOMBIA (ELECTIVA) }\end{array}$ & 5 & 02 & 4 & 0 & 1201-311 PERIODISMO II \\
\hline & $\begin{array}{l}\text { 1201-473 SMN VIII } \\
\text { PERIODISMO POLÍTICO } \\
\text { (ELECTIVA) }\end{array}$ & 5 & 02 & 2 & 0 & 1201-311 PERIODISMO II \\
\hline & $\begin{array}{l}\text { 1201-481 PRÁCTICAS } \\
\text { ACADÉMICAS }\end{array}$ & 2 & 08 & 480 & 0 & 130 CRÉDITOS (*) \\
\hline & $\begin{array}{ll}1201-489 & \text { TRABAJO DE } \\
\text { GRADO } & \\
\end{array}$ & 2 & 08 & & & $\begin{array}{l}\text { 1201-305 INVESTIGACIÓN II } \\
135 \text { CRÉDITOS (**) }\end{array}$ \\
\hline
\end{tabular}

\section{Universidades Globalizadas}

4.3 Universidad Externado de Colombia_- $\underline{294}$

- Características e Missão da Instituição

El 15 de febrero de 1886 nació el Externado de Colombia como respuesta al absolutismo y a la supresión de la libertad de enseñanza impuestos por la dictadura de La Regeneración.

La Universidad fue fundada por el joven jurista y educador Nicolás Pinzón Warlosten, quien, con el apoyo de un grupo de ilustres maestros del liberalismo radical, estableció una institución

294 Universidad Externado de Colômbia, Disponível em

http://www.uexternado.edu.co/comunicacion/enfasis.htm acesso em 10/08/2006

SAKATA, Marici Cristine Gramacho, Globalização e Educação: A formação do comunicador social na América Latina, 2008312 p. (Doutorado - Orientação BACCEGA, M. A.) Escola de Comunicações e Artes da Universidade de São Paulo, São Paulo, SP, 2008 
que, desde sus comienzos, ha permitido el estudio y examen libre de las ideas, ha acogido a alumnos de todas las regiones del país, ha practicado el respeto por los credos religiosos $e$ ideologías políticas y ha promovido la tolerancia como fórmula para alcanzar la convivencia pacifica dentro de la heterogeneidad.

Se le llamó "Externado" porque la nueva institución recibió la influencia de los más modernos centros educativos europeos que, entonces, se oponían al viejo sistema del internado, colegio de origen medieval, inclinado a la catequización e impropio para el desarrollo autónomo de la personalidad. Externado implicaba, pues, apertura, libertad de estudio y de enseñanza.

A lo largo de su historia el Externado ha profesado los principios y valores que alentaron a sus fundadores. Han sido sus rectores Nicolás Pinzón Warlosten, Diego Mendoza Pérez, Ricardo Hinestrosa Daza y Fernando Hinestrosa.

Misión

Como institución de educación superior dedicada a la enseñanza e investigación en Ciencias Sociales, con una concepción humanística, la Universidad Externado de Colombia promueve y practica un absoluto respeto por la vida.

Su actividad se desarrolla dentro de una filosofia pluralista, abierta a todas las corrientes del pensamiento, ajena al dogmatismo y respetuosa de todos los credos religiosos e ideologías políticas. La Universidad promueve la tolerancia como fórmula para alcanzar la paz y el progreso dentro de la heterogeneidad, acoge a estudiantes de todas las regiones del pais y considera a la diversidad como una de sus mayores riquezas.

El Externado de Colombia tiene confianza y optimismo en la viabilidad de Colombia como nación y trabaja por la reafirmación de la identidad nacional; apoya la integración con los paises de América Latina como garantía de una presencia significativa en el concierto internacional y estimula la cooperación con universidades de todo el mundo para mantenerse en contacto con la cultura universal y actualizada frente al avance de las ciencias.

Dentro del espiritu liberal que la anima, la Universidad Externado de Colombia persigue el ideal de la libertad como derecho inalienable del ser humano; tiene fe en la democracia; lucha por el perfeccionamiento del Estado Social de Derecho, en la búsqueda de la igualdad en los planos social y económico, y del respeto por los Derechos Fundamentales.

Asimismo, ha procurado siempre la formación integral de sus alumnos: busca forjar verdaderos ciudadanos conscientes de sus compromisos para con la nación; personas integras, con independencia de carácter y practicantes de una ética cívica intachable, pública y privada; profesionales solidarios, auténticos, austeros, dotados con criterio, capaces de resistir la intimidación, enfrentar la corrupción y contribuir al rescate de la dignidad de la patria.

- Características e Objetivos do Curso de Comunicação ou Especialidade da Instituição

El modelo fundacional

En el mes de febrero de 1976 inicia labores la Facultad de Comunicación Social, habilitada para ello por la licencia de funcionamiento número 285, expedida por el ICFES el 14 de noviembre de 1975. Mediante Resolución 02555 del 31 de diciembre de 1985 se otorga aprobación oficial a la carrera, actualmente vigente por Resolución 002567 de octubre 14 de 1988.

El proyecto formativo inicial, conducido por el maestro José de Recasens, coloca desde el principio su acento en la solidez intelectual del comunicador, proporcionada por las humanidades y por la línea de ciencias sociales, subordinando a este ámbito de la formación la capacitación tecnológica en el manejo de medios de comunicación. Desde esta plataforma básica de formación, el comunicador accederá a los campos de la dinámica sociocultural definidos como de interés específico para el programa:

. La Opinión Pública y el Discurso Informativo

SAKATA, Marici Cristine Gramacho, Globalização e Educação: A formação do comunicador social na América Latina, 2008312 p. (Doutorado - Orientação BACCEGA, M. A.) Escola de Comunicações e Artes da Universidade de São Paulo, São Paulo, SP, 2008 
- La comunicación en la empresa, con una reflexión más allá de la Publicidad y las Relaciones

Públicas.

. La Educación No Formal, enfoque novedoso en ese entonces como área de formación en la Universidad colombiana.

Posteriormente, con motivo de la visita del ICFES para su aprobación oficial (año 1985) y en el marco del debate sobre la reglamentación para la expedición de la tarjeta profesional al periodista, se plantea la posibilidad de otorgar dos títulos: Comunicador Social y Comunicador Social-Periodista. Evaluada la inconveniencia de una doble titulación, se decide unificar el plan de estudios para expedir un único título, el de Comunicador Social-Periodista, en consideración a la vinculación laboral de los profesionales egresados.

Así, en esta segunda etapa se amplía y profundiza la línea de formación en Periodismo, se mantiene la de Comunicación Empresarial y se reemplaza la de Educación no Formal por la de Imagen, ante la evidente masificación de la televisión y la irrupción de la imagen como señal inequivoca de la cultura contemporánea. Se define desde estos parámetros la estructura curricular que se mantiene vigente en la Facultad hasta el año 1994.

Posteriormente, en el primer período académico de 1995, se comienza la implementación de la Reforma Curricular del programa, reforma impulsada por su actual decano, Miguel Méndez Camacho y en la cual participa de manera amplia la comunidad académica de la Facultad. Desde el año 2000 se ofrece el plan de estudios modificado de nueve semestres que corresponde a la tercera época de desarrollo de la Facultad. Dicho plan mantiene como característica el espiritu humanista que inspiró su fundación, incorporando al proyecto de formación las exigencias que plantea para el profesional de la comunicación la sociedad global de la información.

\section{- Grade Curricular}

En los tres últimos semestres, dedicados a los Enfasis Profesionales, las competencias del perfil básico son proyectadas a situaciones y agentes sociales concretos, y se desarrollan las capacidades profesionales del comunicador para actuar la comunicación en campos especificos:

Periodismo y Opinión Pública, conformado por el lenguaje de los diferentes medios masivos y el tratamiento periodístico de la información, que faculta al comunicador externadista para buscar, recoger, analizar, poner en contexto, redactar y transmitir información a una comunidad en los diferentes medios de manera eficaz $y$, prioritariamente, veraz.

Gestión y Comunicación, orientado a posibilitar, desde la comunicación y la cultura, la gestión de las organizaciones en perspectiva de su desarrollo social y su pertinencia cultural; capacita al egresado para: planear estrategias de comunicación acordes con los objetivos de gestión y desarrollo de organizaciones de naturaleza diversa; diseñar y producir mensajes para los medios y los públicos, según lo requieran los múltiples procesos y organizaciones de la sociedad; gerenciar proyectos de desarrollo impulsados por organizaciones de carácter privado

público.

\section{Investigación}

El conocimiento de la realidad nacional e internacional es condición ineludible para el desarrollo de actividades relacionadas con la información y el análisis en los medios masivos. El comunicador debe comprometerse con la construcción ética de la sociedad; en aras de este compromiso la Facultad conforma grupos de trabajo investigativo para evaluar, estudiar, propiciar y mejorar la dinámica de la comunicación en los medios, la organización (privada y/o estatal) y la comunidad.

SAKATA, Marici Cristine Gramacho, Globalização e Educação: A formação do comunicador social na América Latina, 2008312 p. (Doutorado - Orientação BACCEGA, M. A.) Escola de Comunicações e Artes da Universidade de São Paulo, São Paulo, SP, 2008 
Campos de acción

El egresado se podrá desempeñar en los medios de comunicación como:

Director, Jefe de redacción, Redactor o Editor; en las empresas privadas o públicas y en organismos internacionales como Director o asesor de Comunicaciones. Igualmente se podrá establecer como profesional independiente.

Productores de comunicación e información, conocedores de tecnologías de diversa complejidad y capacitados para el uso de los códigos y lenguajes de los medios masivos (comerciales, comunitarios, locales, regionales, etc.)

Estrategas y planificadores que diseñan planes, programas y proyectos para que distintos sectores usen la comunicación como agente del desarrollo social. Gerentes o directores de centros de producción de información y comunicación (empresas de medios, programadoras, oficinas de prensa, departamentos de comunicaciones). Diseñadores y gestores de procesos culturales en varios niveles de intervención social: local, regional, nacional.

\section{PLAN DE ESTUDIOS}

COMUNICACION SOCIAL-PERIODISMO

VIGENTE A PARTIR DEL I SEMESTRE/2005

\begin{tabular}{l|l}
\hline Materias & $\mathrm{H} / \mathrm{sem}$ \\
\hline PRIMER SEMESTRE & 4 \\
Teorías I ( Historia de la Comunicación) & \\
\hline Antropología Cultural & 4 \\
\hline Seminario Historia de la Cultura I & 4 \\
\hline Expresión Escrita I & 6 \\
\hline Fotografía Básica & 6 \\
\hline Lengua Extranjera I & 6 \\
\hline Nivelación Informática I & 2 \\
\hline Curso Libre 1 & 2 \\
\hline Curso Libre de Actividades 1 & 2 \\
\hline SEGUNDO SEMESTRE & 4 \\
Teorías II (El Circuito de la Comunic.) & \\
\hline Introducción al Lenguaje de la Ciencia (Básica) & \\
\hline Instituciones Políticas & 4 \\
\hline Seminario Historia de la Cultura II & 4 \\
\hline Expresión Escrita II & 4 \\
\hline Introducción al Lenguaje Audiovisual & 4 \\
\hline Lengua Extranjera II & 6 \\
\hline Nivelación Informática II & 6 \\
\hline Curso Libre de Actividades 2 & 2 \\
\hline TERCER SEMESTRE & 2 \\
\hline Teorías III (Opinión Pública) & 4 \\
\hline Semiótica I (Básica) & \\
\hline Constitucional Colombiano & 4 \\
\hline Seminario Historia de Colombia & 4 \\
\hline Expresión Escrita III & 4 \\
\hline Taller de Prensa & \\
\hline Lengua Extranjera III & 6 \\
\hline Curso Libre 2 & 6 \\
\hline Curso Libre de Actividades 3 & 2 \\
\hline CUARTO SEMESTRE & 4 \\
Nuevas Tecnologías & \\
\hline & \\
\hline & \\
\hline & \\
\hline & \\
\hline
\end{tabular}

SAKATA, Marici Cristine Gramacho, Globalização e Educação: A formação do comunicador social na América Latina, 2008312 p. (Doutorado - Orientação BACCEGA, M. A.) Escola de Comunicações e Artes da Universidade de São Paulo, São Paulo, SP, 2008 


\begin{tabular}{|c|c|}
\hline Metodología I (Inv. Descrip. y Análisis Estad.) & 4 \\
\hline Etica Ciudadana & 4 \\
\hline Seminario de Cultura Colombiana & 4 \\
\hline Economía I (Mercado) & 4 \\
\hline Taller de Radio & 6 \\
\hline Informática 1 (Graficadores) & 4 \\
\hline Lengua Extranjera IV & 6 \\
\hline Curso Libre 3 & 2 \\
\hline Curso Libre de Actividades 4 & 2 \\
\hline QUINTO SEMESTRE & 4 \\
\hline \multicolumn{2}{|l|}{ Teorías IV ( Industrias Culturales) } \\
\hline Semiótica II (Aplicada) & 4 \\
\hline Metodología II (Interpretación Cultural) & 4 \\
\hline Seminario de Conflictos Internacionales & 4 \\
\hline Economía II (Globalización) & 4 \\
\hline Escritura Audiovisual & 4 \\
\hline Taller de Televisión I & 6 \\
\hline Lengua Extranjera V & 6 \\
\hline Curso Libre 4 & 2 \\
\hline Curso Libre de Actividades 5 & 2 \\
\hline SEXTO SEMESTRE & 4 \\
\hline \multicolumn{2}{|l|}{ Teorías V (Comunicación y Globalización) } \\
\hline Seminario Trabajo de Grado & 2 \\
\hline Comunicación y Políticas Culturales & 4 \\
\hline Economía III (Colombiana) & 4 \\
\hline Taller de Televisión II & 6 \\
\hline Informática II (Multimedia) & 4 \\
\hline Semiótica III (de la Imagen) & 4 \\
\hline Lengua Extranjera VI & 6 \\
\hline Curso Libre de Actividades 6 & 2 \\
\hline SEPTIMO SEMESTRE & 4 \\
\hline \multicolumn{2}{|l|}{ Seminario Problemas Contemporáneos } \\
\hline Legislación & 4 \\
\hline Orientación Trabajo de Grado & 4 \\
\hline Curso Libre de Actividades 7 & 2 \\
\hline Enfasis I & 20 \\
\hline \multicolumn{2}{|l|}{ Periodismo } \\
\hline \multicolumn{2}{|l|}{ Historia Cultural del Periodismo } \\
\hline \multicolumn{2}{|l|}{ Información y Opinión Pública } \\
\hline \multicolumn{2}{|l|}{ Redacción Prensa } \\
\hline \multicolumn{2}{|l|}{ Reportaje } \\
\hline \multicolumn{2}{|l|}{ Periodismo Judicial } \\
\hline \multicolumn{2}{|l|}{ Periodismo Científico } \\
\hline \multicolumn{2}{|l|}{ Periodismo Político } \\
\hline \multicolumn{2}{|l|}{ Cubrimiento del Conflicto } \\
\hline \multicolumn{2}{|l|}{ Periodismo Deportivo } \\
\hline Enfasis I & 20 \\
\hline \multicolumn{2}{|l|}{ Gestión de la Comunicación } \\
\hline \multicolumn{2}{|l|}{ Modelos de Desarrollo y Cultura } \\
\hline \multicolumn{2}{|l|}{ Política Social } \\
\hline \multicolumn{2}{|l|}{ Planeación Estratégica de la comunicación } \\
\hline \multicolumn{2}{|l|}{ Taller de las Organizaciones y Comunicación } \\
\hline \multicolumn{2}{|l|}{ Pedagogía de la Comunicación } \\
\hline \multicolumn{2}{|l|}{ Taller de Estratégias y Proyecto de comunicación I } \\
\hline OCTAVO SEMESTRE & 4 \\
\hline
\end{tabular}

SAKATA, Marici Cristine Gramacho, Globalização e Educação: A formação do comunicador social na América Latina, 2008312 p. (Doutorado - Orientação BACCEGA, M. A.) Escola de Comunicações e Artes da Universidade de São Paulo, São Paulo, SP, 2008 


\begin{tabular}{l|l}
\hline Seminario Estado y Sociedad en Colombia & \\
\hline Tutoría Tesis de Grado & 4 \\
\hline Curso Libre de Actividades 8 & 2 \\
\hline Enfasis II & 20 \\
\hline Periodismo & \\
\hline Redacción Radio & \\
\hline Redacción Televisión & \\
\hline Etica & \\
\hline Planeación y Organizac. de Empresas Periodísticas & \\
\hline Periodismo Internacional & \\
\hline Periodismo Cultural & \\
\hline Periodismo Económico & 20 \\
\hline Enfasis II & \\
\hline Gestión y Comunicación & \\
\hline Finanzas para Comunicadores & \\
\hline Comunicación Virtual & \\
\hline Taller de Estratégias y Proyecto de comunicación II & \\
\hline Creación de Empresas de Comunicación Social & \\
\hline Mercadeo & 25 \\
\hline Gerencia Social & \\
\hline $\begin{array}{l}\text { NOVENO SEMESTRE } \\
\text { Práctica Profesional }\end{array}$ &
\end{tabular}

\section{4 $\underline{\text { Universidad Central - Comunicação Social e Periodismo }}{ }^{\underline{295}}$}

\section{- Características e Missão da Instituição}

El movimiento estudiantil de Córdoba (Argentina), surgido en 1918, poco después de finalizada la primera guerra mundial, y orientado contra el dogmatismo y la rigidez, tuvo decisiva influencia en la formación de las posteriores generaciones de latinoamericanos. Tal movimiento, en efecto, actualizó el acontecer universitario, sacó a los protagonistas del quehacer académico de su artificiosa torre de marfil y los puso a pensar y actuar en consonancia con las realidades, los afanes y las urgencias de nuestra gran patria latinoamericana.

Los ideales de los jóvenes argentinos también habrian de repercutir en nuestro país. Así, un congreso estudiantil reunido en 1921 fundó la primera Federación Nacional de Estudiantes, de cuya directiva formaron parte Germán Arciniegas, Calixto Torres Umaña y Luis López de Mesa, entre otros. Desde entonces, en los países situados al sur del rio Grande se han desarrollado y defendido, con mayor o menor intensidad, principios como el ejercicio de la autonomía universitaria, la enseñanza y la práctica de la ética, el sentido y el sentimiento humanisticos, la vocación latinoamericanista y la identidad con los valores y las prácticas de la democracia.

Enarbolando su entusiasmo por estos postulados, en junio de 1966 ocho visionarios: Raúl Vásquez Vélez, Carlos Medellín, Elberto Gómez Moreno, Eduardo Mendoza Varela, Alberto Téllez Camacho, Jorge Enrique Molina, Dario Samper y Rubén Amaya Reyes, quijotes convencidos, como Shakespeare, de que "El hombre está hecho de la materia de sus sueños", fundaron la Universidad Central. Sueño hecho realidad; realidad nacida de la esperanza en la

295 Universidad Central, Disponível em http://www.ucentral.edu.co/ acesso em 10/08/2006

SAKATA, Marici Cristine Gramacho, Globalização e Educação: A formação do comunicador social na América Latina, 2008312 p. (Doutorado - Orientação BACCEGA, M. A.) Escola de Comunicações e Artes da Universidade de São Paulo, São Paulo, SP, 2008 
patria, que merece un destino más justo y acorde con su historia; y en sus instituciones, que tendrán que amoldarse a los tiempos contemporáneos, más complejos y dificiles.

Desde entonces, la Universidad Central brinda una educación integral a sus estudiantes, cuyos esfuerzos están dirigidos a la formación ética, humanística y científica de éstos, así como al conocimiento e identificación de la realidad social del país.

La Universidad Central se ha propuesto formar profesionales idóneos que sean, a la vez, ciudadanos integros y líderes aptos para dirigir y orientar procesos socioculturales como los que requiere la construcción de un nuevo país. Así pues, el Claustro se ha preocupado por la calidad profesional, la excelencia académica y la proyección social de sus programas de pregrado y de posgrado.

\section{MISIÓN}

Contribuir a la formación de capital social y cultural, mediante el desarrollo de programas universitarios de pregrado, posgrado y educación continuada en ciencias, tecnología, artes y humanidades, que articulen las funciones de docencia, investigación y proyección social en torno a la formación integral de individuos críticos, creativos, sensibles, dotados de un alto sentido de ciudadanía, comprometidos con un proyecto de ciudad y de país ecológicamente viable, productivo, democrático, plural y solidario, $y$ afianzados en su identidad latinoamericana.

VISIÓN

Nuestra Universidad será reconocida en el año 2010 como un centro educativo de excelencia, en el cual:

1. Los estudiantes que lo requieran podrán mantener una actividad remunerada paralela, concediendo la prioridad a su formación, gracias a una organización de la academia y de los servicios de apoyo que les permitirá aprovechar los cambios que se registren en las formas y rutinas de trabajo.

2. La oferta de programas de pregrado duplicará la existente antes de la formulación del PEI.

3. La flexibilidad de la estructura curricular dará acceso a múltiples matices opcionales en la formación y permitirá poner en contexto el conocimiento, generando polivalencia en sus egresados para el desempeño profesional.

4. La formación en la investigación, y para ella, se erigirá como columna vertebral del proceso educativo en el pregrado y el posgrado, y vinculará al estudiante con los problemas nacionales y locales.

5. Se producirá conocimiento científico y tecnológico relevante en todos los campos de desempeño formativo.

6. La investigación pedagógica apoyará la búsqueda de un mejoramiento continuo de la formación.

7. Todas las unidades académicas mantendrán una intensa interacción con el entorno y con los procesos de formación e investigación que se adelanten, se nutran y ganen pertinencia, actualidad y relevancia a partir de ella.

8. El desarrollo tecnológico en informática y telecomunicaciones, así como el logro de una cultura informacional, permitirán la traducción del conocimiento en productos que, al circular internamente, agilizarán los procesos de apropiación y darán el soporte pedagógico necesario para diversificar las alternativas de formación, involucrando lo digital, lo electrónico y lo virtual.

9. Los estudiantes adquirirán una amplia perspectiva de la dinámica internacional y conocerán los escenarios mundiales en que se desenvuelva su profesión o disciplina.

10. Las acciones y servicios de bienestar universitario estarán articulados a procesos y propósitos académicos esenciales y serán coherentes con las condiciones particulares de cada estamento.

11. La Universidad habrá definido una estructura orgánica descentralizada, con procesos regulados, comunicaciones fluidas, decisiones ágiles y sistemas de control y de evaluación eficaces, basados en una gestión moderna.

SAKATA, Marici Cristine Gramacho, Globalização e Educação: A formação do comunicador social na América Latina, 2008312 p. (Doutorado - Orientação BACCEGA, M. A.) Escola de Comunicações e Artes da Universidade de São Paulo, São Paulo, SP, 2008 
12. La Universidad combinará acertadamente una organización por Facultades, constituida por grupos de trabajo responsables de la administración de programas y líderes de proyectos de desarrollo estratégico.

13. El cuerpo profesoral estará rodeado de las condiciones necesarias para sentirse partícipe de un proyecto y actor fundamental de una comunidad.

14. La importancia y la calidad de las acciones de proyección social y de investigación consolidarán capacidad y reconocimiento en áreas diversas de consultoría, asesoría, educación continuada, investigación y desarrollo tecnológico, que constituirán fuentes de financiación importantes para los proyectos de desarrollo.

15. Se habrá afianzado una cultura de proyectos y un sentido de participación y de logro.

16. La Universidad se habrá vinculado a otras instituciones del sistema educativo y desarrollará acciones conjuntas con ellas.

17. La Universidad mantendrá programas de apoyo a sus graduados y, a través de tales programas, retroalimentará sus procesos y evaluará sistemáticamente su impacto.

18. La cultura de la evaluación de los procesos y los procedimientos permitirá la realización de un continuo y permanente seguimiento a la ejecución del plan de desarrollo, con el fin de implementar y adecuar los recursos necesarios para el logro de los objetivos y las metas institucionales.

19. Los niveles de calidad, cobertura y eficiencia interna serán plenamente satisfactorios, confrontados con los estándares nacionales

- Características e Objetivos do Curso de Comunicação ou Especialidade da Instituição

Objetivo

Formar comunicadores sociales y periodistas en la produccion de medios en la gerstion de proyectos y estrategias de comunicacion de alto impacto social en una exploracion creativa de los diversos lenguajes.

Formacion Profesional

Nuestros comunicadores sociales y periodistas tienen la capacidad de

desenvolverse en los escenarios de diseno y produccion de informacion de los medios de comunicacion masivos, organizacionales y alternativos

asumir los retos de la formulacion y gestion de proyectos sociales

adaptarse a las necessidades del mercado laboral em sus aspectos cambiantes de gestion de la comunicacion y del periodismo

comprender a partir de la propia subjetividad, los problemas politicos, sociales y c ulturales de nuestro pais y del mundo y generar propuests que desde la comunicacion, logren transformalos

- Grade Curricular

SAKATA, Marici Cristine Gramacho, Globalização e Educação: A formação do comunicador social na América Latina, 2008312 p. (Doutorado - Orientação BACCEGA, M. A.) Escola de Comunicações e Artes da Universidade de São Paulo, São Paulo, SP, 2008 

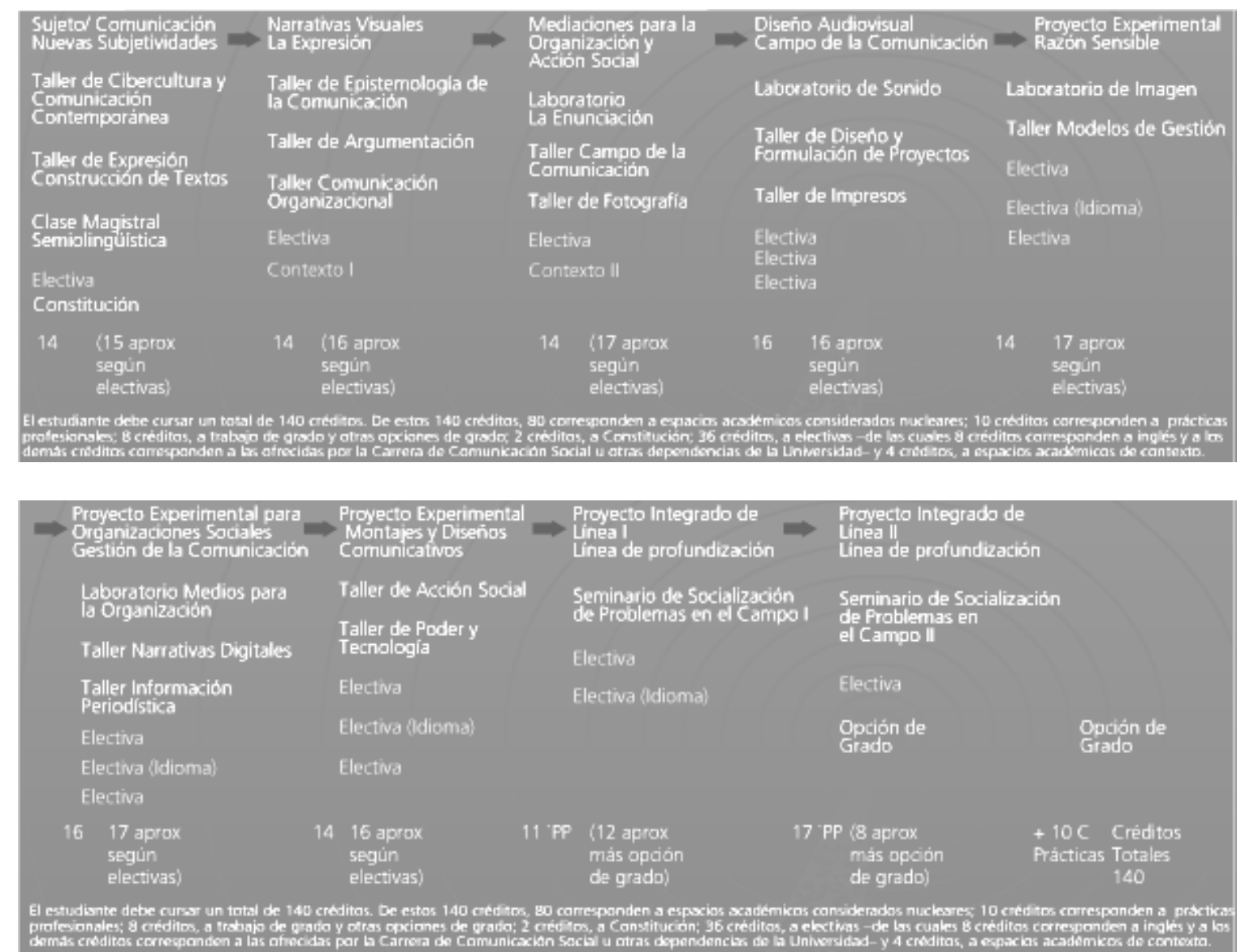

Plano no Site

http://www.ucentral.edu.co/pregrado/facultades/ciencias\%20arte.htm

\section{MEXICO}

\begin{tabular}{|l|l|l|l|l|}
\hline $\begin{array}{l}\text { 5. } \\
\text { México }\end{array}$ & $\begin{array}{l}\text { 5.1 Universidad } \\
\text { Nacional } \\
\text { Autonoma de } \\
\text { Mexico }\end{array}$ & $\begin{array}{l}5.2 \text { Universidad de } \\
\text { Guadalajara } \\
\text { (UdeG) }\end{array}$ & $\begin{array}{l}5.3 \text { Universidad } \\
\text { Del Valle } \\
\text { (Laureate) }\end{array}$ & $\begin{array}{l}5.4 \text { Endicott } \\
\text { College Mexico }\end{array}$ \\
\hline
\end{tabular}

\section{Universidades Nacionais}

5.1 Universidad Nacional Autonoma de Mexico - Facultad de Ciencias Políticas y $\underline{\text { Sociales }}^{296}$

- Características e Missão da Instituição

The National Autonomous University of Mexico (Spanish: Universidad Nacional Autónoma de México, abbreviated as UNAM) is today the most important Mexican university and was founded in 1551 by Royal Decree signed by Charles V. Holy Roman Emperor at Valladolid, Spain. Born as Real Universidad de la Nueva España, is the oldest Univeristy in North America.

${ }^{296}$ Universidad Nacional Autonoma de Mexico, Disponível em www.unam.mx, acesso em 01/11/2006

SAKATA, Marici Cristine Gramacho, Globalização e Educação: A formação do comunicador social na América Latina, 2008312 p. (Doutorado - Orientação BACCEGA, M. A.) Escola de Comunicações e Artes da Universidade de São Paulo, São Paulo, SP, 2008 
It is the largest university in Latin America and is ranked the best in Latin America, Spain and Portugal according to a study conducted by The Times released in 2005-2006. A study by Beijing University also considered UNAM to be the best university in the region and also the sole most important University in the Spanish-speaking world.

It consists of faculties rather than departments. Both undergraduate and graduate studies are available. UNAM is also responsible for the Escuela Nacional Preparatoria (ENP) (National Preparatory School), and the Colegio de Ciencias y Humanidades (CCH), which consist of several high schools, spread around Mexico City. Counting ENEP, CCH, undergraduate and graduate students, UNAM has over 269,000 students, making it one of the world's largest universities.

In addition, it is the only university in Mexico with three Nobel Laureates among its former students: Alfonso García Robles (Peace), Octavio Paz (Literature), and Mario Molina (Chemistry). (There is arguably a fourth Nobel Prize awarded twice to a UNAM member: Ana Maria Cetto was awarded the 1995 Nobel Peace Prize as a member of the Pugwash Conferences and the 2005 Nobel Peace Prize as a member of the IAEA).

La Ley Orgánica de la UNAM es el máximo ordenamiento jurídico que regula su personalidad, su estructura y su vida interna. En el artículo primero de dicha norma se establece que "La Universidad Nacional Autónoma de México es una corporación pública, organismo descentralizado del Estado, dotado de plena capacidad jurídica y que tiene por fines impartir educación superior para formar profesionistas, investigadores, profesores universitarios y técnicos útiles a la sociedad; organizar y realizar investigaciones, principalmente acerca de las condiciones y problemas nacionales, y extender con la mayor amplitud posible los beneficios de la cultura".

$\underline{\text { Lema }}$

El lema que anima a la Universidad Nacional, Por mi raza hablará el espiritu, revela la vocación humanistica con la que fue concebida. El autor de esta célebre frase, José Vasconcelos, asumió la rectoría en 1920, en una época en que las esperanzas de la Revolución aún estaban vivas, había una gran fé en la Patria y el ánimo redentor se extendía en el ambiente. Se "significa en este lema la convicción de que la raza nuestra elaborará una cultura de tendencias nuevas, de esencia espiritual y libérrima", explicó el "Maestro de América" al presentar la propuesta. Más tarde, precisaría: "Imaginé asi el escudo universitario que presenté al Consejo, toscamente y con una leyenda: Por mi raza hablará el espiritu, pretendiendo significar que despertábamos de una larga noche de opresión".

- Características e Objetivos do Curso de Comunicação ou Especialidade da Instituição

Licenciado en Ciencias de la Comunicación: Unidad Académica: Facultad de Ciencias Políticas y Sociales - Plan de Estudio: Licenciado en Ciencias de la Comunicación: Area de Conocimiento: Ciencias Sociales

Perfil Profesional:

Es el egresado que cuenta con una sólida formación social y humanistica, cuyos referentes principales son las ciencias sociales, la cultura y las artes, auxiliares de él para poder desempeñarse como profesional interesado en el bienestar social y en los derechos de la sociedad a la información. Cuenta asimismo, con una formación teórico, metodológica y técnica en el campo de la comunicación que le permite comprender, explicar, analizar, criticar y teorizar los procesos de la comunicación, las formas, los medios, las tecnologías empleadas y los contexto en que dichos procesos ocurren. También es capaz de realizar investigaciones en cualquier ámbito de su

ejercicio profesional.

Duración de la carrera: 9 semestres

Valor en créditos del plan de estudios:Total: $376(*)$

Obligatorios: 352 Optativos: 24

SAKATA, Marici Cristine Gramacho, Globalização e Educação: A formação do comunicador social na América Latina, 2008312 p. (Doutorado - Orientação BACCEGA, M. A.) Escola de Comunicações e Artes da Universidade de São Paulo, São Paulo, SP, 2008 
Seriación:

El plan de estudios incluye seriación obligatoria por asignaturas. La seriación implica que el alumno no se podrá inscribir en la materia subsecuente sin antes haber acreditado la materia antecedente.

Organización del plan de estudios:

El plan de estudios está organizado en nueve semestres, con un total de 47 asignaturas de las cuales 44 son obligatorias y 3 son optativas, éstas pueden cursarse a partir del sexto semestre, eligiéndose dentro del grupo de las optativas contenidas en el plan de estudios. Asimismo se contempla la comprensión de dos idiomas (Inglés o Francés obligatorio y cualquier otro idioma) o la posesión de uno (Inglés o Francés). El plan de estudios a su vez está dividido en dos ciclos. El inicial constituido por 30 asignaturas distribuidas en los cinco primeros semestres (240 créditos); el segundo ciclo, del sexto al noveno semestre lo conforman 17 asignaturas con carácter terminal: 14 obligatorias y 3 optativas (136 créditos), esta fase consta a su vez de cinco opciones como Periodismo, Producción, Publicidad, Comunicación Política y Comunicación Organizacional, donde el alumno elegirá una de acuerdo a su interés profesional.

- Grade Curricular

Asignaturas Obligatorias: Tronco Comum-

PRIMER SEMESTRE

110208 Economía y Comunicación

110408 Estado, Sistema y Poder Político

110908 Introducción al Estudio de la Ciencia

111108 Introducción al Estudio del Lenguaje

111608 Taller de Expresión Oral y Escrita

112008 Sociedad y Comunicación

SEGUNDO SEMESTRE

120608 Geopolítica y Comunicación

120908 Introducción a las Teorías de la Comunicación

121108 Metodología de la Investigación en Comunicación

121308 Historia de México y Procesos de Comunicación I

121608 Taller de Redacción

121808 Teorías del Discurso

TERCER SEMESTRE

130608 Géneros Periodísticos I

131408 Historia de México y Procesos de Comunicación II

131508 Psicología y Comunicación

131608 Semiótica

131708 Técnicas de Investigación en Comunicación

132108 Teorías de la Comunicación I

CUARTO SEMESTRE

140908 Géneros Periodísticos II

141408 Historia de México y Procesos de Comunicación III

141508 Procesos y Técnicas Informacionales

141608 Propaganda y Opinión Pública

142008 Teoría de la Imagen

142108 Teorías de la Comunicación II

QUINTO SEMESTRE

150308 Discurso Audiovisual

150708 Géneros Periodisticos III

151508 Historia Contemporánea y Procesos de Comunicación

151608 Publicidad

151908 Taller de Diseño de Proyectos en Comunicación

152308 Teorías de la Comunicación III

SAKATA, Marici Cristine Gramacho, Globalização e Educação: A formação do comunicador social na América Latina, 2008312 p. (Doutorado - Orientação BACCEGA, M. A.) Escola de Comunicações e Artes da Universidade de São Paulo, São Paulo, SP, 2008 
OPCION: COMUNICACION ORGANIZACIONAL

SEXTO SEMESTRE

160608 Comunicación Organizacional

161108 Entorno Social de las Organizaciones

161708 Identidad Cultural e Identidad Corporativa

163508 Teoría de las Organizaciones

08 Asignatura Optativa

SEPTIMO SEMESTRE

170208 Asesoría y Servicios de Comunicación

170708 Diagnóstico de la Imagen Corporativa

170908 Estrategias de Comunicación Organizacional

171408 Las Organizaciones Emergentes

08 Asignatura Optativa

OCTAVO SEMESTRE

180708 Diseño de Comunicación en las Organizaciones

180908 Gestión de la Comunicación en las Organizaciones

182108 Seminario de Tesis I

182708 Taller de Imagen

183008 Taller de Planeación

NOVENO SEMESTRE

190108 Seminario de Tesis II

4

OPCION: PERIODISMO

SEXTO SEMESTRE

160108 Análisis de Política de Comunicación

162008 Metodología de la Investigación Periodística

162108 Planeación y Organización de Empresas Editoriales

163308 Taller de Periodismo

08 Asignatura Optativa

SEPTIMO SEMESTRE

171808 Organización de Unidades de Comunicación

171908 Periodismo Gráfico

172008 Periodismo y Lenguaje Narrativo

173108 Taller de Periodismo Especializado I

08 Asignatura Optativa

OCTAVO SEMESTRE

181308 Periodismo en las Unidades de Comunicación Social

5

182108 Seminario de Tesis I

182408 Taller de Corrección de Originales

182608 Taller de Diseño Editorial

182908 Taller de Periodismo Especializado II

NOVENO SEMESTRE

190108 Seminario de Tesis II

08 Asignatura Optativa

5.2 Universidad de Guadalajara (UdeG) - Departamento de Estudios de la Comunicación Social ${ }^{297}$

\footnotetext{
${ }^{297}$ Universidad de Guadalajara (UdeG), Disponível em http://www.cucsh.udg.mx/categoria.php?id=30 acesso em 01/11/2006
}

SAKATA, Marici Cristine Gramacho, Globalização e Educação: A formação do comunicador social na América Latina, 2008312 p. (Doutorado - Orientação BACCEGA, M. A.) Escola de Comunicações e Artes da Universidade de São Paulo, São Paulo, SP, 2008 


\section{- Características e Missão da Instituição}

\section{Presentacion}

Avalada por una tradición educativa de más de doscientos años en los cuales ha realizando actividades de enseñanza, investigación y difusión de la ciencia y la cultura, y justo al cumplirse 77 años de su etapa moderna, la Universidad de Guadalajara se adapta a los retos del presente y del futuro para mejorar y mantenerse a la vanguardia en el siglo XXI.

Actualmente estamos aprovechando las ventajas de las Tecnologías de Información y Comunicación para hacer más eficientes nuestros procesos administrativos y académicos, a través de este portal universitario. También aumentamos nuestro potencial de comunicación e interacción entre las diversas instancias y miembros de la Red Universitaria en Jalisco para elevar la calidad de nuestros servicios y mantener una comunicación más directa con el público usuario.

En este portal encontrarás información sobre los planes y programas de estudio que conforman nuestra oferta educativa en los niveles medio superior, licenciatura, especialidad y posgrado, además de tener acceso a las publicaciones electrónicas y proyectos de investigación de cada uno de los departamentos, institutos y centros que conforman la Red Universitaria.

\section{Misión de la UdeG}

La Universidad de Guadalajara es un organismo público descentralizado del Gobierno del Estado de Jalisco que goza de autonomía, personalidad jurídica y patrimonio propios, cuyos fines son formar y actualizar los técnicos, bachilleres, técnicos profesionales, profesionistas, graduados y demás recursos humanos que requiere el desarrollo socioeconómico; organizar, realizar, fomentar y difundir la investigación científica, tecnológica y humanística; rescatar, conservar, acrecentar y difundir la cultura, la ciencia y la tecnología.

La educación que se imparte tiende a la formación integral de los alumnos, al desenvolvimiento pleno de sus capacidades y su personalidad; fomenta en ellos la tolerancia, el amor a la patria y a la humanidad, así como la conciencia de la solidaridad en la democracia, en la justicia y en la libertad.

De acuerdo con el Artículo 9no. de la Ley Orgánica, en la realización de sus funciones y en el cumplimiento de sus fines la Universidad de Guadalajara.

Se orienta por un propósito de solidaridad social, anteponiéndolo a cualquier interés individual.

Norma sus actividades, así como la convivencia y participación plural de los universitarios en los asuntos de la Institución, de conformidad con los principios constitucionales de libertad de cátedra, de investigación y de difusión de la cultura.

Examina todas las corrientes de pensamiento y los procesos históricos y sociales sin restricción alguna, con el rigor y objetividad que corresponde a su naturaleza académica.

Garantiza la participación de la comunidad universitaria en la elaboración y determinación colectiva de las politicas, planes y programas orientados al logro de sus fines, el desenvolvimiento de las actividades inherentes a sus funciones académicas y de servicio social y al cumplimiento de sus responsabilidades con la sociedad, procura la vinculación armónica entre las funciones de docencia, investigación y extensión; contribuye, con base en los resultados de su quehacer académico, por sí misma o en coordinación con otras personas físicas o jurídicas, al progreso del pueblo mexicano y jalisciense, al estudio y solución de sus problemas así como a la preservación de la soberanía nacional; y no hace discriminación por razones ideológicas, religiosas, morales, sociales, de raza, sexo, o nacionalidad, ni de ninguna otra naturaleza.

CUCSH Centro Universitario de Ciencias Sociales y Humanidades de la Universidad de Guadalajara se constituyó formalmente en 1994, en el marco de la reforma estructural iniciada por la Universidad de Guadalajara en 1989 y que dio lugar a la configuración de la Red Universitaria de Jalisco, lo que impulsó una nueva concepción del quehacer académico para responder a la creciente demanda de profesionistas e investigadores formados sobre la base de procesos de renovación y actualización de la oferta académica.

SAKATA, Marici Cristine Gramacho, Globalização e Educação: A formação do comunicador social na América Latina, 2008312 p. (Doutorado - Orientação BACCEGA, M. A.) Escola de Comunicações e Artes da Universidade de São Paulo, São Paulo, SP, 2008 
- Características e Objetivos do Curso de Comunicação ou Especialidade da Instituição

Licenciatura en Comunicación Pública

División de Estudios de la Cultura

Departamento de Estudios de la Comunicación Social

Presentación

La comunicación pública que se genera en una sociedad condiciona el espacio en donde se definen y discuten los asuntos que calificamos de interés público. La comunicación pública puede facilitar o entorpecer las discusiones sociales, y la participación de los diversos actores en ellas. La comunicación pública determina la calidad de las relaciones sociales, al establecer las formas de acceso a la información y al ejercicio de las libertades de opinión y expresión en las discusiones sobre las preocupaciones y controversias de interés público. Es una condición para la participación de los ciudadanos en la construcción de un espacio público democrático.

La importancia que la comunicación pública tiene en la definición del espacio público, puede ilustrarse señalando :

- el lugar que la comunicación ha tomado en el ejercicio de los gobiernos contemporáneos,

- el creciente protagonismo del periodismo como poder y como contrapeso de otros poderes,

- el papel de la publicidad comercial como reguladora de la economía, y

- la refuncionalización de los métodos de la mercadotecnia comercial para promover la transformación de conductas sociales y colectivas con fines sociales (mercadotecnia social).

Como campo especifico de conocimientos sobre un ámbito de la comunicación social, la comunicación pública examina:

- Cómo contribuyen las actividades de comunicación a los debates o discusiones sociales;

- cómo estas actividades de comunicación son utilizadas para hacer prevalecer un punto de vista en el espacio público, $y$

- cómo las prácticas de comunicación participan en la controversia social.

Lo que distingue el ámbito de la comunicación pública del de la comunicación social es que: la comunicación pública aborda las actividades de comunicación social sólo en tanto se relacionen con la discusión, el debate y la definición de posturas sociales ante temas de interés público.

Una de las dimensiones más importantes de la comunicación pública es su incidencia ética : La comunicación pública plantea toda suerte de problemas éticos y deontológicos, entre otros:

- el respeto a la vida privada y a la integridad de las personas en el periodismo;

- la propaganda y la desinformación en comunicación política;

- la manipulación en relaciones públicas y

- la mentira en publicidad.

La comunicación pública involucra a los actores que intervienen en la plaza pública sobre un asunto que es tema de debate social: medios, individuos, instituciones, empresas, movimientos sociales y otros grupos. La comunicación pública tiene relación con:

- las decisiones de la sociedad,

- los proyectos colectivos,

- las medidas sociales, $y$

- los problemas sociales.

La comunicación pública se cristaliza parcialmente en algunas prácticas profesionales existentes y socialmente reconocidas, entre las que sobresalen el periodismo, las relaciones públicas (en su nivel institucional) y la publicidad (social). De la misma manera se realiza a través de prácticas profesionales emergentes, relacionadas con el análisis y manejo del espacio público, como es el caso de la comunicación política.

SAKATA, Marici Cristine Gramacho, Globalização e Educação: A formação do comunicador social na América Latina, 2008312 p. (Doutorado - Orientação BACCEGA, M. A.) Escola de Comunicações e Artes da Universidade de São Paulo, São Paulo, SP, 2008 
Todo agente social, dirigente de empresa, representante de un cuerpo intermediario, vocero de un grupo de presión u organización social, etcétera, que toma posición en el espacio público sobre una cuestión de interés social se convierte en actor de la comunicación pública.

Perfil del Egresado

El egresado de la licenciatura en Comunicación Pública:

1) Analizará e integrara los saberes de distintas disciplinas del campo de las ciencias sociales (antropología, sociología, politica, historia) para el estudio del espacio público, a fin de comprender desde esta perspectiva multidisciplinar los procesos de significación, comunicación, lenguaje y cultura constitutivos del espacio público.

2) Analizará a partir de modelos teórico-metodológicos pertinentes, los nuevos escenarios de la comunicación pública y los cambios culturales y socioculturales producidos por las nuevas tecnologías de la información, en las prácticas de comunicación que inciden en el espacio público.

3) Conocerá y comprenderá los diferentes lenguajes verbales, no verbales e icónicos de la comunicación pública; sus sintaxis, sus modos de producir sentido y las prácticas comunicativas predominantes, en el marco de su contexto socio histórico y cultural.

4) Analizará el proceso histórico de los medios y de la conformación de la esfera pública, sus consecuencias y sus usos a partir de su contexto sociocultural.

5) Conocerá las lógicas de producción y el funcionamiento técnico-operativo de los diferentes medios de comunicación en su interacción con las instituciones, organizaciones y actores que intervienen en la construcción del espacio público.

6) Identificará los componentes comunicacionales y diagnosticará las problemáticas comunicativas que se presentan en los procesos de construcción del espacio público. 7) Planeará, diseñará, gestionará, instrumentará, intervendrá y evaluará sistemas, políticas, proyectos, procesos, programas, campañas y productos de comunicación pública en distintos ámbitos sociales.

8) Desarrollará procesos de gestión, negociación y relaciones públicas, en instituciones, organizaciones y grupos que intervienen en el campo de la comunicación pública. 9) Dominará el idioma español para elaborar, transmitir y comunicar con eficiencia mensajes - orales y escritos- orientados a públicos diversos, además desarrollará la capacidad para leer y comprender textos del idioma Inglés.

10) Fomentará una actitud de liderazgo reflexiva, crítica e innovadora frente al ejercicio de la comunicación pública, basada en la colaboración, la tolerancia y el respeto hacia la diversidad y dignidad humanas, con una postura ética hacia su profesión y un alto compromiso con su comunidad.

\section{Campo Profesional}

El egresado de Comunicación Pública podrá desempeñarse como estratega y analista de la comunicación en los sectores público, privado y social, tanto en las prácticas existentes de la comunicación social, como en las emergentes (de las cuales forma parte su perfil). Sus conocimientos y habilidades adquiridos le permitirán, igualmente, ingresar a campos profesionales en los que confluyen y se hibridan las prácticas del periodismo, las relaciones públicas, la publicidad social, la comunicación política y la intervención sociológica.

\section{- Grade Curricular}

Plan de Estudios

Área de formación básica común obligatoria

Comunicación Oral

Comunicación Escrita

Fundamentos de análisis literario

SAKATA, Marici Cristine Gramacho, Globalização e Educação: A formação do comunicador social na América Latina, 2008312 p. (Doutorado - Orientação BACCEGA, M. A.) Escola de Comunicações e Artes da Universidade de São Paulo, São Paulo, SP, 2008 
Lengua Extranjera I

Lengua Extranjera II

Lengua Extranjera III

Lengua Extranjera IV

Lengua Extranjera $V$

Lógica y Retórica

Ética de la comunicación

Problemas socioeconómicos y politicos de México

Estadísticas Descriptiva

Estadística Inferencial paramétrica

Totales

Área de formación básica particular obligatoria

Redacción de documentos de Comunicación Pública

Comunicación Interpersonal

Teoría Social (Sociedad)

Teoría Social (Política)

Teoría Social (Cultura)

Teorías de la Globalización

Teorías de la Comunicación (modelos)

Teorías de la comunicación masiva

Teorías de la comunicación pública

Economía política de la información y la comunicación

Opinión Pública

Legislación internacional y nacional de medios

Sociedad de la información y nuevas tecnologías

Técnicas de encuesta

Métodos cualitativos de investigación

Investigación documental y electrónica

Lenguajes y lógicas de la producción periodística

Investigación periodística

Lenguajes y lógicas de producción audiovisual

Gestión Estratégica

Relaciones Públicas

Mercadotecnia Social y Política

Teorías de la Organización

Prospectiva y Teoría de los Escenarios

Teorías del Liderazgo y Habilidades Directivas

Modelos de Planeación

Área de formación especializante obligatoria

Comunicación Política

Comunicación Institucional

Los medios de comunicación en México

Los medios de comunicación en Jalisco

Diseño de proyectos de comunicación pública I

Diseño de proyectos de comunicación pública II

Seminario de Titulación

Laboratorio de Lenguaje Multimedia

Taller de Gestión y Producción Audiovisual

Auditoria de la Comunicación

Diseño y Evaluación de Campañas Públicas

Área de formación especializante

Orientación en investigación de la Comunicación Pública

SAKATA, Marici Cristine Gramacho, Globalização e Educação: A formação do comunicador social na América Latina, 2008312 p. (Doutorado - Orientação BACCEGA, M. A.) Escola de Comunicações e Artes da Universidade de São Paulo, São Paulo, SP, 2008 


\section{NOMBRE}

Paradigmas Teóricos de la Comunicación Pública

Metodología y técnicas avanzadas de la investigación en comunicación pública

Estudios de casos en investigación de la comunicación pública

Diseño de proyectos de investigación en Comunicación Pública

Orientación en intervención para el Cambio Social

Comunicación para el cambio social

Comunicación de Riesgo

Comunicación para la Salud

Diseño de proyectos en intervención social

Orientación en Comunicación Política

Comportamiento político ciudadano

Métodos y técnicas del cabildeo

Demoscopía de medios

Diseño de proyectos de mercadotecnia política

\section{Universidades Globalizadas}

\section{$5.3 \underline{\text { Universidad del Valle de México - Ciencias Sociales }} \underline{298}$}

\section{- Características e Missão da Instituição}

Misión

Crear en los miembros de la Comunidad Egresada un permanente vínculo de comunicación que se traduzca en la exhaltación de su sentido de pertenencia y orgullo por la Universidad del Valle de México.

Objetivos

- Determinar la Estrategia Institucional de la labor de la Universidad respecto a la Comunidad Egresada.

- Diagnosticar, investigar, analizar y brindar información a las diversas áreas Institucionales respecto a la ubicación y desempeño de los Egresados UVM

- Detectar las necesidades de formación de los Egresados, y contribuir a su consolidación en propuestas que promuevan de manera continua la renovación y enriquecimiento del conocimiento que se imparte en la Universidad

Función

La Dirección General de Egresados establece los planes, programas y procedimientos que hacen posible a las Coordinaciones de los Campus la localización, identificación e integración de la Comunidad Egresada de los niveles medio superior y superior de la Universidad, a fin de brindar a las diversas áreas de la Institución información valiosa acerca de los egresados, que nos permitan establecer un canal permanente de vinculación para lograr su reintegración a UVM.

- Características e Objetivos do Curso de Comunicação ou Especialidade da Instituição

${ }^{298}$ Universidad del Valle de México, Disponível em http://www.uvmnet.edu/, acesso em 02/12/2006

SAKATA, Marici Cristine Gramacho, Globalização e Educação: A formação do comunicador social na América Latina, 2008312 p. (Doutorado - Orientação BACCEGA, M. A.) Escola de Comunicações e Artes da Universidade de São Paulo, São Paulo, SP, 2008 
Licenciatura Ciencias de la Comunicación

¿Qué me ofrece esta carrera?

Formarte como un profesionista capaz de detectar, analizar, crear y resolver situaciones de comunicación con una visión humanista mediante el dominio del lenguaje oral, escrito y audiovisual, incorporados a las nuevas tecnologías de información con un enfoque interdisciplinario.

¿Cuáles habilidades profesionales desarrollaré?

- Dominar los lenguajes básicos de los medios de comunicación.

- Desarrollarás estrategias fundamentales para la transmisión de mensajes.

- Ser un profesionista multicompetente y multifuncional.

- Crear nuevas estructuras comunicativas orientadas y sustentadas en los cambios tecnológicos, el mercado y la competencia global.

- Propiciar la retroalimentación de tu labor basada en el desarrollo integral de las habilidades comunicativas de las organizaciones.

¿Dónde trabajaré?

Según el área de especialización, el egresado de Ciencias de la Comunicación se desempeñará en:

Medios electrónicos

- En el área creativa, noticias, programación o producción. Desarrollarás ideas, producirás, dirigirás programas, escribirás guiones o participarás como locutor, productor o comentarista. Medios impresos

- En el área de redacción o noticias. Escribirás, editarás y dirigirás a reporteros.

Agencias de publicidad

- En el área creativa, tráfico, producción y administración de cuentas. Escribirás, crearás, dirigirás mensajes y campañas publicitarias.

Empresas de bienes o servicios

- En el área de comunicación interna o externa, publicidad y recursos humanos.

- En el área de guionismo, producción y dirección de la industria cinematográfica.

Despachos independientes

- Proporcionarás asesoría sobre estrategias de comunicación e imagen; principalmente sobre los aspectos relacionados con la comunicación y la producción de mensajes.

Academia

- Ejercerás la docencia o el desarrollo de estudios especificos e innovaciones en instituciones educativas y de investigación.

- Grade Curricular

Plan de Estudios (9 Semestres)

Área Profesional Obligatoria

Asignaturas

Taller de Estética y Arte

Fundamentos de Mercadotecnia

Comunicación Organizacional

Introducción a la Teoría de Comunicación

Procesos Psicológicos de la Comunicación

Taller de Redacción

Comunicación Virtual

Escritura Creativa

Estudios Cuantitativos en Comunicación

Función Social de los Medios
Laboratorio de Producción Radiofónica

Proyectos Radiofónicos

Producción Televisiva

Proyectos Televisivos

Laboratorio de Proyectos Interactivos

Proyectos de Creatividad e Innovación en

Hipermedios

Área Profesional Optativa Asignaturas

Dirección de Marketing

Estrategias de Publicidad

Marketing Industrial y Electoral

Plan de Mercadotecnia

Reingeniería en la Organización

SAKATA, Marici Cristine Gramacho, Globalização e Educação: A formação do comunicador social na América Latina, 2008312 p. (Doutorado - Orientação BACCEGA, M. A.) Escola de Comunicações e Artes da Universidade de São Paulo, São Paulo, SP, 2008 
Escribir para los Medios

Estudios Cualitativos en Comunicación

Letras Contemporáneas

Teorías Contemporáneas de la Comunicación

Ética y Normatividad de la Comunicación

Gestión de Empresas de Comunicación

Habilidades Periodísticas

Competencias Lingüisticas

Prácticas Periodísticas

Problemas y Proyectos de Comunicación

Análisis y Diseño de Contenidos

Apreciación Cinematográfica

Paradigmas del Pensamiento Actual

Taller de Medios Virtuales

Comunicación Publicitaria

Periodismo Especializado

Comunicación Política

Estudios de la Opinión Pública

Taller de Fortalecimiento al Egreso

Taller de Imagen

Laboratorio de Producción Fotográfica

Laboratorio de Sonido
Relaciones Públicas en la Organización

Auditoria en Comunicación

Consultaría en Comunicación

Diseño de Audio

Escritura de Ficción para Medios

Estrategias de Comunicación en la

Organización

Fotografía Publicitaria

Guión y Producción Documental

Laboratorio de Campañas

Locución y Doblaje

Los Medios de Comunicación en la

Organización

Medios Educativos

Plan de Medios

Planeación Estratégica en Comunicación

Producción Editorial

Psicología Social en las Organizaciones

Seminario de Temas Contemporáneos I

Seminario de Temas Contemporáneos II

Seminario de Temas Contemporáneos III

Seminario de Temas Contemporáneos IV

Seminario de Temas Contemporáneos $V$

Video Corporativo y Comercial

Video de Ficción y Artístico

Área Sello

Asignaturas

Desarrollo Empresarial

Habilidades de Interacción

Liderazgo

Habilidades de Negociación

Identidad e Imagen

Habilidades de Influencia

Comunicación Efectiva

Desarrollo Universitario

Desarrollo Humano

Formación Cultural

Visión Global

Entorno Sociopolítico y Económico de México

Calidad

Prospectiva

Desarrollo Emprendedor

Responsabilidad Social

Total Créditos del Área

Área Sello

Área Profesional Obligatoria

Área Profesional Optativa

SAKATA, Marici Cristine Gramacho, Globalização e Educação: A formação do comunicador social na América Latina, 2008312 p. (Doutorado - Orientação BACCEGA, M. A.) Escola de Comunicações e Artes da Universidade de São Paulo, São Paulo, SP, 2008 


\subsection{Endicott College Mexico - Facultad de Ciencias Sociales $\underline{299}$}

\section{- Características e Missão da Instituição}

Founded in 1939, Endicott College is a private, four-year college located just north of Boston, in Beverly, Massachusetts. In 1996, Endicott opened a branch campus in Mexico City to help prepare Mexican residents for life in an increasingly interdependent global community. Classes on both campuses are small and students are taught by a highly qualified and dedicated faculty, all of whom have graduate degrees and extensive professional experience, thus assuring that every Endicott student receives the highest quality academic training and close personalized attention.

Today, Endicott College Mexico offers its flagship undergraduate program in which students study part of their degree in Mexico and the remainder in Beverly, as well as an accelerated bachelor's degree for adult learners and two master's degrees which are delivered completely in Mexico.

Endicott College's Mexico City Campus was established in 1996 to serve the need for an academic and cultural center where students from the United States and Mexico can come together to share a high quality academic experience.

Two types of programs take place here.

Degree programs in English for students from Mexico, and

Study abroad programs for students from the United States and other countries.

Bachelor's Degree

Students from Mexico can study in the traditional undergraduate program, in which they study their core curriculum for up to two years on the Mexico campus before transferring to Endicott's Beverly campus to complete their degrees.

Accelerated Bachelor's degrees in Business and Psychology for non-traditional aged students are also offered to students from Mexico.

Master's Degree

Master's degrees in Education with specialization in International Education and Organization Management are offered to all Mexican residents.

In addition, students from the U.S. and other countries can also spend a summer, a semester, or an academic year here through the study abroad program. They may choose from language, culture, and literature courses offered in Spanish for study abroad students and from the full array of core curriculum courses and courses in business, communication, art, and other disciplines, which are offered in English.

- Características e Objetivos do Curso de Comunicação ou Especialidade da Instituição

School of Communication-Bachelor of Science in Communication

Concentration in: · Advertising $\cdot$ Contemporary Journalism $\cdot$ Media Production $\cdot$ Media Studies

Have you ever wondered what went on behind the scenes at a TV station, advertising agency, or newspaper? Are you interested in the role media plays in our everyday lives? The School of Communication offers a door into the high profile, exciting world of media production, advertising, contemporary journalism, and media studies. Along with the required internship, talented faculty provides instruction that prepares you with the skills and knowledge to be successful in your professional career.

\footnotetext{
${ }^{299}$ Endicott College Mexico, Disponível em http://www.endicott.edu/servlet/RetrievePage?site=endicott\&page=Mexico, acesso em 02/12/2006
}

SAKATA, Marici Cristine Gramacho, Globalização e Educação: A formação do comunicador social na América Latina, 2008312 p. (Doutorado - Orientação BACCEGA, M. A.) Escola de Comunicações e Artes da Universidade de São Paulo, São Paulo, SP, 2008 
The state-of-the-art Scangas Media and Learning Center, a fully-equipped, digital production studio, places media students at the cutting edge of the media industry. Advertising students are exposed to the theories and skills that drive the industry. Students who concentrate in Contemporary Journalism will fine tune writing skills as they work to understand the driving forces behind what we read in the newspapers, see on TV news, and listen to on the radio. Media Studies students will delve deeply into how all media, from television and newspapers to the World Wide Web, impact us each and every day. Specialized courses and internships are designed to complement a common core of study in Communication.

Many Communication students choose to go on to graduate school. For others, their career paths may lead to the rapidly evolving high-tech media industry. A Communication degree from Endicott presents endless possibilities. Endicott graduates can be found at local and national broadcast facilities and at Boston area public relations firms as well as international advertising agencies.

\section{- Grade Curricular}

Bachelor of Science in Communication

Credits Required: 124-125

The baccalaureate degree program in Communication is a demanding curriculum designed to provide strong options and prepare the student for entry into the field of communication. The program integrates a basic core of communication skill and theory courses in Advertising, Contemporary Journalism, Media Production or Media Studies. Combined with the strong liberal arts background provided by the College's core curriculum, the student is amply prepared to enter the industry or go on to graduate level study in Communication or other fields.

Opportunities for intense, professional application in individual interest areas are available through a series of internships including the semester-long internship and the thesis in the senior year. ECTV, the College's 24-hour, closed circuit cable television and radio network, is available to showcase student productions, including news broadcasts.

The Advertising concentration requires seven courses in addition to the Communication Core. These courses provide an overview of the wide variety of activities that make up the everchanging and evolving world of advertising and public relations. Students develop critical thinking and writing skills that are necessary to function in the demanding environment of advertising and marketing communications. The concentration gives students a basic understanding of the industry and prepares them to succeed as they move into their one month and semester-long internships.

The Contemporary Journalism concentration requires seven courses in addition to the Communication Core. Journalism, in its many forms, from broadcast and print to online publications holds a significant historical and social presence world-wide. These courses provide students with a look at the way the "news of the day" is communicated as well as the way our reality is constructed via the media. This concentration provides an overview of the field and gives students the basic skills to craft a view of the world for others.

The Media Production concentration requires seven courses in addition to the Communication Core. These courses provide students with a complete understanding of basic video production techniques and aesthetics. Hands-on experience in the Scangas Center's state-of-the-art digital television studio combined with an extensive use of field equipment give students an understanding of the challenges they will face when they go out on their internships. The history, market, and regulatory environment of the industry are also covered in courses that prepare students for managerial roles in this exciting and expanding industry.

The Media Studies concentration requires seven courses in addition to the Communication Core. The Media Studies concentration allows students who wish to explore, on a more substantial level, the impact media has on a global society. This concentration is designed for students looking for a more scholarly degree in the field. Social and critical issues as they relate to the media are explored in the depth through course work. This concentration provides students with the skills they need to be successful in graduate programs. Internships are an

SAKATA, Marici Cristine Gramacho, Globalização e Educação: A formação do comunicador social na América Latina, 2008312 p. (Doutorado - Orientação BACCEGA, M. A.) Escola de Comunicações e Artes da Universidade de São Paulo, São Paulo, SP, 2008 
integral part of the curriculum. Through multi-level experiences in industry, students learn how to prepare for their professions.

\section{ESPANHA}

\begin{tabular}{|l|l|l|l|l|}
\hline 1. Espanha & $\begin{array}{l}1.1 \text { Universidad de } \\
\text { Deusto }\end{array}$ & $\begin{array}{l}\text { 1.2. Universidad } \\
\text { Complutense de } \\
\text { Madrid }\end{array}$ & $\begin{array}{l}1.3 \text { Mondragon } \\
\text { Unibertsitatea }\end{array}$ & $\begin{array}{l}1.4 \text { Universidad } \\
\text { Antonio de } \\
\text { Nebrija }\end{array}$ \\
\hline
\end{tabular}

\section{Espanha - Universidades Nacionais}

\subsection{Universidad de Deusto - Humanidades HUCO Comunicación $\underline{300}$}

\section{- Características e Missão da Instituição}

La Universidad de Deusto se inaugura en 1886. En su nacimiento coinciden las preocupaciones e intereses culturales tanto del país Vasco por tener una universidad propia como de la Compañia de Jesús por establecer estudios superiores en alguna parte del estado español. Se elige Bilbao, un puerto y ciudad comercial que estaba experimentando en esa época un considerable crecimiento industrial. Bilbao es el centro de un área metropolitana con más de un millón de habitantes, una ciudad tradicionalmente abierta a Europa. Es, además, un importante centro portuario, comercial y financiero del país Vasco y del Norte de España. Desde Noviembre de 1997, se ha transformado significativamente bajo un simbolo, un edificio emblemático, el Museo Guggenheim Bilbao. La sede central de la Universidad de Deusto se sitúa al otro lado de la ría, frente al Museo Guggenheim En 1916, la "Universidad Comercial de Deusto" recibió al primer grupo de estudiantes que serían los primeros graduados en Ciencias Económicas en España, 25 años antes de que este título fuera oficialmente reconocido. En 1963, se formó el Instituto de Estudios Universitarios y Técnicos de Guipuzkoa en San Sebastián, a partir de la integración de tres entidades ya existentes. Este instituto, posteriormente, formaría parte de la Universidad de Deusto. La Universidad, por lo tanto, está localizada en dos campus, en las dos capitales costeras del País Vasco: Bilbao y San Sebastián. Más allá de la investigación individual y de las que se coordinan desde cátedras como la de Derecho y Genoma Humano o la de Ocio y Minusvalías, hay, en el ámbito institucional, una opción clara por temas sociales de interdependencia, distribución de recursos, migraciones, derechos humanos, desarrollo, pobreza y medio ambiente, ética y sociedad, así como estudios sobre identidad cultural (individual y colectiva) y procesos de integración europea tomando parte en varios grupos internacionales de investigación. La internacionalización, sin excluir otras regiones, muestra un compromiso claro con Europa y América Latina, teniendo firmados acuerdos con más de 200 universidades. Con una movilidad de alrededor de 1.300 estudiantes y 50 profesores, las facultades, institutos y escuelas se implican también en programas intensivos, módulos europeos y diseños curriculares conjuntos a varios niveles, al tiempo que participan en actividades transfronterizas, idiomas integrados, educación abierta y a distancia (ODL) y programas Leonardo. Toda la Universidad adopta el sistema de crédito europeo en el año 1994 y trabaja en su promoción y calidad. De hecho, Deusto fue la primera Universidad Europea en extender el crédito europeo a todas sus facultades.

300 Disponível em http://www.deusto.es/ acesso em 01/12/2006 - Campus San Sebastián

SAKATA, Marici Cristine Gramacho, Globalização e Educação: A formação do comunicador social na América Latina, 2008312 p. (Doutorado - Orientação BACCEGA, M. A.) Escola de Comunicações e Artes da Universidade de São Paulo, São Paulo, SP, 2008 
Las universidades jesuíticas comparten con otras universidades la misión de servicio a la persona y a la sociedad mediante su contribución a la ciencia y a la cultura, a la vez que, por su condición de jesuíticas, participan de la misión de la Compañía de Jesús. Su reto y fundamento es, por tanto, cumplir su misión de servicio de la fe, a través de su servicio a la ciencia y a la cultura, evitando toda instrumentación de la cultura y del ser universitario.

La Misión de una Universidad jesuítica exige además que sus objetivos (fe, justicia y cultura) se desarrollen en un clima y con una dinámica de diálogo con aquellos agentes religiosos, culturales o sociales, de cuya cooperación dependen valores fundamentales como son la paz, la justicia, la armonía, los derechos humanos y el respeto, que son compartidos y compartibles entre creyentes y no creyentes.

- Características e Objetivos do Curso de Comunicação ou Especialidade da Instituição

Formación global de profesionales de la comunicación

La licenciatura en Humanidades: Comunicación, HUCO, forma a profesionales de la comunicación capaces de concebir contenidos, elaborarlos, darles la forma más adecuada y gestionarlos en toda su complejidad. Dichos profesionales desarrollan su labor en medios, gabinetes, servicios de información o empresas, elaborando los contenidos y dándoles la forma más adecuada a cada necesidad.

El plan de estudios de la licenciatura está concebido para que los estudiantes adquieran los conocimientos y habilidades necesarias y se incorpore a la actividad profesional en el campo de la comunicación, como creador de contenidos o responsable de las tareas comunicativas en instituciones, empresas y otras organizaciones, planificando su comunicación, gestionando servicios de

A fin de que alcances esos objetivos cursarás las siguientes materias:

Para que comprendas cómo contribuye la comunicación a estructurar todo nuestro sistema de relaciones personales y sociales y conozcas sus principios y mecanismos, cursarás: Teoría de la Comunicación, Historia de la Comunicación Social, Valores Sociales y Derecho de la Comunicación, Opinión Pública y Evaluación de Mensajes, entre otras materias.

Aprenderás a analizar los contextos sociales y culturales de la acción comunicativa y descubrirás cómo esas circunstancias particulares influyen en ella y le dan forma en cada momento histórico, con materias como: Historia Universal y Contemporánea, Literatura (española, vasca, francesa, inglesa), Antropología Social, Geografia Humana, Historia del Pensamiento o Psicología.

Para que domines las formas expresivas que las diversas técnicas comunicativas y artísticas ponen a tu alcance cuando necesites elaborar mensajes, te ejercitarás en el uso oral (Taller de Comunicación Oral, Comunicación Oral en los Medios) y escrito de tu propia lengua y de la lengua extranjera que elijas. El Lenguaje en la Comunicación y los Géneros del Periodismo Escrito te enseñarán las peculiaridades del lenguaje de la comunicación; analizarás los medios de expresión que te ofrece la Historia del Arte, los de la tipografia o la fotografía en La Comunicación Gráfica, los del cine y el cómic en El Relato Cinematográfico y El Cómic y la Narración Gráfica; y los aplicarás cada curso, creando tus propias comunicaciones en los Talleres de Escritura correspondientes.

Para que conozcas a la perfección las posibilidades comunicativas que los últimos desarrollos de los sistemas de información ponen a tu alcance, cursarás Documentación y Sistemas de Información o Nuevas Tecnologías en la Comunicación, y trabajarás con ellas en los Talleres de Informática.

$Y$ a fin de que seas un profesional capaz no sólo de elaborar los mensajes sino también de planificarlos y de gestionar estrategias comunicativas en tu organización, estudiarás: Comunicación Interna en Organizaciones, Gestión de Empresas de Comunicación, Comunicación Institucional y Administración de Proyectos, entre otras materias.

SAKATA, Marici Cristine Gramacho, Globalização e Educação: A formação do comunicador social na América Latina, 2008312 p. (Doutorado - Orientação BACCEGA, M. A.) Escola de Comunicações e Artes da Universidade de São Paulo, São Paulo, SP, 2008 
- Grade Curricular

\begin{tabular}{|c|c|}
\hline Curso 1 Asignatura & Tipo \\
\hline Historia Universal I & troncal \\
\hline Latín y Cultura Clásica & troncal \\
\hline Lengua Española. Expresión Escrita & troncal \\
\hline Lengua Vasca. Expresión Escrita & troncal \\
\hline Teoría de la Comunicación & optativa \\
\hline$\overline{\text { Deontología General y Profesional }}$ & obligatoria \\
\hline El Lenguaje en la Comunicación & optativa \\
\hline Geografia Humana & troncal \\
\hline Historia Universal II & troncal \\
\hline Literatura Española & troncal \\
\hline Literatura Vasca & troncal \\
\hline Taller de Escritura I & optativa \\
\hline Curso 2 Asignatura & Tipo \\
\hline Géneros del Periodismo Escrito & optativa \\
\hline Historia del Pensamiento Filosófico y Científico & troncal \\
\hline Informática I: Maquetación y Diseño & optativa \\
\hline La Comunicación Gráfica I & optativa \\
\hline Lengua Extranjera & troncal \\
\hline Lengua Extranjera & troncal \\
\hline Taller de Comunicación Oral & optativa \\
\hline Historia de la Comunicación Social & optativa \\
\hline Historia del Arte & troncal \\
\hline La Comunicación Gráfica II & optativa \\
\hline Literatura Extranjera & troncal \\
\hline Literatura Extranjera & troncal \\
\hline Medios de Comunicación de Masas & optativa \\
\hline Taller de Escritura II & optativa \\
\hline Ciclo 2 Asignatura & Tipo \\
\hline Informática I: Maquetación y Diseño & optativa \\
\hline La Comunicación Gráfica I & optativa \\
\hline La Comunicación Gráfica II & optativa \\
\hline Taller de Escritura II & optativa \\
\hline Curso 3 Asignatura & Tipo \\
\hline Comunicación Oral en los Medios & optativa \\
\hline Documentación y Sistemas de Información & optativa \\
\hline Gestión de Empresas y Servicios de Comunicación & optativa \\
\hline Historia Contemporánea & troncal \\
\hline Lenguajes Audiovisuales & optativa \\
\hline Psicología & troncal \\
\hline Antropología Social & troncal \\
\hline Boletines Internos y Especializados & optativa \\
\hline Opinión Pública & optativa \\
\hline Publicidad y Propaganda & optativa \\
\hline Taller Audiovisual & optativa \\
\hline Valores Sociales y Derechos en la Comunicación & optativa \\
\hline Curso 4 Asignatura & Tipo \\
\hline Administración de Proyectos de Comunicación & optativa \\
\hline Comunicación Institucional & optativa \\
\hline
\end{tabular}

SAKATA, Marici Cristine Gramacho, Globalização e Educação: A formação do comunicador social na América Latina, 2008312 p. (Doutorado - Orientação BACCEGA, M. A.) Escola de Comunicações e Artes da Universidade de São Paulo, São Paulo, SP, 2008 


\begin{tabular}{l|l}
\hline El Cómic y la Narración Gráfica & optativa \\
\hline El Relato Cinematográfico & optativa \\
\hline Estudios en el Extranjero & optativa \\
\hline Geografia Regional & troncal \\
\hline Nuevas Tecnologías en la Comunicación & optativa \\
\hline Comunicación en las Organizaciones & optativa \\
\hline Diseño y Técnicas de Comunicación Multimedia & optativa \\
\hline Evaluación de Mensajes & optativa \\
\hline Filosofia & troncal \\
\hline Taller de Escritura Multimedia & optativa \\
\hline
\end{tabular}

$\underline{1.2}$ Universidad Complutense de Madrid - Facultad de Ciencias de la Información $\underline{301}$

\section{- Características e Missão da Instituição}

La Universidad Complutense fue fundada en Alcalá de Henares, la antigua Complutum, por el Cardenal Cisneros, mediante Bula Pontificia concedida por el Papa Alejandro VI en 1499. Sin embargo, su verdadero origen se remonta al 20 de mayo de 1293, fecha en que el Rey Sancho IV de Castilla crea el Estudio de Escuelas Generales de Alcalá, que daría lugar dos siglos después a la Universidad Complutense de Cisneros.

En el curso 1509-1510 ya funcionaban cinco Facultades: Artes y Filosofia, Teología, Derecho Canónico, Letras y Medicina.

En 1836, bajo el reinado de Isabel II, la Universidad fue trasladada a Madrid, donde toma el nombre de Universidad Central y se emplaza en la calle San Bernardo.

Posteriormente, en 1927, se planificó la construcción de un área universitaria en la zona de Moncloa, en terrenos cedidos por el Rey Don Alfonso XIII para tal fin. Durante esta etapa se constituyó en núcleo de la denominada Edad de Plata de la cultura española. En sus aulas impartieron magisterio, entre otros, José Ortega y Gasset, Manuel García Morente, Luis Jiménez de Asúa, Santiago Ramón y Cajal y Blas Cabrera.

La Guerra Civil convirtió a la Ciudad Universitaria en frente de batalla, causando la destrucción de edificios de facultades e institutos ubicados en su recinto, así como la pérdida de parte de su rico patrimonio científico, artístico y bibliográfico. Se perdió con ello una buena parte del prestigioso profesorado que hasta entonces había ejercido la docencia en la Universidad Complutense.

En 1970 el Gobierno acomete planes de reforma de la Enseñanza Superior, y la Universidad Central pasa a denominarse Complutense, recuperando la denominación de su lugar de origen. Es por entonces cuando se crea el campus de Somosaguas para albergar el grueso de las facultades de Ciencias Sociales con el fin de descongestionar el Campus de Moncloa.

El Equipo de Dirección de la UCM considera que la Universidad, además de ser un centro de excelencia académica e investigadora, tiene el deber de abrirse a las problemáticas sociales internas y de su entorno social, de ahi que una de las líneas directrices de su Programa de Gobierno sea la necesidad de impulsar permanentemente medidas concretas que favorezcan la integración y la igualdad real de oportunidades de las personas con discapacidad en la UCM. Objetivos

La Oficina para la Integración de Personas con Discapacidad de la UCM proporciona atención directa a toda la Comunidad Universitaria, estudiantes, profesores y personal de Administración y Servicios, ofreciendo un espacio donde plantear dudas y necesidades y recoger sugerencias para ofrecer un servicio de calidad.

301 Disponível em http://www.ucm.es/centros/webs/fcinf/ acesso em 07/12/2006

SAKATA, Marici Cristine Gramacho, Globalização e Educação: A formação do comunicador social na América Latina, 2008312 p. (Doutorado - Orientação BACCEGA, M. A.) Escola de Comunicações e Artes da Universidade de São Paulo, São Paulo, SP, 2008 
La OIPD te facilita:

Atención, información y orientación en el ámbito personal, profesional y social.

Asesoramiento relativo a adaptaciones académicas y ayudas técnicas, así como sobre la orientación y adecuación de las mismas.

Información sobre becas y prestaciones sociales.

Apoyo en la gestión de prácticas externas y en inserción laboral a los estudiantes que lo soliciten, en colaboración con el Centro de Orientación e Información de Empleo (COIE) de la UCM.

Soporte y apoyo en la realización de Pruebas de Acceso a la Universidad.

La OIPD mantiene contactos permanentes con los Centros de Enseñanzas Medias de la Comunidad de Madrid con el fin de conocer las necesidades de los estudiantes de nuevo ingreso.

Además la OIPD:

Realiza actividades de sensibilización de la comunidad universitaria para posibilitar el trato normalizado de todos sus integrantes.

Fomenta el apoyo a las personas con discapacidad a través del Programa de Colaboración en Actividades de Atención a la Discapacidad en los Centros de la UCM.

Mantiene contactos e intercambia experiencias con los servicios homólogos de otras universidades para mejorar la atención a las personas con discapacidad en la Universidad Complutense.

Se coordina con todos los Servicios de la UCM, en especial con los Servicios de Prevención, Obras, Orientación Laboral, Acción Social y Oficina para la Igualdad de Género en pos de una mejora en la accesibilidad de las personas con discapacidad a la Universidad.

Promueve el voluntariado Social en la UCM, con el fin apoyar a las personas con discapacidad de la comunidad universitaria.

Mantiene contacto y coordinación con las administraciones, asociaciones, federaciones, fundaciones y plataformas representativas de los distintos tipos de discapacidad, que desarrollen programas y servicios relacionados, en general, con la misma y, especificamente, la universitaria.

Por su tradición e historia, la Universidad Complutense de Madrid (UCM) es la universidad de referencia en el Estado español. En sus aulas se han formado decenas de miles de titulados universitarios que han dirigido desde los puestos de responsabilidades en la Administración y las empresas el desarrollo económico, social y político de nuestro país.

Su gran potencial docente e investigador hace que la Universidad Complutense sea una gran universidad. Cuenta con el mayor número de estudiantes y de profesores, pero más que por sus aspectos cuantitativos resalta por la alta cualificación de sus profesores, por la importancia de su investigación y por sus instalaciones, entre las que se encuentran laboratorios de vanguardia.

En sus aulas se pueden cursar 77 titulaciones oficiales, en torno a 230 títulos propios y cerca de 200 programas de doctorado. La formación académica se complementa con una gran oferta deportiva y de actividades culturales, con las que la Universidad quiere contribuir a la formación no sólo de buenos técnicos sino también de mejores ciudadanos.

La Universidad Complutense de Madrid se encuentra inmersa en un proceso de adaptación y mejora de la calidad para garantizar la convergencia con el Espacio Europeo de Educación Superior.

Carlos Berzosa

Rector de la Universidad Complutense de Madrid

- Características e Objetivos do Curso de Comunicação ou Especialidade da Instituição

SAKATA, Marici Cristine Gramacho, Globalização e Educação: A formação do comunicador social na América Latina, 2008312 p. (Doutorado - Orientação BACCEGA, M. A.) Escola de Comunicações e Artes da Universidade de São Paulo, São Paulo, SP, 2008 
La Licenciatura de Periodismo de plan de estudios de 1995 tiene una carga lectiva total de 326 créditos distribuidos en 5 cursos académicos

- Grade Curricular

Asignatura

Tecnología de la Información Escrita

$T R$

Teoría de la Comunicación

$T R$

Historia Universal Contemporánea $\quad T R$

Teoría General de la Publicidad TR

Lengua Española $T R$

Principios de Economía $O B$

Estructura de la Comunicación $O B$

Introducción a las Ciencias Jurídicas $O B$

Teoría General de la Imagen $O B$

Redacción Periodística y de la Comunicación Colectiva TR

Teoría de la Información $\quad T R$

Sociología $T R$

Fundamentos de las Relaciones Públicas $T R$

Tecnología de los Medios Audiovisuales TR

Historia de la Comunicación Social OB

Análisis de Textos $\quad O B$

Estructura Social $O B$

Fundamentos Psicosociales de la Información $O B$

Información Audiovisual $\quad T R$

Documentación $\quad T R$

Historia de España Contemporánea $O B$

Historia del Pensamiento Político y Social Contemporáneo OB

Marketing $O B$

Movimientos Literarios Contemporáneos y Periodismo OB

Teoría y Práctica de la Redacción Periodística I OB

OPTATIVAS I Ciclo Tipo
Asignatura

Movimientos Artísticos Contemporáneos opt

Tecnología del Libro opt

Comunicación política opt

Empresas informativas y su relación en los sistemas político opt

Historia del cine informativo opt

Estructura constitucional y organización del estado en España opt

La prensa en el sistema educativo opt

Los soportes de la comunicación en el texto literario opt

Crítica literaria: Metodología opt

Historia de la representación escénica opt 
Arte Español Contemporáneo opt

Economía Mundial opt

Economía de España opt

Comunicación interpersonal opt

Análisis de textos periodísticos I: el relato opt

Escritura y Tipografía opt

Comunicación en la Unión Europea opt

Instituciones comunitarias opt

Influencia sociocultural de las nuevas tecnologías de la informa-ción opt

Semiótica de la comunicación de masas opt

La lengua española en el periodismo opt

Crítica de Arte opt

Economía de la Unión Europea opt

Instituciones Profesionales del Periodismo opt

ASIGNATURAS TRONCALES Y OBLIGATORIAS DEL $2^{\circ}$ CICLO Tipo
Asignatura

Teoría y Práctica de la Redacción Periodística II TR

Teoría y Técnica de la Información Audiovisual I: Radio $T R$

Organización y Gestión de la Empresa Informativa TR

Fundamentos de la Información Periodística Especializada TR

Tipografía y Diseño Gráfico $\quad T R$

Teoría y Análisis del Mensaje Periodístico $\quad T R$

Historia del Periodismo Universal TR

Derecho de la Información I TR

Métodos y Tcas. de Investigación I OB

Estructura y Sistema de la Información $O B$

Opinión Publica $O B$

La Especialización Periodística por Áreas y Medios de Comunicación $\quad T R$

Edición y Producción $\quad T R$

Derecho de la Información II $\quad T R$

Teoría y Práctica de la Redacción Periodística III OB

Ética y Deontología Profesional OB

Relaciones Internacionales $O B$

Métodos y Técnicas de Investigación II OB

Teoría y Práctica de la Dirección de la Empresa Informativa OB

Teoría y Técnica de la Información Audiovisual II: televisión OB

Historia del Periodismo Español OB

OPTATIVAS II Ciclo Tipo
Asignatura

Análisis de Textos Periodísticos II: El Comentario opt

Periodismo de Investigación opt

Estilística Aplicada en el Periodismo Actual opt

Información Política opt

SAKATA, Marici Cristine Gramacho, Globalização e Educação: A formação do comunicador social na América Latina, 2008312 p. (Doutorado - Orientação BACCEGA, M. A.) Escola de Comunicações e Artes da Universidade de São Paulo, São Paulo, SP, 2008 
Información Económica opt

Información deportiva opt

Información Cultural opt

Información Cientifica y Técnica opt

Información sobre Salud y Medioambiente opt

Información sobre Educación y Sociedad opt

El Color en la prensa opt

Dirección de Arte en Comunicación Escrita e Impresa opt

Agencias Informativas opt

Información Audiovisual en las Empresas e Instituciones opt

Diseño y Producción de Programas informativos en radio y TV opt

Información y Desarrollo opt

Empresa Informativa de Medios Impresos opt

Empresa Informativa en Radio y Televisión opt

Empresa de Agencias de Información opt

Concentración Informativa y Libertad de Empresa opt

Historia de la Propaganda opt

Historia del Periodismo Iberoamericano opt

Sociología de la cultura opt

Sociología de la Comunicación opt

Periodismo de precisión $\quad$ opt

Sociología de la Comunicación en las Organizaciones opt

Literatura española del siglo $X X \quad$ opt

Literatura universal del siglo $X X \quad$ opt

Literatura hispanoamericana contemporánea opt

Literatura y periodismo contemporáneos opt

Documentación Periodística opt

Fotografia informativa opt

Video empresarial e Institucional opt

Regulación Jurídica de la Documentación opt

RR. II. Europa Central y Oriental opt

RR. II. Del Magreb y Oriente Medio opt

Relaciones exteriores de España opt

Marketing Social y Político opt

Historia de los Movimientos Sociales del Siglo XX opt

Gabinetes de Prensa opt

Imagen Corporativa opt

Gestión de la Comunicación Corporativa opt

\section{Universidades Globalizadas}

SAKATA, Marici Cristine Gramacho, Globalização e Educação: A formação do comunicador social na América Latina, 2008312 p. (Doutorado - Orientação BACCEGA, M. A.) Escola de Comunicações e Artes da Universidade de São Paulo, São Paulo, SP, 2008 
1.3 Mondragon Unibertsitatea - Licenciatura en Comunicación Audiovisual ${ }^{302}$

- Características e Missão da Instituição

Modelo de gestao do grupo

El Modelo de Gestión globalmente se expresa mediante un gráfico que contiene 3 grandes bloques. En La Estrategia se trata de representar el modo en el que cada Negocio determina el rumbo a seguir, es decir decide hacia dónde ir. Los Agentes tratan de orientar sobre cómo llevar a la práctica la Estrategia, concretando los aspectos en los que debe ponerse énfasis e incluso el estilo con el que debe realizarse la gestión. En Los Resultados se representa el para qué, es decir lo que esperamos obtener y, por lo tanto, lo que vamos a medir y controlar. La Estrategia supone el soporte sobre el que se asientan los Agentes que se conciben como un medio para conseguir los Resultados. El Modelo en su conjunto actúa como un verdadero ciclo PDCA que gira constantemente, desde la Estrategia (P) hasta los Agentes (P y D) para llegar a los Resultados (C) y el Act (A) que representa el cuestionamiento global del Modelo y las acciones derivadas.

Los resultados se constituyen en el principal punto de control de la eficacia del Modelo de Gestión. Si no obtenemos resultados satisfactorios, o bien deberemos cuestionarnos la Estrategia elegida o replantearnos el enfoque de la gestión de los Agentes. No existen empresas excelentes con resultados deficientes.

Mondragón Corporación Cooperativa (MCC)

Situadas mayoritariamente en el País Vasco las empresas de Mondragón Corporación Cooperativa (MCC) ocupan una posición de privilegio entre la Península Ibérica y el resto de Europa. sta favorable situación geográfica se complementa con una buena red viaria de autopistas, tres aeropuertos, a los que se añade la proximidad del de Biarritz en territorio francés y dos puertos de gran capacidad: Pasajes y Bilbao.

Historia y presentación

Mondragon Unibertsitatea es una universidad joven, creada en 1997 y reconocida oficialmente por la ley 4/1997 del 30 de mayo. La Universidad nace por la asociación de tres cooperativas educativas, avaladas por una extensa trayectoria y experiencia en el mundo de la enseñanza, Mondragon Goi Eskola Politeknikoa "Jose $M^{a}$ Arizmendiarrieta” S.Coop., ETEO S.Coop. y Irakasle Eskola S.Coop., lo que a su vez constituyen hoy en día las dos Facultades y Escuela de la Universidad:

Mondragon Unibertsitatea es una Universidad de iniciativa y vocación sociales, declarada de utilidad pública y sin ánimo de lucro. mprometida desde su nacimiento con la calidad en la educación y la orientación práctica de sus estudios, en Mondragon

302 Disponível em http://www.mondragon.edu/estudios/humanidades-y-ciencias-de-laeducacion acesso em 18/01/2007

SAKATA, Marici Cristine Gramacho, Globalização e Educação: A formação do comunicador social na América Latina, 2008312 p. (Doutorado - Orientação BACCEGA, M. A.) Escola de Comunicações e Artes da Universidade de São Paulo, São Paulo, SP, 2008 
Unibertsitatea otorgamos una gran importancia a la formación integral de los estudiantes.

Nuestra pertenencia a la Corporación Cooperativa MCC nos permite mantener una estrecha cercanía al mundo de la empresa, posibilitando a nuestros alumnos que desde el inicio de sus estudios tomen contacto con la realidad laboral. En la actualidad, la universidad tiene en torno a 4.000 alumnos y alcanza las 22 titulaciones de grado. La oferta de postgrado, por su parte, asciende a un total de 15 masters y 8 cursos de experto universitario.

\section{Vocación social}

En Mondragon Unibertsitatea mantenemos un compromiso de transformación social, concretado en nuestro modelo participativo. Somos una universidad cooperativa, perteneciente a la Corporación Cooperativa MCC, con una clara vocación humanista y comprometida con nuestro entorno, con nuestra sociedad y con nuestro tiempo.

Nuestro modelo formativo implica un sistema de relaciones que, teniendo como eje el sistema educativo, busca la implicación de empresas e instituciones de la comarca, para garantizar la accesibilidad social, la compaginación del estudio y el trabajo, el desarrollo de la investigación y la prestación de Formación Continua.

\section{Orientación práctica}

Una de las principales características de Mondragon Unibertsitatea es su estrecha y permanente relación con el mundo laboral, lo que nos permite perfilar nuestra oferta educativa adecuándola a las necesidades de las empresas y organizaciones.

Nuestra relación con MCC -con 230 empresas y entidades en su seno y más de 70.000 trabajadores- así como los convenios con numerosas empresas y organizaciones de diversos sectores permiten que los alumnos tomen contacto con la realidad laboral desde el inicio de sus estudios. Esto se traduce en una serie de actividades:

- Alternancia estudio-trabajo: Los estudiantes tienen la posibilidad de compaginar el estudio con el trabajo, a media jornada, lo que además de complementar su formación académica posibilita la autofinanciación de sus estudios.

- Prácticas en empresas: Los estudiantes realizan prácticas en empresas y centros educativos, como complemento a su formación.

- Proyectos Fin de Carrera: Todos los alumnos culminan sus estudios con un proyecto en la empresa cuya duración puede ser de hasta un año.

- Participación de las empresas en los órganos de gestión de Mondragon Unibertsitatea: Ello permite, además de contar con la visión de agentes directamente relacionados con el mundo laboral, disponer de un conocimiento permanente de las necesidades existentes en el mercado de trabajo, no sólo en relación al tipo de carreras sino también en cuanto a habilidades $y$ competencias requeridas a los titulados.

- Formación Continua: Ofrecemos una amplia oferta de cursos de postgrado, cursos bajo demanda y cursos abiertos de larga y corta duración orientada tanto a alumnos universitarios como a profesionales en activo.

- Proyectos de Investigación: La participación de los profesores de Mondragon Unibertsitatea en proyectos de investigación es uno de los ejes importantes en su proceso de innovación eductiva, ya que posibilita que el profesor obtenga un 
conocimiento real y permanente de las necesidades de la empresa y mantenga permanentemente actualizados sus conocimientos que posteriormente se trasmiten al alumnado.

Comprometidos con la investigación

El desarrollo de la investigación es una de las bases del sistema educativo de Mondragon Unibertsitatea. Para ello aglutinamos una sólida red de entidades de soporte entre las que destacan las específicas del área de la Investigación Tecnológica, IKERLAN e IDEKO, dos Centros Tecnológicos reconocidos a nivel internacional y que constituyen pilares básicos de la organización de la Universidad.

También hemos impulsado la creación del Polo de Innovación Garaia, donde en un mismo espacio fisico conviven la propia Universidad, Centros Tecnológicos y unidades de $I+D$ de empresas, con el objetivo de potenciar el desarrollo de la investigación de manera conjunta. Contamos, asimismo, con la colaboración del grupo empresarial cooperativo MCC, el Grupo Ulma S.Coop., la Fundación Gizabidea y la Mancomunidad del Alto Deba, en calidad de socios colaboradores.

- Características e Objetivos do Curso de Comunicação ou Especialidade da Instituição

Mondragon Unibertsitatea ha puesto en marcha un nuevo Modelo Educativo denominado Proyecto Mendeberri. Se trata de un modelo educativo trilingüe-euskera, castellano, inglés-que se caracteriza por el desarrollo de competencias y valores en el propio proceso formativo, el carácter práctico de su metodología didáctica y por el uso intensivo de las nuevas tecnologías de la información y la comunicación.

Licenciatura en Comunicación Audiovisual

El objetivo de esta carrera es formar comunicadores integrales especializados en el ámbito de la comunicación audiovisual.

- Grade Curricular

\begin{tabular}{|l|l|}
\hline TITULACIÓN: & $\begin{array}{l}\text { Licenciado en Comunicación Audiovisual } \\
\text { Resolución de 26 de OCTUBRE DE 2005 (BOE 30.11.2005) }\end{array}$ \\
\hline CAMPUS: & ESKORIATZA \\
\hline $\begin{array}{l}N^{\circ} \text { DE } \\
\text { CRÉDITOS: }\end{array}$ & 306 \\
\hline DURACIÓN: & 4 años \\
\hline
\end{tabular}

Distribución de los Créditos

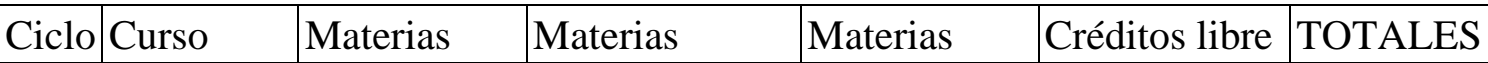

SAKATA, Marici Cristine Gramacho, Globalização e Educação: A formação do comunicador social na América Latina, 2008312 p. (Doutorado - Orientação BACCEGA, M. A.) Escola de Comunicações e Artes da Universidade de São Paulo, São Paulo, SP, 2008 


\begin{tabular}{|l|l|l|l|l|l|l|}
\hline & & troncales & obligatorias & Optativas & elección & \\
\hline $1^{\mathrm{o}}$ & $1^{\mathrm{o}}$ & 42 & 0 & & & 75 \\
\hline $1^{\mathrm{o}}$ & $2^{\mathrm{o}}$ & 30 & 0 & & & 75 \\
\hline $1^{\mathrm{o}}$ & Indiferente & 0 & 0 & 69 & 9 & 78 \\
\hline $2^{\mathrm{o}}$ & $1^{\mathrm{o}}$ & 33 & 0 & & & 75 \\
\hline $2^{\mathrm{o}}$ & $2^{\mathrm{o}}$ & 24 & 12 & & & 75 \\
\hline $2^{\mathrm{o}}$ & Indiferente & 0 & 0 & 60 & 21 & 81 \\
\hline & Totales & 129 & 12 & 129 & 30 & 300 \\
\hline
\end{tabular}

\begin{tabular}{|c|c|c|}
\hline \multicolumn{3}{|c|}{ Plan de Estudios } \\
\hline & Materias troncales y obligatorias & Materias Optativas \\
\hline & $\begin{array}{l}\text { Lengua } \\
\text { Comunicación e información escrita I } \\
\text { Análisis del entorno social y de su } \\
\text { evolución histórica } \\
\text { Teoría de la comunicación y teoría de la } \\
\text { información I } \\
\text { Comunicación e información audiovisual } \\
\text { I } \\
\text { Publicidad }\end{array}$ & $\begin{array}{l}\text { Economía } \\
\text { Introducción a la empresa } \\
\text { Inglés I } \\
\text { Nuevas tecnologías para la información y } \\
\text { la comunicación } \\
\text { Web } 2.0\end{array}$ \\
\hline & $\begin{array}{l}\text { Comunicación e información escrita II } \\
\text { Relaciones públicas } \\
\text { Teoría de la comunicación y teoría de la } \\
\text { información II } \\
\text { Comunicación e información audiovisual } \\
\text { II } \\
\text { Documentación informativa }\end{array}$ & $\begin{array}{l}\text { Inglés II } \\
\text { Taller de lengua } \\
\text { Habilidades de comunicación } \\
\text { Historia del cine } \\
\text { Historia del pensamiento filosófico y } \\
\text { científico } \\
\text { Aspectos legales de la sociedad } \\
\text { Marketing } \\
\text { Liderazo y gestión de personas } \\
\text { Talleres audiovisuales }\end{array}$ \\
\hline & $\begin{array}{l}\text { Derecho de la información I } \\
\text { Narrativa audiovisual I } \\
\text { Producción y realización audiovisual I } \\
\text { Teoría de la comunicación audiovisual }\end{array}$ & $\begin{array}{l}\text { Filosofía } \\
\text { Cooperativismo y cultura empresarial } \\
\text { Comunicación corporativa I } \\
\text { Taller de guiones } \\
\text { Taller de radio } \\
\text { Amortización créditos de libre elección }\end{array}$ \\
\hline & $\begin{array}{l}\text { Estructura del sistema audiovisual } \\
\text { Narrativa audiovisual II } \\
\text { Producción y realización audiovisual II } \\
\text { Prácticas } \\
\text { Proyecto fin de carrera }\end{array}$ & $\begin{array}{l}\text { Historia moderna y contemporánea } \\
\text { Psicología de la comunicación } \\
\text { Comunicación corporativa II } \\
\text { Diseño de la información } \\
\text { Calidad } \\
\text { Taller de radio } \\
\text { Amortización créditos de libre elección } \\
\text { Comunicación internacional }\end{array}$ \\
\hline
\end{tabular}

\subsection{Universidad Antonio de Nebrija - Facultad de Ciencias de la Comunicación $\stackrel{303}{\underline{3}}$}

303 Disponível em http://www.nebrija.com/la_universidad/index.htm acesso em 07/12/2006

SAKATA, Marici Cristine Gramacho, Globalização e Educação: A formação do comunicador social na América Latina, 2008312 p. (Doutorado - Orientação BACCEGA, M. A.) Escola de Comunicações e Artes da Universidade de São Paulo, São Paulo, SP, 2008 


\section{- Características e Missão da Instituição}

La Universidad Antonio de Nebrija es una institución universitaria privada, nacida de la libre iniciativa, con pleno reconocimiento oficial por Ley de las Cortes Generales (Parlamento español) 23/95 de 17 de julio (BOE de 18 de julio de 1995).

La Nebrija es una universidad española, laica e independiente, con clara vocación internacional y espíritu práctico. Nuestra misión es mantener un alto rigor en la enseñanza académica y en la investigación científica de todas nuestras áreas de especialización, para contribuir así tanto a la formación y desarrollo profesional y humano de los estudiantes, como al progreso de la sociedad.

Se dijo de La Nebrija que es "la más pequeña de las grandes universidades españolas", por el acierto en el diseño del tamaño de la Universidad que permite garantizar a nuestros alumnos una formación personalizada con excelentes posibilidades de desarrollo tanto académico como profesional.

La proyección internacional de la Universidad Antonio de Nebrija es otra característica destacada por ser la primera universidad española en porcentaje de alumnos extranjeros y porque muchos alumnos cursan parte de su carrera en el extranjero. La Universidad cuenta con una amplia oferta de programas internacionales, unos con doble titulación y otros que facilitan a los estudiantes españoles la posibilidad de realizar uno o dos semestres o uno o dos cursos en prestigiosas universidades de Europa, Estados Unidos y Canadá.

La preocupación por la formación práctica, el desarrollo profesional y la adaptación a las nuevas tecnologías se manifiesta en la incorporación en todos sus planes de estudios de periodos de prácticas profesionales que complementan la formación de todos nuestros titulados con los conocimientos, habilidades y actitudes adquiridas en el entorno profesional.

Encontrará en la Nebrija una gran oferta en áreas de especialización, con plena validez oficial para los estudios conducentes a las titulaciones de diplomado, ingeniero técnico, licenciado e ingeniero, así como los másteres y de doctorado. De igual forma cuenta con una amplia oferta de títulos propios y programas de extensión universitaria.

La investigación aplicada y la metodología docente interactiva son otras características destacables para la transmisión de conocimientos útiles a la sociedad y al mundo empresarial y para la formación de profesores e investigadores.

Toda la organización está a la disposición de estudiantes y profesores para ofrecerles las mayores oportunidades profesionales y para disfrutar de las ventajas de una buena Universidad.

\section{¿Quién fue Antonio de Nebrija?}

Elio Antonio Nebrija nació en Lebrija (Sevilla) - de ahí su seudónimo-, en 1444. Estudió Humanidades en la Universidad de Salamanca y continuó sus estudios filológicos en Bolonia, donde se relacionó con el humanismo italiano. Su labor docente la inició en la Universidad de Salamanca, a la que dedicó de forma interrumpida gran parte de su vida. Llamado por el Cardenal Cisneros, acudió a la Universidad de Alcalá para participar en la edición de la Biblia Políglota, proyecto que abandonó por diferencias con el grupo de traductores. Los últimos años de su vida los pasó enseñando en la universidad alcalaína, donde murió en 1522.

El ilustre humanista luchó, a lo largo de toda su vida, por recuperar el latín culto que hablaban Cicerón y Quintiliano y que se estaba perdiendo en favor del habla vulgar. Para ello, se basó en el método natural, que partía de un buen conocimiento de la lengua romance-la lengua del pueblo-, como el mejor medio para evitar que se perdiera aquel latín culto.

Entre sus obras destacan: "Introductiones latinae" (1481)," Lexicon latino-castellanum et castellano-latinum" (1492), "Gramática castellana" (1492) y "Reglas de orthographia en la lengua castellana" (1517). De todas ellas, la más importante, por la repercusión que ha tenido

SAKATA, Marici Cristine Gramacho, Globalização e Educação: A formação do comunicador social na América Latina, 2008312 p. (Doutorado - Orientação BACCEGA, M. A.) Escola de Comunicações e Artes da Universidade de São Paulo, São Paulo, SP, 2008 
en la filología hispánica, es la Gramática castellana, primera codificación de una lengua moderna, y cuyo prólogo está dedicado a la reina Isabel la Católica.

- Características e Objetivos do Curso de Comunicação ou Especialidade da Instituição

"La formación del periodista requiere de unos profundos conocimientos teóricos de la comunicación, al tiempo que de una experiencia práctica en el manejo de los distintos medios. Esto es lo que hacemos en la Nebrija, formar periodistas completos que al llegar a cualquier medio de información no les suene nada nuevo y emprendan su trabajo como lo haría cualquier otro profesional experimentado". Guadalupe Aguado Guadalupe

Directora del Departamento de Periodismo y Comunicación Audiovisual

La Licenciatura en Periodismo está dirigida a aquellos jóvenes que deseen tomar parte activa en los procesos de conocimiento, comunicación y difusión de las ideas y acontecimientos que mueven día a día el mundo, siempre en contínua y estrecha relación con los medios de comunicación social.

Los periodistas formados en la Universidad Antonio de Nebrija, además de adquirir una base humanistica y unos conocimientos teóricos indispensables para el dominio del lenguaje y de la expresión escrita, aprenden, trabajando de manera práctica, las técnicas del tratamiento de la información en prensa, radio, $T V$, Internet y en el entorno multimedia. Los alumnos colaboran como redactores en la elaboración de una revista digital, diseñan sus programas de radio y televisión, captan las imágenes y los sonidos, los editan, los montan y presentan los espacios informativos. Todo ello, junto con la realización de prácticas laborales en empresas informativs, obligatorias para la obtención del título de licenciado.

Titulación oficial

Licenciatura en Periodismo + Diploma Nebrija Lidera

Diploma Nebrija Lidera

Área de Especialización

- Radio y Televisión

- Guión y Dirección

- Creatividad Publicitaria

- Gestión de la Comunicación y Protocolo

- Cultura y Humanidades (Programa Sofía)

Área de Desarrollo de Competencias Profesionales (talleres): Comunicación, Solución de problemas, Inteligencia Emocional, Innovación y Creatividad, Negociación, Trabajo en Equipo, Liderazgo, Gestión de Proyectos

Dirigido a Estudiantes que desean trabajar en medios de comunicación y participar en los procesos de comunicación y difusión de las ideas y acontecimientos que mueven día a día el mundo.

Duración 4 años

Total de créditos 348 créditos

Idioma obligatorio Inglés. Nivel exigido en la admisión: 2

Idioma de libre elección Francés o alemán

SAKATA, Marici Cristine Gramacho, Globalização e Educação: A formação do comunicador social na América Latina, 2008312 p. (Doutorado - Orientação BACCEGA, M. A.) Escola de Comunicações e Artes da Universidade de São Paulo, São Paulo, SP, 2008 
Se cursan los estudios en Campus de La Berzosa

Opción internacional Un periodo en alguno de los posibles destinos internacionales reforzará tu visión global, tu formación lingüistica y te capacitará para el desempeño internacional de tu profesión.

Objetivos docentes

El objetivo de la Licenciatura en Periodismo es formar universitarios que, junto a la capacitación instrumental y tecnológica adecuada, adquieran los "sentidos" necesarios para realizar con rigor, profundidad e idoneidad la función informativa, a través de los diversos medios de comunicación social:

El sentido lingüistico, que hace referencia no sólo al conocimiento y buen uso del lenguaje y de las estructuras narrativas en general, sino también, y sobre todo, a su aplicación, vertebración y modulación especifica en el periodismo.

El sentido documental, que exije una continua verificación, actualización y aplicación de conocimientos para cada caso y situación concretos.

El sentido ético, no sólo sobre el deber de ser veraz, sino también acerca del deber de respetar los diversos derechos de las personas, recogidos en la Constitución Española.

El sentido crítico es el que permite a los periodistas diferenciar lo importante de lo accesorio, lo perdurable de lo efímero, lo universal de lo particular, lo cierto de lo dudoso, lo verdadero de lo falso.

La capacitación instrumental y tecnológica requiere adiestrar a los periodistas en el manejo de las herramientas tecnológicas (multimedia, cámaras, micrófonos) y en el conocimiento operativo de los idiomas modernos.

El sentido de la realidad consiste en el conocimiento adecuado de la realidad informativa y de su contexto empresarial, jurídico, social...El sentido histórico, imprescindible para el conocimiento de la realidad presente, a partir de lo acontecido en el pasado.

- Grade Curricular

Plan de estudios

$1^{\circ}$ Curso

Asignaturas básicas y obligatorias

lengua y comunicación

documentación informativa

mundo contemporáneo

introducción a los medios de comunicación

informática aplicada (lc)

lengua inglesa 2 a (lc)

lengua francesa la (lc)

lengua alemana la (lc)

Asignaturas básicas y obligatorias

creatividad literaria

teoría y estructura de la información

españa contemporánea

introducción a la publicidad y rr.pp. maquetación y diseño por ordenador $i$ (op)

lengua inglesa $2 b(l c)$

lengua francesa $1 b(l c)$

lengua alemana $1 \mathrm{~b}(\mathrm{lc})$

\author{
$2^{\circ}$ Curso \\ Asignaturas básicas y obligatorias \\ historia y teoría del cine \\ géneros periodisticos $i$ : la noticia \\ historia de la publicidad y de las rr.pp. \\ asignaturas complementarias \\ literatura y periodismo (op) \\ la empresa y su entorno (lc) \\ lengua inglesa 3 a (lc) \\ lengua francesa $2 a(l c)$ \\ lengua alemana $2 a$ (lc) \\ la ética del voluntariado en la sociedad \\ actual (lc) \\ asignaturas básicas y obligatorias \\ historia y teoría de la televisión \\ géneros periodisticos ii: el reportaje y la \\ entrevista \\ sociología \\ asignaturas complementarias \\ fotografia (op) \\ introducción al derecho (lc) \\ lengua inglesa $3 b$ (lc) \\ lengua francesa $2 b(l c)$ \\ lengua alemana $2 b$ (lc)
}

SAKATA, Marici Cristine Gramacho, Globalização e Educação: A formação do comunicador social na América Latina, 2008312 p. (Doutorado - Orientação BACCEGA, M. A.) Escola de Comunicações e Artes da Universidade de São Paulo, São Paulo, SP, 2008 
$3^{\circ}$ Curso

Asignaturas básicas y obligatorias

periodismo de opinión

periodismo en radio

historia del periodismo

asignaturas complementarias

ética y deontología profesional (op)

lengua inglesa $4 a$ (lc)

lengua francesa $3 a(l c)$

lengua alemana $3 a(l c)$

Asignaturas básicas y obligatorias

tecnología de la edición gráfica(cf)

derecho de la información

tecnología de la producción audiovisual

asignaturas complementarias

información local y regional (op)

lengua inglesa $4 b$ (lc)

lengua francesa $3 b$ (lc)

lengua alemana $3 b$ (lc) $4^{\circ}$ Curso

asignaturas básicas y obligatorias

periodismo de investigación

periodismo de televisión

organización y gestión de la empresa

informativa

english for journalism a

asignaturas complementarias

periodismo internacional

lengua francesa 4 a (lc)

lengua alemana $4 a(l c)$

asignaturas básicas y obligatorias

periodismo especializado

producción en televisión

Asignaturas complementarias

periodismo económico (op)

lengua francesa $4 b(l c)$

lengua alemana $4 b$ (lc)

english for journalism $b$

prácticas laborales o proyecto fin de carrera

diploma nebrija lidera

ler curso (12 créditos)

asignaturas básicas y obligatorias

taller de competencias

taller de solución de problemas

$2^{\circ}$ Curso (12 créditos)

Asignaturas básicas y obligatorias

taller de inteligencia emocional

taller de innovación y creatividad

3 er Curso (12 créditos)

Asignaturas básicas y obligatorias

taller de negociación

taller de trabajo en equipo

$4^{\circ}$ Curso (12 créditos)

Asignaturas básicas y obligatorias

taller de liderazgo

taller de gestión de proyectos

FRANÇA

\begin{tabular}{|l|l|l|l|l|}
\hline $\begin{array}{l}\text { 2. } \\
\text { França }\end{array}$ & $\begin{array}{l}\text { 2.1 Université de } \\
\text { Marseille }\end{array}$ & $\begin{array}{l}2.2 \text { Université de } \\
\text { Bordeaux }\end{array}$ & $\begin{array}{l}2.3 \text { Université } \\
\text { Paris X*** }\end{array}$ & $\begin{array}{l}2.4 \text { Science Po } \\
* * *\end{array}$ \\
\hline
\end{tabular}

*** Universidades Nacionais que, segundo o relatório de Aupetit (2005), são instituições

estrangeiras provedoras de educação na América Latina.

SAKATA, Marici Cristine Gramacho, Globalização e Educação: A formação do comunicador social na América Latina, 2008312 p. (Doutorado - Orientação BACCEGA, M. A.) Escola de Comunicações e Artes da Universidade de São Paulo, São Paulo, SP, 2008 


\section{Características e Missão das Instituições de Ensino Superior do Sistema Educacional Francês}

Como o sistema de educação superior é centralizado, as Universidades fazem parte de um único sistema, e por isso não apresentam as missões e valores individualmente. A Missão se encontra no portal do Ministério (Ministère Èducation National ${ }^{304}$ )

\section{Les grands principes}

Le système d'enseignement français est fondé sur de grands principes, certains inspirés de la Révolution de 1789, de lois votées entre 1881 et 1889 et sous les IVe et Ve Républiques ainsi que de la Constitution du 4 octobre 1958 : "l'organisation de l'enseignement public obligatoire gratuit et laïc à tous les degrés est un devoir de l'État ».

La liberté de l'enseignement

La gratuité

La neutralité

La laïcité

L'obligation scolaire

La liberté de l'enseignement - En France, le service public d'enseignement coexiste avec des établissements privés, soumis au contrôle de l'État et pouvant bénéficier de son aide - en contrepartie d'un contrat signé avec l'État. La liberté d'organiser et de dispenser un enseignement est une manifestation de la liberté d'expression : elle est définie par la "loi Debré " n'59-1557 du 31 décembre 1959 sur la liberté de l'enseignement et les rapports avec l'enseignement privé. Cependant l'État est le seul à délivrer diplômes et grades universitaires : les diplômes délivrés par les écoles privées n'ont pas de valeur officielle sauf s'ils sont reconnus par l'État. La réglementation des examens se fait à l'échelle nationale.

La gratuité - Le principe de gratuité de l'enseignement primaire public a été posé dès la fin du XIXe siècle par la loi du 16 juin 1881. La gratuité a été étendue à l'enseignement secondaire par la loi du 31 mai 1933. L'enseignement dispensé dans les écoles et les établissements publics est gratuit. Les manuels scolaires sont gratuits jusqu'à la classe de troisième, ainsi que les matériels et fournitures à usage collectif. Dans les lycées, les manuels sont le plus souvent à la charge des familles. La neutralitéL'enseignement public est neutre : la neutralité philosophique et politique s'impose aux enseignants et aux élèves.

La laïcité - Le principe de laïcité en matière religieuse est au fondement du système éducatif français depuis la fin du XIXe siècle. L'enseignement public est lä̈que depuis les lois du 28 mars 1882 et du 30 octobre 1886. Elles instaurent l'obligation d'instruction et la laïcité de des personnels et des programmes. L'importance de la laïcité dans les valeurs scolaires républicaines a été accentuée par la loi du 9 décembre 1905 instaurant la laïcité de l'Etat. Le respect des croyances des élèves et de leurs parents implique : l'absence d'instruction religieuse dans les programmes, la laïcité du personnel, l'interdiction du prosélytisme.La liberté religieuse a conduit à instituer une journée libre par semaine laissant du temps pour l'enseignement religieux en dehors de l'école.

L'obligation scolaire - Depuis la loi Jules Ferry du 28 mars 1882, l'instruction est obligatoire. Cette obligation s'applique à partir de 6 ans, pour tous les enfants français ou étrangers résidant en France. À l'origine, la scolarisation était obligatoire jusqu'à l'âge de 13 ans, puis 14 ans à partir de la loi du 9 août 1936. Depuis l'ordonnance $n^{\circ} 59-45$ du 6 janvier 1959, elle a été prolongée jusqu'à l'âge de 16 ans révolus.

\footnotetext{
${ }^{304}$ Ministère Èducation National - Disponível em http://www.education.gouv.fr/pid8/le-systemeeducatif.html Acesso em 16/07/2007
}

SAKATA, Marici Cristine Gramacho, Globalização e Educação: A formação do comunicador social na América Latina, 2008312 p. (Doutorado - Orientação BACCEGA, M. A.) Escola de Comunicações e Artes da Universidade de São Paulo, São Paulo, SP, 2008 
La famille a deux possibilités : assurer elle-même l'instruction des enfants (avec déclaration préalable) ou les scolariser dans un établissement scolaire public ou privé.

\section{Les acteurs}

Les parents, Dans les rectorats et les inspections académiques, Au ministère,

À l'université, Les collectivités territoriales, Les organismes sous tutelle, Les structures de consultation, Les structures de concertation, Au collège et au lycée, À l'école

\section{L'évaluation globale du système éducatif}

Depuis la fin des années 1980, une politique cohérente d'évaluation a été définie au niveau national. Elle vise à insuffler au sein du système éducatif tout entier une nouvelle culture de l'évaluation fondée sur la recherche de la performance.

- évaluations des enseignements

- évaluation des politiques educatives

- évaluation de la gestion

- évaluations-bilans nationales

- comparaisons internationales

- statistiques

Évaluation des enseignements- La Direction de l'évaluation, de la prospective et de la performance du ministère de l'éducation nationale (D.E.P.P.) réalise des études sur les pratiques pédagogiques, seule ou en collaboration avec les inspections générales, avec des équipes de recherche ou des organismes extérieurs nationaux ou internationaux. Les inspecteurs généraux de l'éducation nationale participent à l'évaluation d'ensemble du système éducatif, à l'exception de l'enseignement supérieur. Leur évaluation porte sur les contenus d'enseignement, les programmes, les méthodes pédagogiques et les moyens mis en ouvre. pour en savoir plus sur l'I.G.E.N Des centres de recherche sont spécialistes des questions de pédagogie, en particulier l'Institut national de recherche pédagogique (I.N.R.P.). Concernant l'enseignement supérieur, le Comité national d'évaluation des établissements publics à caractère scientifique, culturel et professionnel (C.N.E.) publie, outre ses rapports sur les établissements, des rapports sur les disciplines enseignées et des rapports d'évaluation thématiques. De plus, il dresse tous les quatre ans un bilan de synthèse sur l'état de l'enseignement supérieur.

Évaluation des politiques éducatives - Les politiques publiques mises en place pour améliorer la réussite des élèves et les résultats du système éducatif sont évaluées par la Direction de l'évaluation, de la prospective et de la performance (D.E.P.P.) ainsi que par des laboratoires de recherche et des instituts. Cette politique d'évaluation devrait être renforcée par la mise en ouvre de la loi organique sur les lois de finances (LOLF). Celle-ci vise en effet à réformer en profondeur la gestion publique en instaurant une culture de la performance et du résultat.

Évaluation de la gestion - L'Inspection générale de l'administration de l'éducation nationale et de la recherche effectue des études sur les aspects administratifs, financiers et organisationnels, à tous les niveaux du système éducatif. pour en savoir plus sur l'I.G.A.E.N.R. Les rapports de la Cour des comptes complètent cette évaluation de l'utilisation des fonds publics par le ministère de l'éducation nationale. le site de la cour des comptes

Évaluations-bilans nationales - Un cycle d'évaluations - bilans dans la plupart des disciplines a été mis en place en 2003 par la DEPP. Chaque année des échantillons d'élèves passent des épreuves standardisées qui permettent d'apprécier les niveaux de connaissances et de compétences des promotions de fin d'école et de fin de collège, en référence aux programmes. Ces évaluations ont été réalisées en lecture en 2003 et en en langues vivantes en 2004 et le seront en histoire-géographie et éducation civique en 2006, en sciences et technologie en 2007,

SAKATA, Marici Cristine Gramacho, Globalização e Educação: A formação do comunicador social na América Latina, 2008312 p. (Doutorado - Orientação BACCEGA, M. A.) Escola de Comunicações e Artes da Universidade de São Paulo, São Paulo, SP, 2008 
puis en mathématiques en 2008 ; le cycle reprendra ensuite. consulter les notes Évaluation: Les Notes Évaluation 04.09, 04.10 (Evaluation-bilan sur la lecture) et Les Notes Évaluation 05.06, 05.07, 05.08, 05.09, 05.10 (Evaluation-bilan sur les langues vivantes)

Comparaisons internationales - Il existe de nombreuses évaluations à caractère international, qui permettent de comparer la performance des systèmes éducatifs à travers le monde. Différents organismes internationaux mènent de telles études : l'association internationale pour l'évaluation de l'efficacité dans le domaine scolaire (I.E.A.), l'organisation de coopération et de développement économiques (O.C.D.E.) ; l'Unesco ; Eurydice, le réseau d'information sur l'éducation en Europe.

C'est la direction de l'évaluation, de la prospective et de la performance (D.E.P.P.) qui participe pour la France aux travaux de ces organismes.

Parmi les études internationales les plus récentes:

l'enquête PISA (programme pour le suivi des acquis des élèves) évalue tous les 3 ans les acquis des jeunes de 15 ans dans divers domaines

l'enquête P.I.R.L.S. (Progress in international reading literacy study) évalue tous les cinq ans les compétences en lecture des élèves de 9 à 10 ans)

consultez le site de l'O.C.D.E. pour connaître les résultats des enquêtes PISA 2003 et P.I.R.L.S. En outre, la Commission européenne publie chaque année des indicateurs permettant de comparer les moyens, le fonctionnement et les résultats des systèmes éducatifs des États membres. Elle va prochainement recueillir de nouvelles données grâce à des études européennes afin de construire de nouveaux indicateurs dans des domaines prioritaires (comme notamment les compétences en langues étrangères), dans le cadre du suivi des objectifs de Lisbonne. Le Réseau européen des responsables des politiques d'évaluation des systèmes éducatifs, que pilote la Direction de l'évaluation, de la prospective et de la performance (D.E.P.P.), organise une réflexion sur les politiques d'évaluation et met en ouvre des études comparatives, en liaison avec la Commission européenne" pour en savoir plus sur le réseau européen des responsables des politiques d'évaluation des systèmes éducatifs

Statistiques - La Direction de l'évaluation, de la prospective et de la performance (D.E.P.P.) définit et met en cuvre le dispositif d'évaluation du système éducatif. Elle contribue à l'évaluation des politiques conduites par le ministère. Elle est chargée de la conception et de la gestion du système d'information statistique du ministère.

La D.E.P.P. publie régulièrement le résultats de des études.

\section{Le financement de l'éducation}

En 2004, la dépense d'éducation a été financée à 82,3\% par l'État (ministère de l'éducation nationale, autres ministères, collectivités territoriales). Les familles et les entreprises participent également au financement de l'éducation. La dépense globale d'éducation (comprenant les activités d'enseignement et les activités connexes, comme l'administration, les cantines, les transports scolaires, les livres scolaires, etc.) a été évaluée, pour l'année 2004, à 116,3 milliards d'euros, ce qui représente 7,1\% du produit intérieur brut (P.I.B.).

Les financeurs du système éducatiff français en 2004

Les financeurs du système éducatif français en 2004

Participation à la dépense Pourcentage de participation à globale d'éducation de 2003 la dépense globale d'éducation (en millions d'euros) de 2003

Le ministère de l'éducation
nationale, de l'enseignement

$63148 \quad 54,3 \%$

SAKATA, Marici Cristine Gramacho, Globalização e Educação: A formação do comunicador social na América Latina, 2008312 p. (Doutorado - Orientação BACCEGA, M. A.) Escola de Comunicações e Artes da Universidade de São Paulo, São Paulo, SP, 2008 
supérieur et de la recherche

$\begin{array}{lll}\text { Les autres ministères } & 6395 & 5,5 \\ \text { Les autres administrations } & 951 & 0,8 \\ \text { Les collectivités territoriales } & \mathbf{2 5 2 7 1} & \mathbf{2 1 , 7} \\ \text { Les entreprises } & 7503 & 6,5 \\ \text { Les familles } & 13009 & 11,2\end{array}$

Source : Ministère de l'éducation nationale, "Repères et références statistiques", 2006.

\section{La répartition des dépenses}

Les postes de dépenses les plus importants pour l'année 2004

Postes de dépenses

Enseignement public du premier degré

Enseignement public du second degré

Enseignement public du supérieur

Enseignement privé subventionné

Services administratifs
Pourcentage de la dépense totale

$21 \%$

36

12

14

7

Source : Ministère de l'éducation nationale, "Repères et références statistiques", 2006.

\section{Comparaisons internationales}

La France dépense plus pour l'éducation en proportion du produit intérieur brut (P.I.B.) que la plupart des pays de l'Organisation de coopération et de développement économiques (O.C.D.E.). Cependant, la part des dépenses publiques d'éducation dans les dépenses publiques totales est inférieure à la moyenne des pays de l'organisation de coopération et de développement économiques (O.C.D.E.).

\section{Le budget 2007}

Le budget du ministère est évalué à 77 milliards d'euros pour 2007. Il a été élaboré pour le développer l'égalité des chances et rechercher une plus grande efficacité du système éducatif. Environ $28 \%$ du budget de l'État est ainsi consacré au Ministère.

\section{Mission "Enseignement scolaire"}

Les crédits prévus pour l'enseignement scolaire en 2007 atteignent 58,28 milliards d'euros, ce qui représente une hausse de 1,32\% par rapport à 2006. Cette mission concourt à la scolarisation de plus de 13 millions d'élèves.

\section{Mission "Recherche et enseignement supérieur"}

Pour la 3e année consécutive, les crédits de l'enseignement supérieur et de la recherche augmenteront pour atteindre 23,9 milliards d'euros en 2007, soit 5\% de plus qu'en 2006. Le budget 2007 est le premier à être préparé dans le cadre de la loi de programme sur la recherche du 18 avril 2006. Celle-ci a pour objectif de rééquilibrer l'effort financier en faveur de l'enseignement supérieur en France. Cela se traduit par 6 milliards d'euros mobilisés pour la recherche depuis 2004. Les établissements d'enseignement privés scolarisent plus de 2 millions d'élèves, soit $17 \%$ de l'ensemble des effectifs.

\section{Les établissements scolaires privés}

Les établissements d'enseignement supérieur privés

SAKATA, Marici Cristine Gramacho, Globalização e Educação: A formação do comunicador social na América Latina, 2008312 p. (Doutorado - Orientação BACCEGA, M. A.) Escola de Comunicações e Artes da Universidade de São Paulo, São Paulo, SP, 2008 
Le statut des établissements d'enseignement privés - Dans une décision rendue le 23 novembre 1977, le Conseil Constitutionnel a considéré que la liberté de l'enseignement faisait partie des principes fondamentaux reconnus par les lois de la République.

Trois lois fondamentales fixent le statut juridique des établissements d'enseignement privés :

- la loi Goblet du 30 octobre 1886 relative à l'enseignement primaire ;

- la loi Falloux du 15 mars 1850 sur l'enseignement secondaire;

- la loi Astier du 25 juillet 1919 sur l'enseignement technique.

La loi $n^{\circ} 59-1557$ du 31 décembre 1959, dite "loi Debré", a permis de définir les rapports actuels entre l'État et les établissements d'enseignement privés, instituant un certain équilibre. La loi ne reconnaît pas d'« enseignement privé » en tant que tel, mais uniquement une pluralité d'établissements.

Les conditions de création d'un établissement d'enseignement privé

Les règles sont les mêmes pour les établissements du premier degré et du second degré. Les Français ou les ressortissants des États membres de l'Union européenne ou de l'espace économique européen sont tenus de déclarer la création d'un établissement privé aux autorités compétentes. Les autres ressortissants étrangers doivent obtenir une autorisation, délivrée après avis du Conseil académique de l'éducation nationale.

\section{Le statut des diplômes octroyés}

L'État détient le monopole des grades et des titres universitaires : les établissements d'enseignement privés ne peuvent donc délivrer à leurs élèves que des certificats de scolarité qui ne sont pas des diplômes. Ils préparent en revanche leurs élèves aux examens officiels en vue des diplômes délivrés par l'État.

\section{Le financement public des établissement privés}

Tous les établissements privés d'enseignement peuvent obtenir des financements publics dans les conditions fixées par la loi.

Certaines dispositions sont applicables à tous les établissements d'enseignement privés : les collectivités territoriales n'ont pas le droit de financer les écoles privées. Les départements et les régions sont autorisées à attribuer un local et/ou une subvention limitée respectivement aux collèges et aux classes d'enseignement général des lycées.

Pour les établissements d'enseignement privés sous contrat, selon la loi $n^{\circ} 59-1557$ du 31 décembre 1959, l'État prend en charge la rémunération des personnels enseignants, les charges sociales et fiscales incombant à l'employeur ainsi que les dépenses de formation initiale et continue des enseignants. Les collectivités locales participent quant à elles au fonctionnement matériel des classes sous contrat sous la forme de forfaits. Pour l'enseignement secondaire sous contrat d'association, la contribution financière des départements et des régions est obligatoire.

Les chiffres de la fréquentation et de la composition des établissements d'enseignement privés primaire et secondaire

Les établissements privés d'enseignement (de la maternelle au post-baccalauréat) scolarisent plus de 2 millions d'élèves, soit 17\% des effectifs, dans une proportion stable: $13 \%$ des élèves dans le premier degré, et autour de $21 \%$ dans le second degré.

\section{Les établissements d'enseignement supérieur privés}

L'enseignement supérieur est libre. Les établissements privés sont essentiellement des instituts confessionnels, des écoles d'ingénieurs ou de commerce dont certains sont financés de façon variable par les pouvoirs publics. $14 \%$ des étudiants sont inscrits dans des établissements 
privés d'enseignement supérieur, qui représentent environ $30 \%$ du nombre total d'établissements d'enseignement supérieur.

\section{Les conditions de création d'un établissement privé d'enseignement supérieur}

En vertu de la loi du 12 juillet 1875, l'enseignement supérieur est libre. De même que pour l'enseignement primaire et secondaire, le Code de l'éducation établit une distinction selon la nationalité de la personne désirant créer un établissement d'enseignement supérieur privé. Les Français et les ressortissants des États membres de l'Union européenne ou de l'Espace économique européen sont libres de créer de tels établissements, sous réserve de déposer une déclaration d'ouverture auprès du rectorat ou du représentant de l'État dans le département et du procureur de la République. Les étrangers non ressortissants de l'Union européenne ou de l'Espace économique européen doivent en revanche obtenir une autorisation.Le recteur détient par ailleurs diverses compétences concernant la scolarité dans les établissements d'enseignement supérieur privé : conditions d'inscription des étudiants, déroulement des études conduisant à un diplôme national, modalités de contrôle des connaissances. L'État a la possibilité de surveiller les enseignements dispensés.

\section{Les grandes catégories d'établissements d'enseignement supérieur privés}

Les établissements privés d'enseignement supérieur libres, au nombre de 13 dont 5 Instituts catholiques Paris, Angers, Lille, Lyon et Toulouse, dispensent un enseignement à caractère généraliste. Ils ne peuvent délivrer de diplômes nationaux, mais peuvent coopérer avec des établissements publics à caractère scientifique, cilturel et professionnel et permettre à leurs étudiants de passer les examens d'obtention d'un diplôme national.

Les établissements privés d'enseignement supérieur technique ont une vocation plus professionnelle : ce sont des écoles d'ingénieurs et des écoles de commerce et de gestion, on compte actuellement 44 écoles d'ingénieurs et 24 écoles de commerce privées.

Les lycées privés proposant des sections de techniciens supérieurs (S.T.S.) et des classes préparatoires aux grandes écoles (C.P.G.E.) sont soumis aux règles régissant les établissements de l'enseignement secondaire; ils peuvent signer un contrat d'association avec l'État ou demeurer hors contrat.

\section{Le financement public des établissements d'enseignement supérieur privés}

L'État peut subventionner les formations d'enseignement supérieur privées. Certaines écoles sont financées par les ministères de l'Agriculture et des Affaires sociales, mais un grand nombre d'entre elles bénéficient d'une subvention du ministère de l'education nationale. L'établissement doit avoir été "reconnu" par l'État : la reconnaissance procède d'un contrôle du fonctionnement de l'établissement, de ses formations et de son personnel d'encadrement et enseignant. La reconnaissance de l'Etat permet ensuite à l'établissement de solliciter des subventions dont l'attribution n'est pas automatique. En 2006, 58 établissements privés d'enseignement supérieur sont subventionnés par le ministère chargé de l'enseignement supérieur, dont 13 établissements d'enseignement supérieur libre, 32 écoles privées d'ingénieurs et 13 écoles privées d'enseignement supérieur de gestion.

Les établissements d'enseignement supérieur présentent en France un ensemble très varié de statuts.

4. les établissements publics à caractère scientifique culturel et professionnel

5. les établissements publics à caractère administratif

6. les autres établissements d'enseignement supérieur

1. Les établissements publics à caractère scientifique, culturel et professionnel (E.P.S.C.P.)La loi du 26 janvier 1984 sur l'enseignement supérieur, dite "loi Savary », reprise par le code de

SAKATA, Marici Cristine Gramacho, Globalização e Educação: A formação do comunicador social na América Latina, 2008312 p. (Doutorado - Orientação BACCEGA, M. A.) Escola de Comunicações e Artes da Universidade de São Paulo, São Paulo, SP, 2008 
l'éducation, a créé les E.P.S.C.P. Leur particularité est de bénéficier d'une autonomie renforcée. Celle-ci se manifeste par:

- l'autonomie statutaire : une bonne part de la vie de chaque établissement est régie, non par des textes généraux, mais par des statuts adoptés par le conseil d'administration.

- de larges pouvoirs de décision en matière pédagogique et scientifique

- un contrôle financier a posteriori.

Les établissements suivants ont le statut d'E.P.S.C.P. :

- les universités auxquelles sont assimilés les trois instituts nationaux polytechniques (I.N.P.),

- les écoles et instituts extérieurs aux universités (par exemple les Instituts nationaux de sciences appliquées, I.N.S.A.),

- les écoles normales supérieures,

- les écoles françaises à l'étranger,

- les grands établissements (article L717-1), établissements "à dérogation » bénéficiant d'un statut particulier par décret pouvant déroger à certaines dispositions législatives.

Le code de l'éducation précise les principes d'organisation et de fonctionnement des universités et des instituts nationaux polytechniques (I.N.P.), mais renvoie à des décrets pris en conseil d'État pour la création et les règles particulières d'organisation et de fonctionnement des autres types d'E.P.S.C.P.

2. Les établissements publics à caractère administratif (E.P.A.)Le décret de création de l'E.P.A. fixe le statut particulier de l'établissement. Le directeur est nommé : ce peut être une nomination effectuée directement par l'autorité de tutelle ou une nomination après avis du conseil d'administration ou encore une nomination sur proposition du conseil d'administration. Les E.P.A sont soumis à un contrôle financier a priori à l'exception des I.U.F.M. pour lesquels il s'exerce à postériori.. L'article L719-10 du code de l'éducation prévoit qu'un établissement d'enseignement supérieur public (ou privé) peut être rattaché ou intégré à un E.P.S.C.P. Les établissements publics administratifs rattachés à un E.P.S.C.P. :

- les instituts universitaires de formation des maîtres (I.U.F.M.) : dans chaque académie, un I.U.F.M. est rattaché à une ou plusieurs universités de l'académie.

- 13 écoles nationales supérieures d'ingénieurs

- les écoles nationales d'ingénieurs (E.N.I.) de Metz (rattachée à l'université de Metz), de Tarbes (rattachée à l'institut national polytechnique de Toulouse) et de Brest (rattachée à l'université de Brest)

- 7 instituts d'études politiques (I.E.P.) de province

- l'institut d'administration des entreprises (I.A.E.) de Paris.

Les établissements publics administratifs autonomes :

- 4 écoles d'ingénieurs

- 13 autres établissements.

3. Les autres établissements d'enseignement supérieurLes établissements publics à caractère industriel et commercial (E.P.I.C.)

Les E.P.I.C. sont des personnes morales de droit public mais qui s'opposent aux E.P.A. en ce que la part de droit privé et de compétence judiciaire est beaucoup plus importante. L'exercice de la tutelle économique et financière, plus souple dans les E.P.I.C. que dans les E.P.A., s'effectue habituellement par l'entremise d'un commissaire du gouvernement désigné par le ministère dont relève l'établissement.

Deux établissements d'enseignement supérieur ont ce statut d'EPIC en vertu de leur décret de création:

- l'école nationale supérieure de création industrielle,

- l'école nationale supérieure des métiers de l'image et du son (ex-Fémis).

Les groupes d'écoles

Le groupe des écoles des télécommunications (G.E.T.) est un établissement public regroupant en son sein plusieurs établissements de formation.Ce groupe est géré par un administrateur

SAKATA, Marici Cristine Gramacho, Globalização e Educação: A formação do comunicador social na América Latina, 2008312 p. (Doutorado - Orientação BACCEGA, M. A.) Escola de Comunicações e Artes da Universidade de São Paulo, São Paulo, SP, 2008 
général et administré par un conseil. Il est composé d'un service d'administration générale et de trois écoles:

- l'école nationale supérieure des télécommunications (E.N.S.T.),

- l'école nationale supérieure des télécommunications de Bretagne (E.N.S.T.B.),

- l'institut national des télécommunications (I.N.T.) qui comprend une école d'ingénieurs et une école de gestion.

Chaque école bénéficie de l'autonomie pédagogique et scientifique.

Le groupe des écoles des affaires maritimes ainsi que le groupe des écoles nationales d'économie et statistique ont le statut de services ministériels déconcentrés.

\section{França - Universidades Nacionais}

\subsection{Université de Aix-Marseille - Sciences de l'Information et de la Communication ${ }^{305}$}

- Características e Missão da Instituição:

L'Université de Provence, héritière d'une riche tradition universitaire, alliant recherche et enseignement de haut niveau, propose une offre de formation très diversifiée. A côté des formations fondamentales débouchant sur les métiers de l'enseignement et de la recherche se sont développés de nombreux cursus professionnalisés dans les deux grands secteurs disciplinaires : Sciences et technologies d'une part, Lettres et sciences humaines d'autre part. Ces formations s'appuient sur plus de soixante unités de recherche labéllisées de niveau international. La production scientifique des équipes contribue à l'élaboration de nouveaux savoirs, mais également à l'innovation technique, économique et sociale en région, tant aux niveaux national qu'international. La réforme du LMD, mise en place à la rentrée 2004, confirme et élargit l'ouverture européenne et les initiatives déjà prises antérieurement en matière de mobilité des étudiants. Les contrats et projets sont nombreux avec l'ensemble des partenaires universitaires des pays étrangers (Méditerranée, Amériques, Afrique, Asie, etc.). Les formations sont ouvertes aux salariés et la validation des acquis leur permet de poursuivre leurs études tout au long de la vie. De nombreux services sont offerts aux étudiants (enseignement à distance, documentation, libre service informatique, activités culturelles, artistiques, vie associative, etc.). Un accueil spécifique est organisé pour les étudiants handicapés. A l'Université de Provence, l'espace de formation et de travail est un espace démocratique et convivial, d'ouverture culturelle, centré sur la mise en æeuvre des conditions de réussite pour les étudiants et sur l'apprentissage de la citoyenneté.

- Características e Objetivos do Curso de Comunicação ou Especialidade da Instituição:

\section{Licence (2 anos) + Master (1 ano) \\ Licence professionnel em Information et communication ${ }^{306}$ \\ Domaine : Sciences Humaines et Sociales}

Les enseignements de la filière information-communication abordent les diverses théories et analyses de la communication, la sémiologie et les interactions du comportement humain. Plus largement, sont abordées l'étude et la pratique des médias audiovisuels (photo, radio, télé, cinéma, vidéo...) et des nouvelles technologies (informatique, multimédia, technologies

\footnotetext{
${ }^{305}$ http://www.aixmarseille-universite.fr/formations.htm

${ }^{306}$ U1 Aix - http://www.up.univ-mrs.fr
}

SAKATA, Marici Cristine Gramacho, Globalização e Educação: A formação do comunicador social na América Latina, 2008312 p. (Doutorado - Orientação BACCEGA, M. A.) Escola de Comunicações e Artes da Universidade de São Paulo, São Paulo, SP, 2008 
numériques, Internet, Intranet...), en favorisant une réflexion critique sur l'état des savoirs. Au tronc commun des enseignements s'ajoute un parcours à choisir entre la thématique de la communication et des médias et celle de la communication des institutions. Un stage de deux mois en milieu professionnel est exigé pendant le dernier semestre. Les études d'information et de communication font appel à une bonne culture générale, des capacités rédactionnelles et de l'aisance dans l'expression orale. Les effectifs attendus sont compris entre 40 et 50 étudiants répartis avec équilibre dans les parcours.

Le département des sciences de l'information et de la communication (SIC) forme des étudiants dans les secteurs professionnels de la communication mais également prépare à la recherche dans le cadre d'un laboratoire (CREPCOM) qui est inscrit dans l'école doctorale "Cognition, Langage, Education 》. Il accueille une année de licence et un master mention "Métiers de la communication et de la médiation ».

La licence propose deux parcours (communication et médias, ou communication des institutions) qui permettent d'aborder l'étude théorique et pratique du champ de la communication, des médias audiovisuels et des nouvelles technologies.

\section{Master Sciences Humaines et Sociales Mention : Métiers de la communication et de la médiation}

Le département des sciences de l'information et de la communication (SIC) forme des étudiants dans les secteurs professionnels de la communication mais également prépare à la recherche dans le cadre d'un laboratoire (CREPCOM) qui est inscrit dans l'école doctorale " Cognition, Langage, Education ». Il accueille une année de licence et un master mention " Métiers de la communication et de la médiation ».

La licence propose deux parcours, communication et médias, ou communication des institutions, qui permettent d'aborder l'étude théorique et pratique du champ de la communication, des médias audiovisuels et des nouvelles technologies. Le master "Métiers de la communication et de la médiation " propose des enseignements en étroite relation avec les activités de recherche développés au sein du laboratoire CREPCOM (Centre de Recherche sur les Pratiques de Communication et de Médiation. Directrice : Françoise Bernard), équipe reconnue par le ministère (JE 2420) qui fédère des chercheurs actifs en SIC et en médiation culturelle. Les questions du changement en organisation, de l'innovation, des médiations, des dispositifs et des pratiques sont abordées au sein de l'enseignement à partir des travaux de recherche récents dans le champ des sciences de l'information et de la communication. Le master s'inscrit tout particulièrement dans un projet plus global de coopération interdisciplinaire et de valorisation de la pluridisciplinarité de l'Université de Provence.

Il prend en compte :

- L'émergence de nouveaux métiers qui requièrent un nouveau découpage des savoirs, des savoir faire et donc un nouvel assemblage de compétences pour les futurs diplômés,

- Des expériences concrètes de coopérations pluridisciplinaires. Dans le domaine de la formation et de l'enseignement entre spécialistes des Sciences de l'Information et de la Communication (SIC) et d'autres disciplines :

- Les arts et médiation culturelle des arts,

- La négociation internationale, les langues, cultures et civilisations,

- La philosophie et plus particulièrement la rhétorique

- La psychologie sociale.

- Une volonté de coopération inter universitaire, entre les trois universités d'Aix-Marseille, appliquée concrètement au parcours recherche.

SAKATA, Marici Cristine Gramacho, Globalização e Educação: A formação do comunicador social na América Latina, 2008312 p. (Doutorado - Orientação BACCEGA, M. A.) Escola de Comunicações e Artes da Universidade de São Paulo, São Paulo, SP, 2008 
- Grade Curricular

\section{Licence}

Les étudiants de l'Université de Provence titulaires de 120 crédits (bac+2) mention : histoire : parcours documentation et média; sociologie : parcours métiers de l'information, de la communication et de la culture; sciences du langage avec mineure en sociologie ou en psychologie ; lettres modernes parcours métiers du livre ; LEA parcours langue, culture et communication ; psychologie ; philosophie ; et ayant suivi les Unités d'Enseignement suivantes, au semestre 3: Champs et problématiques de l'information et de la communication ; au semestre 4: Secteurs d'activité et métiers de l'information et de la communication sont admis de plein droit.

Organisation de l'enseignement :

Après l'obtention de 120 crédits dans les conditions citées ci-dessus, l'enseignement en vue de l'obtention de la licence information-communication est réparti sur deux semestres, constituant la troisième année de licence. Chaque semestre comprend un certain nombre d'Unités d'Enseignement (une U.E correspond à des cours magistraux et des Travaux Dirigés). Deux sessions d'examen sont organisées pour chaque semestre d'enseignement.

Parcours $n^{\circ} 1$ : Communication et médias

Semestre 5

Communication des organisations: Initiation aux théories des organisations et découverte de l'actualité des théories et des pratiques en communication des organisations.

Langue vivante: Anglais spécifique pour étudiants infocom. Analyse de la presse anglophone et auto-formation assistée par le CALUP.

\section{Semestre 6}

Communication et sociétés : Approches théoriques de la sociologie des communications de masse. Analyse critique de la société de communication et de l'espace médiatique dans le contexte de la mondialisation.

Stage : Stage de deux mois dans le secteur d'activité des médias ou des institutions.

À ce contenu commun, il faut ajouter les Unités d'Enseignement suivantes :

Pour le parcours $n^{\circ} 1$ : Semestre 5 : Communication et médias ; Atelier : techniques du journalisme; Atelier : analyse des messages iconiques et sonores. Semestre $6:$ Médiation des savoirs ; Atelier : TIC et médiations ; Atelier : Analyse des médiations et coopérations en organisation.

\section{Master}

Parcours recherche: Sciences et technologies de l'information et de la communication: médiation des connaissances.

Professionnalisation

Chargé ou responsable de communication, chargé ou responsable d'information, chargé ou responsable de la médiation dans les entreprises, institutions publiques et services publics, SEM, associations, Établissements publics (un niveau bac +5 facilitera l'insertion professionnelle). Concours : Tous les concours de catégorie A de la fonction publique. Pour plus d'informations, consulter le site de l'ONISEP rubrique "fiches métiers » et " concours fonction publique ».

SAKATA, Marici Cristine Gramacho, Globalização e Educação: A formação do comunicador social na América Latina, 2008312 p. (Doutorado - Orientação BACCEGA, M. A.) Escola de Comunicações e Artes da Universidade de São Paulo, São Paulo, SP, 2008 
Parcours: "recherche" R1 : Sciences et Technologies de l'Information et de la Communication et Médiation des Connaissances

Semestre 1

- Communication des organisations

Théories des Sciences de l'Information et de la Communication

Médias et nouvelles technologies, usages et détournements

Méthodologie de la recherche et préparation du mémoire de recherche

Semestre 2

Langue Vivante

Connaissances des métiers de la communication

Ecrits professionnels

mémoire de recherche

Le Master recherche associe dans une logique novatrice et transdisciplinaire les trois Universités d'Aix-Marseille I, II (école de journalisme et de com. de Marseille) et III.

Les spécialités du master sont :

-Communication, organisation et innovation,

-Médias information et connaissance,

-Mémoire des organisations et systèmes d'information.

L'architecture générale est organisée sur un principe d'ouverture et de modules communs suivis de cours spécialisés correspondant aux axes de recherche forts de chacune des composantes du master. Il est à noter que le master recherche est fortement articulé avec les différents masters professionnels de chacune des universités. Les objectifs du Master découlent de la nécessité d'une réflexion théorique fondamentale sur les nouveaux enjeux de la "société de l'information» et notamment de la médiation des connaissances. Le Master vise ainsi à favoriser la recherche sur des thèmes essentiels dans le contexte de la "société de l'information»: la théorie des réseaux et la diffusion des connaissances, la théorie de l'information, les représentations des données et les systèmes d'information, l'intelligence économique et la mémoire des organisations, l'analyse cognitive et le transfert des connaissances. Les Sciences et Technologies de l'Information et de la Communication constituent la pierre angulaire de ce Master qui bénéficie d'une logique pluridisciplinaire.

\subsection{Université de Bordeaux 3 - Michel de Montaigne ${ }^{307}$}

- Características e Missão da Instituição:

C'est un héritage - L'Université de Bordeaux a été crée le 7 juin 1441 par le Pape Eugène IV à la demande de l'archevêque Pey Berland

L'université comptait alors quatre facultés : des arts, de médecine, de droit, de théologie

Supprimée en 1793 par les Révolutionnaires, l'Université fut réorganisée par Napoléon Bonaparte qui remplaça la faculté des arts par une faculté de, puis des, Lettres et une faculté des Sciences.

Ce sont des difficultés d'existence - A cause du manque d'étudiants, la faculté fut remplacée en 1816 par une simple commission chargée de délivrer le baccalauréat

\footnotetext{
${ }^{307}$ http://www.u-bordeaux3.fr/Univ/fonction_vie_40p2.htm
}

SAKATA, Marici Cristine Gramacho, Globalização e Educação: A formação do comunicador social na América Latina, 2008312 p. (Doutorado - Orientação BACCEGA, M. A.) Escola de Comunicações e Artes da Universidade de São Paulo, São Paulo, SP, 2008 
Le 24 Août 1838, la faculté des Lettres fut reconstituée et installée rue Montbazon dans les anciennes écuries de Mgr de Rohan, derrière la mairie

Le financement de la faculté reposait presque uniquement sur la perception des droits d'examen et sur la générosité de la dotation municipale

C'est une force des traditions - La force des organisations étudiantes dont les manifestations, parfois les émeutes, inquiétaient les gouverneurs et les intendants de l'Ancien Régime Baccalauréat, licence et doctorat : un système des grades hérité du Moyen-Age Collation des grades en grande pompe et procession à la cathédrale Saint-André sous l'Ancien Régime ; ouverture des cours et cloture des travaux annuels par de grands discours soigneusement surveillés par les recteurs du XIXe siècle

C'est une institution transformée par la IIIe République et les Républicains bordelais - Louis Liard, Achille Luchaire, Emile Durkheim renouvelèrent profondément le statut, le fonctionnement et les habitudes universitaires. Inauguré le 16 janvier 1886, le nouveau" Palais de l'Université " où l'on avait transféré le tombeau de Montaigne fut le plus grand chantier de la ville au XIXe siècle, à proximité de la cathédrale, dans les anciens couvents de la Visitation et des Feuillants. Une large autonomie et un grand dynamisme intellectuel donnèrent aux enseignants l'occasion de proposer des cours novateurs sur la géographie du Sénégal, la France et l'Allemagne au XVIIIe siècle, les sciences de l'éducation... et de créer en 1879 les Annales de la Faculté des Lettres

- Características e Objetivos do Curso de Comunicação ou Especialidade da Instituição

Licence IUT (2 anos $\left.{ }^{308}\right)+$ Master ISIC (1 ano $\left.{ }^{309}\right)$

IUT Michel de Montaigne - Licence Professionnelle Communication et information - Presse et édition d'entreprise

Institut des Sciences de l'Information et de la Communication - ISIC - Masters Recherche

Communication, organisation et territoires

\section{Licence d'Information et Communication}

La licence comprend trois années consacrées à l'acquisition des connaissances théoriques et techniques fondamentales en Information et Communication.

En lère et 2ème année, les étudiants ont accès à des Mineures et à des Disciplines adjuvantes qui leur permettent une éventuelle réorientation. Les disciplines étudiées dans ces cadres-là (Histoire, Lettres, Histoire de l'Art, Philosophie, Psychlogie, Sociologie, Economie) permettent d'acquérir et de renforcer une culture générale et des méthodes de travail nécessaires aux pratiques professionnelles de la communication. A la fin de la 2ème année, les étudiants ont la possibilité de postuler en licence professionnelle (voir sur le site de l'IUT Michel de Montaigne, celles proposées par l'Université de Bordeaux 3). La 3ème année prépare aux spécialités du Master Information et Communication de Bordeaux 3 ou à des formations similaires dans d'autres universités.

La Licence Presse et Edion d'Entreprise de l'IUT (sous l'appellation ministérielle Activités et Techniques de Communication, spécialité Communication et Information) est une formation qualifiante destinée à tous ceux qui ont un bon niveau rédactionnel, le goût de l'écriture, un minimum de connaissances en informatique et en communication. Cette formation est aussi accessible en formation continue (pour les salariés, demandeurs d'emploi), éventuellement avec

\footnotetext{
${ }^{308}$ IUT Michel de Montaigne, http://www.iut.u-bordeaux3.fr/site/jsp/site/Portal.jsp

${ }^{309}$ ISIC Institut des Sciences de l'information et de la Communication, Université Michel de Montaigne http://www.isic.u-bordeaux3.fr/index.php?op=page\&rub_id=787 e http://www.isic.ubordeaux3.fr/upload/documents/guide_Mast_Rech.rtf
}

SAKATA, Marici Cristine Gramacho, Globalização e Educação: A formação do comunicador social na América Latina, 2008312 p. (Doutorado - Orientação BACCEGA, M. A.) Escola de Comunicações e Artes da Universidade de São Paulo, São Paulo, SP, 2008 
un contrat de professionnalisation. Cette formation répond à un besoin quotidien dans les entreprises car les supports éditoriaux sont à la fois variés et indispensables. Les réalisations multimedia prennent un grand essor, quant à l'édition papier, elle garde toujours sa maniabilité et son prestige.

Les entretiens professionnels que nous avons menés et notre expérience de près de 30 ans dans le champ de la communication nous ont montré qu'il était judicieux de conquérir le marché du travail, grâce à la maîtrise des supports d'édition. Les personnes opérationnelles dans ces domaines, sensibilisées de surcroît à l'approche stratégique, sont appréciées par l'ensemble des acteurs économiques, les entreprises mais aussi les collectivités territoriales, les groupements professionnels, les $O N G$, les agents de l'économie sociale, les organisations du domaine culturel, etc. Les diplômés de la Licence Presse et Edition d'Entreprise deviendront chargés d'édition, journalistes dans les entreprises et les organisations, coordinateurs des supports imprimés et des supports multimedia.

\section{Ojectifs}

- Acquérir les connaissances de base en Sciences de l'Information et de la Communication

- Préparer l'accès aux métiers de la Communication, du Journalisme, de la Production audiovisuelle et de la Conception multimédia.

- S'initier aux métiers de la Recherche

Parcours de 3ème année

- Recherche en Sciences de l'Information et de la Communication

- Professionnel (IUP) en Communication des Organisations

- Professionnel (IUP) en Images et Multimédia

- Professionnel en Communication et Générations

- Professionnel en Journalisme

\section{Master recherche en information et communication}

Le Master Recherche en Information et Communication, rattaché administrativement à l'ISIC, l'Institut des Sciences de l'information et de la communication, prépare aux métiers de la recherche en information et communication. Il s'adresse à un public d'étudiants ayant déjà étudié les SIC en premier cycle et qui souhaite développer une spécialisation pointue dans un domaine particulier relevant du champ des Sciences de l'Information et de la communication. Il permet aux étudiants de devenir des experts de haut niveau maîtrisant les connaissances les plus récentes dans leur domaine d'expertise. Il nécessite des qualités de synthèse, d'analyse, un goût pour la lecture et une capacité à rédiger avérés. Des facultés à travailler en groupe, une capacité à être autonome, la bonne maîtrise d'une langue étrangère, et une grande curiosité seront des atouts supplémentaires.

Parcours : Communication, organisations et territoires

Le parcours 2 "Communication, organisations et territoires" propose des enseignements de spécialisation permettant d'aborder les dynamiques communicationnelles qui structurent, régulent et transforment les organisations et les territoires.

Dans ce parcours sont abordées aussi bien les questions qui touchent aux phénomènes de communication organisés qu'aux phénomènes émergeant dans les structures organisationnelles. Une place importante est faite aux phénomènes langagiers, à ceux liés à la pratique des TIC, aux temporalités communicationnelles, aux interactions entre pratiques communicationnelles et espace de travail. Les questions qui touchent à la vie des groupes et des collectifs, à leur capacité à coopérer ou à échanger des savoirs sont aussi abordées.

SAKATA, Marici Cristine Gramacho, Globalização e Educação: A formação do comunicador social na América Latina, 2008312 p. (Doutorado - Orientação BACCEGA, M. A.) Escola de Comunicações e Artes da Universidade de São Paulo, São Paulo, SP, 2008 
Sont également abordées les questions de la ville contemporaine, de ses transformations et du développement d'un monde urbanisé pour analyser la place qu'y occupent aujourd'hui des systèmes communicationnels (qu'il s'agisse de support papier, de mise en lumière ou de logo, par exemple). La ville est devenue un enjeu social et politique majeur. C'est dans le contexte d'une telle évolution socio-politique qu'il faut étudier les formes de communications contemporaines qui mettent en lien, et en réseau, les sociétés et les territoires.

- Grade Curricular

\section{Organisation}

2 semestres d'enseignement, du premier lundi de novembre à la mi avril 8 unités d'enseignement (UE)

150 heures de projets tutorés, 543 heures de cours

16 semaines de stage, de mi avril à mi août (soutenance du rapport d'activité le deuxième lundi du mois de septembre)

\section{Unités d'enseignement}

UE1+UE5 : instrumentation éditoriale (126h, 9+4 ects)

Apprentissage et utilisation des logiciels print, des logiciels web et des logiciels de traitement de l'image

UE2+UE6 : structure éditoriale (213h, $10+10$ ects)

Ateliers, études de cas et réalisations concernant les supports print et les supports web

UE3 : traitement de l'information ( $78 \mathrm{~h}, 8$ ects)

Présentation et emploi des techniques journalistiques et des techniques graphiques

UE7 : communication des organisations (108h, 8 ects)

Etudes des contextes de l'activité éditoriale et des théories des Sciences de l'Information et de la Communication

UE4+UE8 : orientation et insertion professionnelles ( $3+8$ ects)

Construction du projet personnel et professionnel, élaboration du rapport d'activité, projets tutorés et stage (16 semaines)

Validation : Notation continue - Pour obtenir la Licence Professionnelleles étudiants doivent avoir au minimum une moyenne de 8/20 dans chaque Unité d'Enseignement (U.E.) et 10/20 de moyenne générale.

Stage - Les étudiants sont tenus de valider au moins 16 semaines de stage de mi avril à mi août.

Rapport d'activité - Le rapport d'activité correspond à un bilan général du parcours de formation des étudiants stagiaires. C'est un outil pour les aider à préparer leur insertion professionnelle. Il a pour objectif de:

- prendre la mesure de leurs acquis,

- apprécier la valeur du (ou des) stage(s),

- faire le point sur leur parcours.

\section{Le descriptif des cours - Master}

Tableau synoptique des cours 2006-2007

\begin{tabular}{|l|l|}
\hline Noms des UE & TITRE DES COURS \\
\hline MI SEMESTRE 1 & \\
\hline
\end{tabular}

SAKATA, Marici Cristine Gramacho, Globalização e Educação: A formação do comunicador social na América Latina, 2008312 p. (Doutorado - Orientação BACCEGA, M. A.) Escola de Comunicações e Artes da Universidade de São Paulo, São Paulo, SP, 2008 


\begin{tabular}{|c|c|}
\hline $\begin{array}{l}\text { UE1 Tronc commun } \\
\text { Théories }\end{array}$ & $\begin{array}{l}\text { Théorie et épistémologie de l'information communication } \\
36 \mathrm{H} \text {, coef } 3 \text {, crédit } 9\end{array}$ \\
\hline $\begin{array}{l}\text { UE2 Enseignements } \\
\text { partagés niveau } 1\end{array}$ & $\begin{array}{l}\text { Communication stratégique } \\
\text { Information et médias } \\
24 \text { H coef. } 4 \text { crédit } 12 \\
\end{array}$ \\
\hline $\begin{array}{l}\text { UE3 Enseignements } \\
\text { sspécifiques }\end{array}$ & $\begin{array}{l}\text { Inscription de l'info et construction du sens } \\
\text { Problématiques de recherche les plus récentes } \\
24 \text { H Coef } 3 \text { crédit } 9\end{array}$ \\
\hline \multicolumn{2}{|l|}{ M1 SEMESTRE 2} \\
\hline UE4 & $\begin{array}{l}\text { Méthodologie de recherche en information communication } \\
\text { Méthodologie d'analyse du discours } \\
\text { Suivi du travail de préparation à la recherche (TPR) } \\
36 H \text { coef } 3 \text {, crédit } 9 \text { dont TPR crédit } 6\end{array}$ \\
\hline $\begin{array}{l}\text { UE5 Enseignements } \\
\text { partagés niveau } 2\end{array}$ & $\begin{array}{l}\text { Anthropologie de la communication } \\
\text { Analyse de l'image } \\
24 \text { H Coef } 3 \text { crédit } 9 \\
\end{array}$ \\
\hline UE6 Conférences, synthèse & $\begin{array}{l}\text { Droit de l'information et de la communication } \\
\text { Economie de la communication } \\
\text { Recherches en cours } \\
30 H \text { Coef } 4 \text { crédit } 12\end{array}$ \\
\hline \multicolumn{2}{|l|}{ M2 SEMESTRE 3} \\
\hline $\begin{array}{l}\text { UE7 Enseignements de } \\
\text { spécialité }\end{array}$ & $\begin{array}{l}\text { Parcours } 1 \\
\text { Visuel médiatique } \\
\text { Sociopolitique des médias et NTIC } \\
\text { Historiographie } \\
\text { Médias africains } \\
\text { Etudes radiophoniques } \\
\text { Edition électronique } \\
\\
\text { Parcours } 2 \\
\text { Communication des organisations } \\
\text { Les langages des organisations } \\
\text { Communication et territoire } \\
\text { La communication locale } \\
\text { Les modalités de l'information } \\
\text { Communication et motivation } \\
\text { Images et emblèmes des organisations } \\
\\
\text { Parcours } 3 \\
\text { Ecritures, images et intermédialité } \\
\text { L'intermédialité } \\
\text { Espaces, médiations et objets interculturels } \\
\text { L'environnement visuel } \\
\text { 60H, Coef 5, crédit } 15\end{array}$ \\
\hline \multicolumn{2}{|l|}{ UE8 Séminaire de spécialités } \\
\hline \multicolumn{2}{|l|}{ M2 SEMESTRE 4} \\
\hline & $\begin{array}{l}\text { UE9 Séminaire par équipe } \\
\text { UE10 Pratique de la recherche }\end{array}$ \\
\hline & $\begin{array}{l}\text { Mémoire de recherche } \\
\text { Coef } 7 \text { crédit } 21\end{array}$ \\
\hline
\end{tabular}

\section{Universidades Globalizadas}

SAKATA, Marici Cristine Gramacho, Globalização e Educação: A formação do comunicador social na América Latina, 2008312 p. (Doutorado - Orientação BACCEGA, M. A.) Escola de Comunicações e Artes da Universidade de São Paulo, São Paulo, SP, 2008 
2.3 Université Paris X - Licence Art, lettres et langues - Mention : Sciences de l'information et de la communication $\underline{310}$

- Características e Missão da Instituição:

1964 Création de la faculté des Lettres et Sciences Humaines.

Ouverture des premiers bâtiments d'enseignement

1968 Création de la faculté de Droit

1970 Création de l'Université Paris-X Nanterre, établissement public à caractère scientifique et culturel

Développements - L'expansion des formations

1970 Rattachement de l'IUT de Ville d'Avray à l'université

1984 Loi Savary : création des UFR actuelles (renouveau et élargissement de la carte des

diplômes)

1985 Ouverture d'une antenne à Saint-Quentin en Yvelines

1989 Ouverture d'une antenne à Cergy-Pontoise

1991 Saint-Quentin et Cergy deviennent des universités de plein exercice

1992 Elargissement de l'UFR SSA (Sciences Sociales et Administration), l'arrivée d'Internet

avec ses ateliers informatiques

1999 Création de nouvelles filières (IUP)

2000 Création d'un pôle scientifique et technique (Saint-Cloud, Ville-d'Avray, UFR SITEC:

Systèmes Industriels et Techniques de Communication)

- Características e Objetivos do Curso de Comunicação ou Especialidade da Instituição:

\section{Licence Art, lettres et langues - Mention : Sciences de l'information et de la communication}

Diplôme national - Cette formation s'adresse à des étudiants titulaires d'un Bac +2 et a pour but de leur apporter une culture et une méthodologie appropriées pour une orientation vers les métiers de la communication, de l'information et de la documentation. Trois parcours sont possibles:

Documentation et traitement de l'information;

Communication; Métiers du livre.

Lieu(x) d'enseignement : Site de Nanterre, Site de Saint-Cloud

Durée des études : 6 semestres

Mode d'enseignement : en présentiel.

Objectifs :

En termes de savoir :

- Acquisition des connaissances disciplinaires et pluridisciplinaires du champ des sciences de

l'information et de la communication

${ }^{310}$ Université Paris X, Disponível em www.u-paris10.fr/ acesso em 16/07/2007

SAKATA, Marici Cristine Gramacho, Globalização e Educação: A formação do comunicador social na América Latina, 2008312 p. (Doutorado - Orientação BACCEGA, M. A.) Escola de Comunicações e Artes da Universidade de São Paulo, São Paulo, SP, 2008 
- Acquisition des connaissances méthodologiques des sciences de l'information : recherche d'informations, analyse d'objets, étude de cas, synthèse, mise en forme (applications rédactionnelles, audiovisuelles et multimédias)

En termes de savoir-faire :

- Savoir analyser des textes (journalistiques, administratifs, techniques)

- Savoir analyser des dispositifs, des documents et des services audiovisuels et multimédias

- Savoir rechercher, trier, synthétiser, traiter et mettre en forme l'information

- Savoir négocier (cahier des charges...)

- Maîtriser les modes de travail individuel, en groupe et à distance.

Poursuite d'études : Année post-bac : Bac +3

- Grade Curricular

\section{Licence (2 anos) + Máster (1 ano)}

Licence : Sciences de l'Information et de la Communication

Master Recherche Sciences humaines et sociales

Mention : Sciences de l'information et de la communication

Spécialité : Information-communication : mutations et enjeux pour la société

CONTENU DES ENSEIGNEMENTS LALL / Mention : Sciences de l'Information et de la Communication

Vous trouverez ci-dessous le contenu de chacun de 3 parcours proposés :

\section{Parcours 2: Communication}

Semestre 5

\begin{tabular}{|c|c|c|c|c|}
\hline $\begin{array}{l}\text { LLIUF510 Théorie des Sciences de l'information et } \\
\text { de la communication } 1\end{array}$ & $\mathrm{O}$ & 6 ECTS & $\mathrm{Cm}$ & $T d$ \\
\hline LLSIC511 Le champ des SIC & & 3 & 20 & \\
\hline - LLSIC512 Histoire des médias & & 3 & 20 & \\
\hline $\begin{array}{l}\text { LLIUF520 Industrialisation de l'Info et de la } \\
\text { communication }\end{array}$ & $\boldsymbol{O}$ & 6 ECTS & 40 & \\
\hline - LLSIC521 Economie des médias & & 3 & 20 & \\
\hline -LLSIC522 Industries culturelle & & 3 & & \\
\hline LLIUF53C Communication écrite et audiovisuelle 1 & $\mathrm{O}$ & 9 ECTS & & \\
\hline $\begin{array}{l}\text { LLSIC531 Introduction à la } \\
\text { communication audiovisuelle }\end{array}$ & & 3 & 20 & \\
\hline 1) LLSIC532 Atelier d'écriture 1 & & 3 & & 20 \\
\hline $\begin{array}{l}\text { - LLSIC533 Psychanalyse et documents de } \\
\text { fiction }\end{array}$ & & 3 & 20 & \\
\hline LLIUC54C Complémentaire & $\mathrm{O}$ & 6 ECTS & & \\
\hline - LLSIC541 Anglais spécialisé & & 3 & & 20 \\
\hline $\begin{array}{l}\text { - LLSIC542 Introduction à la production } \\
\text { audiovisuelle }\end{array}$ & & 3 & 20 & \\
\hline LLIUL550 Libre & $O$ & 3 ECTS & & \\
\hline
\end{tabular}

Semestre 6

LLIUF610 Théorie des Sciences de l'information et de la communication 2

SAKATA, Marici Cristine Gramacho, Globalização e Educação: A formação do comunicador social na América Latina, 2008312 p. (Doutorado - Orientação BACCEGA, M. A.) Escola de Comunicações e Artes da Universidade de São Paulo, São Paulo, SP, 2008 


\begin{tabular}{|c|c|c|c|c|}
\hline LLSIC611 Sociologie des médias & & 3 & 20 & \\
\hline -LLSIC612 Analyse de discours & & 3 & 20 & \\
\hline LLIUF620 Outils et droit de l'information & $\mathrm{O}$ & 6 ECTS & 40 & \\
\hline - $\quad$ LLSIC621 Droit de l'information & & 3 & 20 & \\
\hline -LLSIC622 Recherche documentaire & & 3 & 20 & \\
\hline LLIUC63C Communication écrite et audiovisuelle 2 & $\boldsymbol{O}$ & 9 ECTS & & \\
\hline $\begin{array}{l}\text { LLSIC631 Gestion et valorisation des ressources } \\
\text { audiovisuelles }\end{array}$ & & 3 & 20 & \\
\hline -LLSIC632 Dispositif & & 3 & 20 & \\
\hline LSIC633 Ateliers d'écriture 2 & & 3 & & 20 \\
\hline LLIUC64C Complémentaire & $\mathrm{O}$ & 6 ECTS & & \\
\hline - LLSIC641 Anglais spécialisé & & 3 & & 20 \\
\hline C642 PAO & & 3 & & 20 \\
\hline LLIUL650 Libre & $X(1.1)$ & 3 ECTS & & \\
\hline
\end{tabular}

\section{Master Recherche Sciences humaines et sociales}

Mention : Sciences de l'information et de la communication

Spécialité : Information-communication : mutations et enjeux pour la société

Diplôme national - Le master "Information et communication : mutation et enjeux de la société " vise à former des professionnels exerçant dans des organismes de recherche en Sciences de l'information et de la communication ou dans les cellules "études et recherche" des entreprises, administrations ou collectivités intéressées par les problèmes d'information et de communication.

Lieu(x) d'enseignement : Site de Nanterre

Durée des études : 4 semestres

Objectifs :

En terme de savoir : Connaissances disciplinaires : champ des sciences de l'information et de la communication - Connaissances pluridisciplinaires sur l'objet étudié : aspects historique, géopolitique, sociologique, esthétique, technique, économique, politiques publiques Connaissance socio-cognitive et informatique des dispositifs et systèmes d'information documentaire - Connaissances méthodologiques : analyse d'objets, étude de cas, synthèse, mise en forme. En terme de savoir-faire : Savoir faire liés au traitement de l'information: rechercher, trier, synthétiser et mettre en forme l'information, connaître les sources d'information et les stratégies de recherche bibliographique, maîtriser des dispositifs d'accès et de filtrage à l'information, maîtriser une démarche de veille et d'intelligence économique, maîtriser la mise en æuvre d'une chaîne documentaire (structuration, accès, ergonomie). En terme de compétence professionnelle: Savoir faire un audit numérique, un cahier des charges d'un dispositif numérique- savoir réaliser un prototype- maîtriser les techniques d'information

Poursuite d'études : Année post-bac : Bac +5

Débouchés professionnels :

Secteurs d'activité :

- Secteur de l'information et de la communication rédactionnelle, audiovisuelle et multimédia

- Service de documentation et d'information

- Service de veille et d'intelligence économique

- Agences et services d'information

SAKATA, Marici Cristine Gramacho, Globalização e Educação: A formação do comunicador social na América Latina, 2008312 p. (Doutorado - Orientação BACCEGA, M. A.) Escola de Comunicações e Artes da Universidade de São Paulo, São Paulo, SP, 2008 
- Collectivités locales et territoriales

- Espaces publics d'accès à Internet

- Mission au développement numérique au niveau municipal, départemental, régional

- Services spécialisés de l'Etat: Agence pour le développement de l'administration électronique (ADAE), Délégation aux usages d'Internet (DUI)

Fonctions :

- Journalistes (y c. rédacteurs en chef)

- Directeurs, responsables de programmation et de production de l'audiovisuel et des spectacles

- Cadres artistiques et technico-artistiques de la réalisation de l'audiovisuel et des spectacles

- Cadres des relations publiques et de la communication

- Chef de projet

- Ingénieur de contenus électroniques,

- Responsable de veille informationnelle,

- Responsable de systèmes d'information documentaire,

- Responsable éditorial de produits d'information,

- Ingénierie du document électronique

- Directeur d'EPN

- Chargé de mission TIC

- Chef de projet pour un dispositif de développement numérique

\subsection{Science Po}

- Características e Missão da Instituição:

L'institution Sciences Po est composée de deux structures juridiques :

une fondation privée d'utilité publique, sans but lucratif, la Fondation nationale des sciences politiques, qui gère neuf centres de recherche, la bibliothèque, les Presses, une librairie et une société de conseil ;

un grand établissement public, au sens de la loi Savary de 1984 sur l'enseignement supérieur, l'Institut d'Etudes Politiques de Paris.

La Fondation Nationale des Sciences Politiques reçoit l'ensemble des ressources financières de Sciences Po, que celles-ci viennent de l'Etat, des collectivités locales, de l'Union européenne, des entreprises ou des élèves.

Institution universitaire, Sciences Po l'est par ses missions :

la recherche, spécialisée en sciences humaines et sociales (histoire, économie, sociologie, science politique, droit) ;

les formations, proposées à tous les niveaux de l'enseignement supérieur ; premiers cycles, masters et doctorats;

la bibliothèque qui permet l'accès à un fonds d'ouvrages exceptionnel (800 000 titres), à plusieurs milliers de revues scientifiques, sous forme numérique aussi bien que papier, et à de multiples ressources documentaires à distance ;

l'édition universitaire, avec les Presses de Sciences Po, qui contribuent à la diffusion de la production intellectuelle française en sciences sociales et humaines (huit revues, 950 titres au catalogue, 30 nouveaux ouvrages par an) et constituent un instrument de rayonnement national et international.

Partout dans le monde, c'est l'accomplissement de telles missions qui caractérisent les universités. 
En France, cependant, les universités ne sont pas définies par leur mission mais par leur statut. Elles disposent d'une très faible autonomie par rapport à l'Etat. Elles ne sélectionnent n'y n'orientent les étudiants lors de leur entrée en première année de licence. L'essentiel des centres et laboratoires de recherche qu'elles peuvent accueillir physiquement sont gérés et gouvernés par les grands organismes de recherche, comme le CNRS ou l'INSERM. Elles sont donc souvent doublement amputées, en comparaison des universités européennes :

pour les premiers cycles, elles sont privées des viviers de très bons bacheliers qui sont orientés vers les classes préparatoires aux grandes écoles plutôt que vers les premiers cycles universitaires ;

la recherche scientifique de haut niveau est gérée par des organismes extérieurs aux universités et qui font peu de cas du développement stratégique de celles-ci.

C'est un peu comme si l'université d'Oxford n'accueillait pas d'étudiants undergrades ; comme si l'université de Cambridge ne maîtrisait pas sa stratégie de recherche.

Sciences Po affirme donc son originalité par rapport aux Universités françaises :

les centres de recherche sont parfaitement intégrés au sein de Sciences Po ;

les élèves de Sciences Po sont très rudement sélectionnés à l'entrée

Sciences Po est maître de sa stratégie éducative et scientifique.

- Características e Objetivos do Curso de Comunicação ou Especialidade da Instituição

La formation en Journalisme de Sciences Po permet d'acquérir les compétences fondamentales du métier de journaliste.

Contenu de la formation - La mention Journalisme permet de lier étroitement formation académique et professionnelle.

La formation académique est fortement valorisée. Elle permet d'acquérir une culture générale pour comprendre et analyser les phénomènes mondiaux, en maîtrisant les concepts qui permettent d'en rendre compte. Dans un contexte où l'analyse des sujets sociaux et politiques ne peut guère trouver de pertinence sans une véritable culture économique, la formation consacre une part importante à la macro-économie et à la micro-économie, dont trop peu de jeunes journalistes maîtrisent les éléments principaux. La mise en perspective des phénomènes contemporains nécessite l'acquisition d'une culture historique. L'histoire permet de hiérarchiser l'information en donnant aux étudiants le sens de la longue durée les moyens d'identifier les véritables nouveautés. Cet enseignement permet également de sensibiliser les étudiants à l'histoire très récente, cette période d'une quinzaine d'années qui précède le moment présent et que les livres d'histoire n'étudient pas encore. Parce que les journalistes doivent avoir conscience qu'ils sont le produit d'une histoire, des enseignements sur les médias seront dispensés aux étudiants (histoire des média, droit des média, sémiologie du récit journalistique, psychosociologie de la réception...). Le journalisme est un métier avec des procédures et des règles fondées sur la rigueur intellectuelle. Cette déontologie ne doit pas être enseignée comme un catéchisme mais comme une manière de vivre le métier de journaliste: elle passe par une réflexion sur cette profession dont la responsabilité est extrême, accompagnée d'un apprentissage par et dans la pratique. La méthode empirique est privilégiée.

La formation professionnelle est également très présente. L'organisation de la scolarité réserve une place importante à l'apprentissage et à la maîtrise de l'écriture journalistique, et des techniques narratives sous la forme d'ateliers d'écriture. Ce cycle de l'écriture comprend également des formations dédiées à la maîtrise des différents supports (technique de l'écriture de dépêches d'agence de presse, d'articles de presse écrite, de l'écriture radio, de l'écriture TV et de l'écriture multimédia). L'apprentissage des techniques de recherche de l'information est

SAKATA, Marici Cristine Gramacho, Globalização e Educação: A formação do comunicador social na América Latina, 2008312 p. (Doutorado - Orientação BACCEGA, M. A.) Escola de Comunicações e Artes da Universidade de São Paulo, São Paulo, SP, 2008 
fondamental. Former les étudiants à l'effort de la recherche de l'information constitue un point clef du projet pédagogique.

Le calendrier de la formation est très riche et alterne périodes à l'école et période de stages en entreprise. De plus, huit semaines par an sont banalisées pour organiser des opérations particulières sur le terrain.

Organisation générale et pédagogie - En première année du master, chaque journée de la semaine est organisée autour d'un thème : le matin se déroulent des enseignements académiques, l'après midi des ateliers professionnels pour la formation à la presse écrite, à la radio ou à la télévision. Chaque ateliers comportent une douzaine d'élèves. Chaque élève a pour obligation de choisir quatre thèmes par semaine : il est donc physiquement présent quatre jours par semaine à l'école, la cinquième journée lui permet de réaliser des reportages à l'extérieur. Cette organisation par journée thématique permet de lier intimement enseignements académiques et formation professionnelle : les thèmes abordés dans les enseignement académiques peuvent être immédiatement réutilisés pour réaliser un sujet journalistique. En deuxième année du master, la scolarité est organisée en quatre modules de sept semaines chacun. Les élèves doivent suivre au moins deux des quatre modules. S'ils ne suivent pas tous les modules, le temps est utilisé soit pour suivre des études à l'étranger pendant un semestre, soit pour suivre des stages longs en entreprise. A ces temps de formation dans l'Ecole s'ajoutent les périodes de stage ou d'apprentissage qui permettent aux élèves d'améliorer leurs compétences et d'entrer dans le monde du travail.

La formation par l'apprentissage - l'Ecole de journalisme de Sciences Po est un centre de formation par l'apprentissage, ce qui permet à des élèves de devenir apprentis, et de bénéficier ainsi d'une formation rémunérée. Les élèves qui obtiennent un statut d'apprentis suivent une partie de leur formation en entreprise et reçoivent une formation au sein de l'école de journalisme, sur la base d'un temps partagé.

\section{- $\quad$ Grade Curricular}

L'Ecole de Journalisme de Sciences Po

Présentation du semestre d'automne 2006-2007

lère année de l'Ecole de journalisme

Le lundi : «Relations internationales : Europe»

Le mardi : «La Défense» - octobre-novembre

Le mardi : «Les médias» - décembre / janvier

Le mercredi : "Connaissance des faits religieux» - octobre-novembre

Le mercredi : «Justice et faits divers»- décembre / janvier

Le jeudi : «Economie»

Le vendredi : "Politique mondiale» - octobre / novembre

Le vendredi : "Politique française» - décembre / janvier

Vous devez choisir, pour le semestre d'automne 2006, quatre modules parmi les cinq proposés, chaque module correspondant à une journée thématique.

Pour chaque module, vous avez le choix entre des ateliers de presse écrite, de radio et de télévision.

Vous devez dans la mesure du possible prendre un atelier de chaque pour maîtriser les trois techniques, avant d'envisager en 5 ème année une spécialisation sur un média.

Vous avez une obligation absolue : l'assiduité aux cours. Un relevé des absences est fait à chaque séance, et les absences entraînent une non validation des modules.

SAKATA, Marici Cristine Gramacho, Globalização e Educação: A formação do comunicador social na América Latina, 2008312 p. (Doutorado - Orientação BACCEGA, M. A.) Escola de Comunicações e Artes da Universidade de São Paulo, São Paulo, SP, 2008 
Le lundi : "Relations internationales : Europe»

L’inscription au module est valable pour la totalité du semestre (périodes 1 et 2).

Les cours-séminaires

Première période - L'enseignement est assuré par Pierre Moscovici (Vice-Président du Parlement européen) qui centrera son propos sur «L'actualité d'une Union européenne en crise».

Deuxième période - Vous pouvez choisir entre deux cours très différents : Jean Picq (Professeur associé à Sciences Po et Président de la Chambre à la Cour des Comptes) et Yves Cusset (enseignant) interviennent sur " L'Europe, objet de philosophie politique ». Ils développent une réflexion sur l'idée européenne en se fondant sur des textes issus de la philosophie, que vous avez à lire avant chaque séance. Un exercice final de présentation d'une chronique face caméra vous sera demandé. Pour cette raison, ce cours est limité à 22 personnes.

Alain Barrau (fonctionnaire européen en charge des relations avec les Parlements nationaux), travaillera sur "L'actualité européenne ». Il est à noter qu'aucun enseignement portant sur l'organisation institutionnelle de l'Europe ou son histoire n'est proposé, partant du principe que beaucoup d'entre vous ont déjà des connaissances de ce type, et que des manuels permettent rapidement de pallier les méconnaissances sur les institutions et leurs fonctionnements.

Les créneaux horaires non utilisés de $8 \mathrm{~h} 30$ à $10 \mathrm{~h}$ lors de la première période sont utilisés pour des formations d'approfondissement technique (tournage...) complétant ainsi la formation donnée dans le module d'intégration. Virginie Linhardt interviendra également en seconde période, le mardi après midi. Des groupes de 8 élèves auront à suivre deux séances chacun.

Les ateliers

Première période

Atelier télévision : Cet atelier sera animé par Thierry Thuillier (France 2) qui vous demandera régulièrement des reportages.

Atelier radio : Cet atelier sera animé par Renaud Bernard (France Info) qui vous demandera régulièrement des reportages.

Atelier presse écrite : Cet atelier sera animé par Philippe Lemaître (ancien journaliste au journal Le Monde, en poste à Bruxelles depuis 1966, intervenant dans une société spécialisée en lobbying) qui vous demandera régulièrement des reportages.

Deuxième période

Atelier télévision : enseignant à confirmer. Il animera un atelier dans lequel des reportages seront demandés régulièrement.

Atelier radio : enseignant à confirmer. Il animera un atelier dans lequel des reportages seront demandés régulièrement.

Atelier presse écrite : Géraldine Baum (Los Angeles Times) vous fera travailler en anglais (niveau 4 ou 5 pré-requis pour suivre cet enseignement).

[retour en haut de la page]

Le mardi : "La Défense »-octobre / novembre

Inscription pour un module de sept séances uniquement.

Les cours-séminaires

Deux cours sont consacrés à la Défense, avec deux approches différentes :

Maurice Vaïsse (historien, spécialiste de l'histoire de la Défense) et Jean Louis Dufour

(Colonel C.R.) interviendront sur les transformations récentes de l'appareil de Défense en

France.

Matthieu Balescut (groupe Dassault) interviendra pour trois séances en novembre sur

l'économie de la Défense et l'industrie européenne de Défense. En octobre, trois intervenants différents se succéderont sur l'actualité de la Défense.

SAKATA, Marici Cristine Gramacho, Globalização e Educação: A formação do comunicador social na América Latina, 2008312 p. (Doutorado - Orientação BACCEGA, M. A.) Escola de Comunicações e Artes da Universidade de São Paulo, São Paulo, SP, 2008 
Les ateliers

Atelier radio : cet atelier sera animé par Stéphane Fort (France Inter) qui vous demandera régulièrement des reportages.

Atelier presse écrite : cet atelier sera animé par Philippe Le Corre (Journaliste, Cabinet du Ministre de la Défense) qui vous demandera régulièrement des reportages.

Atelier télévision : cet atelier sera animé par Hervé Brusini (France 3) qui vous demandera régulièrement des reportages.

Le mardi : "Les médias »-décembre / janvier

Inscription pour un module de sept séances uniquement.

Les cours-séminaires

Hervé Brusini (France 3) interviendra pendant 4 séances de $3 h$ sur «L'histoire du reportage », pour mettre en perspective l'évolution d'un genre.

Les trois séances de 3 h restantes seront utilisées par Gérard Thoris (économiste, Sciences Po) pour préparer avec les étudiants, qui suivent l'enseignement d'initiation économie, le stage en entreprise d'une semaine sur le thème de "La prise de décision dans une entreprise ». Ce stage, qui se déroulera début février 2007, servira également d'appui aux cours d'économie dispensés au second semestre et centrés sur la vie de l'entreprise.

Les ateliers

Dispositif particulier dans l'organisation de ces ateliers, qui se tiennent tous les trois en même temps pour permettre à Didier Epelbaum (France 2), Michel Strulovici (ancien France 2) et Hélène Bellanger (historienne, Sciences Po) d'organiser des moments communs aux trois groupes.

Ils interviendront sur le thème "Images de conflits et histoire » : à travers le visionnage de reportages, de sujets d'information et leur critique, ils déconstruiront avec vous les manières de traiter des sujets qui ont été utilisées.

Le mercredi : "Connaissance des faits religieux »- octobre / novembre

Inscription pour un module de sept séances uniquement.

Les cours-séminaires

Six séances de trois heures se succéderont (le mercredi 1 er novembre est férié).

Les ateliers

Atelier presse écrite : Susan Sachs (journaliste américaine) vous fera travailler en anglais et vous demandera des reportages.

Le mercredi : " Justice et faits divers 》 - décembre / janvier

Inscription pour un module de sept séances uniquement.

Cet enseignement se poursuivra et s'approfondira en périodes 3 et $4:$ pour un bon déroulement des séances, et pour une acquisition régulière des connaissances nécessaires au traitement de tous les sujets qui relèvent de la justice, l'enseignement doit être suivi sur les trois périodes (de décembre à juin).

Par ailleurs, fin novembre, la moitié des élèves passera une semaine soit dans un tribunal soit dans un commissariat, opération qui sera reconduite pour l'autre moitié des élèves en février. Les cours-séminaires

Le premier cours du matin ( $8 h 30$ - 10 h) sera assuré par Michèle Cotta (journaliste) sur le thème de la déontologie et les bonnes pratiques du métier, puis par Michel Zaoui (avocat entre autre de L'Express). Ce dernier interviendra plus spécifiquement sur le droit de la presse.

Les élèves qui ne suivent pas le module justice peuvent assister à ces séances qui concernent la totalité de la profession.

Le second cours (10h15 - 11h45) sera assuré par Laurence Vichnievsky (présidente du Tribunal de Chartres). Elle présentera durant cette première période les fondements du droit français.

SAKATA, Marici Cristine Gramacho, Globalização e Educação: A formação do comunicador social na América Latina, 2008312 p. (Doutorado - Orientação BACCEGA, M. A.) Escola de Comunicações e Artes da Universidade de São Paulo, São Paulo, SP, 2008 
Les ateliers

Atelier presse écrite : il est assuré par Michel Deléan (Journal du Dimanche) qui vous demandera des reportages.

Atelier radio : il est assuré par Anne Brunel (Radio France) qui vous demandera des reportages.

Atelier télévision : il est assuré par Sylvain Gouz (France 3) qui vous demandera des reportages.

Pour tous, de 17h à 19h: François Grangié (rédacteur en Chef de l'AFP) assure une formation au travail en agence. Cette formation est obligatoire pour tous les élèves : la moitié d'entre eux la suivront au premier semestre, l'autre moitié au second semestre, à raison d'une séance tous les quinze jours. (En cinquième année, ceux qui le désirent pourront suivre un enseignement annuel consacré au métier d'agencier, afin de préparer les épreuves de recrutement organisées régulièrement par les agences de presse).

Le jeudi : "Economie 》

Inscription pour le semestre.

L'Ecole de journalisme de Sciences Po a fait le choix d'insister sur la formation en économie, indispensable pour traiter de nombreux sujets d'actualité. Tous les commentaires venant des rédactions dans lesquels les élèves font des stages soulignent la nécessité d'avoir une formation en économie qui vous distinguera le plus souvent.

Suivre cet enseignement sur une base annuelle est très fortement recommandé.

Au premier semestre, l'approche pédagogique tient compte des différences de culture économique entre les élèves, avec deux cours d'économie parallèle s'adressant à des élèves de niveaux et de cultures différentes.

Les cours-séminaires

Economie 1

Ce cours de 3h est assuré en alternance par quinzaine par deux économistes, Mathilde Lemoine (banque HSBC, chargée des analyses macro-économique) et Olivier Storch (économiste, Cabinet du Ministre de l'enseignement supérieur et de la Recherche). Tous les deux souhaitent vous fournir une « boite à outils » pour comprendre les phénomènes macro-économiques.

\section{Economie 2}

Ce cours de 1 h30 s'adresse aux élèves qui ont déjà suivi des enseignements en économie, soit dans le premier cycle de Sciences Po, soit dans le cadre d'une formation universitaire. Il est assuré par François Rachline (économiste, Sciences Po) qui s'intéressera aux "Questions majeures de l'économie contemporaine ».

Gérard Thoris utilisera trois matinées de 3 h pour préparer avec les étudiants le stage en entreprise d'une semaine qui se déroulera fin novembre, sur le thème de "La prise de décision dans une entreprise ». Ce stage servira également d'appui aux cours d'économie dispensés au second semestre et centrés sur la vie de l'entreprise.

Les ateliers

Pour vous permettre d'approfondir vos connaissances, de préciser les notions et les concepts, nous avons fait le choix de vous proposer trois ateliers en presse écrite.

Un atelier presse écrite en anglais (niveau 4 ou 5 pré-requis), animé par des journalistes anglosaxons. Sophie Pedder (responsable du bureau parisien de The Economist) assure les sept premières séances (octobre / novembre). Peter Gumble (Time magazine) assure les sept séances

SAKATA, Marici Cristine Gramacho, Globalização e Educação: A formação do comunicador social na América Latina, 2008312 p. (Doutorado - Orientação BACCEGA, M. A.) Escola de Comunicações e Artes da Universidade de São Paulo, São Paulo, SP, 2008 
suivantes (décembre / janvier). Dans ce groupe, les élèves issus des cours d'Economie 1 ou d'Economie 2 seront mélangés.

La présence des élèves de 4 e année à ces séances est obligatoire.

Le vendredi : "Politique mondiale » - octobre / novembre

Inscription pour un module de sept séances.

Les cours-séminaires

Pierre Grosser (Sciences Po) et Rony Brauman (professeur associé à Sciences Po, médecin, fondateur de Médecin sans frontières, association distinguée par un prix Nobel pour la paix) assurent à tour de rôle des séances de trois heures, centrées sur les crises internationales, avec une optique transnationale.

Les ateliers

Atelier presse écrite : Isabelle Lasserre (Le Figaro) vous demandera des reportages et vous fera travailler au desk.

Atelier radio : Mireille Lemaresquier (Radio France) vous fera travailler à la fois en desk et en reportage.

Atelier télévision : Bernard Volker (TF1) vous fera travailler la présentation sur plateau.

Le vendredi : "Politique française 》 - décembre / janvier

Inscription pour un module de sept séances.

Ce module se poursuivra en période 3 et 4 . Il faut donc envisager l'inscription au semestre de printemps comme nécessaire pour suivre la suite de la formation.

Nous ne saurions trop insister sur l'importance de ce module pendant l'année de l'élection présidentielle (fin avril, début mai) et des élections législatives (juin 2007).

Les cours-séminaires

Les chercheurs du CEVIPOF (Centre d'Etudes de la Vie Politique Française, laboratoire de recherches de l'Institut d'études politiques, dirigé par Pascal Perrinneau) interviendront à tour de rôle sur leur domaine de spécialité. Ces interventions d'une durée de 1 h30 se poursuivront lors de la 3 ème période de cours.

Gilles Achache (chargé des études à France Télévisions) interviendra sur les thèmes des études d'opinion, sans limiter son propos aux seuls sondages politiques.

Les ateliers

Atelier presse écrite : Raphaëlle Bacqué (Le Monde), vous demandera des reportages.

Atelier radio: Patrick Cohen (RTL), vous demandera des reportages.

Atelier télévision: Michèle Cotta vous fera travailler la présentation sur plateau.

Porté par la toute nouvelle Ecole de la Communication (création en septembre 2007), le master Communication s'adresse aux étudiants désireux de s'orienter vers les fonctions liées à la communication, en agence, en entreprise ou en institution, sur des sujets liés à la communication Corporatecomme à la communication produit, que celles-ci s'adressent à des publics externes (clients, prospects, fournisseurs, actionnaires, journalistes, sponsors, mécènes...) ou internes (salariés, réseaux de distribution, filiales,..), en France comme à l'international.

La formation dispensée dans ce master vise à mettre les élèves en capacité d'exercer des responsabilités opérationnelles à haut niveau au sein des organisations dans lesquelles ils seront amenés à évoluer et ce, dès l'obtention de leur diplôme.

\section{Le contenu de la formation}

SAKATA, Marici Cristine Gramacho, Globalização e Educação: A formação do comunicador social na América Latina, 2008312 p. (Doutorado - Orientação BACCEGA, M. A.) Escola de Comunicações e Artes da Universidade de São Paulo, São Paulo, SP, 2008 
La formation dispensée dans le cadre du master Communication de l'Ecole de la Communication de Sciences Po lie étroitement :

- enseignements académiques et approches pratiques,

- enseignements en français et enseignements en anglais (considéré comme un pré-requis dans ce secteur),

- travaux individuels et travaux en groupe,

- $\quad$ présence à Sciences Po et présence de chacun en entreprise grâce à l'apprentissage.

Elle propose aux élèves tout à la fois :

- des enseignements relatifs à la vie des entreprises du secteur (fondamentaux économiques, juridiques, marketing, managériaux,...) ;

- des enseignements relatifs aux pratiques des métiers de la communication et à la connaissance de leurs environnements (stratégie de communication, médias et hors médias, étude de l'opinion ,...)

- des ateliers thématiques en sciences sociales, articulant interventions de chercheurs et de praticiens des métiers de la communication

Elle offre enfin aux étudiants la possibilité, de se mettre en situation professionnelle, à travers des rencontres avec des praticiens de renom, des études de cas, des projets collectifs opérationnels, mais aussi et surtout grâce à l'apprentissage en entreprise en dernière année.

L'ensemble de la scolarité est fortement ancrée dans une dimension internationale, et l'anglais (pré-requis des métiers de la communication) est très présent au sein de la pédagogie : celle-ci comprend notamment un voyage d'études dans un pays anglophone et des enseignements professionnalisants en langue anglaise.

Organisation des enseignements et pédagogie

Le déroulement de la scolarité : e programme repose sur des enseignements communs, relevant des différents champs de la communication et du marketing, ainsi que sur des enseignements de spécialisation répondant aux multiples facettes de ces fonctions.

La première année :

Le premier semestre commun à tous les étudiants vise à leur faire acquérir les éléments fondamentaux de compréhension de l'environnement socio-économique dans lequel les activités de la communication, de l'information et du marketing s'inscrivent et se développent.

Le second semestre oriente les élèves vers les métiers de la communication, de la gestion stratégique de l'information, du marketing ou des études, en permettant un choix définitif d'orientation en deuxième année. Ce semestre commence à décliner les différents parcours de spécialisation et la mise en route du projet collectif.

La deuxième année :

Le troisième semestre est entièrement dédié à la spécialisation professionnelle et prépare les élèves à l'entrée sur le marché du travail.

Les étudiants peuvent choisir parmi l'une des quatre spécialités suivantes:

marketing stratégique et opérationnel, communication des entreprises et des institutions, gestion stratégique de l'information,

études de marché et d'opinion.

Le quatrième semestre est consacré à un stage de fin d'études de six mois, ouvrant directement sur la vie professionnelle.

L'alternance en 2ème année

La deuxième année du master peut également s'effectuer "en alternance», en alternant les périodes de travail de entreprise (environ 3 semaines par mois) et les périodes d'études à Sciences Po (une semaine par mois). Pour en savoir plus consultez la page Formation en alternance - Master de Sciences Po

SAKATA, Marici Cristine Gramacho, Globalização e Educação: A formação do comunicador social na América Latina, 2008312 p. (Doutorado - Orientação BACCEGA, M. A.) Escola de Comunicações e Artes da Universidade de São Paulo, São Paulo, SP, 2008 
Les métiers

Communication des entreprises et des institutions Les élèves de cette spécialité se dirigeront vers les métiers de la communication interne et externe dans des entreprises ou des institutions, dans des agences de conseil en communication globale ou institutionnelles. Ils devraient occuper à l'issue de la formation des postes de chargé de communication, chargé des relations presse, des relations publiques, chargé de communication interne, de communication financière, responsable du sponsoring ou du mécénat, responsable de la promotion ou de la publicité, responsable de la marque, puis de responsables de département et de directeur de la communication. Marketing stratégique et opérationnel Cette spécialité forme des professionnels ayant pour fonction de dynamiser des produits et des marchés existants et de développer de nouvelles offres, chez des fabricants, des distributeurs, mais aussi dans le domaine des médias (agences de publicité, régies, centrales d'achat d'espace,...). A l'issue de la formation les diplômés devraient occuper en début de carrière des postes de chef de produit ou de projet, puis chef de gamme (categorymanager), chef de marché (businessmanager) et évoluer vers des fonctions de responsables et directeurs de départements marketing dans des entreprises, des agences conseils, des régies publicitaires ou des centrales d'achat d'espace. Selon la taille des organisations ils peuvent être amenés à occuper des postes plus spécialisés comme :

responsable de projet marketing, responsable du marketing opérationnel, du merchandising, du marketing direct ou de la promotion, responsable du trade marketing qui pilote en entreprise ou en agence conseil la mise en place d'opérations communes aux industriels et distributeurs, etc., chef de publicité, puis directeur de clientèle, directeur de marque, directeur commercial ou planner stratégique, consultant; chargé d'études médias, chargé d'études planning stratégique, acheteur d'espaces publicitaires ou acheteur médias et media planner.

Organisation des enseignements et pédagogie - La maquette pédagogique du master est conçue selon une logique progressive.

La première année : La première année est celle de l'acquisition des fondamentaux. Elle permet aux étudiants d'acquérir les clefs de compréhension de l'environnement socio-économique dans lequel les activités de la communication, s'inscrivent et se développent.

La deuxième année : Elle est entièrement dédiée à la mise en pratique des savoirs acquis et prépare les élèves à l'entrée sur le marché du travail, grâce notamment à l'alternance.

Gestion stratégique de l'information - Cette spécialité permet de former des chargés de recherche, des chefs de projet ou des consultants capables de prendre en charge le management de systèmes d'information et de communication spécialisés et de conduire les changements organisationnels qu'ils nécessitent. Ces professionnels doivent se situer à l'interface des métiers de l'entreprise et des architectures informatiques pour évaluer au mieux les besoins en information des utilisateurs ou des clients. Ce métier s'exerce dans tout type d'organisation. A l'issue de la formation, ces diplomés devraient occuper des postes de : chef de projets Intra et/Internet, chargé de recherches, chargé de projet en systèmes d'information spécialisés dans l'organisation des processus métiers, consultant en management de projets informationnels, gestionnaire de connaissances, responsable de projets de veille.

Les métiers - A l'issue de la formation, les étudiants devraient occuper des postes de chargé de communication, chargé des relations presse, des relations publiques, chargé de communication interne, de communication financière, responsable du sponsoring ou du mécénat, responsable de la promotion ou de la publicité, responsable de la marque, puis de responsables de département et de directeur de la communication. Ils pourront également évoluer en agence-

SAKATA, Marici Cristine Gramacho, Globalização e Educação: A formação do comunicador social na América Latina, 2008312 p. (Doutorado - Orientação BACCEGA, M. A.) Escola de Comunicações e Artes da Universidade de São Paulo, São Paulo, SP, 2008 
conseil en tant que chef de projet, chef de publicité, puis chef de groupe et directeur de clientèle ou directeur de marque, plannerstratégique, consultant; chargé d'études médias (en agences, en régies, en centrales d'achat d'espace,...).

Etudes de marché et d'opinion - Les diplômés de cette spécialité se dirigeront vers une carrière en institut dans les départements d'études des marchés (analyse des marchés et de la concurrence, identification des nouvelles cibles, tests des offres de biens et services de consommation) ou dans des départements responsables des études d'opinion (mesures et analyse de l'opinion publique sur les phénomènes sociaux ou les grandes questions en débat). Ils pourront aussi accéder à des services d'études chez l'annonceur (suivi des relations avec les instituts pour la réalisation des études, sondages et panels, activités veille sur le marché et la concurrence).

Le master "Communications" s'adresse aux étudiants manifestant un fort intérêt pour les domaines du marketing et des études, de la communication et de la gestion stratégique de l'information, et ce, quelles qu'en soient les formes:

que celles-ci s'adressent à des publics externes (clients, prospects, fournisseurs, actionnaires, journalistes, sponsors, mécènes...) ou internes (salariés, réseaux de distribution, filiales,..), y compris à l'international.

que celles-ci aient pour finalité la promotion de la notoriété et de l'image, l'information, l'organisation des savoirs et des savoir-faire, la mise en place d'une culture d'entreprise à travers la construction d'une identité propre, l'organisation d'études des environnements ou des marchés dans lequel les entreprises évoluent, l'innovation sur les produits, les services ou les modes de distribution, etc.

La formation dispensée dans ce master offre donc aux étudiants une approche de la communication prise dans une acceptation large, puisqu'il prépare aussi bien aux métiers qui touchent à la communication externe qu'interne, au marketing stratégique et opérationnel, à la publicité, à la gestion stratégique de l'information, ainsi qu'aux études de marché ou d'opinion. Elle vise, dans tous les cas, à mettre les élèves en capacité d'exercer des responsabilités opérationnelles à haut niveau, et ce, dès l'obtention de leur diplôme.

Le contenu de la formation

La formation dispensée dans le cadre du master "Communications» est conçue selon une logique progressive: elle permet d'abord aux élèves de s'approprier les grands référentiels socio-économiques et méthodologiques, à travers des enseignements fondamentaux (économie, droit, gestion, théorie des organisations, compréhension des enjeux des nouvelles technologies) ; elle leur offre ensuite l'acquisition de compétences plus spécifiques en communication, information et marketing (veille stratégique et management, pratiques de la communication et du marketing, des méthodologies des études ...) ; elle leur permet enfin, de se mettre en situation professionnelle, à travers des enseignements spécialisés, des études de cas et des projets collectifs très opérationnels, mais aussi et surtout en fin de scolarité, grâce à un stage semestriel, ou au choix de l'apprentissage en entreprise en dernière année.

\section{ESTADOS UNIDOS DA AMERICA}

\begin{tabular}{|l|l|l|l|l|}
\hline $\begin{array}{l}\text { 3. Estados } \\
\text { Unidos da } \\
\text { América }\end{array}$ & $\begin{array}{l}\text { 3.1 University Of } \\
\text { California } \\
\text { (Pública) }\end{array}$ & $\begin{array}{l}\text { 3.2 Pennsylvania } \\
\text { State University } \\
\text { (Pública) }\end{array}$ & $\begin{array}{l}3.3 \\
\text { Massachusetts } \\
\text { Institute of } \\
\text { Technology } \\
\text { (Privada) }\end{array}$ & $\begin{array}{l}\text { 3.4 Stanford } \\
\text { University } \\
\text { (Privada) }\end{array}$ \\
\hline
\end{tabular}

\section{Estados Unidos da América - Universidades Nacionais}

SAKATA, Marici Cristine Gramacho, Globalização e Educação: A formação do comunicador social na América Latina, 2008312 p. (Doutorado - Orientação BACCEGA, M. A.) Escola de Comunicações e Artes da Universidade de São Paulo, São Paulo, SP, 2008 


\section{$\underline{3.1}_{\text {University of Califórnia }}{ }^{311}$ UC Berkeley Graduate School of Journalism ${ }^{312}$.}

\section{- Características e Missão da Instituição}

The UC includes more than 209,000 students, more than 170,000 faculty and staff, 45,000 retirees and more than 1.4 million living alumni. Berkeley, Davis, Irvine, Los Angeles, Merced, Riverside, San Diego, San Francisco, Santa Barbara, Santa Cruz

UCLA is a leader in many fields, pursuing its mission through excellence in education, research and service. Our faculty, students, and staff work together to advance knowledge in the sciences, humanities and professional fields, address contemporary issues and improve the quality of life in our city, region, state and world. Annual Student Fees \$7,393 and Nonresident Tuition \& Ed. Fees $\$ 14,961$

\section{Mission Statement}

"The distinctive mission of the University is to serve society as a center of higher learning, providing long-term societal benefits through transmitting advanced knowledge, discovering new knowledge, and functioning as an active working repository of organized knowledge. That obligation, more specifically, includes undergraduate education, graduate and professional education, research, and other kinds of public service, which are shaped and bounded by the central pervasive mission of discovering and advancing knowledge."

- from the University of California Academic Plan, 1974-1978

- Características e Objetivos do Curso de Comunicação ou Especialidade da Instituição

The goal of the Graduate School of Journalism is to produce professional print, broadcast, and new media journalists who move on to positions of leadership and influence. The two-year Master of Journalism (M.J.) program provides intensive training in journalism skills and teaches the traditions and principles of the field.

Whichever path students choose at the J-School, commitment to reporting is a constant theme. Journalism starts with ethical, effective reporting of facts. Television students learn how to interview. Documentary film students learn how to read a corporation's quarterly report. Magazine writers master public records searches. The basics of reporting cross all journalistic media.

- Grade Curricular

Degree Requirements

J200 / Reporting the News

J211 / Computer Assisted Reporting

Journalism 200, Reporting the News, is a foundation course that meets for six hours each week and demands at least 15 hours of news reporting outside of the classroom. The heavy workload indicates the importance attached to the class. J200 is the boot camp prerequisite to all advanced reporting and broadcast courses. It is the core of the journalism school curriculum

\footnotetext{
${ }^{311}$ University of Califórnia, Disponível em http://www.ucla.edu/welcome.html acesso em 27/07/2007

${ }^{312}$ UC Berkeley Graduate School of Journalism Disponível em http://journalism.berkeley.edu/ acesso em $27 / 07 / 2007$
}

SAKATA, Marici Cristine Gramacho, Globalização e Educação: A formação do comunicador social na América Latina, 2008312 p. (Doutorado - Orientação BACCEGA, M. A.) Escola de Comunicações e Artes da Universidade de São Paulo, São Paulo, SP, 2008 
and immerses students in the basics of reporting fundamental to every journalism mediumprint, broadcast or digital. Each J200 instructor tailors his or her section of 10-14 students to a particular style or emphasis, but the goal is that all first-year students master basic elements of the reporting and writing craft and obtain published clips of work from their J200 section. The course runs concurrently with Computer Assisted Reporting (J211), which instructs students in the use of electronic reporting resources from Web, database, and public records-skills they apply to their J200 and other assignments.

\section{J255 / Law and Ethics}

This course is an introduction to legal and ethical conflicts faced by working reporters. Using case studies, in-class argument, readings and guest lectures, the course examines some of the murkier conflicts that don't necessarily make it to court but nevertheless force difficult newsroom decision-making. The course is co-taught by a practicing lawyer who specializes in First Amendment law and a regular faculty member.

\section{J294 / Master's Project Seminar}

$J$-School culminates in a final master's project, a capstone of each student's experience at Berkeley. Students submit an in-depth reporting project of professional quality prior to graduation. Newspaper series, magazine articles, long-form pieces for radio, TV, new media, or photography or a documentary film can meet the requirement. During the second year, students meet regularly with a faculty advisor to discuss their progress. Many of our students publish or broadcast their projects in major media outlets.

\section{J297 / Internship}

A cornerstone of our program is ensuring that students gain professional experience. In J297, students receive two units of credit for a summer internship between their first and second year, or during the academic year. Students in our program have interned at major newspapers, TV and radio stations and new media outlets, including the The Washington Post, The New York Times, The Sacramento Bee, the San Jose Mercury News, the Anchorage Daily News, NPR, MarketWatch.com, ABC and WIRED magazine. Our career services director and permanent and visiting faculty assist students in finding a challenging internship in print, broadcast or new media. News organizations provide written evaluations of all student interns, providing useful feedback. Students also write reports on their internship experiences and share this information with their colleagues.

\section{Additional Requirements}

The master of journalism degree requires 36 semester units of graduate or upper-division courses and submission of a master's project. A minimum of 24 units must be earned in the Graduate School of Journalism. Up to 12 units of credit may be earned in graduate or upperdivision courses in other departments on campus. In the spring of the first year, and in both semesters of the second year, each student must enroll in at least one advanced reporting course. To satisfy our cross-media requirement, all students must take at least one course in a medium outside of the primary area of interest. All students must enroll full-time (at least eight units each semester in most cases) and must fulfill the four-semester residency requirement

\section{$\underline{3.2}$ Pennsylvania State University $\underline{313} \underline{\text { School of Communications }} \underline{\underline{314}}$}

\section{- Características e Missão da Instituição}

\footnotetext{
313 The Pennsylvania State University Disponível em http://www.psu.edu/bulletins/bluebook/ acesso em 27/07/2007

${ }^{314}$ The Pennsylvania State University, The School of Communications Disponível em http://www.psu.edu/bulletins/bluebook/\$comenu.htm acesso em 27/07/2007
}

SAKATA, Marici Cristine Gramacho, Globalização e Educação: A formação do comunicador social na América Latina, 2008312 p. (Doutorado - Orientação BACCEGA, M. A.) Escola de Comunicações e Artes da Universidade de São Paulo, São Paulo, SP, 2008 
Penn State is a multicampus public land-grant university that improves the lives of people in Pennsylvania, the nation, and the world through integrated, high-quality programs in teaching, research, and outreach.

Our instructional mission includes undergraduate, graduate, and continuing education informed by scholarship and research. Our research, scholarship, and creative activities promote human and economic development through the expansion of knowledge and its applications in the natural and applied sciences, social sciences, arts, humanities, and selected professions.

As a land-grant university, we also hold a unique responsibility for outreach and public service to support the citizens of Pennsylvania. We engage in collaborative activities with industrial, educational, and agricultural partners here and abroad to disseminate and apply knowledge.

- Características e Objetivos do Curso de Comunicação

College of Communications

The School of Communications, approved by the Board of Trustees on May 18, 1985, became the College of Communications in 1995. The college recognizes its mission to educate students for citizenship in a society in which communication and information are a major commodity and the basis of the democratic process; recognizes the complex mosaic of changing employment possibilities available in the information environment and thus prepares students for an employment climate in which the ability to adapt is a fundamental requisite to success; and facilitates the development of sophisticated abilities in the gathering, analysis, and dissemination of information.

The college offers a strong liberal arts education plus rigorous professional preparation to those planning careers in the mass media. The college also offers courses analyzing the role of the mass media in modern society.

- Grade Curricular

COMMUNICATIONS (COMM)

BACHELOR OF ARTS DEGREE REQUIREMENTS

COMM 100 (GS)MASS MEDIA \& SOC (3)

COMM $100 S$ (GS)MASS MEDIA \& SOC (3)

COMM 180 (GS)ELEC MEDIA \& TELCM (3)

COMM $180 H$ FA2007 (GS)ELEC MEDIA \& TELCM (3)

COMM $180 H$ SP2008 (GS)ELEC MEDIA \& TELCM (3)

COMM 205 WOMEN MINOR MEDIA (3:3:0)

COMM 401 MEDIA IN HIST (3:3:0)

COMM 403 MASS COMMUNS LAW (3:3:0)

COMM 405 POL ECON COMM (3:3:0)

COMM 407 ADVTS \& ECONOMY (3:3:0)

COMM 408 CULT FOUND COMM (3:3:0)

COMM 409 NEWS MEDIA ETHICS (3:3:0)

COMM 410 INTERNATIONAL M C (3:3:0)

COMM 411 CLT ASP MASS MEDIA (3:3:0)

COMM 413W MEDIA \& PUBLIC (3:3:0)

COMM 413 MEDIA \& PUBLIC (3:3:0)

COMM 417 ETH \& REG IN AD PR (3:3:0)

COMM 419H WORLD MEDIA SYS (3)

COMM 419 WORLD MEDIA SYS (3:3:0

SAKATA, Marici Cristine Gramacho, Globalização e Educação: A formação do comunicador social na América Latina, 2008312 p. (Doutorado - Orientação BACCEGA, M. A.) Escola de Comunicações e Artes da Universidade de São Paulo, São Paulo, SP, 2008 
Students must select at least 80 credits in non-communications courses including at least 65 credits in the liberal arts and sciences. Students may take a maximum of 3 internship (495) credits.

BACHELOR OF ARTS DEGREE REQUIREMENTS: 9-24 credits

FOREIGN LANGUAGES (0-12 credits)

Student must attain 12th credit level of proficiency in one foreign language

\section{B.A. FIELDS (9 credits)}

Humanities, Social and Behavioral Sciences, Arts, Foreign Languages, Natural Sciences, Quantification (may not be taken in the area of the student's primary major; foreign language credits in this category must be in a second foreign language or beyond the 12th credit level of proficiency in the first langauge)

\section{OTHER CULTURES (0-3 credits)}

Select 3 credits from approved list. Students may count courses in this cateogory in order to meet other major, minor, elective, or General Educaiton rquirements, except for the General Education US/IL requirement. See approved list at www.psu.edu/bulletins/bluebook/gened/bad.html.

\section{Estados Unidos da América - Universidades Globalizadas}

\subsection{Massachusetts Institute of Technology School of Humanities, Arts, and Social $\underline{\text { Sciences - Comparative Media Studies (CMS) }}$}

\section{- Características e Missão da Instituição}

The mission of MIT is to advance knowledge and educate students in science, technology, and other areas of scholarship that will best serve the nation and the world in the 21st century.

The Institute is committed to generating, disseminating, and preserving knowledge, and to working with others to bring this knowledge to bear on the world's great challenges. MIT is dedicated to providing its students with an education that combines rigorous academic study and the excitement of discovery with the support and intellectual stimulation of a diverse campus community. We seek to develop in each member of the MIT community the ability and passion to work wisely, creatively, and effectively for the betterment of humankind.

The Institute admitted its first students in 1865, four years after the approval of its founding charter. The opening marked the culmination of an extended effort by William Barton Rogers, a distinguished natural scientist, to establish a new kind of independent educational institution relevant to an increasingly industrialized America. Rogers stressed the pragmatic and practicable. He believed that professional competence is best fostered by coupling teaching and research and by focusing attention on real-world problems. Toward this end, he pioneered the development of the teaching laboratory.

Today MIT is a world-class educational institution. Teaching and research-with relevance to the practical world as a guiding principle-continue to be its primary purpose. MIT is independent, coeducational, and privately endowed. Its five schools and one college encompass numerous academic departments, divisions, and degree-granting programs, as well as interdisciplinary centers, laboratories, and programs whose work cuts across traditional departmental boundaries.

- Características e Objetivos do Curso de Comunicação ou Especialidade da Instituição

315 School of Humanities, Arts, and Social Sciences - Comparative Media Studies Disponivel em http://cms.mit.edu/academics/undergrad/ acesso em 25/07/2007

SAKATA, Marici Cristine Gramacho, Globalização e Educação: A formação do comunicador social na América Latina, 2008312 p. (Doutorado - Orientação BACCEGA, M. A.) Escola de Comunicações e Artes da Universidade de São Paulo, São Paulo, SP, 2008 
The MIT Comparative Media Studies (CMS) program is committed to the art of thinking across media forms, theoretical domains, cultural contexts, and historical periods. Both our graduate and undergraduate programs encourage the bridging of theory and practice, as much through course work as through participation in faculty and independent research projects.

The goal of our program is not to replicate existing paradigms, but as an early CMS backer said, to prepare students for jobs that don't yet exist. We consult regularly with leaders in industry, the arts, public policy, journalism, education, and the nonprofit sector, trying to understand contemporary developments, identify job and internship opportunities, and pinpoint skills and knowledge which will help prepare our students for new opportunities.

Our courses are designed to teach students to both make and reflect upon media and in the process, to acquire important skills in team work, leadership, problem solving, collaboration, brainstorming, communications, and project completion, which will prepare them for a broad range of academic and professional careers.

Both the undergraduate and masters programs manifest CMS's commitment to thinking across media forms, theoretical domains, cultural contexts, and historical periods. Both programs encourage the bridging of theory and practice, as much through course work as through participation in faculty and independent research projects. The logic behind the programs is simple: a core of CMS-specific courses establishes the overarching logic and connections that enables students to make the most of a wide array of interdisciplinary electives available both at MIT and Harvard. Students are encouraged to develop a broad understanding of key issues surrounding media change which cut across different national borders and delivery techniques; they are also encouraged to develop an in-depth understanding of multiple media traditions, old and new. In this way, the program manages to provide coherence while being uniquely shaped to fit the needs of each student.

The goal of our program is not to replicate existing paradigms, but as an early CMS backer said, to prepare students for jobs that don't yet exist. We consult regularly with leaders in industry, the arts, public policy, journalism, education, and the nonprofit sector, trying to understand contemporary developments, identify job and internship opportunities, and pinpoint skills and knowledge which will help prepare our students for new opportunities. Our courses are designed to teach students to both make and reflect upon media and in the process, to acquire important skills in team work, leadership, problem solving, collaboration, brainstorming, communications, and project completion, which will prepare them for a broad range of academic and professional careers. A growing portion of our students are double majors, combining technical skills acquired elsewhere at MIT with the social and cultural expertise which has become the hallmark of the Comparative Media Studies Program.

\section{- $\quad$ Grade Curricular}

The Full Major requires ten subjects. Majors are required to take $21 \mathrm{~L} .011$ The Film Experience, 21L.015 Introduction to Media Studies; CMS.400 Media Systems and Texts; and one of the following capstone subjects: 21L.706 Studies in Film, CMS.605 Topics in International Media, or $21 \mathrm{~L} .715$ Media in Cultural Context; and six electives. It is strongly recommended that majors take a practicum that includes a substantial hands-on component as one of their electives. Major Advisor is Prof. Marty Marks (mmarks@mit.edu), 10-268.

The undergraduate program in Comparative Media Studies - established in 1982 under its former name, Film and Media Studies - offers students an opportunity for an interdisciplinary study of film, television, and other communications media. The program's goal is to develop an understanding of the historical, cultural, and artistic significance of film and other modern media.

SAKATA, Marici Cristine Gramacho, Globalização e Educação: A formação do comunicador social na América Latina, 2008312 p. (Doutorado - Orientação BACCEGA, M. A.) Escola de Comunicações e Artes da Universidade de São Paulo, São Paulo, SP, 2008 
Many subjects focus on the notion of 'comparative' media, in several distinct senses:

comparison among media forms

comparison across history

comparision across cultures

comparison across disciplines and methodologies

comparison of theory and practice

The undergraduate program in CMS also incorporates courses in what is traditionally known as Film Studies and Mass Media Studies.

Faculty drawn from the following participating departments regularly teach subjects in the core curriculum:

Art and Architecture (4)

Anthropology (21A)

Foreign Languages and Literatures $(21 F)$

History (21H)

Literatura $(21 L)$

Music and Theater Arts (21M)

Writing and Humanistic Studies $(21 \mathrm{~W})$

Philosophy (24)

Media Arts and Sciences (MAS)

Science, Technology, and Society (STS)

\subsection{Stanford University - Department of Communication $\underline{316}$}

\section{- Características e Missão da Instituição}

On Oct. 1, 1891, Stanford University opened its doors after six years of planning and building. They settled on creating a great university, one that, from the outset, was untraditional: coeducational in a time when most private universities were all-male; nondenominational when most were associated with a religious organization; and avowedly practical, producing "cultured and useful citizens" when most were concerned only with the former.

Leland Stanford devoted to the university the fortune he had amassed, first by supplying provisions to the '49ers mining for California gold and later as one of the "Big Four," whose Central Pacific Railroad laid tracks eastward to meet the Union Pacific and complete the transcontinental railway

\section{University Motto}

"Die Luft der Freiheit weht" is Stanford's unofficial motto and translates as "the wind of freedom blows." The phrase is a quote from Ulrich von Hutten, a 16th-century humanist. Stanford's first president, David Starr Jordan, embraced the questioning, critical spirit of von Hutten's words and included them on his presidential seal. Gerhard Casper, president of Stanford from 1992 to 2000, adopted the motto as the basis of his inaugural address and encouraged its widespread use across the campus. The motto has been incorporated into the university seal, depicted on the left.

The Stanford motto, 'The wind of freedom blows, 'is an invitation to free an open inquiry in the pursuit of teaching and research. The freedom of scholarly inquiry granted to faculty and students at Stanford is our greatest privilege; using this privilege is our objective. - President John Hennessy

\footnotetext{
${ }^{316}$ Stanford University - Department of Communication Disponível em http://communication.stanford.edu/courses/index.html acesso em 27/07/2007
}

SAKATA, Marici Cristine Gramacho, Globalização e Educação: A formação do comunicador social na América Latina, 2008312 p. (Doutorado - Orientação BACCEGA, M. A.) Escola de Comunicações e Artes da Universidade de São Paulo, São Paulo, SP, 2008 
- Características e Objetivos do Curso de Comunicação ou Especialidade da Instituição

Journalism education at Stanford University began in 1911 in the Department of English with two courses, "News Writing" and "Current Newspapers," taught by the same instructor. Within a few years journalism became section of the department and then in 1921 became a department division with nine of its own courses. Students interested in journalism needed to major in English, history, economics, or political science, but if they completed their "special journalism subjects" their diplomas would list their major as "preparatory to journalism."

By the mid 1920s journalism became an independent division in the School of Social Sciences. It continued to require a "broad foundation of general information" and "more specific knowledge of economics, political science, history and other subjects" but now also expected "some technical ability in journalism and an intelligent comprehension of the obligations and responsibilities of the profession."

In 1948 the division was renamed the Institute for Journalistic Studies, which was located in the new School of Humanities and Sciences that was created by combing the schools of Social Sciences and Letters. A few years later the name changed again, to Department of Communication and Journalism, which included a separate Institute for Communication Research. What is now the Department of Communication, a designation that has endured more than 30 years of change and growth, continues to educate journalists through its Graduate Program in Journalism.

Department of Communication

The Department of Communication engages in research in communication and offers curricula leading to the B.A., M.A., and Ph.D. degrees. The M.A. degree prepares students for research on mass media or for careers in journalism. The Ph.D degree leads to careers in teaching and research-related specialties.

- Grade Curricular

Major in Communication

Students should declare the major during either the sophomore or junior year. To declare, students MUST have completed or be concurrently enrolled in one of the following:

Comm 1 A (formerly Comm 1): Media Technologies, People, and Society, or Comm 1B: Media, Culture, and Society

Comm 106: Communication Research Methods

Comm 108: Media Processes \& Effects

Once the prerequisites have been met, prospective majors should declare via Axess and then email the Student Services Administrator to set up an appointment to complete the minimal paperwork, to be assigned an advisor and to discuss any questions they may have.

Transfer Students

Required Communication courses usually must be taken at Stanford. Not more than 10 units of transfer or Summer session credit may be applied to meet departmental requirements.

The Office of Undergraduate Admissions asks transfer students to furnish an official transcript, which is evaluated by the University. Students who transfer to Stanford and enter the

SAKATA, Marici Cristine Gramacho, Globalização e Educação: A formação do comunicador social na América Latina, 2008312 p. (Doutorado - Orientação BACCEGA, M. A.) Escola de Comunicações e Artes da Universidade de São Paulo, São Paulo, SP, 2008 
Department of Communication should know the only Communication course likely to be waived is Communication 1.

Combined and Multiple Majors

Formal options exist for all Stanford undergraduates who are interested in pursuing more than one academic discipline. Students should refer to Stanford Bulletin and the Academic Standing office. Remember that participation in any multiple major program requires declaration of each major.

Students pursuing this option must complete a Multiple Major Form indicating which courses they plan to apply toward each major and/or minor. Multiple Major Forms are available from the Registrar's Office website.

\section{Major Curriculum}

1. Communication Five Core Courses:

A. Comm 1A (formerly Comm 1): Media Technologies, People, and Society, or Comm 1B: Media, Culture, and Society

B. Psychology 10 or Statistics 60

C. Comm 104: Reporting, Writing and Understanding the News (WIM)

D. Comm 106: Communication Research Methods (prerequisite-statistics)

E. Comm 108: Media Process and Effects

2. Students must take courses in the following areas as specified below:

Area I: Communication Processes and Effects

(minimum of two courses must be taken)

Comm 146: Language and Discourse: Race, Class and Gender

Comm 149: Ethnography of Modern Speech Communities

Comm 160: The Press \& the Political Process

Comm 162: Analysis of Political Campaigns

Comm 166: Virtual People

Comm 169: Computers \& Interfaces: Psychology \& Design

Comm 170: Communication \& Children I

Comm 172: Psychological Processing

Area II: Communication Systems/Institutions

(minimum of two courses must be taken)

Comm 104: Reporting, Writing, and Understanding the News

Comm 116: Journalism Law

Comm 117: Digital Journalism

Comm 120: Digital Media in Society

Comm 125: Perspectives on American Journalism

Comm 131: Media Ethics \& Responsibilities

Comm 136: Democracy \& the Communication of Consent

Comm 138: Democratic Theory

Comm 140: New Media Entrepreneurship

Comm 147: History and Future of Journalism

Comm 148: Hip-hop and Don't Stop: Introduction to Modern Speech Communities

Comm 182: Virtual Communities and Social Networks

The remainder of the 60 required units may be fulfilled with any elective communication courses, or pre-approved courses in affiliated departments. Up to 15 of the 60 units can come from pre-approved non-Communication electives.

Possible Tracks

SAKATA, Marici Cristine Gramacho, Globalização e Educação: A formação do comunicador social na América Latina, 2008312 p. (Doutorado - Orientação BACCEGA, M. A.) Escola de Comunicações e Artes da Universidade de São Paulo, São Paulo, SP, 2008 
The communication curriculum is designed to provide a theoretical base that can be effectively applied to numerous environments. Below we offer some potential tracks to guide you. These are not intended to restrict you but rather suggest examples of ways to focus your interests.

A. Communication Technologies

Department Offerings

Comm 120: Digital Media in Society

Comm 169: Computers \& Interfaces: Psychology \& Design

Comm 172: Psychological Processing

Affiliated Department Offerings (elective credit toward the major). All courses are not offered each year. See the Stanford Bulletin.

Computer Science

CS 105: Introduction to Computers

CS 106A: Programming Methodology

CS 147: Introduction to HCI

CS 247A: Interaction Design Studio

CS 201/STS 215: Computers, Ethics, \& Social Responsibility

CS 377: Topics in Human Computer Interaction

Science, Technology \& Society

STS 101: Science, Technology, \& Contemporary Society

STS 215/CS 201: Computers, Ethics, \& Social Responsibility

B. Communication and Public Affairs

Department Offerings

Comm 125: Perspectives on American Journalism

Comm 136: Democracy \& the Communication of Consent

Comm 138: Democratic Theory

Comm 160: The Press \& the Political Process

Comm 162: Analysis of Political Campaigns

Comm 170: Communication \& Children

Affiliated Department Offerings (elective credit toward the major). All courses are not offered each year. See the Stanford Bulletin.

Political Science

PolSci 123: Politics of Public Policy

PolSci 126: Issues of Representation in American Politics

Psychology

Psych 75: Cultural Psychology

Psych 167: Seminar on Aggression

Psych 180/245: Social Psychological Perspectives on Stereotyping \& Prejudice

Public Policy

PubPol 104: Economic Policy

PubPol 194: Technology Policy

C. Media Practices and Performance

Department Offerings

Comm 120: Digital Media in Society

Comm 125: Perspectives on American Journalism

Comm 131: Media Ethics \& Responsibilities

Comm 160: The Press \& the Political Process

SAKATA, Marici Cristine Gramacho, Globalização e Educação: A formação do comunicador social na América Latina, 2008312 p. (Doutorado - Orientação BACCEGA, M. A.) Escola de Comunicações e Artes da Universidade de São Paulo, São Paulo, SP, 2008 


\title{
ANEXO III - DIRETRIZES CURRICULARES - BRASIL
}

\author{
CONSELHO NACIONAL DE EDUCAÇÃO \\ CÂMARA DE EDUCAÇÃO SUPERIOR \\ RESOLUÇÃO CNE/CES 16, DE 13 DE MARÇO DE 2002. ${ }^{*}$
}

Estabelece as Diretrizes Curriculares para a área de Comunicação Social e suas habilitações.

O Presidente Câmara de Educação Superior, no uso de suas atribuições legais e tendo em vista o disposto na Lei 9.131, de 25 de novembro de 1995, e ainda o Parecer CNE/CES 492/2001, homologado pelo Senhor Ministro de Estado da Educação em 9 de julho de 2001, e o Parecer CNE/CES 1.363/2001, homologado em 25 de janeiro de 2002, resolve:

Art. $1^{\circ}$ As Diretrizes Curriculares para a área de Comunicação Social e suas habilitações, integrantes dos Pareceres CNE/CES 492/2001 e 1.363/2001, deverão orientar a formulação do projeto pedagógico do referido curso.

Art. $2^{\circ} \mathrm{O}$ projeto pedagógico de formação profissional na área de Comunicação Social e suas habilitações deverá explicitar:
a) o perfil comum e os perfis específicos por habilitação;
b) as competências e habilidades gerais e específicas por habilitação a serem desenvolvidas, durante o período de formação;
c) os conteúdos básicos relacionados à parte comum e às diferentes habilitações e os conteúdos específicos escolhidos pela instituição para organizar seu currículo pleno;
d) as características dos estágios;
e) as atividades complementares e respectiva carga horária;
f) a estrutura do curso;
g) as formas de acompanhamento e avaliação da formação ministrada.

Art. $3^{\circ}$ A carga horária do curso de Comunicação Social e respectivas habilitações deverá obedecer ao determinado em Resolução própria que normatiza a oferta de cursos de bacharelado.

Art. $4^{\circ}$ Esta Resolução entra em vigor na data de sua publicação, revogadas as disposições em contrário.

\section{ARTHUR ROQUETE DE MACEDO}

Presidente da Câmara de Educação Superior

${ }^{(*)}$ CNE. Resolução CNE/CES 16/2002. Diário Oficial da União, Brasília, 9 de abril de 2002. Seção 1, p. 34.

SAKATA, Marici Cristine Gramacho, Globalização e Educação: A formação do comunicador social na América Latina, 2008312 p. (Doutorado - Orientação BACCEGA, M. A.) Escola de Comunicações e Artes da Universidade de São Paulo, São Paulo, SP, 2008 
Parecer CNE/CES n ${ }^{\circ} 492$, de 3 de abril de 2001

http://portal.mec.gov.br/cne/arquivos/pdf/CES0492.pdf

Aprova as Diretrizes Curriculares Nacionais dos cursos de Arquivologia, Biblioteconomia, Ciências Sociais - Antropologia, Ciência Política e Sociologia, Comunicação Social, Filosofia, Geografia, História, Letras, Museologia e Serviço Social.

\section{CONSELHO NACIONAL DE EDUCAÇÃO}

INTERESSADO: Conselho Nacional de Educação/Câmara Superior de Educação

UF: DF

ASSUNTO: Diretrizes Curriculares Nacionais dos cursos de Filosofia, História, Geografia, Serviço Social, Comunicação Social, Ciências Sociais, Letras, Biblioteconomia, Arquivologia e Museologia

RELATOR(A): Eunice Ribeiro Durham, Silke Weber e Vilma de Mendonça Figueiredo

PROCESSO(S) N.'(S): 23001.000126/2001-69

PARECER N. ${ }^{\circ}$ : CNE/CES 492/2001

COLEGIADO: CES

APROVADO EM: 03/04/2001

\section{I - RELATÓRIO}

Trata o presente de diversos processos acerca das Diretrizes Curriculares Nacionais dos cursos de Filosofia, História, Geografia, Serviço Social, Comunicação Social, Ciências Sociais, Letras, Biblioteconomia, Arquivologia e Museologia remetidas pela $\mathrm{SESu} / \mathrm{MEC}$ para apreciação da CES/CNE.

A Comissão constituída pelas Conselheiras Eunice Ribeiro Durham, Vilma de Mendonça Figueiredo e Silke Weber analisou as propostas provindas da SESu referentes aos cursos mencionados e procedeu a algumas alterações com o objetivo de adequá- las ao Parecer 776/97 da Câmara de Educação Superior, respeitando, no entanto, o formato adotado pelas respectivas Comissões de Especialistas que as elaboraram. A Comissão retirou, apenas de cada uma das propostas, o item relativo à duração do curso, considerando o entendimento de que o mesmo não constitui propriamente uma diretriz e será objeto de uma Resolução específica da Câmara de Educação Superior, o que foi objeto do Parecer CNE/CES 583/2001.

\section{II - VOTO DO(A) RELATOR(A)}

A Comissão recomenda a aprovação das propostas de diretrizes dos cursos mencionados na forma ora apresentada.

Brasília(DF), 03 de abril de 2001.

Conselheiro(a) Silke Weber - Relator(a)

Conselheiro(a) Eunice Ribeiro Durham

Conselheiro(a) Vilma de Mendonça Figueiredo

\section{III - DECISÃO DA CÂMARA}

A Câmara de Educação Superior aprova por unanimidade o voto do(a) Relator(a).

Sala das Sessões, em 03 de abril de 2001.

Conselheiro Arthur Roquete de Macedo - Presidente

Conselheiro Jose Carlos Almeida da Silva - Vice-Presidente 


\section{DIRETRIZES CURRICULARES A ÁREA DE COMUNICAÇÃO SOCIAL E SUAS HABILITAÇÕES \\ Introdução}

Estas Diretrizes Curriculares da Área da Comunicação foram elaboradas procurando atender a dois objetivos fundamentais:

a) flexibilizar a estruturação dos cursos, tanto para atender a variedades de circunstâncias

geográficas, político-sociais e acadêmicas, como para ajustar-se ao dinamismo da área, e para viabilizar o surgimento de propostas pedagógicas inovadoras e eficientes;

b) estabelecer orientações para a obtenção de padrão de qualidade na formação oferecida.

O presente texto estabelece um padrão básico de referência para todas as instituições que mantenham Cursos de Graduação em Comunicação com habilitações em Jornalismo, Relações Públicas, Publicidade e Propaganda, Cinema, Radialismo, Editoração, ou outras habilitações pertinentes ao campo da Comunicação que venham a ser criadas.

\section{Diretrizes Curriculares}

1. Perfil dos Formandos

PERFIL COMUM

O perfil comum do egresso corresponde a um objetivo de formação geral que deve ser atendido por todos os Cursos da área e em todas as habilitações de Comunicação, qualquer que seja sua ênfase ou especificidade. Trata-se de base que garanta a identidade do Curso como de Comunicação.

O egresso de Curso de Graduação em Comunicação, em qualquer de suas habilitações, caracteriza-se por:

1. sua capacidade de criação, produção, distribuição, recepção, e análise crítica referentes às mídias, às práticas profissionais e sociais relacionadas com estas, e a suas inserções culturais, políticas e econômicas;

2. sua habilidade em refletir a variedade e mutabilidade de demandas sociais e profissionais na área, adequando-se à complexidade e velocidade do mundo contemporâneo;

3. sua visão integradora e horizontalizada - genérica e ao mesmo tempo especializada de seu campo de trabalho possibilitando o entendimento da dinâmica das diversas modalidades comunicacionais e das suas relações com os processos sociais que as originam e que destas decorrem.

4. utilizar criticamente o instrumental teórico-prático oferecido em seu curso, sendo portanto competente para posicionar-se de um ponto de vista ético-político sobre o exercício do poder na comunicação, sobre os constrangimentos a que a comunicação pode ser submetida, sobre as repercussões sociais que enseja e ainda sobre as necessidades da sociedade contemporânea em relação à comunicação social.

\section{PERFIS ESPECÍFICOS}

Os perfis específicos resultam das habilitações diferenciadas do campo da Comunicação, que se caracteriza por uma abrangência sobre diferentes meios, linguagens e práticas profissionais e de pesquisa e, na atualidade, por envolver um acelerado dinamismo social e tecnológico.

Para assegurar o desenvolvimento histórico desta área de formação, estudos e exercício profissional, serão desenvolvidas habilitações com uma variedade de perfis específicos. 
Estas habilitações, definidoras dos perfis específicos, se organizam conforme as seguintes premissas:

a) é mantida a referência básica às habilitações historicamente estabelecidas: jornalismo, relações públicas, publicidade e propaganda, radialismo, editoração, e cinema (assim como à sua denominação alternativa, cinema e vídeo);

b) podem ser criadas ênfases específicas em cada uma destas habilitações, que serão então referidas pela denominação básica, acrescida de denominação complementar que caracterize a ênfase adotada;

c) podem ser criadas novas habilitações pertinentes ao campo da Comunicação. As habilitações referidas nos itens "b" e "c" acima serão reconhecidas como pertinentes ao campo da Comunicação na medida em que contemplem:

- a dimensão e a complexidade temática e de objeto de estudo;

- a existência de vinculações profissionais e conceituais com o campo da Comunicação;

- a delimitação de uma habilitação específica, que comporte linguagem e práticas profissionais próprias. 